\title{
LU ASPRI
}

Advanced

Social and Political Research

Institute

STRATĒGISKĀAS

ANALİZES

KOMISIJA

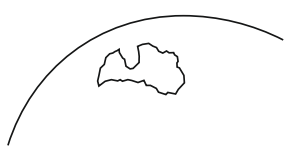





\section{UNCERTAIN TRANSFORMATIONS - NEW DOMESTIC AND INTERNATIONAL CHALLENGES}

\section{NESKAIDRĀS TRANSFORMĀCIJAS - JAUNI IZAICINĀJUMI NACIONĀLĀ UN STARPTAUTISKĀ LĪMEN̄̄}

Proceedings of the International Conference Riga, November 9-11, 2006

Starptautiskās konferences ziṇojumi Rìga, 2006. gada 9.-11. novembris 
UDK $316+32(063)$

Un 150

\section{Uncertain Transformations - New Domestic and International Challenges}

Proceedings of the International Conference, Riga, November 9-11, 2006

Rīga, Latvijas Universitāte, 2006. 390 lpp.

Riga, University of Latvia, 2006. 390 pages

\section{International Conference organised by}

University of Latvia

Faculty of Social Sciences

Advanced Social and Political Research Institute

and

Strategic Analysis Commission under the Auspices

of the President of the Republic of Latvia

Editors: Prof. Žaneta Ozoliṇa and Dr. Nils Muižnieks

\section{Editorial Board:}

Prof. Žaneta Ozoliṇa, Head, Department of Political Science, Faculty of Social Sciences, University of Latvia

Dr. Nils Muižnieks, Director, Advanced Social and Political Research Institute, University of Latvia

Assist. prof. Andris Runcis, Department of Political Science, Faculty of Social Sciences, University of Latvia

Prof. Aija Zobena, Head, Department of Sociology, Faculty of Social Sciences, University of Latvia

Prof. Aleksander Surdej, Cracow University of Economics

$D r$. Lassi Heininen, University of Lapland

Project Coordinators:

Inga Kanasta and Ieva Zlemeta

Latvian language editor: Vija Kan̦epe

Lay-out: Arnis Čakstiņš

Cover design: Ieva Tiltina

All the papers published in the present volume have been reviewed.

No part of the volume may be reproduced in any form without the written permission of the publisher. 


\section{Contents}

Address by H.E. Dr. Vaira Vỉkse-Freiberga, President of Latvia ................................... 7

1. EUROPE AND ITS NEIGHBOURS FACING NEW CHALLENGES .............. 9

Geoffrey Pridham The Political Challenge of E.U. Enlargement:

Democratic Conditionality, Its International Implications and Domestic Consequences

David J. Galbreath, Jeremy W. Lamoreaux Punching above your Weight?

The Baltic States as 'Small States' and the European Neighbourhood Policy

Kasper Andersson Elite Democratic Discourses in Ukraine:

Preliminary Results from the Study of Ukrainian Members of Parliament

Kārlis Bukovskis Foreign Policy Discourse in the Republic Of Latvia from the Point of View of the Civilian Power Conception

Ruslans Osipovs Alternatives of Russian Institutional Development in 1993

(Krievijas institucionālās attīistības alternatīvas 1993. gadā)

2. KNOWLEDGE SOCIETY AND ECONOMY

Tatyana Boikova The Efficiency of Economic Transformation in the New Europe ........ 77

Andrejs Čirjevksis, Iveta Ludviga Competitive Advantage Based

on Cultural Identities of Localities in the Era of Globalisation

Andris Denins Major Management Problems

of Knowledge Based Economic Development

Edvins Karnitis Development of a Knowledge-based Society and

a Knowledge Economy in Latvia: Uncertainties and Risks of Transformations

3. NGOs, SOCIAL CAPITAL AND SOCIAL WELFARE REFORM

Jūratė Imbrasaitė The Contribution of Non-Governmental

Organisations to Urban and Rural Development in Lithuania

Inta Ostrovska The Role of Education in the Creation of Social Capital

Liga Mirlina The Impact of Civil Initiative on Latvian Public Administration

Māra Majore NGO-Government Cooperation in Latvia

(Nevalstisko organizāciju un valdības sadarbība Latvijā)

Arvydas Guogis, Harald Koht On the Differences between Lithuanian and Norwegian Models of Social Welfare Provision

Annika Staaf, Monica Larsson Central Regulation versus Local Self-determination Regarding Work in Human Services Organisations: A Case Study

4. INFORMATION AND SOCIETY

Baiba Holma Functional Approach to the Subject of a Document:

Does It Change Access to Information?

(Funkcionālā pieeja dokumenta priekšmetam: vai tā maina piekḷuvi informācijai?)

Daina Pakalna Quantitative Aspects of Scientific Publications Research (Infometrics, Bibliometrics, Scientometrics, Vebometrics) (Zinātnisko publikāciju pētī̌sanas kvantitatīvie aspekti (infometrija, bibliometrija, scientometrija, vebometrija)) 
Baiba Sporāne The Library as an Auxiliary Investigative Instrument (Bibliotēka kā izziņas palīginstruments)

Maira Dudareva Digital Photography Reading Skills

(Digitālo fotogrāfiju lasītprasme)

Dženija Dzirkale-Mal̦avkina Reform of Primary Education and the Role of Libraries (Pamatizglìtības reforma un bibliotēku loma tajā)

Gita Komarova Management of Infiormation in the Educational Institutions

(Informācijas pārvaldība izglîtības iestāžu bibliotēkās)

Elita Lazda Valeology of Libraries - New Scientific Subject?

(Bibliotekārā valeolog̣ija - jauna zinātniskā disciplīna?)

Baiba Mūze Transformation of Information into Knowledge: Limitations and dilemmas (Informācijas transformācija zināšanās: ierobežojumi un dilemmas)

5. EDUCATION, KNOWLEDGE AND SOCIAL CHANGE

Monica Kjørstad The Production of Knowledge in Social Work - The Importance of Learning from Practice (A 'Mode 2' Perspective on Doing Research in Social Work)

Olga Lavrinenko Knowledge Society: The Position of a Family

Ludmila Panina The Components of the Quality of Education:

Opinions of Social Groups Involved in the Education System

Juris Tipa Education and Its Consequences in a Changing World:

A Challenge to the Knowledge Society .....

Vladimirs Meņšikovs, Elita Jermolajeva Social Partnership and the Quality of Education in Latvia

6. CHANGING MINORITY/IMMIGRANT IDENTITIES

Kjetil Duvold If Push Comes to Shove. Territorial Identification among the Baltic Russians

Vladislavs Volkovs The Behavioural Strategy of the Russian Ethnic

Minority in Latvia: Peculiarities of Structuration

Andrey Lukyanov Russian Migrants in Denmark:

Phenomenon of Double Marginality

Parsla Eglite The Challenge of Emigration for Population Policy in Latvia

Jolanta Kuznecoviene (New) Markers of Lithuanian National Identity:

Re-Defining Global and Native

7. LATVIA: SOCIAL AND POLITICAL DILEMMAS

Liga Rasnaca, Zenija Kruzmetra, Dina Bite Changes in the Towns

and Countryside of Latvia after Accession to the European Union

Kristine Beinarovica Corruption in Public Procurement: Corruption Risks

Ilona Golubeva Formation of Coalition Governments During the $8^{\text {th }}$ Saeima in Latvia

Maruta Lāce Causes of Cabinet Instability in Central and Eastern Europe 


\section{Address by H.E. Dr. Vaira Vīkse-Freiberga, President of Latvia}

The third international conference organised by the Strategic Analysis Commission under the auspices of the President of Latvia and the University of Latvia's Advanced Social and Political Research Institute (ASPRI) is devoted to the timely theme of "uncertain transformations." The NATO summit that was held in Riga in November of 2006 dealt primarily with the Alliance's military transformation, which certainly will have to continue in order for us to strengthen our security. However, other transformations continue to affect all aspects of social, economic, cultural, and political life at the local, national, regional and international levels.

Demographic trends in Europe over the last decade have contributed to feelings of insecurity and created difficult policy dilemmas pertaining to social welfare, immigration and other areas. Technological change continues to outpace our ability to reform our institutions. The growing importance of knowledge and information in economic development underlines the importance of education and human capital. Transformations are often accelerated by external pressures. Latvia is undergoing deep changes as a result of accession to the European Union and NATO. At the same time, these organisations themselves are in a state of flux. The future of deeper integration among the EU's member States is uncertain, as is the degree to which we will be able to forge a common European foreign policy towards the EU's candidate countries, neighbours, strategic partners and other geographically more distant nations. The ability of NATO to transform itself into a more active global player and to meet new threats, such as those pertaining to energy security, were also on the agenda at the NATO summit in Riga.

Since the outcome of all these transformations is uncertain, the insecurity, fear and anxiety that many people feel is understandable. On the other hand, these transformations present us with new opportunities to improve our institutions, organisations and modes of operation. In order to take advantage of these opportunities, we need to understand the processes of transformation themselves, their causes, possible consequences and implications. Here, we look to social scientists for assistance and analysis in the face of the difficult choices that confront us. As President of the Republic of Latvia, I have been honoured to support the social sciences in this country, and to promote international cooperation between our own researchers and our partners abroad. I wish you success in your important task!

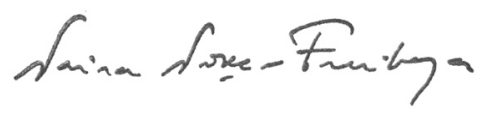





\section{Europe and Its Neighbours Facing New Challenges}





\title{
The Political Challenge of E.U. Enlargement: Democratic Conditionality, Its International Implications and Domestic Consequences ${ }^{1}$
}

\author{
Geoffrey Pridham \\ University of Bristol, UK
}

\section{INTRODUCTION: THE INTERSECTION BETWEEN TRANSFORMATIONS, INTERNAL AND EXTERNAL}

Transformations of a political kind are inherently uncertain, for this comes from the very nature of the exercise whereby existing structures are abandoned and replaced by new ones or existing structures are so challenged by new developments that their response involves a basic form of adaptation. The most obvious recent example of the former in Europe has been post-Communist regime change in Central and Eastern Europe (CEE), a process that is not yet complete with respect to democratic consolidation in the EU-8 (soon to be the EU-10) and certainly not if we include further such regime change in former Soviet republics. The early stages of regime change - especially its transition phase - are normally marked by uncertainty about the direction it might take at least until the choice of regime type and then its constitutional settlement are clear. That provides a direction to regime change; and, thereafter uncertainty about the eventual outcome (as distinct from its direction) should gradually diminish - this process being called regime consolidation. Of course, in practice, uncertainty may continue to prevail in the short-term context; but the question then is whether the challenges in question are basic or secondary or even marginal.

The transformation of existing structures comes about when their role, their functioning and perhaps even their purpose are challenged. This often occurs when the settled pattern of their operation is no longer feasible because outside developments and internal pressures require a new formula and modus operandi. Existing structures may obviously include international ones when they enjoy recognised political weight and their actions possess a capacity for producing change. The most obvious example of this in Europe is the European Union, whose policy impact has expanded over time, whose institutions and decision-making increasingly deserves the description of "EU political system" (albeit not one similar to systems in member states), but whose operation is under a greater challenge than ever before. European integration has faced basic crises before, such as in the mid-1960s and early 
mid-1990s; but the combined challenge - external from continuing enlargement, internal from the crisis over the proposed Constitution - has a transformative potential with possible negative as well as positive aspects.

Clearly, this combined challenge is a new and rather discomforting version of the long-standing debate about the "widening" and the "deepening" of the EU. Strong differences here have sometimes emerged, ranging between the two positions as to whether "widening" and "deepening" are compatible or not - viewpoints that have invariably been overlaid by political causes. Furthermore, this dual challenge to the EU has also interrelated with post-Communist regime change, mentioned above. The direct link comes from the EU requirement that candidate countries should have "achieved stability of institutions guaranteeing democracy, the rule of law, human rights and respect for and protection of minorities", according to the original Copenhagen political conditions of 1993 which were subsequently elaborated during the EU accession process that led to the mega-enlargement in 2004. Crucial stages in that process have been determined, among other things, by the continuing satisfaction of the EU's political conditions in order to proceed with membership negotiations, but also notably to secure the successful conclusion of those negotiations and move ahead into the EU.

Democratic conditionality thus plays a central part at the intersection between post-Communist regime change, enlargement but also now - and somewhat controversially - the EU's own difficulties over "deepening". The last link comes from the way these difficulties are projected onto further enlargement prospects, with political conditions of one kind or other being presented as a problem in this or that applicant country. Accordingly, democratic conditionality's act has been itself raised as a factor in all these developments; while, at the same time, its operation has become rather more complicated precisely because of this intersection. This paper explores this changing situation by comparing democratic conditionality during the 2004 enlargement process and since then with respect to further enlargement. The discussion is constructed around a three-dimensional analysis, based on three relationships involving this conditionality: with post-Communist democratisation; with enlargement; and, with the EU itself.

\section{MANAGING POLITICAL CONVERGENCE}

Writ large, democratic conditionality may be viewed as the EU's most active form of promoting political convergence between its pre-existing and enlarged entities - a process of change that officially has to be accomplished prior to accession; but in reality is achieved only imperfectly - as seen in the case of the 2004 enlargement, notwithstanding the plaudits accorded that process usually by Brussels circles. In general, political convergence may be seen as gradual movement in system conformity based on a grouping of established democratic states that has the power and institutional mechanisms to attract transiting countries and to help secure their democratic outcomes.

Viewed in policy terms, the EU's political conditionality has much expanded its scope in the context of post-Communist democratisation since 1989. During the 1990s, it moved well beyond the (somewhat bland) formal democracy criteria 
utilised in previous decades into areas of substantive democracy. The Copenhagen criteria as defined in 1993 covered the stability of democratic institutions, the rule of law and human and minority rights. These criteria reflected trends in the growing interest of conditionality in the post-Cold War world, such as a priority to minorities and a new attention by the EU to human rights. But, rather importantly, they were also introduced to reassure some member states that in going ahead with enlargement the EU's deepening process would not be endangered. That constituted a first reference to the problem of the EU's absorption capacity which has now recently acquired a central place in EU discussions about enlargement. ${ }^{2}$ Since then, the EU has also specified in its political conditionality the strengthening of state capacity, the independence of judiciaries, the pursuit of anti-corruption measures and the elaboration of a series of particular human and minority rights. It has also highlighted the severe condition of the Roma and introduced economic, social and cultural rights such as relating to trafficking in women and children, gender equality and prison conditions. These additions were made during the years from 1997 once the accession process started to move and the first set of negotiations commenced in early 1998.

Crucial to the operation of the EU's conditionality has been the leverage exercised by the EU over applicant and candidate countries. Dependent on their determination to accede to the EU, Brussels has been able to impose its political conditions and thus take advantage of the enlargement escalator. Unlike in the previous case of new democracies - those from Southern Europe - joining the then EEC, the EU's predecessor organisation, the conditions have to be satisfied prior to becoming a member state. Violations of the conditions may lead to membership negotiations being suspended, although with the enlargement process the procedure for this was cumbersome and in any case was never properly used (although some threats were made towards one or two then candidate countries, most seriously Romania). ${ }^{3}$ In this way, the satisfaction of the political conditions became locked into the accession process and so acquired momentum and force. Their impact was strengthened by various programmes of assistance, notably the Phare Democracy Programme; and, procedurally, by the intensive monitoring of the conditions by the European Commission on an annual basis.

However, the EU does not enjoy a straightforward power of leverage. It is, as noted, strongly influenced by the dynamics of accession; and, ultimately, it depends on an assumed trade-off between the satisfaction of conditionality and the promise of eventual EU membership. Any serious problems in this interactive dynamic can help to undermine the whole process. While the 2004 enlargement to East-Central Europe more or less preserved these dynamics, developments over further enlargement since then have begun to call into question whether they can be maintained, with possibly damaging consequences not only for enlargement, but also for the EU itself and even the chances of still new democracies in the Western Balkans and elsewhere for consolidating themselves.

In other words, the very future of political convergence appears to be at stake. The nature of the problem therefore requires a broad-range analysis. This emerging and challenging situation is examined using a three-dimensional framework. It is approached by discussing three relationships: between democratic conditionality and 
post-Communist democratisation (the diachronic dimension); between democratic conditionality and EU enlargement (the "widening" dimension); and, between democratic conditionality and developments within the EU itself (the "deepening" dimension). In all three relationships, comparisons will be drawn between the 2004 enlargement process and moves towards further enlargement since 2004 in order to highlight similarities and differences. Conclusions will be drawn about possible or likely future developments.

\section{DEMOCRATIC CONDITIONALITY AND POST-COMMUNIST DEMOCRATISATION}

The relationship between conditionality and post-Communist democratisation is basically about a potentially reinforcing process so far as the latter is concerned. Candidate countries from CEE have sought as new democracies to join "Europe" and its prosperous liberal democracies and, to that end, are willing to submit themselves to the EU's wide-ranging conditionality albeit under some compulsion. At the same time, the one (EU conditionality) is not tantamount to the other (democratisation), for this relationship also highlights differences between them, as underlined by the limitations of timing and scope placed on the EU's conditionality.

The temporal limitation refers to the EU's political conditions as developed in the 1990s, for these did not embrace first-order democratisation or systemic concerns such as constitution-making or problems of the state or preferred versions of liberal democracy. To put it another way, conditionality did not address democratic transition; rather, it was in effect concerned with furthering democratic consolidation (a term used quite freely in the Commission's progress reports on accession countries). The original Copenhagen political conditions, presented in 1993, spoke of the need to achieve "stability of institutions guaranteeing democracy, the rule of law, human rights and respect for and protection of minorities"; but they did not specify what form of democratic institutions they should be. By the time this conditionality came into operation, with the avis of 1997, it could be said that democratic transition in East-Central Europe was over - the obvious exception being Slovakia, which, under Meciar, was the only country to be barred from an invitation to negotiate on political grounds.

The other limitation is in the EU conditionality's scope, reflecting on political constraints on the Commission despite its having acquired institutional ascendancy over conditionality policy with Eastern enlargement. ${ }^{4}$ Even though the scope of the political conditions has evolved since 1993, certain areas of political activity usually regarded as rather important in democratic life - have remained outside the range of conditionality, notably political parties and essentially civil society. This has followed the Commission's focus on the official or the institutional; but it also represents a political reluctance on the part of the Commission (as becomes clearer when comparing its progress reports with the more overtly political ones of the European Parliament (EP) that also monitor conditionality matters). The Commission's reluctance was demonstrated in an avoidance of political or institutional models, as for example over regionalisation; and, of course, this lack of prescriptiveness may be related to the Commission's cautious attitude to systemic 
questions. Furthermore, the Commission has been reluctant to engage with political conditions where the record of certain member states has not been exemplary, such as political control over the media in Italy, often mentioned as a blatant case in point.

The EU is now facing a further major enlargement to the Balkans although in mini-stages, beginning with Romania and Bulgaria in 2007, followed possibly by Croatia and then other countries of the Western Balkans (a geographical and now an official Commission term), which have in recent times moved visibly along the integration path under the Stabilisation and Association Programme. The controversial accession of Turkey would, if successfully concluded, count as an important Balkan addition. Further East there are former Soviet republics like Ukraine, Georgia and Moldova which, presently served by the European Neighbourhood Programme, have serious intentions of joining the EU. Except for the first three mentioned above (and possibly Turkey in some respects), these further accession possibilities all represent cases of nominal or formal democracies which, as of now, fall well short of the conditionality requirements of Brussels.

The relationship between conditionality and democratisation is thus different since 2004, as the latter in the Western Balkans is a rather more arduous process than before and one less assured of success because of severe legacy and systemic problems. That would suggest both more basic demands on conditionality (thus placing a real onus on its limitations), but also potentially more opportunities. It should be noted that in some respects the EU faces in the Western Balkans firstorder democratisation concerns, such as those relating to state-building, while having to confront problems of regional stability deriving from recent war, as well as difficulties of political consensus, ethnic harmony and socio-economic development far more taxing than those encountered in East-Central Europe at a similar stage a decade ago. In other words, conditionality has had to deal with some questions that relate more to democratic transition and not just democratic consolidation. This has had the effect of further expanding the conditionality agenda; but, it has at the same time made the reinforcing process of conditionality with respect to democratisation rather more difficult.

\section{DEMOCRATIC CONDITIONALITY AND THE ENLARGEMENT PROCESS}

The relationship between conditionality and enlargement is essentially a dynamic one, for the former has depended crucially on accession prospects and momentum. Without these factors, the motivation for compliance with conditionality would be decidedly less. In other words, the drive behind conditionality has been predominantly extrinsic, although some political elites in candidate countries have been intrinsically motivated to strengthen democratic values and procedures in their still new democracies through European means. Much therefore depends on movement in enlargement prospects, both in the period before the invitation to negotiate and in that of negotiations which follows, and on the increasing probability of success. In other words, EU leverage over these countries certainly exists during enlargement; but it is continuously dependent on the understood trade-off between compliance with conditionality and accession promise. 
The relationship between conditionality and enlargement since 2004 is obviously still a dynamic one, with the latter providing the motive power behind the former and the EU's leverage over candidate countries to comply with conditionality demands. But there are two qualifications: firstly, there is more of a vicious circle than before because of serious and in some ways fundamental democratic deficiencies not easily overcome in prospective accession states; and, secondly, the assumed trade-off in these dynamics - namely, the real prospect of EU membership as a result of persistent compliance with conditionality (and the acquis) - is now complicated by the EU having introduced new mechanisms to stop the accession escalator once negotiations start. As a consequence, eventual EU entry is no longer an increasing probability; and, this has cast some doubt over the EU's credibility with enlargement - which, in turn, may act to weaken the political will of further candidate states in pushing through conditionality. In short, the priority to conditionality has been maintained if not enhanced because the requirements have become even stricter; but at a possible price in terms of enlargement outcomes.

\section{DEMOCRATIC CONDITIONALITY AND THE EU POLITICAL SYSTEM}

The relationship between conditionality and the EU itself is relevant concerning institutional responsibility for enlargement matters. This is because conditionality and with it enlargement is a dependent variable in relation to the EU as a system and the integration process in general, as the discussion of "widening" in relation to "deepening" indicates. Major changes in conditionality's ambitions in the 1990s followed both integration's expanding agenda from the 1980s, as well as the changed international environment with the fall of Communism, to which the EU (then the EC) found it had to respond. But complications arose because of institutional diffusion in the EU system, with the European Council, the EP and sometimes even member states also involved, even though the Commission was accorded an unprecedented role over enlargement.

By and large, these complications were held in check during the 2004 enlargement process because of the momentum this achieved - due in particular to a convergence of enlargement ambitions between the Commission and the CEE countries in question - but also because of effective leadership from the Commission. ${ }^{5}$ However, since 2004 greater rivalry has emerged among institutions at the EU level and this has affected conditionality policy.

In this recent period, the relationship between conditionality and the EU itself has become noticeably different from before. While the Commission still officially drives the conditionality agenda and procedure, other EU institutions have claimed a more interventionist role, including the Council of Foreign Ministers and the European Parliament, but also individual member states. This is significant because it reflects a direct influence of "enlargement fatigue". But the effects have not been uniform, because, on the one hand, the EP and to some extent member states have pressed for a tougher approach to conditionality while, on the other, the Council has sometimes argued for moderating conditionality requirements. Their common impact has been to place new constraints on Enlargement Commissioner Rehn compared 
with his predecessor Verheugen's period in office. Thus, conditionality policy has become more difficult to operationalise; and, there have occasionally been tensions and even contradictions, notably between Rehn and the Council.

The crisis in the EU over the proposed Constitution arose only a few months after Rehn took office as Commissioner. It not only reinforced his more cautious approach to conditionality matters, but also created a rather less enlargement-friendly environment in the EU. Problems of public support for new integration projects had existed for some years, but the Constitution's rejection in the French and Dutch referenda in spring 2005 introduced a backlash against the pace of integration. While the actual importance of enlargement in motivating French and Dutch voters is debatable in terms of campaign issues, except for the case of Turkey in France, the outcome of the referenda released a feeling of "enlargement fatigue" drawing on the plausible argument that the EU should first absorb the biggest enlargement ever before moving on to further accession cases. It reflected the more pessimistic view of the 2004 enlargement and was mixed with a pattern of economic stagnation in the old member states, as well as divisive debates among the EU-25, such as over liberalising economic reforms as against social and trade protection. As Rehn himself remarked, "the enlargement blues could equally be called the unemployment blues, the globalisation blues or the welfare state blues". ${ }^{6}$

"Enlargement" became in effect a dirty word, as evident now in media treatment of the question. It brought forth statements during 2005-6 from some leading politicians, especially in France and Germany, calling for a slowing-down in accession business. It now became fashionable to voice cautious, if not implicitly hostile views over enlargement. The result was to make the Commission's work more complicated and at times it showed a defensiveness, such as in Rehn's statement that "rumours of the death of EU enlargement policy are evidently exaggerated".? Recently, President Barroso remarked after announcing the accession of Romania and Bulgaria for January 2007 that there would be no more accessions until the deadlock over institutional reform in the EU had been resolved - an example of putting "deepening" before "widening", but one made in response to hostile pressures from within the EU. ${ }^{8}$

One should add here that the broader range of conditionality, dealing with remaining legacies from the conflict in the Western Balkans - notably on the security front and on stateness questions - brought greater overlap between conditionality and EU foreign policy. Unlike enlargement policy, Brussels' foreign policy has adopted a more ambiguous approach to democracy promotion because of familiar rival concerns such as security, economic interests and strategic diplomacy. The Foreign Affairs Commissioner (Ferrero Waldner) was noticeably less enthusiastic about further enlargement from late 2004, in particular dampening Ukraine's expectations towards the EU after the Orange Revolution. Moreover, the EU's foreign policy had traditionally been more open to differences among the member states than enlargement policy. 


\section{CONCLUSION: LOOKING TO THE FUTURE}

Conditionality policy during 2004-6 may be summarised by saying that its scope has been extended to further issues like those of statehood, while the EU's leverage over candidate countries has been qualified by new doubts about EU credibility. However, the limitations on it have both weakened (in relation to the timing of democratisation), but also increased due to greater political restrictions on the Commission's role against a background of "enlargement fatigue". There have indeed been some important elements of continuity, for conditionality policy since 2004 has developed from that which evolved in the 1990s in response to prospective enlargement to East-Central Europe. However, there have also been important changes not least because this policy since 2004 has sought to differentiate if not distance itself from pre-2004 policy with a new Commission and in rather different, less favourable circumstances in the EU.

As a result, political conditionality has become more broad in its scope, much tighter in its procedures and less easy to control within a less enlargementfriendly environment in the EU and against less certainty about enlargement prospects. At the same time, the priority accorded conditionality has been upgraded, while its mechanisms have been much strengthened with a view to improving its implementation by candidate countries. However, the combination of greater institutional diffusion, stronger demands over conditionality together with high expectations from applicant countries and emerging counter-pressures against further enlargement have seriously compromised the push/pull dynamics that had worked fairly well during the 2004 enlargement process. As a result a potential vicious circle has entered the policy environment, although it remains to be seen how this actually works out with further enlargement.

The impact of "enlargement fatigue" represents a change of atmosphere in European integration which might in different circumstances change somewhat. A resolution of its main direct cause, the problem of the EU Constitution, would albeit difficult to achieve - probably alleviate "fatigue" pressure, particularly as it was originally intended among other things to respond to the institutional challenges of the 2004 enlargement. A clearer or more widespread awareness of the real achievements of the 2004 enlargement and its advantages might also counter the "fatigue" atmosphere. Furthermore, changes of power in some member states might influence the persistence of "enlargement fatigue"; but this scenario is difficult to predict.

Such musings lie somewhat in the realm of informed speculation. What meanwhile seems to be happening is that the dynamics affecting political convergence in European integration have changed qualitatively. In consequence, the relationship between "widening" and "deepening" - never in any case an easy one to manage, quite apart from the decision-making complexities of the EU system - has become more fragile. Furthermore, the prospects for securing democratisation in the Western Balkans and elsewhere might accordingly be dimmed. This is because the degree to which the post-Communist Balkan countries have depended on external support and assistance has been particularly strong. The underlying challenge posed by the Western Balkans, with its basic problems of state capacity, political consensus, ethnic 
harmony and socio-economic development - all of these affected adversely by the wars of the earlier 1990s - was summarised by the International Commission on the Balkans in 2005:

The consensus uniting governments and people in the Balkans is that the region cannot achieve prosperity and stability outside the process of European integration. At the same time, it is quite clear that the dysfunctional states and protectorates that characterise the region actively hinder the inclusion of the Balkans into the European mainstream. In this sense, the status quo is a problem because it is blocking the road to EU accession. $^{9}$

\section{BIBLIOGRAPHY}

Emerson, Michael (ed.), Democratization in the European Neighbourhood (Brussels: Centre for European Policy Studies, 2005)

Grabbe, Heather, The EU's Transformative Power: Europeanisation through Conditionality in Central and Eastern Europe (Basingstoke: Palgrave Macmillan, 2006)

Kubicek, Paul (ed.), The European Union and Democratization (London: Routledge, 2003)

O'Brennan, John, The Eastern Enlargement of the European Union (London: Routledge, 2006)

Pridham, Geoffrey, Designing Democracy: EU Enlargement and Regime Change in PostCommunist Europe (Basingstoke: Palgrave Macmillan, 2005)

Schimmelfennig, Frank and Sedelmeier, Ulrich (eds.), The Politics of European Union Enlargement: Theoretical Approaches (London: Routledge, 2005)

Vachudova, Milada, Europe Undivided: Democracy, Leverage and Integration after Communism (Oxford: Oxford University Press, 2005)

\section{ENDNOTES}

1 This paper provides a distillation of project work for a Fellowship from the UK Economic \& Social Research Council for 2004-07, looking at Europeanising Democratisation?: EU Accession and Post-Communist Politics in Slovakia, Latvia and Romania. The primary source has been elite interviews in these three countries and in Brussels. Categories of interview respondents have included government ministers, ministerial advisers and senior civil servants; chairs or members of European and also Foreign Relations committees in parliaments; party leaders and international secretaries of political parties; heads and members of EU delegations in accession countries; NGO leaders; colleagues in policy institutes; and, journalists working on EU affairs. In addition, this project work has utilised much internet and also some press material as well as official documentation of both European and national levels.

2 http://www.euractiv, 10 October 2006.

3 G. Pridham, "EU enlargement and consolidating democracy in post-Communist states: formality and reality," Journal of Common Market Studies, December 2002, vol. 40, no. 5 , p. 958.

4 John O'Brennan, The Eastern Enlargement of the European Union (London: Routledge, 2006), chapter 6.

5 Ibid, pp. 81-83.

6 Olli Rehn, speech 19 May 2006, European Commission 06/316. 
7 http://www.euractiv, 29 June 2005.

$8 \mathrm{http} / / /$ www.euractiv, 9 November 2006.

9 International Commission on the Balkans, The Balkans in Europe's Future (Sofia: Centre for Liberal Strategies, 2005), p. 12. 


\title{
Punching above your Weight? The Baltic States as 'Small States' and the European Neighbourhood Policy ${ }^{1}$
}

\author{
David J. Galbreath and Jeremy W. Lamoreaux \\ Department of Politics and International Relations \\ University of Aberdeen
}

Whether by population, territory or economic impact, Estonia, Latvia and Lithuania are small states. In 1944, smallness meant forceful inclusion into the Soviet Union. From 1991, the Baltic States sat between two geo-political spaces: one Russian and one European. After years of occupation, the Baltic States were keen to overcome their size and the dangers that are inherent in being small. Thus, in 2004 Estonia, Latvia and Lithuania became part of Europe and the 'West'. Membership of the European Union and North Atlantic Treaty Organization provides opportunities and creates constraints, yet also allows the Baltic States to play geopolitical gamesmanship in the post-Soviet area vis-à-vis the Russian Federation. The EU's European Neighbourhood Policy (ENP) is an attempt by Brussels and its memberstates to project into what was once considered Russia's 'Near Abroad'. Thus, the Baltic States have much to gain from the EU's focus on the East.

The Baltic States provide a unique area for the study of foreign and security policies. While it is true that the foreign and security issues in this region are not entirely relevant to many actors across the globe, the region is unique primarily because of its geopolitical location and the challenges that inherently come therewith. The three Baltic States are a border between the West and the 'new outsiders'.' It is the geographical point where Nordic, Baltic, Central European, and Russian 'cultures' meet. The Baltic sub-region includes states of various size (ranging from Denmark to Russia) and ideologies (from authoritarian Belarus to democracy which is solidly embedded in the Nordic States), and plays an important role in the foreign and security policies of these states. More importantly, it is the point where the current embodiments of the EU and NATO end, and meet with potential partner or competitor, Russia.

In this paper, we engage with two explicit questions. Firstly, what is the Baltic States' perspective on the ENP and how can they use it to their own benefit? Secondly, what is the logic behind the Baltic approach to the 'Neighbourhood' and how does this differ from the approach of either Brussels or Moscow? We also engage with two implicit questions. Can we look at the Baltic States as similar actors and discuss a 'Baltic logic' of the 'Neighbourhood'? Finally, what does the Baltic 
States' focus on the ENP say about the ability of the three states to influence EU Common Foreign and Security Policy (CFSP)? In order to answer these questions, we first take a look at approaches to small state foreign policy before moving on to discuss Baltic foreign policy after the dual enlargement. Next, we look at the specific relationship between the Baltic States and the ENP. Overall, our goal is to illustrate how international organisations, in our case the EU and to a lesser extent NATO, influence the notion of size.

\section{SMALLNESS AND INTERNATIONAL RELATIONS}

Reflecting on the notion of state size, we consider how small states behave in the international system. We engage with three frameworks that suggest small state capabilities: David Vital's small state theory, Stephen Walt's analysis of alliances, and Regional Security Complex Theory (RSCT) relying on Buzan and Wæver. By engaging with these frameworks, we can then consider the ability of small states to impact the agenda of international organisations.

Vital's small state theory is heavily based on realist theory, which holds that the international system is anarchic, states are the central actors within that anarchy, and states are egoistic and rational. ${ }^{3}$ The primary goal of every state is to retain sovereignty and the means for doing that is by obtaining power, primarily military power. ${ }^{4}$ These characteristics hold true for large and small states alike. Small states, however, regardless of how one interprets 'smallness', have very few resources available to help secure their sovereignty, and thus very few options available relative to their attempt to remain sovereign. ${ }^{5}$ The sole way for small states to remain entirely sovereign is to remain neutral and hope that no other, larger state develops malicious designs toward the small state. ${ }^{6}$ If any challenge to their sovereignty arises (as is bound to happen in an anarchic system), they are forced either to contend on their own and face the very real possibility of losing their sovereignty entirely, or ally with a larger state in some manner and by so doing retain the majority of their sovereignty, but lose a portion of it to that larger state. Thus, according to Vital's theory, the only real way for a small state to retain some degree of sovereignty is to ally with a larger power. ${ }^{7}$

Developing this concept one step further, Walt argues that states have only two options when forming an alliance: balance or bandwagon. ${ }^{8}$ Balancing refers to joining the weaker side of a conflict to prevent the other (stronger) side from dominating the international system. This practice is often engaged by large/powerful states in an attempt to prevent a potential rival from becoming too powerful. Bandwagoning refers to joining the stronger side of a potential conflict/rivalry with the assumption that one has chosen the 'winning side'. According to Walt, 'the weaker the state, the more likely it is to bandwagon'. ${ }^{9}$ This is so, he argues, because small/weak states very rarely influence the outcome of a conflict, but can still incur the wrath of larger states if they are on the losing side. Consequently, it is in their best interest to choose the winning side in the first instance. ${ }^{10}$

However, what explanatory power do these traditional realist arguments have in explaining international politics within the EU? If Europe has moved past an anarchic order, what is the value added in examining the Baltic States (as EU 
member-states) with the realist paradigm? While the Baltic States are indeed part of the EU, NATO, and other organisations, they still perceive one of the greatest threats to their national security (military, economic, societal) as coming from Russia. Thus, Baltic perceptions of Russia are still based on realist assumptions. Baltic foreign policies are still based on a zero-sum, power politics view of regional geopolitics.

According to RSCT, security in any geographical location on the globe can be studied in any or all of four specific contexts: security within the state; security between states (most often within 'complexes'); security between complexes; and security on the global level. ${ }^{11}$ Buzan and Wæver focus on the regional level primarily because "most threats travel more easily over short distances than over long ones', and thus 'security interdependence is normally patterned into regionally based clusters: security complexes'. ${ }^{12}$ Regional security complexes (RSCs) are "a set of units (generally states) whose major processes of securitisation, desecuritisation, or both are so interlinked that their security problems cannot reasonably be analysed or resolved apart from one another". ${ }^{13}$ According to Buzan and Wæver there exist several regional complexes across the globe as well as supercomplexes, protocomplexes, subcomplexes, insulators, buffers, great and super powers, all of which play integral parts in the international system of security. There are, however, several characteristics that differentiate complexes from the remainder of these units and highlight their importance in our study. First, RSCs are socially constructed. ${ }^{14}$ Security threats stem from the interaction that decision makers within states have with each other. It stands to reason that such interaction is what leads to security issues. It also stands to reason that states in close geographical proximity to one another are more likely to interact than states at a great distance from each other, a point which specifically distinguishes one complex from another and which leads to the second and third characteristics: RSCs are mutually exclusive and (despite being mutually exclusive) they are anarchical within. ${ }^{15}$

Mutual exclusion does not imply that there is no interaction across complex boundaries. Indeed, sovereign actors are mutually exclusive, but in many cases they have very extensive interaction. Such is the case with RSCs. As long as the natures of the international and regional systems are anarchic, there will be interaction between independent actors. Anarchical interaction often leads to disharmony, which spawns the securitisation and desecuritisation of certain issues as well as balancing and bandwagoning. Within anarchy actors often turn to alliances as a means of securing against a perceived threat. Despite the mutual exclusion of the individual complexes, states will naturally not limit their alliances to those states within their region. Buzan and Wæver address this when they outline two specific interaction concepts relevant to RSCs: penetration and overlay. Penetration occurs when states from outside a certain RSC make alliances with states within that RSC. ${ }^{16}$ In this way, RSCs are linked together, but still remain exclusive. Overlay, on the other hand, is a situation where an RSC cannot form. It is when two great powers are so interested in an area that a local pattern of security ceases to exist: the entire pattern of security is dominated by two great powers. ${ }^{17}$

The fourth and final characteristic is that RSCs and the remainder of the security entities listed above can exist simultaneously, which is a vital aspect of our paper, specifically regarding entities such as subcomplexes, great powers, superpowers 
and insulator states. These aspects are vital because of the nature of the Baltic Sea Region. According to Knudsen, the Baltic Sea Region forms a security subcomplex, which includes not only two mutually exclusive RSCs (European and Post-Soviet), but it also includes influence from a superpower in the form of US-led NATO. ${ }^{18}$ Additionally, Buzan and Wæver consider the Baltic States to be insulator states between the European RSC and the Post-Soviet RSC. ${ }^{19}$ Although they are members of NATO and the EU, their largest perceived threat still arises from Russia and there still exists a possibility that the Baltic States could play the role of a 'bastion', preventing the spread of issues from the Post-Soviet RSC into the European RSC. ${ }^{20}$

From what we have seen thus far, what should we expect of small states? According to small state theory, we should see small states attempting to form alliances as means of protection against perceptions of threat. Additionally, they should attempt to align with the largest, 'most likely to win' entity. According to RSCT, their primary perceived threat ought to come from an entity geographically close to them, but their alliance need not be limited to other entities within their RSC. Once small states have allied with a stronger entity, they are rarely considered influential actors: they are just there for the ride. However, membership within institutionalised regional structures such as organisations means small states have the potential to impact the organisation's agenda. This agenda-sitting power alters the action capacity of the small states. While it seems logical that small states on their own are limited as to what actions they can take, it also seems logical that as a member of an organisation, their capacity to act increases. In the next section we illustrate that the action capacity of the Baltic States has increased within the postSoviet sphere because of their membership within regional organisations.

\section{BALTIC FOREIGN POLICY AFTER ENLARGEMENT}

As can be imagined, Baltic foreign policy objectives were primarily aimed westward in the period between independence and the dual enlargement. While relations with Russia demanded a great deal of attention, relations with other postSoviet states were understandably less active. However, following enlargement, the Baltic States now find themselves with dynamic economies, stable governments and peaceful, although not necessarily harmonious, inter-ethnic relations. As mentioned earlier, all three governments released new foreign policy documents that outlined the agendas of the post-enlargement era. Estonia set out its agenda within the EU in The Estonian Government's European Union Policy for 2004-2006 approved in April 2004 just prior to accession. In the section entitled, 'The European Union and its neighbours: expanding security and prosperity', the Estonian Government lays out its agenda for the EU's 'new outsiders'. Firstly, the document identifies two EU policies towards the region through which to work: the ENP and the NDI. Referring to the ENP specifically, the Estonian Government uses a broad approach to security with the mention of projects to engage,

- Environmental issues,

- Nuclear safety,

- Organised crime, 
- Health security,

- Societal security.

Furthermore, the document ties security in the region directly to democratisation in 'Ukraine, Moldova, Byelorussia, Georgia and other Southern Caucasian states'. While the link between democratisation and security remains a major foreign policy theme, this link has been debated in the academic literature. ${ }^{21}$ Furthermore, the document illustrates the eclipse of the NDI by the ENP as the method by which the EU should engage with the Eastern neighbours of the EU. In addition to the concentration on security in the larger region, the Estonian Government stresses the need for common values between the EU and Russia specifically. This is firmly separate from the discussion of the ENP and instead relates to Russia's acceptance of Estonia as a part of the EU.

Estonian focus on the East has also been formalised in the Estonian Government's 'Aims of the Estonian Government during the UK Presidency'. Under the section entitled 'Foreign and security policy', the document further reiterates Estonia's commitment to Eastern engagement in four sub-sections. First, again the Estonian government focuses on the EU's relationship with Russia but largely in the context of the Common Spaces agreement. ${ }^{22}$ From the perspective of Estonia, the relationship with Russia is partly governed by insecurities in the Baltic Sea region, including environmental concerns, but also by an economic dimension. In such a timely document, we can see specifically that Tallinn is concerned with Estonian investments in Russia as well as the abolition of rail tariffs on the Russian side of the rail network. Second, the document again stresses the need for a neighbourhood strategy in the region. As part of the ENP, the Estonian government focuses on strengthening civil society in areas of regional instability: Belarus, Transdniester, South Ossetia and Abkhazia. Third, seen separately is the potential for EU enlargement with the accession of Turkey and the Western Balkans. At least in terms of this short-term document, we see that there is clear distinction between those states that are potential EU member-states and those that fit within a larger EU foreign policy. Finally, again the Estonian foreign policy document highlights the security dimension of the region stressing the implementation of the European Security Strategy. Specifically, the Estonian government focuses its potential role in various missions in the EU's eastern neighbourhood under the ESDP. Overall, while we do see a general regard for events in the Middle East, Estonian foreign policy is firmly focused eastward.

The Latvian strategy has been as formalised but is far less specific. First in 2004 and then updated in 2005, the Latvian Government set out its foreign policy objectives in a document entitled The Latvian Foreign Policy Direction Project 2005-2010. ${ }^{23}$ As stated above, much of the document is centred around Latvia's role in the EU and NATO following enlargement. In other words, the focus is the continued integration process that membership demands. However, in the section entitled 'Latvian Foreign Policy in the Baltic Sea Region and the European Eastern Neighbourhood Political Region', the Latvian Government establishes a focus on the EU's eastern neighbours. The document states that Latvia has a role to play in six issue-areas, including:

- Economic relations,

- Market reform, 
- Customs,

- Regional security,

- Illegal migration, and

- Organised crime.

In the document, the Latvian Government stresses the need for the same dual transition in the Western NIS that the Baltic States themselves had to go through in order to integrate into Europe. The third transition of de-Sovietisation is implied but not stated outright. Again, we see a direct link between security and democratisation in the region. Placed within the context of the larger document, by and large the focus on the EU's eastern neighbourhood is limited. Needless to say, when we come to see policy put into practice, we will see that Latvia's commitment to helping other former Soviet republics make the quadruple transition is as real as in any other Baltic state.

Lithuania's foreign policy objectives in the NIS are illustrated by three government documents following enlargement. Firstly, the Resolution on Directions in Foreign Policy passed by the Lithuanian Parliament (Seimas) in May 2004 is a timely response redirecting Lithuanian foreign policy following dual enlargement. The resolution declares to seek "to continue expanding the zone of security and stability in Europe and its neighbourhood." This expansion is to be done under the auspices of the EU and NATO. Furthermore, the resolution expresses the desire to "promote the policy of solidarity, confidence and transparency, to advance democratic values, to continue cooperation with the countries lying off the eastern border of the European Union, aiming at their rapprochement with the European Union, and to draw the three Transcaucasian republics - Armenia, Azerbaijan and Georgia into the European Union initiative of neighbourliness." Following this, the resolution argues for the continued support of the 'open door' policy for entry of the EU and NATO for those countries in the western NIS. Here we see the first explicit statement supporting future membership as leverage for reform in the region. Overall, the resolution is interesting because it illustrates the sudden change in direction of Lithuania's (and the Baltic States') foreign policy objectives.

Secondly, the 'foreign policy chapter' of the Programme of the Government of the Republic of Lithuania for 2004-2008 gives us some insight into the Lithuanian Government's focus on the EU's eastern neighbourhood. Like Estonia and Latvia, the Lithuanian Government stresses the link between democracy and security in the NIS. In this regard, the Lithuanian document goes a step further by encouraging an 'open door policy' of EU and NATO enlargement for states in the East. ${ }^{24}$ In other words, the Lithuanian Government states outright what the other two states leave implicit. However, the Estonian and Latvian Governments have both stressed their role in encouraging further membership for countries in the east. The Programme further aims 'to establish Lithuania as an expert of the European Neighbourhood Policy.' No doubt Lithuania's role as an 'expert' of the ENP is an attempt to establish the Baltic state as a director of EU foreign policy towards the eastern neighbourhood. Furthermore, as the most southern Baltic state, Lithuania is in a key geostrategic location to maintain the EU's interest in the western NIS.

Finally, the Agreement between Political Parties of the Republic of Lithuania on the Main Foreign Policy Goals and Objectives for 2004-2008 sets out a political 
consensus for the country's foreign policy goals. The agreement stressed regional cooperation in general with a specific focus on supporting "democratic processes in Ukraine, Belarus, Moldova, the countries of the South Caucasus and the Russian Federation, in particular the Kaliningrad region." 25 The agreement goes further to support those countries that are trying to integrate into the Western institutions. It is this support that we turn to now. All three states have shown a greater focus on the East at least in policies established around the time of enlargement. The question now is to what extent have these states turned policy into practice?

\section{THE BALTIC STATES AND THE ENP}

Ministry press releases and media reports on foreign policy focus largely on the following states: Moldova, Georgia and Ukraine as well as to a lesser extent on Belarus, Armenia and Azerbaijan. It is important to note that the Central Asia states sit firmly outside the Baltic States' and likewise the EU's perception of the European 'neighbourhood'. Moldova, Georgia and Ukraine are considerably more important for the EU and Baltic States because of changes mentioned earlier in Ukraine and Georgia as well as the ongoing reform in Moldova despite the stalemate in the Transdniester region. Regarding Armenia and Azerbaijan, the three Baltic governments were keen to have the southern Caucasus included in the ENP. All of the states mentioned have their problems in overcoming the triple transition. However, Belarus is by far the most sensitive. In July and August of 2005, the Belarussian government perceived that it was coming under greater pressure from the 'West'. According to the Russian media source RIA Novosti, the Belarussian foreign ministry said on 3 August that "the unilateral and politicised approach of evaluating the situation in Belarus confirms [the "West's"] aim to change the independent course of the Belarussian state." ${ }^{26}$ This statement followed increased tensions between Belarus and Poland that on the surface were about the Polish minority in Belarus and led to the expulsion of three Polish diplomats in two months, including the charge d'affaires. Furthermore, Minsk's close relationship with Moscow makes it a particularly prickly part of the 'neighbourhood'. ${ }^{27}$ Nevertheless, for this very reason, Belarus is an important part of the Baltic States' foreign policy to play the 'neighbourhood' off against the "near abroad'.

Looking across the three Baltic States, we can see that two states receive the majority of Baltic attention: Moldova and Georgia. The focus on Moldova has been most intense by Latvia. In the Latvian foreign ministries 'Development Cooperation Plan' for 2005, Riga gives Moldova priority over other states. ${ }^{28}$ On the one hand, Latvian projects in Moldova have supported ensuring EU borders by focusing on 'state border security, border guarding and control, as well as surveillance of foreigners.' In August 2005, Moldovan border guards visited Latvia for observation and to further cooperation agreements between the two states' border services. ${ }^{29}$ Furthermore, the Latvian government is currently supporting two programmes associated with Moldovan customs. They include establishing a service of customs brokers and burden-sharing responsibilities between border guard services. On the other hand, the Latvian government is supporting projects that prepare Moldova for European integration. These include developing a model of coordination between 
the two states for European integration, encouraging further trade liberalisation and reforms of the penitentiary system and institutions. Latvia's support for Moldovan inclusion into the EU and NATO was illustrated in the speech given by the two states' presidents on 26 September 2005. ${ }^{30}$ Latvian President Vaira Viķe-Freiberga stated that Latvia was ready to help Moldova into 'Euro-Atlantic' institutions, while the Moldovan President Vladimir Voronin stressed the importance of Latvia's help on the road to European integration. While a diplomatic press conference between two heads of state would ordinarily not be particularly illuminating, the general theme is particularly important for this analysis. Both presidents stated that Latvia was key for Moldova's future because it served as an example of how to make way through the triple transition to European integration.

The relationship between Moldova and the other two Baltic States has also been significant. In September and November 2005, the Lithuanian government held several meetings with Moldovan officials to discuss issues of European integration. In particular, according to a Lithuanian foreign ministry press release, "much attention was paid to the development of Moldova's relations with the European Union and possibilities provided by the [ENP]." ${ }^{31}$ While the nature of much of the bilateral relationships is characterised by practical matters, such as establishing diplomatic missions in the two countries, there has been a reiteration of Moldova as a future EU and NATO member despite its problems in Transdniester. Estonia has focused on two particular areas in Moldova: public service delivery as well as European integration. In 2004, the Estonian foreign ministry established a training programme in Moldova and five other South East European states for the use of information and communication technology in the public sector. ${ }^{32}$ Regarding integration, like the Lithuanian Government the Estonian Government also established a project in 2004 to support the Department of European Integration in the Moldovan Foreign Ministry. In 2005, the Estonian government provided scholarships for Moldovan junior civil servants in the foreign ministry in order to support studies in the field of European integration and international relations. ${ }^{33}$ The scholarships were provided by the Estonian School of Diplomacy. Finally, Estonia has begun a project to assist Moldova in harmonising policy with EU legislation. For the Baltic States, and Latvia in particular, harmonisation was (and still is in some cases) a burdensome part of European integration. In the case of Baltic-Moldovan bilateral relations, we see that Chisinau's path to European integration is a strategic priority for the Baltic States. This focus is further reiterated when we look at other states.

In February 2005, the Baltic States came together with Bulgaria, Poland and Romania to form 'Georgia's New Group of Friends'. The purpose was to concentrate on the changing nature of politics in Georgia following the Rose Revolution. The group's focus has been to promote 'Georgian-EU relations, Georgian-NATO dialogue, and cooperation in the Baltic and the Black Sea regions. ${ }^{34}$ The group's meetings in Tbilisi and Bucharest illustrate the multilateral approach of the Baltic States and others to the European integration project in the Western NIS. Interestingly, multilateralism to this degree has been formalised primarily in relation to Georgia over other states. Needless to say, Baltic-Georgian bilateral relations are also quite strong, especially Tallinn's relations with Tbilisi. Estonia's relationship with Tbilisi is similar to that of Latvia to Moldova. In 2004, the Estonian foreign ministry 
established a plethora of projects involving diplomatic corps training, public service delivery, the environment and the development of non-governmental organisations. Several of these projects where continued in 2005 as well. The development assistance from Estonia is characterised by a great deal of inter-institutional cooperation. For example, for development in Georgia in 2005, the Estonian foreign ministry worked with several other organisations including the ministry of education and research, the Estonian Parliament (Riigikogu), and the Estonian E-governance Academy.

Ukrainian relations with the Baltic States were altered after the Orange Revolution brought a change in politics and intentions towards the west in Kiev. Therefore, we should expect that relations with Ukraine became more developed in 2005. A review of the development projects and coordination programmes with Ukraine among Estonia, Latvia and Lithuania shows this to be the case. ${ }^{35}$ The Estonian foreign ministry has established similar projects with Ukraine as it has in Moldova and Georgia. These projects include training for Ukrainian diplomats, local government officials and the Ukrainian Chamber of Commerce. Latvia's role in helping Ukraine towards European integration has been as a 'cheer leader' in Brussels and the region. When the crisis arose that led to the Orange Revolution, Latvian foreign minister Artis Pabriks criticised the EU for being too cautious in its support for Ukraine. ${ }^{36}$ Shortly after the Yushchenko inauguration, the Latvian president argued for a strengthened relationship between Latvia and Ukraine. Yushchenko for his part highlighted Latvia's experience in European integration as a model. ${ }^{37}$ In February 2005, the Latvian President went even further by calling for Ukraine to become a NATO member-state at the NATO-Ukraine summit in Brussels. ${ }^{38}$ Finally, Lithuania's relationship with Ukraine has been one of a trilateral relationship including Poland. The three countries have begun discussions for the establishment of a trilateral Lithuanian, Polish and Ukrainian Parliamentary Assembly. ${ }^{39}$ No doubt the value added will be more difficult to see in the Baltic-Ukrainian relationship as opposed to smaller states like Moldova or Georgia. Nevertheless, the Baltic governments know that winning over Ukraine means a new dynamic in the post-Soviet region. Overall, the European Neighbourhood Policy is an instrument to integrate Moldova, Georgia and Ukraine into the European sphere of influence.

\section{CONCLUSION}

The objective of this paper has been to illustrate the Baltic States' use of the ENP as an instrument by which to change the power dynamics in the western NIS. The paper illustrated how the Baltic States have changed their foreign policy objectives after over a decade of concentration on EU and NATO accession. We have also seen how with enlargement, the EU in particular has set out on a new course to establish a stable region both in the East and South through the ENP. With the political changes in Georgia and Ukraine as well as a consistently stable Moldova, the EU's own foreign policy towards the region has changed. With this change, the Baltic States have attempted to maximise their influence in the European organisations to offer assistance and cooperation to these states in particular. While the Baltic governments are keen to see changes in Belarus, Armenia and Azerbaijan, their attention has been 
primarily on Moldova, Georgia and Ukraine. Several questions remain unanswered: How far is the EU willing to go to integrate these states into the European project? Does this mean membership or rather cooperation on the scale of alternative associated membership? Finally, will the Baltic foreign policy strategy towards what at least used to be known as Russia's 'near abroad' be enough to change the nature of the political dynamics in the post-Soviet region? While we can make estimated guesses, only time will offer the real answers.

\section{BIBLIOGRAPHY}

Burant, Stephen R. 1993. International Relations in a Regional Context: Poland and Its Eastern Neighbours - Lithuania, Belarus, Ukraine. Europe-Asia Studies 45 (3):395-418.

Burant, Stephen R. 1995. Foreign Policy and National Identity: A Comparison of Ukraine and Belarus. Europe-Asia Studies 47 (7):1125-1144.

Buzan, Barry, and Ole Waever. 2003. Regions and Powers: The Structure of International Security. Cambridge: Cambridge University Press.

Galbreath, David J. 2004. Democratisation and Inter-State War: Why Reform does not Encourage Conflict. Politics 24 (3):212-220.

Galbreath, David J. 2004 'Kurp talak? Recenzija par Latvijas arpolitikas pamatvirzienu projektu (iepriekšējo projektu)' May, Politika.lv.

Galbreath, David J., and Jeremy W. Lamoreaux. 2007. Bastion, Beacon or Bridge? Conceptualising the Baltic logic of the EU's Neighbourhood. Geopolitics 12 (1):1-24.

Knudsen, Olav F. 1999. Stability and Security in the Baltic Sea Region. London: Frank Cass.

Kolodziej, E. A. 2005. Security and International Relations Cambridge University Press.

Mansfield, Edward D., and Jack Snyder. 1995. Democratization and the Danger of War. International Security 20 (1):5-38.

Tsygankov, Andrei P. 2000. Defining state interests after empire: national identity, domestic structures and foreign trade policies of Latvia and Belarus. Review of International Political Economy 7 (1):101-137.

Vital, David. 1967. The Inequality of States: A Study of the Small Power in International Relations. Oxford: Clarendon Press.

Vital, David. 1971. The Survival of Small States: Studies in Small Power/Great Power Conflict. London, New York: Oxford University Press.

Walt, Stephen M. 1985. Alliance Formation and the Balance of World Power. International Security 9 (4):3-43.

Walt, S. M. 2001. Beyond bin Laden: Reshaping U.S. Foreign Policy. International Security 26 (3):56-78(23).

White, Stephen, Ian McAllister, and Margot Light. 2002. Enlargement and the New Outsiders. Journal of Common Market Studies 40 (1):135-53.

Zagorski, Andrei. 2004. Policies Towards Russia, Ukraine, Moldova and Belarus. In European Union Foreign and Security Policy: Towards a Neighbourhood Strategy, edited by R. Dannreuther. London: Routledge.

\section{WEB SOURCES}

\section{Estonian Government}

The Estonian Government's European Union Policy for 2004-2006

Estonian Development Co-operation Projects in 2004 
Estonia Today: Development Co-operation

Latvian Government

Development Co-operation Plan of the Republic of Latvia for 2005

\section{Lithuanian Government}

Programme of the Government of the Republic of Lithuania for 2004-2008

Agreement between Political Parties of the Republic of Lithuania on the Main Foreign Policy Goals and Objectives for 2004-2008

European Union

Common Strategy between the European Union and Russia

\section{NEWS SOURCES}

Diena

LETA News Agency

RIA Novosti

Estonian Ministry of Foreign Affairs Press Releases

Latvian Ministry of Foreign Affairs Press Releases

Lithuanian Ministry of Foreign Affairs Press Releases

\section{ENDNOTES}

1 This paper borrows from Galbreath, David J., and Jeremy W. Lamoreaux. 2007. Bastion, Beacon or Bridge? Conceptualising the Baltic logic of the EU's Neighbourhood. Geopolitics 12 (1) and Galbreath, David J. 2006. The Baltic States and the European Neighbourhood Policy: Maximising the Voices of Small Nations. In Baltic Outlooks on European Foreign and Security Policy, edited by H. Tiirmaa-Klaar. Tallinn: Tallinn University Press. This conference paper illustrates the latest thinking in our work on Baltic foreign policy and the geopolitics of the post-Soviet region.

2 White, Stephen, Ian McAllister, and Margot Light. 2002. Enlargement and the New Outsiders. Journal of Common Market Studies 40 (1):135-53.

3 Vital, David. 1967. The Inequality of States: A Study of the Small Power in International Relations. Oxford: Clarendon Press, Vital, David. 1971. The Survival of Small States: Studies in Small Power/Great Power Conflict. London, New York: Oxford University Press.

4 Kolodziej, E. A. 2005. Security and International Relations. Cambridge University Press, 129.

5 Vital, David. 1971. The Survival of Small States: Studies in Small Power/Great Power Conflict. London, New York: Oxford University Press, 120.

${ }^{6}$ Ibid., 12.

7 Ibid., 123-124.

8 Walt, Stephen M. 1985. Alliance Formation and the Balance of World Power. International Security 9 (4):3-43.

9 Walt, S. M. 2001. Beyond bin Laden: Reshaping U.S. Foreign Policy. International Security 26 (3): 96.

10 Ibid., 100.

11 Buzan, Barry, and Ole Waever. 2003. Regions and Powers: The Structure of International Security. Cambridge: Cambridge University Press, 51.

12 Ibid., 4. 
13 Ibid., 44, emphasis added.

14 Ibid., 48.

15 Ibid., 48, 53.

16 Ibid., 46.

17 Ibid., 61.

18 Knudsen, Olav F. 1999. Stability and Security in the Baltic Sea Region. London: Frank Cass.

19 Buzan and Waever. 2003. Regions and Powers, xxvi.

20 Galbreath, David J., and Jeremy W. Lamoreaux. 2007. Bastion, Beacon or Bridge? Conceptualising the Baltic logic of the EU's Neighbourhood. Geopolitics 12 (1):1-24.

21 Section 152 of The Estonian Government's European Union Policy for 2004-2006 which can be found at http://web-static.vm.ee/static/failid/038/Governments_European Policy_for_2004-2006.pdf (Last Accessed: 5 December 2005). See D. J. Galbreath, 'Democratisation and Inter-State War: Why Reform does not Encourage Conflict' Politics 24/3 (2004) pp.212-220, E. D. Mansfield and J. Snyder, 'Democratization and the Danger of War' International Security 20/1 (1995) pp. 5-38.

22 Common Strategy between the European Union and Russia, http://europa.eu.int/comm/ external_relations/ceeca/com_strat/russia_99.pdf (Date accessed: 14 December 2005).

23 D. J. Galbreath, 'Kurp talak? Recenzija par Latvijas arpolitikas pamatvirzienu projektu (iepriekšējo projektu)' May 2004 Politika.lv.

24 Sub-sections 16.4-16.6 of the Programme of the Government of the Republic of Lithuania for 2004-2008 http://www.lrv.lt/main_en.php?cat=16\&gr=4\&d=2001 (Date accessed: 5 December 2005).

25 Sub-Section 3.3 in the Agreement between Political Parties of the Republic of Lithuania on the Main Foreign Policy Goals and Objectives for 2004-2008

26 RIA Novosti, 4 August 2005. Alternatively, see Itar-Tass, 4 August 2005.

27 S. R. Burant, 'Foreign Policy and National Identity: A Comparison of Ukraine and Belarus' Europe-Asia Studies $47 / 7$ (1995) pp.1125-1144, S. R. Burant, 'International Relations in a Regional Context: Poland and Its Eastern Neighbours - Lithuania, Belarus, Ukraine' Europe-Asia Studies 45/3 (1993) pp. 395-418, A. P. Tsygankov, 'Defining state interests after empire: national identity, domestic structures and foreign trade policies of Latvia and Belarus.' Review of International Political Economy 7/1 (2000) pp.101-137, A. Zagorski, 'Policies Towards Russia, Ukraine, Moldova and Belarus' in R. Dannreuther (ed.), European Union Foreign and Security Policy: Towards a Neighbourhood Strategy (London: Routledge 2004) pp.79-97.

28 Latvian Ministry of Foreign Affairs, Development Co-operation Plan of the Republic of Latvia for 2005 http://www.mfa.gov.lv/en/DevelopmentCo-operation/Projects/ (Date accessed: 8 December 2005).

29 Latvian Ministry of Foreign Affairs Press Release, 25 August 2005.

${ }^{30}$ LETA, 26 September 2006.

31 Lithuanian Ministry of Foreign Affairs Press Release, 28 September 2005.

32 Estonian Ministry of Foreign Affairs, Estonian Development Co-operation Projects in 2004, http://www.vm.ee/eng/kat_178/5306.html (Date accessed: 9 December 2005). Note that the project list only reflects those development projects coordinated by the Estonian Ministry of Foreign Affairs.

33 Estonian Ministry of Foreign Affairs, Estonia Today: Development Co-operation, http://web-static.vm.ee/static/failid/224/Development_co-operation.pdf (Date accessed: 9 December 2005).

34 Latvian Ministry of Foreign Affairs Press Release, 11 October 2005. 
35 In fact, the Estonian Foreign Ministry did have a development project in Ukraine in 2004 for diplomatic training with the Estonian School of Diplomacy. See Estonian Ministry of Foreign Affairs, Estonian Development Co-operation Projects in 2004.

36 Diena, 25 November 2004. Pabriks once again argued for support for Ukraine a week later. See LETA, 1 December 2005.

37 LETA, 24 January 2005.

38 LETA, 22 February 2005.

39 Lithuanian Ministry of Foreign Affairs Press Release, 14 April 2005. 


\title{
Elite Democratic Discourses in Ukraine: Preliminary Results from the Study of Ukrainian Members of Parliament
}

\author{
Kasper Andersson \\ Uppsala University
}

At the International Conference held in Riga in November last year, Professor Li Bennich-Björkman presented an outline of her new research project at Uppsala University called 'Between 'Soft' Europeanisation and National Cultural Legacies: Democratic Discourses and Political Elites in Romania, Bulgaria, Ukraine and the Czech Republic (Bennich-Björkman, 2006, 293-300). The main goal of the project is to see whether the process of becoming future EU members has affected the democratic values and beliefs of the political elites (defined as members of parliament) in the countries mentioned. Of special interest are the Joint Parliamentary Committees (JPC) that have been set up between the European Union and various applicant countries. In these JPC's, the interaction and co-operation between EU officials and MPs of the applicant countries can be expected to be closer than in other committees. Therefore, it should be interesting to see whether or how these contacts have had a measurable effect on how the JPC-members view democracy compared to members of other committees. Put in other words: is membership in a JPC a factor that affects the democratic discourse of MPs?

Working as a research assistant on this project, I spent six weeks in Kyev this fall and met with a number of Ukrainian MPs. This paper is a short summary of the work carried out and it also contains some preliminary results of the research conducted. The same kind of study is now being done in Bulgaria and Romania. Unfortunately, the case of Ukraine stands out when compared to the other two countries since there is no JPC established in the state parliament, a fact that renders it difficult to make a clear comparison with the other cases. There is however a Committee for European Integration (CEI) and it has been chosen as a substitute on the assumption that it bears most resemblance with a JPC. The goal is to meet with as many members of this committee as possible and compare their views on democracy with a selection of other committee members. So far, 23 Ukrainian MPs have been included in the study and two of them are members of the CEI. Hopefully, more MPs can be included in the study later on, at this stage this paper should be regarded as an attempt to identify the factors that affect the democratic discourse of Ukrainian MPs in general, regardless of committee membership. 


\section{QMETHODOLOGY}

When trying to investigate what people think of democracy, the researcher can choose between a wide set of tools. Some of the more common ones are surveys, discussions groups and interviews. One of the problems with these methods is that they often require the researcher to make assumptions on what questions or topics the individuals should answer to. For example, when choosing what questions should be included in a survey, it is often the researcher alone who decides which ones are most interesting from his point of view and then articulates them in his own words. There exists however also a methodology that is concerned with the scientific study of human subjectivity: Q methodology. It was developed originally in psychological research by William Stephenson (Stephenson, 1953) and makes it possible to identify common groupings of opinion within a given population on a particular topic, while at the same time it is concerned with ensuring the individual's self-reference. The basic idea of Q methodology is to ask persons (often referred to as "subjects" in literature on Q methodology) to rank a set of statements, usually between 40-60, that deal with a certain topic. The statements are not created by the researcher, but generated from discussion groups where people, in their own words, express what they think and feel about the topic of interest. With the help of factor analysis, it is thereafter possible to identify common groupings of opinion among the subjects and see what factors have affected them. In comparison with traditional surveys, it is a more qualitative methodology that seldom requires a number of subjects greater than 40 to be included in a study, yet the use of factor analysis makes it a combination of both qualitative and quantitative techniques.

\section{THE Q STUDY CONDUCTED IN UKRAINE}

The first task of a Q study is to define a population of statements on a particular topic within a given population. For this purpose, it was possible to make practical use of earlier work carried out by professors John S. Dryzek and Leslie Holmes in their study on democratic discourses found among citizens in thirteen postcommunist countries (including Bulgaria, Romania and Ukraine). Dryzek and Holmes were interested in the topic of democracy and identified the population of statements as concerned with the "collective construction, application, distribution, and limitation of political authority" (Dryzek \& Holmes 2002, 24-27). In each country, they used two kinds of sources for the statements: discussion groups, from which they obtained the larger proportion of statements, and publications such as newspapers and magazines. There were four discussion groups, each with around ten participants of different backgrounds, and they all met once in one-hour sessions. The conversations were recorded and transcribed and together with the material from published sources Dryzek and Holmes found themselves with around 300 statements. Once a selection had been made, based on the principles of political discourse analysis, the 300 statements were reduced to a more manageable yet representative number of 64 statements, called the Q sample.

The next step, where this study departs from the earlier work of Dryzek and Holmes, is to meet with subjects and have them rank the statements of the $Q$ sample. This procedure is known as Q sorting and here the Ukrainian Q sample was 
"recycled" with Ukrainian MPs, meaning that the Q sample that Dryzek and Holmes had retrieved from and used with representatives of the Ukrainian population as a whole was now used with a new population consisting of members of parliament. There are some minor variations in how a Q sorting can be carried out. In this case the procedure was as follows: firstly, each of the 64 statements was written onto a card of similar size, shape and colour, which resulted in something resembling a deck of playing cards. Next, each subject had to read through all the statements and, according to his personal opinion, make a first rough sorting of them into three piles labelled agree, disagree and indifferent. After that, a score sheet was placed on the desk in front of each subject, depicted below.

\begin{tabular}{|l|l|l|l|l|l|l|l|l|l|l|l|l|}
\hline & & & & & & & & & & & & \\
\hline & & & & & & & & & & & & \\
\hline & & & & & & & & & & & & \\
\hline & & & & & & & & & & & & \\
\hline & & & & & & & & & & & & \\
\hline & & & & & & & & & & & & \\
\hline & & & & & & & & & & & & \\
\hline & & & & & & & & & & & & \\
\hline-6 & -5 & -4 & -3 & -2 & -1 & 0 & 1 & 2 & 3 & 4 & 5 & 6 \\
\hline
\end{tabular}

Figure 1, Score sheet

The last phase of the Q sorting allows the subject to make more detailed distinctions of his rankings with the help of a scale at the bottom of the score sheet, ranging from +6 indicating the statements that he agrees with most and -6 indicating the opposite. The subject was instructed to begin with the agree-pile of cards. Out of these, he was told to choose the two statements that he agreed with most and place them on the score sheet above the +6 score. Then, out of the remaining statements, he picked out the three statements that he agreed with most and placed them above +5 and so on until there were no cards left in the agree-pile. The process was then repeated with the cards from the disagree-pile. Finally, the cards from the indifferent-pile were placed in between the other statements so that in the end all 64 squares of the score sheet were occupied. This practise is called forced sorting and is recommended because it encourages the subjects to make distinctions that they might not always do voluntarily but are capable of.

The reader might object that there exists a risk of the subjects ranking the statements in such a way as they might think they are "expected to do". Steven Brown, author of the most often quoted book on Q methodology (Brown, 1980), acknowledges this influence of so-called "social desirability" and suggests controlling the conditions under which social desirability works so as to achieve a better understanding of it. This could be done by having the subjects rank the statements several times and alter the conditions of instruction each time. The first time they could be instructed to rank the statements as honestly as possible according to their liking, the second time as they think others would rank them, etc. This was not possible to carry out in this study because of lack of time and the busy schedule of most MPs. However, "conventional" follow-up interviews were conducted with five MPs of different party affiliation. During these interviews the subjects had the 
opportunity to explain in their own words why they had ranked the statements in such and not another way. These interviews turned out to be very interesting and useful for the later analysis of the Q sortings. The reason that follow-up interviews were not carried out with all the subjects was, once again, the difficulty of setting up meetings with the MPs due to their busy schedule.

In the end, 23 MPs conducted a Q sort and were included in the study. They represent all the political parties/blocs in parliament (Party of Regions, Yulia Tymoshenko Bloc, Our Ukraine Bloc, Socialist Party of Ukraine, Ukrainian Communist Party) and 14 out of 26 committees (Budget, Constitutional Issues, Ecology, Education, Energy and Fuel, European Integration, Finance and Banking, Foreign Affairs, Freedom of Speech, Human Rights, Justice, National Security, Regional Politics, Rule of Law).

\section{PRELIMINARY RESULTS}

Once all the Q sorts had been conducted, it was time to perform a factor analysis of the collected data with the help of a computer programme called PQMethod 2.11 ${ }^{1}$. I will not go into too much detail here on how the programme works, but only give a short explanation of how to interpret the preliminary results. Those who wish to read more about the programme and its technical features can do so on the web page where it's available as freeware (for those already familiar with PQMethod, the results were obtained through centroid factor analysis followed by varimax rotation).

The preliminary results from Ukraine suggest that there are three prevalent factors that affect the democratic discourses of MPs. To interpret these factors it is common to first show a listing of all the statements in the Q sample and how a hypothetical individual that only is affected by one factor at a time would rank the statements. Since space is limited and this is a preliminary report, I have decided to include only ten statements from each factor instead. These are the statements that caused most agreement and disagreement $(+6,+5,-6,-5$ on the score sheet) and even though they do not give a detailed narrative of each factor, it is enough to provide the reader with an overall view.

\section{Factor A}

\section{Most agree:}

Democracy presumes great participation in the process of decision-making.

It is important to know two languages in a bilingual country.

All societal levels should be represented in parliamentary organs.

For democracy to be valuable, it should be widely accepted in society.

All the treasures of the state should serve the people, not one group of people. Unfortunately, this is not the case now.

\section{Most disagree:}

There is no order in the collective farm, where collective property exists. 
We must proceed from collectivism to individualism, to the way of thinking of a market society.

Each person should work for himself or herself, and struggle for self-survival.

Communists refurbished into democrats rule over Ukraine.

Communist society was moral in some aspects, but it was a means to reach immoral goals. Only rich people should come to power; they will not steal from the state because they already have everything.

\section{Factor B}

Most agree:

A fully realized democratic system includes three conditions: political equality, non-tyranny, and deliberation.

To be democratic, the nation or state should be sovereign.

Democracy is the power of the people.

Power starts from responsibility, which our politics has lacked.

The Ukrainian national idea should stimulate the growing economic and cultural potential of the Ukrainian people.

Most disagree:

Money and power mean more than equality in all so-called democratic systems.

Only rich people should come to power; they will not steal from the state because they already have everything.

Politicians care about their own interests first, and then about the people.

Democracy combined with some forms of liberty threatens equality and therefore, finally, democracy itself.

Money is the most important thing everywhere, including in elections.

\section{Factor C}

\section{Most agree:}

Democracy is the power of the people.

For democracy to be valuable, it should be widely accepted in society.

Democracy means freedom of speech.

No democratic reform is possible without economic reform.

A person bears power for just a small time designated for them to be on Earth. The rest of the time one is just the same citizen as all the rest. That is why he must think while he is in power.

\section{Most disagree:}

We must proceed from collectivism to individualism, to the way of thinking of a market society. Each person should work for himself or herself, and struggle for self-survival. 
To launch the process of de-liberalization, society should move to a more direct, more majoritarian democracy.

All directions in our declining region are decided by the political elite of converted communists, who seek a basis for further rule over the impoverished and discontented masses. There is no order in the collective farm, where collective property exists.

Theoretically a woman can become president of Ukraine, but in practice it would not be allowed.

One can also see to what extent the actual subjects are affected by each factor, which also is an interesting feature of Q methodology since it allows the researcher to make a more detailed analysis. In the table below all subjects and their party/bloc affiliation is shown as well as how much their unique Q sort corresponds to the three factors. This correspondence is labelled as loading and can vary from 100 to -100 (even though such high loadings are hardly ever seen since they would imply perfect agreement and disagreement respectively) and loadings of 30-40 can be viewed as substantial.

Judging by the preliminary results at this stage of the project, it seems that there is a connection between the factors that affect Ukrainian MPs and their party, rather than committee, affiliation. The subjects from the Yulia Tymoshenko Bloc tend to be more affected by factors $\mathrm{B}$ and $\mathrm{C}$, even though some also load to a lesser degree on factor A. As for the subjects from Our Ukraine, their loadings are much higher on factor B while they even reach negative values for factor A. The subjects from the Party of Regions also load on factor $\mathrm{C}$ but their loadings on factor A are not as low as in the case of the previous two parties. Finally, MPs from the Ukrainian Communist Party and the Socialist Party of Ukraine consistently show high loadings on factor A, with two subjects even reaching loadings above 70 and 80 .

Factor

\begin{tabular}{|l|c|c|c|}
\hline \multicolumn{1}{|c|}{ Subject, Party/Bloc Affiliation } & A & B & C \\
\hline 1, Yulia Tymoshenko Bloc & 34 & 25 & 26 \\
\hline 2, Yulia Tymoshenko Bloc & 2 & 59 & 42 \\
\hline 3, Yulia Tymoshenko Bloc & 5 & 24 & 5 \\
\hline 4, Yulia Tymoshenko Bloc & 29 & 49 & 43 \\
\hline 5, Our Ukraine & -7 & 52 & 35 \\
\hline 6, Our Ukraine & -6 & 24 & 28 \\
\hline 7, Our Ukraine & -5 & 66 & 17 \\
\hline 8, Our Ukraine & 19 & 12 & 11 \\
\hline 9, Our Ukraine & 14 & 57 & 25 \\
\hline 10, Our Ukraine & -9 & 32 & 45 \\
\hline 11, Our Ukraine & -3 & 77 & 5 \\
\hline 12, Party of Regions & 15 & 24 & 61 \\
\hline 13, Party of Regions & 23 & 26 & 52 \\
\hline 14, Party of Regions & 25 & 7 & 20 \\
\hline 15, Party of Regions & 17 & 15 & 61 \\
\hline 16, Ukrainian Communist Party & 57 & -11 & 15 \\
\hline
\end{tabular}




\begin{tabular}{|l|c|c|c|}
\hline 17, Ukrainian Communist Party & 83 & 12 & -5 \\
\hline 18, Ukrainian Communist Party & 73 & -7 & 19 \\
\hline 19, Ukrainian Communist Party & 58 & 19 & 41 \\
\hline 20, Socialist Party of Ukraine & 24 & 25 & 54 \\
\hline 21, Socialist Party of Ukraine & 46 & 29 & 32 \\
\hline 22, Social Democratic Party of Ukraine & 22 & 54 & 17 \\
\hline 23, Lytvyn's People's Bloc & 30 & 9 & 68 \\
\hline
\end{tabular}

Table 1. Subject Loadings

\section{CONCLUSIONS}

The Q study that is being conducted with Ukrainian MPs so far includes 23 subjects. The long-term goal is to see whether membership in certain committees tends to affect their view on democracy, especially the ones in the Committee for European Integration. At this stage, three prevalent factors that affect the democratic discourses among MPs have been identified. However, it seems that the correlation between each MP's democratic discourse and the factor that affects him the most is more dependent on party rather than committee affiliation.

\section{REFERENCES}

Bennich-Björkman, Li, 2006, "Between "Soft" Europeanization and National Cultural Legacies: Democratic Discourses and Political Elites in Romania, Bulgaria, Ukraine and the Czech Republic", Expanding Borders: Communities and Identities, University of Latvia, Riga, pp. 293-300.

Brown, Steven, 1980, Political Subjectivity, New haven: Yale University Press.

Dryzek, John \& Holmes, Leslie, 2002, Post-Communist Democratization. Political Discourses Across Thirteen Countries, Cambridge: Cambridge University Press.

Stephenson, William, 1953, The Study of Behaviour: $Q$ technique and Its Methodology, Chicago: University of Chicago Press.

\section{ENDNOTES}

1 PQMethod 2.11 for PC, available as freeware on http://www.qmethod.org/Tutorials/ pqmethod.htm. 


\title{
Foreign Policy Discourse in the Republic Of Latvia from the Point of View of the Civilian Power Conception
}

\author{
Kārlis Bukovskis
}

\section{INTRODUCTION}

The Civilian Power (Zivilmacht) conception is relatively new in international relations. It offers an alternative solution and system of principles for the international system. The Civilian Power conception is not only a matrix for the theoretical analysis and evaluation of state actions. It can also simultaneously be an ideal type for the functioning of state relations and of the international system in general or an instrument which states should use in foreign policy to change the character of the international system. Traditionally, one speaks about the Civilian Power conception with reference to the Federal Republic of Germany, Japan, as well as the European Union. However, the majority of states are small states which have relatively few resources when compared to the few great powers. Therefore the circumstances of the modern international system, the plurality of little states and foreign-policy complexity obliges one to look at the Civilian Power conception also from the point of view of small states.

Changes in the international system, which include the development of international institutions and international law, generate new possibilities and challenges for small states, including the Republic of Latvia. Accordingly, small states, including Latvia, could aspire to change relations between powerful states through multilateral institutions, international relations and world public opinion. Reducing the probability of warfare could facilitate the 'civilising' (Zivilisierung) of international politics and contribute to an increase in the level of internal and external security for states.

The basic question to be analysed here is how the principles of the Civilian Power conception are reflected in foreign policy principles and strategies and in the views of foreign policy makers themselves in the foreign policy discourse of the Republic of Latvia. While the dominant approach is likely to be Realpolitik, one can ascertain the presence of Civilian Power principles in Latvian foreign policy discourse. The aim is not to analyse Latvian foreign policy discourse in general, but to determine the dominant themes and to verify the presence of concrete aspects, ideas and values of the Civilian Power conception in this discourse. In the framework of this essay, the term 'foreign policy discourse of the Republic of Latvia' can be defined as the 
totality of principles that express themselves in the foreign policy documents of Latvia and judgments of officials about the foreign policy activities of the Republic of Latvia, and in the state's official declared stands.

The objects of analysis include "The Declaration of the Intended Activities of the Cabinet of Ministers of December $1^{\text {st }} 2004$," which called for fulfilling the main foreign policy aims defined in the Foreign Policy Conception of 1995, namely, joining NATO and the European Union. The analysis also examines the 2003 State Defence Concept and the National Security Concept of the Republic of Latvia of 2005. In conducting the research, the author interviewed representatives of the Ministry of Foreign Affairs, the Commission of Strategic Analysis under the Auspices of the President of the Republic of Latvia and the Saeima Committee on Foreign Affairs. The conclusion seeks for Civilian Power principles in the official statements of the President, the Minister of Foreign Affairs and in the statements of the Committee on Foreign Affairs, which includes the official opinion of the state.

\section{THE CIVILIAN POWER CONCEPTION IN INTERNATIONAL RELATIONS}

\section{Civilian Power Theory}

The genesis of the conception is related to the prospects for civilising the international system developed by French scientist François Duchêne, who saw the principles of civilised foreign policy in the EU. ${ }^{1}$ At the same time, the idea of civilisation is borrowed from German sociologist Norbert Elias and his empirical explorations on the development of civilisations. ${ }^{2}$ Parallel to this one also notes ideas by Dieter Senghaas on the use of power in interstate relations and criticisms of scare politics (Abschrekungskritik), and the author's attempts for the first time to adjust Elias' writings to the international system. ${ }^{3}$ The German theorist Hanns $W$. Maull, however, should be considered the primary Civilian Power analyst, as in the beginning of 1990 the author structured Duchene's ideas and adapted them for the analysis of Germany's and Japan's foreign policy. In subsequent works, the Civilian Power conception was related and explained from the point of view of role theory (Rollentheorie) and constructivist theories.

Maull defines the term 'Civilian Power' as 'states (or other political entities), which are willing to take initiatives and exercise influence over events, and which use particular strategies, means and instruments to achieve their objectives; ... 'Civilian Power' represents a foreign policy role concept - a complex bundle of norms, beliefs, attitudes and perceptions - which tells a state (or, more precisely, its decision makers) how to behave." 'Civilian Power' could be referred to as a state that is able to promote and initiate the civilising of the international system, and which has enough resources to influence the international system.

In the works of several authors, including Volker Rittberger, the Civilian Power

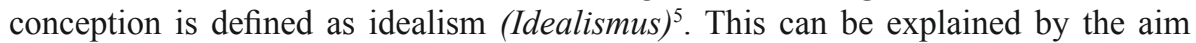
of changing the international system and relations between states by emphasising new possibilities and needs in interstate actions and attempting to convince large and powerful states to give up their potential influence and power in international 
relations and interstate relations. The Civilian Power conception can be characterised or defined as 'Idealism' or a 'Normative approach', insofar as interstate relations have traditionally been determined by rationality and interest maximisation. The Civilian Power conception and its Ideal Type, however, appeals to abandoning the traditional means and approaches in the formation of interstate relations, and the use of power for interest maximisation in general, in order to implement their security, welfare and other interests through multilateral institutions and the development of economic relations. This means that the adjustment of the means does not change the principle of rational self-interest. The idealistic approach of the Civilian Power conception is manifested only when solidarity, human rights, the development of international law and other aspects in contradiction to the traditional understanding of interstate relations are put on the agenda.

\section{THE IDEAL TYPE CIVILIAN POWER ROLE CONCEPT}

Maull has developed a Civilian Power ideal type which can be used for analysing foreign policy, as well as the understanding of policy makers about the role of the state in international relations, its potential to act, and even defining the state's aims and interests. ${ }^{6}$ Subsequently, Knut Kirste systematised Maull's work and created the Ideal Type Civilian Power Category Scheme (das Idealtypische Kategorienschema der Zivilmachtrolle) ${ }^{7}$ (see table 2).

Table 1

The Ideal Type Civilian Power Category Scheme ${ }^{8}$

\begin{tabular}{|c|c|}
\hline \multicolumn{2}{|r|}{ Leadership/ initiative } \\
\hline Initiator/ promoter & $\begin{array}{l}\text { Initiate/lead collective action in regional or global settings; } \\
\text { function as example and avant-garde in international } \\
\text { cooperation; assume international responsibility but do NOT } \\
\text { try to run the show alone! }\end{array}$ \\
\hline Key institution member & Play responsible and constructive role in international relations \\
\hline \multicolumn{2}{|r|}{ National aims } \\
\hline $\begin{array}{l}\text { Welfare maximiser (absolute } \\
\text { gains) }\end{array}$ & $\begin{array}{c}\text { Search for wealth and welfare, social justice, democratic } \\
\text { stability; primacy of domestic and welfare objectives in } \\
\text { foreign policy }\end{array}$ \\
\hline \multicolumn{2}{|r|}{ International aims: organisationally } \\
\hline Supranationalist & $\begin{array}{l}\text { Accept transfer of sovereignty and division of labour; support } \\
\text { integration and self-binding policies; renounce autonomy if } \\
\text { there are other gains; accept international norms as binding }\end{array}$ \\
\hline Regime builder/deepener & $\begin{array}{c}\text { Promote international regimes and institutions; deepen } \\
\text { existing regimes and institutions }\end{array}$ \\
\hline Promoter of rule of law & Promote growing weight of international law and enforcement \\
\hline Regime/institution enlarger & Promote widening of regimes/institutions \\
\hline \multicolumn{2}{|r|}{ International aims: substance } \\
\hline $\begin{array}{c}\text { Propagator of interdependent } \\
\text { interests }\end{array}$ & $\begin{array}{c}\text { Define national interests as intertwined with others' interests; } \\
\text { cooperative solutions to global problems }\end{array}$ \\
\hline Values-based foreign policy & $\begin{array}{l}\text { Accept universal values as defining national interests; pursue } \\
\text { values-based foreign policy; sense of 'mission' }\end{array}$ \\
\hline
\end{tabular}




\begin{tabular}{|c|c|}
\hline $\begin{array}{l}\text { Promoter of good governance } \\
\text { and rule of law/ intervener }\end{array}$ & $\begin{array}{c}\text { Promote 'good governance'; intervene in internal affairs, if } \\
\text { necessary and possible }\end{array}$ \\
\hline $\begin{array}{l}\text { Promoter of democratisation } \\
\text { and human rights }\end{array}$ & Promote democracy and human rights \\
\hline $\begin{array}{c}\text { Promoter of sustainable } \\
\text { development }\end{array}$ & $\begin{array}{l}\text { Promote sustainable development (environmental protection, } \\
\text { social equity, economic development in Third World) }\end{array}$ \\
\hline \multicolumn{2}{|r|}{ Foreign policy style } \\
\hline Collective actor & $\begin{array}{l}\text { Accept collective action/multilateralism as norm; behave as } \\
\text { good partner }\end{array}$ \\
\hline Opponent of unilateral action & Oppose unilateralism \\
\hline $\begin{array}{l}\text { Promoter of bargaining, } \\
\text { compromise and mediation }\end{array}$ & $\begin{array}{c}\text { Promote negotiations, compromise, mediation; material } \\
\text { conflicts can be solved as positive-sum game; unilateral use of } \\
\text { force ruled out }\end{array}$ \\
\hline Regime/institution user & $\begin{array}{l}\text { Look to institutions for solving your problems and promoting } \\
\text { your interests }\end{array}$ \\
\hline Partner & $\begin{array}{l}\text { Base your relations with your partners on solidarity, } \\
\text { community of values; promote fair burden-sharing }\end{array}$ \\
\hline Sanctions promoter & $\begin{array}{l}\text { Use/promote/participate in collective economic sanctions to } \\
\text { enforce international norms }\end{array}$ \\
\hline \multicolumn{2}{|r|}{ Foreign policy instruments } \\
\hline Promoter of collective security & $\begin{array}{l}\text { Collective security as an ideal goal; the use of military force } \\
\text { and its threats is reduced with international legitimising and } \\
\text { collective implementation }\end{array}$ \\
\hline $\begin{array}{l}\text { Promoter of cooperative } \\
\text { security }\end{array}$ & $\begin{array}{l}\text { Arms control, disarmament, collective solution of security } \\
\text { problems }\end{array}$ \\
\hline $\begin{array}{l}\text { Promoter of multilateral, } \\
\text { legitimate action/integrated } \\
\text { instruments }\end{array}$ & $\begin{array}{l}\text { To recognise the importance of division of labour and } \\
\text { integrated foreign policy instruments; promote the integration } \\
\text { of foreign policy instruments }\end{array}$ \\
\hline
\end{tabular}

\section{THE CIVILIAN POWER CONCEPTION IN THE ANALYSIS OF SMALL STATES' FOREIGN POLICY}

\section{Small State Foreign Policy Challenges}

The problems of small states in international relations are basically related to the lack of state influence, political means and various resources, including territorial, geographical, human resources, economic and military potential, etc. compared with the great powers. Decisions about foreign and security goals in relations with other small states and great powers are made to enhance welfare, influence, prestige and other principles.

Here, we examine the traditional analysis of international politics of large state interests which influence and change the international system. Regarding the role of small states, the dominant perception held by great powers is that of "the small state [...] as a helpless pawn in world politics." Nowadays, for small states, the possibilities of using multilateral political instruments in order to attain their interests equally with great-powers are becoming increasingly realistic. International institutions in particular provide such opportunities. As Jeanne A. K. Hey writes, 
"The international system has undergone fundamental changes in the past fifteen years; ... Small states today enjoy more international prestige and visibility than at any other time in history". ${ }^{10}$

Allen Sens presumes that in the European framework small states attempt to secure "maintenance of territorial sovereignty and claim to be acting as independent, sovereign entities; establishment of security guarantees; maintenance of the widespread adherence to non-confrontational and non-violent norms; prevention of the spread of existing ethno-religious conflict; prevention of the growth of domestic separatist or irredentist sentiments; maintenance of patterns of cooperation and the operation of multilateral political, security, and economic institutions, and inclusion in the consultative processes of these institutions; prevention, as much as possible, of dominance by a great power or by a concert of great powers." 11

Hence it should be concluded that to the recent security strategies of small states one could add also the involvement, participation and activity in international and interstate political, military, economic organisations as well as support for international non-governmental organisations. In this framework of different opinions and judicial regulations, appropriate effective mechanisms could be promoted and created that secure the binding of great-powers and reduce the potential use of force in relations with the small states and in the international system altogether. Raimo Väyrynen also highlights, that after the Cold War, "small states are also protected more than before by international institutions, which establish norms and develop mechanisms; ... Small states can also exercise influence through international institutions, at least in peace time; ... therefore small states have an interest in developing international law and, in general, instruments and institutions of peaceful change."12

$J$. Hey has codified a range of small state traditional behaviour and actions in the international system that are most mentioned in characterisations of small states; she analyses different authors, and concludes that "small states tend to: exhibit a low level of participation in world affairs; address a narrow scope of foreign policy issues; limit their behaviour to their immediate geographic arena; employ diplomatic and economic foreign policy instruments, as opposed to military instruments; emphasise internationalist principles, international law, and other 'morally minded' ideals; secure multinational agreements and join multinational institutions whenever possible; choose neutral positions; rely on superpowers for protection, partnerships, and resources; aim to cooperate and to avoid conflict with others; spend a disproportionate amount of foreign policy resources on ensuring physical and political security and survival." 13 These principles also show that in order for small states to attain their security goals and maximise their national interests, they attempt to facilitate interstate cooperation, develop and strengthen international institutions and international law, and reduce the use of force in the international system.

As a result, one should conclude that small states are theoretically interested in supporting Civilian Power principles in the international system, which is aimed at reducing the use of force and strengthening international institutions. Small states, by engaging themselves in international organisations and promoting the principles of multilateralism in international politics, promote their own security and are able to increase their influence and rights in the international system. Small states are interested in developing international institutions, international law and multilateral 
politics. Through international organisations like the United Nations, the European Union, the Organisation for Security and Cooperation in Europe small states gain extra impact, which places them in line with other states, sometimes even great powers. Civilising the international system is important to the small states, while the evolution of international law and international norms, in general, tends toward the protection of smaller and weaker members of the community. Norms and laws create opportunities for small states and their inhabitants to save their sovereign decisionmaking processes and territorial integrity, improve the chances for independent development and avoid warfare. The effectiveness of institutions can be achieved by consensus, not by constant objections and protests which fragment the work of international institutions.

\section{THE CIVILIAN POWER CONCEPTION AND SMALL STATE FOREIGN POLICY STRATEGIES}

Håkan Wiberg distinguishes four foreign policy strategies for small states: "1) a bilateral alliance with a major power; 2) an alliance of two or several small states; 3) membership of a multilateral alliance around one or more major powers; 4) nonalignment, whether aiming at neutrality in any war or without such a generalised commitment." 14 It should be noticed that this and similar classifications are based on a realist view of the international system and interstate relations. The strategies mentioned before include the struggle for state security in a confrontational situation against one or more countries. Therefore it is important to understand alternative security strategies for small states.

One alternative strategy for small states includes international organisations and delegating sovereignty to international institutions, participation in peace-keeping operations, active promotion of the functioning of military alliances, and cooperation with different regions and states in promoting soft security. Small states can promote self-preservation in the international system if their foreign policy strategy includes the goal of civilising the international system - reduction of the use of force, promotion of cooperation, economic and social interdependence, and creation of a non-violent international arena and interstate relations.

At the same time, it could be noticed that traditionally small states lack resources and influence to promote and/or lead the civilisation of the international arena. Small states have difficulties initiating any changes in the international system because of an insufficient level of military, economic, political or any other type of influence on other states and on the global system in general. Maull acknowledges that the term 'Civilian Power' includes an aspect of the capacity to promote or implement changes in the relations between political entities and countries. The author in this situation understands the small state as a state which is not able to accumulate enough resources to be able to actively facilitate the change of the international arena.

Nonetheless, this opinion does not apply to all small states. Small countries are not able to change the international system alone, but they still can promote, support or even hinder proposed changes in interstate relations. The opinion of Maull could be related to the definitions of a 'weak power' or 'weak state' in Barry Buzan's works, where 'weak powers' are weak institutionally and also vulnerable to security threats; 
the terms 'weak power' and 'strong power' traditionally refer to a state's military and economic resources and relations as the outcome of these aspects. ${ }^{15}$ Yet small states which have sufficient resources, will and interest in civilising international relations by implementing the principles of the Civilian Power conception in their foreign policy actions could be regarded as Civilian Powers. The lack of resources does not prevent small states from following Civilian Power principles in their foreign policy, even if for them it is impossible to influence the system. Maull himself has recognised the potential need for a Civilian Power to cooperate militarily with one or more countries (traditionally the United States of America) aimed at securing compliance with international norms. ${ }^{16}$ That, in turn, shows that a Civilian Power could not have enough resources to civilise the international system alone and as a result, help and support from other states is needed.

\section{THE CIVILIAN POWER CONCEPTION IN THE FOREIGN POLICY DISCOURSE OF THE REPUBLIC OF LATVIA}

\section{Civilian Power Principles in the Foreign Policy Documents of the Republic of Latvia}

Decision-makers and legislators use the documents defining the foreign policy of the Republic of Latvia as guides during the process of policy making. As the Civilian Power conception relates primarily to foreign policy, with aspects touching also security policy, one must seek Civilian Power principles in both foreign policy and security documents.

In relation to leadership/initiative capacity in the foreign policy of Latvia, it should be noted that the will to initiate collective action in the regional or global arena appears, especially in the framework of international institutions. The state does not attempt to act unilaterally but chooses to act in cooperation with other states. Latvia declares its readiness to take part in international actions together with other states and also emphasises its obligation to contribute to the effective work of international institutions and play a constructive role in interstate organisations. Nevertheless the support of institutions is directly related to the interests of the state. In the state's national aims one can easily detect the welfare maximiser, while in various documents foreign policy is defined as a means of furthering the national interest, such as public welfare, security, democratic stability, etc.

In relation to international aims: organisationally, supranationalist principles are clearly present in the foreign policy of Latvia. The state aspires to integrate into international organisations; it accepts that the delegation of sovereignty promotes integration and respects international norms as binding. Latvia acknowledges that it "will continue de facto integration into the European Union" 17 in the future. Similarly Latvia could be recognised as a regime builder/deepener, while the foreign policy principles define the need to support international regimes and institutions: "We will advocate the creation of an effective and united Foreign and Security Policy of the European Union, for it to be able to actively participate in the formation of world politics." 18 
Latvia recognises the necessity of contributing to the growth of the significance and implementation of international norms. Hence the state becomes a promoter of rule of law. The foreign policy interests of Latvia include the aim of creation and qualitative implementation of the international norms that altogether facilitate security and resource creation for Latvia as a small state. The state wants to implement Western values and actively participate in important international organisations that are based on recognising and obeying international law. Latvia is interested in taking on the function of institution/regime enlarger. Notwithstanding the fact that support for the enlargement of the European Union and NATO is not clearly stated in the documents, the principles of cooperation between the EU, NATO and third countries or regions are common.

At the same time in the category of international aims: substance, these principles are not so clearly represented in the foreign policy documents of Latvia. Frequently mentioned is the interest in cooperation with the US and EU member states, allowing for the conclusion that Latvia takes into account the interests of other states and the international system when defining its national interests. Nevertheless, the state's support for collective solutions of global problems is not stated in the documents. This can be explained by the fact that Latvia concentrates more on solving its own domestic policy issues with the help of other countries, while helping other regions and states is not clearly defined in the documents. Therefore, Latvia cannot be considered a propagator of interdependent interests.

Neither can Latvia's foreign policy be characterised as value-based. The official foreign policy of Latvia is based on considerations of Realpolitik, not on the idealistic goals of changing the international system or civilising interstate relations, where universal values could be characterised as the defining element of national interests. At the same time, however, the analysis of foreign policy documents shows that Latvia recognises the importance of universal values in the international system. Similarly, the sense of 'mission' is not a common feature of any of the most important foreign and security policy documents. Accordingly, support for universal values in the documents indicates the importance of principles, but not the primacy of values in foreign policy. Latvia's approach to universal values is mainly to support them, rather than to promote them actively, therefore accordance with the Civilian Power conception is only partial. The principles of promoter of good governance and intervener are not present in Latvian foreign policy documents.

Conformity with the promoter of democratisation and human rights category is strictly related to membership in the EU and NATO. Latvia points to state interests in democratisation of other countries, and current documents could be considered as a sign of Latvia being a promoter of democracy and human rights, even if concrete actions are not present.

Likewise, Latvia does not actively perform as a promoter of sustainable development in international politics, since no concrete actions are on the agenda. It is not specified that state interests conform with principles of environmental protection, as in the category of global problem solution. Accordance is connected with trends on the domestic level and the principles are not presented as a universally achievable end in the international system. Latvia recognises as one of its state priorities the facilitation of social equality, economic development in Third World countries and 
other principles. At the same time this facilitation is directly related to collective actions and is generally based on the desire to solve its own political, economic and social problems first. Therefore, it should be concluded that Latvia does not appear as a promoter of sustainable development, but in its aims, even if not directly, these aspects are present, hence the accordance with the principles of this particular category is only partial.

Foreign policy style is a set of Civilian Power principles which includes six categories. Latvia can be recognised as a collective actor, because the state's foreign policy takes collective action, accepts multilateralism as a norm and accepts the need to act as a good partner. The foreign policy goals and means included in the documents proclaim that Latvia holds in high regard multilateral relations and policy implementation through international institutions, considering them an integral part of its foreign policy actions.

In the foreign policy documents opposition to unilateral action is not clearly stated or condemned. Therefore, the state does not clearly oppose unilateralism, but at the same time, it does not exclude the importance of multilateralism. This fact could be explained by the inability of Latvia to solve all of its problems in the international system on its own, its inability to act unilaterally. The result is that the state looks for allies and tries to avoid criticising certain allied states, including the US. Hence, the conclusion is that Latvia is not in accord with this category. Latvia also does not match the category promoter of bargaining, compromise and mediation. The principles of bargaining, mediation, and the search for compromises, as well as limiting the use of force are not present in the foreign policy documents of the Republic of Latvia.

At the same time, Latvia is an active user of regimes/institutions, as the state tends to solve its problems and reach its goals through the help of international institutions. An example could be mentioned: "We will take actions so that Latvia will receive and use EU funds on conditions as advantageous as possible, that the interests of Latvia's economic development will be secured in EU legislation... Using the advantages provided by the status of EU member state, we will develop economic relations with Russia and other CIS member states." 19

Latvia tends to act as a good partner for other states in the international system, basing its relationship on solidarity. Latvia declares that it belongs to European and transatlantic structures and adheres to common, universal Western values, legal principles and history, and points to the country's accession into regional intergovernmental institutions. Latvia also acknowledges the need in some cases to implement sanctions, even if not clearly stating their relation, but only with regard to non-compliance with international norms. Yet the use of sanctions or the collective use of force, which Latvia recognises, can be based both on legitimate actions and can also be implemented without a United Nations mandate. Altogether, it can be concluded that Latvia acts as a sanction promoter.

Foreign policy instruments is the sixth set of Civilian Power principles, and should be sought in the foreign policy documents of the Republic of Latvia. Promoter of collective security is a category which includes collective security as an ideal goal and the will to limit the use of military force or the threat thereof in the international system. In this particular case the conclusion is that both the National 
Security Concept and the State Defence Concept recognise collective security as a goal that finds its expression in the stabilisation of the international system and the securitisation of the international arena. In the interim, the denial of the use of military force is not expressed clearly. It is not indicated that Latvia concentrates on the traditional understanding of international relations and consequently also on the constraint of the use of force only when internationally legitimised. The use of force only collectively is also not indicated, but the values and principles expressed in the documents confirm this tendency. It can be concluded from this that the official foreign policy of Latvia partially accords to the category of promoter of collective security.

According to its foreign policy documents, Latvia is a promoter of cooperative security. The state emphasises the principles of arms control and disarmament as a possible collective solution for security problems. Latvia's particular position, however, can be explained with reference to a small state's low military potential and a lack of resources needed to increase this capacity to fulfil the country's security needs on its own. The last category is promoter of multilateral, legitimate action/integrated instruments; this includes an understanding about the division of labour and the importance of integrated foreign policy instruments, and the backing for the integration of foreign policy instruments in general. Latvia corresponds to these criteria, while the analysed documents suggest an understanding of the need to cooperate and the potential gains from cooperation.

It can be concluded that from the twenty-one categories of Civilian Power principles, only thirteen may be found in Latvia's foreign policy documents. In four categories accordance with the Civilian Power conception is partial and in four categories it is absent. For the most part, the values expressed in the documents indicate a pragmatic rather than a normative stance that supports system change in interstate relations. The principles of cooperation, multilateralism, promotion of international institutions and international law are advocated by Latvia only on the basis of pragmatic calculations of national interest, as well as domestic social and economic welfare considerations. Accordance with the principles of Civilian Power is related to the support for international society and allied states and is not related to the active initiation of proposals and actions which are associated with the civilising of the international system or promoting principles in Kirste's classification. While the motivation for these political trends is rational and mainly grounded in Realpolitik, rather than collective interests, Latvia in general follows the principles of the Civilian Power conception; it supports civilising the international arena, even if it doesn't always express this support explicitly. This fact can be explained by Latvia's lack of experience, resources and concretely defined foreign policy aims and strategies, which leads to attempts to adjust to the dominant opinions and tendencies in the international system. Foreign policy documents are thus just attempts to absorb some of the ideas and practice which include Civilian Power principles, while adjusting them to the state's national interests. 


\section{CIVILIAN POWER PRINCIPLES IN THE RESPONSES OF INTERVIEWED FOREIGN POLICY MAKERS OF THE REPUBLIC OF LATVIA}

Latvian policy makers views should be investigated to complete the analysis of foreign policy discourse, its accordance with the Civilian Power conception or the presence of the principles of the conceptions in the discourse. The leadership/ initiative segment includes two categories: initiator/promoter and key institution member. Regarding the category of initiator/promoter almost all interviewed persons responded sceptically about Latvia's ability to initiate and lead international processes, but no one denied this possibility in the future; in this sense accordance with the category is partial. At the same time all those interviewed admitted that Latvia can play and is already playing a responsible and constructive role in international institutions. Latvia's actions in the international arena were evaluated as positive, as was engagement with international norms and organisations.

The national aims segment, which includes the category of welfare maximiser, is common in the foreign policy of Latvia, and was mentioned in all the interviews. Several foreign policy makers underlined the absence of clearly defined foreign policy goals or future visions. International aims: organisationally is a segment which includes principles of supporting international law, norms and institutions. The foreign policy of Latvia can be termed supranationalist according to the responses of all those interviewed. Respondents repeatedly noted that Latvia supports international institutions and is interested in their effectiveness and positive development.

The category of regime builder/deepener, however, is less prominent in the responses of those interviewed. Foreign policy makers emphasised Latvia's gains from participation in these institutions rather than Latvia's support for strengthening and deepening the institutions. According to one respondent, Latvia's support for deepening and widening of international regimes exists "due to the very fact that we have joined them". The next category is promoter of the rule of law - whether Latvia tends to support the development and implementation of international law. In this particular category, there are contradictory tendencies and various opinions can be identified. Several of the interviewed persons were sceptical about the implementation of international norms, at the same time expressing the hope about change in the future and indicating an understanding of the meaning and positive influence of law. In the category institution/regime enlarger, a direct and clear opinion on the necessity of the expansion of institutions could not be identified.

The international aims: substance segment includes five categories that relate to the state's goals and interests in international organisations and the international system in general. The first category is propagator of interdependent interests, where the opinions of foreign policy makers are mostly in accordance with the Civilian Power conception. In the responses of several of those interviewed the consciousness of the need to define interests in coordination with those of other states and to take other states' aims into account can be clearly identified. At the same time, there was a lack of support for collective global problem solving. It was even noted that the interests of NATO and EU member states are rather similar and therefore easy to coordinate. It was also mentioned that Latvia frequently seeks to define its national interests independently from other states, which is a negative trait. 
The next category is a value-based foreign policy, where universal values are accepted as the defining element of national interests and the main guidelines in foreign policy, and a sense of mission is present. A sense of mission was not present in any of the respondent's answers. Similarly, all those interviewed responded that the presence of universal values in the foreign policy of Latvia is connected with membership in international organisations, while noone considered that values should be the basic feature of foreign policy or that universal values could play a more influential role in Latvia's foreign policy formulation and actions. Therefore, it is possible to speak about partial accordance with a particular Civilian Power category - values are recognised, but their importance is not great enough, which shows more pragmatism than in the values-based foreign policy approach.

In the category promoter of good governance and the rule of law and a readiness to intervene in another state's domestic politics to promote and secure good governance, responses generally indicated a sceptical attitude due to a lack of resources and Latvia's own development needs. Some noted that Latvia attempts to assist other countries in solving their domestic problems, but this assistance cannot be considered sufficient to characterise Latvia as possessing a will to promote good governance.

The promoter of democratisation and human rights category can be examined together with the last category of this particular segment - promoter of sustainable development, which includes ideas about environmental protection, social equality, and economic development in Third World Countries. In both categories, the answers of those interviewed showed mainly a pragmatic approach towards helping other states, promoting democracy and human rights. This pragmatism is determined by the post-Soviet economic, political, and social transformation in Latvia and the material and human resources available. At the same time, the principles of democracy, human rights and the rule of law are supported through Latvia's activities in the European Union and other international organisations or institutions. In the views of the foreign policy makers interviewed, Latvia's capabilities and will to promote democracy and human rights in the international system and to assist Third World Countries are shaped by resource constraints.

The next Civilian Power segment is foreign policy style, which includes six categories, the first of which is a collective actor that accepts multilateralism as a norm and acts as a good partner. From the answers of those interviewed, it can be concluded that multilateralism is a self-understood norm. Similarly, several of those interviewed also concluded that foreign policy could be implemented through bilateral rather than multilateral actions, as bilateral politics are simpler for a small state. All those interviewed expressed opposition to unilateral actions.

Promoter of bargaining, compromise and mediation includes attempts to solve international conflicts using peaceful methods for reaching a consensus and multilateral bargaining, and opposing the use of unilateral means. In this category, opinions vary: some claimed that multilateral solutions are not always effective, but others were more in favour of Civilian Power and the promotion of bargaining, compromise and mediation.

Regime/institution user is a category that presumes the attempts of states to solve their problems through international institutions. The interviews point to 
the conclusion that Latvia had the will to use international institutions for solving different problems even before joining the EU and NATO. The second to last category to analyse in this block is partner - does the state base its relations with partners on solidarity and community values. Explaining Latvia's accession to Euro-Atlantic structures, respondents mention the emotional need to affirm Latvia's place in Western society and identification with Western values. Similarly, in most cases respondents recognised the principle of solidarity regarding allied countries and international institutions, although solidarity is traditionally based on pragmatic calculations.

The last category is sanction promoter that presumes the readiness to implement collective sanctions in order to secure the implementation of international norms. This particular category is present in the responses of all those interviewed except one, who as a positive aspect stated that Latvia's participation in military actions is generally based on interests other than human rights. Human rights is merely a subissue, and participation in military actions considering only human rights violations is not advantageous for the country, therefore there is no accordance with the Civilian Power conception.

The sixth segment in the Ideal Type Civilian Power Category Scheme is foreign policy instruments. The first category is promoter of collective security, where the respondents noted the importance of limiting the use of force, not avoiding it altogether, which was explained by the inability of organisations like the UN. Respondents agreed that the reduction of the use of military means in the international system is largely based on international law, but most notably collective security organisations like NATO. Therefore, accordance with Civilian Power principles is partial. The responses in a promoter of cooperative security category show support for a collective solution of security problems, in particular as regards Latvia's accession to the European Union and NATO. In the category of a promoter of multilateral, legitimate action/integrated instruments, there was no clearly stated support for the integration of foreign policy instruments, but there was some understanding of the advantages that a particular policy facilitates the enhancement of Latvia's influence on international processes. At the same time, respondents did not indicate a need for deepening the integration of foreign policy instruments.

Therefore, it can be concluded that the interviewed foreign policy makers recognise the importance of cooperation with international institutions. Respondents value the potential that cooperation creates for Latvia, at the same time showing a pragmatic and sceptical attitude towards several aspects which could facilitate the civilisation of the international system. Pragmatism and international constraints rather than attempts to implement idealistic goals define the foreign policy of Latvia in interstate relations. This is confirmed by interviews with foreign policy makers on the state's role in international relations, the country's capacity, resources, actions, and defined goals. Peace missions, participation, attempts to promote international law and the development of institutions are strictly related to the realisation of political and security interests, while idealistic and humanitarian goals are secondary. Policy makers did not demonstrate an understanding of the need to civilise the international order - there is no aim to promote changes in the international system, foreign policy is based on pragmatic Realpolitik rather than on idealistic considerations. 
At the same time it should be noted that several principles which are defined in the Ideal Type Civilian Power Category Scheme are present in the foreign policy documents and in the answers of those interviewed. However, this aspect is neither pronounced nor widely present. Nevertheless, in general it should be concluded that in the responses of the interviewed foreign policy makers of the Republic of Latvia the Civilian Power principles can be discovered, even though in most cases awareness levels are low. Most of the considerations about participation in international organisations, the reduction of the use of force in interstate relations and other aspects result from a Realpolitik evaluation of the situation, where an important aspect is not the will to change international politics for the benefit of small states, but attempts to adjust the state's foreign policy to existing obstacles and capabilities. The odds are that the responses of the interviewed foreign policy makers were partially influenced by the fact that since Latvia's accession into European and Transatlantic structures in 2004 a new foreign policy conception is still in development, foreign policy principles and goals are not clearly defined, therefore the state has not yet clearly positioned itself in the international system. The fact that a new Foreign Policy Conception has not been approved in the parliament creates the need to adjust to this particular situation as opposed to proceeding according to prescribed regulations and understandings.

\section{CIVILIAN POWER PRINCIPLES IN THE OFFICIAL STATEMENTS OF HIGH-RANKING OFFICIALS OF THE REPUBLIC OF LATVIA}

A more complete analysis of Latvian foreign policy discourse requires paying regard to the official state position pronounced by the President, the Prime Minister, the Minister of Foreign Affairs and the Saeima Committee on Foreign Policy since accession to the EU and NATO. After analysing sources since May 2004, when Latvia officially became a member of the EU and NATO, it can be concluded that several of the Civilian Power conception principles are partially or fully present in the statements of the main state officials.

The leadership/initiative block includes two categories. The initiator/promoter's category's principles are not present in official speeches and interviews; state officials do not stress any initiatives to lead any multilateral actions on a regional or global scale, merely announce support for and readiness to take part in such actions. Latvia does not position itself as an example of cooperation. At the same time, official state opinion is in support of international institutions, especially the EU and the UN, and for the reform process of the latter, suggesting that Latvia tries to play a responsible and constructive role in international institutions. Latvia belongs to a national aims block, it clearly stresses that foreign policy is aimed at achieving national interests such as welfare, income, functioning democracy, etc.: "Foreign policy is indivisible from domestic politics. One of the main domestic goals is facilitation of our welfare, social security and confidence. ${ }^{20}$

International aims: organisationally is a block with four categories, the principles of which are all present in the official state positions of the Republic of Latvia. As a supranationalist, Latvia accepts a transfer of sovereignty and a division of labour, and also supports integration and the creation of binding international 
norms. Similarly in the category of regime builder/deepener accordance can be seen, as Latvia has attempted to promote the development of international regimes and institutions by both supporting an effective reform process in the UN and ratifying the Draft Treaty establishing a Constitution for Europe, while promoting cooperation with states desiring to join transatlantic structures in the future. Latvia also supports the observance of international norms: "International law has been important for Latvia already since its foundation and also afterwards, while international law offers additional strength and influence particularly for small subjects. ... In the end I would like once again to emphasise that Latvia as a small state cannot get along without international support and the strict implementation of international law is not possible without powerful international organisations." ${ }^{21}$ Similarly, Latvia seeks to promote the enlargement of international regimes and institutions, supporting new state membership in organisations like the European Union.

International aims: substance is a Civilian Power block, the first category of which is propagator of interdependent interests. Here, Latvia's official opinion accords partially, because high-ranking state officials in their official statements, speeches and meetings do not directly stress the matching of Latvia's national interests to the concerns of other states, although they have mentioned the collective aims of the member states of international organisations. At the same time, the state supports and expresses readiness to give support to collective solving of global problems. Similarly, in the value-based foreign policy category accordance is also only partial, while from the statements it is impossible to conclude that Latvia's national interests are being defined on the basis of universal values, although common values and interests are acknowledged. A concrete and clearly defined sense of mission in the foreign policy of Latvia is also lacking.

Promoter of good governance and the rule of law/intervener is inconsistent, but present in the statements of high-ranking officials. Changes in opinion can be noted primarily after accession to the EU and NATO. From the analysis of official statements and changes in the attitude towards trends in Belarussian domestic politics, it can be concluded that Latvian foreign policy to some degree has evolved from a Realpolitik approach, where intervention in another state's domestic politics is seen as undesirable, to a more value-based attitude about the international system. Nevertheless, it should be concluded that Latvia actively positions itself as a promoter of good governance and rule of law in interstate relations with countries like Georgia, Moldova and others, stressing the will and capacity to offer help and advice. Latvia also constantly appears as a promoter of sustainable development in speeches and official meetings, stressing the need and the will to help in solving various global problems, including economic development of Third World Countries, tackling the North-South conflict, etc. By supporting the UN reform process Latvia also emphasises its potential and abilities.

The foreign policy style category block includes six categories, where the first that should be noticed is a collective actor. The statements of Latvia's state officials accord to this particular category only partially, while the state does not clearly declare support for collective action and multilateralism as a norm, but, at the same time, the country is trying to act as a good partner both for particular states and in the framework of international organisations, promising its assistance to friendly 
states and support for organisations and their activities. At the same time the second category - opponent of unilateral action - cannot be detected in official statements.

The third category is a promoter of bargaining, compromise and mediation, to which Latvia corresponds. High-ranking officials stress both the possibility and the need to solve problems in a positive-sum way, while appealing for a reduction in the use of force. However, the opposition to unilateralism is not clearly defined, but is manifested in Latvia's support and cooperation with states which frequently attempt to use unilateral political means in international relations. The role of mediator and compromiser, which is characterised by the quest to solve conflicts in different regions, is present in the state's official statements.

Latvia widely appears in the international system as a regime/institution user. The state seeks to solve its domestic and foreign policy problems through international institutions. Hence Latvia bases its relationship with other partners not only on pragmatic calculations, but also on solidarity and common values. Solidarity principles also express themselves in support for Georgia, Ukraine, and Moldova. Accordance with the Civilian Power principles in this particular category is therefore apparent. At the same time, in official statements the principles of a sanctions promoter - support for the use of sanctions in order to implement international norms, are not present.

The last block to be analysed is foreign policy instruments, where three categories are included related to international security issues. A promoter of collective security is partially present, while in the speeches of high-ranking officials support for collective security is widely mentioned, but there is no mention of the need to limit the use of military force or the threat thereof to internationally legitimate actions and collective implementation.

The second principle in the foreign policy instrument block is a promoter of cooperative security, which is generally related with disarmament, arms control and collective security issues. The high-ranking officials indirectly point to the nonproliferation of weapons of mass destruction, but not the reduction of armaments in general. Thus, Latvia's accordance in this category is only partial. The last principle of the Civilian Power conception that should be analysed is a promoter of multilateral, legitimate action/integrated instruments. Latvia's official state opinion is in accordance with this particular category. It should also be noticed that official opinion includes the integration not just of foreign policy instruments, but also other policy instruments in order to reach common, collective goals. In the statements of Latvia's high-ranking officials one also finds an understanding of a division of labour.

Consequently it can be concluded that the presence of the Civilian Power conception principles does not depend on the object of the analysis, but can be identified in various categories. In the official statements of the high-ranking officials it can clearly be seen that discourse does not include all of the categories defined by Kirste. Nevertheless, unlike the official documents and the principles conveyed in interviews with foreign policy makers, the state's official opinion is more in line with Civilian Power principles. The explanation for this can be found in the characteristics of the official statements - official statements are made in international institutions and in diplomatic meetings, and therefore more commonly touch on global problems, 
such as values and principles of cooperation etc., while less concentration is focused on Latvia's national interests and the projection of international relations through a pragmatic and rational understanding. Another explanation could be the present attempts to formulate new foreign policy goals and interests of the Republic of Latvia, hence in the official statements one can find new, previously unencountered aspects of understanding the international system and Latvia's role in it. A third explanation could be changes in the foreign policy understanding of Latvia after joining the EU and NATO related to the attainment of basic political and security goals, which set the groundwork for future economic growth. Consequently, new principles, including values, solving global environmental problems, poverty, human rights problems and other issues have entered into the foreign policy discourse.

Examining the general results of the analysis in each (see table 2) category, including all three objects of analysis, one can conclude that there is full or nearly full (a gap exists in the opinion of only one of the interviewed) accordance with Civilian Power principles. The principles are identifiable in six of twenty-one categories used in the analysis. In the foreign policy discourse of the Republic of Latvia there are clearly identifiable attempts to be a key institution member playing a constructive and responsible role in international institutions. Also in the foreign policy aims of Latvia the principles of societal and state welfare, economic development, democracy and other principles are present. The analysis of the foreign policy discourse of the Republic of Latvia confirms accordance with principles of supranationalism and a promoter of the rule of law, where the former includes the readiness and the willingness to accept a delegation of sovereignty and a division of labour, as well as support for integration and self-binding policy and international norms. Meanwhile, the latter category includes efforts for the promotion of international law. Latvia also tries to promote democracy and human rights in international politics, thus falling into the category of a promoter of democracy and human rights. The last category to which Latvia accords fully is a regime/institution user - the state seeks to solve its problems through international institutions. In none of the categories can one see a total nonconformity with Civilian Power principles, but the weak presence of Kirste's classified principles are in the initiator/ promoter category, and also in a category of a propagator of interdependent interests. In all other categories accordance with the Civilian Power conception can be classified as partial.

Therefore it can be concluded that the main accordance of Latvia's foreign policy discourse with Civilian Power is in spheres strongly related to Latvia's (as a small state's) security and welfare goals, and interests in the modern international system. Latvia's support for supranational and other international institutions, their assistance in the promotion of the rule of law, their use of institutions, their struggle for economic development and welfare maximisation as well as the support for values and the strengthening of the importance and influence of these values in international relations are typical small state interests in the international arena, while these values promote the securitisation of interstate relations in general. Accordingly - Latvia generally follows those Civilian Power principles that concur with considerations of Realpolitik. This particular fact can be explained with reference to the fact that previous national security and development goals were reached only in May 2004 and Latvia has not yet completely adjusted to the new international environment. 
Table 2

Latvia's Accordance with Civilian Power Principles as Manifested in Interviews with Policy Makers, Foreign Policy Documents and Official Statements

\begin{tabular}{|c|c|c|c|c|c|c|}
\hline $\begin{array}{c}\text { The principles of the Ideal Type Civilian } \\
\text { Power Role Category Scheme }\end{array}$ & 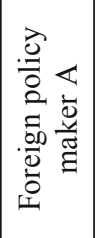 & 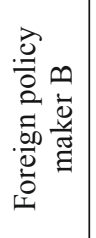 & 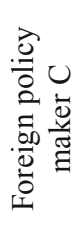 & 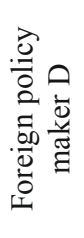 & 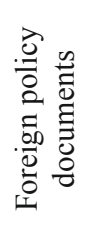 & 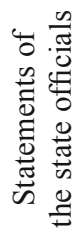 \\
\hline \multicolumn{7}{|c|}{ Leadership/ initiative } \\
\hline Initiator/promoter & $+/-$ & $+/-$ & $+/-$ & - & $+/-$ & - \\
\hline Key institution member & + & + & + & + & + & + \\
\hline \multicolumn{7}{|c|}{ National aims } \\
\hline Welfare maximiser (absolute gains) & $+/{ }^{+*}$ & + & + & + & + & + \\
\hline \multicolumn{7}{|c|}{ International aims: organisationally } \\
\hline Supranationalist & + & + & + & + & + & + \\
\hline Regime builder/deepener & + & - & + & $+/-$ & + & + \\
\hline Promoter of rule of law & + & + & - & + & + & + \\
\hline Institution/regime enlarger & $+/ \_*$ & $-*$ & $-*$ & $+/$-* $^{+}$ & + & + \\
\hline \multicolumn{7}{|c|}{ International aims: substance } \\
\hline Propagator of interdependent interests & \begin{tabular}{|l|}
$+/-$ \\
\end{tabular} & $+/-$ & $+/-$ & $+/-$ & - & $+/-$ \\
\hline Value based foreign policy & $+/-$ & $+/-$ & $+/-$ & $+/-$ & $+/-$ & $+/-$ \\
\hline $\begin{array}{c}\text { Promoter of good governance and the rule of } \\
\text { law/intervener }\end{array}$ & + & - & - & - & - & + \\
\hline Promoter of democratisation and human rights & + & + & + & - & + & + \\
\hline Promoter of sustainable developement & + & + & + & - & $+/-$ & + \\
\hline \multicolumn{7}{|c|}{$\begin{array}{ll}\text { Foreign policy style } \\
\end{array}$} \\
\hline Collective actor & \begin{tabular}{|l|}
$+/-$ \\
\end{tabular} & + & - & + & + & $+/-$ \\
\hline Opponent of unilateral action & + & + & - & + & - & - \\
\hline $\begin{array}{l}\text { Promoter of bargaining, compromise and } \\
\text { mediation }\end{array}$ & + & + & - & + & - & $+/-$ \\
\hline Regime/institution user & + & + & + & + & + & + \\
\hline Partner & + & + & $+/-$ & - & + & + \\
\hline Sanction promoter & - & + & + & + & + & - \\
\hline \multicolumn{7}{|c|}{$\begin{array}{l}\text { Foreign policy instruments } \\
\end{array}$} \\
\hline Promoter of collective security & + & + & $+/-$ & + & $+/-$ & $+/-$ \\
\hline Promoter of cooperative security & $+/-$ & $+/-$ & $+/-$ & + & + & $+/-$ \\
\hline $\begin{array}{l}\text { Promoter of multilateral, legitimate action/ } \\
\text { integrated instruments }\end{array}$ & $+/-$ & $+/-$ & $+/-$ & + & + & + \\
\hline
\end{tabular}

' +' - Matches with the Civilian Power principles;

' - '- Doesn't match with the Civilian Power principles;

' +/- ' - Partly matches with the Civilian Power principles;

' * - Response doesn't allow for exact conclusions about accordance with the Civilian Power conception. 


\section{CONCLUSIONS}

The theoretical analysis of the interaction of small states and Civilian Power confirmed that for small states the civilisation of international politics is beneficial, as it helps them not only to attain their interests, but also to increase their influence and prestige in international politics. Small states are interested in the promotion of international norms, collective and cooperative security, and economic development consistent with Civilian Power principles. In order to enact a civilised international order, great powers also require support from small states. In the traditional understanding of small state resources and influence in international politics, small states cannot be civilian powers. Yet this assumption could be flawed, as, from a theoretical perspective, small states are also interested in the civilising of international relations. Moreover 'small power' type states, due to their sufficiency of resources, could further the civilising of international politics.

It can be concluded that the expression of Civilian Power principles in different objects of analysis varies. Differences appear not just between the objects of analysis, but among foreign policy makers' opinions. From the foreign policy documents of the Republic of Latvia, it can be concluded that all of the Civilian Power principles are not present. This situation can basically be explained by the fact that Latvia does not yet have a new Foreign Policy Conception that would clearly define state goals and strategies in the international system after joining the EU and NATO. Accession has brought about significant changes in the international standing of Latvia, creating new types of challenges and opportunities, solving several of its previous problems and allowing alternative interests and approaches to develop in the state's foreign policy. Accordingly, in the new foreign policy document new types of principles and understandings regarding the promotion of values in the international system, the solution of global problems, etc. can appear.

The second object of analysis was interviews with foreign policy makers in the Republic of Latvia and the people whose work directly influences the basic vectors of Latvian foreign policy. In general it can be concluded from the answers of the people interviewed that a Realpolitik approach is more widespread than the will to support values or the civilising of the international system. Support for several civilian power principles, including the strengthening of values, interstate cooperation and the growth of the influence of international institutions, was motivated by a pragmatic philosophy. Moreover, if there was strong support for international institutions, international security politics, and welfare maximisation, then it was pragmatic and aimed toward the achievement of national interests. At the same time, support for values and lower gain facilitating categories were weaker.

The third object of analysis was official opinions expressed by high-ranking officials and the Saeima Committee on Foreign Affairs. Here, one notes a more frequent expression of values. Foreign policy is more motivated by values and principles, than by pragmatic national interest. It should be taken into account that a new Foreign Policy Conception of the Republic of Latvia is still in development; therefore, increased interest is possible in value promotion, international security, economic and solving other problems rather than just attempts to manage Latvian domestic issues. These changes could also be defined by the new international situation in which Latvia finds itself after joining Euro-Atlantic structures. 
In general it can be concluded that the main thesis of this essay is confirmed in the foreign policy discourse of the Republic of Latvia all the Civilian Power principles are present but the dominant approach is still Realpolitik; in none of the categories can a complete non-compliance with the Civilian Power conception be identified. At least partial accordance with Civilian Power principles is detected in the foreign policy discourse of the Republic of Latvia. Yet in the foreign policy of Latvia the dominant approach is Realpolitik, not idealism. The presence of the Civilian Power conception principles depends on a rational, Realpolitik evaluation of the situation.

The dominance of Realpolitik principles in the foreign policy discourse of Latvia can also be explained by an insufficient level of international socialisation Latvia has not fully accepted or understood the importance of international values and norms in interstate relations. Latvia has not fully incorporated the liberal norms of interstate relations of Western Europe and the EU in general. Latvia as a rational actor has basically accepted those norms which were important from the Realpolitik point of view. At the same time, the analysis suggested that there is an increasing influence in the foreign policy of Latvia of the values, principles of interstate relations and methods of problem solving expressed by the EU. This phenomenon has been accentuated since Latvia joined NATO. Such international socialisation is likely to gradually continue.

The second most important conclusion from the interviews is that the lack of resources strongly defines Latvia's approach, which is to adjust to obstacles, not change the international environment or try to civilise it. The lack of resources is the main factor constraining Latvia's active participation in international politics, global problem solving, promoting good governance protection. Therefore, it can be concluded that Latvia could not be recognised as a Civilian Power in the traditional understanding of the term, as one of the main elements is the emphasis on the presence of resources to facilitate the civilising of international politics. The second factor that should be mentioned is that foreign policy is dominated not by Civilian Power principles or the will to civilise international relations, but by a Realpolitik approach to interstate relations. As mentioned earlier, this could change as a result of international socialisation.

This essay suggests that the Civilian Power conception can also be used for analysing a small state's foreign policy. The main difference between great powers and small states is that the latter lack the resources needed to promote the civilisation of international politics. Therefore, the Civilian Power conception in the future should focus not only on the foreign policy analysis of great powers, but also on small states, the practical side of foreign policy, and especially support for implementing such a policy and the use of foreign policy instruments appropriate to Civilian Power conceptions.

In order to facilitate the implementation of the Civilian Power ideal-type in the future, there is a need for wider support of international organisations to states (including small states) in implementing the Civilian Power conception in practice through greater limits on military resources, development of international law, international institutions and values, and also furthering trust in interstate relations which is an inalienable aspect of successful cooperation. The foreign 
policy of small states in general could be aimed not just at further cooperation, but also at the promotion and propagation of universal values. Thereby small states, including Latvia, could convey the principles of morality and justice. In 'the Melian dialogue' Thucydides already noted that smaller actors tend to secure a desirable environment.

\section{BIBLIOGRAPHY}

Baker, Fox A. The Power of Small States: Diplomacy in World War II (Chicago: University of Chicago Press, 1959).

Buzan B. People, States, and Fear. An Agenda for International Security Studies in the PostCold War Era (New York: Harvester Wheatsneaft, 1991).

Duchêne F. "Die Rolle Europas im Weltsystem. Von der regionalen zur planetarischen Interdependenz" Zivilmacht Europa - Supermacht oder Partner? Hrsg. von M. Kohnstamm, W. Hager (Frankfurt: Suhrkamp, 1973), pp. 11-35.

Germany as a Civilian Power? The Foreign Policy of the Berlin Republic, ed. by S. Harnisch, H. W. Maull (Manchester: Manchester University Press, 2001).

Small States in World Politics: Explaining Foreign Policy Behavior, ed. by J. A. K. Hey (Boulder: Lynne Riener Publishers, 2003), pp. 1-11.

Höll O. "Introduction: Towards a Broadening of the Small States perspective," in Small States in Europe and Dependence, ed. by O. Höll (Wien: Braumüller, 1983), pp. 13-34.

Kirste K., Maull H. W. "Zivilmacht und Rollentheorie," Zeitschrift für Internationale Beziehungen. (1996) 3. Jg., Heft 2. - S, pp. 283-312.

Knudsen O. F. "Analysing Small-State Security: The Role of External Factors," in Small States and the Security Challenge in the New Europe, ed. by W. Bauwens, A. Clease, O. F. Knudsen (London: Brassey's, 1996), pp. 3-20.

Maull H. W. "Zivilmacht Bundesrepublik Deutschland. Vierzehn Thesen für eine neue deutsche Aussenpolitik,"Zeitschrift für Internationale Politik. - Europa-Archiv. (1992), Folge 10. - S, pp. 269-278.

Pfeil F. Zivilmacht für die Menschenrechte? Menschenrechte in der deutschen Außenpolitik 1990-1998 (Hamburg: Kovač, 2000).

Rittberger V. "Deutschlands Aussenpolitik Nach Vereinigung. Zur Anwendbarkeit Theoretischer Modelle Der Aussenpolitik: Machtstaat, Handelstaat Oder Zivilstaat?" Friedenspolitik In Und Für Europa, Hrsg. Von W. Bergem (Opladen: Leske+Budrich, 1999), pp. 83-106.

Senghaas D. Abschreckung und Frieden (Frankfurt am Main: Europäische Veranstalt, 1969).

Sens A. "Small-State Security in Europe: Threats, Anxieties, and. Strategies After the Cold War,"Small States and the Security Challenge in the New Europe, ed. by W. Bauwens, A. Clease, O. F. Knudsen (London: Brassey's, 1996), pp. 74-99.

Tewes H. "Das Zivilmachtkonzept und der Theorie der Internationalen Beziehungen," Zeitschrift für Internationale Beziehungen (1997). - 4. Jg. - Heft 2. - pp. 347-359.

Tewes H. Germany, Civilian Power and New Europe. Enlarging NATO and the European Union (New York: Palgrave Macmillan, 2002).

Väyrynen R. "Small States in the New European Context," Small States and the Security Challenge in the New Europe, ed. by W. Bauwens, A. Clease, O. F. Knudsen (London: Brassey's, 1996), pp. 109-121.

Väyrynen R. "Small States on Different Theoretical Traditions of International Relations Research," Small States in Europe and Dependence, ed. by O. Höll (Wien: Braumüller, 1983), pp. 83-104. 
Vital D. The Inequality of States. A Study of the Small Power in International Relations (Westport: Greenwood Press, 1980).

Wiberg H. "Security Problems of Small Nations," Small States and the Security Challenge in the New Europe, ed. by W. Bauwens, A. Clease, O. F. Knudsen (London: Brassey's, 1996), pp. 21-41.

\section{ENDNOTES}

1 Duchêne F. Die Rolle Europas im Weltsystem. Von der regionalen zur planetarischen Interdependenz // Zivilmacht Europa - Supermacht oder Partner?/ Hrsg. von M. Kohnstamm, W. Hager. - Frankfurt: Suhrkamp, 1973. - pp. 11-35.

2 Elias N. Über den Prozess der Zivilisation: soziogenetische und psychogenetische Untersuchungen. - Bd. 2. -Wandlungen der Gesellschaft Entwurf zu einer Theorie der Zivilisation. - Baden-Baden: Suhrkamp, 1976.

3 Senghaas D. Abschrenkung und Frieden. - Frankfurt am Main: Europäische Veranstalt, 1969. - 83. S.

4 Maull H. W. German Foreign Policy Post-Kosovo // German Politics. - Trier: University of Trier. - August 2000. - Vol. 9 - No. 2. - p. 14.

5 Rittberger V. Deutschlands Aussenpolitik Nach Vereinigung. Zur Anwendbarkeit Theoretischer Modelle Der Aussenpolitik: Machtstaat, Handelstaat Oder Zivilstaat? // Friedenspolitik In Und Für Europal Hrsg. von W. Bergem. - Opladen: Leske+Budrich, 1999. - 83-106.

${ }^{6}$ Kirste K., Maull H. W. Zivilmacht und Rollentheorie // Zeitschrift für Internationale Beziehungen. - 1996. - 3. Jg. - Heft 2. - S. 301-3.

7 Maull H. W. Germany's Foreign Policy post-Kosovo: still a 'Civilian Power'? // Germany as a Civilian Power? The Foreign Policy of the Berlin Republic/ Ed. by S. Harnisch, H. W. Maull. - Manchester-New York: Manchester University Press, 2001. - pp. 124-6.

8 Source: 1) Maull H. W. Germany's Foreign Policy Post-Kosovo: Still a "Civilian Power"? // Germany as a Civilian Power? The Foreign Policy of the Berlin Republic/ Ed. by S. Harnisch, H. W. Maull. - Manchester-New York: Manchester University Press, 2001. - pp. 124-126.; and 2) Pfeil F. Zivilmacht für die Menschenrechte? Menschenrechte in der deutschen Außenpolitik 1990-1998. - Hamburg: Kovač, 2000. - S. 23-6.

9 Baker Fox A. The Power of Small States: Diplomacy in World War II. - Chicago: University of Chicago Press, 1959. - p. 1.

10 Hey A. K. J. Introducing Small State Foreign Policy // Small States in World Politics: Explaining Foreign Policy Behavior/ Ed. by J. A. K. Hey. - Boulder: Lynne Riener Publishers, 2003. - p. 1.

11 Sens A. Small-State Security in Europe // Small States and the Security Challenge in the New Europe/ Ed. by W. Bauwens, A. Clease, O. F. Knudsen. - London-Washington: Brassey's, 1996. - p. 85.

12 Väyrynen R. Small States in the New European Context // Small States and the Security Challenge in the New Europe/ Ed. by W. Bauwens, A. Clease, O. F. Knudsen. - LondonWashington: Brassey's, 1996. - p. 114.

13 Hey A. K. J. Introducing Small State Foreign Policy // Small States in World Politics: Explaining Foreign Policy Behavior/ Ed. by J. A. K. Hey. - Boulder: Lynne Riener Publishers, 2003. - p. 5.

14 Wiberg H. Security Problems of Small Nations // Small States and the Security Challenge in the New Europe/Ed. by W. Bauwens, A. Clease, O. F. Knudsen. - London-Washington: Brassey's, 1996. - p. 36. 
15 Buzan B. People, States, and Fear. An Agenda for International Security Studies in the Post-Cold War Era. - New York-London-Toronto-Sydney-Tokyo-Singapore: Harvester Wheatsneaft, 1991. - pp. 98-9.

16 Harnisch S. Maull H. W. Conclusion: "Learned its Lessons Well? Germany as a Civilian Power Ten Years after Unification // Germany as a Civilian Power? The Foreign Policy of the Berlin Republic/Ed. by S. Harnisch, H. W. Maull. - Manchester-New York: Manchester University Press, 2001. - p. 140.

17 The Declaration of the Intended Activities of the Cabinet of Ministers of December 1st 2004. - The State Chancellery, 2002. - http://www.mk.gov.lv/index.php/?id=38 (accessed 01.05.2006).

18 The Declaration of the Intended Activities of the Cabinet of Ministers of December 1st 2004. - The State Chancellery, 2002. - http://www.mk.gov.lv/index.php/?id=38 (accessed 01.05.2006).

19 The Declaration of the Intended Activities of the Cabinet of Ministers of December 1st 2004. - The State Chancellery, 2002. - http://www.mk.gov.lv/index.php/?id=38 (accessed 01.05.2006).

20 „Foreign Policy as a Part of National Politics" A speech of the Minister of Foreign Affairs Artis Pabriks on a plenary session of the 64th conference of the University of Latvia in Riga, February 1st 2006. - The Ministry of Foreign Affairs of the Republic of Latvia, 2006. - http://www.mfa.gov.lv/lv/Jaunumi/Runas/2006/februaris/01/ (accessed 01.05.2006).

${ }^{21}$ A report by the Minister of Foreign Affairs Artis Pabriks "Strategic Interests and Foreign Policy Priorities of Latvia in 21st Century" in Riga, October 22nd 2005. - The Ministry of Foreign Affairs of the Republic of Latvia, 2005. - http://www.mfa.gov.lv/lv/Jaunumi/ Runas/2005/Oktobris/07-2-copy/ (accessed 01.05.2006). 


\section{Krievijas institucionālās attīstības alternatīvas 1993. gadā}

\section{Ruslans Osipovs}

\section{IEVADS}

Lai gan Krievijas Konstitūcijas un institucionālā ietvara izvēle notikusi pirms vairāk nekā 13 gadiem - 1993. gadā, šīs valsts turpmākā attīstība būs lielā mērā atkarīga no tā, kādā veidā tiks īstenots Pamatlikumā ,ietvertais” prezidenta pilnvaru potenciāla apjoms. 2007. gada parlamenta un 2008. gada prezidenta vēlēšanas ir kārtējā pārbaude demokrātijas līmenim Krievijā: no tā, kādā veidā iespējami mainīsies pilnvaru balanss, būs atkarīga kaimiņvalsts nākotne. Krievijas pēdējo 15 gadu politiskā vēsture pierādīja, ka institucionālais potenciāls var realizēties vismaz divos scenārijos - savstarpējos konfliktos starp prezidentu un parlamentu Borisa Jel̦cina laikā un abu institūtu sadarb̄̄ibā Vladimira Putina prezidentūras laikā. 2008. gada prezidenta vēlēšanas Krievijā aktualizē šīs valsts institucionālās iekārtas problemātikas izpēti un l̦auj pievērsties kaimiņvalsts attīstības prognozēm.

Krievijas institucionālās iekārtas būtības izvērtējums ir lietderīgs arī tāpēc, ka analīze l̦auj veidot analogijas ar citām bijušajām PSRS valstīm, piemēram, Ukrainu, kuras politiskā nestabilitāte un īpaši situācijas specifika 2007. gada pavasar $\overline{1}^{1}$ atgādina Krievijas institucionālos konfliktus B. Jel̦cina laikā, īpaši 1992.1993. gadā. Krievijas institucionālo konfliktu cēloṇu un seku, kā arī to regulēšanas prakses analīze var veidot priekšnosacījumus Ukrainas politiskās situācijas prognozēm.

Tā kā institucionālā iekārta ir formāls ietvars, kas nodrošina kopējas attīstības pamatvektoru un kura robežās mijiedarbojas politiskie "aktieri”, ir pamats apgalvot, ka cita veida institucionālās iekārtas akceptēšana Krievijā 1993. gadā būtiski mainītu kaiminvvalsts turpmāko attīstību. Tādējādi š̄ pētījuma galvenā uzmanība tiks pievērsta jautājumam, ,kādi faktori ietekmēja Krievijas institucionālās iekārtas izvēli 1993. gadā", respektīvi, tiks analizēts, kāpēc Krievijā tika dibināta prezidentāli parlamentārā sistēma. Vai bija iespējami institucionālās iekārtas izvēles alternatīvie varianti, piemēram, - Krievijas kā parlamentārās valsts tiesiskā nostiprināšana?

\section{KRIEVIJAS INSTITUCIONĀLĀ IEKĀRTA KĀ ATŠK়IRĪGU FAKTORU MIJIEDARBĪBAS REZULTĀTS}

Institucionālās pieejas galvenais trūkums Krievijas prezidenta un parlamenta savstarpējo attiecību pētīšanā ir saistīts ar to, ka ar šīs pieejas palīizzību nav iespējams izanalizēt formāli un strukturāli līdzīgu institūciju funkcionēšanas atšksirības dažādu 
sociāli kulturālo apstākḷu kontekstā. Piemēram, vairāku Latīṇamerikas valstu institucionālo iekārtu veidošanas procesā bija aizgūta (pārņemta) ASV institucionālās iekārtas attīstības pieredze, tomēr minēto valstu politiskās prakses būtiski atšķiras, un ar jaunievedumu palīdzību neizdevās stabilizēt Latīṇamerikas valstu politiskās sistēmas. Šī iemesla dēḷ, analizējot prezidenta varu Krievijā, nepieciešams ne tikai vērsties pie konstitucionālisma pamatiem un varas formālajām struktūrām, bet izskatīt un izanalizēt tādus faktorus kā uzvedības stereotipi, iekšējā vide, sociālās preferences, sabiedrības politiskā kultūra, tradīcijas utt.

Krievijas institucionālās iekārtas izvēles īpatnības ir skaidrotas ar vairākiem vēsturiski filozofiskiem un uzvedības tradīciju faktoriem. Vēsturiski filozofisko faktoru vidū ir gan absolūtisma un monarhijas tradīcijas, gan negatīva parlamentārā pieredze, gan Krievijas politiskās filozofijas specifika, gan specifiskā politiskā kultūra Krievijā. Turklāt svarīgas ir tādas dimensijas kā iepriekšèjā PSRS politiskā režīma specifika, cīṇa starp parlamentu un prezidentu, kā arī Krievijas pirmā prezidenta Borisa Jel̦cina personiskā loma Krievijas politiskajos procesos.

Pārstāvniecības institūcijas esamība valstī ir svarīgs indikators politiskā režīma raksturojumam: valstis, kurās nepastāv prezidenta institūts, var uzskatīt par demokrātiskām, savukārt tās valstis, kurās nav institualizēta pārstāvnieciskā institūcija, nav uzskatāmas par demokrātiskām valstīm. Krievijas prezidenta pilnvaru apjoms saskaņā ar esošo Konstitūciju piedāvā daudziem politologiem iespējas šaubīties ja ne par iekārtas atbilstību demokrātijas ietvariem, tad vismaz par parlamentāro institūtu stabilitāti Krievijā. ${ }^{2}$ Viens no pārmetumiem bijušajam prezidentam Borisam Jel̦cinam, ko joprojām izsaka gan kreisie, gan labējie politiskie spēki, ir 1993. gadā pieņemtā Konstitūcija, kurā sašaurināta parlamenta loma.

\section{PARLAMENTĀRISMA TRADĪCIJAS KRIEVIJĀ LĪDZ XX GADSIMTA SĀKUMAM}

Raksturojot Krievijas politiskos procesus retrospektīvajā aspektā, nepieciešams atbildēt uz jautājumu, - cik lielā mērā parlamentārisms vispār ir raksturīgs Krievijai? Pastāv viedoklis, ka „no tautas apziņas izrādījās iznīdēta pati atmiņa par demokrātiskās ekonomikas un sabiedrības iekārtas funkcionēšanas pamatiedīgl̦iem, attiecīgas normas un cilvēku uzvedības tradīcijas, sabiedrības loma tiesību, tiesas, privātīpašuma, varas pārstāvniecībā, vārda brīvība utt., kas pakāpeniski sāka ieviesties pirmsrevolūcijas Krievijas sociālajos audos"3. Vēsture liecina, ka Krievijas pagātnē visām politiskajām sistēmām raksturīga spēcīga izpildvaras koncentrācija vienas personas rokās; carisma periodā centralizētā vara bija organizēta hierarhijas bāzē, cara amats bija reliǵiski leǵitimēts, un politiskā sistēma bija bāzēta uz viņa lēmumu pieņemšanas prerogatīvām ${ }^{4}$. Tautas pārstāvības un pārstāvības iestāžu veidošanas idejām bija vieta Krievijā jau no viduslaikiem, jāatceras, ka runas par tautas suverenitāti Rietumu izpratnē nebija un tauta bija identificēta ar knazistes, valsts iedzīvotāju kopumu. Šādas pārstāvniecības izpratne bija attiecināta uz privilegètām kārtām. Sākumā bija izveidotas vietējās pārstāvniecības iestādes (mūsdienu terminologijā runājot). Visas Krievijas mērogā (federālajā līmenīmūsdienu izpratnē) bija izveidotas konsultatīvas iestādes - bajāru domes. Šādu iestāžu uzdevums bija valsts jautājumu apspriešana, taču jau tanī laikā var runāt 
par pārstāvniecību, jo bajāru domes locekḷi pārstāvēja savas kārtas. 19. gadsimtā bija īstenoti mēǵinājumi attīstīt pārstāvnieciskās institūcijas - no Zemstes kongresa (Zemskij Sobor) līdz ievēlēto padomju un asambleju veidošanai. Tomēr parlamentārās tradīcijas bija ieviestas Krievijā XX gadsimta sākumā, kad bija pieṇemts lēmums izsludināt vēlēšanas un izveidot parlamentu - Valsts Domi. Lai gan Valsts Domes veidošana XX gadsimta sākumā ir skaidrojama ar Krievijas impērijas politiskā režīma stabilizācijas mēginājumiem, jaunizveidotais institūts jau tūlīt pēc izveidošanas kḷuva par nestabilitātes avotu, un toreizējā situācijā Valsts Domei neizdevās pierādīt savu dzīvotspēju.

\section{KRIEVIJAS POLITISKĀS KULTŪRAS UN KRIEVU FILOZOFIJAS FAKTORI}

Politiskās kultūras dimensija. Izmantojot Gabriela Almonda un Sidneja Verbas klasifikācijus: politiskā kultūra jāsaprot kā ,indivīda attieksme pret politisko sistēmu un tās dažādām dal̦ām, kā arī pret paša lomu šinī sistēmā”, var apgalvot, ka Krievijas (piemēram, XV-XVI gadsimtā) politiskā kultūra atbilda diviem tipiem, kuri ir raksturīgi tradicionālajām sabiedrībām - patriarhālajam jeb tradicionālajam $\left(\right.$ parochial $^{6}$ ) politiskās kultūras tipam, un atkarības jeb pavalstnieciskajai (subject) politiskajai kultūrai. Politiskās kultūras pirmā tipa (parochial) iezīme ir orientācija uz lokālā rakstura vērtībām (klana, ǵimenes, dzimtes vērtības), un tā izpaužas lokālā patriotisma, ǵimenes attiecību, korupcijas formā. Šis tips tiek raksturots šādi: „.. politiskās orientācijas nav atdalītas no reliğijas vai sociālajām orientācijām"’ . Šo raksturojumu var attiecināt uz Krievijas valsti (piemēram, XVI gadsimtā). Lìdz ar to tai piemīt ar̄̄ politiskās kultūras nākamā tipa (subject) iezīmes. Šāda tipa politiskajai kultūrai ir raksturīga indivīda lielāka informētība par politiku nekā patriarhālajai, taču pret politisko sistēmu ir pasīva attieksme: indivīds uzskata sevi par varas darbības pasīvu objektu, baidās no varas diktāta un gaida labumu. Krievzemē bija „specializētas politiskās lomas” (piemēram, Maskavas valstī - cars, bajāri, diakoni utt.), un pavalstnieki pauda noteiktu attieksmi pret varu, neapšaubīja arī tās tiesības pārvaldīt.

Tā kā valsts tika identificēta galvenokārt ar valdnieku', lēmumu pieñemšana bija koncentrēta cara rokās, un politika tika uztverta kā vienotais, nedalītais kopums. Konflikti šī kopuma iekšienē (piemēram, nesaskaņas bajāru vidū tika nopeltas kā velna intrigas: respektīvi, domas par apdomātu cīņu par varu nebija. Dominēja uzskats, ka konflikti izjauc Krievijas valsts „mieru” un tos inspirē nelabais. Cīña par varu valsts iekšienē bija pretlikumīga rīcība: varu nedrīkst sagrābt, jo Dievs varas pilnvaras ir uzticējis Maskavas caru dzimtei, un tās pāriet no tēva uz dēlu (par to ir runājis Ivans Bargais savos vēstījumos). Šajā kontekstā svarīgi atzīmēt Maskavas valsts politiskās kultūras īpatnību, kuru formulējis ASV eksperts Krievijas politikā Edvards Kīnans: „Maskavas valsts politika bija statusa, nevis funkcijas politika" .

Kolektīvisma un individuālisma problemātika Krievijas politiskajā domā. Diskusija par parlamentārisma vietu Krievijas politiskajā izkārtojumā rod savus avotus jau XIX gadsimtā slavofilu un rietumnieku diskusijās. Gan rietumnieku, gan slavofilu diskusiju objekts bija jautājumi par Krievijas un Rietumeiropas savstarpējam attiecībām, par veco (pirms Pētera I) un jauno Krieviju, par Krievijas 
vēsturiskā ceḷa īpatnībām un Krievijas nākotni. Rietumnieku (P. Čaadajevs, V. Beļinskis, A. Hercens) politiskās filozofijas centrā bija pārliecība, ka Rietumu kultūra ir daudz progresīvāka nekā Krievijas kultūra. Pēc C̆aadajeva domām, Krievija vairāku apstākḷu dēḷ - pareizticības izplatīšanās, tatāru-mongoḷu jūgs, pati verdzība - dzimtbūšanas - ,izkrita" no Rietumu pasaules attīstības procesa un atrodas vēsturiskā progresa strupcel̦ā. Rietumnieki par savu ideālu uzskatīja Rietumu parauga likumdošanas parlamentu, bet slavofili (A. Homjakovs, I. Kirijevskis, K. Aksakovs, J. Samarins) - parlamentu vai Zemstes Soboru (Kongresu) tā tradicionālajā variantā. Slavofilu politiskās domas centrā bija pārliecība, ka kaitīga ir nevis absolūtā monarhija, bet saiknes pazaudēšana starp monarhu un tautu. Tāpēc likumdošanas apspriešanas institūta - Sobora, kura darbības pamats nav kārtu kritērijs, - institucionalizācija varētu aizpildīt šo robu, likt pamatu jaunās Krievijas veidošanai un tajā pašā laikā tradicionālās Krievijas atjaunošanai.

Tomēr slavofilu Sobora izpratnei nav nekā kopīga ar Rietumu vērtībām. Piemēram, dz̄ives regulēšanai ar Konstitūciju krievu tauta nebija gatava: „tautas Konstitūcija pagaidām nav iespējama, savukārt, ja Konstitūcija nav tautas, tā ir mazākuma valdīšana, mazākuma, kurš darbojas bez vairākuma uzticības; tā ir meli un krāpšana" (J. Samarins). Slavofilu pozīcija bija pirmām kārtām vērsta uz organiskās saiknes akcentēšanu starp personību un kopumu jeb veselumu - Baznīcu, kopienu. Atsevišķs cilvēks atrod sevi garīgajā vienotībā ar brāliem, pārvarot „,savas garīgas vientulības bezspēcīgumu" (A. Homjakovs). Slavofili izmanto priekšstatu par „sakopojošo (sobornuju) (iekšēji organizētu) personību”. Šāda tipa personība ir pretstats Rietumu individuālismam un utilitārismam. Respektīvi, saskaņā ar šādu pozīciju cilvēks, garīgi piederošs kopumam, ir augstākās tikumības nesējs. Pazaudēta tikumība tiek atjaunota dvēseles spēku sakopošanas procesā. Vēl viens slavofilu filozofijas elements ir cilvēciskās dvēseles veseluma (kurā prāts un ticība ir identificēti) un Rietumu racionālo zināšanu (kuram nav saskarsmes ar tikumību) pretstatǐšana. Rezultātā rodas īpatnēja koncepcija, kuras centrā ir t. s. „krievu ideja”, t. i., priekšstats par īpašu garīgu cel̦u, kas piemērots vien̄̄gi Krievijai. Pēc slavofilu domām, Krievija ir spējīga atjaunot personības nedalāmību, kura ir pazaudēta Rietumos. Īpaša uzmanība slavofilu politiskajā domā ir veltīta Krievijas tradicionālajam raksturam - attieksmei pret reliǵiju, kopienai, caram. Tautas pārstāvniecības modeli vai ,parlamentārisma” ideju mūsdienu izpratnē slavofili skatīja caur „tautas augstākās gudrības” un kopienas izpratni. Slavofili uzstājās par Zemstes Soboru darbības atjaunošanu, kuru, viņuprāt, raksturo vienprātība un kurai bija sveša cīṇa starp frakcijām un kārtām ${ }^{10}$. Slavofili izstrādāja Krievijas vēsturiskās savdabības koncepciju, kurā Krievija de facto tika pretstatîta Rietumu civilizācijai.

Atšḳirībā no Rietumiem, kur valsts veidojas vardarbības un iekarošanas ceḷā, Krievijā valsts veidošanas iemesls bija „varas brīvprātīg $\bar{a}$ misija”, brīvprātīgas saskaņas cel̦a izvēle, kurā tika panākta varas un tautas vienprātība. Šāda tipa attiecības izslēdz naidu starp kārtām un Rietumos izplatītās pretrunas starp tautu un varu. Meklējot izeju no krīzes, Rietumu sabiedrības bija spiestas slēgt kontraktu sabiedrisko līgumu. Tādējādi naids nebija likvidēts, bet ,ielikts” sabiedrības iekšienē, ierobežots ar formālo likumu, nevis ar brālīgo saskaņu un vienprātību. Savukārt, slavofilu koncepcija uzsver, ka Krievijā attiecības starp tautu un varu, starp kārtām ir veidotas nevis juridiska akta cel̦ā, bet cilvēcisko attiecību ceḷā. Slavofilu ideāls ir 
cilvēks kā "kopīgas sajūtas elements", viens no kopienas locekḷiem, ticīgs cilvēks, kurš ir pārṇemts ar "хоровым чувством, соборностью". Turpretim rietumnieku personības ideāls ir atšķirīgs. Šāds ideāls ir neatkarīgs cilvēks, individuālists, taču nevis egoistisks individuālists-patmīlis, bet saprotošs egoists, kurš darbojas, apzinoties, ka apkārt ir līdzīgas neatkarīgas un suverēnas personības. Rietumniekiem galvenais cilvēkā ir civilizācijas sajūta, opozīcija mežonīgajam, haotiskajam. Tāda opozīcija paredz racionālu pieeju, t. i., pārdomātu lēmumu, nevis emociju pārsvaru. Šāda rakstura personība var eksistēt tikai ārpus vardarbības un piespiešanas. Respektīvi, rietumnieciskais virziens, jau ar personības ideāliem un interesēm, loǵiski iestājas par tiesiskās valsts nodibināšanu Krievijā, liberālu sociālo un politisko reformu uzsākšanas nepieciešamību. Krievijas apstākḷos tās bija - dzimtbūšanas tiesību atcelšana vai vismaz mīkstināšana, valsts aparāta reformas īstenošana. Ideāli - valsts varu sadale, tolerance pret citu viedokḷiem, garantija pret patvalıu - šādus Rietumeiropas sociālās dz̄ives elementus rietumnieki projicēja Krievzemes apstākḷos. Šajā ziṇā rietumnieki gan psiholog̣iski, gan politiski sagatavoja 60. gadu reformas - dzimtbūšanas tiesību atcelšanu, tiesu, militārās, pilsētu reformas. Rietumnieku strāva, kā arī slavofilisma strāva XIX gadsimta 40.-50. gados izveidoja noteiktu opozīciju pastāvošajai iekārtai.

,,Tautiskuma” un ,, sobornostj” tradīciju nozìme. Viena no Krievijas politiskās kultūras centrālajām idejām, kura eksistēja un bija aktuāla līdz XX gadsimta sākumam, bija t. s. „tautiskuma” (narodnostj) izpratne. „Tautiskuma” ideja kopā ar patvaldības (samoderžavije) un pareizticības idejām kopā veidoja Krievijas imperatora Nikolaja II oficiālās politiskās doktrīnas trīs komponentus. Turklāt pie „tautiskuma” idejas apelēja ne tikai Krievijas oficiālā vara, bet arī opozicionārie spēki. Kaut vai „tautiskuma” traktējums, būtība, saturs un nozīme, kā arī tautas intereses tika izprastas un traktētas atšksirīgi, pie tautiskuma idejas kā politiskās darbības augstākā principa apelēja gan reakcionārie, gan revolucionārie spēki. Kopumā tautiskuma idejas izpratne bija saistīta ar pārliecību, ka tautas nozīme nevar būt reducēta tikai līdz cilvēku kopienai, kurai nepieciešama augstākas šķiras patronāža. Tieši otrādi, tauta (narod) ir īpašas, specifiskas augstākās gudrības iemiesojums un nesējs, turklāt šì gudrība ne vienmēr ir pieejama izglìtotajiem cilvēkiem, jo to var uztvert ar citām kategorijām, piemēram, dvēseli u. c. (N. Berdjajevs, Loskijs, L,. Tolstojs).

Krievijas tautiskuma idejas integrācija politiskajā dz̄ivē veido specifisku, vienīgi Krievijai piemītošo uzstādījumu, kurš nozīmīgi atšķ̄īās no tautas suverenitātes izpratnes Rietumu politisko tradīciju garā. Rietumu politiskā tradīcija apelē pie indivīda pašvērtības kā tautas suverenitātes izpausmes, bet Krievijas politiskā tradīcija neidentificē tautu, kura ir augstākās gudrības un taisnības nesēja, ar konkrēto indivīdu, kurš ir disponēts maldiem un kḷūdām, it īpaši ņemot vērā izglītības līmeni Krievijā. Veidojas paradoksāla situācija: no vienas puses, tautai pieder augstākā taisnība un gudrība, bet, no otras puses, tauta - stratificēta kā indivīids un sociālās grupas - nav spējīga risināt valsts mēroga uzdevumus.

Tādējādi tautas vairākuma pašvērtība nevar kḷūt par tautas gribas īstenošanas demokrātisko procedūru priekšnoteikumu. Demokrātiskās procedūras ir nepieciešamas dažādu sociālo grupu atšķirīgu interešu saskaņošanai un apvienošanai sabiedrības vairākuma apmierināšanai, bet Krievijas tradīcijās uzskata tautu kā kopējo masu, noteiktu nedalītu kopumu un noliedz jebkurus mēginājumus strukturēt 
sabiedrību. Šādos apstākḷlos nav nepieciešamības meklēt savstarpēji saskaņotu lēmumu. Rezultātā pieņemtais lēmums ir pozicionēts kā acīmredzams, saistošs visai sabiedrībai un tāpēc obligāts izpildīšanai. Vienīgā procedūra, kura ir nepieciešama, ir sanākšana (sapulcēšana, apvienošana, ,sbor”). Š̄ ì ideja vislabāk izpaužas „sobornostj” koncepcijā.

Jēdziens ,sobornostj” ir slavofila A. Homjakova filozofijas centrālais motīvs. Ar to viņš saprata cilvēku brīvu apvienību, kuras pamatā ir kristīgā mīlestība un kura ir vērsta uz kopīgā, kolektīvā glābšanas cel̦a meklējumiem. Sobornostj A. Homjakova izpratnē ir „neformāls baznīcas kolektīvisms”, kopienas piederības izjūta ${ }^{11}$. Jēdzienam ,sobornostj” ir arī kritisks potenciāls, kas vērsts pret Rietumu - katoḷu un protestantu dominējošām vērtībām - individuālismu, sadrumstalotību, atsevišķa indivīda glābšanu utt.

Sobornostj nozīmē personiskā un kopīgā saplūšanu, kura izpaužas nevis sociālpolitiska vai ekonomiska rakstura kategorijās, bet cilvēka garīgajā attīstībā. Jēdzienam ,sobornostj”, lai gan tā skaidrojums ir daudzveidīgs, pirmām kārtām ir saikne ar Maskavas valsts pārstāvības iestādi viduslaikos ${ }^{12}$. Maskavas valsts Sobor nevar uzskatīt par demokrātisku institūtu, tāpat kā arī citus Eiropas pārstāvības veidojumus - Anglijas parlamentu, Francijas Ģenerālos Štatus u. c. Tomēr Eiropas pārstāvības iestādes no Krievijas parlamenta atšksiras ar darbības ilglaicīgumu: mūsdienu parlamenti ir vairāku gadsimtu evolūcijas rezultāts. Lai gan Krievijas parlamenta priekšgājēju - soboru vēsture ir fragmentāra, sobornostj un zemste ir fundamentālie faktori, kas noteica Krievijas vēsturiskā ceḷa savdabīgumu ${ }^{13}$.

Sobori tika sasaukti galvenokārt ārkārtējo problēmu risināšanai, un tiem nebija darba pieredzes normālos, rutinētos apstākḷos. Soboru dalībniekus nevar uzskatīt par savu vēlētāju vai savu partiju pārstāvjiem, jo Sobors drīzāk tikai simboliski pārstāvēja (reprezentēja) sabiedrību kopumā. Sobora svarīgākā funkcija bija saskaņas meklēšana starp tautu un varu krīzes situācijās. Šādos apstākḷos Sobora dalībnieki nemēǵināja spēlēt „opozīcijas” lomu vai veidot kaut kādas frakcijas.

Patvaldības turpmākā attīstība bija saistīta ar pārstāvības iestāžu faktisko likvidāciju Krievijas impērijā. No 1684. gada Zemstes Sobori vairs netika sasaukti. Taču ,sobornostj” idejai ir sava vieta Krievijas politiskajā filozofijā. Tā bija pretstatīta Rietumu individuālismam. Ar jēdzienu ,sobornostj” apzīmēja cilvēces dzimtes kādu mistisku vienotību, par kuras paraugu un iemiesojumu tika uzskatīta krievu lauku kopiena - „mir” (,„мup”).

Tādējādi Krievijas iedzīvotāju politiskās kultūras īpatnības un spēcīgas vienpersoniskās varas tradīcijas, kuras atrada savu turpinājumu PSRS politiskajā sistēmā, kḷuva par Krievijas jaunas institucionālās iekārtas izvēles faktoriem.

\section{POLITISKĀ CĪṆA JAUNĀS KRIEVIJAS VEIDOŠANĀ}

1991. gada augustā neveiksmi cieta valsts antidemokrātiskā apvērsuma mēǵinājums. Puča neveiksme noteica komunistiskās partijas aizliegumu. Institucionālajā ziṇā situācija pēc puča tika raksturota ar īpatnēju divvaldību. Jau pēc PSRS sabrukuma Krievijas politikā stipri iezīmējās vienpersoniskās varas faktors, vienlaikus Krievijas politiskā attīstība bija saistīta ar valstiskuma institucionālo 
noformējumu: piemēram, prezidenta vadībā izveidotas struktūras - Droš̄ības padome un Prezidenta padome. Bija ieviests prezidenta pārstāvju institūts uz vietām, kas apšaubīja vietējo padomju statusu un darbību. Jaunās Krievijas valdība bija izveidota un visas amatpersonas ieceltas saskaņā ar prezidenta pieņemtiem lēmumiem. Visa pārvaldes procesa centrā bija prezidents Boriss Jel̦cins, kurš pamatoja šādu kārtību ar politisko lietderīgumu - nepieciešamību paātrinātā tempā likvidēt padomju sistēmu. 1991. gada jūlijā izveidotā Konstitucionālā tiesa un tā paša gada decembrī pien̦emtā Deklarācija par tiesībām un brīvību bija tiesiskās valsts elementi, kuri radās sakarā ar PSRS sabrukumu. Krievijai bija vajadz̄iga jauna Konstitūcija. Taču formāli Krievijas pamatlikums bija 1978. gadā pieņemtā Konstitūcija, kura neparedzēja varas dalīšanas principa ieviešanu. Saskaņā ar Konstitūciju visa centrālā un vietējā vara piederēja Tautas deputātu padomēm, savukārt Tautas deputātu kongress bija nostiprināts kā valsts varas augstākā institūcija, bet laikā starp kongresiem augstākā vara piederēja KPFSR Augstākajai Padomei. Valdība bija pakḷauta Augstākajai Padomei.

Tādējādi pēc PSRS sabrukuma Krievijā izveidojās divi varas centri - prezidenta vienpersoniskās varas centrs un padomju varas institūciju sistēma, starp kuriem pretrunas laika gaitā saasinājās. T. s. „divvaldības” sākumā, kamēr prezidentu atbalstīja parlamenta deputātu vairākums, spriedze attiecībās nebija redzama. Taču nepopulāro ekonomisko reformu sākums iezīmējās ar sociālo spriedzi, opozicionāro noskaņojumu pieaugumu, protestiem un prezidenta B. Jel̦cina kursa kritiku, ko pauda KF Augstākajā Padomē R. Hasbulatovs un viceprezidents A. Ruckojs. 1992. gada aprīlī VI Tautas deputātu kongresā notika prezidenta Jel̦cina un reformu pretinieku konsolidācija: par opozīcijas centru kḷuva KF Augstākā Padome. Par kritikas objektu kḷuva arī liberāli radikālie J. Gaidara vald̄̄bas pasākumi ekonomikā, tā ka tajā laikā centrbēdzes kustība plosīja Federāciju ${ }^{14}$. Pēc Tautas deputātu VI kongresa izveidojās valdības un prezidenta pretinieku bloks; šis bloks Konstitūcijas projektā noprotestēja likumus par zemes pirkšanu-pārdošanu. Tas nozīmēja tirgus ekonomikas noraidīšanu. Savukārt B. Jel̦cins uzstāja, lai pieņemtu stipras Prezidenta varas likumu.

Tādējādi pretstatā viena otrai izveidojās divas dažādu viedokḷu grupas. Viena no tām, pagaidām spēcīga, bet jau ar panīkuma iezīmēm, sastāvēja no deputātiem komunistiem un konservatoriem no bijušajā KPFSR izveidotā parlamenta pēc 1990. gada marta vēlēšanām. Otru grupu veidoja 1991. gada aprīlī vispārējās vēlēšanās ievēlētā republikas prezidenta B. Jel̦cina, kurš 1991. gada augusta puča izgāšanos neizmantoja parlamenta atlaišanai, piekritēji. Abu grupu pretrunas realizējās konfrontācijā starp prezidentu un parlamentu un turpinājās visu 1992. gadu, sasniedzot apogeju 1993. gadā.

Jaunas Konstitūcijas pirmo projektu bija izvirzījuši prezidenta piekritēji 1993. gada aprīî̄, lai to apspriestu ar dekrētu noteiktajā Konstitucionālās sapulces sasaukumā. Projektā piedalījās valsts varas institūcijas (no federatīvā līmeņa līdz reǵionālo un autonomo apvidu līmenim), partijas, arodbiedrības un citas organizācijas, Zinātņu akadēmijas pārstāvji, parlamentārieši (to vidū konstitucionālās komisijas apakšpalātas locekḷi) un speciālisti, kurus iecēla valdība un prezidents. Jel̦cina variantam bija pretnostatīts parlamentārais variants. 12. jūlijā sapulce piekrita divu sākotnējo projektu zināmai sintēzei. Tajā laikā parlaments pieñēma virkni likumu par reliǵisko brīvību, krimināltiesībām, bet Prezidents, cenzdamies cīnīties ar inflāciju, izdeva dekrētus, kas bija liberāli tirgus ekonomikai. 
Tomēr institucionālā situācija bija iesaldēta. 1993. gada 21. septembrī Jel̦cins ar dekrētu atlaida parlamentu, bet dal̦a deputātu atsacījās pakḷauties un balsoja par Prezidenta atcelšanu no amata. Krīze izpaudās „konstitucionālā” apvērsuma mēǵinājumā, ko centās realizēt tie Krievijas parlamenta deputāti, kuri cīnījās pret Jel̦cina lēmumu par tā atlaišanu. Parlamenta èka („Baltais nams”) bija ielenkts, bet iespītējušies deputāti - komunisti/konservatori, - kuriem bija ieroči, mēǵināja ar spēku ieņemt televīzijas ēku. Šì pretošanās tika apspiesta ar spēku, un parlamentārā dumpja vadītājus drīz vien arestēja. Tanki, ar kuriem tika apšaudīts „Baltais nams” 1993. gada oktobrī, uzskatāmi parādīja aso konfliktu starp komunistiskajiem konservatoriem un jaunajiem spēkiem, kuri nāca pie varas; tādējādi formāli konflikts izpaudās varas divu nozarojumu pretnostatījumu veidā.

9. novembrī B. Jel̦cins iesniedza Konstitūciju, kura 1993. gada 12. decembrī jāizskata referendumā; tās atbalstam bija vajadzīgi $50 \%$ pozitīvi balsojušo vēlētāju balsu. Oficiāli paziņotais referenduma dalības līmenis - 54,8\% no sarakstos ierakstītajiem vēlētājiem (tomēr daži šaubījās, vai tiešām bija pārvarēts $50 \%$ slieksnis); „par” nobalsoja 58,4\%, ,pret” - 41,6\% vēlētāju. Tātad Krievijas valstī jauno Konstitūciju, ja rēķina no visa pilsoņu skaita, atbalstījusi tikai aptuveni trešdal̦a vēlētāju.

Krievijā bija pieņemta tā dēvētā ,stingrā” Konstitūcija: tās caurskatǐšanai nepieciešams parlamentāriešu kvalificētais vairākums. To var vērtēt kā tās nolikumu aizsardzību gadījumā, ja tiks mēǵināts īstenot dažas tajā deklarētās tiesības, kas pārejas perioda nenoteiktajā situācijā bīstamas konstitucionālajai kārtībai. Prezidenta prerogatīvas kopumā ierobežo parlamenta iniciatīvas un uzraudzības iespējas. Pie tam konstitucionālo nolikumu reālai ieviešanai pilnā to apjomā nepieciešams liels skaits balsošanā pieņemto tiesisko aktu, lai regulētu no padomju laika mantoto administratīvo aparātu, kura pārveidošana par demokrātisku bieži vien ierobežojās ar izkārtnes nomaiņu.

1993. gadā nodibinātie institūti un visa likumdošana galvenokārt bija pārņemta ar ekonomiskās politikas jautājumu risināšanu. 1994. gada februārī jaunievēlētā Dome, uzsākusi savu ofensīvu pret Prezidentu, it kā viņam par spīti nobalsoja par 1991. gada augusta un 1993. gada oktobra dumpinieku amnestiju. Tomēr Jel̦cins jau nākamajā dienā ierosināja parakstīt paktu par nacionālo vienprātību, kuru atbalstìtu partiju vairākums. Līdz ar to tika atzîts, ka nav iespējama brīva parlamentārā darbība, un bija institucionalizēts izpildvaras primāts ${ }^{15}$.

Tādā veidā institucionālās iekārtas izvēle un jaunas Konstitūcijas pieņemšana bija saistita ar B. Jel̦cina personisko faktoru Krievijas politiskajos procesos: „.. Prezidents Jel̦cins bija visvarenākā figūra postpadomju politiskajā attīstībā. (..) Jel̦cina autoritātei un spēcīgajam līdera stilam bija galvenā nozīme stipras federālās izpildvaras konstruēšanas mēgeinājumos (..)" ${ }^{16}$

\section{NOBEIGUMS}

Mūsdienu Krievijas konstitucionālā attīstība ir Krievijas sabiedrības un valsts politiski tiesisko reformu un modernizācijas XIX-XX gadsimta sastāvdaļa ${ }^{17}$. Krievijas institucionālās iekārtas varianta savdabība saistīta ar pirmsrevolūcijas un pēcrevolūcijas vēstures īpatnībām, ar patvaldības mūžsenajām tradīcijām, tāpat arī ar 
PSRS pieredzi. Varas despotiskās sistēmas kundzība Krievijā daudzu gadsimtu laikā, personības reālo tiesību un brīvību trūkums, valsts galvenā orientācija uz piespiedu spēka metodēm iekšpolitikā un ārpolitikā, visstingrākā pārvaldīšanas centralizācija un citādu uzskatu apspiešana noteica spēcīgas prezidenta varas izveidi mūsdienu Krievijā un konstitucionālo disbalansu starp dažādiem varas nozarojumiem.

Jaunās Krievijas institucionālās iekārtas izvēlē zināma nozīme ir arī politiskās domas un iedzīvotāju politiskās kultūras faktoram. Krievijas vēsturē nebija demokrātisku tradīciju, tieši otrādi, spēcīga vienpersoniskā vara bija Krievijas pārvaldes galvenā pazīme. Optimālā pārvaldes model̦a izvēlei bija veltīta arī Krievijas politisko filozofu uzmanība: kaut arī daži Krievijas politiskās domas komponenti neiekļaujas mūsdienu teorētiskajās konstrukcijās un, piemēram, slavofilu idejas var uzskatìt par utopiskām, tām ir liela nozīme kontekstā, jo, pirmkārt, tās atspoguḷo gan politiskās domas briedumu Krievijāa, gan iedzīvotāju politisko kultūru un, otrkārt, dod informāciju par Krievijas vēsturiski politisko attīstību. No otras puses, Krievijas parlamenta institucionalizācijas ilgais un sarežǵītais process liecina, ka parlamentārisma iezīmes sāka parādīties Krievijā tikai XX gadsimta sākumā, kad kḷuva skaidrs, ka Krievijas patvaldības periods beidzas un sākas jauns konstitucionālisma un parlamentārisma etaps. Valsts Domes darbības pieredze liecina, ka valdošās aprindas nebija ieinteresētas parlamentārisma ieviešanā Krievijā. Parlamentārisma veidošana un attīstība notika apstākļos, kad nācās cīnīties ar patvaldību. Atsevišķs posms Krievijas vēsturē ir padomju periods, kad nedemokrātiskā politiskā režīma apstākḷlos vara bija koncentrēta vienas valdošās partijas rokās, tādējādi 20. gadsimtā Krievija faktiski bija izslēgta no pasaules demokrātijas attīstības procesiem. PSRS likvidācija nevarēja veicināt Krievijas tūlītējo demokrātijas sasniegšanu. Pārejas procesa periodā īpaši liela nozīme bija Krievijas prezidentam Borisam Jel̦cinam, kuram izdevās ieņemt vadošo pozīciju gan PSRS sabrukuma, gan jaunas Krievijas veidošanas procesāa, saņemot iedzīvotāju milzīgas uzticības mandātu. Prezidenta Jel̦cina īpašās līdera spējas nodrošināja viņam iespēju vadīt politiskos procesus, arī institucionālās iekārtas izvēles jomā.

Šinī rakstā netika izanalizēti vēl citi faktori, kuri ietekmēja pārvaldes formas izvēli Krievijā. Viens no tiem - starptautiskā pieredze. Cenšoties izvairīties no klišejas institūtu nosaukumos, kas atgādinātu padomju sistēmu, Konstitūcijas projekta izstrādātāji izmantoja ārzemju terminologisko pieredzi. Tāda veidā tika izstrādāta parlamenta vēlēšanu sistēma, kas bija analoǵiska Vācijas 1949. gada Konstitūcijai. Piemēram, termins "konstitucionālās iekārtas pamatprincipi" nomainīja padomju Konstitūcijā lietoto terminu "sabiedriskās iekārtas pamatprincipi”. Kaut ko pārṇēma arī no ASV pieredzes ${ }^{18}$ (piemēram, prezidenta tiešo pārvaldi, vismaz par spēka struktūrām), bet īpaša uzmanība acīmredzot tika pievērsta Francijas V Republikas Konstitūcijai, tās pusprezidentālās republikas formai ${ }^{19}$.

\section{ENDNOTES}

1 Runa ir par 2007. gada aprīḷa politisko krīzi, kuras pamatā ir pretrunas starp prezidentu un parlamentu Ukrainā, kas izpaužas abu resoru gatavībā sākt pretinieka atstādināšanas procedūras: prezidents V. Juščenko ir parakstījis lēmumu par parlamenta (Verhovnaja Rada) atstādināšanu, savukārt parlamentā pārstāvētie politiskie spēki aicina sākt prezidenta impīčmenta procedūru. Pastāv pamatoti draudi, ka šāda tipa konflikts var 
pārvērsties situācijās, līdzīgās Krievijas politiskajai krīzei, kuras apogejs bija sasniegts 1993. gada rudenī ar tanku apšaudi pie parlamenta.

2 Богацкий, И. Благо управляемой демократии. Русский Журнал. Политика. 31.10.2003. Доступно на: www.russ.ru/politics/20031031-bogaz.html

3 Горшков, М. К., Петухов, В. В. Перспективы демократии в России: угрозы реальные и мнимые. Социологические исследования. 2004, № 8.

${ }^{4}$ Willerton, John. P. JR. Presidential Power. Developments in Russian Politics. Ed. by Stephen White, Alex Pravda and Zvi Gitelman. Macmillan press LTD, 1997, p. 37.

5 Almond, G. A., Verba, S. The Civic Culture: Political Attitudes and Democracy in Five Nations. $2^{\text {nd }}$ ed. Newbury Park, London, New Delhi : Sage Publications, 1989, p. 12.

${ }^{6}$ Parochial - draudzes (parochial school - draudzes skola), šaurais, lokālais. No grieķu val. para - blakus, oikos - dzīves vieta, mājsaimniecība.

7 Almond, G. A., Verba, S. The Civic Culture: Political Attitudes and Democracy in Five Nations. $2^{\text {nd }}$ ed. Newbury Park, London, New Delhi : Sage Publications, 1989, p. 17.

8 Хархордин, О. Что такое «государство»? Русский термин в европейском контексте. Понятие государства в четырех языках. Сборник статей. Под ред. О. Хархордина. СПб. - М., 2002, с. 152-217.

9 Keenan, Edward L. Muscovite Political Folkways. The Russian Review, vol. 45, 1986, p. 138.

10 Бутаков, Я. Какой парламент нужен России? И нужен ли вообще? Русский Журнал, 02.03.2005.

11 Новиков, А. И. История русской философии. СПб, 1998, с. 99.

12 Черепнин Л.В. Земские соборы Русского государства в XVI-XVII вв. М., Наука, 1978 .

13 Земство, соборность и будущее России. Сборник статей профессора Г. Г. Сильицкого. Смоленск, 2000.

14 Согрин, В. Политическая история современной России. М. : Прогресс-Академия, 1994, c. 109-132.

15 Кола, Д. Противоречия в конституционной истории СССР/России и строительство многонационального правового государства. Политические Исследования, 1998, № 6 .

16 Willerton, John P. JR. Presidential Power. Developments in Russian Politics. Ed. by Stephen White, Alex Pravda and Zvi Gitelman. Macmillan press LTD, 1997, p. 37.

17 Кравец, И. А. Конституциионализм и российская государственность в начале ХХ века. Н., 2000, с. 3.

18 Конституции зарубежных государств: США, Великобритания, Франция, Германия, Италия, Япония, Канада. М., 1996, с. 7-13.

19 Президент-Правительство-Исполнительная власть-Российская модель. М., 1997, c. $44-45$. 



\section{Knowledge Society and Economy}





\title{
The Efficiency of Economic Transformation in the New Europe
}

\author{
Dr. Tatyana Boikova \\ Associate Professor \\ Riga International School of Economics and Business Administration \\ Latvia
}

\section{INTRODUCTION}

We live in a united world, but this world is multifaceted and full of contradictions. There should be certain interconnections among its various parts, and the interconnections show the way to collaboration and cooperation. Currently, the determinant factors of development are not processes taking place in distinct national economies, but trends in the world economy as a whole.

The contemporary European economy is entering one of the most important stages of its post-industrial development, a stage connected with achieving freedom and progress in an emerging new society. EU interests and priorities are to create a competitive and dynamic knowledge-driven economy capable of long-term growth with more economic security, a developed knowledge infrastructure and enhanced innovations, a modernising social model and investment in science and high-tech business.

Under conditions of rapid and accelerating European integration, the search for new macroeconomic methods of strategic governance for the European economic system requires investigation of:

- the effect of enlargement on European integration,

- the differences in the level of economic and social development of old and new EU countries, and

- the qualitative changes in economic dynamics of the new EU member states and their competitiveness in the European market.

Implementing the strategy of the transition to a knowledge-based economy in the EU, new countries will achieve the balanced development of their economic system, a sound macroeconomic background for R\&D and effective transformation of the technical structure of production. 


\section{THE EFFECT OF ENLARGEMENT ON EUROPEAN INTEGRATION AND DEVELOPMENT TRENDS}

Under the conditions of increasing dynamism in the European economy, knowledge-driven economic growth and strong competitive positions on world markets will become determinants of future social welfare and greater social cohesion. Hence, it is necessary to ensure a coherent strategic direction of long-term development and to introduce innovative flexible methods of regional coordination in the EU. Undoubtedly, the rapid pace of expansion of the regional market enables use of the full benefits of the new opportunities. Improving the transformation processes is impossible without effective monitoring of innovation and the economic, social and political factors which will sustain the gains of enlargement. But the European economy now is facing problems of primary importance:

- How to create conditions for full employment and innovative long-term growth of the EU national economies?

- What are the obstacles to economic and social sustainability and how can they be overcome?

- What will drive the transition to a knowledge-based economy in the new EU members?

- How can the EU become the world's most competitive economy?

- How will the European economic system be adapted to exogenous and endogenous factors of cyclic fluctuations?

- What kind of sustainable development strategy will be chosen?

- How to sustain favourable growth prospects by applying appropriate financial, monetary and fiscal regulation?

The fifth large-scale EU enlargement has brought economic growth, accelerated rates of changes to institutions and a new way of life for many. But on the other hand, asymmetric business cycles in the European economy compound the difficulties in integration after enlargement. The analysis of development trends showed that there is still a considerable gap between old and new members of the EU in GDP per capita (see Figure 1).

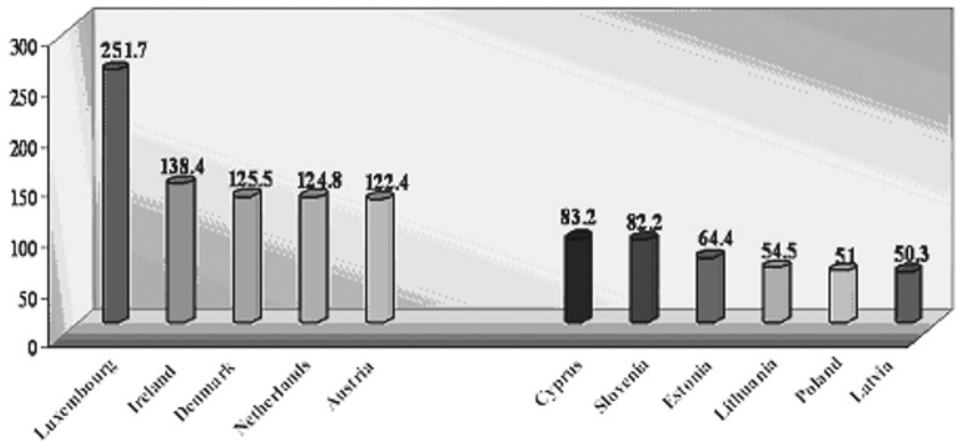

Fig. 1. GDP per capita in PPS in $2006 \mathrm{f}(\mathrm{EU}-25=100)$

Source: Eurostat, Structural indicators 
In spite of increasing labour productivity and a decreasing total unemployment rate in the new EU member states, there remains a substantial lag in labour productivity from the EU mean. Figure 2 reflects such changes, for example, in the Baltic States.

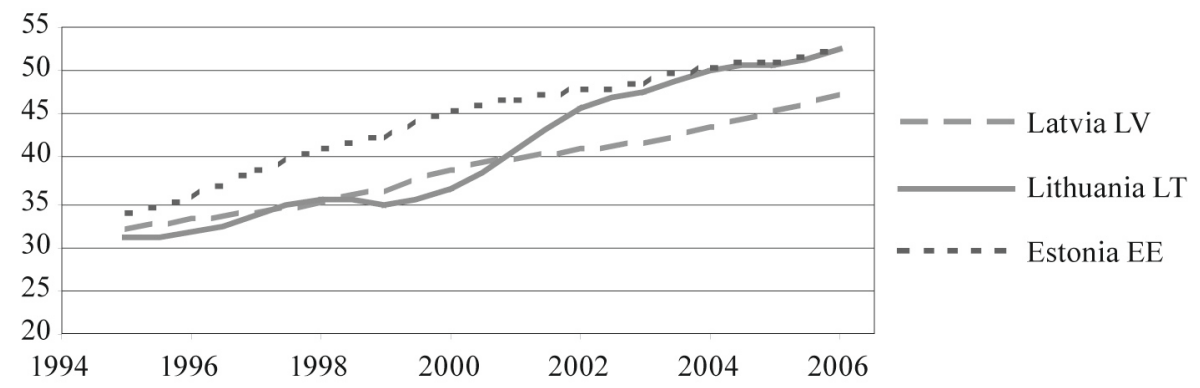

Fig. 2. Labour productivity per person employed

Source: Eurostat, Structural indicators

What is more, considerable dispersion can be observed in indicators of economic innovation, first of all, for high-tech exports, public and business R\&D expenditures (\% of GDP) and employment in high-tech manufacturing (on data of the EU Innovation Scoreboard). The principal problem, especially for new EU member states, is a low investment rate in high technology sectors and significant cyclical fluctuations of innovative activity relative to the trend in old EU member states (see Economic Development of Latvia report, 2006).

In the conditions of growing global competition and deepening integration, the obvious priorities for the economy of the New Europe will become the growth of innovation, scale qualitative transformation, strengthening the position of the euro and economic security. An analysis of market and structural factors of economic, social and technological development of euro and non-euro countries points to a differentiation in economic dynamics and an absence of harmonisation of the business cycle even inside the European Monetary Union (EMU). If one considers the common monetary policy from the point of view of preservation of a stable, trusted euro, monetary regulation remains the stabilising factor. But regarding anti-cyclical regulation, measures implemented in the monetary and financial spheres have often been pro-cyclical, promoting recession and slowing down the growth rate. Economic transformation of the new EU member states and inevitable expansion of the EMU will demand financial convergence for stabilisation of the euro. At the same time, the unevenness of progress in balancing budgets within the EMU has led to diverging interests. How will the euro affect a business cycle in the euro area if national fiscal policy will depend on common monetary regulation in the EU? National methods of fiscal stabilisation will have the desirable effect if they are compatible with the tools of common monetary policy of anti-cyclical regulation in the EU. It is necessary to note that a vital problem here is a-synchronisation of business cycles, especially during the rise. Therefore, the costs of macroeconomic adjustment in the EMU under conditions of a common currency and monetary policy can exceed the advantages from introduction of the euro. The efficiency of market tools of regulation in the EMU will be defined by the degree of correlation with the dynamics of asymmetric cycles. 
We must note that if velocity of money and the short-term interest rate is highly coordinated with the dynamics of an economic cycle, long-term interest rates differ and have a low degree of coordination. Andres, Lopez-Salido and Valles (2006) find that money demand shocks mainly help to forecast real balances while real shocks explain the bulk of price, output and interest rate fluctuations. The calculation of the model consistent natural rate of interest reveals that the evolution of the interest rate in the eurozone is mostly accounted for by the real sources of fluctuations.

The adjusting function of monetary policy of the euro area countries can be used for these strategic tasks:

- creating long-term high growth rates, promoting innovation and international competitiveness,

- raising employment and increasing private investment into high technology manufactures,

- strengthening euro stability in global financial markets and economic security in the euro area.

A methodological problem of research is estimating the influence of financial markets on long-term economic development and the correlation of cyclical changes in financial and industrial sectors. It should define:

- ways of financing the introduction of technological innovation in conditions of uncertainty about their prospects,

- incentives for investment of real and financial sectors during crisis and depression, a drop in the value of financial and capital assets, changes of rational expectations in a financial system,

- components of profitability, system and project risks of investment,

- correlation of savings and opportunities for investment, maximal dynamics of financial sector profit, and

- financial innovations necessary for commercialisation of radical technical innovation clusters.

Companies must become more innovative, creating demand for new knowledge, while universities must direct their capabilities towards industrial applications, creating supply (Innovating Regions in Europe, 2004).

From the point of view of creating anti-inflationary effects, exchange rate policy should supplement monetary regulation. Such an approach assumes that the rate of the euro should define changes of macroeconomic parameters, for example, the price and wage levels, instead of changing their fluctuations. Having received signals concerning the dynamics of inflation, the private sector can make adequate decisions regarding development strategy. Devereux, Lane and $\mathrm{Xu}$ (2006) argue that in a low pass-through environment, the policy maker can simultaneously strictly target (CPI) inflation, but still allow high nominal exchange rate volatility in order to stabilise the real economy in the face of external shocks. The low rate of pass-through ensures that exchange rate shocks do not destabilise the price level.

The problem of increasing macroeconomic efficiency in financial markets is connected with overcoming the gap with the real sector, a disproportion between short-term resources of financial intermediaries and long-term needs of financing 
economic growth, capitalisation of financial market institutions, high transaction costs and the strengthening influence of oligopolies in the economy. With the aim of increasing trust in the financial market, economic adjustment should provide market transparency, decrease system risk, and protect the rights and interests of investors, instead of forming more favourable conditions for individual professional participants in the market.

Research on correlations between synergetic factors of economic growth and stock exchange crises are necessary for the development of a steady financial market model. Thus, it is important to define whether stock exchange crisis is a casual process or not. What are the opportunities for trend forecasting? How can we estimate efficiency in investment strategies using bifurcation models and considering the preferences of the rational investor concerning permissible risk?

\section{INNOVATIVE GROWTH OF TRANSFORMATION ECONOMY}

Intensive development of an innovative transformation economy is necessary with a view to obtaining the effect of synergy from the consolidation of scientific and technical connections, integration of intellectual resources and transition to a new knowledge-driven model of long-term economic growth (Figure 3).

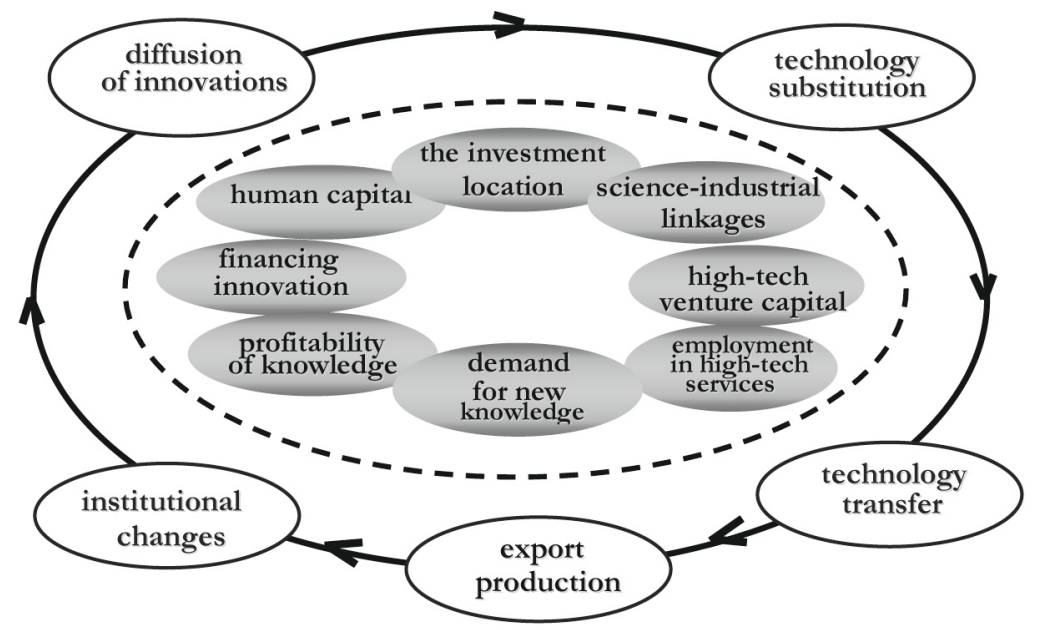

Fig. 3. The endogenous factors of long-term economic growth

It is very important for this purpose to create financial stability and an efficient infrastructure to ensure innovative activity by high-tech business. In innovative activity, cyclical wave fluctuations are seen in the infinite number of falls and upswings of various frequency and amplitude. A leap in economic development is expressed by a qualitative transition to a new level of stable equilibrium. A decisive role in the longterm growth of the knowledge economy can be played by a cluster of technological and basic innovations. Bernanke and Gurkaynak (2001) showed that savings rates differ across countries for long periods of time and countries with high savings rates grow faster than those with low savings rates. Moroever, McGrattan (1998) has argued a strong positive correlation between growth rates and investment ratios. Farmer and 
Lahiri (2006) note the fact that savings is so closely correlated with investment implies, to a first approximation, not only that countries are not borrowing to acquire human capital, but also that they are not borrowing to acquire physical capital.

Research on long-wave innovation cyclic fluctuations in economic dynamics suggests identifying the "points of growth" in a new production structure. Exploration of interconnections between innovations and forming a new technicaleconomic structure shows that the evaluation of the dynamics of the diffusion of innovation is highly significant. While innovation supersedes old production, it is necessary to evaluate the degree of substitution of old technology over time. Then the scale of innovation spread can be determined as the relative part of use of innovation in the technical-economic structure. Introduction and spreading of new technology is connected with a constant disturbance of the equilibrium level of use of the existing technologies. This approach to analysing technology diffusion as a process of technology substitution is the most adequate for explaining the long-term characteristics of technology diffusion, as it takes into account the feature of nonequilibrium. In addition, the parameters of substitution of the old technology by the new one meets practical needs, for example, for forecasting processes of successive change of technologies and commercial realisation of innovative production. It is interesting to note that in the Fisher-Pry model, there exist three basic versions which give possible descriptions of the process of technology substitution:

- technology substitution reflects the uneven character of the process of diffusion. The unevenness of the whole innovation system is determined by the leap from the old technology to the new and is connected with deviations from the levels of equilibrium separately for each of them;

- the speed of introduction of a product is proportional to the share of the old product that is still usable;

- the greater the split in use of the new and the old technology, the sooner the substitution.

We consider the function showing the velocity of diffusion of new technology introduced

$$
K(t)=\lim _{\Delta t \rightarrow 0} \frac{\Delta K(t)}{\Delta t},
$$

where $\Delta K$ - additional number of new technology units introduced during the time span $[\mathrm{t}, \mathrm{t}+\Delta \mathrm{t}]$.

Uninterrupted function characterising the velocity of diffusion is received as a result. The following form of function $K(t)$ is suggested on the basis of the FisherPry model.

$$
K(t)=\frac{\exp \left(b(t)\left(t-t_{0}\right)\right)}{1+\exp \left(b(t)\left(t-t_{0}\right)\right)}
$$

where

$$
b(t)=\frac{1}{1+\exp \left(t-t_{1}\right)}
$$

$b(t)$ - is interpreted as Long-term Average Total Costs (LATC) on the stage of positive effect of the scale of production. 
For the changed Europe, the sustainable economic development of the Baltic States - Estonia, Latvia, Lithuania can become rather promising from the point of view of real GDP growth dynamics (Figure 4).

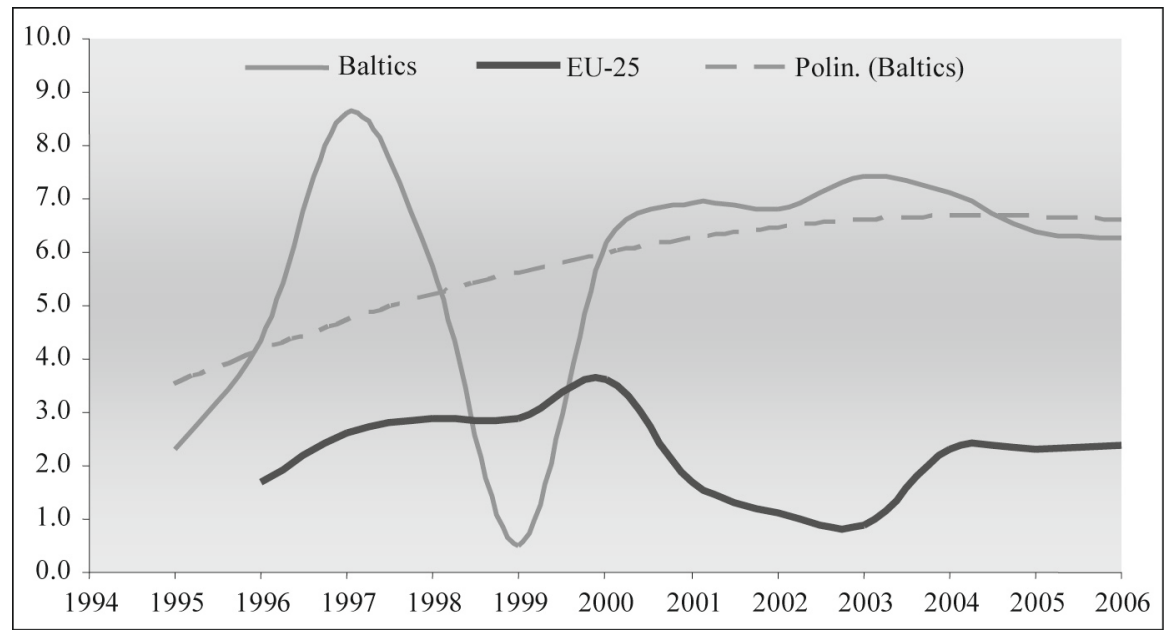

Fig.4. Real GDP growth in the Baltic States

Source: Eurostat, Structural indicators

According to data of Business Monitor International (2006), the overall business environment score for Estonia was 70.4, for Latvia - 64.0, and Lithuania - 65.8. According to the World Bank, Latvia is among the 15 countries that have been most active in carrying out pro-business reforms over the past year, having made dealing with licences, paying taxes and closing a business all easier. At the same time, it should be noted that the need for science-intensive production of high technology branches has steadily increased, and the process of meeting demand by this production is far from being completed. This is connected with the necessity of a constantly increasing share of manufacturing value-added in high-tech sectors and $R \& D$ and financing innovations. International market strategy is today tightly linked with business globalisation and enhanced rivalry for leadership. It should be noted that small and medium sized companies are the biggest sector of the EU (99\% of all companies in the EU) with 23 million companies employing around 75 million people, responsible for one in every two new jobs (European Venture Contest, 2006). Sustainable development of the Baltic economy in the EU induces the need of proper access for SME's to venture capital and promoting regional innovation networking. Boikova (2005) suggested developing a knowledge-driven business network. The system approach to science, innovations and knowledgedriven business development can set priorities for the transformation economy:

- increasing the flow of business R\&D expenditure and growth of venture and innovations companies value;

- raising the capacity of Small and Medium Enterprises to absorb new technologies and know-how;

- increasing the proportion of innovation products with high value-added in the total amount of industrial production; 
- transformation of the industrial structure and growth of total factor productivity;

- restoration of the equity capital and ensuring high-tech level of economics;

- enforcement of export specialisation and diversification, cooperation of the new producers in order to implement large-scale innovation projects.

\section{CONCLUSION}

Stepping up the process of effective structural changes which will favour stronger competitiveness and balanced development of the new EU member states should become the priority of European integration. Here, an effect of synergy of the European economy as a united system is required, ensuring its enhanced stability.

The new model of the Latvian knowledge-based economy can be developed on condition of using European financial instruments to invest in research and innovative activities, commercialisation of $R \& D$ results and system transformation of branch structure. It is advisable to increase investment in the development of promising high technology branches, ensuring leadership of Latvia in the Baltic States. Competitiveness of the Latvian economy, especially in terms of the relative small size of the domestic market, will depend on the speed with which new resourcesaving technologies are diffused and the extent to which support is given for starting up and developing innovative businesses. The main directions of developing our own innovative strategy may be introduced as follows:

- joining innovative activities in specialised knowledge-driven networks of high-tech companies (R\&D - technology - commercialisation);

- promotion of strategic partnerships, technology transfer;

- increasing employment in science-intensive production;

- strengthening academic-industrial links.

\section{REFERENCES}

Andres, J., Lopez-Salido, J.D. and Vallez, J. (2006). "Money in an estimating business cycle model of the euro area", The Economic Journal, vol.116 (511) (April), pp.457-477.

Bernanke, B. and Gurkaynak, R. (2001). "Is growth exogenous? Taking Mankiw, Romer and Weil seriously", in (B.Bernanke and K. Rogoff, eds.), NBER Macroeconomics Annual, pp. 11-72, Cambridge MA: MIT Press.

Boikova, T. (2005). "High-Tech Business as a Precondition of Latvian Innovative Economy Growth". Knowledge Based Entrepreneurship, Cento-Ferrara, Italy, pp.69-80.

Business Monitor International's monthly regional report on political risk and macroeconomic prospects (2006). Central Europe \& Baltic States, vol. 13, Issue 12, December, pp.10-12.

Devereux, M.B., Lane, P.R. and Xu, J. (2006). "Exchange rates and monetary policy in emerging market economies", The Economic Journal, vol.116 (511) (April), pp. 478-506.

Economic Development of Latvia report, Ministry of Economic Republic of Latvia, Riga, July 2006, pp.75-77.

EU Innovation Scoreboard (2004). Knowledge creation. 
European Venture Contest (2006). Lisbon, 4 December.

Farmer, R.E. and Lahiri, A. (2006). "Economic Growth in an interdependent world economy", The Economic Journal, vol.116 (514), pp.969-990.

Fisher, J. and Pry, R.(1971). "A simple substitution model of technological change", Technological Forecasting and Social Change, N3, pp.75-88.

Innovating Regions in Europe. (2004). Thematic Networks-sharing our experiences, European Communities, pp.4-7.

McGrattan, E.R. (1998). "A defense of AK growth models", Federal Reserve Bank of Minneapolis Quarterly Review, vol.22, pp.13-27.

Sahal, D. (1981). Patterns of Technological Innovation. New York University. 


\title{
Competitive Advantage Based on Cultural Identities of Localities in the Era of Globalisation
}

\author{
Andrejs Čirjevksis \\ Riga International School of Economics and Business Administration \\ (RISEBA) \\ Iveta Ludviga \\ entrepreneur
}

\section{INTRODUCTION}

The current period is commonly described as "The Era of Globalisation". The growing integration of economies and societies around the world brings changes into everyday life for small and medium-sized enterprises (SMEs), particularly by aggregating competition, increasing the presence of a large number of international companies in local markets, and generating workforce mobility. Environmental changes require cutting production costs and adding higher value in order to raise the competitiveness of companies.

Entrepreneurs face several dilemmas - is it necessary to homogenise products and services or the opposite, as differentiation can provide advantages. How should companies tailor their strategies in connection with ongoing globalisation? This paper aims to present the close interconnectedness of the issues of cultural identity and globalisation and suggest opportunities for business to benefit from the current situation.

\section{GLOBALISATION, CULTURE AND CULTURAL IDENTITY OF LOCALITIES}

It is difficult to define globalisation. In his book Globalisation: Threat or Opportunity?, Paul Streeten (2001) devotes an entire chapter to definitions, of which he lists 36 . The most succinct definition to his mind is: "The power to act instantaneously at a distance." Eriksen (1999) proposes a view of globalisation as all the socio-cultural processes that contribute to making distances irrelevant.

Professor Michael Hitt (2004) offers a concept of globalisation: "Increased economic interdependence among countries as reflected in the flow of goods and 
services, financial capital and knowledge across country borders." According to Hitt, globalisation is also: "increased range of opportunities for companies competing in the $21^{\text {st }}$ century competitive landscape." The pace of globalisation as a historical process has increased during the last decades with the advent of new technologies, especially in the area of telecommunications. These changes and information capabilities allow for increased financial flows across borders, which in turn provide opportunities for companies to locate operations throughout the world and to deliver goods and services to consumers everywhere.

During the mid-nineteenth century the concept of mass culture and popular culture emerged and the idea of culture acquired the main features of its current meaning. We all live in terms of the definitions, names, and categories that culture creates. According to Sotshangane (2002), today culture is best thought of as a resource like other resources, such as energy, food, air etc. Culture refers to:

Firstly, the ways, means, and results of human interaction with and material transformation of nature towards an environment suitable to human existence, and to the total strategy of human orientation within the environment.

Secondly, culture also refers to the common form of life of a national community which has achieved a common identity and homogenous value system and lifestyle, either by the forging of a common identity through the process of industrialisation and modernisation.

Culture can also be defined as capital, which is cumulative, leads to benefits in the social world, can be converted into other forms of capital and can be reproduced (Denner, 1998). It is also defined as a "set of universally adaptive tools".

The definition of "identity" can be developed as a "sense of culture" (Keillor, 1999). Identity is the extent to which a given culture recognises and identifies its unique characteristics. Thus, the cultural identity of a locality becomes: the "set of meanings" owned by a given culture which sets it apart from other cultures. It is the degree to which a nation and its individuals have a strong sense of cultural and national uniqueness.

Many authors suggest that the impact of globalisation on culture is contradictory: on the one hand, globalisation works towards the unification of the world, but on the other, it awakens tendencies towards the local and culture becomes more and more visible. Some authors characterise the effects of globalisation on local cultures as an expanding form of cultural imperialism (Held, 2004); they describe the process as "Westernisation and Americanisation of values". Still there is also another point of view. According to Castells (2004), the idea of cultural uniformisation through globalisation has become totally obsolete. There is an apparently paradoxical situation, in which local factors are becoming more important as globalisation is gaining ground. The global information age may strengthen rather than weaken local cultures (Nye, 2004).

The anti-globalisation movement and the defenders of globalisation have an important common feature, and that is the desire to maintain cultural differences and to avert homogenisation. According to Nye (2004), those who argue in favour of cultural identity and against globalisation betray a stagnant attitude towards culture. 
Cultures converge, but they do not disappear (Dahl, 2001). There is a growing body of opinion that globalisation processes strengthen, rather than weaken different cultures. As Cowen (2003) stated in his Creative Destruction, decline and creation belong to the same movement linked to globalisation. The same process that gives us a lot of McDonald's also gives us the choice of French, Italian, Thai, Indian, Mexican, Chinese, Arabic, and other food. Over the past years there has been an increased availability of foreign products, movies, music and television, and as a result, a lot more foreign culture available to people everywhere.

Globalisation has led to increased awareness of differences and similarities both within and across cultures (Denner, 1998). The information revolution may reinforce rather than reduce cultural diversity. The internet allows dispersed customers to come together in a way that encourages niche markets (Nye, 2004). Cowen (2003) contends that cross-cultural exchange creates a plethora of innovative and high quality creations in many different genres, styles, media, as well as industries and branches. Such exchange expands the menu of choice and trade and markets are allowed to flourish.

In the public debate about globalisation's impact on culture, the view that globalisation promotes cultural differences predominates. Although, to some extent, the world is becoming homogenised, national and regional cultures prevail, individuals seek differences which may or may not be based on natural or cultural distinctions; they consequently seek something new and diverse, and inevitably demand more choices. In such an environment, companies can secure competitive advantages by being innovative and different, and the cultures of localities can be adaptable as sources for innovation and new opportunities. The cultural identity of any locality can be used as a unique source of ideas and innovations, as well as convertible capital and a set of tools which can be put into business practice. Viewing cultural differences organisationally and strategically as options for success, rather than barriers to be overcome, one can discover the solutions to the global challenges in the world around.

\section{SUSTAINED COMPETITIVE ADVANTAGE (SCA) AND THE CULTURAL IDENTITY OF A LOCALITY AS A SOURCE OF WEALTH IN A GLOBALISED ENVIRONMENT.}

Understanding the sources of Sustained Competitive Advantage for firms has become a major area of research in the field of strategic management. Current changes in the competitive landscape, including the presence of foreign competitors in domestic markets, are raising the adrenaline level of the business community and driving businesses to rethink their strategies. The best way for communities to preserve their local control is to become more competitive globally (Kanter, 1995). According to Kanter, the way in which one can derive benefit locally from the global economy is by capitalising on the availability of those resources that distinguish one place from another, including local cultural identities. 


\section{OPPORTUNITY APPROACH}

A good beginning to analyse SCA is Jay Barney's work. According to him, firms obtain sustained competitive advantage by implementing strategies that exploit their internal strengths, through responding to environmental opportunities, wile neutralising their internal threats and avoiding internal weaknesses (Barney, 1991). Both models of competitive advantage analysis presented by Barney (resource based and environmental), if combined, show how companies can use environmental opportunities and an entrepreneurial mindset in order to transform them through the organisation's strengths into competitive advantage. In this case, the environment is to be viewed in a broad sense, as not just the industry environment, but the environment of the given locality and global forces influencing the company. The relation is shown in Figure 1 with red arrows.

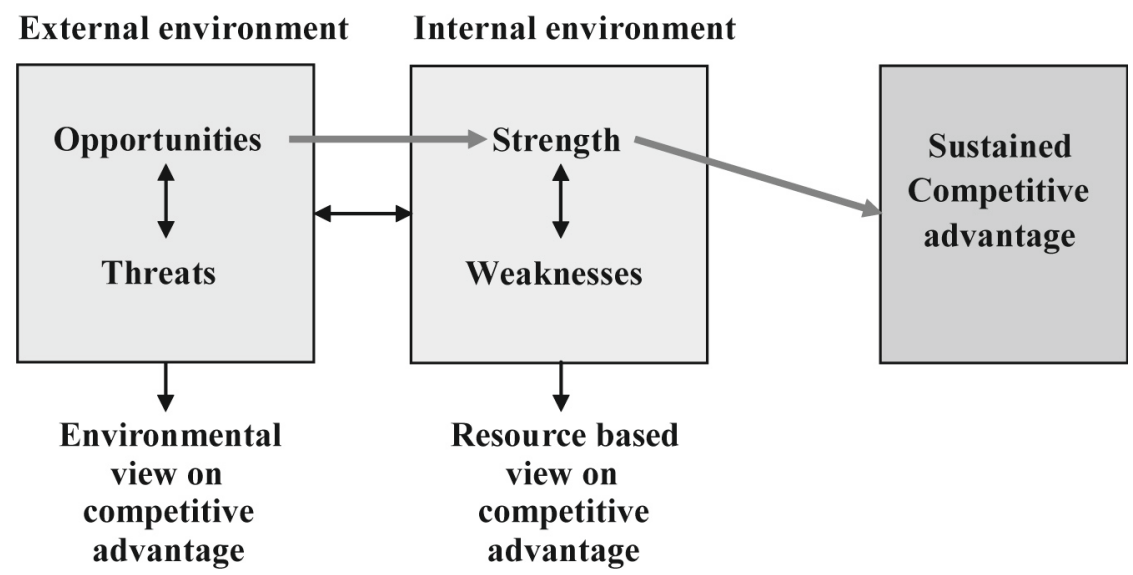

Figure 1: Competitive advantage from environmental opportunities

Culture, including an organisation's culture, the cultural identities of a locality and also the cultures of other localities, combined with the impact from the global environment provide a number of opportunities. These, in turn, pose challenges for the entrepreneurial mindset to utilise them as the basis for new capabilities and competences and further development of SCA.

The emergence of culturally based competitive advantage in the environment of globalisation can occur as depicted in Figure 2. The globalised environment has a dual effect on culturally based competitive advantage: 1) distances become irrelevant, making local cultures more visible and accessible to people worldwide, as well as creating interest about them, and 2) as competition becomes global and more severe, companies are forced to seek for new sources of success and distinctive resources and capabilities, and cultural identities can serve as a basis for them.

Globalisation opens doors and widens horizons, it enables alliances among businesses, international operations and collaboration, facilitates trade, transportation, and information exchange. It provides all the necessary connections. Localities and their cultures are naturally rich in stories, designs, ideas, formulations for products and services; actually, they are rich in different concepts. Every locality also possesses 
its unique competences - special abilities to transform ideas into applications, some culturally based processes, skills, technologies, rituals and knowledge. All three: concepts, competences and connections are necessary intangible assets which characterise hard-to-replicate capabilities of a company and can be the basis of SCA.

Globalisation and the changes which accompany it work in favour of business, and cultural identities of localities turn into treasure stores which can be successfully utilised by business organisations. These resources enable entrepreneurs to start new businesses, move into new lines of business, or promote new products, services or processes that create wealth. Hypothesis: Globalisation makes local cultures more visible and provides companies with the necessary connections for cultural identities of localities to serve as the basis for strategically important Sustained Competitive Advantages.

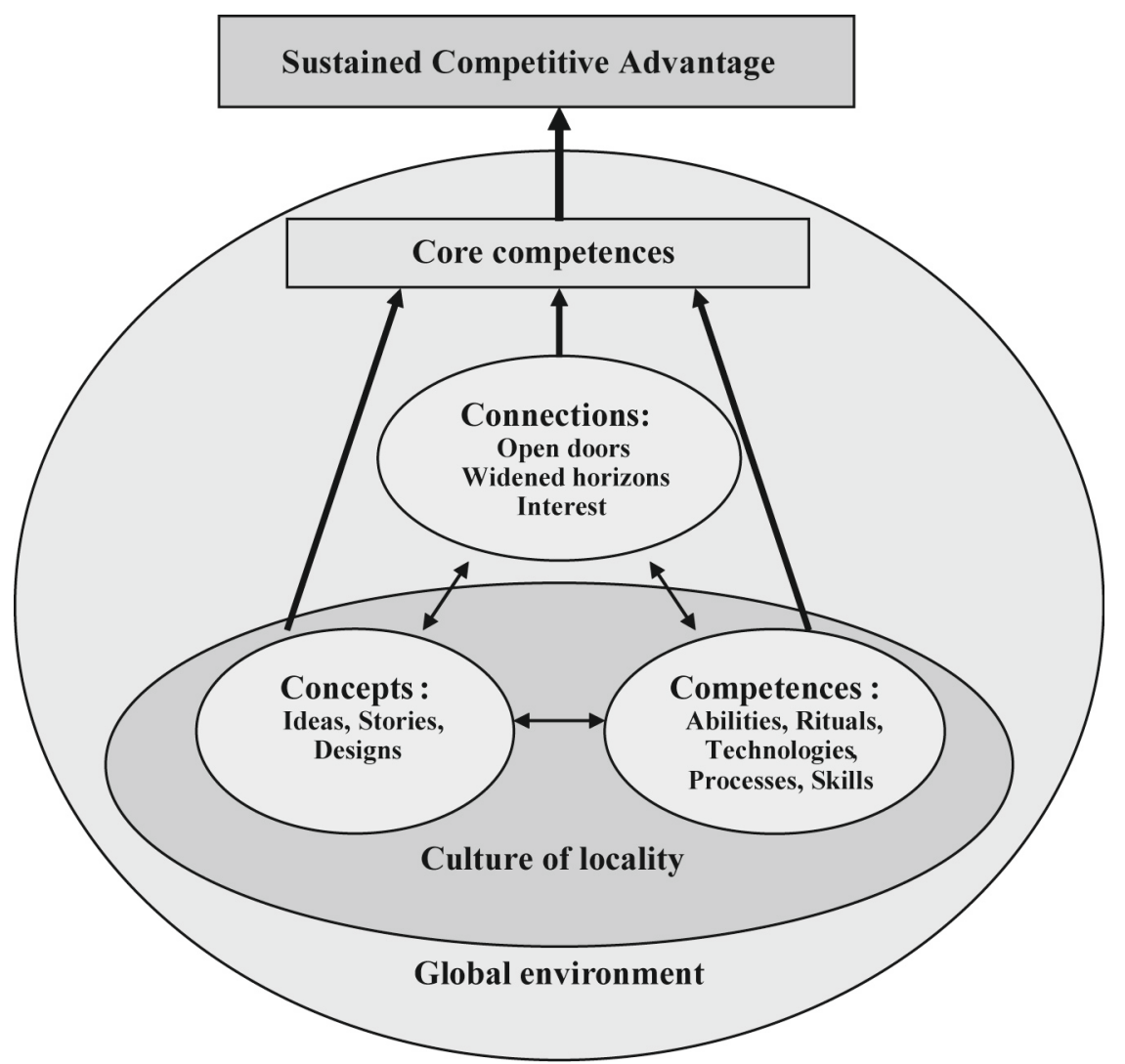

Figure 2: Competitive advantage from local concepts and competences through global connections

\section{EMPIRICAL EVIDENCE}

Many companies successfully exploit competitive advantages based on cultural identities of localities. There can be distinguished two forms of such SCA: 
1. SCA based on the cultural identity of a company's home locality, which is more sustainable, and

2. SCA based on cultures of different and other localities.

Globalisation provides the necessary connections for culturally based competences to become the basis for sustained competitive advantage, as shown in Figure 2.

\section{COMPANIES - EXAMPLES PROVING THE HYPOTHESIS}

IKEA: a furniture producing company which successfully exploits Scandinavian minimalist design to differentiate itself and exploits low cost advantages.

THE BODY SHOP: a cosmetics and toiletries manufacturing company, whose products, packaging and retail environment are physically differentiated and associated with ethnic traditions from around the world.

A number of other fashion companies, for example ZARA, LINDEX, CUBUS, $\mathrm{H} \& \mathrm{M}$ and others search for inspiration for their unique designs in different cultures throughout the world.

There are also many successful examples in Latvia. In most cases it is difficult to separate whether their advantages are based on Latvian cultural identities or those of our neighbours, but the importance is in the fact that cultural attributes are strongly present in their designs and processes.

STENDERA ZIEPJU FABRIKA: to some extent similar to The Body Shop, yet their packaging and retail environment is different and deeply embedded in Latvian culture. Founded in 2001, the company sells its products in 8 countries through franchises and is becoming a well-recognised brand with more than 50 stores abroad. Its development plan envisages entering markets in Great Britain, France and the Scandinavian countries.

The company's other branch, "Emīla Gustava šokolāde", also has a product, packaging and retail process that is deeply culturally embedded. Their forthcoming branch "Stendera Iebrauktuves" is going to be Latvian-style hotels and catering establishments exploiting cultural identities not only as ideas, skills and processes, but the environment as such - nature in the countryside.

LIDO: extremely popular catering facilities and cuisine which have became almost national symbols and are widely visited by tourists. Their products, service style and organisation are deeply embedded in Latvian culture and traditions with some aspects of German culture.

A/S "BRIVAIS VILNIS": a fish processing enterprise exporting its production to EU and CIS states, extremely popular for its smoked sprats in oil, with a taste and production process embedded in Latvian national cuisine. Currently the company is working with new markets in China, Mexico, and Latin America, where the sprat is not a usual component of meals, yet the company is going to compete particularly with the exotic nature of the product.

SIA"LĀČI": a bakery which exploits knowledge from ancient masters and culturally embedded technologies in production of their famous "true brown bread" 
and "sweet-and-sour bread", very healthy products still absolutely unfamiliar in many countries.

BAUSKAS ALUS: a beer producer, whose main wealth is traditions and old classical beer production technologies, which are kept in place although the enterprise is modernised.

VARIS Toys: a producer of a variety of wood products, such as finished wood panel, furniture parts and solid furniture pieces for export. Since 2001 it produces and successfully exports to the EU market children's wooden construction sets based on ancient technologies of wooden house construction.

LARELINI: deals with flax fiber processing - a traditional national process. It produces linen yarn and weaves linen fabric; it also has a sewing department.

\section{CONCEPTS}

Every time a company exploits some culturally based concept or competence, it creates a story about cultural legacy, some new history which underpins the company's image. Many companies successfully exploit cultural stories thus making the unfamiliar new enterprise more familiar, understandable, acceptable and trustworthy.

These stories help construct the company's identity as successor of a well-known cultural wealth and aim to build confidence that the enterprise would succeed, as it is based on old and tested values. For example, Irish Pubs throughout the world are different and managed by different people, but their story makes them familiar and trustworthy. The same holds true for Sushi bars, Chinese restaurants and other national cuisines. These stories may be true in the case when the company really is the legatee of an ancient and trustworthy enterprise, but they can also be invented. In the sub-consciousness of customers, they seem familiar and trustworthy. Actually the whole story can be only the name of the company or product line, if it creates the image and generates interest.

"Stendera Ziepju Fabrika" successfully exploits such stories in connection with all its business units. In cases with soap and chocolate these stories are invented, still they provide the products with the necessary image and create interest. In the case of "Stendera Iebrauktuves," the forthcoming branch, the story is partly true. The company has really cleaned the dust and aired out old mills, which are to be used as hotels and catering establishments.

Culturally based designs are widely exploited in the fashion and clothing industry, as well as in other industries. Oriental design is widely used in the textile and fashion industry, interior appliances, furniture and elsewhere. Well known is Scandinavian design which is successfully utilised by IKEA in furniture production. "The Body Shop" (Steingard, 1995) is especially creative in seeking for various culturally based attributes. An example of cultural design is the wristbands produced by women in four villages in Brazil for sale in Body Shops the world over. "Latgales keramika" is culturally based Latvian design of pottery with good prospects in international markets.

Culturally based ideas can be about finding applications for traditional things in new ways or using unusual things in ways traditional to different cultures. Such an 
example is the body scrub mitts from "The Body Shop" which are crocheted from the fibres of indigenous maguey from Mexquital Valley in Mexico, the traditional Mexican application of indigenous maguey. The Latvian company VARIS Toys has utilised the idea of wooden construction sets from Latvian traditional structures of horizontal logs in children's toys, which are high quality wooden construction sets and are sold in the EU market.

\section{COMPETENCES}

Culturally based assets are intangible and it is difficult to distinguish whether a company exploits culturally based concepts or competences, as they are usually merged and the same thing may be simultaneously an idea, process and skill. The packaging process used by "Stendera Ziepju Fabrika" is a culturally based idea, skill, process and also attitude to a present at the same time. "The Body Shop" widely used Brazil nut oil as the basis for its best-selling conditioner. This oil is produced in Kyapo village utilising traditional cultural cycles and traditions while using appropriate, purpose-built technology, so exploiting culturally based process and abilities. The same company produces shea butter in Ghana in accordance with their particular cultural knowledge and rituals. The traditional Latvian process of preserving sprats used by "Brīvais Vilnis" is unique and all attempts to replicate it by competitors have failed.

\section{TYPES OF COMPETITIVE ADVANTAGE AND CORRESPONDING STRATEGIES FOR CULTURAL EMBEDDING}

Porter (1985) distinguished two types of competitive advantage: cost advantage, which means similar products at lower cost, and differential advantage, which encompasses price premium from a unique product. He also has defined three generic strategies combining two types of competitive advantage with the firm's choice of scope - broad market or narrow segment. Porter's generic strategies are cost leadership, differentiation and focus. Culturally based factors can be successfully implemented in all these strategies.

As globalisation progresses, factors necessary for cost leadership strategies and cost advantages become rare or extremely difficult to obtain for SME. Financial and human resources are highly mobile, it is almost impossible to exploit scale-efficient plants. The advantages of having a wide choice of skilled and low-cost workforce are not more valid, at least it is not possible to count on this in the long run.

Some unique processes, abilities, skills, designs or knowledge present in cultural identities of localities can help to organise production processes, enabling companies to exploit low cost advantages and be competitive. Differentiation strategies are becoming more and more important, because customers today have a wide choice of everything and the product or service needs to differ even if it is at comparatively low price. The benefits of international business are benefits of more choice globally and locally (King, 2002). "Be different or die", the famous slogan of marketing specialist Jack Trout, who formulated his principles of "positioning" in 1969, is still current today. The main idea, that companies sell not products and services, but 
their differences as perceived by the customer, is even more important in the era of globalisation.

The cultural identities of localities are an extremely useful pool of stories, ideas and abilities which can differentiate the companies' products and services. Focus strategies are aimed to serve niche markets. Globalisation, particularly the internet, allows dispersed customers to come together in a way that encourages niche markets, for example, hundreds of websites dedicated to cheese (Nye, 2004). For companies it becomes more advantageous to serve niche markets, no matter where the company or its customers are situated. Schlie and Goldhar (1995) propose multiple niche competition as an addition to Porter's competitive scope situation.

Cultural diversities are very valuable as sources of ideas and as bases for niche market formation, because a wide variety of tastes can come together with a wide variety of choices. In such a situation differentiation strategies and multiple niche competition can be a great chance for SME to compete successfully in international and even global markets using culturally based advantages. Today many companies successfully exploit integrated cost leadership/differentiation strategy, as IKEA, for example. Concepts and competences based on cultural identities can be helpful in creating such differentiated products and produce them at costs below average. For all the generic strategies, the cultural identities of localities can serve as bases for sustainable competitive advantages because of uniqueness and the quantity of ideas, designs, abilities, processes and skills provided by different cultures.

\section{SUSTAIN COMPETITIVE ADVANTAGE ACCORDING TO THE VRIO FRAMEWORK}

The VRIO framework helps managers recognise sources of competitive advantage. Competitive advantage stems from resources and capabilities that meet the VRIO criteria. According to Jay Barney, firm resources must have four attributes to have the potential of generating SCA (VRIO framework):

1. it must be Valuable (V),

2. it must be Rare among a firm's current and potential competitors (R),

3. it must be imperfectly Imitable (I), there cannot be equivalent substitutes for this resource that are valuable but neither rare nor imperfectly imitable,

4. is the firm Organised in such a way that the resources that the resource can be exploited $(\mathbf{O})$ ?

If resources or a capability is valuable, rare, and costly to imitate, exploiting it will generate a sustained competitive advantage. Of course, there will be many resources or capabilities that meet some, but not all of the criteria. Those types of resources or capabilities can be thought of as an organisational competitive parity in case of valuable-but-not-rare resources. Or they can be thought of as a temporary competitive advantage of an organisation in the event that a resource or capability is valuable and rare, but not costly to imitate (Barney, 2006).

The question is: if the firm's resource is developed based on cultural attributes of a locality, does this resource correspond to the VRIO framework? Resources are 
Valuable when they enable a firm to conceive or implement strategies that improve its efficiency or effectiveness. The empirical evidence shows that culturally based resources allow companies to implement such strategies. These resources allow companies to differentiate themselves internationally or globally or produce at lower costs, as well as focus on niche markets. All the companies mentioned above serve as examples.

At first sight, it seems that culturally based resources are not rare, but it is not true in a context of global or international competition. The resource may be common in one relatively small locality, but $\boldsymbol{R}$ are globally, as in the case with "The Body Shop" and resources based on Mexican, Brazilian and African cultures. In other cases, a company can make a traditional thing rare by adding to it specific stories or organisational capabilities, as in the case with "Stendera Ziepju Fabrika".

Resources based on local culture, viewed globally, have all the attributes of imperfectly imitable resources, as explained by Barney: the ability of a firm to obtain such a resource depends on the unique historical condition of the particular locality, the link between the resources possessed by a firm's SCA is causally ambiguous - it is hard to determine why "Stendera Ziepju Fabrika" succeeds, but another company ("Labo Ziepju Fabrika") trying to imitate them doesn't. In general, it is impossible or very costly to Imitate cultural identities of localities, as these are complex social phenomena. Companies which are Organised to exploit their internal resources based on local culture can have the resources within the VRIO framework and use them as a basis for SCA.

\section{INQUIRY AMONG SME IN LATVIA}

In order to investigate the situation in Latvia, the attitudes of entrepreneurs towards globalisation, and the possibility of culturally based SCA, a research instrument in the form of a Likert-type questionnaire and unstructured interviews was applied. Small and medium size enterprises (SME) were chosen as the sample for the survey, because the majority of Latvian companies are such size, they have been described as having enormous economic potential, but also as being rather vulnerable. In total 38 companies engaged in manufacturing, trade and services were involved.

The questionnaire revealed that $63 \%$ of entrepreneurs and managers of SMEs find the Latvian market too small for their company's growth and development. Half of the respondents feel growing serious competition from international companies during the last years and the opportunity to engage in international operations would remarkably improve the position and indicators of $71 \%$ of companies. $70 \%$ of respondents agree that the presence of Latvia in the EU creates a positive environment and eases access to international markets.

These answers provide conclusive evidence of the fact that the Latvian market is small in terms of size and purchasing power, and this situation, together with growing competition from international companies in the domestic market, creates the desire and need for engagement in international operations. The presence of Latvia in the EU facilitates this engagement. The attitude of $61 \%$ of Latvian business people towards globalisation in general is positive, and everybody agrees 
that globalisation tends to ease international connections for business. $61 \%$ of the respondents don't feel any threats for Latvian cultural identity and are not afraid of cultural homogenisation.

$80 \%$ of involved entrepreneurs agree that in the cultural environment of Latvia there are plenty of ideas and skills which can be used in the creation of new ventures. Only 2 respondents disagree, but that is because they have never thought about such ideas before and never looked for ideas or skills in the cultural environment. The same refers to those who are undecided, still they suggest that such ideas and skills are possibly present. A majority of the respondents (92\%) suggest that globalisation creates an interest towards different cultures and the possibility to get acquainted with them. Although not so consistent, they also agree about the presence of culturally based ideas and skills in the environment of other localities in the Baltic. From the customer point of view, $76 \%$ are interested in products having cultural attributes.

The question "As sources of ideas for some of my products and services, I have already used cultural identities of Latvia's or another region's environment" was included to explore whether the idea developed above is currently working in the respondent's company. A majority of the respondents didn't know the answer and this situation suggests that they have never thought about the origin of ideas and skills used. Still $26 \%$ or 8 companies noted that they utilise culturally based ideas or skills in their ventures. Among them are companies producing souvenirs, implementing educational programmes, providing consultations, and engaging in trade and service.

Latvian business people are not threatened by cultural homogenisation and they see opportunities provided by globalisation, as well as they agree that local cultures can provide sources for new ideas and ventures. They actually agree with the hypothesis that globalisation makes cultures more visible and provides companies with the necessary connections for cultural identities of a locality to serve as the basis for sustained competitive advantages. These opportunities can be utilised through the organisation's internal environment and form a basis on which new SCA can be built.

Small businesses operate within an environment that is dynamic, turbulent and that offers great challenges. These challenges can be source of problems, but they can also present opportunities for SMEs. Latvia's market environment presents problems such as limited market size, low demand for some kinds of products and services and considerable competition. Therefore, the challenges offered by the presence of Latvia in the EU and current trends of globalisation must not be eliminated, but used as sources for opportunities.

\section{CONCLUSION}

Globalisation makes local cultures more visible and creates interest towards them; it provides companies with the necessary connections for cultural identities of localities to serve as the basis for strategically important Sustained Competitive Advantage. Having organised to exploit their internal resources based on a locality's cultures, companies can have the resources which correspond with the entire VRIO framework (valuable, rare, costly to imitate, exploiting) and use them as the basis for SCA. 
This source of opportunities has become particularly important in the era of globalisation. Such sources can be found in the cultural identities of localities and they are:

- Concepts (ideas, designs, stories),

- Competences (abilities, skills, knowledge, processes, technologies, attitudes and rituals).

The third necessary ingredient for formulation of culturally based SCA can be found in globalisation processes and that is:

- Connections (open doors and widened horizons, creation of interest).

The survey among Latvian SMEs has revealed their positive and opportunity seeking attitude towards globalisation. They possess the desire and feel the necessity to widen their operations internationally and agree that globalisation trends can be helpful in this process. Latvian entrepreneurs and managers feel culturally strong and interested in promoting their culture, as well as getting acquainted with other cultures.

Small countries, such as Latvia and the other Baltic states, are economically interdependent, they buy and sell internationally. They understand values other than their own, they speak many languages, and they love and preserve their own cultures. Because they want to live better, they cannot isolate themselves; they cannot be selfsufficient in the manner of a 19th century farm (King, 2002). Latvian and even Baltic markets are small in terms of declining population served and income available to consumers.

Most Baltic entrepreneurs have to look beyond their national borders for new markets. Catching up with new opportunities may be challenging. Global choices of the Baltic are increased by innovation and through acceptance of change. Baltic cultures and value systems are not in conflict with those of neighbouring nations and other western countries, so Baltic cultural achievements can be cultivated, maintained, and even exported.

Those who agree with globalisation's positive impact on the business environment can find multiple opportunities in cultural identities of localities and implement them in favour of their business ventures. Those who disagree with globalisation's positive impact can still make a contribution by promoting their culture and showing an interest towards other cultures, thus averting cultural homogenisation.

Business people can do even more by adding cultural stories or other attributes to their products and services, thus achieving simultaneously two objectives: promoting their culture and promoting their products through differentiation and creation of a special image. Globalisation makes local cultures more visible and provides companies with the necessary connections for cultural identities of localities to serve as the basis for strategically important Sustained Competitive Advantages.

\section{REFERENCES}

Barney, Jay (1991): "Firm Resources and Sustained Competitive Advantage". Journal of Management 1991, Volume 17, No.1, pp. 99-120.

Castells, Manuel (2004): The Relationship between Globalisation and Cultural Identity in the early $21^{\text {st }}$ Century. Forum Barcelona, Session summaries. 
Cowen, Tylor (2003): Creative Destruction: How Globalisation is changing the World's cultures. Princeton University Press.

Dahl, Stephan (2000): Communications and Culture Transformation: Cultural Diversity, Globalisation and Cultural Convergence. London: ECE.

Denner, Jill, Cooper, Catherine R. (1998): "Theories linking culture and psychology: Universal and community-specific processes.” Annual Review of Psychology, Annual 1998 v49p 559.

Eriksen, Hylland Thomas (1999): Globalisation and the politics of identity. UN Chronicle, autumn.

Held, David (2004): Globalisation: An Empirical Assessment and an Analytical Interpretation. Forum Barcelona, Session summaries.

Hitt, Michael, Ireland Diane, Hoskinson Robert E. (2004): Strategic Management: Competitiveness and Globalisation. Sixth Edition, Cincinnati: South-Western Publishing.

Kanter, Rosabeth Moss (1995): "Thriving Locally in the Global Economy". Harvard Business Review September-October.

Keillor, Bruce D., Hutt, Thomas G. (1999): “A five-country study of national identity; Implications for international marketing research and practice". International Marketing Review, Volume 16 Number 1 pp. 65-84.

King, Gundar J. (2002): “Global Choice and Innovation”. Baltic Studies Newsletter \# 101-01.

Nye, Joshef S. (2004): "Globalisation Promotes Cultural diversity". Africa News Service, Oct 19.

Porter, Michael E. (1985): Competitive Advantage. The Free Press, New York. Ch. 1, pp. 11-15

Schlie, W., Goldhar, Joel D.: "Advanced manufacturing and new directions for competitive strategy". Journal of Business Research, Volume 33, Issue 2, June 1995, p 103-114.

Sotshagane, Nkosinathi (2002): "What Impact Globalisation has on Cultural Diversity?" Alternatives, Volume 1, Number 4.

Streeten, Paul (2001): Globalisation: Threat or Opportunity? Copenhagen; Herndon, VA: Copenhagen Business School Press.

Steingard, David S., Fitzgibons Dale E. (1995): "Challenging the juggernaut of globalisation". Journal of Organisational Change Management, Volume 8 Number 41995 pp.30-54. 


\title{
Major Management Problems of Knowledge Based Economic Development
}

\author{
Andris Denins \\ Professor, Dr.oec., University of Latvia
}

The previous presentations have already highlighted a number of relevant focus areas related with integration of education, science and entrepreneurship. All these aspects taken together form the foundation of a knowledge-based economy, which has to be the guiding principle for all contemporary economists. However, in my brief presentation I would like to focus on the introduction and use of new, state-of-the-art products in business. And as for this aspect, we are really having an "uncertain transformation".

Despite the fact that Latvia is becoming more and more competitive year by year, its national innovation system may be classified as insufficiently strong, not to say weak and fragmented. At the same time, according to the Global Competitiveness Report 2005-2006, the co-director of which is Harvard University professor M.E.Porter, Latvia is ranked $48^{\text {th }}$ among 117 countries included in the research. However, the interrelationship of education, research and entrepreneurship is still insufficient. In terms of innovation development Latvia is still lagging behind many countries of the European Union. In 2005, only $17.5 \%$ of companies were evaluated as innovative. In the EU this indicator is on average $45 \%$ (Komersantu véstnesis, 23.10.2006, p. 13).

There are several innovation development and commercialisation management and organisation-related problems at the state level. I would like to particularly outline:

1) Stagnation and even reduction of $R \& D$. The indicators for 15 years show that the number of staff involved in R\&D activities has decreased almost 7-fold. Another problem is aging staff engaged in this field. The material and technological base of R\&D is not sufficiently upgraded. The financing allocated to this branch is only $0.4 \%$ of the GDP. This is 4 times lower than the average indicator in the European Union or Asian countries.

2) The interest of private entrepreneurs in $R \& D$ is insufficient. This can be seen from the unutilised financing from the structural funds allocated for these purposes, as well as by the fact that more than $80 \%$ of all R\&D activities are financed by the state sector. It is a generally known fact that the higher the share of investments made by private 
investors in R\&D on the whole, the higher the technological maturity of the state. This once again shows that Latvia is lagging behind the advanced or rapidly emerging developing states. There is also disproportional distribution of R\&D activities among big, medium and small enterprises. SMEs are practically not involved in R\&D.

3) The gainfully employed part of the population with a higher education (20\%) cannot generate and use high-tech capacities. Only $4 \%$ of the employed are working in the high-tech sector, only $4 \%$ of export value comes from high-tech. For Latvia, this is especially critical, since such a situation cannot be explained by the pressure from other EU member states. In Estonia, the Czech Republic and Slovakia high-tech export exceeds $20 \%$ of total national export value.

4) Research shows that less than one fifth (19\%) of companies are introducing innovations. On average, in the EU member states this indicator is twice as high.

5) The present distribution of students by scientific branches shows that almost two thirds of students have chosen to study social sciences, which does not contribute to the development of a knowledge-based economy in the future. Already today we can see that the rapidly developing Latvian electronics, machine building and metal processing industries offering competitive products to global markets experience a dramatic shortage of engineering staff. According to the survey conducted by LEIERA in 2005, the supply of engineers in electronics covered only $30 \%$ of the demand for these specialists. This year the percentage of the supply is even smaller (Jaunais Inženieris, RTU newspaper No. 3 (1318), 28 September 2006). At the same time the supply of engineers needed in machine building covered only $40 \%$ of the demand; this year (in 2006) the number of students enrolled in these specialities covers only $17 \%$ of the demand. The forecasts show that the number of specialists will decline even more in the years to come, due to a reduction in the number of secondary school graduates (this year $-18,000$ ). Moreover, already to date the quality of secondary education has become a topical issue. The present contingent of teachers (approximately 25\% of them being in the retirement age) cannot provide appropriate instruction and cannot pass the knowledge required by school curricula to schoolchildren. Therefore according to the data of the research carried out by TATeRA (Latvian Association of Economy and Electronic Industry), every year applicants undertaking studies at universities demonstrate lower academic performance (Jaunais Inženieris, RTU newspaper No. 3 (1318) 28 September, 2006). There is high demand for knowledge in the exact sciences and appropriate skills to eliminate labour-intensive processes and to ensure higher material cost effectiveness aimed at knowledge-based business activity. In order to transfer to knowledge-based entrepreneurship, it is necessary to have an appropriate professional education. Currently, the ratio of professional education and general education can be expressed 
as $1: 3$, in Germany it is 3:1. It is clear that young specialists are stronger in new technologies. Therefore, speaking about the new economy, I do not see any basis for the opinion that one of the advantages of doing business in Latvia is its cheap labour force. Our competitive edge has to be highly professional, educated labour knowing how to use the advantages offered by high-tech to streamline different processes. Economists have to clearly understand that in such a situation the resulting substantial growth of labour productivity should consequently contribute to the rise of the average wage;

6) Access to financing for innovative projects is also limited. It is generally known that such projects are exposed to a higher risk. At the same time, in the event of success, such projects ensure a high return on investments. The operation of funds in Latvia is only in its embryonic stage. In 2006, three venture capital funds were established supported by the state, the total amount envisaged to finance investment was 21.8 million LVL (Komersantu vēstnesis, 01.11.2006, pp. 4-5, V. Tamuzs. "Venture Capitalist - assistance or threat to a start-up"). This could be a pilot project for further development of venture capital and expansion of financial opportunities for innovation projects.

Each of these problems calls for a solution. It is clear that the most relevant of them are:

1) improvement of acquisition of exact sciences not only at higher educational establishments, but also at secondary schools;

2) increase of financing for R\&D which would yield effects in 10-15 years time;

3) promotion of the development of venture capital funds.

In conclusion, we have to remember the maxim that science is a process in which cash is transferred into knowledge and in the innovation process knowledge, in turn, is transferred into cash. 


\title{
Development of a Knowledge-based Society and a Knowledge Economy in Latvia: Uncertainties and Risks of Transformations
}

\author{
Prof. Edvins Karnitis \\ Leading Researcher, University of Latvia
}

Two strategic political documents that are extremely significant for the further development of Latvia have been approved during the last year. They minimise the major strategic braking factor for growth of the country - uncertainty related to sustainability of the development trend and continuity of activities.

In October 2005 the Saeima of the Republic of Latvia approved the conceptual document A Growth Model for Latvia: People First which defines a knowledgebased human-centred long-term development scenario ${ }^{1}$. Its principal feature is strong unity of the strategic trinity resources - goal - strategic activities and their cohesion around the central kernel - the human, inhabitant of Latvia (fig. 1).

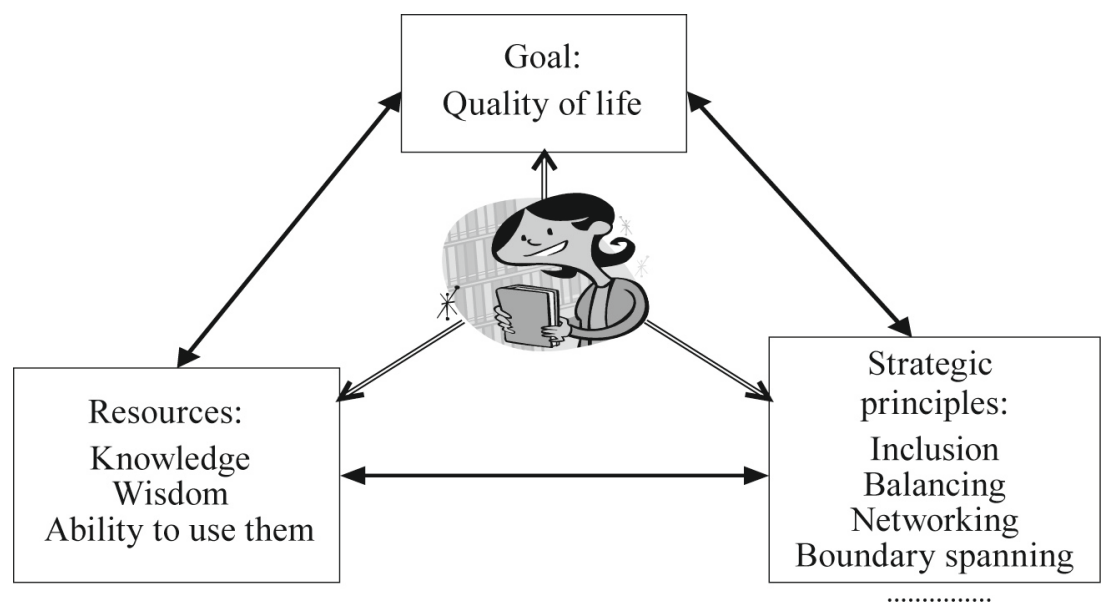

Fig. 1, Knowledge-based human-centred growth model

The decisive resource for growth is the knowledge and wisdom of Latvia's inhabitants and the ability of each individual to make use of this resource. It follows that human beings, as the creators, carriers and sole proprietors of knowledge, are and will increasingly be the most important factor in Latvia. Development that is based on human capacity should be targeted to human-centred goals, which are 
understandable for everyone and correspond to the interests of humans. Therefore raising the quality of human life is announced to be the goal of the country's growth. The collective knowledge of the people must be used to achieve this.

Latvia's main resource for future development can be utilised effectively only by all persons who live and work here, by common unified and synchronised efforts of all us. Everybody should be provided an opportunity to participate in the process, to use the knowledge at work and in everyday life, ensuring an increase in the quality of life. In achieving the defined goal, we must make use of coordinated and balanced development of each aspect of life, taking into account the unity of activities and the expansion of these activities beyond frameworks of individual sectors, institutions, formal state structures and across borders. People become the focal point of Latvia's policies - this clause really can be evaluated as the golden thesis of the Model.

Analysis of global development (Japan and Korea, Ireland and Finland, etc.) shows that strong, coordinated and purposeful activities are necessary to implement a knowledge-based strategy. Therefore, the National Development Plan (NDP) ${ }^{2}$ has been developed and approved by the government in July 2006 as a mid-term programme for implementation of the Model in the period from 2007 until 2013 (fig. 2).

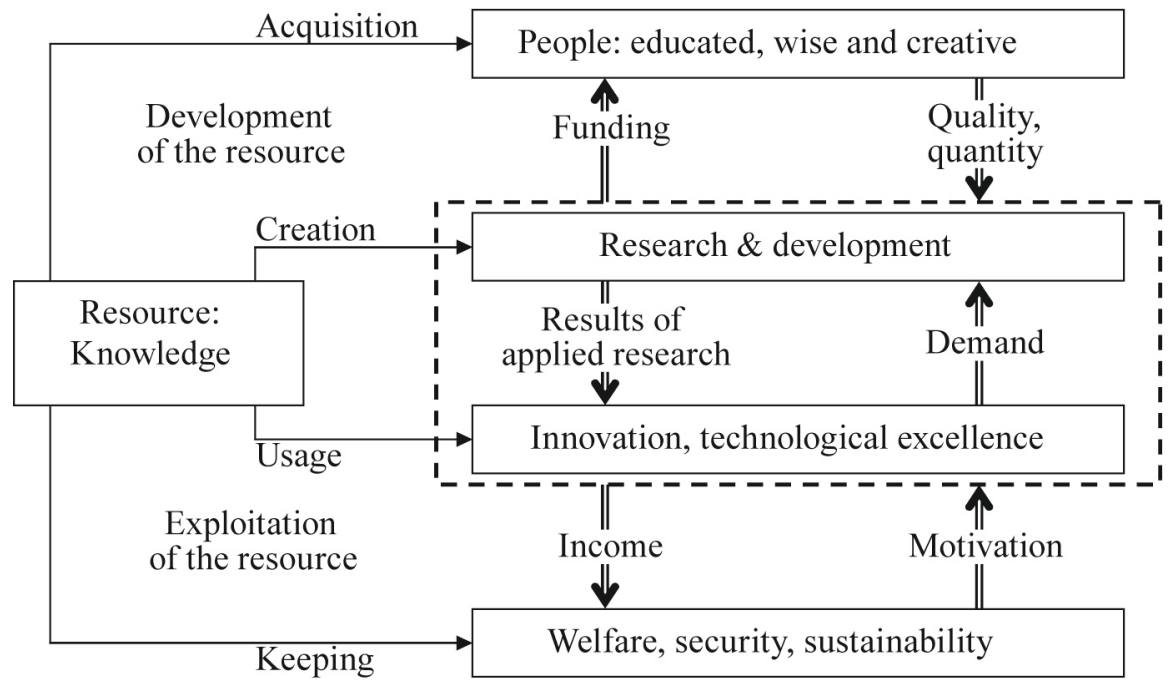

Fig. 2, National Development Plan: policy

The strategic goal of the Model cannot be reached within seven years but it is important to outline a national development strategy, to work in a coordinated and purposeful manner. The objective of the NDP is to facilitate balanced and sustainable development of the country, as well as to ensure an increase in Latvia's competitiveness; this should be achieved by gradual transition to a knowledgebased development model. A number of harmonised activities will be implemented to ensure development and exploitation of the growth resource (knowledge) and to increase the quality of life for everybody. As a strategic document, the NDP sets forth guidelines for drafting planning documents at all levels and sectors as well facilitates formation of a common understanding and involvement of the entire society. 
To be successful in the implementation of the approved development trend and to overcome possible obstacles, we have to concentrate all our available resources. Let us analyse briefly the basic possible uncertainties and risks of forthcoming radical transformations.

The system of development planning should include a set of interconnected long-term, mid-term and short-term documents, related to both sectoral and regional aspects (fig. 3). Only several strategic documents correspond in full to this principle at present $^{3}$, thus supplementing the Model and the NDP.

It is necessary to develop a long-term integrated concept that will strongly interlink the Model with mid-term programmatic NDP and with follow-up plans after 2013. Using the strategic foundation of the model, ministries and other administrative institutions in cooperation with professional associations and nongovernmental organisations must draft, correct and implement detailed strategic concepts, programmes and plans for the development of the various sectors and growth paths. They must define concrete criteria, actions and instruments that are necessary to achieve the goals set out in this document.

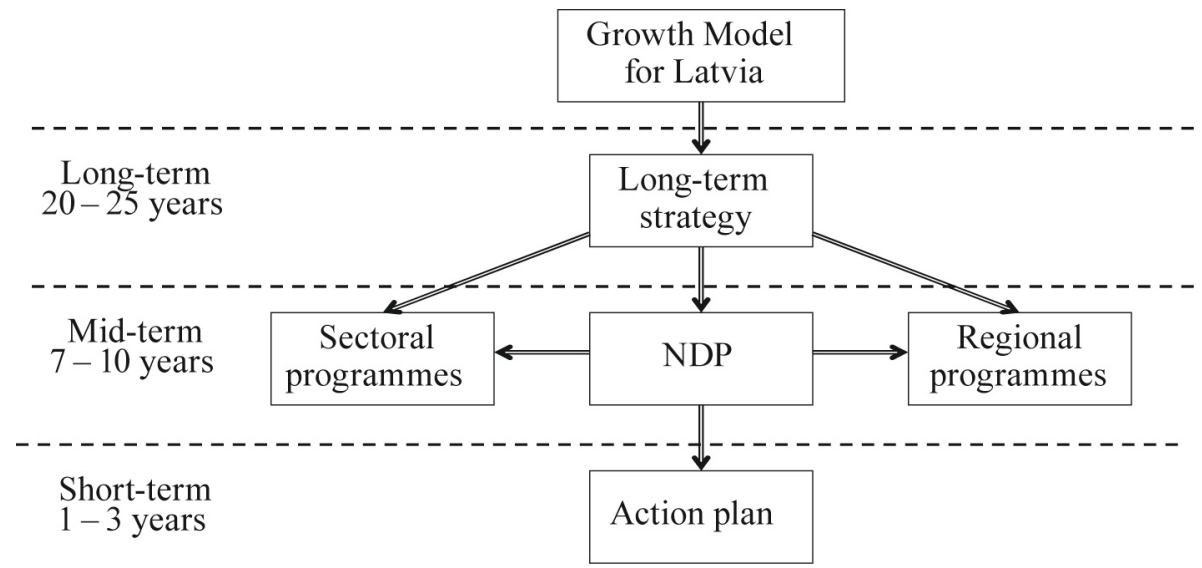

Fig. 3, System of development planning

The linkage of business with $\mathbf{R} \& \mathbf{D}$ traditionally is the weakest segment of innovative processes. Profit is the basic goal for any businessman; the sector of activities and products are second-rate issues that really are instruments for the high profitability of business. But the risk factors in creative processes are much higher than in standard production processes. The development of a new product is a leap into the unknown; neither experience and previous successes nor the use of tried and trusted ideas and methods can guarantee success. It is planned to change existing flat business support policy and to provide more support to enterprises that are seeking to intellectualise their business, to increase turnover of new-to-market and new-tofirm products, to modernise their technology. Innovative business has to become profitable.

Innovative capacity and the knowledge potential of our industry is not high enough; successful development of a knowledge economy is unthinkable without the usage of the potential of academic society. On the other hand, only in cooperation with 
manufacturing industries can new ideas, discoveries and approaches of researchers be turned into new products. Commercialisation of the created knowledge is an important task in achieving practical applications of research-capacious ideas and turning them into products with high added value.

Therefore the NDP has defined the task for the administration: to support a full cycle of creation and development of new products, to change radically the existing governmental support principle, to introduce special promotion of innovative activities. A favourable environment for creativity and a blossoming knowledge economy has to be developed; everybody and every company have to be motivated to be innovative and to invest in innovation. Research and technology commercialisation, closer ties between research institutions and companies, and the ties of these institutions with the real market situation - this trend has to be implemented.

It comprises much more than just high tech industry. It includes knowledgebased activities in any field, in the most traditional industries and services, in any job or area of activity. We have to use in full all possible freedom of movement that is given us by EU regulations and directives. Without creation of a legal environment and tax policy favourable for innovative business, a synergy between production and new knowledge cannot be achieved (the market will solve it is old-style thinking). And various measures should be devised in order to motivate young people to choose research.

The capacity of the education system plays the key role in a knowledge-based development strategy. On the one hand, "access to education is a fundamental right, as well as a tool for combating illiteracy, marginalisation, poverty and exclusion", i.e., for increasing the quality of life. On the other hand, education is no longer a matter of personal choice. It is a central economic and political factor; highly qualified specialists become the strategic potential of the country. The basic criterion is no longer what we know, but how we apply that which we know.

Even several world standard gurus will not ensure development of the country; today's knowledge-based process is characterised by general participation, by massproduction and mass-usage of knowledge. It is necessary to improve the quality of general education in primary and secondary school without delay; today's mediocre graduates cannot serve as a stable basis for knowledge-based development (fig. 4).

The limited availability of human resources in our country can be partly compensated by increasing the availability and quality of education at all levels, by compulsory secondary education, by increasing the number of students who pursue higher education and by sharply decreasing the drop-out rate. The renewal of the prestige of work of pedagogues, inviting high-quality foreign professors to deliver specialised training courses in Latvian universities, assistance to new doctoral students, ensuring top level professional studies in the specialities of prime importance for the country at the best foreign universities, increasing significantly the proportion of students studying natural sciences, medicine and engineering, as well as the number of specialists with the highest qualification (master's degree and doctoral degree) - these and other activities will improve our knowledge resource. 


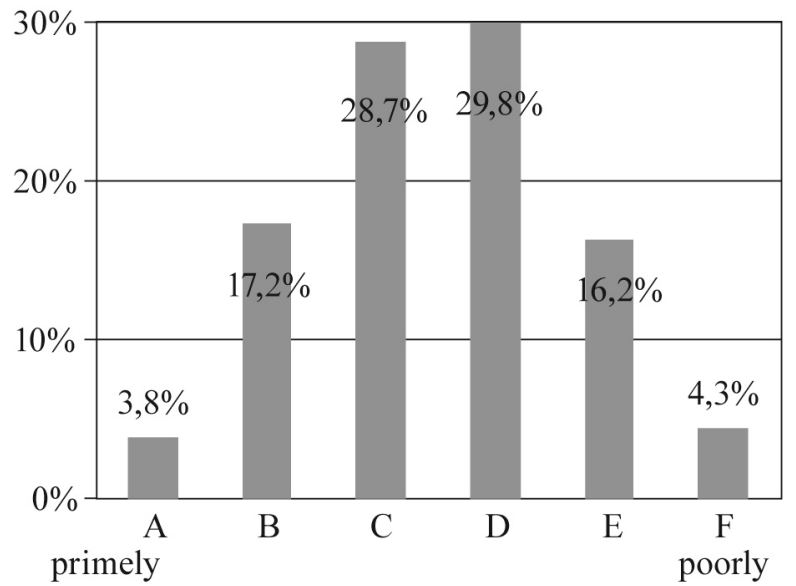

Fig. 4, Secondary education, results of unitary examinations 2006

Nevertheless current negative demographic trends could prevail over all activities. Controlled immigration of specialists from third countries via tertiary education establishments is a tool popular in many developed countries, but unused in Latvia. The learning process will give us full possibilities to control professions and the quantity of specialists that is optimum for the growth of Latvia. From a current brain donor, Latvia has to become the brain beneficiary.

Close cooperation within the Baltic Sea Region is the chance and challenge for Latvia. The highest added value will be produced if we could implement the complete creative process, starting with R\&D (even education) up to the final production and sale of the knowledge-capacious product. But limited human resources and a small economy ${ }^{5}$ are objective restrictive factors for Latvia and its companies. For this reason, transnational partnerships become an extremely substantial issue for us. The country needs to participate in the innovation process as a full-fledged partner. Participation in partnership networks and the division of labour is our challenge.

All Baltic Sea Region (BSR) countries (including northern Germany, northern Poland and north-western Russia) individually are not among the leading world powers, but for centuries they have been linked through their location in a region of pronounced geopolitical interest, common history, multicultural societies and also a similar vision of the future. Today the BSR is an excellent composition of strong and dynamic countries. ${ }^{6}$ The region has a strong international position in various rankings of world countries while the Baltic States have witnessed the most rapid growth. ${ }^{7}$

At the same time, to become more competitive on a global scale, countries of the region have to act as a single body. The opportunities of larger partners in our networked world are much higher ${ }^{8}$; therefore stronger partnership and unity is the challenge for all countries of the region. The Hanseatic League, the economic political formation that in the 14th-15th century united the cities of the Baltic and North Sea region, showed the region's trend to mutual cooperation. This becomes 
very significant again in the 21 st century, as it will help all region countries to achieve the effect of synergy.

The region is a very smart area; it has always respected knowledge and, at present, it has accumulated enough wisdom and human resources to develop a knowledge economy. Knowledge-capacious products and services comprise a significant part of the national economies already today. Creation of a single knowledge space in the whole BSR, that includes the whole process education $-R \& D-$ innovation business, consolidation of resources and mutual learning will become beneficial for all partners.

Practical realisation of the knowledge space could be based on a network of metropolises of the BSR (a Hanseatic League of the 21st century); it will provide the necessary preconditions for the development of a well-balanced region. The creation of a network of metropolises will strengthen their mutual cooperation abilities; it will be an effective instrument to achieve the needed synergy. On the other hand, metropolises as knowledge hubs of national significance have to become an important force driving development in each country.

Raising the quality of life for each individual, particularly for the middle class (because traditionally the middle class is a carrier of the strategic knowledge potential of any country), a human-centred social model, balanced investments in infrastructure and the social sphere are the principal preconditions for people to prefer living and working in our country and not others in an open Europe, and particularly neighbouring BSR countries. ${ }^{9}$ It is an important, but difficult task; according to the human development indicators, all EU countries have been included in the highly developed group meaning they have a high quality of life (fig 5). ${ }^{10}$

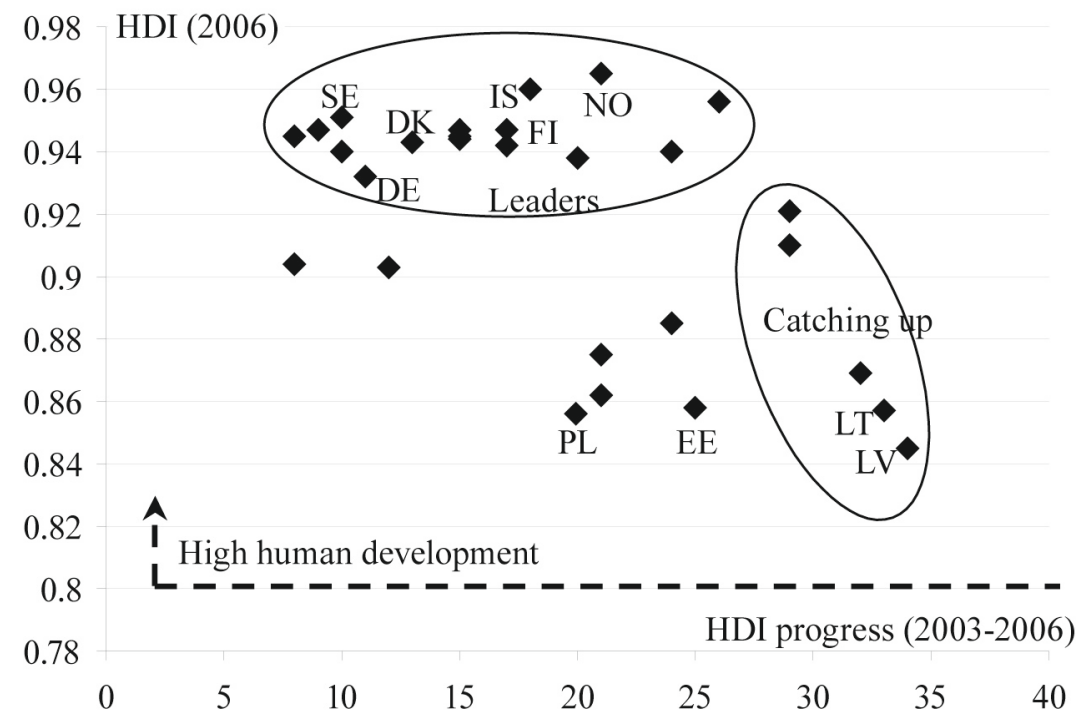

Fig. 5, Human Development Index; ranking positions of EU countries

Low and flat tax rates, flexible work organisation, a qualitative living area (healthcare and culture traditions, protected environment, water and food quality, 
security on the street and in school, etc.) - these and other factors characterise quality of life and attractiveness of the country. Therefore our success depends on our capacity to transfer economic progress to all spheres of living. The quality of life in Latvia has to become better than in neighbouring countries.

In addition progress has to be achieved in the entire territory of the country, consequently, there is a need for polycentric development. The common saying is that Riga as the knowledge, business, research, cultural metropolis in the Baltic Sea Region attracts the brains of Latvia. It is time to find an algorithm for successful usage of Riga's excellence, potential and resources for the development of other regions of Latvia.

Funding for implementation without any doubt is a problem and challenge. There will be several EU, national, municipal and other sources of funding for implementation of the NDP. Latvia has to ensure targeted and focused application of funding according to the main principles and guidelines of the NDP and, at the same time, prioritise the supported areas and concentrate the funding in the areas of highest necessity and most considerable return.

The central and local government budget planning system is under revision at present. The Cabinet of Ministers has approved the concept on mid-term budget planning in August 2006 in order to improve budget planning, to make it more reliable and continuous. It is planned to institute new procedures - five years conceptual planning and current budget for two years with annual particularisation. This will give significant support for the innovation-based development strategy (let us remember the long time necessary for R\&D, innovation and manufacturing of knowledge-capacious products). The budget of 2008-2009 will be developed according to this algorithm.

The National Strategic Reference Framework 2007-2013 has been developed and approved ${ }^{11}$; it is aimed at efficient attraction of EU Structural Funds and Cohesion Fund co-financing. An optimal distribution of EU funding among sectors on the macro level has been achieved at present. The next important task is adequate activities on the micro level - the development of programmes and determination of project criteria. First come, first served cannot be considered the best principle; our experience shows that innovative projects are not among winners in such competitions.

By seeking potential resources for further development of infrastructure and services, the public-private partnership model has to be developed. The model should be based on the capacity to combine the strengths of both (public and private) sectors through harnessing the innovative potential of a private entrepreneur and rationally using funds from the state budget. Enlisting private capital, active public-private partnerships starting from the early product development stages has to become a decisive tool for beneficial innovation. Let us not consider PPP as an activity that is compatible with some unsuccessful privatisation cases. 


\section{CONCLUSION}

Knowledge management on the national scale denotes wisdom and efficient (skilful, unified, coordinated, immediate) usage of knowledge by the whole population. We lack time for implementation of the Growth Model - our knowledge resource without its processing becomes smaller in comparison with that at the global level. More and more countries choose knowledge-based development, and competition becomes stronger. We are too small a country to lose time and energy in conflict and even contradictory activities, e.g., on issues such as the threat of an overheating Latvia's economy. Delays would result in irreversible negative consequences for our country.

\section{ENDNOTES}

1 Growth Model for Latvia (in Latvian). - http://www.nap.lv (01.12.2006). See detailed description in: E. Karnitis. "A knowledge-based human-centred growth model for Latvia," Journal of Business Economics and Management, Vol VII, 2006 N3.

2 Latvian National Development Plan. - http://www.nap.lv (01.12.2006).

3 E.g., Information Society Development Guidelines 2006 - 2013; Operation Strategy for Ministry of Health 2007 - 2009; ICT for Quality of Education 2007 - 2013 (in Latvian). - http://www.mk.gov.lv (01.12.2006).

${ }^{4}$ Communiqué; Ministerial Round Table on "Towards Knowledge Societies". UNESCO, 2003. - http://portal.unesco.org/ci/en/ev.php-URL_ID $=10593 \& U R L \_D O=D O \_$ TOPIC\&URL_SECTION=201.html (01.12.2006).

${ }_{5}^{5}$ We are only $0.035 \%$ of humanity and our demographic prognosis does not show an increasing population in the nearest future; our GDP in PPS is about $0.053 \%$ of world GDP. See, e.g., The World Factbook. - https://www.cia.gov/cia/publications/factbook/ index.html (01.12.2006).

${ }^{6}$ BSR is home to nearly $1 \%$ of the world population, which produces more than $2.5 \%$ of world GDP.

7 E.g., Global Competitiveness Index 2006-2007 (http://www.weforum.org/en/index.htm) (01.12.2006) ranks Finland, Sweden, Denmark at the top of list, while Norway, Sweden, Latvia show impressive progress in ranking position. European Innovation Scoreboard 2005 (http://trendchart.cordis.lu) (01.12.2006) shows Sweden, Finland, Denmark, Germany among leading countries, while Iceland, Lithuania and Latvia are among the most successful catching-up countries. Denmark, Iceland, Finland have the highest Networked Readiness Index 2005-2006 (http://www.weforum.org/gitr) (01.12.2006), while Poland and Latvia are among the European countries with the most progress.

8 Although capacity of small partners sharply increases after networking, they really cannot take all occurring opportunities; therefore the gap between small and strong partners increases in comparison with the pre-networking situation; it is one of the networking paradoxes.

9 Quality of life index for Latvia. Commission of strategic analysis; publications. - http:// www.president.lv/pk/content/?cat_id=1852\&lng=en (01.12.2006).

${ }_{10}$ In the ranking of Human Development Index 2006 (http://www.undp.org/hdro) (01.12.2006) Norway, Iceland, Sweden placed at the top, while Latvia and Lithuania are the most dynamic catching-up countries in Europe.

11 National Strategic Reference Framework (NSRF) 2007-2013. - http://www.esfondi.lv/ page.php?id=690 $(01.12 .2006)$. 



\section{NGOs, Social Capital and Social Welfare Reform}





\title{
The Contribution of Non-Governmental Organisations to Urban and Rural Development in Lithuania
}

\author{
Jūratė Imbrasaitė \\ Vytautas Magnus University, Lithuania
}

Most scholars agree that civil society in post-communist countries is distinctively weak and differs from that in other regions of the world. Civil society in postcommunist countries is characterised by low levels of organisational membership, low levels of social capital and ambiguous boundary relationships between the third sector, the state and the free market (Degutis, 1995; Degutis, 2002; Howard, 2003; Matonyte, 2004; Palidauskaite, 1997; Ramonaitè, 2005; Žaliukaite, 2005).

The democratic ideal refers to equal consideration and representation of the needs and preferences of all citizens, but the reality of citizens' participation in Lithuania is different. Because of the low levels of human and social capital, rural people are not equally represented in political life and the market economy (Imbrasaite, 2006). The focus of this study is the contribution of non-governmental organisations (NGOs) to urban and rural development in Lithuania. The method of the study is a survey sample and an in-depth interview.

\section{THE ROLE OF NON-GOVERNMENTAL ORGANISATIONS IN A DEMOCRACY}

Fung (2003) indicates that associations contribute to democracy in particular ways because of their citizen socialisation, the public sphere, resistance and checking power, and interest representation effect. Participation in associations can have effects on individuals (Putnam, 1993; Verba, Brady \& Schlozman, 1995) such as increasing their sense of efficacy, providing them with political information, imbuing them with political skills, developing their civic virtues, and teaching them to be critical.

Associations provide the social infrastructure for public deliberation and a setting for an agenda. Warren argues that those associations that are able to keep the public sphere vital are those that have something to gain by going to the public: "... they must have the capacity to project their voice over time and space". Finally, associations can have institutional effects when they interact with state structures. Associations can improve the quality of representation by transmitting the needs and preferences of their members to government, mitigating representational inequalities. 
Badescu (2003) argue that the three main mechanisms through which associations might produce democratic effects in post-communist countries are social learning, the public sphere, and institutional effects. Organisations may contribute to forming and enhancing attitudes, knowledge and behaviours of individuals in ways that benefit democracy. Participating in associations, individuals are able to develop cognitive and deliberative skills, civic virtues, and a sense of efficacy (Badescu, 2003).

The concept of civil society is usually identified with an ideal type. Uphoff (1993) indicates that each society includes three sectors such as the state, the market and the "third sector", which each have a distinctive logic. The logic for the state is that of hierarchical authority, for the market it is profit and loss, for the voluntary sector, it is voluntarism. Some scholars (Edwards and Foley, 1998; Alexander, 1998) argue that it is important to understand the "boundary relations" between civil and uncivil spheres. Civil society is interconnected and interpenetrated by other differentiated spheres such as the economy, the state, religion, and the family, which have their own criteria of justice and their own systems of rewards (Alexander, 1998). Alexander (1998) indicates that the economic sphere structured by markets may facilitate the construction of a civil society, because independent, rational, and self-controlled behaviour is enhanced. The boundary relations between the economic sphere and civil society have a positive impact on the civil sphere as long as the market economy promotes independence, self-control, rationality, equality, self-realisation, and cooperation (Alexander, 1998). Because of economic inequalities, the market economy may have a negative impact on the civil sphere as well.

\section{METHODS}

The method of the study is a survey sample and in-depth interviews. The survey was carried out within the framework of the Civil Society Institute project in June 2005. The sample of the survey was a stratified multi-stage sample, which represents the total number of the inhabitants of Lithuania aged 18-75. 40 in-depth interviews with members of non-governmental organisations were conducted in 2 towns with a population of over 400,000 residents and in 8 villages with a population of less than 2000 residents. 2 selected towns and 8 selected villages represent the 5 regions of Lithuania. Although more detailed research and analysis still needs to be extended to additional villages in Lithuania, particularly to those located in the remaining 5 regions of Lithuania, I argue that the same causal processes apply, in varying ways and to varying degrees, to the rest of the region as well. The interviews were conducted with members of officially registered non-governmental organisations active in a particular village or a town.

\section{THE MAIN TYPES OF NON-GOVERNMENTAL ORGANISATIONS AND THEIR AIMS IN RURAL AND URBAN COMMUNITIES IN LITHUANIA}

Most non-governmental organisations in urban areas were initiated by a few active persons who had concrete ideas concerning aims and activities of their organisation and often were supported by local government, national (Lithuanian 
trade union) or international organisations (United Nations, Caritas, Montessori, Rotary).

Our organisation was established by... a group of women who have experience of divorce. (Member of Women's help for women in an urban area)

A woman who became a member of the Seimas established the Centre twelve years ago. She was the first director of the Centre and I was the second person who was employed by her. The Centre was the result of a partnership between the Kaunas municipality and the United Nations development programme for Eastern and Central Europe. (Leader of Woman's employment and information centre in an urban area)

Most non-governmental organisations, especially local community organisations, in rural areas were created "from above" by officials of local government.

... the head of the neighbourhood called us, we gathered and decided to found it [a local community organisation], ... a local community organisation may apply for funds ... all local officials have been dreaming that territorial communities would write projects....and would get money, and they would fold their arms and would only sit... (Leader of a local community organisation in a rural area 5)

... local community organisations were not founded themselves. ....They were established by the government from above. Because a region, a local community may get financing through local community organisations .... more serious projects are financed through local community organisations... (Member of a patriotic organisation in a rural area)

Sometimes local government officials established a local community organisation "from above" in urban areas, but mostly they were created "from below" by a group of active persons.

The centre of the local community was established in a library, where I worked. I had some supporters in our library. The leader of another local community centre induced me to do it. (Leader of a local community organisation in an urban area 2)

The leaders and members of local community organisations in rural and urban areas indicated that officially declared aims have not been not fully implemented in the activities of their organisation:

They [goals and tasks] are not fully implemented, but some of them, just say, yes. (Leader of a local community organisation in a rural area 6)

We have been able to implement about eighty percent of our goals and tasks. (Leader of a local community organisation in an urban area 2)

Leaders and members of local community organisations in urban and rural areas emphasised that the main aim of their organisations was to identify local problems and to mobilise local people to solve them.

The aim of the local community organisation is to organise events, to get money and to do something together. To take out local people from the 
shell of an egg in order for them to become a collective group. (Leader of a local community organisation in a rural area 8)

On the contrary, most leisure organisations in rural areas have been established from "below" and mostly have been oriented to leisure activities and sharing of information related to hobbies:

We did not have serious aims. Our organisation was really devoted to women's spare-time activities $\langle\ldots\rangle$ we had small aims when we established our organisation. We did not raise huge aims, because we really were not able to do that. Our aim was to see as much as possible, to go to various parks, to discuss issues of domestic chores ...we sought to solve our leisure time problems... It was what we could not get in families, somewhere else... something that would be only for women - to express ourselves. (Leader of rural women's organisation 1)

It was an internal need to get and to give what you are not able to get in your own house. You could not get it from your friends, it was a wish for a broader life... It was not a need for independence, but we simply wished to participate somewhere, to do something that we could not do alone or with our families. (Leader of rural women's organisation 1)

Most leaders of non-governmental organisations in rural and urban areas indicated that non-governmental organisations were registered officially in order to get financial support from the local or national government or from foreign foundations:

An organisation is better than a formal group... it ensures more opportunities... it is possible to contact state institutions, write projects. (Leader of a local community organisation in an urban area 1)

Table 1

Membership in non-governmental organisations by population of residence

\begin{tabular}{|l|c|c|c|c|}
\hline \multicolumn{1}{|c|}{ Type of organisation } & $\begin{array}{c}\text { Population from } \\
100,000 \text { to } 500,000 \\
\text { inhabitants, } \%\end{array}$ & $\begin{array}{c}\text { Population from } \\
2000 \text { to } 100,000 \\
\text { inhabitants, } \%\end{array}$ & $\begin{array}{c}\text { Population } \\
\text { less than 2000 } \\
\text { inhabitants, } \%\end{array}$ & $\begin{array}{c}\text { Total } \\
\text { population of } \\
\text { Lithuania, } \%\end{array}$ \\
\hline Social work & 0.9 & 1.1 & 1.7 & 1.2 \\
\hline Religious & 2.5 & 2.3 & 2.6 & 2.5 \\
\hline Cultural (art, music, education) & 2.2 & 3.5 & 2.3 & 2.6 \\
\hline Trade unions & 3.3 & 5.2 & 1.6 & 3.2 \\
\hline Local community & 0.4 & 1.5 & 1.5 & 1.1 \\
\hline Human rights & 0.2 & - & - & 0.1 \\
\hline Environmental & 0.9 & - & 0.5 & 0.5 \\
\hline Professional & 1.2 & 2.7 & 0.7 & 1.5 \\
\hline Youth (scouts, youth clubs) & 2.6 & 2.1 & 2.6 & 2.5 \\
\hline Sports and active leisure & 2.9 & 4.7 & 3.2 & 3.5 \\
\hline Women's & 1.1 & 0.8 & 1.2 & 1.1 \\
\hline Movements for peace & 0.2 & - & 0.3 & 0.1 \\
\hline Health clubs & 3.2 & 1.8 & - & 1.7 \\
\hline School board & 5.7 & 5.9 & 4.4 & 5.3 \\
\hline
\end{tabular}




\begin{tabular}{|l|c|c|c|c|}
\hline Housing & 5.2 & 5.1 & 1.8 & 4.0 \\
\hline Other & 1.6 & 1.9 & 2.5 & 2.0 \\
\hline Total in all organisations, \% (N) & $27.7(395)$ & $30.7(276)$ & $21.8(338)$ & $26.6(1010)$ \\
\hline
\end{tabular}

The results of the survey show that people in rural areas with a population of less than 2000 inhabitants participate in social work, religious, cultural, local community, sports and active leisure, women's and other organisations more than urban people who live in towns with a population of over 100,000 inhabitants (Table 1). On the other hand, people in rural areas with a population of less than 2000 inhabitants participate in trade unions, human rights, environmental, professional, health clubs, school boards, and housing organisations less than urban people who live in towns with a population of over 100,000 inhabitants.

Non-governmental organisations in urban and rural areas may be divided into four types according to their aims and activities: activist (Amnesty International, human rights, movement for peace, environmental), interest (trade unions, local community organisations, social work, women's, professional, school board, housing organisations), leisure (sports and active leisure, health clubs, cultural) and interestleisure oriented (religious, women's) organisations.

\section{THE IMPACT OF THE SOVIET LEGACY AND FREE MARKET ON PARTICIPATION IN NON-GOVERNMENTAL ORGANISATIONS IN RURAL AND URBAN AREAS}

People enjoyed material guarantees and security in Soviet times. Most interviewees indicated that people's economic situation, especially in rural areas, was better in the Soviet era.

...well, there is no [COMMUNIST] Party, no single truth ... and, I say, there is no terror against people now. ... material well-being?... the Lithuanians' economic situation was not bad then [in the Soviet time]... material well-being decreased, and moral well-being increased in comparison with the Soviet time...(Leader of a local community organisation a rural area 4)

Interviewees in rural areas indicated that the market economy increased the workload on farms and led to decreased relations with other members of the local community.

...there is alienation .... Now all have their own groups separately.... And now ... if you are a member of a political party, you have a group, if you are a member of a folk group, you have the second group, if you are a member of a neighbourhood community, you have the third group and neighbours - there are four groups in which you are participating. (Leader of a local community organisation a rural area 6)

The total control of the State and people's inability to have a real impact on their lives in the Soviet period caused indifference to community affairs and a low sense of personal efficacy. People were used to somebody taking responsibility for their problems and caring for them. 
People's understanding that somebody has to care for them, and, especially the State, comes from the Soviet system. (Leader of rural women's organisation 1)

...our society is entirely post-Soviet so far, we are brought up so [that] the Government is the Government and it is impossible to change it and there is no use to do it... (Member of Sauliai in a rural area)

People are still rather indifferent. If there is a problem really related to them, lack of something, they start raising it, but, in general, they are not interested in anything. (Leader of women's organisation in a rural area 1)

The efforts of a local community organisation to associate with local people and to consolidate them are often rather successful.

...on state holidays some people came from the church....Well, on Midsummer Day we organised a party... If a party was ....and there was some financing ... - then it is possible to expect that more local people would participate ... (Leader of a local community organisation in a rural area 6) affairs.

Only more educated and more active people participate in local community

Educated people are more interested in activities of the local community organisation. I think those people who are less educated are afraid of something. They think, "well, noblemen do it for themselves"... when we were building a funeral hall, women from a religious community were always saying "You are doing that....you are doing that for yourselves". (Leader of a local community organisation in a rural area 3 )

The same group of active and more educated persons usually work in all nongovernmental organisations of a rural local community.

I am a member of all organisations in our local community. Well, yes, a group [of active people] is divided into a few small [groups or organisations]... (Leader of a rural women's organisation 2)

.... eleven persons are in the community Council, five persons come to the meetings... a local community organisation is like that... I am a member of a Sauliai organisation as well... (Member of a local community organisation in a rural area 3 )

Even if an organisation was registered officially in order to get financial support, most rural people indicated that they participated in because of a need for socialising or self-realization.

She rests for about four or five hours at night in summer and it makes no difference. She participates in local community activities and even participates actively. A person needs something, because work... farmer's work... it is complicated... it is difficult for a person... a need to socialise with others... (Leader of a local community organisation in a rural area 2)

Members of urban non-governmental organisations identified the passivity of their members as a major problem. 
...maybe the main problem of the organisations is our members' passivity. Well, the passivity of people in general. (Member of small businessmen's organisation in an urban area 2)

\section{THE ROLE OF NON-GOVERNMENTAL ORGANISATIONS IN RURAL AND URBAN COMMUNITIES}

Leaders of local communities in rural and urban areas indicated that the establishment of a formal organisation helped them to put pressure on the local government.

... we are no longer just a private individual ... We can talk, for example, to the mayor, they look at us in a different way. If it were an entirely informal group, it would seem as if a group gathered and made ruffles .... We have some power already ... we are organised to a certain extent. This is an organised group, not just any group. (Leader of a local community organisation in a rural area 8)

Local community organisations in rural and urban communities mostly aggregate and transmit local people's claims to the local government.

The local community organisation has an influence on the work of the local government... Look at our last meeting....if there were no local community organisation, those high chiefs, starting with the mayor, the chief of roads, the chief of a bus park ...would have not appeared. If the local community organisation had not made claims about the improvement of roads, especially about cleaning them in winter, on lighting, on protection from assaults last winter... they would not have done anything. (Leader of a local community organisation in a rural area 6)

Practically, the head of the neighbourhood participates in our meetings; he is a representative of the local government. We cooperate with the local government. ... whether it is cooperation, we "torture" him, we really press him ... delicately and nicely. (Leader of a local community organisation in an urban area 4)

Local community organisations in rural and urban areas are not always able to influence local officials because of the indifference of local people.

... why a leader of the local community organisation is responsible for serving everybody, when there is an institution, the neighbourhood paid by the state which has to do their work. (Leader of a local community organisation in a rural area 7 )

On the other hand, even leaders and members of non-governmental organisations in rural and urban areas mostly think they are able to solve their problems only with the help of the local government.

... our organisation is able to do very little in terms of material things. It can only raise an issue and try to solve it with somebody's help. ... with the help of others. ... we are not capable of doing anything without the help of the local government. (Leader of a rural women's organisation 1) 
Some non-governmental organisations in rural and urban areas provide the social infrastructure for public deliberation and a setting for an agenda.

We discuss political and social matters in our organisation. Everything from a to z; from programmes of political parties to their implementation. (Leader of a local community organisation in a rural area 8)

We raise the problems that are most important for us and we raise them on a higher level so that all pay attention to them. (Leader of a local community organisation in an urban area 2)

Associations with private or non-political purposes contribute to the public sphere less.

We decided not to poke our noses in politics. But social questions are on the agenda, naturally. We wish to help people who have been overtaken by misfortune. It is not serious work, perhaps, but simply to help, when you have some time. (Leader of a rural women's organisation 3)

Participation in non-governmental organisations has effects on individuals such as providing them with information, imbuing civic skills, developing their civic virtues, teaching them to be critical, and increasing their sense of efficacy.

It has changed my attitude towards social life... when you sit at home and do not see anything except TV and violence...you cannot really understand how people live. As long as you do not visit and do not see....then you come down and see everything differently. (Leader of a rural women's organisation 2)

What do I get by participating in the local community organisation? ... You do not always work for payment. Do you agree? The moral is such...We have done it or we are able to do it ... it is a pleasure. (Leader of a local community organisation in an urban area 6)

\section{CONCLUSIONS}

Urban non-governmental organisations are characterised by a wider diversity of aims and activities than rural ones. Non-governmental organisations in rural areas are oriented towards private or non-political purposes such as leisure activities. The exception is local community organisations which are oriented towards the improvement of living conditions in a local community. Urban non-governmental organisations are oriented towards private and public purposes, more universal goals, solving local and national social problems.

NGOs in rural areas mostly have been established by one or a few active persons, who have worked in the local government, cultural centres, schools, or religious communities. Local community organisations in rural areas were mostly created "from above" by local government officials, while others, such as leisure organisations, were mostly established "from below". Most non-governmental organisations, including local community organisations, were established "from below" in order to represent the interests of their members. Even if an organisation in rural and urban areas was registered officially in order to get financial support, 
people participated in non-governmental organisations because of a need for socialising or self-realisation.

The control of the State and people's inability to have a real impact on their lives in Soviet times caused their indifference to community affairs and low sense of personal efficacy. Most rural residents and some urban residents are used to somebody taking responsibility for their problems and caring for them.

The same group of active and educated persons is usually at the core of all non-governmental organisations in a rural community. Urban non-governmental organisations are characterised by a wider distribution of power within an organisation and local community than rural ones.

Non-governmental organisations in rural and urban areas contribute to democracy and urban and rural development because of their citizen socialisation, the public sphere and interest representation effect. Local community organisations in rural and urban areas mostly aggregate and transmit people's claims on the local level, and provide the social infrastructure for public deliberation and civic socialisation. Leisure associations contribute to democracy and rural development because of their civic socialisation effect.

\section{REFERENCES}

Alexander, J. 1998. Civil Society I, II, III: Constructing an Empirical Concept from Normative Controversies and Historical Transformations. In Real Civil Societies. Dilemmas of Institutionalization, J.Alexander (ed.). SAGE Studies in International Sociology 48:1-21.

Badescu, G. 2003. Social Trust and Democratization in the Post-Communist Societies. In Gabriel Badescu \& Eric M. Uslaner (eds). Social Capital and the Transition to Democracy. London and New York: Routledge, 120-140.

Degutis, M. 1995. Penkeri pilietinès visuomenès formavimosi metai: visuomenès reformos ir politinè kultūra. Politologija 1(6): 22-54.

Degutis, M. 2002. Rinkiminio elgesio dinamika 1992-2001 m. Vilniaus universitetas / Daktaro dissertacija: socialiniai mokslai, politikos mokslai, 2002.

Edwards B. and Foley M. W. 1998. Civil society and social capital beyond Putnam. American Behavioral Scientist, 42(1): 124-139.

Fung, A. 2003. Associations and Democracy: Between theories, hopes, and realities. Annual Review of Sociology 29:515-39.

Howard, M. M. 2003. The weakness of civil society in post-communist Europe. Cambridge: Cambridge University Press.

Imbrasaitè, J. 2006. Civic Resources and Political Exclusion in Lithuania: Urban-Rural Inequalities. Socialiniai mokslai 3 (53):32-39.

Matonyte, I. 2004. Socialinis kapitalas: nuo mokslinių tyrimo perspektyvu prie empiriniu pastebejimu. "Gero valdymo" klausimas. / Kn. Vietos valdžios ir NVO bendradarbiavimo skaidrumas. Kaunas: Knygiai : 9-59.

Palidauskaite J. (1997). Lietuvos politinès kultūros raida valstybingumo atkūrimo ir ịtvirtinimo laikotarpiu. Kauno technologijos universitetas/Daktaro disertacija: socialiniai mokslai, sociologija.

Putnam, R. 1993. Making Democracy Work: Civic Traditions in Modern Italy. Princeton, NJ: Princeton University Press. 
Ramonaitè, A. 2005. Piliečiu ir valstybès santykis pokomunistinèje demokratijoje: politinio susvetimejimo Lietuvoje analizé. Vilniaus universitetas / Daktaro disertacija: socialiniai mokslai, politikos mokslai.

Uphoff, N. 1993. Grassroots Organisations and NGOs in Rural Development: Opportunities with Diminishing States and Expanding Markets. World Development, 21(4), 607-622.

Žaliukaite, R. 2005. Socialinio kapitalo dinamika pokomunistinejje Lietuvos visuomeneje: socialinès ir kultūriness efektyvios demokratijos prielaidos. Vilniaus universitetas I Socialinių tyrimų institutas / Daktaro disertacija: socialiniai mokslai, sociologija.

Verba, S., Schlozman, K. L. and Brady H. E. 1995. Voice and equality. Civic voluntarism in American politics. Cambridge, MA: Harvard University Press. 


\section{The Role of Education in the Creation of Social Capital}

Inta Ostrovska

Daugavpils University, Latvia

First of all, it is necessary to specify several notions: physical capital, human capital and social capital. It is well-known that capital as such is an economic category and an important component of economic resources. Physical capital includes tools, machinery and other equipment, materials, raw materials, etc., which are used in the process of production. Human capital is an aggregate of qualities and characteristics (mainly linguistic knowledge, abilities and skills), which let a person act, work and be a member of society. Social capital is generally based on relations and interrelations of individuals. Physical capital can be seen and touched. However, human capital is not so evident, as it is expressed in knowledge and skills that people use. Social capital is even less evident, because it is displayed only in individuals' relations, which are based on respect, trust, friendship and other values (which in this case can be called resources). All social relations, social structures, social institutions, as well as education can make social capital. In order to let it happen, the social organisations should have a closed character. Norms usually appear in order to limit negative external influences and to strengthen positive influences. However, in various social structures norms do not appear even if there are enough prerequisites for their appearance. As a rule, it happens because these groups or organisations are not sufficiently closed.

American economist and sociologist James Coleman analysed the correlation of social capital and the social context of society. He has proved the necessity and significance of social capital in one definite sphere of life - in education. Coleman asserts that the family and interrelationships between different generations have a significant role in the formation of social capital, the younger generation having particular importance. Social capital, both that of a family and that of the society, is significant only when human capital consists of the young generation.

When pupils' poor progress in studies at schools is discussed, it is usually related to the poor educational level of the family; it is believed that in such a family situation, poor progress in studies is inevitable. Coleman, on the contrary, says that a pupil's progress in studies and the level of education of a family are not inseparable. According to him, education depends on 3 components: the financial, human and social capital of a family. The financial capital of a family consists of income and the prosperity of a family (including the equipment of the place where a pupil studies, 
teaching aids, books, as well as the home environment with or without problems caused by money or its absence).

The human capital of a family is related to the education of parents, who can help their children socialise and get acquainted with the world, and influence to a great extent the learning process. Social capital in a family is relationships between parents and children; their communication during the process of studies, i.e. time a mother or father spends on studies together with his or her child. The abovementioned idea means that human capital of parents will not have much influence on the development and education of children if they spend little time together. The level of children's education depends much on relationships between children and their parents. Time that a child spends with his or her parents (a child should be in constant contact with both parents - mother and father, as well as with other close relatives) is a significant element in the creation of social capital. This is a big problem for modern society, because there are many families consisting of only one parent, either mother or father. Coleman thinks that even full families can fail in providing necessary social capital if parents work too much and do not spend enough time with their children. Moreover, there is a lack of social capital even if parents are at home, but they do not have close, intimate, confiding relationships with their children. Coleman has proved in his research that more children in a family often leads to worse results in studies among the youngest children because they lack the attention of their parents. Children who give up school, as a rule, come from oneparent families. Another factor which has a great influence on a child's education is families moving from one place to another. Each time a family moves to another place of living, relationships, which create social capital, get worse. Coleman has proved that social capital of a family is a resource for raising a child's level of education.

One more important aspect should be mentioned. Social capital has one feature which distinguishes it from other types of capital. Physical capital is related to money. People are interested in it, and in order to get profit, a person invests something. This investment is often repaid with interest. Investment into human capital works the same way. It especially concerns one's education - a person who is willing to spend money and time on studies is likely to get well-paid work, a better position or, at least satisfaction from better understanding of the world around him or her. However, profit from social capital cannot be noticed at once, and sometimes a person who invests in social capital does not get any profit at all. Coleman is afraid that in the future the amount of social capital will decrease, and as a consequence, there will be a decrease in human capital, which in its turn will influence development of the young generation [1].

Several aspects of creation of social capital can be, at least indirectly, traced in research, which are dedicated to other issues. For instance, the authors of the research "Sociological Portrait of Young People in Latvia" (Institute of Philosophy and Sociology at the University of Latvia, 1999) assert that background and family have the most significant influence on one's education, formation of career and successful social integration. Social estrangement is more typical of young people from less developed rural regions, minorities, those who have been brought up at orphanages, as well as young disabled people [3]. 
In this respect, another piece of research can be mentioned. In 2002 research on "Transition of Young People from Education to the Labour Market" (Institute of Social Research at Daugavpils University) was conducted. Some of its data can be related to social capital. For example, a question „Who do you turn to in a difficult life situation?" reflects interrelationships of children and parents. Answers to this question were the following: 61\% of the young people (aged 15-29) turn to their mothers, $32 \%$ - to fathers, $25 \%$ - to other members of their family. Moreover, $41 \%$ of the respondents have chosen their profession following the advice of their parents. Other answers to the question "Why have you chosen this profession, speciality?" are also interesting (see Table 1).

Table 1

Answers to the question: "Why have you chosen this profession, speciality?" (in $\%, \mathrm{n}=359,2002$ )

\begin{tabular}{|c|c|c|c|}
\hline Answers & $\begin{array}{c}\text { Significant } \\
\text { reason }\end{array}$ & $\begin{array}{c}\text { Insignificant } \\
\text { reason }\end{array}$ & $\begin{array}{c}\text { It is difficult } \\
\text { to say }\end{array}$ \\
\hline parents' advice & 41 & 37 & 22 \\
\hline friends' advice & 17 & 63 & 20 \\
\hline $\begin{array}{c}\text { specialists of this profession are in demand in } \\
\text { the labour market }\end{array}$ & 55 & 21 & 24 \\
\hline $\begin{array}{c}\text { this profession, speciality corresponds to my } \\
\text { abilities and desires }\end{array}$ & 69 & 16 & 21 \\
\hline $\begin{array}{c}\text { specialists of this profession have very high } \\
\text { salaries }\end{array}$ & 63 & 16 & 21 \\
\hline $\begin{array}{c}\text { specialists of this profession have a very } \\
\text { interesting job }\end{array}$ & 55 & 24 & 28 \\
\hline this profession is very prestigious nowadays & 48 & 24 & 46 \\
\hline Other & 35 & 19 & \\
\hline
\end{tabular}

As is clearly seen in the table, the first positions in the list are occupied by the motives related to value orientations - there is a struggle between pragmatic values (good salary takes $2^{\text {nd }}$ place, demand in the labour market $-3-4^{\text {th }}$ place) and nonpragmatic ones (correspondence of the profession to students' abilities and desires $1^{\text {st }}$ place, an interesting job $-3-4^{\text {th }}$ place).

The respondents also give a high evaluation of the importance of education in a person's life. Answering the question: "To what extent, in your opinion, does a person's education influence his or her material position?", $81 \%$ of the respondents said that the influence is significant. For comparison, it is possible to give data from other research ("Educated Young People on the Local Labour Market and on the Labour Market of the European Union", 2004). Answering the same question, 83\% of the respondents said that education has a major influence on the welfare of a person.

The respondents of the above-mentioned research evaluated as well several factors in achieving success in one's life (see Table 2). 
Table 2,

Evaluation of factors necessary to achieve success in one's life

\begin{tabular}{|c|c|c|c|}
\hline Factors & $\begin{array}{c}\text { Young people, } \\
2002, \mathrm{n}=359 .\end{array}$ & $\begin{array}{c}\text { Their parents, } \\
\text { 2002, } \mathrm{n}=120 .\end{array}$ & $\begin{array}{c}\text { Educated young } \\
\text { people, 2002, } \\
\mathrm{n}=300 .\end{array}$ \\
\hline Good education & 1 & 2 & 4 \\
\hline $\begin{array}{c}\text { Knowledge of technical equipment, } \\
\text { ability to work with computer }\end{array}$ & 2 & 1 & 3 \\
\hline Painstaking work & 3 & 4 & 5 \\
\hline Personal contacts & 4 & 3 & 2 \\
\hline Ability to work well with people & 5 & 6 & 1 \\
\hline Availability of money & 6 & 5 & 6 \\
\hline $\begin{array}{c}\text { Willingness to take responsibility for } \\
\text { the results of the work they perform }\end{array}$ & 7 & 7 & 7 \\
\hline Willingness to take a risk & 8 & $8-9$ & 10 \\
\hline Physical power, endurance & 9 & 10 & 8 \\
\hline $\begin{array}{c}\text { Willingness to do a lot of things in } \\
\text { another manner }\end{array}$ & 10 & $8-9$ & 11 \\
\hline $\begin{array}{c}\text { Knowledge of western business } \\
\text { experience }\end{array}$ & 11 & 11 & 12 \\
\hline Background, family status & 12 & 12 & \\
\hline
\end{tabular}

It is evident that education as a factor in achieving success is evaluated differently: young people with varying levels of education put it in first place. This can be explained by the fact that among these young people, there are 15-19 year olds who do not even have a secondary education. Their parents also consider education an important factor. As to educated young people (those who are 18-30 and have either a professional secondary or higher education), they put this factor in $4^{\text {th }}$ place. Most probably, they have already reached the desired level of education and it is not topical for them at the moment. As is shown in Table 2, they consider personal contacts and communication skills the most important factors. 18-30 years is the period when young people start their professional career - they look for a job (if personal contacts are necessary, it means that social capital will be used) and strengthen their status in a work collective (in this case they have to know how to cooperate with people). Data in the table show a contradiction: personal contacts are highly evaluated by all groups $\left(4^{\text {th }}, 3^{\text {rd }}, 2^{\text {nd }}\right.$ place $)$; however, social status and the background of a family are unanimously put in last place. The respondents probably do not see any connection between these two factors, though the connection is obvious. Young people, especially when they only start social life, do not have many personal contacts of their own, and they mainly use the contacts of their parents $[4,5]$.

To conclude, it is possible to say the following: the data of the research show that education is a significant factor in achieving success in one's life. It means that it is also important in the creation of social capital for each person, the family and, finally, government as a whole. 


\section{BIBLIOGRAPHY}

1. Коулман Дж. Капитал социальный и человеческий. // в журн. „Общественные науки и современность.”№ 3, 2001.

2. Smelser Neil G. Sociology. - New Jersey: University of California, 1984.

3. Latvijas jaunatnes socioloǵiskais portrets. - Rīga: LU FSI, 1999.

4. Ostrovska I., Boroņenko V. Jaunatne cel̦ā no izglītības uz darba tirgu. - Daugavpils: Saule, 2004.

5. Zinātniskais projekts „Daugavpils izglītotā jaunatne vietējā un Eiropas darba tirgū” (vadītājs prof. V. Meņšikovs). - Daugavpils: DU SPI, 2004. 


\title{
The Impact of Civil Initiative on Latvian Public Administration
}

\author{
Līga Mirlina \\ Doctoral student, University of Latvia
}

In a democratic society, public administration is effective if it has clear aims and the support of the public. That requires promoting popular participation in decision-making processes, as well as informing society. One way to accomplish this is to involve non-governmental organisations (NGOs) in public administration, since NGOs have at least two important roles in a democratic society: firstly, NGOs aggregate and mediate public opinion for formulating public policy; secondly, NGOs inform the public and often serve as an instrument of policy implementation. ${ }^{1}$

In order to understand the role of NGOs in public administration, the author has studied trends in public administration-NGO relations during several stages of state reform in Latvia. I have also examined NGO activities during the Soviet era in Latvia to provide a point of reference.

In totalitarian and authoritarian regimes NGOs are formed and strictly controlled by the state. The role of NGOs is clearly characterised by the slogan: "Trade unions are the party's gear-chain". During the Soviet era, medical institutions and recreation centres, where various amateur hobby groups flourished, were under the authority of trade unions. In totalitarian and authoritarian regimes some state administration functions could be assigned to NGOs. However, state authority was ideologised and the connection with NGOs involved only one-way communication, because the ruling party controlled both information access and freedom of association.

In a democratic society, the relation is more complex, as public administration, political parties, NGOs, and society as a whole is built on two-way communication. It should be added that in a democratic regime as well, political authorities do not always consider society's or at least the majority's opinion when making decisions and forming social policy. Thus, there are cases in a democracy when one-way communication takes place.

In other words, in totalitarian and authoritarian regimes, public administration can assign functions to NGOs, strictly defining the framework, without granting them power to influence decision making processes. In a democratic society, relations between state authorities and NGOs that have been delegated some state administration functions are interactive. These relations include public debate which aims to achieve rational and open agreement between competitive opinions, on the basis of the public interest. However, it is important to point out that in totalitarian 
and authoritarian regimes NGOs can develop as a form of protest, a resistance movement seeking revolutionary change.

When analysing the role of the Popular Front of Latvia (PFL) and other NGOs in the process of restoring independence in Latvia, the differences between the activities of NGOs and political parties become clear. As we know, the PFL was established as a public, i.e. non-governmental organisation, and initially it did not position itself as a political party. However, later the PFL began to undertake activities characteristic of parties - participation in elections and the struggle for political power. Gaining a majority at the Supreme Council of the Latvian Soviet Socialist Republic, the PFL started to take control of public administration from above, although usually an NGO joins the public administration from below. After gaining political power, the PFL faction at the Supreme Council broke up quite soon. Several new political parties formed on its base, and they gained political power in 1993 at the elections of the $5^{\text {th }}$ Saeima. But the PFL was out of the parliament, out of political power and did not continue to work as an NGO.

The role of the PFL in the Soviet period, when it used non-violent resistance methods, reveals the role of NGOs as articulators of protest sentiment and mobilisers of the public. Thus, it is possible to define two main vectors of NGO activities: NGOs as a partner for public administration and as a promulgator of public protest.

In Latvia the formalisation process of relations between NGOs and state authority started after the restoration of independence. A new post for Minister of State Reforms was formed in the first government during the $5^{\text {th }}$ Saeima. This Ministry developed the "Latvian State Reform Concept"2 in 1995, wherein one of the aims was to promote the involvement and personal interest of people in the process of public administration, as well as to ensure society with the possibility to receive current and accurate information on issues related to public administration issues.

The government reverted to the NGO and state authority relations formalisation process just six years later, when the Cabinet of Ministers passed two important documents: "The Basic Postulates of Policy Planning"3 and "The Basic Postulates of Government Communication Policy"4. These envisaged society's participation in government decision making processes and raising public awareness of public administration issues.

Two years later, in 2003, the government passed amendments in the Cabinet's rules of order $^{5}$, which envisaged that NGO representatives would have advisory rights and would be able to participate in State Secretaries' meetings. Since 2002 government relations with NGOs have been entrusted to a particular, specially formed institution - the Secretariat of the Special Assignments Minister for Social Integration Affairs. There are two very important documents developed by the secretariat and passed by the government that have to be mentioned: the state policy planning document "The Basic Postulates of Civil Society" ${ }^{2}$ and the National Programme "Strengthening of Civil Society 2005 - 2009"7.

When analysing relations between the government and NGOs, it is also necessary to mention "The Memorandum of Cooperation between NGOs and the Government" that was signed by 57 NGOs and Prime Minister Aigars Kalvīis in March 2005. The aim of the memorandum is to promote effective operation of state administration 
for public benefit and to ensure involvement of civil society in decision making processes. In 2006 Saeima also passed "The Declaration on the Development of Civil Society in Latvia and Cooperation with NGOs". This document is intended to improve cooperation of the parliament and NGOs on legislative issues. Thus, those laws and regulations defined a clear framework for NGO involvement in public administration decision-making processes.

NGOs are also involved in decision-making processes at various Ministries. Already in 1997 the Ministry of the Interior was one of the first ministries that had formed an advisory council with the participation of NGOs. Cooperation with NGOs also occurs in local municipalities, several of which have formed advisory councils with the participation of NGOs. Often they are formed for a special purpose or field, for example, the advisory council of the Riga City Council Environmental Fund.

When studying the role of advisory councils attached to ministries and local municipalities, it can be concluded that their functions, activities and content are very different, and this is often explained by the particularities of institutions. The advisory council that has been formed at the Ministry of Environment can be named as a well functioning example with clear procedures. Its aim is to involve the public in decision-making processes concerning environmental issues and to develop cooperation and information exchange in the field of environmental protection ${ }^{10}$. Every year the council organises a forum for environmental NGOs where current issues are discussed with the participation of state institutions, all environmental public organisations and professional associations in Latvia.

Thus, it can be concluded that on the political level several governments of Latvia have declared their position on NGO participation in public administration, and passed laws and regulations for ensuring this. Good practice has also already developed.

While studying laws and regulations that govern relations between NGOs and the public administration, it is important to identify the aim of those documents. The trend is as follows: on the basis of rules that are known and understood by the public, NGOs have been ensured the role of equal partner in public administration. Thus, cooperation between NGOs and public administration proceeds within the formal framework clearly set by regulating documents that ensure the participation of NGOs in the public administration processes.

Thus two aims are reached - NGOs have guaranteed rights to take part in decision-making processes, but the public administration achieves effective involvement of NGOs in those processes. This creates high requirements for the professionalism of NGOs.

However, when analysing the place of NGOs in current social and political processes in Latvia, it becomes clear that NGOs have a role in addition to being participants in implementing public administration functions and getting involved in decision-making in accordance with interests of some public group. The other vector of NGO activities is protest against political and/or administrative decisions, when NGOs mobilise the public and influence public opinion. In this case, the protest act is not related to disregard of laws and regulations and violation of public policy.

This trend in NGO activities is clearly seen not only during revolutionary changes in totalitarian and authoritarian regimes, for example, in Latvia during the 
Awakening. It also exists also in democratic regimes in a wide range of activities, from legal means such as pickets and demonstrations to civil disobedience.

In particularly critical cases NGOs act as an opposition, trying to change or reverse decisions made by the state and drawing public attention through radical methods. Several crisis situations in Latvia can be mentioned when public pressure was exerted on the state administration. This pressure can show itself as a strike, demonstration or other particular protest campaign with the power of a communicative act. One example was a protest campaign by nurses who were demanding higher pay. During this campaign, one of the participants impersonated death with a scythe holding a poster saying: "Nurses will go away, I will come instead of them!" In another example, activists from the Environmental Protection Club captured a sea platform during their protest campaign against Butinge oil terminal.

It is paradoxical, but in this case NGO protest can be considered an attempt to find public consensus, as in German philosopher Jürgen Habermas' theory of communicative action ${ }^{11}$. Communicative activities at their root are directed to delivery of the message, but they function as discussion, because their aim is to turn the message into an object of public discussion and to reach consensus. The message is delivered in a particular way through symbolic verbal or non-verbal acts (e.g., using the character of death with a scythe in the nurses' protest, activists of the Environmental Protection Club "capturing" the Butinge oil terminal).

Thus, it is possible to speak not only about resistance, but about the opportunity and right of civil society to attract public attention to some phenomenon or process by using particular campaigns or to change society's value orientation. NGO activities reflect a certain dualism. On the one hand, NGOs participate in public administration as a partner and representative of an interest group, with the aim of achieving a particular decision in the interests of this particular group. On the other hand, NGOs play the role of an idea multiplier for a particular group. In the latter case, NGOs take part in public debate using various methods that sometimes verge on the scandalous in order to gain publicity, with the aim of changing not only a particular decision of the state administration, but also public values.

During various historical, social and political conditions the importance and proportion of each facet of NGO activity forms a particular pattern of public administration-NGO relations. They contribute to social transformation and express themselves in changes in legislation, political culture, public opinion and the mass media.

\section{BIBLIOGRAPHY}

1. Deklarācija par pilsoniskās sabiedrības attīstību Latvijā un sadarbību ar nevalstiskajām organizācijäm. - http://www.saeima.lv/bi8/lasa?dd=LM0927_0 - - 14.12.2006.

2. Habermas J. Moral Consciousness and Communicative Action. Cambridge: Polity Press, 1995.

3. Habermas J. The Structural Transformations of the Public Sphere. - Cambridge: Polity Press, 1989.

4. Habermas J. The Theory of Communicative Action. Cambridge, Oxford: Polity Press, 1998. 
5. Jansone D., Vilka I. Pārvaldes struktūru atsaucīgums. - Cik demokrātiska ir Latvija. Demokrātijas audits. - Rīga, LU, 2005.

6. Latvijas Valsts pārvaldes koncepcija. // Laikraksta Diena pielikums Saiemā un Ministru kabinetā. - 1995. - 25.janv.

7. Ministru kabineta kārtības rullis. - http://www.mk.gov.lv/index.php/lv/2053 14.12.2006.

8. Nevalstisko organizāciju un Ministru kabineta sadarbības memorands. -http://www. mk.gov.lv/site/publikacijas/sadarbibas_memorands.tif - 14.12.2006.

9. Palubinskas G. T. Democratization: The Development of Nongovernmental Organizations (NGOs) in Central and Eastern Europe. - Public Administration and Management: An Interactive Journal, 8, 3, 2003, 150-163 p. - [http://www.pamij.com/] - 14.12.2006.

10. Pilsoniskās sabiedrības pamatnostādnes. - http://www.integracija.gov.lv/doc_upl/ pilsoniska-sabiedriba-pamatnostadnes(2).doc - 14.12.2006.

11. Pilsoniskās sabiedrības stiprināšana 2005. - 2009. gadam. - http://www.integracija.gov. lv/doc_upl/ValstsProgrammaPIlsSabJauns(2).doc - 14.12.2006.

12. Politikas plānošanas pamatnostādnes - http://ppd.mk.gov.lv/ui/DocumentContent. aspx?ID=1620 - 14.12.2006.

13. Reeder F. S. Back to Basics in Eastern Europe. Government Executive. September, 1999 - http://www.govexec.com/features/0999/0999view.htm - 14.12.2006.

14. Valdības komunikācijas politikas pamatnostādnes. - http://ppd.mk.gov.lv/ui/ DocumentContent.aspx?ID=1625 - 14.12.2006.

15. Vides konsultatīvās padomes nolikums. - http://www.vidm.gov.lv/varam/videsKP/ Lnolik.htm - 14.12.2006.

\section{ENDNOTES}

1 Reeder Franklin S. Back to Basics in Eastern Europe. Government Executive. September, 1999. - http://www.govexec.com/features/0999/0999view.htm - 14.12.2006.

2 Latvijas Valsts pārvaldes koncepcija. // Laikraksta Diena pielikums Saiemā un Ministru kabinetā. - 1995. - 25.janv.

3 Politikas plānošanas pamatnostādnes - http://ppd.mk.gov.lv/ui/DocumentContent. aspx?ID=1620 - 14.12.2006.

${ }^{4}$ Valdības komunikācijas politikas pamatnostādnes. - http://ppd.mk.gov.lv/ui/ DocumentContent.aspx?ID=1625 - 14.12.2006.

${ }_{5}$ Ministru kabineta kārtības rullis. - http://www.mk.gov.lv/index.php/lv/2053 - 14.12.2006.

${ }^{6}$ Pilsoniskās sabiedrības pamatnostādnes. - http://www.integracija.gov.lv/doc_upl/ pilsoniska-sabiedriba-pamatnostadnes(2).doc - 14.12.2006.

7 Pilsoniskās sabiedrības stiprināšana 2005. - 2009. gadam. - http://www.integracija.gov. lv/doc_upl/ValstsProgrammaPIlsSabJauns(2).doc - 14.12.2006.

8 Nevalstisko organizāciju un Ministru kabineta sadarbỉbas memorands. -http://www. mk.gov.lv/site/publikacijas/sadarbibas_memorands.tif - 14.12.2006.

9 Deklarācija par pilsoniskās sabiedrības attīstību Latvijā un sadarbību ar nevalstiskajām organizācijām. - http://www.saeima.lv/bi8/lasa?dd=LM0927_0 - - 14.12.2006.

10 Vides konsultatīvās padomes nolikums. - http://www.vidm.gov.lv/varam/videsKP/ Lnolik.htm - 14.12.2006.

11 Habermas J. The Theory of Communicative Action. Cambridge, Oxford: Polity Press, 1998, p. 137. 


\title{
Nevalstisko organizāciju un valdības sadarbība Latvijā
}

\author{
Māra Majore \\ Latvijas Universitāte
}

Interest groups provide the institutionalized linkage between government or the state and a major sector of society ${ }^{l}$. Interest groups are in short part of the nerves of government, keeping policymakers in touch with the realities of the world ${ }^{2}$.

/Graham K. Wilson/

\section{IEVADS}

Jāpiekrīt Centrālās un Austrumeiropas pētniekam Markam Hovardam (Marc Howard), ka pilsoniskā sabiedrība kopš 20. gadsimta 80. gadiem ir kḷuvusi par plaši izmantotu jēdzienu gan akadēmiskajā vidē, gan arī ikdienas sarunās. Šajā laika periodā līdz ar opozīcijas kustības aktivitātēm Polijā un demokratizācijas vilni Austrumeiropā pilsoniskās sabiedrības jēdziens kḷuvis par būtisku demokratizācijas indikatoru ${ }^{3}$.

Šì demokratizācijas vil̦na ietvaros par neatkarīgu, demokrātisku valsti pirms nu jau 16 gadiem kḷuva arī Latvija, tomēr 20. gs. 90. gados sabiedrības un valsts pārvaldes institūciju sadarbība nebija prioritāra, arī valsts pārvaldes reformai nebija prioritārs statuss.

Taču pētnieks Roberts Patnams (Robert Putnam) norāda, ka tieši pilsoniskajai sabiedrībai ir būtiska nozīme demokrātiskas valdības efektivitātes un stabilitātes veicināšanā. Pētnieks skaidro, ka pilsoniskā sabiedrība iekšēji ieaudzina to dalībniekiem kooperācijas, solidaritātes, sabiedriskā dzīvīguma tradīcijas, kā arī kopatbildības sajūtu. Ārēji - biedrības vairo interešu artikulācijư ${ }^{4}$ R. Patnams norāda - jo blīvāks ir sociālais tīklojums sabiedrībā (kaimiņu asociācijas, korporatīvi, sporta klubi, masu partijas utt.), jo lielāka iespējamība, ka iedzīvotāji spēs sadarboties kopēja labuma sasniegšanai, turklāt līdzdalība šādās horizontāli veidotās grupās būtu jāsaista ar labu pārvaldību ${ }^{5}$. Tīklojumi veicina dažādu kolektīvo darbību dilemmu atrisināšanu, turklāt tie ir spēcīgi ietekmējuši publiskās dzīves un sociālo institūciju darbības kvalitāti un ietekmē reprezentatīvo vald̄̄ibu' .

Šajā pētījumā analizēta nevalstisko organizāciju (NVO) un Ministru kabineta (MK) sadarbība Latvijā. Latvijas Republikas normatīvie akti paredz dažādus mehānismus sadarbībai gan dienaskārtības veidošanas un politikas izstrādes, gan lēmumu pieņemšanas un politikas ieviešanas procesā, piemēram: dalība darba 
grupās, Valsts sekretāru sanāksmēs, MK un MK komiteju sēdēs, turklāt arī viedokḷa paušanu, tiekoties ar ministriju pārstāvjiem vai presē un tamlīdzīgi. Politiksi ir izrādījuši ieinteresētību valdības un sabiedrības sadarbībai un tās attīstîbai (NVO un MK sadarbības memorands), ir sakārtota arī tiesiskā bāze pilsoniskās sabiedrības darbībai.

Lai sadarbību analizētu padziļināti, autore pētījusi vienu no mehānismiem atzinumu sniegšanu tiesību aktu un politikas plānošanas dokumentu projektiem laika periodā no 2004. gada janvāra līdz 2006. gada aprīlim MK instrukcijas „Kārtība, kādā aizpildāma normatīvā akta projekta anotācija" kārtībā, kopā apskatot 6055 projektus. Instrukcija paredz, ka anotācijas 6. sadal̦ā jābūt norādītai informācijai par konsultācijām ar NVO un sabiedrības informēšanas pasākumiem - tajā jānorāda NVO, ar kurām notikušas konsultācijas; kritēriji, pēc kādiem tās tika izvērtētas; veids, kādā organizācijas ir saistītas ar regulējamo jautājumu, kā arī NVO ierosinātā priekšlikuma būtība un tas, vai priekšlikumi ņemti vērầ ${ }^{8}$.

Pētījumam tika izvirzīta hipotēze: NVO un MK sadarbības mehānisma atzinumu sniegšana tiesību aktu un politikas dokumentu projektiem - izmantošanu ietekmē organizāciju kapacitāte. Pētījuma gaitā būtiski bija noskaidrot, cik plašs loks NVO izmanto atzinumu sniegšanas mehānismu, kuru ministriju projektu tapšanā visbiežāk ir notikušas konsultācijas ar NVO un kādi ir šksēršļi šādai sadarbībai.

Papildus projektu anotāciju analīzei darba gaitā tika nosūtìtas anketas visām ministrijām, no kurām atbildi sniedza 5 ministrijas (to skaitā viena ministrija iesniedza divas atbildes anketas no dažādiem departamentiem), kā arī 25 NVO, kas sniegušas atzinumus projektiem, no kurām atbildēja 4 NVO. Tika veiktas arī divas tiešās intervijas ar NVO pārstāvjiem un viena intervija ar Valsts kancelejas pārstāvi. Anketēšanas un interviju mērķis bija noskaidrot abu pušu viedokli par sadarbību: pozitīviem, negatīviem aspektiem, veiksmīgiem piemēriem, arī kavējošiem faktoriem.

\section{PILSONISKĀ SABIEDRĪBA AKADĒMISKAJĀ LITERATŪRĀ}

Kas ir pilsoniskā sabiedrība un NVO? Akadēmiskajā literatūrā NVO jēdziens aplūkots maz, taču, pamatojoties uz M. Hovarda pilsoniskās sabiedrības definīciju NVO uzskatāmas par pilsoniskās sabiedrības elementu. NVO ietver plašu loku formāli organizētas, legāli aizsargātas, autonomas, brīvprātīgas grupas, asociācijas un organizācijas, to skaitā reliǵiskas, lokālā līmeņa, izglītības un kultūras aktivitāšu, pašpalīdzības, jauniešu u.c. organizācijas, cilvēktiesību, miera, vides un dzīvnieku aizsardzības grupas, sporta klubus. ${ }^{9}$ Definīcijā iekḷautas arī politiskās partijas, politiskās un ekonomiskās interešu grupas, NVO, arodbiedrības, darba devēju un ņēmēju asociācijas. ${ }^{10}$

Savukārt, H. Lincs (Juan Linz) un A. Stepans (Alfred Stepan) norāda, ka pie pilsoniskās sabiedrības pieder arī tie indivīdi, kuri nav iesaistījušies organizācijās, un tieši šiem indivīdiem var būt izšķiroša nozīme režīma un opozīcijas balansa situācijās ${ }^{11}$.

Deivids Trūmens (David B. Truman) izmanto jēdzienu interešu grupa, kas raksturo jebkuru grupu, kura uz kopīgu nostāju pamata veido noteiktas prasības pret citām, lai nostiprinātu, uzturētu vai palielinātu kādas uzvedības formas, ko 
vieno kopīgas attieksmes. No savstarpējās mijiedarbības izveidojas kopīgi ieradumi, normas, attieksmes, vajadzības un prasības pret citām grupām, turklāt attieksmes rada intereses. D. Trūmens secina - visas grupas ir interešu grupas, jo tās ir kopīgu attieksmju grupas ${ }^{12}$. Ja grupas veido noteiktas prasības pret valdības institūcijām vai ar to starpniecību, tās kḷūst par politiskām interešu grupām,-- tas iespējams jebkurai grupai (ekonomiskai, tirdzniecības, profesionālai, pat ǵimenes grupai) ${ }^{13}$.

D. Trūmens norāda, ka tas, cik lielā mērā grupas sasniegs efektīvu pieeju valdībai, ir atkarīgs no vairākiem neatkarīgiem faktoriem, kurus var klasificēt trīs kategorijās - pirmkārt, faktori, kas saistīti ar grupas stratēgisko pozīciju sabiedrībā; otrkārt, faktori, kas saistīti ar grupas iekšējām pazīmēm, kā arī, treškārt, faktori, kas ir īpaši pašām institūcijām ${ }^{14}$. R. Patnams atzīst, ka liela nozīme ir politiskajām zināšanām, lai indivīdi varētu efektīvi iesaistīties publiskajos notikumos ${ }^{15}$.

\section{TIESİBU AKTU UN POLITIKAS PLĀNOŠANAS DOKUMENTU PROJEKTU ANOTĀCIJU 6. SADAL,AS ANALĪZE}

Kopumā pētījuma ietvaros aplūkoti 6055 tiesību aktu un politikas plānošanas dokumentu projekti Tiesību aktu projektu reǵistrā (MK mājaslapā).

Vislielāko projektu skaitu šajā laika periodā iesniegusi Finanšu ministrija (FM) (695 projekti), tai seko Ekonomikas ministrija (EM) (617), Zemkopības ministrija (ZM) (570), Iekšlietu ministrija (IeM) (502), savukārt vismazāk projektus iesniegušas İpašu uzdevumu ministrija bērnu un gimenes lietās (İUMBGL) - 10 projektus, Īpašu uzdevumu ministra sekretariāts sabiedrības integrācijas lietās (ĪUMSILS) - 44, Bērnu un gimenes lietu ministrija (BM) - 52 projektus. No 6055 projektiem 1565 ir pievienotas anotācijas, balstoties uz MK Kārtības rulli - ja anotācija nav pievienota, tā nav bijusi nepieciešama ${ }^{16}$. Anotācijas procentuāli visvairāk pievienotas ĪUMBGL (70\%), İUMSILS (55\%), BM (50\%), kā arī Vides ministrijas (VIDM) (41\%) projektiem, savukārt, 83\% Reǵionālās attīstības un pašvaldību lietu ministrijas (RAPLM) un $82 \%$ FM iesniegtajiem projektiem tās nav pievienotas.

Analizējot projektu anotāciju 6. sadaļu vidēji tikai 12\% projektiem (sk. 2. attēlu), norādīts, ka notikušas konsultācijas ar NVO. Pārējos gadījumos norādīts: likumprojekts šo jomu neskar, konsultācijas nav veiktas bez detalizētāka paskaidrojuma. Latvijas Pilsoniskās alianses (LPA) pārstāve Zinta Miezaine intervijā atzīst: „Iemesli tam var būt vairāki, piemēram, organizācijas ir bijušas projekta iniciatores vai bijušas iesaistītas izstrādes darba grupā, un tad atzinums nav nepieciešams, tomēr ir iespējamas situācijas, ka tas ir ministrijas vai organizācijas kapacitātes trūkuma rezultāts"17.

VIDM regulāri konsultējusies ar apmēram 51 organizāciju, piemēram, Vides konsultatīvo padomi, Latvijas Elektrotehnikas un elektronikas rūpniecības asociāciju, Latvijas Ķīmijas un farmācijas uzṇēmēju asociāciju, Latvijas Pašvaldību savienību (LPS), Latvijas Dabas fondu, Vides aizsardzības klubu (VAK), Latvijas Ornitologiijas biedrību. VIDM Valsts sekretāra padomnieks Ēriks Leitis norāda, ka sadarbība ar NVO ir veiksmīga, īpaši aktīva tā ir ar Vides konsultatīvo padomi, kurā iekḷautas 14 organizācijas: „Sadarbība ir veiksmīga. Katrs likumprojekts tiek diskutēts padomē, informācija tiek ievietota mājaslapā, un jebkura NVO var iesniegt priekšlikumus." ${ }^{18}$ 
Tiesību aktu un politikas plānošanas dokumentu projekti, kuru anotāciju 6. sadaḷā norādīts, ka notikušas konsultācijas ar NVO (\%; laika periodā no 2004.01. līdz 2006.04.)

\begin{tabular}{|c|c|c|}
\hline Ministrija & $\begin{array}{c}\text { Atzinumi no } \\
\text { NVO ir (\%) }\end{array}$ & $\begin{array}{c}\text { Atzinumi no } \\
\text { NVO nav (\%) }\end{array}$ \\
\hline Īpašu uzdevumu ministrija bērnu un ǵimenes lietās & 60 & 40 \\
\hline $\begin{array}{c}\text { İpašu uzdevumu ministra sekretariāts sabiedrības } \\
\text { integrācijas lietās }\end{array}$ & 48 & 52 \\
\hline Bērnu un ǵimenes lietu ministrija & 25 & 75 \\
\hline Labklājības ministrija & 20 & 80 \\
\hline Vides ministrija & 19 & 81 \\
\hline Zemkopības ministrija & 17 & 83 \\
\hline Izglīīibas un zinātnes ministrija & 14 & 86 \\
\hline Reǵionālās att̄̄stības un pašvaldību lietu ministrija & 11 & 89 \\
\hline Tieslietu ministrija & 10 & 90 \\
\hline Ministru prezidents, Satiksmes ministrija & 9 & 91 \\
\hline Kultūras ministrija, Ekonomikas ministrija & 7 & 93 \\
\hline Veselības ministrija, Finanšu ministrija & 6 & 94 \\
\hline Iekšlietu ministrija & 3 & 97 \\
\hline Aizsardzības ministrija & 2 & 98 \\
\hline Ārlietu ministrija & 1 & 99 \\
\hline Citi & 0 & 100 \\
\hline Vidēji & 12 & 88 \\
\hline
\end{tabular}

Avots: Tiesību aktu projektu registrs. www.mk.gov.lv (Latvijas Republikas Ministru kabineta mājaslapa; aplūkota 2006.26.IV).

Ārlietu ministrijas (ĀM) projektus konsultējušas starptautisko organizāciju Latvijas nodal̦as. $\bar{A} M$ Humanitāro jautājumu nodaļas vecākā referente Maija Mauriņa norāda: „ĀM pastāvīgi uztur sadarbību ar NVO. Izveidota ļoti veiksmīga prakse politikas plānošanas dokumentu izvērtēšanā, iesaistot gan jau esošos, gan jaunus sadarbības partnerus. Tā, piemēram, 2006.21.IV Nacionālā attīstības plāna apspriešanas pasākumu ietvaros $\bar{A} M$ organizēja stratēgijas „Latvijas dalība ES pamatprincipi, mērķis, prioritātes un darbība 2007.- 2013.” sabiedrisko apspriešanu. Šobrīd atzinumu sniegšanai ir nodots LR Attīstības sadarbības politikas plāns 2007. gadam. Iniciatīva sadarbībai ir abpusēja. Ja konsultācijas nav notikušas, to var skaidrot ar to, ka trūkst NVO partneri, kuri darbotos attiecīgajā sfērā, vai pietrūkst ieinteresētība no NVO puses, jo, ja ir atsaucība, tad konsultācijas notiek vienmēr"19.

Savukārt, ĀM Attīstības sadarbības politikas departamenta vecākā referente Karina Kovale norādīja, ka sadarbība lielākoties notiek ar Latvijas NVO platformu attīstības sadarbību “LAPAS”: „Izstrādājot politikas plānošanas dokumentus, Latvijas pozīcijas un citus dokumentus, kuru īstenošana ir saistīta ar NVO, ĀM aicina NVO izteikt savu nostāju un ierosinājumus. 2004. gadā ir izveidota Konsultatīvā padome par attīstības sadarbības jautājumiem, kurā piedalās arī nevalstiskais sektors. Pašlaik tiek apkopota visu valsts, privātā un nevalstiskā sektora pārstāvju iesaistīšanās attīstības sadarbības projektos" ${ }^{\prime 20}$. 
Analizējot NVO (apmēram 42), kas sniegušas atzinumus EM projektiem, var secināt, ka regulāri konsultācijas notiek ar vienām un tām pašām organizācijām, piemēram, Mazo un vidējo uzṇēmumu padomi, Latvijas investīciju un attīstības aǵentūru, Patērētāju interešu aizstāvības asociāciju, Latvijas Tirdzniecības un rūpniecības kameru, Latvijas Darba devēju konfederāciju (LDDK), Latvijas Lielo pilsētu asociāciju u. c.

FM iesniegtajos projektos norādītas konsultācijas ar dažādām NVO, tomēr vērojams, ka sadarbība izveidojusies ar valsts mēroga organizācijām, piemēram, Latvijas Komercbanku asociāciju, Latvijas Apdrošinātāju asociāciju, Finanšu un kapitāla tirgus komisijas konsultatīvo finanšu un kapitāla tirgus padomi, Latvijas Informāciju tehnologiju un telekomunikāciju asociāciju, Latvijas Vērtspapīru tirgus profesionālo dalībnieku asociāciju un LPS, kopā apmēram ar 83 organizācijām. Tikai aptuveni 4 projekti no NVO puses netiek atbalstīti.

FM preses sekretāra p. i., Komunikācijas departamenta direktora p. i. Daiga Reihmane atz̄̄st, ka sadarbības iniciators var būt gan ministrija, gan NVO: „Sadarbība vērtējama kā laba. Pagaidām to veido katras jomas pārstāvji (departamenti) ar ieinteresētajiem partneriem, un ir izveidojies sadarbības partneru loks. Nevalstisko partneru iesaistes veicināšanai un sadarbības koordinēšanai tuvākajā laikā ir plānots veikt vairākus pasākumus, to vidū plānota arī mājaslapas sadalıas Sabiedrības lìdzdalība pilnveide. Atzinumu sniegšanai noteikti ir nozīme, jo iespējams, ka saskaņošanas procesā - vēl likumdošanas akta izstrādes stadijā izdodas novērst kādus tā trūkumus. Bet sadarbību noteikti iespējams vēl uzlabot un darīt efektīiāku"21.

D. Reihmane apšauba, ka būtu nepieciešams sīkāk paskaidrot ierakstu Konsultācijas ar NVO nav notikušas: „Ne visas politikas plānošanas jomas ir NVO interešu lokā, bet ministrijai ir pienākums sagatavot likumprojektu arī tad, ja NVO š̄ joma nešķiet atraktīva. Pieprasot papildu paskaidrojumus, kādēl konsultācijas nav notikušas, tiks veicināta formālu atbilžu sniegšana, un tas nebūt neveicinās nevalstisko partneru iesaisti" 22 .

IeM projektu anotācijās norādīts, ka ar Latvijas Policistu biedrību konsultācijas notikušas trīs reizes, vairākas reizes ar Nacionālo trīspusējās sadarbības padomi un LPS. Ar pārējām apmēram 17 organizācijām konsultācijas notikušas tikai vienreiz.

Visus İUMBGLS iesniegtos projektus NVO ir atbalstījušas (Latvijas Zvērināto tiesu izpildītāju padome, „Glābiet bērnus” un Latvijas Bāriņtiesu un pagasttiesu darbinieku asociācija), turklāt par visiem projektiem informēta arī plašāka sabiedrība. BM, kas turpināja ĪUMBĢLS darbu, projektiem atzinumus analizētajā periodā sniegušas 13 organizācijas, piemēram, Latvijas Jaunatnes padome, „Glābiet bērnus", Latvijas Audžuǵimeņu biedrība, LPS, Latvijas Studentu apvienība (LSA) u. c. NVO atbalsta projektus, ir izteikušas priekšlikumus, daļa piedalījusies arī izstrādes procesā.

İUMSILS sadarbībā ar NVO (kopā 37) parādās pozitīva tendence iesaistīt arī reǵionālās NVO, piemēram, Cēsīs, Daugavpilī, Jelgavā, Talsos, Liepājāa, Rīgās/o „Daugavpils rajona partnerība”, Rīgas Samariešu apvienība, Preiļu NVO atbalsta centru. Konsultācijas notikušas ar biedrību „Mūsmājas”, Cilvēku ar īpašām vajadzībām apvienību „Sustento”, Invalīdu un viņu draugu apvienību „Apeirons”, 
resursu centru sievietēm „Marta”. Tomēr vislielākais konsultāciju skaits bijis ar Latvijas Cilvēktiesību un etnisko studiju centru (13), sabiedrību par atklātību „Delna”, Latvijas Pilsonisko aliansi (LPA), LPS.

ĪUMSILS Sabiedrības integrācijas departamenta direktore Evita Kirilova norāda, ka ministrijai ir visciešākā sadarbība ar NVO, jo tā ir vadošā valsts pārvaldes iestāde, kas atbildīga par pilsoniskās sabiedrības stiprināšanu Latvijā: „Visās darba grupās, politikas plānošanas dokumentu izstrādes darba grupās, uzraudzības konsultatīvajās padomēs ir iesaistītas NVO. Sadarbība ir abpusēja. Pastāv noteikta kārtība - NVO pārstāvis piedalās VSS, un līdz ar to ir iespējams pieteikties uz atzinumu sniegšanu. Tas ir viens no sadarbības veidiem, kas ir atklāts - visām NVO ir iespēja iepazīties ar VSS uzsauktajiem normatīvajiem aktiem un sniegt savus atzinumus. İUMSILS, strādājot pie normatīvajiem aktiem, konsultējas ar NVO, un tādu gadījumu, kad nebūtu notikušas konsultācijas, lai gan tas būtu bijis nepieciešams, nav bijuši" ${ }^{23}$.

Par Izglītības un Zinātnes ministrijas (IzM) projektiem aktīvi notiek konsultācijas ar LSA, Latvijas profesionālās izglītības mācību iestāžu asociāciju un profesionālās izglītības un nodarbinātības reǵionālajām padomēm, Latvijas Rektoru padomi, Latvijas Privātskolu asociāciju, LPS, Latvijas Brīvo arodbiedrību savienību (LBAS), arī Latvijas Izglītības un zinātnes arodbiedrību, Latvijas Izglītības vadītāju arodbiedrību u. c. - kopā ap 50 dažādām organizācijām. Norādīts, ka priekšlikumi iestrādāti projektos un tiek atbalstīti. Arī LSA prezidents Uldis Luckāns atzīst: „Sadarbību ar ministrijām vērtējam pozitīvi, lai gan dažkārt tās neievēro normatīvo aktu un politikas plānošanas dokumentu virzības prasības"24.

U. Luckāns norāda, ka tas, vai iniciatīva sadarbībai nāk no LSA vai ministrijas puses, atkarīgs no projektu rakstura: „Par tiem normatīvajiem aktiem, kuri ir diezgan viennozīmīgi atbalstāmi, ministrija piedāvā sniegt atzinumu. Savukārt, par tiem normatīvajiem aktiem, kur sagaidāmas asas diskusijas, visbiežāk mums jāpiesakās pašiem. Tomēr atzinumu sniegšana ir pietiekami būtisks līdzeklis, lai arī jāatzīst, ka tā efektivitāte lēmumu pieņemšanā ir lielā mērā atkarīga no politiskās gribas. Sadarb̄̄ba ar MK ir visnotal̦ laba - kā piemērus jāmin visas reizes, kad, apspriežot kādu normatīvo aktu vai politikas plānošanas dokumentu, vienmēr iespēja izteikties bijusi arī LSA pārstāvjiem. Jāatzīst, ka priekšlikumi tiek iekļauti un atbalstīit, gan virzot normatīvos aktus MK, gan Saeimā. Piemēram, MK nesen uzklausīts LSA viedoklis augstākās izglīî̄bas studiju programmu saistībā par Noteikumu projektu „Augstskolu, koledžu un augstākās izglītības programmu akreditācijas kārtība”. Arī, skatot grozījumus MK 2001. 29. 05. noteikumos nr. 220 "Kārtība, kādā tiek pieškşirts, atmaksāts un dzēsts studiju kredīts un studējošā kredīts no kredītiestādes līdzekḷiem ar valsts vārdā sniegtu galvojumu", tika iekl̦auta prasība palielināt studējošā kredīta apjomu. Daži no neiekḷautajiem LSA ierosinājumiem tika iekḷauti IzM priekšlikumos noteikumu projekta grozīšanai vēlāk. Tomēr IzM neñēma vērā ierosinājumus Augstskolu likuma grozījumu virzībā MK 2005. gada vasarā Satversmes 81 . panta kārtībā. LSA ierosinājumi tika apstiprināti tad, kad likumprojekts tika virzīts Saeimā" ${ }^{25}$.

Apmēram 117 organizācijas konsultējušās ar ZM par tiesību aktu projektiem 46 atzinumus sniegusi Lauksaimniecības organizāciju sadarbības padome (LOSP). Pārējās NVO sniegušas konsultācijas vai tām nosūtīta informācija par projektiem no 1 līdz 5 reizēm, piemēram, Latvijas Veterinārārstu biedrībai, Latvijas Dzīvnieku 
aizsardzības biedrībai, Latvijas biškopības biedrībai, Latvijas Ornitologu biedrībai. ZM konsultējusies arī ar reǵionālām NVO - Cēsu rajona zemnieku apvienību, Kurzemes reǵiona Zvejnieku savienību.

LOSP pārstāve Linda Bille par sadarbību ar ZM norāda: „Iniciatīva ir abpusēja. LOSP katru gadu tiek slēgts līgums ar ZM, kurā tiek paredzēts, ka ministrija iesniedz izskatīšanai un organizācija sniedz atzinumu par aktuāliem un stratēgiskiem jautājumiem, kā arī normatīvo aktu un to grozījumu projektiem, kas saistīti ar lauksaimniecību un lauku attīstību. ZM regulāri sniedz informāciju par aktualitātēm, uz kurām pamatojoties, arī pēc LOSP iniciatīvas, tiek sniegti atzinumi un priekšlikumi. Attiecībā uz citu ministriju kompetencē esošajiem jautājumiem iniciators diezgan bieži ir LOSP" ${ }^{26}$.

L. Bille atzīst: „LOSP iesniegtie priekšlikumi un ieteikumi parasti tiek iekļauti likumprojektos dal̦ēji. Piemēram, dal̦ēji atbalstīti LOSP priekšlikumi lauksaimniecības struktūrfondu 4.1.pasākumam „Investīcijas lauksaimniecības uzṇēmumos”. N̦emti vērā arī LOSP priekšlikumi, plānojot nākamā plānošanas perioda Lauku attīstības programmas pasākumus. Ir bijis, ka konsultācijas nav notikušas, lai gan bijušas nepieciešamas, piemēram, netika saskan,oti grozījumi „Lauksaimniecības un lauku attīstības likumā”, kas veikti š̄ gada pavasarī. Atzinumu sniegšana ir efektīvs sadarbības veids, ņemot vērā, ka ministrijās strādājošo ierēdṇu zināšanas bieži vien ir diezgan teorētiskas, kā rezultātā bieži vien, piemēram, tiek uzliktas praktiski neizpildāmas saistības. Šajā gadījumā lauksaimnieku organizāciju pārstāvji var novērtēt no praktiskā viedokḷa, vai attiecīgā norma ir ieviešama un varētu praktiski darboties dzīvē"27.

Kultūras ministrija (KM) bija iesniegusi nelielu skaitu projektu, taču konsultējusies ar 27 organizācijām, to skaitā,Latvijas Bibliotekāru biedrība, Latvijas Informācijas tehnoloǵiju un telekomunikāciju asociācija, Latvijas Vīru koru biedrība. Savukārt, Ministru prezidents konsultācijas veicis ar LPS, Latvijas Komercbanku asociāciju, sabiedrību par atklātību „Delna” u. c. - kopā 11 organizācijām.

Labklājības ministrijai (LM) aktīva sadarbība izveidojusies ar LBAS un LDDK, arī Nacionālās trīspusējās sadarbības padomi un Latvijas Pensionāru federāciju (LPF), LPS. Atzinumus sniegušas arī organizācijas „Glābiet bērnus”, Invalīdu un viņu draugu apvienība „Apeirons”, sabiedriskā organizācija „Rūpju bērns”, Latvijas Sieviešu invalīdu asociācija „ASPAZIJA” u. c. - pavisam 40 dažādas organizācijas.

LPF priekšsēdētāja Aina Verze norāda: „LPF sadarbība ar LM un VM ir vērtējama kā veiksmīga - LPF sniedz savus priekšlikumus ikmēneša tikšanās reizēs ar VM, pārrunā problēmas ar LM, n̦em dalību darba grupās projektu izstrādē, konsultatīvās padomēs un sniedz atzinumus. Kā politiskās plānošanas dokuments minams Nacionālais rīcības plāns nabadzības un sociālās atstumtības mazināšanai, kura izstrādē piedalījās LPF pārstāvji. N̦emam dalību arī dokumenta izpildes pārraudzības padomē. LPF nāk ar iniciatīvu, priekšlikumiem likumprojektu izstrādē, ministrijas ar piedāvājumu darboties dažādās darba grupās, komisijās un padomēs"28.

A. Verze: „LPF iesniegtie priekšlikumi tiek ņemti vērā aptuveni 80\% gadījumu, piemēram, priekšlikumi likuma "Par valsts pensijām" grozījumu projektā (pēdējos 5 gados - 11 priekšlikumi); veselības aprūpes sistēmā par pacientu iemaksām, medikamentu references cenām, valsts kompensējamo medikamentu un diagnožu 
saraksta papildināšanu, priekšlikumi par ǵimenes ārstu pakalpojumu uzlabošanu. Ir jāpiemin vairāki priekšlikumi, kas likuma "Par valsts pensijām" projektā netika iekļauti. LPF tos atkārtoti iesniedza un panāca labvēlīgu atrisinājumu. Sadarbībā ar MK organizācija izjūt patiesu atsaucīgumu un pretimnākšanu, īpaši no politiķu puses. Ierēdņiem nereti ir savs viedoklis un skatījums. Kompromiss ir panākams, kopējās sarunās pamatojot LPF viedokli ar saviem argumentiem"29.

Invalīdu un viņu draugu apvienība „Apeirons” pārstāvis atzīst: „Ik palaikam ministrijas lūdz mūsu viedokli, tomēr tas nav sistemātiski un notiek kampaņveidīgi. Tas nozīmē, ka NVO ne vienmēr ir laiks piesaistīt attiecīgus speciālistus, lai novērtētu tiesību akta projektu - tad iespēja ir tikai virspusēji iepazīties ar dokumentu, un tas nedod iespēju izvērtēt dokumenta sekas. Bieži notiek tā, ka veidojam pārrunas ar ministriju darbiniekiem, lai paskaidrotu vienas vai otras normas nozīmi un nolūku, bet priekšlikumi tiek ņemti vērā, ja piedalāmies darba grupā un kopā darbojamies normu izstrādē. Tomēr atzinumu sniegšanai noteikti ir nozīme. Sadarbības iniciēšana nāk gan no organizācijas puses, gan ministrijām, turklāt no Valsts Kancelejas (VK) puses jūtams atsaucīgums un pretimnākšana, tomēr konsultāciju process ir jāuzlabo" ${ }^{30}$.

RAPLM visaktīvāk sadarbība notiek ar LPS (par 21 projektu notikušas konsultācijas), taču arī ar Latvijas Lielo pilsētu asociāciju, LPS, Koalīciju intelektuālā īpašuma tiesību aizsardzībai, LOSP, Latvijas Mērnieku biedrību, arī sabiedrisko organizāciju „Zemnieku saeima”, Latvijas Juristu biedrību, Latvijas Namsaimnieku biedrību un Nacionālo trīspusējās sadarbības padomi (kopā 15 organizācijām). Savukārt, Satiksmes ministrijai (SM) konsultācijas notikušas ar Latvijas Pasažieru autopārvadātāju asociāciju, biedrību Autopārvadātāju asociācija „Latvijas Auto”, LPS, Latvijas Kuǵu brokeru un aǵentu nacionālo asociāciju, pavisam 40 organizācijām.

Veselības ministrijas (VM) projektu atzinumu sniegšanā sadarbojas ar 42 organizācijām, no kurām vairāk nekā divas reizes atzinumus sniegušas Zāḷu ražotāju asociācija, Latvijas Ķīmijas un farmācijas uzṇēmēju asociācija, Latvijas Zālu lieltirgotāju asociācija, Ģenērisko medikamentu ražotāju asociācija, Starptautisko inovatīvo farmaceitisko firmu asociācija, Ārvalstu farmaceitisko firmu pārstāvniecību asociācija. Arī Latvijas Farmaceitu biedrība, Latvijas Ārstu biedrība, Krūts ēdināšanas veicināšanas un aizsardzības biedrība un „Sustento”.

VM Sabiedrības veselības departamenta direktors Ainārs Civičs atzīst, ka sadarbība ar NVO ir laba: „Ministrija to piedāvā, bet, ja NVO ir īpaša interese par kādu projektu, tad tā pieprasa, kas gan notiek reti." A. Civičs norāda, ka iemesls tam, kādēl konsultācijas ar NVO nenotiek un līdz ar to anotācijas 6. sadaḷā ierakstīts Konsultācijas ar NVO nav notikušas, ir: „Dokumenti parasti jāvirza ḷoti ātri, un tāpēc nav iespēju saskaņot, otrkārt, NVO l̦oti reti atbild." Tajā pašā laikā atzīst, ka atzinumu sniegšana ir ,praktiski vienīgais sadarbības veids, kas dod kaut cik konstruktīvu atbildi" "31. Uz jautājumu, vai sadarbībā ar NVO jūt atsaucīgumu un pretimnākšanu, VM pārstāvis norāda uz vairākiem pozitīvi vērtējamas sadarbības piemēriem - ar Latvijas Ārstu biedrību, Latvijas Veselības aprūpes vadības speciālistu asociāciju, Latvijas Veselības un sociālās aprūpes darbinieku arodbiedrību u. c.

Var novērot, ka konsultēšanās un atzinumu sniegšanas mehānismu aktīvi izmanto dažādu jomu padomes, kas ietver vairākas NVO, piemēram, LOSP, Vides konsultatīvā padome. Šāda NVO apvienošanās un kopīga darbība vērtējama pozitīvi, 
jo l̦auj mazajām organizācijām izvairīties no finansiālām, cilvēkresursu un zināšanu trūkuma problēmām, kas citādi apgrūtina līdzdalību.

\section{PROBLĒMAS NVO UN MINISTRIJU SADARBĪBĀ}

Gan intervijās, gan arī anketās atklājās dažādi elementi, kas ietekmē abu pušu sadarbību, to vidū organizāciju vai ministriju kapacitātes vai ieinteresētības trūkums, resursu nepietiekamība utt.

Par informācijas koordinācijas problēmām liecina „Apeirons” pārstāvja norādītais: „Tā kā mēs nezinām ministriju plānus un datumus, kad dokumenti ir jāsniedz tālāk, tad arī savlaicīgi nevaram lūgt dokumentu apskatīt un novērtēt. Bieži nav notikušas konsultācijas, lai gan tas būtu bijis nepieciešams - tās ir tās ministrijas, kas tieši neietekmē mūsu sfēru, bet gan sekundāri, piemēram, BM, IzM"’32.

VK pārstāve I. Greiškalna intervijā norāda: „Ja vērtējam sadarbības efektivitāti pēc sasniegtā, tad jānorāda, ka būtībā visi NVO sniegtie priekšlikumi ir iekḷauti likumprojektos" ${ }^{33}$. Tomēr vairāku NVO biedri anketās norādījuši, ka ne visi priekšlikumi tiek n̦emti vērā. Tā, piemēram, Latvijas Informācijas un komunikācijas tehnolog̣ijas asociācijas (LIKTA) biedrs Kaspars Semēvics intervijā norāda: „Vairumā gadījumu iestādes ņem vērā maigākos labojumus un anotācijā uzraksta, ka daḷa ieteikumu ņemti vērā. Būtiskākie ieteikumi parasti tiek ignorēti, jo tie parāda projekta zemo kvalitāti" ${ }^{34}$. Arī LSA prezidents norāda uz ministriju zemo kapacitāti, kas kavē veiksmīgu sadarbību: „Traucē IzM pasīvā vēlme kardināli mainīt sistēmu vai nu politisku, vai finansiālu apsvērumu dēḷ. Kā piemērs jāmin nespēja radikāli pārskatīt vispārējās vidējās izglītības klašu novirzienu sistēmu vai panākt augstākās izglītības finansējuma pieaugumu valdības deklarācijā paredzētajā apmērā. Jānorāda arī, ka dažkārt ministriju administratīvā kapacitāte ir tik zema, ka būtisku normatîvo aktu virzība tiek kavēta ierēdņu neizdarības dēl’"35.

Savukārt, LOSP pārstāve vērš uzmanību uz kapacitātes jautājumu: „Biroja kapacitāte pašreiz ir salīdzinoši maza, ņemot vērā darba apjomu, taču ir izstrādāta sistēma, kādā veidā LOSP dalīborganizāciju pārstāvji tiek iesaistīti likumprojektu un to grozījumu izvērtēšanā. Respektīivi, ja tiek saņemts dokuments izvērtēšanai, tas tiek nosūtīts elektroniski visām dalīborganizācijām izvērtēšanai, par atbildīgo nosakot vienu salīdzinoši kompetentāko biedru. Šis pārstāvis attiecīgi visus priekšlikumus apkopo un iesniedz LOSP birojam, kas to nosūta attiecīgajām institūcijām" "36. Arī K. Semēvics norāda: „Parasti lūgumi tiek saņemti, kad atlikusi nedēļa, lai sagatavotu atzinumu, kas ir pārāk mazs laiks. Turklāt NVO ar lielu biedru skaitu vēl ir nepieciešams laiks, lai izstrādātu konkrētās NVO viedokli un apkopotu visus priekšlikumus. Turklāt NVO tiek iesaistìta normatīvā akta projekta izstrādē tikai beidzamajā fāzē - tad var mainīt tikai atsevišksus formulējumus, atsevišķas normas un izdarīt redakcionālus labojumus" ${ }^{37}$.

Savukārt, LPF priekšsēdētāja norāda uz finanšu un cilvēkresursu nepietiekamību: „Veidojot atzinumus, jūtamu šķēršlu nav - viss atkarīgs no organizācijas kompetences līmeņa un LPF laika, zināšanu un informācijas resursu ir pietiekoši, taču traucē finansiālās problēmas, lai piesaistītu nepieciešamos cilvēkresursus. Tomēr, atzīstam, ka atzinumu sniegšana ir efektīvs sadarbības veids, jo tā ir iespējams apturēt pensionāriem nelabvēlīgus likumprojektu pantus vai MK noteikumus, kuri skar 
pensionāru intereses" ${ }^{38}$. Uz NVO cilvēkresursu un administratīvo kapacitātes faktoru norāda arī ĪUMSILS pārstāve E. Kirilova un „Apeirons” pārstāvis. Būtisks ir arī informācijas trūkums un nepietiekamās zināšanas, piemēram, LOSP pārstāve L. Bille atz̄̄st: „Bieži vien gadās, ka lauksaimnieku izteiktie priekšlikumi nav juridiski korekti, jo tie tiek iesniegti, balstoties uz praktisko izpratni, kas dažreiz nav iekļaujama likumprojektos - lauksaimniekam ir ideja par to, kā vajadzētu būt, taču juridiskais formulējums sagādā problēmas. Tas, manuprāt, ir nepareizi, ka ZM un citas valsts institūcijas prasa jau juridiski korektu formulējumu un skaitliski pamatotus pierādījumus attiecīgajam priekšlikumam. Dziḷāka analīze būtu jāveic pašai ministrijai, nevis lauksaimniekam"39.

ĀM pārstāve K. Kovale kā apgrūtinošu faktoru min NVO neizpratni par valsts pārvaldes dienaskārtību, pienākumiem un lēmumu pieņemšanas procesu. Arī D. Reihmane atzīst: ja konsultācijas nav notikušas, lai gan bijušas nepieciešamas (par ko pārstāvei nav informācijas), to varētu skaidrot šādi: „Iemesls varētu būt informācijas trūkums - ministrijai par to, ka ir kāda NVO, kas ir ieinteresēta konkrētā jautājuma apspriešanā, bet NVO aktīvi neseko līdzi politikas plānošanai, tādēl nav vērsusies ministrijā. Ja NVO izsaka vēlmi sniegt komentārus vai citādi piedalīties, tas vienmēr tiek ņemts vērā" ${ }^{40}$.

Kā problēmas sadarbībai VM pārstāvis A. Civičs, savukārt, min vairākus faktorus - NVO reti atbild, turklāt ar novēlošanos; NVO ir mazas un sadrumstalotas; dažādu NVO viedoklis ir pretējs un saskaņošanas sanāksmēs nav iespēju panākt vienošanos starp tām. Interesanti, ka A. Civičs norāda uz vēl vienu faktoru - NVO saistību ar ražotājiem un to interešu aizstāvēšanu, turklāt tiek norādīts, ka vairumā NVO viedoklis ir vispārējs, nepamatots, pat utopisks.

\section{SECINĀJUMI}

Pētījumā izvirzịtā hipotēze, ka NVO un MK sadarbības mehānisma - atzinumu sniegšana tiesību aktu un politikas dokumentu projektiem - izmantošanu ietekmē organizāciju kapacitāte, pētījuma gaitā pierādījusies dal̦ēji, jo sadarbība ir atkarīga no vairākiem main̄̄gajiem ne tikai no NVO kapacitātes (informācijas, zināšanām, cilvēkresursiem, finansēm, laika resursiem), bet arī no normatīvajos aktos iestrādātajiem mehānismiem, ministriju kapacitātes, iesaistîto personu, institūciju un organizāciju individuālās ieinteresētības. Nebūtu korekti secināt, ka sadarbību visbūtiskāk ietekmē kāds no mainīgajiem, jo rezultāts ir visu šo komponentu korelācija.

Tā kā sadarbības kvalitāte ir atkarīga arī no ministrijas darbinieku atvērtības sadarbībai, zināšanām u.c. faktoriem, intervijā I. Greiškalna vērš uzmanību, ka, ja sadarbība nav veiksmīga, „Nevar arī secināt, ka tam par iemeslu ir ierēdṇu nevēlēšanās sadarboties. Jāṇem vērā, ka ne visām ministrijām ir pietiekami resursi sadarbības attīstībai, piemēram, apspriežu organizēšanai utt. Organizācijām arī pašām savā starpā nepieciešams sadarboties - ne jau katrai vajag juristu, sekretāri utt. Ir organizācijas, kurām tas jau ir, un tad, piemēram, uz atzinumu sniegšanu organizācijas var sadarboties" ${ }^{41}$.

Atzinumu sniegšanas mehānisms tiek izmantots $12 \%$ šo aktu, ko atklāja veiktā tiesību aktu un politikas plānošanas dokumentu projektu analīze. Tomēr, ja gan ministrijas, gan NVO norāda, ka sadarbība un atzinumu sniegšanas mehānisms ir 
veiksmīgs un efektīvs, nepieciešams analizēt, kādi šksēršli pastāv plašākai sadarbībai, kā arī detalizēti jāizvērtē projektu būtība, jo ne visiem no tiem ir nepieciešamas anotācijas, kā arī konsultācijas ar NVO.

Analizējot anotāciju 6. sadaḷu aizpildi, jāatzīst, ka liela daḷa ir formāli aizpildītas. Lielākajā daḷā atzinumu norādīts tikai: organizācijas; tas, vai NVO atbalsta vai neatbalsta projektu; vai priekšlikumi ir iestrādāti projektā. Turklāt jāpiezīmē: atklājas, ka lielākoties NVO projektus ir atbalstījušas. Šādi aizpildītas sadaļas rosina secināt, ka daļa no tām aizpildītas pienākuma pēc un nepietiekami detalizēti. Tomēr FM, EM, VM, arī IzM, ZM projektu anotācijās iekḷauti bija arī detalizētāki paskaidrojumi par priekšlikumiem un NVO viedokli.

Organizāciju skaits, ar kurām notikušās konsultācijas norādītas anotācijā, ir no 1 līdz 115 vienai ministrijai (vislielākais skaits, piemēram, ZM un FM). NVO, ar kurām notiek konsultācijas, varētu definēt kā valstiska mēroga, lielās organizācijas, piemēram, LPS, LSA, LLPA, LOSP, LBAS u.c., taču mehānisms tiek minimāli izmantots reǵionālo organizāciju sadarbībai ar MK. Analīze rāda, ka katrai ministrijai izveidojies noteikts organizāciju loks, ar kurām konsultācijas notiek regulāri, turklāt šīs NVO sadarbojas ar vairākām ministrijām.

Apskatot NVO skaitu, kas sniegušas atzinumus, jāņem vērā fakts, kas var liecināt par ministriju neizpratni par NVO un nevalstiskā sektora būtību vai/gan arī par tehniskām nepilnībām anotāciju aizpildē - netiek nodalīts, kur atzīmēt konsultācijas ar NVO, kur ar uzṇēmumiem, akciju sabiedrībām, institūcijām un privātpersonām. Rezultātā 6. sadal̦ā, kur jānorāda, kādas konsultācijas notikušas, sagatavojot projektu, 1. apakšsadaḷā - Ar kurām NVO konsultācijas ir notikušas - tiek iekḷautas visa veida konsultācijas - gan ar NVO, gan dažādām asociācijām, uzņēmumiem, dienestiem utt., piemēram, a/s „Latvenergo”, a/s „Ventamonjaks”, „Ventspils nafta”, „Olainfarm”, SIA „LatRos Trans”, Latvijas investīciju un attīstības aǵentūru, VAS „Latvijas Dzelzcel̦š̌, Valsts Meža dienestu, Cel̦u satiksmes drošības direkciju utt. Respektīvi, analizējot priekšlikumu iesniedzējus, var pat secināt, ka dažās ministrijās aktīvāk par NVO atzinumu sniegšanu izmanto uzṇēmumi.

Analīzi apgrūtināja tehniskas kḷūmes, kas radušās vai nu Tiesību aktu registra izveidē, vai ministriju un VK savstarpējā koordinācijā, piemēram, pievienoto anotāciju neatbilstība noteiktajam projektam. KM projektiem vairākkārt pievienotas bija VM projektu anotācijas, savukārt IeM pievienotas ZM anotācijas, kas apgrūtināja darbu un izvērtēšanu, jo nevarēja noteikt projektam atbilstošās anotācijas.

Novērojama arī NVO pārstāvju neinformētība un neizpratne, piemēram, LBAS pārstāvis uz pētījuma ietvaros nosūtīto anketu atbildēja, ka LBAS nav nevalstiskā sektora daļa, lai gan teorētiķi un pētnieki atzīst arodbiedrības par nevalstiskā sektora elementu, turklāt arī anotāciju 6. sadaḷā arodbiedrību, to skaitā arī LBAS, viedoklis tiek iekḷauts.

Kopumā analizētā MK un NVO sadarbības mehānisma izpēte un intervijas liecina, ka sadarbība ir attīstības procesā, taču abas iesaistītās puses ir ieinteresētas to attīstīt un risināt esošās problēmas un šķēršlısus.

Pieņemu, ka būtiskākais mērķis pilsoniskās sabiedrības sadarbībai ar valsts institūcijām ir lēmumu, dokumentu, politikas un sabiedrības pārvaldes kvalitātes un efektivitātes paaugstināšana. Ja lēmumu pieņemšanas, kā arī lēmumu ieviešanas 
procesā līdzdarbojas sabiedrības pārstāvji, NVO, tad izveidotajai politikai, likumiem un lēmumiem, kā arī to realizācijai vajadzētu būt kvalitatīvākai un sabiedrības interesēm atbilstošākai.

Darba gaitā radies secinājums, ka normatīvajos aktos ir iestrādāti dažādi mehānismi sadarbībai, kā arī politikas plānošanas dokumentos, valsts programmās, arī MK un NVO sadarbības memorandā tiek likts uzsvars uz sadarbības veicināšanu, informācijas pieejamības palielināšanu un iespēju nodrošināšanu. Tas, ka atzinumu sniegšanas mehānismu izmanto noteikta grupa NVO, kā arī tikai par daļu no projektiem notikušas konsultācijas ar NVO, liek secināt to, ka šāda veida sadarbība netiek pietiekami plaši izmantota. Tomēr to var skaidrot ar iespējamību, ka NVO ir piedalījušās projekta izstrādes darba grupā vai bijušas iniciatores projektam, kas gan nav pietiekami ticams apgalvojums, jo anotāciju 6. sadaḷā tika norādītas arī tās organizācijas, kas piedalījušās darba grupā, kura izstrādājusi projektu. Jāṇem vērā arī fakts, ka aptaujāto un intervēto ministriju un NVO pārstāvji, minot dažādas problēmas un šksēršlıs, tomēr norāda uz veiksmīgu sadarbību un atzinumu sniegšanas mehānisma efektivitāti.

Lai veicinātu sadarbību, gan NVO, gan ministrijām ieteicams ņemt vērā abu pušu viedokli un problēmu izpratni, kā arī palielināt informācijas pieejamību un saprotamību, arī vienkāršot priekšlikumu iesniegšanas formu. Respektīvi, tā kā vairāki NVO pārstāvji kā šķērsli sadarbībai minēja arī problēmas priekšlikumus noformulēt juridiski korekti, iespējams, nepieciešams no ministriju puses piedāvāt iespēju idejas iesniegt neformālā formātā.

Lai palielinātu caurspīdīgumu un saprotamību atzinumu sniegšanas mehānismā, ieteicams būtu 6. sadaḷā, ja konsultācijas nav notikušas, norādīt tam iemeslu, kā arī noteikt vienādus standartus visām ministrijām sadaļas aizpildē, lai būtu pieejama vienlīdz detalizēta informācija par NVO, kas sniegušas atzinumus, par iesniegtajiem priekšlikumiem un to atbalstǐšanu. Turklāt ir jānodala konsultācijas ar NVO, uzņēmumiem un valsts dienestiem, aǵentūrām.

Šis pētījums uzskatāms par iesākumu plašākam pētījumam, kurā tiktu analizēti arī citi sadarbības mehānismi, piemēram, NVO līdzdalība darba grupās, konsultāciju process, turklāt nepieciešams būtu veikt plašāku NVO aptauju, kā ar̄i padziḷināti analizēt iemeslus, kādēḷ daḷa organizāciju neizmanto esošos sadarbības mehānismus. Vairāku mehānismu analīze un salīdzinājums dotu iespēju analizēt pastāvošās korelācijas un varbūt pat nonākt pie secinājuma par kāda mehānisma efektivitāti/ neefektivitāti un nepieciešamību/nelietderību.

\section{IZMANTOTIE AVOTI UN LITERATŪRA}

\section{Izmantotie avoti}

1. Latvijas Republikas Ministru kabinets. Ministru kabineta instrukcija Nr. 4. „Kārtība, kādā aizpildāma normatīvā akta projekta anotācija" (pieņemta 2001.18.IX). Latvijas Vēstnesis. Nr. 138., 2001.28.sept.

2. Latvijas Republikas Ministru kabinets. Ministru kabineta kārtības rullis (spēkā no 2002.01.jūn.). www.mk.gov.Iv (LR Ministru kabineta mājaslapa, aplūkota 2006.10.IV). 


\section{Izmantotā literatūra}

3. Howard, M. M. The Weakness of Civil Society in Post - Communist Europe. Cambridge: Cambridge University Press, 2003, 206 p.

4. Linz, J., Stepan, A. Problems of Democratic Transition and Consolidation Southern Europe, South America and Post - Communist Europe. Baltimore: The Johns Hopkins University Press, 1996, 479 p.

5. Putnam, R. D. Bowling Alone: America's Declining Social Capital. Journal of Democracy. 1995, vol. 6, 65. - 78.p.

6. Putnam, R. D. Bowling Alone. The Collapse and Revival of American Community. New York: Simon\&Schuster, 2000, 541 p.

7. Putnam, R. D. Making Democracy Work: Civic Traditions in Modern Italy. Princeton University Press, 1994, $258 \mathrm{p}$.

8. Wilson, G. K. Interest groups. Oxford and Cambridge: Basil Blackwell, 1990, 198 p.

\section{Interneta resursi}

9. Latvijas Republikas Finanšu ministrija. www.fm.gov.lv (aplūkota 2006. 20. V).

10. Latvijas Republikas Īpašu uzdevumu ministra sabiedrības integrācijas lietās sekretariāta mājas lapa. www.integracija.gov.lv (aplūkota 2006. 20. V).

11. Latvijas Republikas Ministru kabineta mājaslapa. www.mk.gov.lv (aplūkota 2006.20.IV).

12. Latvijas Republikas Vides ministrija. www.vidm.gov.lv (aplūkota 2006. 20. V).

13. Lursoft mājaslapa. www.lursoft.lv (aplūkota 2006. 01. V).

14. NVO centra mājaslapa. www.nvo.lv (aplūkota 2006.12.IV).

15. Sabiedriskās politikas portāls. www.politika.lv (aplūkota 2006.25.IV).

16. Tiesību aktu reǵistrs. www.mk.gov.lv (Ministru kabineta mājaslapa; aplūkota 2006.26. IV).

\section{Intervijas}

17. Aptauja ar ĀM Attīstības sadarbības politikas departamenta vecāko referenti (par komunikāciju stratēǵijas īstenošanu attīstības sadarbības jautājumos) Karīnu Kovali. 2006.18.05.

18. Aptauja ar ĀM Starptautisko organizāciju un humanitāro jautājumu departamenta Humanitāro jautājumu nodaļas vecāko referenti Maiju Mauriņu. 2006.18.05.

19. Aptauja ar FM preses sekretāra p.i., Komumunikācijas departamenta direktora p.i. Daigu Reihmani. 2006.18.05.

20. Aptauja ar Invalīdu un viņu draugu apvienības „Apeirons” pārstāvi. 2006.18.05.

21. Aptauja ar ĪUMSILS Sekretariāta vadītājas vietnieci, Sabiedrības integrācijas departamenta direktori Evitu Kirilovu. 2006.18.05.

22. Aptauja ar Latvijas Pensionāru federācijas priekšsēdētāju Ainu Verzi. 2006.18.05.

23. Aptauja ar Latvijas Studentu apvienības prezidentu Uldi Luckānu. 2006.18.05.

24. Aptauja ar Lauksaimniecības organizāciju sadarbības padomes pārstāvi Lindu Billi. 2006.18.05.

25. Aptauja ar VIDM Valsts sekretāra padomnieku Ēriku Leiti. 2006.18.05.

26. Aptauja ar VM Sabiedrības veselības departamenta direktoru Aināru Civiču. 2006.18.05.

27. Intervija ar Latvijas informācijas un komunikācijas tehnoloǵiju asociācijas biedru Kasparu Semēvicu 2006.12.04.

28. Intervija ar Latvijas Pilsoniskās alianses pārstāvi Zintu Miezaini. 2006.25.04.

29. Intervija ar Valsts kancelejas Komunikācijas departamenta konsultanti Ilze Greiškalni 2006.24.04. 


\section{ENDNOTES}

1 Wilson, G.K. Interest Groups. Oxford and Cambridge: Basil Blackwell, 1990, p. 1.

2 Turpat, 153 lpp.

3 Howard, M. M. The Weakness of Civil Society in Post - Communist Europe. Cambridge: Cambridge University Press, 2003, p. 31.

${ }^{4}$ Putnam, R.D. Making Democracy Work: Civic Traditions in Modern Italy. Princeton University Press, 1994, p. 90.

5 Turpat, 173.-175. 1pp.

6 Putnam, R.D.Bowling Alone: America's Declining Social Capital. Journal of Democracy. 1995, vol. 6, p. 66-67.

7 Latvijas Republikas Ministru kabinets. Ministru kabineta instrukcija „Kārtība, kādā aizpildāma normatīvā akta projekta anotācija" (pieņemta 2001.18.IX). Latvijas Vēstnesis. Nr. 138., 2001. 28.sept.

8 Latvijas Republikas Ministru kabinets. Ministru kabineta instrukcija Nr.4. „Kārtība, kādā aizpildāma normatīvā akta projekta anotācija" (pieņemta 2001.18.IX). Latvijas Vēstnesis. Nr. 138., 2001.28.sept.

9 Howard, M. M. The Weakness of Civil Society in Post - Communist Europe. Cambridge: Cambridge University Press, 2003, p. 35- 37.

10 Turpat, 36.-37. 1pp.

11 Linz, J.J., Stepan, A. Problems of Democratic Transition and Consolidation Southern Europe, South America and Post - Communist Europe. Baltimore: The Johns Hopkins University Press, 1996, p. 8.

12 Truman, D.B. The Governmental Process. Political Interests and Public Opinion. $2^{\text {rd }}$ Ed. New York: Alfred A. Knopf, 1971, p. 33-34.

13 Turpat, 37.-38. lpp.

14 Turpat, 506.-507. lpp.

15 Putnam, R.D.Bowling Alone. The Collapse and Revival of American Community.New York: Simon\&Schuster, 2000, p. 35.

16 Latvijas Republikas Ministru kabinets. Ministru kabineta kārtības rullis (spēkā no 2002.01.jūn.). www.mk.gov.lv (Latvijas Republikas Ministru kabineta mājaslapa; aplūkota 2006.10.IV).

17 Intervija ar Latvijas Pilsoniskās alianses pārstāvi Zintu Miezaini. 2006.25.04.

18 VIDM Valsts sekretāra padomnieka Ērika Leiša anketa. 2006.18.05.

19 ĀM Starptautisko organizāciju un humanitāro jautājumu departamenta Humanitāro jautājumu nodaļas vecākās referentes Maijas Mauriṇas anketa. 2006.18.05.

20 ĀM Attīstības sadarbības politikas departamenta vecākās referentes (par komunikāciju stratēgijas īstenošanu attīstības sadarbības jautājumos) Karinas Kovales anketa. 2006.18.05.

${ }^{21}$ FM preses sekretāra p.i., Komumunikācijas departamenta direktora p.i. Daigas Reihmanes anketa. 2006.18.05.

${ }^{22}$ FM preses sekretāra p.i., Komumunikācijas departamenta direktora p.i. Daigas Reihmanes anketa. 2006.18.05.

${ }^{23}$ İUMSILS Sekretariāta vadītājas vietnieces, Sabiedrības integrācijas departamenta direktores Evitas Kirilovas anketa. 2006.18.05.

${ }^{24}$ LSA prezidenta Ulda Luckāna anketa. 2006.18.05.

25 LSA prezidenta Ulda Luckāna anketa. 2006.18.05.

26 LOSP pārstāves Lindas Billes anketa. 2006.18.05. 
27 LOSP pārstāves Lindas Billes anketa. 2006.18.05.

${ }^{28}$ LPF priekšsēdētājas Ainas Verzes anketa. 2006.18.05.

29 LPF priekšsēdētājas Ainas Verzes anketa. 2006.18.05.

30 Invalīdu un viṇu draugu apvienības Apeirons pārstāvja anketa. 2006.18.05.

31 VM Sabiedrības veselības departamenta direktora Aināra Civiča anketa. 2006.18.05.

32 Invalīdu un vinuu draugu apvienības Apeirons pārstāvja anketa. 2006.18.05.

33 Intervija ar Valsts kancelejas Komunikācijas departamenta konsultanti Ilzi Greiškalni 2006.24.04.

34 Intervija ar LIKTA biedru Kasparu Semēvicu 2006.12.04.

35 LSA prezidenta Ulda Luckāna anketa. 2006.18.05.

36 LOSP pārstāves Lindas Billes anketa. 2006.18.05.

37 Intervija ar LIKTA biedru Kasparu Semēvicu 2006.12.04.

38 LPF priekšsēdētājas Ainas Verzes anketa. 2006.18.05.

39 LOSP pārstāves Lindas Billes anketa. 2006.18.05.

40 FM preses sekretāra p.i., Komumunikācijas departamenta direktora p.i. Daigas Reihmanes anketa. 2006.18.05.

${ }^{41}$ Intervija ar Valsts kancelejas Komunikācijas departamenta konsultanti Ilzi Greiškalni 2006.24.04. 


\title{
On the Differences between Lithuanian and Norwegian Models of Social Welfare Provision
}

\author{
Arvydas Guogis \\ University of Lithuania, \\ Harald Koht \\ Oslo University College, Norway
}

\section{INTRODUCTION}

Since 1988, the political support of the Nordic countries for the re-establishment of the Lithuanian state, for building democracy and for reforming the economy have contributed to close cooperation between the Baltic States and the Nordic countries. In 1995, Sweden and Finland joined the European Union and along with the other Member States encouraged Lithuania's accession to the EU. The EU's favourable attitude to regional cooperation specifically includes close ties between Nordic and Baltic countries. In addition, the "Nordic Dimension" of the EU is an additional factor that strengthens cooperation between Nordic countries and Lithuania, not only in the geopolitical field but also in regard to economic and cultural relations.

Norwegian and Lithuanian entrepreneurs are successfully making use of the advantages provided by a market economy. Norwegian companies have invested in the Lithuanian economy and their investments include the purchase of real estate, manufacturing and retail businesses. Personal contacts between scientists and artists of both countries are also expanding. But this cannot be said about relations between architects of social security systems, which still remain weak. Why have the experiences and achievements of the Norwegian and of the other Nordic welfare states received so little consideration in Lithuania? This is a question that remains to be answered.

For numerous reasons, the institutional social democratic Norwegian welfare state model might have been chosen as a point of reference for developing the Lithuanian social security system. One might argue that during the last decade the political situation for such a development was quite favourable. After all, Social Democratic parties ruled Lithuania in the period 1992-1996 and from 2001-2004. The Norwegian Labour Party held power throughout the greater part of the $20^{\text {th }}$ century and currently leads a governmental coalition in the $21^{\text {st }}$ century. Even under 
the growing influence of globalisation, social democracy has been able to keep Norway on a rather favourable path without sacrificing its own social programmes.

One must, however, admit that Norway and Lithuania have experienced completely different stages in the historical growth and development of their states. The two countries differ considerably in their levels of economic development and in the characteristics of their welfare states. Norwegian capitalism, conditions within various markets and social conditions developed in a sustainable way during most of the $20^{\text {th }}$ century. The general welfare in society gradually improved. The Lithuanian experience of Soviet socialism has been less beneficial. There are the well known negative consequences of a bureaucratically planned economy and the inefficiencies of the Soviet social supply model, which offered free but limited and very lowquality social services.

In addition, Norway's oil economy may seem to make the country an inappropriate choice for comparative purposes. However, the main elements of the Norwegian welfare state were put in place in legal and economic terms (as a proportion of GDP) long before the income from the oil industry significantly affected the economy. Norwegian politicians share the concerns of Josef Knecht (the leading character in the novel by Hermann Hesse entitled The Glass Bead Game), who feared that the dependence upon the glass bead game of his beloved Castalia would sooner or later make the province "vulnerable to the danger of aging, sterility, and decadence" (Hesse 2002, 274). These concerns have led to strict, self-imposed limits on government spending by most political parties.

One purpose of this paper is to compare the welfare state models in Norway and Lithuania. A second purpose is to identify the reasons why the Norwegian welfare state model has, thus far, been so little considered in Lithuania. A third purpose is to consider the possibilities for implementing the Norwegian welfare state model in Lithuania, taking into consideration some changes in that model that were enacted in the last decade of the $20^{\text {th }}$ century. The methodology of this study applies critical social analysis, comparative methods and macro-social data from Norway and Lithuania.

\section{MODELS OF WELFARE STATES}

In Western political science discourse three basic models of the welfare state are identified: liberal, conservative and social democratic. The liberal model acknowledges the dominance of the market. Accordingly, the state, in the liberal model, has only a limited impact upon the distribution of welfare. It only guarantees minimal supports to citizens and it promotes self-reliance as the dominating ideology for citizenship. In the context of a liberal model, individuals are responsible for providing their own welfare and the state is a resource only when individuals fail to do so. The liberal welfare state system of provision addresses the individual who cannot provide for himself or solve his own problems. The various markets are expected to provide the basis for the general welfare of individuals in society. The state attempts to mitigate the problems of poverty, inequality and unemployment by providing a low-level of benefits. Keeping benefits low is a way of inducing people to participate in the labour market. The architects of liberal welfare state systems 
worry that high benefit levels erode the will to work for a living. Generally speaking, social programmes focus upon elderly people and individuals with physical and/or psychological problems, i.e. they benefit people who are already wholly or partially excluded from participation in the labour market. The criteria for entitlement to state supports are generally very strict ones. The features of the liberal welfare state model include limited and low-level state supports and emphasise market forces and a selfreliant citizenry.

In the conservative welfare state model, the state is the main sponsor; however, the family assumes responsibility for the social situation of family members. Social services are provided only when the family is unable to cope with the responsibility of providing welfare to its members. The state preserves class differences, class subordination, and status differences through a variety of social insurance schemes, i.e. families from different classes with unequal status have a right to different social benefits and services, although the size of support depends upon contributions. The social insurance system is intended for working persons only; social benefits are calculated according to the size of income and work record; the unemployed are not insured. Allowances are distributed through various voluntary organisations and benefit funds. The main state concern is to guarantee that public expenses for welfare provision reflect the level of economic performance and growth. Social insurance schemes are financed from contributions by employees and their employers. There is a strong emphasis on the principle of subsidiarity. This principle is based upon family responsibility. If and when families fail to meet their obligations, the community, i.e. voluntary organisations that are often affiliated with the Church assume responsibility. The state will then provide support to help finance the efforts of these voluntary organisations. Only if and when the voluntary organisations fail to provide welfare in a satisfactory manner will the state directly engage itself in the provision of welfare. This strategy of subsidiarity emphasises decentralisation. The state is always the last option in a chain of responsibility that begins with membership in a family, and leads to membership in a community, which again is linked to membership in the general society.

In the social democratic model, the state assumes responsibility for the provision of welfare to every individual. The state pursues a full-employment policy and ensures that all individuals are provided with a dignified standard of living. All citizens enjoy an assortment of health and social rights. A social democratic welfare state pays decent social benefits and every individual has equal rights irrespective of gender, race and marital status. Poverty, inequality and unemployment are problems that are ameliorated by effective progressive taxation. Commitments to the individual, by society, are, in principle, unlimited. Social democratic welfare states doubt that the family or the market will be able to competently provide optimal welfare distribution (Esping-Andersen \& Korpi 1987, 40-41). The characteristics of the social democratic welfare model are as follows: social rights are generally based upon citizenship, i.e. welfare is treated as a civil right; the public sector provides the primary services that are available to all individuals and a comprehensive cradle to grave health and social policy is practiced (Arter 1999, 185). Solidarity is an ideology that is promoted by public institutions. Traditional welfare state limits are overstepped, i.e. new needs are uncovered and new programmes address those 
needs, there is a progressive development in the variety of services that are fostered by public institutions; the commitment to principles of universality and equality are maintained and a high degree of 'de-commodification' is preserved'. The social democratic model is characterised by high social expenditures, decent benefits, proper services, and a high degree of social inclusion.

Since Lithuania was a part of the Soviet state, the Soviet model needs to be summarised briefly in this paper. The Soviet model (Manding \& Shaw 1998) was typified by centralised planning and it provided a basic level of welfare for its citizens by highly subsidising the costs of basic material needs. Health care and education were essentially free, apart from the practice of "tipping" professionals to get access to special facilities or preferential treatment. Housing and housing costs were almost free, food and transport were very inexpensive. However, welfare provision was closely linked to the labour market in several respects. First and foremost, much of welfare provision was provided by the employing enterprise rather than by an independent bureaucracy. In addition, there was considerable duplication between enterprise services and local government health, education, and housing services. The price of consumer goods was kept very low, and as a consequence, demand was effectively controlled through queuing. The provision of better services, or at least rapid access, was used to manipulate the supply of labour to strategic industries (such as the military) or geographically remote areas (such as the Far East). The social security system was explicitly linked to the length of one's working life and to the level of one's pay in its benefit eligibility formulae. The market was not allowed to dominate social life and the state guaranteed only minimal supports to the individual and did not encourage the individual to secure his or her own welfare. The family had only a limited impact upon the social situation of its members. This model was widespread throughout the Soviet republics constituting the USSR, including Lithuania.

\section{SOCIAL POLICY IN NORWAY AND LITHUANIA AFTER WORLD WAR II}

The Norwegian welfare state is an ambitious project and its goals are greater than merely satisfying the basic needs of its citizens. The social democratic welfare state model balances the goal of fully promoting individual freedom with the promotion of an assortment of comprehensive health and social programmes that are implemented by the state and its institutions. The understood presupposition for the complex network of services and supports is the realisation that they are needed to secure each and every individual and to provide each and every individual with an opportunity to fully develop and express their inborn potential. The ideals that grounded the social policies pursued by the Labour Party after World War II were not merely nominally referred to as being universal. The universal aspect of health and social welfare provision was meant to be a serious and determined approach to counteract the divisive workings of class in order to enable every individual to have opportunities for development.

The social rights of citizens, in this particular vision and version of the good society, obtain equal importance with the economic rights to private property and the 
political rights to participate in the decision-making processes of a democratic society. Parties and trade unions representing the working class had supported welfare state reforms for a long time. Labour organisations put their trust in the institutions of the state. The state itself would be organised to secure social rights. Strong Norwegian employer associations consented to a high degree of state regulation and a state-run social insurance system. They understood that the regulations and the high social security costs would work to reduce class conflict in society. Social stability had a price, but in the long haul stability would lessen economic burdens and reduce some of the risks and transaction costs of doing business.

Economic growth in Norway after World War II coincided with the rule of the Norwegian Labour Party and its close relationship with the trade union movement and with business and industry representatives. Conditions were favourable for the development of a social democratic welfare state. Welfare state development occurred in phases that reflect the ways in which Norwegian social democrats aimed at balancing power relationships in society. Programmes that fostered equality in society were balanced by programmes that promoted economic efficiency. The Norwegian social democrats framed a welfare state policy that supported the expansion of the middle class. The traditional separation between social and economic policy was gradually dismantled and the two concerns were seen as being two sides of the same coin. One policy that fostered both social and economic goals was the national pursuit of full employment. This common goal and the programmes and practices that were designed to achieve this goal lead to the incremental development of an institutionalised universal social welfare model by incrementally implementing one universal welfare programme after another (Kangas $\&$ Palme 2005). The consequence of achieving a consensus on national goals led to the development of a successful economy and a stable society with generally high levels of social capital. The modern roots of Norwegian social policy are embedded in the reconstruction era following WWII. In the joint programme prepared for the national elections in 1945, four and later six political parties spelled out the ideas behind a consensual and universal approach to social policy. ${ }^{2}$

In their vision, social legislation would be developed to make the public assistance system (i.e. the poor law) superfluous. Social insurance would be undertaken in a national programme which would be coordinated to enable a joint public insurance system for illness, disability, unemployment, and old age. The issue of child allowances would be reconsidered (Bull 1979, 343). ${ }^{3}$

Despite the fact that the Labour party governed with an absolute majority in the years 1945-61, only the child allowance was immediately introduced to replace a similar benefit provided by the Nazi occupation government in the years 194045. The social insurance system from the pre-war era was gradually extended to encompass the entire population, but the 1945 ambition of a joint legal framework had to wait until 1966, when the government was in the hands of the non-socialist parties. The generosity of the welfare state - which was introduced as a concept around 1950 - increased from 5.8 percent of GDP in 1948, to 10.6 percent in 1966. In the next decade this fraction would double again to 22.5 percent (Kuhnle 1983, 63). In 1998, public social expenditure had reached a 27.0 percent share of GDP, compared to the EU average of 24.6 percent (Stjernø 2004). 
The goal of doing away with the Poor Law of 1900 has yet to be completely realised. New social welfare laws to replace the old law were adopted in 1964 and 1991, but both laws carried with them aspects of the past, such as the importance of allowing for local discretion in deciding benefits. A major improvement, however, was the replacement of lay people with professionals in the decision-making that allows for discretionary powers. Reformers hoped that a comprehensive social insurance system would do away with the need for supplementary social assistance. However, as late 2000 there were 130,000 recipients of social assistance (Hatland og Terum 2005, 137).

Despite the universalistic ambitions of the social democrats, the Norwegian welfare state did not fully bloom into a comprehensive and generous entity until the 1970s (cf. Kangas and Palme 2005, 31). The Labour Party had an absolute majority and it faced a weak opposition until the year 1961. As a consequence, the Labour Party could allow itself to pursue other political priorities, such as creating jobs in industry and stimulating economic growth. The Norwegian historian Edvard Bull claimed that the improved social insurance benefits of the 1950s resulted from fundamental changes in the labour market, which had little use for the elderly or for very young workers (Bull 1979, 341-2). On the other hand, the British social historian Asa Briggs points out that Great Britain, at this time (the 1950s), "was in a period of relative 'affluence', not of austerity, [and] that both the ideals and the practices of the welfare state came under closer scrutiny" (Briggs 1983, 286). The Norwegian Labour government could not fail to notice that the British social revolution of the late 1940s was followed by a Conservative victory in the elections of 1951. The prime minister at the time, Einar Gerhardsen, devoted only four pages to social policy in his memoirs of this period. He insisted that from 1945 to 1955 , reconstruction had to be given the highest priority and this meant that the Labour government could not accept Conservative party demands to abolish the meanstest for old-age pensions (Gerhardsen 1971, 167-168). However, the social and economic priority par excellence of the period, that of providing employment to all was included in a 1954 amendment to the Constitution of 1814, which did not mention any other social rights.

Thus, there was no Norwegian social revolution after WWII. The future welfare state was to be developed in incremental steps, in close cooperation with labour unions, major business interests and the other political parties. During the 1970s, the Social Insurance Law of 1966 was made more comprehensive by including sickness benefits to the self-employed. In 1978, full pay was introduced for the employed during periods of illness. Equal benefits for wed and for unwed mothers were enacted in 1981. The pension age was reduced from 70 to 67 in 1973. Pensioners with no accrued pension benefits were provided with a supplement that almost doubled (79.33 percent) the amount of their basic pensions in 1998 (Hatland 2005, 38).

As Stein Kuhnle has remarked, Norwegian, as well as Nordic social policy can be characterised by consensual solutions (Kuhnle 2000, cited by Kangas \& Palme 2005, 286). This emphasis on consensus correlates with the conceptualisation of solidarity shared by modern social democratic parties. As outlined by Steinar Stjernø (2004), the contemporary version of this idea seeks to create social integration and a sense of community in a way that includes the whole nation, irrespective of 
classes. Accordingly, the "universal welfare state corresponds rather closely to this most recent development of the concept of solidarity" adopted by social democrats in the 1960s and 70s (Stjernø 2005, 153). In effect, the social reforms of this period institutionalised the universal character of the Norwegian welfare system.

While Lithuania formed part of the Soviet Union, the dominating political and ideological statements and actions consistently denied the necessity of developing a welfare policy. Welfare problems were considered to be non-existent and it was claimed that the few social problems that did exist would disappear automatically because the state satisfied all of the needs of its working people. The characteristics of the Soviet social development model are as follows: centralised planning, the provision of a basic standard of living and a basic level of welfare solely from the workings of the state, free health care and education, the possibility of free housing and the availability of low-cost housing, inexpensive food and transport costs for the individual. In the former Soviet Union, there was no recognition of the need to have a social policy and what one might refer to as a labour market did not actually exist.

The official ideological position stated that all people who were able to work would be employed and in this way they would earn a living. There was full employment and the social security system was organised for all people who were employed in the USSR. In the case of illness, everyone was provided with free medical treatment and sickness benefits were paid out that equalled the wages one received. The amount of a pension was, to some extent, dependent upon the income one had during the final working years. The social security system was linked to work experience and pay levels were used to calculate benefits. Social security was administered by trade unions, which were also responsible for administering kindergartens attached to industrial enterprises, employee housing, sanatoriums and holiday matters.

The workplace mattered a great deal whenever benefits or other forms of participation in the social welfare system were at issue. From 1950, rapid economic growth did occur in the Soviet Union and particular enterprises were able to attract a workforce by offering their employees a professionally manned welfare system. Resources for social security were allocated from the state budget, with no contributions for social security paid by employees/citizens. Officially, there was no unemployment and, consequently, there were no social problems. Nevertheless, the Soviet model did provide comprehensive welfare services at a relatively low level (Manding \& Shaw 1998, 3-7).

\section{THE DEVELOPMENT OF A SOCIAL SECURITY SYSTEM IN INDEPENDENT LITHUANIA (1990-2006) AND ITS MAIN CHARACTERISTICS}

At first glance, the Soviet Lithuanian social welfare system would seem to have more in common with the Norwegian social welfare system than the current Lithuanian model. As a consequence, it would seem logical to suppose that the transformation to the social democratic social welfare system would have been easier to accomplish during the early stages of the rebirth of Lithuanian independence in 1990-1991. However, the mood in Lithuania, at that time, and the coalescing political 
forces rejected any ideas that too closely resembled ideas from the recent Soviet past. Even suggestions that reminded one of any aspects of the Soviet past were denigrated. The voices demanding change spoke about building a free market economy and they were uninterested in hearing about alternatives to that plan. Gradually, a kind of market fundamentalism dominated Lithuanian political discourse. Representatives of differing political parties and the mass-media were active in this political process, but the agenda was set by the Lithuanian Free Market Institute, which provided the debate with its key concepts. An aura of urgency pervaded political discourse. The ideological undercurrent which provided the basis for discussion was the sometimes uttered understanding that this is a moment of fundamental importance. Our window of opportunity will not last very long and we have to get it right, here and now, or we will fall far behind all of the others. We need a scientific approach to be able to develop our economy.

After the collapse of the Soviet Union and the restoration of Lithuanian independence, there have been some discussions about the choice of an appropriate welfare state model (Paluckienè 1999, 37). Representatives of the Ministry of Social Security and Labour and some advisers from the Social Policy Group decided upon support for a Bismarckian model. The Bismarckian model is based upon contributions made by employees who participate in the labour market and who pay state social insurance contributions to the State Social Insurance Fund. A corporative Bismarckian development in the Lithuanian social security system is confirmed by an analysis of the major social security laws that were passed in 1990-1991 and the reform of the state social insurance system in 1995. A new social security system was designed which was based upon the contributions of the employed. Its characteristics include:

- The amount of a pension would depend upon previous pay and the employee's work record.

- The amount paid for sickness benefits would be linked to pay.

- The calculation of social benefits would be based upon the idea of a negative income tax. (In practice, this meant that total personal income, including wages and social benefits, were always larger for those whose wages had been larger.)

- The State Social Insurance Fund was to be financed by contributions deducted from one's wages.

- The amount paid for child care benefits was always larger for insured women than for non-insured women, for example, students (Guogis, Bernotas \& Ūselis, 2000, 136).

The establishment of the State Social Insurance Fund, which was completely separated from the state (national) budget, testifies to the fact that social security in Lithuania was based upon the labour market. It is particularly well illustrated by the fact that unemployed people, who were not registered at the Labour Exchange, had no access to health care apart from vital primary health care services.

A limited number of welfare state functions and services were created in Lithuania in 1990-1991. There were social security and health care systems, an education system, housing and transport compensations, and a few social benefits. The Lithuanian state social security system consisted of social insurance, social assistance and special 
additional state pensions. The state social security system was created to serve and was adjusted by the free market system. It was administered by centralised institutions and by local authorities. However, in Lithuania, most of the political, media, and academic voice understood the proper role of the state as being a passive rule-keeper, i.e. an attitude which supports a weak state and provides considerable latitude for a free market economy. This attitude did not provide a favourable environment for the development of a social democratic welfare state, which would need to acknowledge a strong state role and a high degree of state intervention.

In the early days of the re-establishment of Lithuanian independence, and while the aforementioned reforms were being made, there was considerable external pressure from the IMF, the WB, the WTO and the OECD. These are all organisations that aim at building a liberal welfare state in which the market and non-profit organisations dominate in society. As time passed, the mood in the country began to change and internal political support for the development of a liberal welfare state diminished. Opposition against the idea of a liberal welfare state increased and became quite strong, as the election results in 2000 and 2002 verify. The ordinary people living in Lithuania wanted their state to assume responsibility for combating unemployment, inflation and poverty. Some wished to return to the safety provided by a truly socialist system and to a predictable daily life and future. Many people, especially elderly ones, believed that the state should provide people with care in all of the difficult stages of life. However, no fully progressive tax system was ever created in Lithuania. There has always been an exemption for a minimum income in the taxation levied upon an individual's work income. It should be noted that a recent opinion poll estimated that $62.1 \%$ of the population responded negatively to the idea of paying higher taxes in order to secure better social benefits. Nevertheless, the results of a 1999 sociological survey indicate that most of the Lithuanian population consider social benefits to be a necessary component of their state. A primary complaint uttered by many respondents pointed to the low pensions in Lithuania and to the low amounts provided by unemployment benefits (Morkūnienè 1999).

As a matter of fact, from 1990 to 2006, a Bismarkian social insurance system did exist in Lithuania. In theory, the scheme belongs to a category containing corporative welfare states, but in practice only very low benefits were paid to recipients because of the relatively low level of economic development achieved in Lithuania during that time frame. Only a very few of the social assistance programmes were aimed at fighting poverty, and programmes to fight poverty are also a characteristic of corporative welfare states. In the period 1997-2006, state social security allocations for social insurance accounted for about $85 \%$, approximately $13 \%$ was allocated for social assistance and about 2\% for special additional state pensions (Lazutka 2001, 141).

The corporative model was specifically selected in an attempt to increase incentives to participate in the labour market. Motives were very different from the imperial blood and iron policies that Bismarck supported when he created the model. No pressures were felt from labour movement leaders or from employers' organisations and the political agenda in Lithuania was far removed from Bismark's own political agenda (Guogis 2003, 7). It should be noted that the Lithuanian corporative model differed considerably from the model that Bismarck originally introduced in Germany, and that it differs from the Bismarkian systems created 
in Belgium and in Luxembourg. The differences refer to the special state benefits reserved for particular groups (privileged clients of the new state). The new state clients spring from the roots of former privileged groups within the Soviet nomenclature. Their privileges do not contribute to social justice in the country. On the contrary, social justice is the victim when special additional state pensions are awarded to particular groups of people, including former members of the armed services, scientists, judges, artists and the like.

The introduction of voluntary private pension funds has further contributed to social inequality and differentiation. They are particularly popular among those young people who earn considerably more than most other workers do. Two years after the legislation permitting voluntary private pension funds, (2003-2006 private pension reforms were enacted) half of the labour force in Lithuania are already participants. From a critical analytic point of view, the introduction and the popularity of private pension funds mean that Lithuania will gradually abandon the corporative model. By introducing institutions which shore up the basic presuppositions of a residual or marginal model for social welfare provision, the liberal and free market fundamentalists are entrenching their position.

The intensification of the trend toward the residual or marginal model in Lithuania is testified to by the increased dependency upon the market. Quantitatively, it is expressed by calculating the degree of decommodification. The degree of decommodification in the Lithuanian social security system was never high, but the low scores have continued to decrease. In 1997, the degree of decommodification reached 23.8, while the indicator for 2000 only stood at 22.2 (Guogis 2002a, 43). The Conservative government's withdrawal of many exemptions for welfare recipients, in the beginning of 2000 , also testifies to the conclusion that Lithuania has been turning away from the provision of state supports. The intensification of liberal free market thinking and residual or marginal welfare system supports during the period of 2003-2004 was predicted by Guogis, Bernotas and Uselis in their study "Lithuanian Political Parties' Notion of Social Security", which was completed in 2000. This report points out that only 3 marginal political parties came out in favour of the universal institutional model of social security, while the 17 other parties either did not have any prevailing opinion or supported the liberal residual or marginal model for social provision (Guogis, Bernotas \& Ūselis, 2000, 88).

The Nordic experience demonstrates how welfare state policy can depend upon the voice of the electorate and the relative strength of different political forces. Under the rule of a left of centre government the boundaries of the welfare state tend to expand, while under the rule of a right of centre government the boundaries of the welfare state tend to narrow. This responsiveness to the voice of the electorate is difficult to uncover in Lithuanian politics, thus far, in the short history of a reemerged period of independence. Most Lithuanian political parties have accepted the ideology of market fundamentalism and they have not dared to dismantle existing state economic and social structures, due to the fear of inadvertently catalysing a social cataclysm. According to the widespread understanding of social democratic welfare states, the representation of left of centre parties in government is seen as being an important guarantee for the maintenance of a strong welfare state policy, but in the Lithuanian case this understanding can only partially be confirmed. The 
provision of social support is relatively low in Lithuania, and the rule of Lithuanian Social Democrats in coalition with Social Liberals, in the years 2001-2004, did not substantially change matters. Cash payments remain all too low. There is a great need to develop a common point of view, one that can unite the entire political spectrum, regarding family needs and the role of the state in support of families. Social services are developing, but much still needs to be done.

The rule of the coalition of Social Democratic and Social Liberal parties did contribute to some developments in regards to social welfare supports, but change has been very limited and mostly symbolic. In 2001-2003, the increase of old-age pensions amounted to 26 Litas $(€ 7.50)$ on the average. Group I disability pensions rose by 32 Litas (€9.25) on the average. The automatic exemption allowed for work income increased by 40 Litas $(€ 11.60)$. Minimal wages increased from 430 Litas to 450 Litas, i.e. from $€ 125$ to $€ 130$. Fees paid by full-time students decreased ( $€ 140$ for 1 semester). During the rule of this coalition, unemployment decreased from $14 \%$ to $10 \%$ and, approximately 10,000 new workplaces were created in Lithuania. However, critics of the Social Democratic party did not acknowledge that these gains had anything at all to do with the policies of the governing coalition. The claim was made that all of the gains were due to the general economic recovery and to the accelerated growth of business. Some analysts made left-handed compliments by pointing out that they were willing to acknowledge that the Social Democrats, somehow, avoided doing things that might have prevented the economic recovery.

Although Lithuania has achieved a relatively high rate of economic growth this past decade, social developments have not kept pace. In the period 2000-2003, the economy and labour productivity grew by more than $6 \%$ (Starkevičiūte 2004), but in 2003, average wages only reached 1185 Litas (€343), which is less than $38 \%$ of the average wage in the European Union. In other words, only those who earned 3000 Litas or more per month $(€ 869)$ in 2003 , were on a par with the average standard of living in the EU, and only $3 \%$ of all Lithuanian employees actually earned that much. Many more Lithuanians, i.e. 17.3\% earned minimal wages (Lietuvos profsajungos, $2003.12 .24,7)$. In 2003 , the average old-age pension comprised only $38 \%$ of the average wage, amounting to 340 Litas $(€ 98,50)$.

One must add that in 2004 many social indicators slightly improved (minimal wages increased to 500 Litas and the average old-age pensions to 400 Litas). The years 1998-1999 brought an economic crisis to Lithuania, but most social indicators have greatly improved in the period following. During 2000-2004, a slow, but gradual rise in the payments to old-age pensioners and to those with disability pensions has been registered. In addition, there have been improvements in the minimum wage and in average wages, a gradual lowering of the unemployment rate and, finally, a significant decline in the level of poverty in 2003. Many people do believe that continued good economic performance in Lithuania (annual GDP growth 7-9\%) will, in itself, produce better social supports. Be that as it may, the year 2006 still finds Lithuania lagging far behind the other EU countries when the quantity and quality of social provision is scrutinised. Lithuania is performing better than the EU average when economic growth and the growth in labour productivity are measured.

One of the obstacles on the road to higher salaries and better working conditions in the country has to do with the low rate of trade union membership and the 
insufficient performance and activities undertaken by trade unions in the working world. This is true in spite of the fact that the Lithuanian Social Democratic Party has maintained closer relationships to trade unions than the other Lithuanian political parties have done. According to the experts of the Finnish Ministry of Labour and to researchers at the University of Helsinki, a survey entitled "Barometer of Labour Life in Baltic States" claims that membership in a trade union is less common in Lithuania than in it is in Latvia and in Estonia. Trade union membership decreased from $15 \%$ to $11 \%$ in a three year period (Lietuvos profsajungos, 2003.04.19, 7). The political weight of trade unions in the formation of social policy and in the decision-making processes determining social policy was, and remains, insignificant. An employer association (The Confederation of Business Employers) is far more influential.

At the turn of the present century, there were no organisations that exerted strong social power in society. There were no social movements or institutions of civil society that were particularly interested in increasing state powers, or state responsibilities, in Lithuania. The role of the state continues to be a diminished one, when compared to neighbouring states, and institutions within civil society remain very weak. At present there seem to be no prospects for the notion that Lithuanian civil society can be aroused enough to take sufficient action to promote the development of social policy goals or to begin any movement in the direction of a social democratic welfare state. The low level of participation in organisations within civil society has precluded the possibility for any echoing reverberation, in the event that any one voice or group called out for the construction of a social democratic welfare state in Lithuania.

According to the usual theory regarding the development of a social democratic welfare state (Paluckienè 1999, 39-40), strong social movements, and particularly, the mobilisation of working class wage-earners within the trade union movement are necessary. In addition, the development of other labour associations is recommended. This must then be combined with the power of left-wing and left of centre political parties. Together, these elements are seen as being the most important guarantors of a strong and social democratic welfare state. In Lithuania, the trade union movement and the actions of left-wing and left of centre political parties have had little influence in the struggle for greater social justice and income redistribution. This claim is confirmed by the share of state expenses in GDP, which in Lithuania varies between $20-30 \%$ at the beginning of the $21^{\text {st }}$ century. In neighbouring countries, on the other hand, the share is much larger. In Estonia, Latvia and Poland this share accounted for 35\%-40\% in 2002 (Gylys 2003, 33), although mass-media presentations of these three countries consistently portray them as being more liberal than Lithuania. The share of social security expenses made up only about 11\% of the GDP in 1997-2005 in Lithuania; with health care expenses included - only 16\% of the GDP (Guogis 2002b, 84).

Potentially, an assortment of institutions within civil society can be used to develop and express social engagement and their activities could enhance and spread social attitudes that might support the idea that society should take more responsibility for the care of its citizens. However, the development of civil society in Lithuania is still moving at a slow pace, but this is similar to the experiences of other countries 
in the region. The Baltic region is generally characterised by low participation in voluntary organisations within civil society. Communitarian sentiments are still too weak. The absence of stronger bonds allows individuals to forget about the problems that others face. Many groups are dependent upon the social policies and the level of social provision in society, including aged and disabled pensioners, the unemployed, etc. From a historical perspective, the expression of solidarity in Lithuania was a prevalent phenomenon at only a few crucial turning points in the past. These turning points include: the struggle for independence in 1918, the reconstruction period after World War II (1945-1949), and the re-emergence of Lithuanian independence from 1988-1991. Solidarity was not a prevalent sentiment in the Lithuanian population at the turn of the present century.

We might expect that collectivist sentiments would have been strengthened during the Soviet period in Lithuania. However, historical accounts testify to the fact that the collectivist orientation during that period was rather artificial in Lithuania, as it was in the other Baltic States. The collectivist orientation was an imposed attitude. In fact, Lithuanians were keen to act individually rather than collectively, and this fact may help to explain why there have never been strong trade unions, or influential social democratic parties, or movements to protest globalisation, or other well-known social movements in the history of Lithuania (Guogis 2003, 7).

Apart from the complicated economic situation (especially in the years 19901999) in the re-emerging independent Lithuanian state, the following reasons can be posited to account for the lack of activity or interest in the development of a Nordic style social democratic welfare state: 1. Left-wing and left of centre parties, and particularly, the Lithuanian Social Democratic Party, which was in power, did not aim to create a social democratic welfare state. This is probably due to the recent experiences and memories connected to the Soviet period in Lithuanian history. Anything seen as being too close to the rhetoric or ideology of the Soviet period was rejected. A desire for a completely different alternative reflected the general hopes for the future. 2. Lithuania lacked strong trade unions and there was insufficient experience in the ways in which corporative institutions work and no tradition of consensual decision-making between powerful societal organisations. 3 . The general consensus to rely heavily upon market forces in order to promote economic growth led (almost by default) to the support for a residual or marginal model for welfare state provision. In tune with the thinking that grounds the residual model, the state allocations to pay for social programmes were kept at a low level. Relatively small expenditures for social programmes, which are only provided to people who are beyond the boundaries of the labour market, are seen as being necessary in order to motivate people to take the available jobs. The social rights that are guaranteed are insufficient to cover expenditures for those others who are not seen as being the worthy poor. 4 . The consequences of the preceding three reasons shifted the burden of creating welfare to the family. When families are responsible for providing welfare to individuals needing care, the traditional role for women is strengthened. 5. Solidarity does not fully develop in the general society if it is firmly relegated to inner family relationships and, particularly, to the women in the family. 6 . The role of corporative welfare institutions was de-emphasised after the pension reform of 2003-2004, when private pension funds were established. 


\section{SOCIAL WELFARE IN NORWAY UNDER GLOBALISATION}

The end of the Cold War and the collapse of the Soviet Union coincided with the intensification of globalisation processes. In addition, there has been a coinciding entrenchment of neo-conservative thinking. Most Western countries, and this category now particularly includes most of the countries in central and eastern Europe that were formerly in the Soviet camp, have been profoundly influenced by the neoconservative theory and policies referred to in this paper as market fundamentalism. Under globalisation, the Social Democrats have been retreating from left-wing thinking or any policies that would expand the parameters of the welfare state. They have consistently taken slightly left of centre positions in the developed European countries where they are most entrenched. Market fundamentalism in the ideas and practices of the USA, and the UK, have engendered similar thinking and parallel policies and practices in each and every Western country. Although there is resistance to facing the consequences of market fundamentalism in the USA and to a slightly lesser degree in the UK, the authors of this article recognise the spread of this way of thinking as a very serious setback to ameliorative social processes, social justice and income redistribution in society.

In the public administration of Western countries, there has been a shift in thinking that has provided support for the ideology and practice of New Public Management. This ideology now dominates the thinking in public administration in the USA, and in the UK, and to a lesser degree the thinking in continental European states. One general consequence of this development in most Western countries has been that social welfare provision has been seen as being an obstacle hindering the attainment of economic efficiency. This understanding has also gained ground in all of the Nordic countries, and it has influenced the practices in public administration in the social democratic welfare states, but the force of this trend has been weakest in Norway.

In the early 1990s, Norway suffered least from the economic recession that seriously affected its neighbours, Finland and Sweden. These two countries were forced to re-examine core aspects of their welfare states and to accept cuts in social expenditures. Norwegian GDP continued to increase by 2.9 percent annually, compared to the OECD average of 1.6 percent (Kangas \& Palme 2005, 52). The Labour Party continued in power for most of the decade, and as a consequence, there were few domestic political challenges to the established social policy. Despite its oil-based economy, the Norwegian social welfare system was not insulated from international tendencies to enhance market reform, to modernise public administration, i.e. to privatise some public services by allowing the lowest bidders to provide those services under contract, and to relate to citizens by reducing them to consumers or users of public services. Incremental policy changes led to the introduction and augmentation of user fees for public services, including doctor visits.

Even with the accomplishments of Norwegian social democracy in promoting social policy goals, reducing poverty and inequality, and increasing employment and social inclusion during the $1970 \mathrm{~s}$, there were also critical voices on the left, at the beginning of the 1980s. Social philosopher Rune Slagstad (1981) expressed doubts about whether welfare state issues could continue to be solved satisfactorily by 
continuing with the established social policies. The public debate about social policy became increasingly concerned about moral issues and demographic challenges. One fear concerned (what was assumed to be) the excessive consumption of health services and sick leave. Regarding old-age pensions, there was a continued tugof-war between two political positions. On the one hand, there existed a wish to improve the lot of the elderly by providing them with more generous pensions. On the other hand, there was the persistent concern about mounting costs, as the number of retired people continued to grow and the build-up of income-related pension supplements continued (Hatland 2005, 39). These concerns accelerated under the non-socialist government that was returned to power in 1997.

\section{Sickness benefits}

To combat the spiralling costs of the health sector, recent policy has been characterised by efforts to rein in public expenses for health care and illness benefits. On the micro level there was an increasing emphasis on regulating the consumption of out-patient services by introducing and increasing user fees. In 2006, the basic consultation fee is NKR 125 or $€ 15.70$. Similar fees have been introduced to cover specialised out-patient services such as physiotherapy.

Employers who made proposals to reduce the incidence of sickness leave and the costs of sickness pay were met by resistance from labour unions. The corporative channel was put into action and, in 2001 the government, the unions and the employers reached voluntary agreement to modify current regulations, in the hopes that their modifications would reduce absences due to illness by 20 percent. Thus far, there is no indication that this goal will be reached (Blekesaune 2005).

In 2002, the non-socialist government that succeeded the Labour government of Jens Stoltenberg (2000-01) finalised the nationalisation of hospitals previously owned by local government. The object was to control costs by introducing performancebased budgeting. In this respect, the reform has been unsuccessful. After three years, hospitals exceeded their targeted activity by 17 percent and accumulated a deficit of NKR 5.3 billion (Aftenposten 1.6.05).

\section{Unemployment insurance}

Since unemployment insurance only covers people who have had periods of regular work, policy reforms since the 1990s have particularly been aimed at reaching the long-term unemployed and young people with little or irregular work experience. The ambition has been to get members of this marginalised group sufficiently trained to succeed in the regular job market (Hyggen 2005). These efforts were combined with a workfare approach for the provision of social welfare benefits. However, recent studies show that many participants in these programmes actually end up with disability pensions, rather than job incomes.

\section{Workman compensation insurance}

Established in the Bismarckian tradition as the first social insurance in 1894, workman compensation is the first, and thus far, the only insurance to be fully privatised. In 2004, the then current mixture of private and public insurance was replaced by compulsory private insurance to be paid by employers. 


\section{Disability pension}

In an effort to encourage people with long periods of illness to return to work, a short-term disability pension was introduced in 2004. A committee, led by Labour politician Matz Sandman, saw this as a means to stem the increase in the number of recipients of permanent disability pensions, which in 2003 were paid to 300,000 people (Blekesaune 2005, 194-5).

\section{Old-age pension}

Changes in the old-age pension system have been slow to appear and quite limited in their extensiveness. Perhaps this is true because these pensions concern the entire population as contributors and recipients. In the Nordic countries, Norway has the highest level of pensions (Kangas \& Palme 2005, 285). Worries that the total costs of future pensions will exceed available funding, has led to a series of proposals to reform the pension system, to reduce costs and to encourage people to work longer. A proposal to do away with an early retirement plan that was enacted for a specific period of time was rejected by the labour unions. As a consequence, the pension system will continue to include contradictory measures that encourage early as well as late retirement. However, in 2005, the Norwegian Parliament decided that while the income equalisation aspect of pensions will continue to be a government responsibility, employers will have to contribute to the income-based parts of future pensions from 2006. The private sector will thus be obliged to make income level related contributions in addition to the basic pensions that are provided by the state. This will equalise pension entitlements in the private and in the public sectors.

Looking at all these changes, there is a slight trend to emphasise the principle of individual choice. This primarily means the creation of economic incentives to encourage particular behaviours, such as going back to work after illness, or finding work after periods of unemployment or disability, and for reducing the demand for out-patient services.

\section{Marginal groups}

At the margins of the Norwegian welfare state, there are still people who have been socially, culturally and economically excluded. Rather than including them in existing social programmes, there have been a number of ad hoc solutions to provide restitution for abuses of the past. Groups that have successfully claimed compensation include wartime sailors, gypsies, Jews, orphanage children, lobotomised psychiatric patients, and maltreated hospital patients. Linguistic minorities, such as the Sami and Finnish-speaking population, have been secured the right to use their own languages for official purposes. Homosexual practice has gradually been accepted and Norway was an early supporter for the right of homosexual couples to establish recognised partnerships. These modifications of the Norwegian welfare system have taken place under the blue skies of an expanding economy that has provided increased income and wealth to most Norwegians, but also increased income disparities that have been exacerbated by tax reforms favouring high-income earners. The Labour party, which was returned to power in the elections of 2005, has promised to end poverty. Kangas and Palme $(2005,45)$ point to empirical evidence that reducing inequality is beneficial for economic growth. It remains to be seen whether the Labour led 
coalition government, which includes Left Socialist and Centre Party participation, will adopt the measures needed to accomplish the goal of ending poverty or whether their policies will reduce inequality in Norwegian society.

\section{LITHUANIA AND NORWAY COMPARED}

At the beginning of the present century, only small differences between the political parties in Lithuania could be recognised. Already when the initial reforms were made in1990-1991, market liberalism was the prevailing tendency. The usual clarification proposes that Lithuanians needed to completely reject the Soviet legacy and market liberalism offered them a clear way to do so, while promoting a free market and democracy in Lithuania. Lithuanian economic structures and companies had to fight for their niche in the global division of labour. Competition and the grasp upon market segments were so keen that in some fields Lithuanian producers could only enter the global market by providing new products and new services. Lithuanian business representatives and most of the political parties agreed that Lithuanians needed to increase labour productivity and to reduce social expenditures.

Table 1

Selection of Social Indicators for Lithuania and Norway

\begin{tabular}{|c|c|c|c|c|c|c|}
\hline & 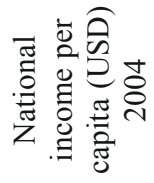 & 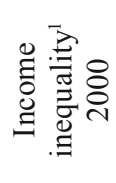 & 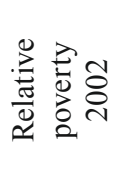 & 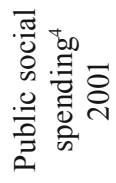 & 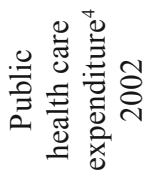 & 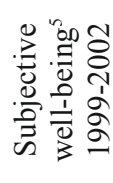 \\
\hline Lithuania & 5740 & 31.6 & $24.1^{2}$ & 14.7 & 4.1 & 36.0 \\
\hline Norway & 52030 & 26.1 & $6.3^{3}$ & 23.9 & 7.4 & 94.5 \\
\hline $\begin{array}{c}\text { OECD average } \\
\text { EU average }\end{array}$ & 33470 & $\begin{array}{l}30.8 \\
29.0\end{array}$ & $10.2^{3}$ & $\begin{array}{l}20.9 \\
27.1\end{array}$ & 6.0 & 88.2 \\
\hline
\end{tabular}

Notes: ${ }^{1}$ Evolution of the gini coefficient. ${ }^{2}$ The share of persons with equivalised disposable income, before social transfers and below the risk-of-poverty threshold, which is set at $60 \%$ of the national median for equivalised disposable income after social transfers. Retirement and survivor's pensions are counted as income before transfers and not as social transfers. ${ }^{3}$ Proportion of the population below $50 \%$ median income poverty threshold. ${ }^{4}$ In percentage of GDP. ${ }^{5}$ Proportion of respondents with feeling of happiness "very happy" or "quite happy." Source for national income data: World Bank (2006) World Development Indicators.

Source for other Lithuanian data: Eurostat data base/ESSPROS and Baltijos tyrimai 20022005.

Source for other Norwegian data: OECD (2005) Society at a Glance: OECD Social Indicators.

It is important to underscore the fact that after the fall of the Soviet Union, the new economic and political elite of Lithuania viewed the public sector and the possibilities to increase its efficiency with great distrust. This distrustful attitude toward the public sector is not found in Norway. Partial privatisation has been implemented in some spheres of Norwegian life. But the movement to privatise some aspects of the services provided by the public sector do not reflect a public 
attitude that holds the public sector in disrepute. The move to completely privatise the public sector in Lithuania does reflect general attitudes of distrust and disfavour in large segments of the Lithuanian populace. The fact that the Nordic countries, in recent years, have privatised some public services has only served to reinforce opinion in Lithuania that privatisation is the correct path to follow. Questions of social justice are not raised when the paradigm for social democratic welfare states, i.e. The Nordic countries, appear to be following a route that will eventually lead them to the liberal state and the residual model for social welfare provision.

By and large, the new economic and political elites in Lithuania have only seemed to notice the successful business practices in Scandinavia. Achievements in other areas go unnoticed and unrecognised. Even the fact that Norway has huge public reserves, due to its oil resources, has seemed to escape recognition in the Lithuanian media. Whenever the Norwegian social security system is mentioned in the Lithuanian media, outlandish claims are made about its wastes and costs and there is no voice to correct the views that are expressed. The Lithuanian electorate has not encouraged its elite to formulate and implement a social democratic policy. On the contrary, a substantial part of the Lithuanian electorate leans toward right wing political and economic thought and action. This became particularly evident during the presidential crisis in 2003-2004. A paradoxical political and social situation arose. A major part of the electorate would clearly benefit from the adoption of social democratic policies, since the absolute majority of Lithuanians must manage on very small incomes. These facts of life would lead one to believe that Lithuanians would support social democratic and left-wing political parties. But this is not the case. The greater part of the Lithuanian electorate has systematically avoided any contact with left-wing parties or with any proposals to expand the public sector.

Rather than ask why Lithuanians made no efforts in the years 1990-2006 to create a welfare state based upon the Nordic welfare state model, the authors ask the following questions:

1) Given the recent moves to partial privatisation in Norway and in the other Nordic countries, does an institutional social democratic welfare state have a future given the pressures of globalisation and intensified economic competition? At first glance, globalisation and the concomitant intensification of economic competition seem to be deconstructing the social democratic welfare state.

2) Will the EU eventually establish its own common social welfare model for all EU Member States? If so, in what way will the Nordic model influence the future common EU model?

3) If the EU fails to agree upon a common social welfare model, will this failure negatively affect the possibilities for developing socially just programmes in the new Member States, including Lithuania?

4) If Norway and the other Nordic countries develop into liberal states, due to the pressures of globalisation, will this development destroy all hope of the establishment of a social democratic welfare state elsewhere in the world? 
5) If globalisation slows or stops altogether, will that mean that the world has decisively divided into large and mutually hostile economic and political regions?

The authors believe that the above questions are the ones that need to be addressed in future studies. This paper has only provided a limited analysis about a few questions of importance that affect Norway and Lithuania and their relations. Obviously, further research is needed, and such research should include social and psychological insights and be historically anchored in order to characterise and distinguish the Norwegian and the Lithuanian cultures.

\section{CONCLUSIONS}

In comparing the Norwegian and Lithuanian welfare state models in the years 1990-2006, the following civil, political, social and economic factors should be emphasised.

First, unlike Norway, Lithuanian political parties, labour organisations and employer associations did not show substantial support for the development of a welfare state. There were no political movements in Lithuania which were interested in promoting extensive state regulation. On the contrary, there were extensive movements to limit the role of the state in Lithuanian society.

Second, the Norwegian experience of a welfare state includes a successful economy and a well-organised society. Lithuania's economic and social development since 1990 has been marked by relatively high rates of economic growth. However, social conditions have not improved in tandem with improvements in the economy. Living standards are still relatively low. Trade unions, labour organisations and employer associations lacked political influence in society in this period. The institutions of civil society in Lithuania were weak and continue to be weak.

Third, the Norwegian welfare state experience shows that welfare state policy is determined by the electorate. Left-wing and left of centre parties generally expand the welfare state, while right of centre and right-wing parties generally reduce the welfare state. However, neither tendency was found in Lithuania, since the reestablishment of Lithuanian independence in 1990.

The Norwegian social democratic welfare state experience has not been seriously discussed in the Lithuanian media at any time since the re-establishment of Lithuanian independence. This is due to the weak position of many central organisations within civil society, i.e. labour unions and to the external pressures that impinge upon the new Lithuanian state, i.e. the WB, the IMF, and other forces promoting globalisation. Finally, public opinion is still reacting against the idea of a strong central state, due to the negative experiences connected to Soviet rule.

\section{The Positions Taken by Internal Forces within Lithuanian Society}

Lithuanian political forces did not show any aspirations in the direction of building a welfare state based upon the Norwegian model or any other model within the Nordic countries. In Lithuania, since 1990, most of the elite groups, including 
economic, political, academic, and media-based forces prefer the idea of the liberal state and the role this kind of state plays as a relatively passive enforcer of the rules of fair-play in the economic and political life of the nation. This attitude is, obviously, not a favourable environment for building a social democratic welfare state. On the contrary, the ideas and the practices of what the authors refer to as market fundamentalism has become the prevalent and dominating perspective in Lithuania.

\section{External Pressures}

Since 1990, all reforms were undertaken under the influence of powerful international financial organisations that aimed at creating a society characterised by economic liberalism. Those kinds of societies generally have a residual or marginal welfare state and those individuals who can afford to do so voluntarily pay for private insurance policies to cover the economic costs associated with disability, poor health, old age, etc. The emphasis and reliance upon pro-market solutions to welfare problems is ordinarily associated with the idea that the state should play a lesser role in society and that private groups and organisations are better able to create programmes that are tailor-made for the individual. Given these conditions, the interest in following a Bismarkian corporative direction for welfare service development slowly declined and a liberal path became dominant and entrenched.

\section{Public Opinion}

Internal political support for the building of a social democratic welfare state within the country was insufficient. The Lithuanian population demanded greater responsibility from the state for ways to combat unemployment, inflation and poverty. Some people wanted to return to the safety provided by a truly socialist society. Many people, particularly older people, believed that the state should take care of the needs of the elderly and of other people struggling with difficult life situations and trying stages of life. However, the majority of the population refused to pay higher taxes to have more social benefits. The Lithuanian electorate did not encourage the elite to formulate and implement a left-wing or left of centre social policy, although a major part of the electorate would have benefited from the services provided by a social democratic welfare state.

\section{ENDNOTES}

1 De-commodification means that individuals are relatively independent of social security provisions stemming from the market powers (previous earnings and work record). Decomodification also means that there is an "easy entry" to the social security system and an "easy exit" from it (Guogis 2000, 79).

2 The four original parties were the Labour Party, the Conservatives, the Liberals, and the Agrarian party. They were later joined by the Norwegian Communist Party and the Christian People's Party.

3 The text has been translated from the Norwegian by the authors. 


\section{REFERENCES}

Arter, David. 1999. The Nordic Welfare Model. Manchester and New York: Manchester University Press.

Bay, Ann-Helén a.o., eds. 2005. De norske trygdene [Norwegian social security], Gyldendal: Oslo

Blekesaune, Morten. 2005. Uførhet [Disability]. In: Bay 2005.

Bull, Edvard. 1979. Norge $i$ den rike verden [Norway in the rich world]. Volume 14 of Knut Mykland, ed. Norges Historie, Oslo: Cappelen.

Esping-Andersen, Gösta. 1992. 'The Making of a Social Democratic Welfare State', in Misgeld, K., Molin, K. \& Åmark, K., eds, Creating Social Democracy. A Century of the Social Democratic Labour Party in Sweden. Pennsylvania: University Park.

Esping-Andersen, Gösta. \& Korpi, W. 1987. 'From Poor Relief to Institutional Welfare States: the Development of Scandinavian Social Policy', International Journal of Sociology XVI (3-4).

Gerhardsen, Einar. 1971. Samarbeid og strid. Erindringer 1945-55 [Cooperation and struggle: memoirs 1945-55]. Oslo: Tiden.

Guogis, A., Bernotas, D. \& Ūselis, D. 2000. Lietuvos politiniu partiju samprata apie socialinę apsaugq. Vilnius: Eugrimas.

Guogis, A. 2000. 'Švedijos socialdemokratų ideologija 1932-1994 metais',Vilnius: Eugrimas.

---- , 2002a. 'Dekomodifikacijos reikšmè socialinèje apsaugoje', Filosofija. Sociologija 4.

---- , 2002b. 'Dèl Lietuvos socialinès politikos modelio', Politologija 28 (4).

---- , 2003. 'On the Lithuanian Social Policy Model and Factors Influencing it', Socialinis darbas 2(4).

Gylys, P. 2003. 'Lietuvos socialinès bei ekonominès plètros dimensijos ir veiksniai: paradigmų konkurencija', Filosofija. Sociologija 3.

Hatland, Aksel. 2005. Historiske utviklingslinjer [Historical development]. In: Bay 2005.

Hesse, Hermann: The Glass Bead Game. Translated from the German. New York: Picador 2002 [1943]

Hyggen, Christer. 2005. Arbeidsledighet [Unemployment]. In: Bay 2005.

Kangas, Olli, and Joakim Palme, eds. 2005. Social Policy and Economic Development in the Nordic Countries. Basingstoke: Palgrave Macmillan.

Koren. 2005. Eldres inntektssikring [Income insurance for the elderly]. In: Bay 2005.

Kuhnle, Stein. 1983. Velferdsstaten [The Welfare State], Oslo: Tiden.

Kulčinskaja, M. 2002. Švedija. Mitai ir tikrovè. Klaipeda: Libra Memelensis.

Lazutka, R. 2001. 'Socialinè apsauga', in Rimkutè, J., eds, Žmogaus socialiné raida. Vilnius: Homo Liber.

Manding, N. \& Shaw, I. 1998. 'The Transferability of Welfare Models: a Comparison of the Scandinavian and State Socialist Models in relation to Finland and Estonia', Social Policy \& Administration 32(5).Merkel, W. 2001. 'Europos socialdemokratija XX a.pab.: trečiojo kelio paieškos', Politologija 21(1).

Paluckienè, J. 1999. 'Baltic Welfare State', Revue Baltique 15.

Slagstad, Rune. 1981. 'Velferdsstaten' [The welfare state]. In Pax leksikon. Oslo: Pax.

Stjernø, Steinar. 2004. Solidarity in Europe: the History of an Idea. Cambridge: Cambridge University Press.

Stjernø, Steinar. 2005. Solidarity and the Welfare State. In: Harald Koht and Lawrence Young, eds. Perspectives on the Public Sector and Social Policy for the 21 $1^{\text {st }}$ Century, Oslo: Oslo University College Report 2005 no 30. 


\section{Daily Press}

'Kada gyvensime geriau?', Lietuvos profsajungos 2003.12.24.

'Pengesluk skal tettes igjen', Aftenposten 2005.06.01

'Profsajungos narių šalyje sumažèjo nuo $15 \%$ iki 11 \%?', Lietuvos profsajungos 2003.04.19.

\section{Internet Sources}

European Commision: http://epp.eurostat.cec.eu.int

OECD: http://caliban.sourceoecd.org

Morkūnienè, A. 'Ką žmonès mano apie socialinę apsaugą Lietuvoje'. http://www.lrinka.lt/ Leidinys/pensiju.reforma/1999.2amorkuniene2.phtml

'Sodra iregistravo 15,5 tūkst. pensijų kaupimo sutarčių'

http://www.delfi.lt/news/economy/business/article.php?id=3925142

Starkevičiūtè, M. 'Ir vèl pavasario vejjas plaiksto Kovo 11-osios vèliavas'

http://www.omni.lt/?i\$9359_70693\$z_153299

World Bank: http://web.worldbank.org/ 


\title{
Central Regulation versus Local Self-determination Regarding Work in Human Services Organisations: A Case Study
}

\author{
Annika Staaf \\ Malmö University College \\ Monica Larsson \\ Malmö University College
}

In Sweden strong demands for local self-governance have been put forth since the early 1980s, and in some cases even earlier. In most areas of municipal work this claim has also been fulfilled with a decreasing amount of detailed legal norms provided by the State. In the field of human services organisations, the use of so called soft-laws has been particularly frequent. Soft-laws can be described as goaloriented regulations which usually only create a framework for legislation, thereby allowing local authorities and sometimes even a single legal decision-maker to adapt their decisions to the current context. In some cases and authorities, this adaptation is allowed to a great extent. The reason for this is obvious, as different people have different needs and it would be impossible to regulate such matters in a detailed sense at the State level. The decisions of what is considered best treatment and care are highly individual and have to be matched with the person receiving it. The decision-making process is therefore delegated to the level of local authorities. The benefits from local or municipality decision-making are also obvious; the theory is that the closer the decision-maker is to the issues and the people being dealt with, the better or well-matched decisions he or she will make (Nonet \& Selznick 1978).

However, some problems do arise when the national or State level, through legislation, leaves the discretionary space or powers to local authorities; different practises may occur in different municipalities or even authorities, and different decision-makers may use their powers in an unintended way. All of this might lead to risks of arbitrariness and discrimination in matters that have great significance for the individual (Lipsky 1980). This is true especially when it comes to exposed groups of people that usually have great difficulties in claiming their rights with regard to local authorities. The rule of law or legal security, which is a term we will use in this article, may in such cases be threatened (Gustafsson 2002, Henrichsen 1997, Lyons 1984, Peczenik 1995).

The aim of this article is to discuss the tension between regulating at a national or State level, through legislation in a more detailed sense, and regulating at a 
local level, through soft-law, by letting the local authorities themselves decide various matters. In order to exemplify this tension we will use a legislative process concerning a specified type of aid called a personal representative (ombud) for mentally disabled persons.

The reasons for this choice are several and we will present some of them below. During the 1990s the Swedish government decided that psychiatric clinics or asylums should be used only in a very limited way, as a result of an extensive psychiatric reform in 1995 (Brusén 2005, Hydén 2005). The reason was humanitarian. Several studies showed that the long-term effects of institutional care were often negative and meant great difficulties in returning to society.

This led to a lot of psychiatric institutions being closed or severely diminished and mentally disabled people having to live outside the institutions and take part in ordinary life. The local social authorities, not the psychiatric hospitals or health or medical authorities, were supposed to provide for the needs of the former patients. One of the problems of this organisational shift was that the transition in responsibility did not include providing sufficient funding for the social authorities to fulfil their task (Socialstyrelsen 1999:1).

Demands for local self-governance continued to grow during the 1990s as well (Teubner 1986). Earlier, the the state or national level linked funding for work by municipalities to certain conditions. Part of the funding of social authority work was supposed to pay for drug addicts' institutional care, another part for treatment of young criminals, etc. But since the mid-1990s the state has decreased its intervention in such matters, leaving it to local authorities themselves to decide how to prioritise use of their own resources. Expensive institutional care has been given low priority, while higher priority has been given to less expensive voluntary treatment and care where the client or patient is still living at home (SOU 2006:100).

The group of mentally disabled persons has some difficulties in claiming rights in relation to the authorities. When it comes to matters of priority, this group is not highly prioritised within the social and health care systems, especially if the mentally disabled person also has an addiction, a so called dual-diagnosis (Holmström 1992). In those cases it also becomes evident that two different care-giving systems, the health care and the social care, have to cooperate, which has turned out to be very difficult.

This group has become more marginalised in Sweden, especially during the last 5-10 years. The rates of homelessness in this group are high and the statistics concerning death by accidents or suicide are also over-representative. Most significant is the loneliness and marginalisation of the group. Work or other forms of employment are more infrequent for this group than any other disability group. The group is also found far below the average citizen income level and below the poverty level in Sweden (SOU 2006:100).

One of the things the State has decided in order to limit these marginalisation effects is to give the local authorities economic means to install a special service called a personal representative (a PO or ombud) for persons belonging to this group. In the social services act this intervention is optional and not compulsory for the local authorities. This means that the State considers this service important and 
recommends that it be used, but the municipalities are not forced to do it. The result of this is that some municipalities have installed this service and some have not. In some of the municipalities that have installed the service, it is found in the ordinary social support system provided by the social services act. That means you can apply for the service and if your application is rejected you have the right to appeal. In other municipalities, the service is found outside the social services act, application for the service and appeal against a rejection is not possible.

A personal representative is supposed to give personal support and guidance especially in relation to the authorities. Together with the mentally disabled person, she or he is responsible for the coordination of different social interventions, since this is a group that requires a lot of interventions from different organisational units. The support is further supposed to be given in an untraditional way, on non-office hours, in a field-based manner, visiting the persons in their home-environment. Emphasis has been put in the non-bureaucratic manner the PO is supposed to work. This also means that the PO needs to have a clearly separated role in relation to the authorities in order to reach the individuals. The reason is that mentally disabled persons sometimes express suspicion towards the authorities, which has in some cases led to the delay or absence of necessary treatment and care (Järkestig Berggren 2006).

The PO, it is said, has to be suited for the work and studies show that most POs were between the age of 36-55 years old and about 50\% had some kind of care-giving education before they became POs. As many as $90 \%$ had previous work-related experiences with mentally disabled persons. Some also had relatives or friends with this kind of disability or had been engaged in specific issues, for example in non-governmental organisations (NGOs) concerning this specific group. About 230 of the 290 municipalities in Sweden have this service installed.

There are also other forms of municipality services for mentally disabled persons, like the personal assistant (PA), whose work is of a more practical kind and can only be applied to a very specified and limited circle of people with more extensive needs. The disabled persons belonging to this circle have several rights that others do not (Hollander 1995, Åström 2005). Similar to the personal assistants, there is another service provided by the social authorities called residential support, which includes very practical support aiming at the household care of the clients. There are also administrator trustees and guardians who are legal representatives and whose mandate is relatively clearly described by law, often concerning economic guidance and support of a more economic kind. Case managers are another professional group who coordinate the users' access to different interventions, usually in the health-care system. In Sweden we also have a system called support- and contact persons usually employed for non-professional personal support and recreational aid, mostly during the client's or patient's spare time. The service of the PO is the only service that is clearly without legal regulation for its work. See the following table for further information.

Recent studies of the effects of the personal representative (PO) show that the mentally disabled individuals think this service has made major improvements in their quality of life, their psychological and physical health (SOU 2006:100). It is also shown that the number of emergency care and psychiatric institutional care 
interventions decreases dramatically, and the possibility to get a place to live and work (often protected worksites) increases. The studies show only positive results so far. On the whole it seems that it is far less expensive for society to legally install this service. So why is it that the State has made this an option in legislation and has not required municipalities and local social authorities to install this service everywhere when the results are so good? There are many reasons for this, of which this article will mention a few:

Table 1

Summary of the most important services for support and increased accessibility

\begin{tabular}{|c|c|c|c|c|}
\hline Function & $\begin{array}{c}\text { Degree of } \\
\text { professionalism }\end{array}$ & $\begin{array}{c}\text { Degree } \\
\text { of legal } \\
\text { competence }\end{array}$ & $\begin{array}{l}\text { Degree of } \\
\text { voluntary }\end{array}$ & Main work areas \\
\hline Guardian & Layperson & High & High & $\begin{array}{l}\text { Economy, housing rights, } \\
\text { support }\end{array}$ \\
\hline $\begin{array}{c}\text { Administator } \\
\text { trustees }\end{array}$ & Layperson & High & Low & See above \\
\hline $\mathrm{PO}$ & Professional & Low & High & $\begin{array}{l}\text { Wide tasks by order of the } \\
\text { private }\end{array}$ \\
\hline $\begin{array}{l}\text { Residential } \\
\text { support }\end{array}$ & Professional & Low & High & Support in the household, etc. \\
\hline Case manager & Professional & Middle & Middle & $\begin{array}{l}\text { Providing aid in the care } \\
\text { system }\end{array}$ \\
\hline Contactperson & Layperson & Low & $\begin{array}{l}\text { Often } \\
\text { high }\end{array}$ & Usually a defined mission \\
\hline PA & Professional & Low & High & $\begin{array}{l}\text { Aid in practical issues for a } \\
\text { specific group of disabled }\end{array}$ \\
\hline
\end{tabular}

Source: SOU 2006:100 p 351.

The first reason is that local self-governance policies in the different municipalities limit discussions of the legal installation of this service. Some municipalities feel that it is not an issue for the State to legally regulate, but that it should be up to the local authorities to decide how to meet the specific needs of the municipality and its habitants.

The second reason is that the results are lower costs as a whole for care giving of this group of people. But this means that it is medical and psychiatric care that are the big winners, not the social authorities of the municipalities. They will instead get a small increase of costs in their budgets. This means you must be able to "get the whole picture" of decreased costs, even though a specific part of authority does not economically gain from installing the service. This is a problem that occurs often in Sweden, since the responsibility has been divided in various ways to small results-orientated units. These units tend to look at their gains and costs in a very limited way.

The third reason is that the mentally disabled persons themselves often are afraid that more extensive legislation will mean a higher level of bureaucracy, and quite many of these persons have a more or less troublesome relation with different care giving authorities, meaning the POs will not be able to help them in intended ways. 
The tension between the national or State level and the local or municipality level is clearly defined in these kinds of cases. Somehow a balance must be found between local self-governance and national legislation. Otherwise this group of individuals will get even further marginalised. It has obvious legal security effects as well, if people will be treated very differently due to where they live in the country. If that gap gets too wide there will be difficulties in upholding the values of equal rights and opportunities. There is insecurity in the current situation since the nonregulated areas tend to create unclear definitions concerning responsibility and cooperation demands. Legislation has to underline the value of the service PO and to guarantee its continuance. Some municipalities have already ceased their operation with POs, others have decreased theirs. Legislation should provide the means to counteract this kind of development.

Legislation would also provide further clarity for the municipalities which would provide for extended legal security for the mentally disabled group members. There are unclear rules concerning secrecy of the POs in relation to other authorities, but also in the duty to report facts that means the social authorities have to intervene to protect a child or other persons with disabilities or the elderly (Social Services Act, Chapter 14 Para. 1-2). There are no rules concerning supervision of the service, which is a lack of clarity that cannot be said to uphold the demands of legal security for a very vulnerable group of people.

Legislation should be built on the responsibility of the municipality, since the municipalities so far have been responsible for the project and have extensive experience with this kind of work, which must be preserved. The social authorities are responsible for mentally disabled persons when clinical treatment is finished. It is nevertheless important to remind other organisations of their responsibilities concerning this group of persons and of cooperation between the different organisational units. The health-care organisations play an essential role for the wellbeing of persons with mental disabilities.

Legislation must not interfere and obstruct the present work of the POs. It is absolutely essential that the PO's present position as independent of other authorities is guaranteed. Different physical locations or letting other organisations do the actual work to safeguard the autonomy of the POs is of central significance and must be regulated specifically.

Legislation should be able to facilitate the cooperation of voluntary client organisations. These kinds of organisations have a strong position in the work of the POs. The need to cooperate for these groups is crucial, but should be defined and further developed in the local context from the specific needs and conditions. The organisations should be able to affect the design of the work performed by the POs and in issues of employment.

A norm concerning suitability should be formulated and implemented in legislation. The formal demands in relation to the PO, that is, issues of education and previous experience, knowledge and other aspects should be regulated in a directive from the National Board of Health and Welfare (Socialstyrelsen).

Demands of documentation should be claimed for the POs. The lack of documentation is usually something the clients find positive and an important reason that they 
seek support from the POs. Against this argument is the fact that it is important to supervise the services municipalities supply for their citizens. The documentation should be limited to some aspects of the work, for example, in order to evaluate the services. The Act of Secrecy must also be supplemented to include the work of the POs.

It is hard to avoid completely exercising public authority, and there is a risk that the more informal ways of the POs will be lost. This is something the organisations implementing the regulation must strongly consider. This risk must be weighed against the legal security of the private individual. The private individual will get a chance to appeal to court if an application of a PO is rejected, thereby have clearly defined access to justice which will increase legal security (SOU 2006:100).

It seems that legislation will have more positive than negative effects, even though we will not really know the full consequences until the law has been implemented in the different municipalities and further evaluated in future studies. In order for the group of mentally disabled persons to become active participants in society or social citizens (Marshall 1963/1950, Johansson 2001) the services of the PO are a crucial means. There is a risk that a process of formalising the PO's work tasks will decrease confidence in the PO, but this risk has to be weighed against the dangers of legal security not being upheld for the citizens.

\section{BIBLIOGRAPHY}

Brusén, P (2005) Psykiatrireformen. I: Från psykiskt sjuk till psykiskt funktionshindrad (red. Lars-Christer Hydén) Lund: Studentlitteratur.

Gustafsson, H. (2002). Rättens Polyvalens. En rättsvetenskaplig studie av sociala rättigheter och rättssäkerhet. Lund; Sociologiska institutionen.

Henrichsen, C. (1997) Rettssikkerhed og moderne forvaltning. En retspolitisk studie i samspillet mellan stat, forvaltning og borger. Akademisk Forlag: Köpenhamn.

Hollander, A (1995) Rättighetslag i teori och praxis. Uppsala: Iustus förlag.

Holmgren, B(1993) En psykiskt störd vårdapparat?- Vården och narkotikamissbrukare med allvarliga psykiska störningar. Stockholm: Nordnark 1993:3.

Hydén, L-C. (2005) Inledning. I: Från psykiskt sjuk till psykiskt funktionshindrad (red. LarsChrister Hydén) Lund: Studentlitteratur.

Johansson, H. (2001) I det sociala medborgarskapets skugga. Rätten till socialbidrag under 1980- och 1990-talen. Arkiv Förlag, Lund.

Järkestig Berggren, U (2006) Personligt ombud: Social praktik i medicinsk diskurs. Växjö universitet, Fakulteten för humaniora och samhällsvetenskap, Institutionen för vårdvetenskap och socialt arbete. Licentiatavhandling.

Lipski,M. (1980). Street- Level Bureancracy. New York: Russell Sage Foundation.

Lyons, D.(1984) Ehtics and the rule of law. Cambridge: University Press.

Marshall T.H, (1963/1950) s.74) Citizenship and social class and other essays. Cambridge: CUP.

Nonet,P. \& Selznick, P. (1978). Law and Society in transition. Toward a Responsive Law. New York; Harper \& Row.

Peczenik, A, (1995). Vad är rätt? Om demokrati, rättssäkerhet, etik och juridisk argumentation. Stockholm; Norstedts Juridik AB.

Socialstyrelsen (1999) Socialstyrelsen följer upp och utvärderar 1999:1. Välfärd och valfrihet? Slutrapport från utvärderingen av 1995 års psykiatrireform. Stockholm. 
SOU 2006:100 Ambition och ansvar. Nationell strategi för utveckling av samhällets insatser till personer med psykiska sjukdomar och funktionshinder Slutbetänkande av Nationell psykiatrisamordning: Stockholm.

Szebehely, M. (2000) Äldreomsorg i förändring - knappare resurser och nya organisationsformer. I: Szebehely, M. (red) SOU 2000:38: Välfärd, vård och omsorg Antologi/ Kommittén Välfärdsbokslut.

Teubner, G. (1986) After Legal Instrumentalism? Strategic Models of Post- regulatory Law. pp 299- 326 in Teubner(ed), Dilemmas in the Welfare state. Berlin: de Gruyter.

Vahlne-Westerhäll,L red. (2002) Rättssäkerhetsfrågor inom socialrätten. Norstedts Juridik: Stockholm

Åström, K (2005) Normbildning och beslutsfattande. I: Bengtsson, H. (red) Politik, lag och praktik. Implementeringen av 1994 års handikappreform. Lund: Studentlitteratur. 
4. Information and Society 



\title{
Funkcionālā pieeja dokumenta priekšmetam: vai tā maina piekḷuvi informācijai?
}

\author{
Baiba Holma \\ Latvijas Universitāte
}

\section{IEVADS}

21.gadsimts tiek raksturots kā pārmainu laiks dažādos sabiedrības dzīves aspektos, bet it īpaši - informācijas pieejamības ziņā. Informācijas pieejamību būtiski ietekmējusi informācijas un komunikācijas tehnologiju attīstība, taču šīs jaunās iespējas arī likušas pārskatīt izpratni par procesiem, kas ir pamatā informācijas pieejamībai, - informācijas apstrādi. Tās mērķis - pilnveidot dokumentu izguvi, nodrošinot pilnīgākus un precīzākus meklēšanas rezultātus.

Dokumentu indeksēšana ir viens no informācijas apstrādes procesiem, kuru izpratnei pēdējos gados tiek pievērsta īpaša uzmanība. Standartā ${ }^{1}$ dokumentu indeksēšana tiek definēta kā "dokumenta aprakstīšana vai identificēšana ar terminiem, kas raksturo tā priekšmetu”. Dokumentu indeksēšanas rezultātu - priekšmetu iedaļas, kontrolētos atslēgvārdus - izmanto, lai piedāvātu pieejas punktus tematiskās meklēšanas gadījumos dažādās informācijas izguves sistēmās (piem., bibliotēku katalogos). Mūsdienu bibliotēku praksē galvenā metode tematiskās meklēšanas nodrošināšanai ir priekšmetiskā indeksēšana (priekšmetošana). Bibliotēkzinātnē šis process ir raksturots divējādi: vai nu kā divu posmu modelis, vai kā trīs posmu modelis. Divu posmu modeli veido šãdi posmi: 1.posms: dokumenta izpēte un tā priekšmeta (dokumenta priekšmeta (DP)) noteikšana; 2.posms: DP "pārtulkošana" informācijas meklējumvalodā (jēdzienu izteikšana indeksēšanas valodā). Savukārt trīs posmu modelis, atškiirībā no divu posmu modeḷa, ir papildināts ar starpposmu, kurā ir izdalīts priekšmetam raksturīgo jēdzienu noteikšanas process. Kā atzīmē J.E. Mejs (Jens-Erik Mai) rakstā "Analysis in indexing: document and domain centered approaches"', pirmais posms (dokumenta izpēte un tā priekšmeta noteikšana) ir visvājāk izprastais posms, kaut arī tas ir pats nozīmīgākais un arī vissarežǵîtākais posms: visnozīmīgākais tāpēc, ka tas ir pamats dokumenta priekšmeta atveidošanai, bet vissarežgî̄tākais tāpēc, ka šim posmam ir visvājāk izstrādātās instrukcijas, bieži vien norādot uz šî procesa intuitīvo raksturu.

Samērā ilgi bibliotēku praksē š̄ posma īstenošana pamatojās uz principiem, kas izrietēja no priekšstata par tekstu un valodu kā abstraktu, formālu sistēmu, kas tiek lietota ideju, zināšanu pārraidei. Tā rezultātā priekšmetošanā dominēja 
dokumentorientētā pieeja. Pēdējos gados, pamatojoties uz pētījumiem dažādās zinātṇu nozarēs par tekstu un valodu, aizvien vairāk tiek uzsvērta nepieciešamība šādu formālu pieeju nomainīt ar funkcionālu pieeju un dokumentorientētu indeksēšanu aizstāt ar lietotājorientētu indeksēšanu. Arī š̄ raksta mērķis ir parādīt formālās pieejas ierobežojumus DP atklāšanā un pierādīt funkcionālās pieejas atbilstîbu un piemērotību š̀i procesa īstenošanā.

Raksta struktūru veido divas daļas: pirmajā daļā tiek aprakstīts empīrisks pētījums, kas ilustrē mūsdienās dominējošo formālās pieejas izpratni par DP un tā noteikšanu, par pamatu izmantojot viena dokumenta bibliogrāfisko ierakstu dažādos katalogos, otrajā dal̦ā tiek raksturota funkcionālā pieeja DP: tās teorētiskais pamatojums un praktiskā realizācija. Rakstu noslēdz secinājumi.

\section{FORMĀLĀ PIEEJA DP NOTEIKŠANĀ UN APRAKSTİ̌̌SANĀ}

Lai noskaidrotu pieeju, kura dominē priekšmetošanā, tika veikta vienai grāmatai piešķirto priekšmetu analīze, izmantojot ziṇas, kas atrodamas e-kataloga bibliogrāfiskajos ierakstos.

Priekšmetu analīzei bibliogrāfiskajos ierakstos bija šādi uzdevumi:

1) noskaidrot, cik daudz priekšmetu tiek piešķirti viena izdevuma raksturošanai;

2) noskaidrot, cik dažādi priekšmeti tiek piešķirti viena izdevuma raksturošanai;

3) noskaidrot, cik atbilstoši piešķirtie priekšmeti ir izdevuma satura raksturošanai.

Tātad analīzes mērķis bija noskaidrot, kādus pieejas punktus piedāvā bibliotēku katalogi šīs grāmatas tematiskajai meklēšanai, vai citiem vārdiem - kādas zināšanas tiek "izceltas" no dokumenta satura un padarītas pieejamas sabiedrībai? Analīzei tika izvēlēti grāmatas: Svenonius, Elaine. The intellectual foundation of information organization / Elaine Svenonius. Cambridge (MA) ; London : The MIT Press, 2001. ${ }^{3}$ bibliogrāfiskie ieraksti.

Grāmatas izvēli noteica šādi apsvērumi:

1) grāmatas saturs ir labi zināms š̄ raksta autorei, kurai ir padziḷināta interese par informācijas organizāciju;

2) grāmata ir nozīmīga nozarē (bibliotēkzinātnē un informācijas zinātnē u.c. ar informācijas apstrādi saistītās nozarēs, piem., datorzinātnē), jo tajā ir vērtīgas un mūsdien̄̄gas zināšanas par dokumentu apstrādes jautājumiem un tāpēc tā ir atrodama daudzu bibliotēku krājumos.

Atbilstoši ieteikumiem DP noteikšanai, kas atrodami mācību grāmatās un standartā $\overline{4}^{4}$ šīs grāmatas analīzei tika izmantoti tipiskie dokumenta saturu raksturojošie elementi, kurus izmanto dokumentorientētā indeksēšanā: nosaukums, anotācija, priekšvārds, satura rādītājs, nodaļu nosaukumi, kā arī veikta teksta caurskatīšana. Grāmatas nosaukums "The intellectual foundation of information organization" (Informācijas organizācijas intelektuālie pamati) ir pietiekami precīzs, taču tajā pašā laikā samērā vispārīgs, jo nepasaka neko par to, kas veido šo intelektuālo pamatu. 
Taču grāmatai ir izvērsta anotācija un priekšvārds, kuros ir uzsvērta šāda intelektuālā pamata nozīme. Tajos ir rakstīts, ka "sistēmas efektivitāte ir sistēmā iestrādāto intelektuālo pamatu tieša funkcija. Līdzīgi kā teorētiskā fizika ir inženierzinātņu pamats, tā sistēmu izstrādei ir jāpamatojas uz intelektuālu pamatu"s. Priekšvārdā ir arī precīzi norādīts, ka darbā ir integrētas tādas atsevišksas disciplīnas kā aprakstošā (deskriptīvā) kataloǵizācija, priekšmetu (priekšmetiskā) kataloǵizācija, indeksēšana un klasificēšana, lai izveidotu vienotu, konceptuālu ietvaru, kas aplūko informācijas organizācijas procesu kā speciālas valodas - bibliogrāfiskās valodas lietojumu. Tātad intelektuālo pamatu veido zināšanas par valodu un tās izmantošanu. Gan anotācijā, gan priekšvārdā ir arī atzīmēts, ka grāmatai ir divas dal̦as: pirmā dal̦a aplūko informācijas organizācijas intelektuālos pamatus vispārināti, otrā daļa sniedz analīzi par bibliogrāfiskām valodām: darba valodu, dokumenta valodu, priekšmetu valodu (to vārdu krājumu, semantiku un sintaksi).

Savukārt, no satura rādītāja redzams, ka grāmatā ir nodaļas par informācijas organizāciju, bibliogrāfijas mērķiem, bibliogrāfiskajām entītijām; bibliogrāfiskajām valodām, aprakstīšanas principiem, darba valodām, dokumentu valodām un trīs nodaļas par priekšmetu valodām (leksiku, semantiskajām attiecībām un sintaksi) (sk. 3. pielikumu). Arī pēc teksta pārskatīšanas varēja nonākt pie secinājuma, ka informācijas organizācijas jautājumi aplūkoti valodas izmantošanas aspektā. Gan pamatojoties uz autores E.Svenoniusas norādījumiem sava darba priekšvārdā, gan arī šn raksta autoresprāt, grāmatas potenciālie interesenti (potenciālie lietotāji vai potenciālā informācijas lietotāju kategorija) ir divas speciālistu grupas ${ }^{6}$ : speciālisti, kuri interesējas par informācijas organizēšanu kā zinātniskas izpētes objektu, un speciālisti, kuri nodarbojas ar organizējošu sistēmu dizainu un izstrādi. Tātad tie ir cilvēki, kuriem jau ir priekšzināšanas par informācijas organizēšanu un kuriem š̄ grāmata l̦autu padziļināt zināšanas, aplūkojot tās valodas lietošanas aspektā. No tā izriet, ka tematiskās pieejas punktiem jābūt tādiem, kas piedāvātu šìm lietotāju grupām atbilstošus pieejas punktus, "izcel̦ot" padzilinātās zināšanas par informācijas organizācijas jautājumiem, it îpaši - valodas pieeju un aspektiem, kas raksturo valodas izmantošanu: leksiku, semantiku, sintaksi.

Grāmatas raksturošanai piešķirto priekšmetu analīzei tika atlasīti bibliogrāfiskie ieraksti no 24 dažādu valstu un bibliotēku (nacionālo bibliotēku, zinātnisko bibliotēku) e-katalogiem un e-kopkatalogiem (katalogu sarakstu sk. 1. pielikumā). Piekḷuve šo katalogu ierakstiem tika īstenota caur Karlsrūhes virtuālo katalogu (http://www.ubka.uni-karlsruhe.de/hylib/en/kvk.html).

Bibliogrāfisko ierakstu (25 ieraksti) ${ }^{7}$ priekšmetu analīzes rezultātā ir redzams, ka DP raksturošanai ir piešķirti 14 atšķirīgi priekšmeti (sk. priekšmetu sarakstu 4. pielikumā). 1. attēlā redzami priekšmetu klasteri (priekšmeti pēc piešksiršanas (lietojuma) biežuma). 


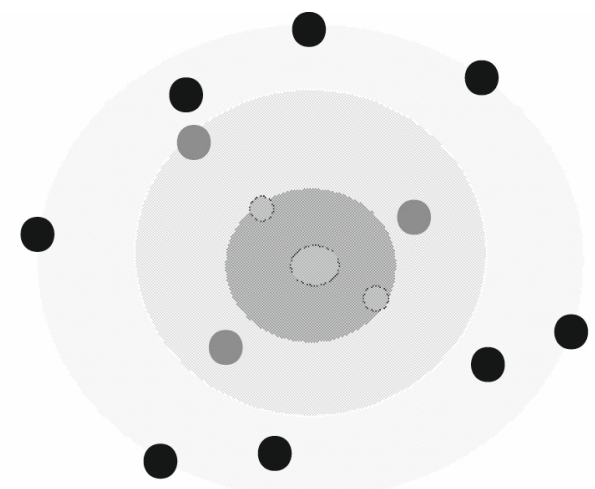

\section{1. attēls. Priekšmetu klasteri pēc to piešķiršanas biežuma}

Visbiežāk piešksirtie priekšmeti (trīs priekšmeti, kas veido klastera centru 1.attēlā) ir parādīti 1.tabulā.

\section{Visbiežāk piešksirtie priekšmeti}

\begin{tabular}{|c|c|}
\hline Priekšmets & Biežums \\
\hline Kataloǵizēšana & 25 \\
\hline Bibliografēšana - Metodologija (lìdzīgà forma - Bibliografēšana) & 17 \\
\hline Informācijas organizēšana (līdzīgā forma -Informācija, organizēšana) & 16 \\
\hline
\end{tabular}

Nākamā priekšmetu grupa pēc biežuma ir parādīta 2. tabulā.

Priekšmeti, kas sastopami vidēji bieži

\begin{tabular}{|c|c|}
\hline Priekšmets & Biežums \\
\hline Informācijas izguve & 6 \\
\hline Klasificēšana (grāmatas) & 5 \\
\hline Priekšmetošana & 4 \\
\hline
\end{tabular}

Trešā grupa ir priekšmeti, kuri sastopami vai nu tikai vienā ierakstā, vai divos. Tie parādīti 3. tabulā.

3. tabula

Vienu vai divas reizes piešķirtie priekšmeti

\begin{tabular}{|c|c|}
\hline Priekšmets & Biežums \\
\hline Bibliogrāfiskā aprakstī̌sana & 2 \\
\hline Bibliotēkzinātne & 2 \\
\hline Informācijas zinātne & 2 \\
\hline Indeksēšana & 1 \\
\hline Informācijas pakalpojumi & 1 \\
\hline Informācijas teorija & 1 \\
\hline Informācijas pārvaldība & 1 \\
\hline Informācijas nodrošinājums -Semantiskā analīze & \\
\hline
\end{tabular}


Šos datus var analizēt, izmantojot indeksēšanas kvalitāti raksturojošus rādītājus:

1) priekšmetošanas / indeksēšanas konsekvenci;

2) atbilstību (precizitāti, piln̄̄gumu).

\section{Priekšmetošanas konsekvence}

Literatūrā bieži vien tiek uzsvērts, ka viens no priekšmetošanas kvalitātes rādītājiem ir priekšmetošanas konsekvence, t.i., dokumentam vienādi pieškirtie priekšmeta pieejas punkti dažādu bibliotēku katalogos ${ }^{8,9}$.

Pēc iegūtajiem rezultātiem redzams, ka $52 \%$ ierakstos (sk. 2. attēlu) ir atrodami visi trīs kopīgie priekšmeti vienlaikus: "Informācijas organizācija"; "BibliografěšanaMetodologiija"; "Kataloğizēšana". Novērtējot šos priekšmetus kā tematiskās pieejas punktus šim izdevumam, jāsecina, ka tie samērā vispārīgi atsedz izdevuma saturu un līdz ar to nodrošina arī l̦oti vispārīgu meklēšanu, tādējādi pagarinot meklēšanas laiku šīs grāmatas galvenajam adresātam - informācijas organizēšanas jautājumu speciālistam.

Ar ko izskaidrojama šī vispārinātā konsekvence? Pirmkārt, ar samērā stabilo uzskatu bibliotekāru vidū par DP kā objektīvu un no lietotāja neatkarīgu lielumu (šie paši priekšmeti redzami arī grāmatas bibliogrāfiskajās ziņās tās titullapas otrajā pusē). Otrkārt, (kas arī izriet no šìs izpratnes) ar kooperatīvo kataloǵizāciju, kas nodrošina iespēju iekopēt nepieciešamo ierakstu no kādas bibliotēkas kataloga (šajā gadījumā, iespējams, autoritatīvo lomu "nospēlējis" ieraksts ASV Kongresa bibliotēkas katalogā) savā katalogā, neveicot īpašas izmaiņas ierakstā.

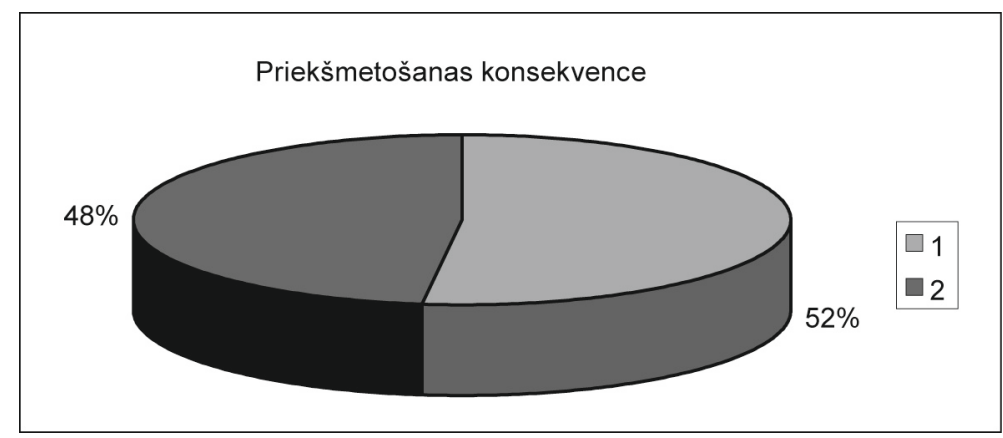

\section{2. attēls. Vienādais dokumenta priekšmeta raksturojums (priekšmetošanas konsekvence) bibliotēku katalogos}

Te ir redzamas gan kooperatīvās kataloǵizācijas (to skaitā arī - centralizētās kataloǵizācijas), gan priekšmetošanas konsekvences priekšrocības un trūkumi. Nozīmīgākā priekšrocība ir šī procesa racionalitāte, kas l̦auj, samazinot darbu pie ieraksta izveides, nodrošināt operatīvāku dokumentu apstrādi. Par priekšmetošanu: var redzēt, ka šādas pieejas pamatā dominē atziṇa, ka dokumentam ir objektīvs pamattemats, kuru var raksturot ar vienādiem pieejas punktiem visos katalogos, un līdz ar to visos katalogos to var sameklēt pēc vienādiem priekšmetiem. Taču tam ir negatīvās sekas: šāda pieeja nodrošina ierobežotu piekḷuvi zināšanām, kas fiksētas dokumentos, un tas nozīmēe, ka informācijas meklētājam jāpatērē ilgāks laiks izdevuma atrašanai. Tātad jāsecina, ka attiecībā uz priekšmetu pieejas punktu 
nodrošinājumu, izmantojot formālo pieeju DP aprakstǐšanā, lielākā daḷa bibliotēku ietaupa darbinieku laiku, bet neietaupa informācijas meklētāja laiku.

\section{Indeksēšanas atbilstība}

Otrs indeksēšanas kvalitātes rādītājs ir indeksēšanas atbilstība, kuru var novērtēt arī pēc dokumenta raksturošanai piešķirto priekšmetu tematiskā aptvēruma pilnīguma un precizitātes (konkrētības).

Rezultāti parāda, ka šajā gadījumā dominē vispārīga līmeņa priekšmetošana un nav izcelti (vai - ir "aprakti”) speciālistam būtiski priekšmeta pieejas punkti. Tā, piemēram, grāmata nav atrodama, ja informācijas lietotājs (speciālists) izvēlētos meklēšanai tādus terminus kā "bibliogrāfiskās valodas", "priekšmetu valodas", "informācijas meklējumvalodas", "meklējumvalodu semantika", "semantikas veidi", "bibliogrāfiskās valodas-semantika”. Jāatzīmē, ka nozares leksikā šie termini jau tiek lietoti samērā ilgi (vairāki no tiem apmēram 50 gadus). Tātad piešķirtie priekšmeti, būdami pārāk vispārīgi, kā arī nepiln̄igi aprakstot grāmatā aplūkotos jautājumus, nenodrošina pietiekamu ierakstu "atlases spēku"10.

Šie rezultāti liek uzdot jautājumu: kas, pēc informācijas darbinieku (bibliotekāru) domām, ir potenciālais dokumenta meklētājs un izmantotājs: zinošs speciālists par informācijas organizācijas jautājumiem, nozares pārstāvis vai ikviens interesents? Lielākā daḷa bibliotēku (tās, kuras ir piešks̄irušas vispārīgus priekšmetus) ir uzskatījušas, ka tas ir nozares pārstāvis, kuram varētu būt interese par kataloǵizēšanu, informācijas organizēšanu, bibliografěšanu, bet ne informācijas organizēšanas speciālists. Ja tiktu ņemts vērā speciālists, tad pieejas punktiem būtu jābūt specifiskākiem, konkrētākiem, kā minēts iepriekš. Tikai vienas bibliotēkas kataloga ierakstā bija atrodams priekšmeta apraksts ("Informācijas nodrošinājums Semantiskā analīze"), kas būtu noderīgs informācijas lietotājam - nozares speciālistam.

Pārāk vispārīga priekšmetošana liek apšaubīt arī piešķirto priekšmetu atbilstību. Protams, zināmā mērā šāda priekšmetošana ir izskaidrojama gan ar priekšmetu valodas leksiku (piem., priekšmetu valodā (LCSH $\left.{ }^{11}\right)$ trūkst detalizētu priekšmetu), gan ar indeksēšanas politiku, kura nacionālām un universitāšu bibliotēkām mēdz būt vispārīgāka, jo tās lietotāju grupas ir visdaudzveidīgākās. Taču jautājums ir, - vai šādas politikas rezultātā pieejas punkti netiek nodrošināti abstraktam informācijas lietotājam un kā tas saskan ar jau standartā doto ieteikumu", ka "jēdzieni jānosaka pēc iespējas konkrētāk"?

No iegūtajiem rezultātiem un to interpretācijas redzams, ka formālā pieeja DP noteikšanai un tā aprakstam pārāk vispārīgi identificē dokumentu un netaupa informācijas meklētāja (īpaši - nozares speciālista) laiku vajadzīgā avota atrašanai, jo tā ir dokumentorientēta, bet ne lietotājorientēta.

\section{FUNKCIONĀLĀS PIEEJAS RAKSTUROJUMS}

Pēdējos gados aizvien vairāk literatūrā ir atrodami pētījumi, kas DP noteikšanu un aprakstīšanu liek pārskatīt, pamatojot to ar dziḷāku izpratni par valodu, tekstu un to uztveri (piem., B. Hjorlands (B. Hjørland), J.E. Mejs (J.E. Mai) u.c.). 
Kompleksu skatījumu teksta uztveres izpratnei nodrošina vairākas nozares: semiotika, semantika, valodas filozofija, valodniecība, izziņas psihologija u. c. Lai labāk ieraudzìtu formālās pieejas ierobežotību tekstu DP aprakstǐšanā, šajā rakstā tiks izmantotas tikai dažas semiotikas atziṇas. Viens no mūsdienās biežāk izmantotajiem zīmes model̦iem ir Č.Pīrsa zīmes modelis, kurā nozīmīgākais elements salīdzinājumā ar iepriekš izstrādātajiem zīmi skaidrojošajiem model̦iem ir interpretants (nosaka nozīmi, kas ir piešķirta zīmei, kura apzīmē kādu objektu ${ }^{13}$. Tālāk tekstā sekos dažu piemēru analīze, izmantojot semiotikas atziņas par interpretantu un tā ietekmi uz teksta ${ }^{14}$ DP noteikšanu. Piemēri ilustrēs atziņu, ka DP nav "meklējams tikai tekstā”, bet to nosaka informācijas uztvērējs, viņa zināšanas, dzīves pieredze, lietu izpratne.

Pirmais piemērs: attēls

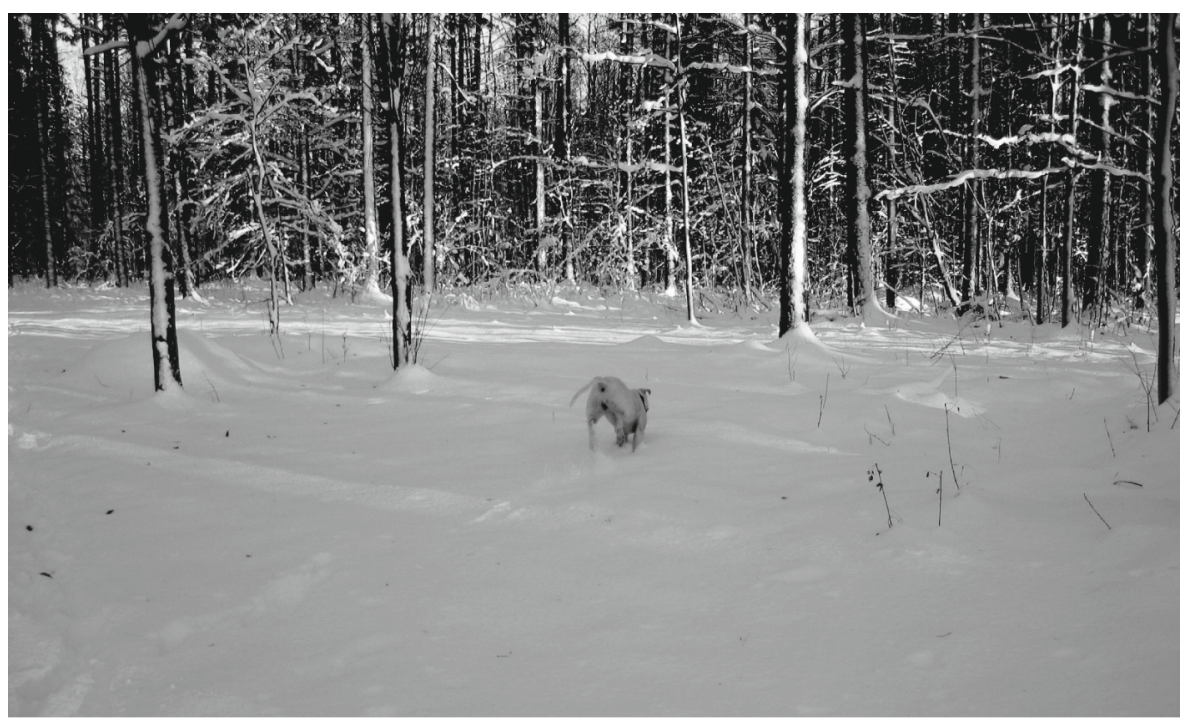

\section{3.attēls. Attēls, kas ilustrē DP dažādību}

Attēli ir teksti, kurus var visdaudzveidīgāk raksturot. Tā, piemēram, 3. attēlā ir redzami noteikti objekti, kurus var raksturot šādi atslēgvārdi: apsnidzis mežs; saulains mežs; balts suns, skrienošs suns. Taču, pamatojoties uz interpretantu kā nozīmes noteicēju, varam prognozēt: kādam dotais attēls var radīt arī personiska rakstura simbolisku nozīmi, piem., "ātri aizskrienošs suņa gads” u.c.

Mūsdienu attēlu indeksēšanas teorijas jau ir izstrādātas, pamatojoties uz atziṇām par attēlu nozīmes vairākiem līmeņiem (piem., vispārīgo, specifisko, abstrakto), kas savukārt ir atkarīgi no uztverošā (lasošā) subjekta pieredzes un vizuālās pratības.

P. Rafertija (P.Rafferty) un R. Hiderlejs (R.Hidderley) uzsver, ka multimēdiju izguves sistēmām būtu jābūt tādām, kuras darbotos, pamatojoties uz izpratni, ka mēdiju nozīmes ir meklējamas sabiedrībā (komunikācijā starp lietotāju un sistēmu), un ka nozìmes nav abstraktas un absolūtas ${ }^{15}$.

\section{Otrais piemērs: seriāls (filma) "Sekss un lielpilsēta"}

Daudznozīmīgi raksturojamas ir arī filmas. Tā, piemēram, Ilmārs Šlāpins rakstā "Seksuālā antropolog̣ija"16 raksta: "..fokusgrupu aptaujās atklājies, ka skatītāji 
seriālu [Sekss un lielpilsēta] uztver l̦oti atšksirīgi. Uz jautājumu, kāda ir tā pamattēma, vienā vecuma grupā tiek minēta ideālā vīrieša meklēšana, citā - sieviešu draudzība." Šis piemērs parāda, ka priekšmeta noteikšanu ietekmē uztverošā subjekta vecuma grupa un attiecīgi - vecuma grupai dominējošās intereses un vērtības.

Trešais piemērs: grāmatas teksts ("Intellectual foundation of information organization")

Ja runā par DP tekstu, pamatotu skaidrojumu tā dabai sniedz hermeneitika. Hermeneitiķi (piem., M.Heidegers) norāda, ka teksta saprašana ir interpretācija, kurai svarīga iepriekšsapratne. Tā ir cilvēka dzīves pieredze, kultūra un vēsturiskā situācija (horizonts), kas ietekmē tekstu saprašanu un dažādu nozīmju "izvilkšanu". Šī atziņa norāda uz to, ka DP var būt dažāds cilvēkiem, kuriem ir atšksirīgas zināšanas kādā jomā, dzīves pieredze un lietu izpratne. Hermeneitikas atziṇas var uzskatīt, ka ir pamatā lietotājorientētai tekstu indeksēšanai, un viena no iespējām, kā tā izpaužas, ir vispārinātu vai konkrētu terminu izvēle DP raksturošanai. Tā, piemēram, ja informācijas lietotājs ir nozares speciālists, darbs jāindeksē ar konkrētākiem terminiem, ja nespeciālists - ar vispārinātākiem terminiem. Piemēram, lai nozares speciālisti varētu atrast grāmatu "Intellectual foundation of information organization”, būtu jāpiešķir šādi tematiskās meklēšanas pieejas punkti: "Bibliogrāfiskās valodas - Semantika", "Priekšmetu valodas - Semantika"; "Priekšmetu valodas - Pragmatika"; "Priekšmetu valodas - Sintakse", savukārt nespeciālistiem pieejas punkti varētu būt: "Kataloǵizēšana"; "Informācijas organizēšana", "Informācijas organizēšanas valodas". Lietotājorientētā pieeja ir funkcionāla pieeja, jo tā, nosakot DP, prasa analizēt dokumentu kontekstā ar tā pielietojumu, t.i., tā funkcionālo vērtību noteiktai lietotāju grupai, kuras informācijas vajadzības veidojas konkrētas darbības ietvaros ar atbilstošu diskursu. Šīs pieejas pragmatiskais raksturs izpaužas tādējādi, ka viens un tas pats dokuments atbilstoši potenciālajai lietotāju grupai var tikt dažādi priekšmetiski raksturots. Piemēram, tā kā grāmata "Intellectual foundation of information organization" var izraisīt interesi arī valodniekiem, tai kā tematiskās meklēšanas pieejas punkti varētu būt arī šādi priekšmeti: "Valodas informācijas organizācijas sistēmas"; "Leksika informācijas organizācijā̄" un tamlīdzīgi.

Viena no šobrīd jaunākajām izpratnēm lietotājorientētajā indeksēšanā pamatojas uz atziņu, ka tekstu interpretēšanu un DP noteikšanu ierobežo sociālie konteksti darbības lauki (domēni), t.i., cilvēks vienmēr ir kādas lielākas vai mazākas sociālas grupas pārstāvis, un šīm grupām ir noteiktas "tradīcijas" lietu uztverē, valodas lietojumā, kas izpaužas diskursā un ietekmē tekstu interpretāciju un nozīmi. Darbības lauka pieeju padziļināti izstrādājis B.Hjorlands ${ }^{17}$. Indeksēšanas jomā to tālāk attīsta arī J.E. Mejs. Viņš savā rakstā ${ }^{18}$ norāda, ka darbībā-orientētā pieeja indeksēšanā prasa no indeksētāja zināšanas par darbību (darbības lauku, nozari), potenciālo dokumentu lietotāju vajadzībām saistībā ar šo darbību (darbības lauku), un DP ir jānosaka, pamatojoties uz šìm zināšanām. Šī pieeja ir pretēja dokumentorientētai indeksēšanai, jo izejas punkts ir nevis dokumenta teksts, bet darbības lauks (nozare) un tās dalībnieks - potenciālais informācijas lietotājs. Viṇaprāt, darbībā-orientētā pieeja indeksēšanā spēj izskaidrot indeksēšanas procesu, piedāvājot skaidru, pamatotu atskaites sistēmu, pēc kuras vadīties, nosakot DP. 
Tātad DP izpratne un tā noteikšana ir būtiskākās formālās un funkcionālās pieejas atšķirīibas. 4. tabulā dots šo pieeju vispārīgs salīdzinājums: formālajā pieejā DP tiek uzskatīts par dokumenta pamattematu (dominējošo tematu), kurš ir objektīvs un no uztvērēja neatkarīgs temats, tāpēc tam ir jāparādās visu katalogu attiecīgajos ierakstos; savukārt funkcionālā pieeja prasa noteikt informatīvo tematu - tematu, kas būtu atbilstošs noteiktai informācijas lietotāju grupai un kura noteikšana ir saistīta ar darbības lauka (nozares) zināšanu pārziṇu.

\section{4. tabula}

DP noteikšana: formālās un funkcionālās pieejas salīdzinājums

\begin{tabular}{|c|c|c|}
\hline $\begin{array}{c}\text { Pieeja / raksturojošie } \\
\text { parametri }\end{array}$ & Formālā pieeja & Funkcionālā pieeja \\
\hline Ko nosaka? & Dokumenta pamattematu & Dokumenta informatīvo tematu \\
\hline $\begin{array}{c}\text { Kas ir analīzes } \\
\text { vienība? }\end{array}$ & $\begin{array}{c}\text { Dokuments un tā elementi } \\
\text { (nosaukums, satura } \\
\text { rādītājs, anotācija u.c.) }\end{array}$ & $\begin{array}{c}\text { Dokuments kontekstā zinăsar par } \\
\text { nozari un lietotāju grupu informacionālās } \\
\text { vajadzības, tām atbilstoši izvēlēts temats }\end{array}$ \\
\hline
\end{tabular}

Lai nodrošinātu šīs pieejas realizāciju bibliotēku u.c. informācijas iestāžu darbā, ir svarīgi divi faktori. Pirmkārt, bibliotekāru vidū ir jāmaina izpratne par DP, apgūstot zināšanas, kas izskaidro tekstu saprašanas, uztveres un valodas lietošanas jautājumus, kā arī jāapgūst zināšanas par kontekstu - darbības lauku, kurā dokumenti potenciāli tiktu izmantoti. Otrkārt, pamatojoties uz izpratni par DP, kā arī, ņemot vērā bibliotēkas tipu, lietotāju grupas un viṇu informacionālās vajadzības, krājuma sastāvu un apjomu, bibliotēkās ir nepieciešams izstrādāt indeksēšanas politiku. Tā kalpotu kā atskaites sistēma, lai noteiktu, cik vispārīgiem vai konkrētiem ir jābūt priekšmetu aprakstiem, cik pilnīgi (daudzpusīgi) jāatklāj dokumentu saturs, kā efektīvi izmantot kooperatīvās katalogizācijas priekšrocības arī tematiskās pieejas nodrošināšanā. Latvijas situācijā šobrīd vēl ir svarīgi izstrādāt arī priekšmetu valodu un apgūt tās pielietošanas iespējas.

Galvenie ieguvumi funkcionālās pieejas īstenošanas rezultātā būtu daudzveidīgie pieejas punkti dokumentos fiksētajām zināšanām, kas savukārt nodrošinātu "dziḷāku" (gan pilnīgāku, gan precīzāku) informācijas meklēšanu un izguvi. Tas varētu būtiski samazināt informācijas meklētāju laiku un uzlabot informācijas izguves sistēmu kvalitātes rādītājus informācijas atlasē, aizstājot formālo atbilstību ar semantisko un pragmatisko atbilstību.

\section{SECINĀJUMI}

Tekstu semantiskās apstrādes pilnveides pētījumi ir viens no aktuālākajiem izpētes jautājumiem visās nozarēs, kas saistītas ar mūsdienu informācijas resursu (īpaši - elektronisko resursu) organizēšanu. Ir skaidrs, ka gan līdzšinējās intelektuālās, gan automatizētās metodes ir nepilnīgas, jo daudzos gadījumos meklēšanas rezultāti ir neprecīzi.

Viens no intelektuālo metožu pilnveides cel̦iem ir funkcionālā pieeja. Tā prasa mainīt izpratni par faktoriem, kas jāņem vērā dokumenta analīzē un DP noteikšanā, kā arī apgūt papildu zināšanas par nozarēm, kurās dokumenti funkcionē. Turpinot DP noteikšanu, izmantojot formālo pieeju, saglabāsies konceptuāli novecojusī 
izpratne par viennozīmīgo tekstu uztveri un abstrakto informācijas lietotāju, kurai jau ir zināmas sekas informācijas izguvē.

\section{LITERATŪRA}

1. Chandler, Daniel. Signs. In: Chandler, Daniel. Semiotics for Beginners [tiešsaiste]. [skatīts 2006. g. 20.decembrī]. Pieejams: http://www.aber.ac.uk/media/Documents/S4B/ sem02.html

2. Hjørland, Birger. Consistency in Knowledge Organization [tiešsaiste]. [skatīts 2006. g. 18.decembrī]. Pieejams: http://www.db.dk/bh/Lifeboat_KO/CONCEPTS/consistency_ in_knowledge_organiz.htm

3. Hjørland, Birger. Domain analysis in information science. Eleven approaches traditional as well as innovative. Journal of Documentation, No. 58(4), 2002, p. 422462.

4. Hjørland, Birger. Approaches to knowledge organization. PPT presentation

5. Lancaster, F.E. Indexing and Abstracting. London: Library Association Publishing, 1998. 412 p. ISBN 1-85604-268-5

6. LVS ISO 5963 - 2003 Dokumentācija. Dokumentu izpētes un to priekšmetu noteikšanas un indeksēšanas terminu izvēles metodes. Rīga: Latvijas Standarts, 2003. 15 lpp.

7. Mai, Jens-Erik. Analysis in indexing: document and domain centered approaches. Information Processing \& Management, No. 41, 2005, p. 599-611.

8. Rafferty, P., Hidderley, R. Indexing Multimedia and Creative Works: the problems of meaning and interpretation. Aldershot; Burlington: Ashgate, 2005. 208 p. ISBN 0754632547

9. Svenonius, Elaine. The Intellectual Foundation of Information Organization / Elaine Svenonius. Cambridge (MA) ; London : The MIT Press, 2001. 255 p.

10. Šlāpins, Ilmārs. Seksuālā antropologiija. Rīgas Laiks. Nr.10, 2006, okt., 63., 65.-67.lpp. ISSN 1407-1622

\section{PIELIKUMS}

\section{Katalogu saraksts}

\section{Nacionālo bibliotēku katalogi}

- ASV Kongresa bibliotēkas katalogs http://www.loc.gov/

- Austrālijas Nacionālās bibliotēkas katalogs http://catalogue.nla.gov.au/cgi-bin/Pwebrecon.cgi?DB=local\&PAGE=First

- Britu bibliotēkas katalogs (2 ieraksti vienam izdevumam) http://catalogue.bl.uk/F/?func=file\&file_name=login-bl-list

- Dānijas Nacionālās un universitātes bibliotēkas katalogs https://rex.kb.dk/F/-?func=option-update-lng\&file_name=find-b\&local_base=kg101\&p_ con_lng=eng

- Igaunijas Nacionālās bibliotēkas katalogs http://ester.nlib.ee/search

- Latvijas Nacionālās bibliotēkas katalogs http://www.lnb.lv

- Nīderlandes Nacionālās bibliotēkas katalogs http://opc4.kb.nl/ 
- Vācijas Zinātnes un tehnoloǵiju Nacionālās bibliotēkas katalogs http://tiborder.gbv.de/DB=2.63/LNG=EN/

- Zviedrijas Nacionālās bibliotēkas katalogs http://embla.kb.se/F/MCLD5UG59JGH2UGT64J5LCI7E95QDLUGH35YGDN6S1U42 R6JBP-02921?func $=$ file \&file $\_$name $=$find-b

\section{Kopkatalogi u.c. katalogi}

- Austrijas zinātnisko bibliotēku kopkatalogs http://meteor.bibvb.ac.at/F/XYT219R5C8AFYJFDYMB8EGGI9P3DXEKGS6 4LU3B9Y4ESRNB8ME-00814? func $=$ full-set-set\&set_number $=037044 \&$ set entry $=000003 \&$ format $=999$

- Francijas zinātnisko (akadēmisko) bibliotēku kopkatalogi (2): http://corail.sudoc.abes.fr/DB=2.1/LNG=EN/ http://ccfr.bnf.fr/accdis/accdis.htm

- Itālijas bibliotēku kopkatalogs $\mathrm{http} / / /$ opac.internetculturale.it/cgi-bin/main.cgi?type=free

- Lielbritānijas zinātnisko (akadēmisko) bibliotēku kopkatalogs http://copac.ac.uk/about/

- Somijas Universitātes bibliotēkas katalogs https://helka.linneanet.fi/cgi-bin/Pwebrecon.cgi?LANGUAGE=English\&DB=local\&PA $\mathrm{GE}=$ First

- Šveices (Bāzes, Bernes) bibliotēku kopkatalogs http://aleph.unibas.ch/F?con_lng=ENG\&func=file\&file_name=login Šveices Bibliotēku un informācijas centru kopkatalogs http://www.nebis.ch/index_e.html

- Vācijas zinātnisko (akadēmisko) bibliotēku kopkatalogi (3): http://gso.gbv.de/LNG=EN/DB=2.1/ http://bvba2.bib-bvb.de/V/EQEGLNIC6GUL3ELMPRAT2N45YKHG6KCE9IRYML5 DYDVLJFPUMB-17852?func=find-0\&list_type=HOME http://193.30.112.134/F/72T17UCNDRY8MU5142G5UEVX2MV42MBQHJFUU4LL2 AVFPGF766-00661? func $=$ file\&file_name $=$ logout Bādenes - Vurtenbergas bibliotēku pakalpojumu centrs (2) http://www2.bsz-bw.de/cms/index_html

- Zviedrijas zinātnisko bibliotēku kopkatalogs http://www.libris.kb.se/english/indexeng.jsp 


\section{PIELIKUMS}

Grāmatas "Intellectual Foundation of Information Organization" bibliogrāfiskais ieraksts katalogā

Author(s): Svenonius, Elaine

Title: The intellectual foundation of information organization / Elaine Svenonius

Published: Cambridge(MA) : MIT Press, 2000

Material: xiv, 255 s. ; $24 \mathrm{~cm}$

Series: (Digital libraries and electronic publishing)

Bibliography: Includes bibliographical references (p. [223]-243) and index

Reprintings: [Repr.] 2001

Format: Book

ISBN: 0-262-19433-3 ((hc alk. paper))

LCSH: Information organization

Bibliography --Methodology

cataloging

\section{PIELIKUMS}

Grāmatas "Intellectual Foundation of Information Organization" satura rādītājs

Preface ix

Acknowledgments $\mathrm{xv}$

1 Information Organization 1

2 Bibliographic Objectives 15

3 Bibliographic Entities 31

4 Bibliographic Languages 53

5 Principles of Description 67

6 Work Languages 87

7 Document Languages 107

8 Subject Languages: Introduction, Vocabulary Selection, and Classification 127

9 Subject Languages: Referential and Relational Semantics 147

10 Subject-Language Syntax 173

Afterword 193

Notes 199

References 223 


\section{PIELIKUMS}

\section{Grāmatai “Intellectual Foundation of Information Organization” piešķirto priekšmetu saraksts}

\begin{tabular}{|c|c|c|}
\hline & Priekšmets & Biežums \\
\hline 1. & Katalog̣izēšana & 25 \\
\hline 2. & $\begin{array}{l}\text { Bibliografēšana - Metodologiija } \\
\text { (lìdzìga forma - Bibliografēšana) }\end{array}$ & 17 \\
\hline 3. & $\begin{array}{l}\text { Informācijas organizēšana } \\
\text { (lìdzīgā forma -Informācija, organizēšana) }\end{array}$ & 16 \\
\hline 4. & Informācijas izguve & 6 \\
\hline 5. & Klasificēšana (grāmatas) & 5 \\
\hline 6. & Priekšmetošana & 4 \\
\hline 7. & Bibliogrāfiskā aprakstīšana & 2 \\
\hline 8. & Bibliotēkzinātne & 2 \\
\hline 9. & Informācijas zinātne & 2 \\
\hline 10. & Indeksēšana & 1 \\
\hline 11. & Informācijas pakalpojumi & 1 \\
\hline 12. & Informācijas teorija & 1 \\
\hline 13. & Informācijas pārvaldība & 1 \\
\hline 14. & Informācijas nodrošinājums - Semantiskā analīze & 1 \\
\hline
\end{tabular}

\section{ENDNOTES}

${ }^{1}$ LVS ISO 5963 - 2003 Dokumentācija. Dokumentu izpētes un to priekšmetu noteikšanas un indeksēšanas terminu izvēles metodes. Rīga: Latvijas Standarts, 2003. 7.lpp.

2 Mai, Jens-Erik. Analysis in indexing: document and domain centered approaches. Information Processing \& Management, No. 41, 2005, p. 600 - 601.

3 Svenonius, Elaine. The Intellectual Foundation of Information Organization. Cambridge (MA); London: The MIT Press, 2001. 255 p.

${ }^{4}$ LVS ISO 5963 - 2003 Dokumentācija. Dokumentu izpētes un to priekšmetu noteikšanas un indeksēšanas terminu izvēles metodes. Rīga: Latvijas Standarts, 2003. 8.lpp.

5 Svenonius, Elaine. Preface. In: Svenonius, Elaine. The Intellectual Foundation of Information Organization. Cambridge (MA) ; London : The MIT Press, 2001, ix p.

${ }^{6}$ Svenonius, Elaine. Preface. In: Svenonius, Elaine. The Intellectual Foundation of Information Organization. Cambridge (MA); London : The MIT Press, 2001, x p.

7 Britu bibliotēkas katalogā grāmatai bija divi ieraksti.

8 Hjørland, Birger. Consistency in Knowledge Organization [tiešsaiste]. [skatîts 2006. g. 18.decembrī]. Pieejams: http://www.db.dk/bh/Lifeboat_KO/CONCEPTS/consistency in_knowledge_organiz.htm

9 Lancaster, F.E. Indexing and Abstracting. London: Library Association Publishing, 1998, p. 62-76.

${ }^{10}$ Hjørland, Birger. Approaches to knowledge organization. PPT presentation

11 LCSH - Library of Congress Subject Headings - ASV Kongresa bibliotēkas priekšmetu saraksts 
12 LVS ISO 5963 - 2003 Dokumentācija. Dokumentu izpētes un to priekšmetu noteikšanas un indeksēšanas terminu izvēles metodes. Rīga: Latvijas Standarts, 2003. 11.lpp.

13 Chandler, Daniel. Signs. In: Chandler, Daniel. Semiotics for Beginners [tiešsaiste]. [skatîts 2006. g. 20.decembrī]. Pieejams: http://www.aber.ac.uk/media/Documents/S4B/ sem02.html

14 Teksts visplašākajā nozīmē: gan attēls, gan filma, gan grāmatā rakstīts teksts. Teksts kā zīmju kopums, kas veido vienu vienību, pārraida nozīmi.

15 Rafferty,P., Hidderley, R. Indexing Multimedia and Creative Works: the problems of meaning and interpretation. Aldershot; Burlington: Ashgate, 2005. 97.p

16 Šlāpins, IImārs. Seksuālā antropolog̣ija. Rīgas Laiks. Nr.10, 2006, okt., 63.lpp.

17 Hjørland, Birger. Domain analysis in information science. Eleven approaches traditional as well as innovative. Journal of Documentation, No. 58(4), 2002, p. 422462.

18 Mai, Jens-Erik. Analysis in indexing: document and domain centered approaches. Information Processing \& Management, No. 41, 2005, p.607-609. 


\title{
Zinātnisko publikāciju pētīšanas kvantitatīvie aspekti (infometrija, bibliometrija, scientometrija, vebometrija)
}

\author{
Daina Pakalna \\ Latvijas Universitāte
}

\begin{abstract}
Infometrija, bibliometrija, scientometrija - informācijas zinātnes apakšnozares zinātnes kvantitatīvo aspektu pētī̌sanai
\end{abstract}

Veicot bibliotēkzinātnes un informācijas zinātnes darbības lauka analīzi, profesors Birgers Hjorlands izvirzịjis vienpadsmit elementus, no kuriem divi ir saistīti ar šī raksta tematu - zinātnes pētīšanas kvantitatīvajiem aspektiem:

1. bibliometriskās izpētes nodrošināšana un interpretēšana;

2. zināšanas un pētījumi par nozaru zinātnisko un profesionālo komunikāciju struktūrām un institūcijām ${ }^{1}$.

Lai realizētu šos darbības lauka elementus, palīgā tiek ņemtas informācijas zinātnes apakšnozares (dažos avotos sauktas arī par pētniecības metodēm) infometrija, bibliometrija, scientometrija. Šie apzīmējumi reizēm tiek uztverti kā sinonīmi.

Kā pirmā no šīm apakšnozarēm tika definēta bibliometrija. 1969. gadā A. Pričards (Pritchard A.) Journal of Documentation 1969. gadā publicējis rakstu „Statistiskā bibliogrāfija vai bibliometrija" (Statistical Bibliography or bibliometrics?), kurā dod šādu metodes raksturojumu: ,Matemātisko un statistisko metožu pielietošana grāmatu un citu komunikācijas līdzekļu pētišanā. "'

Tajā pašā gadā divi krievu zinātnieki - Nalimovs un Mulčenko piedāvā citu metodes apzīmējumu - „naukometrija” vai ,scientometrija”. Arī šis nosaukums joprojām tiek lietots. Iznāk ar̄̄ elektroniskie žurnāli „Scientometrics” un „Cybermetrics"3. „Cybermetrics” definē sevi kā starptautisku scientometrijas, infometrijas un bibliometrijas žurnālu.

Etimoloǵiski analizējot terminu „bibliometrija”, šķiet, ka š̄̄ nozare pievēršas tikai grāmatās publicētās informācijas analīzei, kā tas pārsvarā arī bija laikā, kad termins tika definēts. Mūsdienās bibliometrija uzskatāma par nozari, kas nodarbojas ar visa veida zinātniskās komunikācijas izpēti.

1994. gadā V. Diodato definē bibliometriju kā ,nozari, kas, lietojot matemātiskos un statistiskos paṇēmienus, pēta publicēšanas un komunikācijas model̦us informācijas zinātnē"'4. 
Infometrija, bibliometrija, scientometrija un vebometrija uzskatāmas par starpdisciplinārām nozarēm, kuru galvenais uzdevums ir pētīt ar informāciju saistîtos procesus.

Dānijas Karaliskās bibliotēku un informācijas zinātnes skolas asociētais profesors Birgers Larsens (Birger Larsen) savā doktora disertācijā piedāvā šādu nozaru savstarpējās pakārtotības shēmu (skat. 1. att.) ${ }^{5}$.

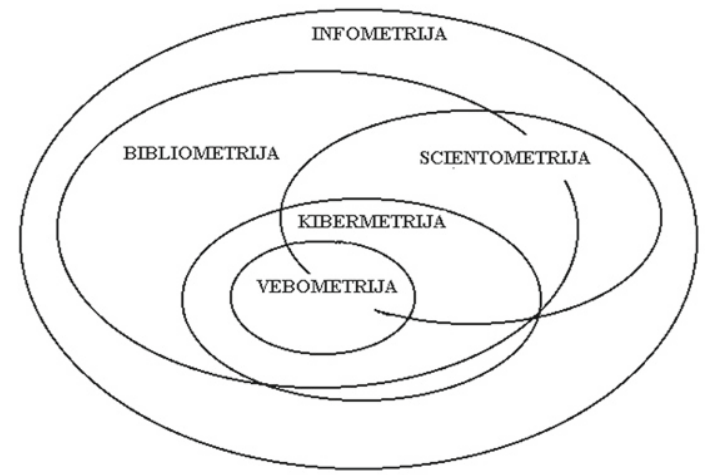

1. attēls. Infometrijas, bibliometrijas, scientometrijas un vebometrijas savstarpējā saistība

Viņš dod šādas infometrijas, bibliometrijas, scientometrijas un vebometrijas definīcijas:

- infometrija - zinātnes nozare, kas pēta jebkuras informācijas formas;

- bibliometrija - zinātnes nozare, kas pēta rakstîtās informācijas izplatības un lietošanas kvantitatīvos aspektus;

- scientometrija - zinātnes kvantitatīvo aspektu pētīšana;

- vebometrija - elektronisko informācijas resursu uzbūves un lietošanas kvantitatīvo aspektu pētǐšana ${ }^{6}$.

Šajā rakstā tiks izmantots termins ,,bibliometrija”, jo tas visprecīzāk atspoguḷo izvirzìtos mērķus.

\section{PIRMIE PĒTĪJUMI, IZMANTOJOT METODES}

Vairumā avotu kā pirmais pētījums, kur izmantota bibliometrija, tiek nosaukts 1917. gadā publicētais F. J. Kola (Cole) un N. Îlsas (Eales) darbs praktiskajā anatomijā, kurā tika apkopotas nozares publikācijas no 1550. līdz 1860. gadam. Tajā tika veikta arī šo publikāciju statistiskā analīze.

Lietuviešu profesore Ona Voveriene grāmatā „Bibliometrija” min kādu citu publikāciju, kura, viņasprāt, uzskatāma par pirmo pētījumu, kurā izmantota bibliometrija kā informācijas kvantitatīvās analīzes metode. Tās autors ir rīdzinieks, ķīmiķis un ķ̄imijas vēsturnieks Pauls Valdens, kurš 1915. gadā, strādājot pie Krievijas ķīmijas vēstures izpētes, analizējis citās valstīs publicētās grāmatas par nozares vēsturi, lai matemātiski aprēķinātu, kuri Krievijas k̦īmiķi tajās visvairāk pieminēti, lai noteiktu katra zinātnieka ietekmes faktoru? 
1927. gadā P. Gross (Gros) un E. Gross (Gros) pirmie sāka izmantot bibliogrāfiskās norādes kā avotu bibliometriskam pētījumam. Viṇi secināja, ka pēc tā, kādi autori un kādi izdevumi visvairāk tiek citēti, var noteikt to ietekmi un vietu nozares attīstībā.

\section{GALVENIE BIBLIOMETRIJAS IZPĒTES VIRZIENI}

Bibliometrija uzskatāma par metožu kompleksu, kurā var izdalīt šādus galvenos izpētes virzienus:

- produktīvā bibliometrija;

- citēšanas analīze;

- bibliometrijas likumi.

\section{PRODUKTİVĀ BIBLIOMETRIJA}

Produktīvās bibliometrijas virziens tiek izmantots, lai ar kvantitatīvām metodēm pētītu zinātnisko publikāciju daudzumu kādā nozarē vai reǵionā noteiktā laika posmā. Šādiem pētījumiem parasti tiek veidotas lielas zinātnieku grupas.

Pirmais lielākais šāda veida pētījums, kas sniedza pārskatu par zinātnes attīstību valstī un bija pamats zinātnes politikas izstrādei, bija ASV Nacionālā zinātnes fonda publicētais ,Zinātnes un tehnolog̣iju rādītājs” (1972. gadā), kas apkopoja skaitliskos datus par zinātniskajām publikācijām valstī iepriekšējā gada laikā.

Pirmās Eiropas valstis, kuras sāka veikt šādus apjomīgus zinātnisko publikāciju pētījumus, bija Lielbritānija un Nīderlande.

\section{CITĒ ŠANAS ANALĪZE}

Citēšanas analīze ir plašs bibliometrijas virziens, kurš pēta, kā dokumenti tiek citēti $^{8}$. Bibliometrijā par citēšanu uzskata to, ja dokuments A ir pieminēts dokumentā B un iekḷauts tā bibliogrāfisko norāžu sarakstā. Šajā gadījumā dokuments A ir citētais dokuments, bet dokuments B - citējošais. No bibliometrijas viedokḷa ieguvējs nenoliedzami ir dokuments A, jo tas sañēmis citējumu.

Citēšanas analīzes pamatā ir pieņēmums, ka raksts, kurš saņēmis vairāk citējumu, ir bijis nozarē nozīmīgākais. Citēšanas biežums ir ne tikai kvantitatīvs rādītājs, bet arī sava veida zinātniskās darbības kvalitātes rādīiājs.

Ir pieņemts, ka pastāv droša pozitīva savstarpēja saistība starp to, cik reizes dokuments citēts, un tā ietekmes kvalitāti. Tie autori, kuri nozarē konkrētā laika posmā visbiežāk citēti citu autoru darbos, tiek uzskatīti par nozīmīgākajiem.

Citēšana veido saistību starp autoriem un rāda, kādā mērā šie autori netieši, ar dokumentu starpniecību savstarpēji sazinās.

Ar citēšanas analīzes palīdzību tiek pētīti:

- zinātniskās komunikācijas model̦i (saikne starp autoriem, kuri viens otru citē savos zinātniskajos rakstos);

- publikāciju un žurnālu izplatība un ietekmes faktors. 
Pētot zinātniskās komunikācijas model̦us, tiek aprēķinātas bibliogrāfiskās un kopcitēšanas saites. Bibliogrāfiskās saites divu dokumentu starpā veidojas, ja tie abi citē vienu un to pašu dokumentu (sk. 2. att.). Bibliogrāfisko saišu stiprumu nosaka dokumentu skaits, kurus abi dokumenti citē vienlaikus.

$$
\text { ( } A, B \text { - citējošie, } C, D, E, F-\text { citētie) }
$$

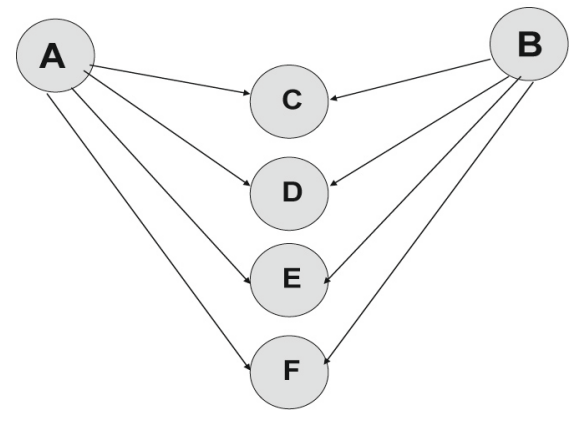

\section{2. attēls. Bibliogrāfisko saišu veidošanās starp diviem dokumentiem (A un B)}

Kopcitēšanas saites rāda, cik bieži divi dokumenti tikuši citēti kopā (sk. 3. att.). Tās parāda, cik radniecīgi ir abi šie dokumenti.

$$
\text { (A,B - citētie, C, D, E, F - citējošie }
$$

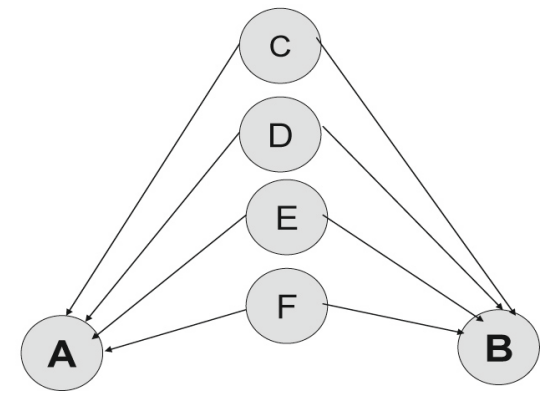

\section{3. attēls. Kopcitēšanas saišu veidošanās starp diviem dokumentiem (A un B)}

Citātu analīze tiek veikta, izmantojot bibliogrāfiskās datu bāzes. Pirmās citēšanas datu bāzes (tās ietver arī reǵistrēto tekstu bibliogrāfisko norāžu sarakstus) sāka veidot Zinātniskās informācijas institūts (Institute for Scientific Information (ISI)). Šādas datubāzes izveidošanas iniciators bija Jūdžins Garfîlds (Eugene Garfield). Lai izvēlētos pašus nozīmīgākos zinātniskos žurnālus, ko tajā iekḷaut, tika izmantots Bredforda likums. Kā viens no kritērijiem tika izvirzìts saņemto citējumu skaits, aprēķinot žurnāla ietekmes faktoru (impact factor), ko iegūst, dalot žurnālā iekḷauto rakstu saņemto citējumu skaitu ar kopējo rakstu skaitu ${ }^{9}$.

\section{BIBLIOMETRIJAS LIKUMI}

Visplašāk lietotie ir šie trīs bibliometrijas likumi:

1. Lotkas likums (1926. g.) - zinātnieku produktivitātes aprēķināšanai; 
2. Bredforda likums (1934. g.) - zinātniskās informācijas izkliedes aprēķināšanai;

3. Cipfa likums - vārdu biežuma izpētei tekstos.

\section{BIBLIOMETRIJAS PRAKTISKĀS PIELIETOŠANAS IESPĒJAS}

Bibliometrija kā pētniecības metožu kopums veiksmīgi tiek izmantota zinātniskās informācijas mērīšanai gan tradicionālajā, gan elektroniskajā formā. Tā sniedz pārskatu par nozaru attīstību kopumā, palīdz atklāt attīstības tendences atsevišşās zinātṇu nozarēs un pētīt zinātniskās komunikācijas model̦us.

Bibliometrija tiek izmantota tezauru veidošanā.

Praktiskajā darbības sfērā - bibliotēkās - bibliometrija var būt lielisks palīgs krājuma komplektēšanas procesā. Palielinoties gan drukāto, gan elektronisko informācijas resursu daudzumam (un arī to cenām), ir svarīgi izvēlēties pašus vērtīgākos resursus. Lai zinātniskās bibliotēkas varētu izvēlēties no plašā publikāciju klāsta visnozīmīgākās, var izmantot gan bibliometrijas likumus (Bredforda likums, lai noteiktu, kuri zinātniskie žurnāli satur nozīmīgākās publikācijas), gan citēšanas analīzi (nozīmīgākie būs tie autori, kuri tiek visbiežāk citēti).

Grāmatām to nozīmīgumu var uzzināt tikai retrospektīvi - tad, kad konkrētā grāmata nopirkta. Tomēr iespējams prognozēt iegādājamās zinātniskās literatūras nozīmīgumu, pētot autora iepriekšējo publikāciju citējamību ${ }^{10}$.

Citādi tas ir ar nozaru zinātniskajiem periodiskajiem izdevumiem - izpētot to ietekmes faktoru, ir iespējams diezgan droši prognozēt, kuri izdevumi būtu iekḷaujami bibliotēkas krājumā.

\section{IZMANTOTIE INFORMĀCIJAS AVOTI}

1. Cybermetrics : International Journal of Scientometrics, Infometrics and Bibliometrics [online] Available: http://www.cindoc.csic.es/cybermetrics/journal.html

2. Diodato, Virgil. Dictionary of bibliometrics. New-York : The Haworth Press, 1994. 183 p. ISBN 1560248521.

3. Hjørlands, Birgers Darbības lauka (domēna, nozares) analīze bibliotēku un informācijas zinātnē : prezentācijas materiāls. 2006.

4. Larsen, Birger. References and citations in automatic indexing and retrieval systems : experiments with the boomerang effect : $\mathrm{PhD}$ dissertation Copenhagen: Department of Information Studies, Royal School of Library and Information Science. XIII, 297 p. ISBN: 87-7415-275-0.

5. Meadows, Jack. A practical line in bibliometrics. Interlending \$ Document Supply, No. 33/2, 2005. 90 - 94 pp. ISSN 0264-1615.

6. Pritchard A. Statistical Bibliography or bibliometrics? Journal of Documentation. 1969, 25(24). p. 348-349.

7. Voveriene, Ona. Bibliometrija. Vilnius, 1999. ISBN 9986-479-50-9.

8. Wormel, Irene. Informetrics: an emerging subdiscipline in information science. Asien Libraries, Volume 7, No. 10, 1998. 257-268 pp. 


\section{ENDNOTES}

1 Hjørlands, Birgers Darbības lauka (domēna, nozares) analīze bibliotēku un informācijas zinātnē : prezentācijas materiāls. 2006.

2 Pritchard, A. Statistical Bibliography or bibliometrics? Journal of Documentation. 1969, 25(24). p. 348-349.

3 Cybermetrics : International Journal of Scientometrics, Infometrics and Bibliometrics [online] Available: http://www.cindoc.csic.es/cybermetrics/journal.html

4 Diodato, Virgil. Dictionary of bibliometrics. New-York: The Haworth Press, 1994. p. 33. ISBN 1560248521.

5 Larsen, Birger. References and citations in automatic indexing and retrieval systems : experiments with the boomerang effect : PhD dissertation Copenhagen: Department of Information Studies, Royal School of Library and Information Science. XIII, 297 p. ISBN: 87-7415-275-0.

${ }^{6}$ Larsen, Birger. References and citations in automatic indexing and retrieval systems : experiments with the boomerang effect : $\mathrm{PhD}$ dissertation Copenhagen: Department of Information Studies, Royal School of Library and Information Science. XIII, 297 p. ISBN: 87-7415-275-0.

7 Voveriene, Ona. Bibliometrija. Vilnius, 1999. ISBN 9986-479-50-9.

8 Diodato, Virgil. Dictionary of bibliometrics. New-York:The Haworth Press, 1994. p. 33. ISBN 1560248521.

9 Diodato, Virgil. Dictionary of bibliometrics. New-York : The Haworth Press, 1994. p. 83. ISBN 1560248521.

10 Meadows, Jack. A practical line in bibliometrics. Interlending \$ Document Supply, No. 33/2, 2005. 90-94 pp. ISSN 0264-1615. 


\title{
Bibliotēka kā izziņas palīginstruments
}

\author{
Baiba Sporāne \\ Latvijas Universitāte
}

Bibliotēkas pastāvēšanai šobrīd izvirzās vairākas dilemmas. Viena no tām, pati būtiskākā - kādam konceptuālam priekšstatam (tātad - arī konceptuālajai stratēgijai un taktikai) par bibliotēku jādod priekšroka. Vai bibliotēka ir vieta, kurā indivīdi (iedzīvotāji) atnāk un saņem izdevumus lasīšanai mājās, vai arī vieta, kurā kopā savāktas grāmatas, dažādi mediji, interneta resursi (gan materiālā formā uz vietas, gan virtuāli - attālinātai pieejai) un kurp mēs varam doties (atkal - fiziski vai virtuāli) vai pieslēgties un profesionāls personāls palīdzēs mums piekḷūt un iegūt nepieciešamās artikulētās vai neartikulētās zināšanas. Autoresprāt, bibliotēku konceptuāli jāvērtē šajā pēdējā aspektā - gan kā izziņas instrumentu, gan izziņas procesu, gan izziņas rezultātu, nevis tikai kā grāmatu izsniegšanas vietu. Apgalvojumu iespējams pierādīt, analizējot tā struktūras elementus jeb četras sastāvdaļas (sk. 1. att.):

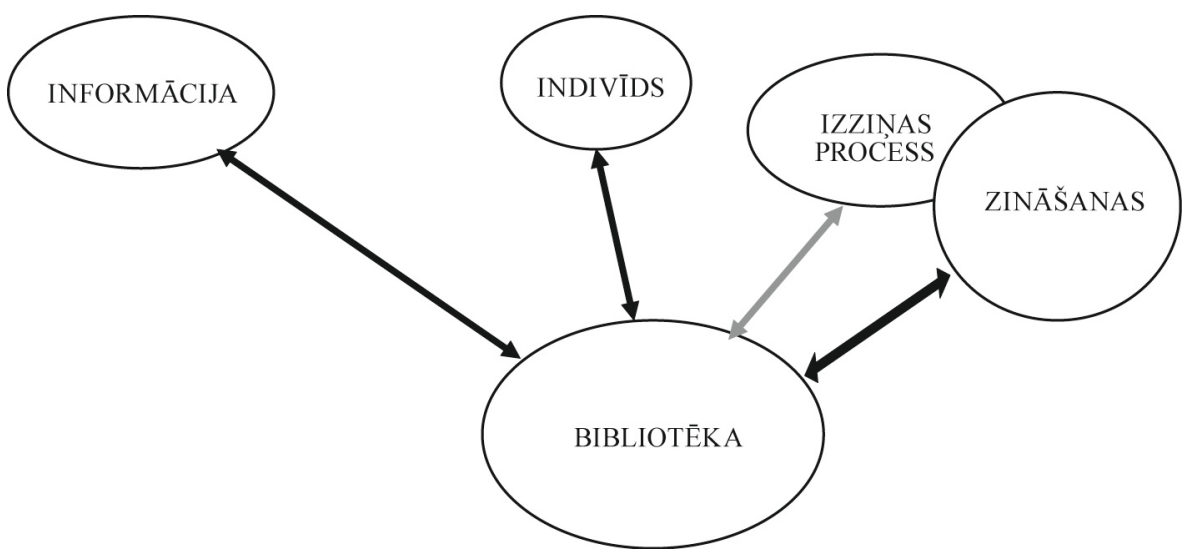

1. attēls. Apgalvojuma struktūra

Informācija - apgalvojuma pirmā komponente - ir zināšanas, kas ievadītas komunikācijās. Informācija veidojas gan no artikulētajām zināšanām (fiksētas uz materiāliem nesējiem), gan neartikulētām (glabā un publisko indivīds kā informācijas avots). Informācija eksistē kā neatkarīga komponente un rosina izziṇas procesu, kas savukārt nodrošina indivīda dzīvotspēju. Process ir divvirzienu, jo izgūta un izmantota informācija atgriežas izziņas sistēmā kā jauns zināšanu avots.

Indivīds - personība, kam š̄̄ informācija nepieciešama dzīves cikla nodrošināšanai. Personība izziņas procesā veido savstarpējo saiti starp informāciju 
(zināšanām) un bibliotēku, kurā š̄ informācija iegūstama. Personība darbojas arī kā jaunu zināšanu un informācijas radītāja, kuras nonāk bibliotēkā tālākai apstrādei, sakārtošanai un iekḷaušanai izguves sistēmās indivīdu nākamo vajadzību apmierināšanai. Arī personība, tāpat kā informācija, nodrošina divvirzienu izziņas procesu, tikai informācija ir pasīvā komponente, bet personība - aktīvā.

Izziņa, izziņas process. Mācība par izziņu pamatojas uz subjekta un objekta pretstatı̌šanu - subjekts tiecas izskaidrot objektu (6). Izziņa, pirmkārt, ir aktīva, radoša apziņas darbība, kuras mērķis ir adekvāts īstenības atspoguḷojums izziņas tēlos jeb pasaules ainas radīšana indivīda apziņā. Otrkārt, izziņa raksturojama kā indivīda attiecību veidošana ar pasauli, meklējot zināšanas, to skaitā $A R \bar{I} A R$

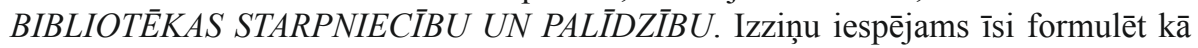
indivīda (arī lietotāja, lasītāja) attiecību veidošanu (izziņas process bibliotēkā) ar pasauli, meklējot zināšanas. Izziņas procesa rezultātā rodas zināšanas.

Zināšanas - indivīda informācijas telpā izgūtās informācijas izmantošanas produkts, t.sk. arī AR BIBLIOTEEKAS STARPNIECİBU - informācijas kopums, ko indivīds apguvis savas dzīves laikā, logiiski pierādāms, praksē pārbaudāms izziṇas rezultāts. Zināšanas ir adekvāts esamības atspoguḷojums, kas veido katras pārliecības, hipotēzes un teorijas saturu. Zināšanas, ievadītas komunikācijās, veido informāciju. Zināšanu dabas analīzi uzsāka jau antīkie filozofi Sokrāts, Platons un Aristotelis (1). Sokrāts uzskatīja, ka izziņas process sākas ar sevi, sevis izzināšanu, Platons - ka nopietnām zināšanām, kas iegūtas izziṇas procesā, jābūt patiesām, bet Aristotelis ka izziņas procesā iegūtās zināšanas ir norišu un lietu izskaidrojums.

Viduslaiku filozofiskajās mācībās tika sludināts, ka pastāv cilvēka vienotība ar pasauli, tādēl katra objekta vērtību var izzināt Dieva noteiktajā lietu kārtībā, ja tic Dievam. Lai zinātu, vajag ticēt Dievam un saprast viņa radīto pasauli. Ja ir ticība, nevajag izziṇu. Ticībā nav iespējama subjekta un objekta pretnostatīšana, jo tā virzās uz pretstatu likvidēšanu.

Jauno laiku filozofijā pētnieki atgriezās pie antīkās pasaules atzin̄ām. Antīko filozofu mācību par zināšanu dabu turpināja G.V.F.Hēgelis (Georg Wilhelm Friedrich Hegel) (2). Viņš uzskatīja, ka īstenība ir process, bet zinātniski teorētiskās zināšanas - vēsturiskās attīstības produkts. Pētnieki izstrādāja gan empīrisko izziņas metodi (zināšanu avots - pieredze), gan racionālo izziņas metodi (zināšanu avots - prāts un ar to saistītā domāšana), gan apvienoja prāta un pieredzes darbību vienotā zināšanu avota skaidrojumā (5). Zināšanas ir ideālas, tādēḷ tām nepieciešama objektivizācija, kas realizējas darba produktos, tehnoloǵijās, sociālos institūtos, kultūras priekšmetos. Zināšanas objektivizējas ar dabisko un mākslīgo valodu zīmju simboliskiem līdzekliem. Ar rakstîbas un grāmatiespiešanas rašanos un attīstību šis objektivizācijas veids kḷūst par visizplatītāko un adekvātāko zināšanu fiksācijas un vēsturiskās translēšanas paṇēmienu. Ar datortehnikas un elektronisko komunikāciju sistēmu attīstību arvien lielāku nozīmi iegūst tādi zināšanu fiksēšanas paṇēmieni kā datubāzes, elektroniskie katalogi, portāli, informācijas sistēmas. Īpaša zināšanu esamības forma - personiskās zināšanas, kas iegūst arvien lielāku izmantojamību līdz ar ekspertsistēmu attīstību. Apgūstot esošās zināšanas, indivīds tās pārvērš savās spējās, profesionālajā kompetencē, domāšanas radošajā spēkā, kas savukārt kḷūst par bāzi jaunām zināšanām, ko ievada komunikācijās. Zināšanu attīstības procesiem raksturīga kustība no nezināšanas uz zināšanām. 
Bibliotēka augšminētajā apgalvojuma struktūrā ieņem palīginstrumenta vietu, ir saistīta ar visiem elementiem un ir bāze sistēmas funkcionēšanai, pati iekḷaujoties šajā sistēmā kā starpnieks un izziņas instruments, process un rezultāts. Bibliotēka pilda cilvēces fiksētas atmiņas lomu, jo darbojas gan informācijas, gan indivīda, gan izziņas nodrošināšanā. Bibliotēka, pati būdama sarežğīta informācijas sistēma, kā sistēma kopumā kalpo par izziņas bāzi un rada jaunu resursu izziņai. Bibliotēkā norit esošo zināšanu sakārtošanas, izguves nodrošināšanas, jaunu zināšanu savākšanas un sakārtošanas process, kas kopumā tiek izmantots kā indivīda izziņas palīginstruments.

Raksta sākumā izziņa raksturota kā aktīva, radoša apziņas darbība, kuras mērķis ir adekvāts īstenības atspoguļojums izziņas tēlos. Turpinot aizsākto raksturojumu, jāmin, ka pastāv vairāki izziņas veidi - uz ārpasauli vērsta izziņa, uz indivīda iekšējo pasauli vērsta izziņa un uz pašu izziņas procesu vērsta izziņa, to pēta izziņas teorija, ko sauc par epistemoloǵiju. Uz ārpasauli vērsta izziņa ietilpst visu eksakto un sociālo zinātņu sfērā, uz indivīda iekšējo pasauli vērsta izziņa ietilpst psiholoǵijas un citu zinātņu sfērā, kas pēta cilvēka apziņas struktūras, uz pašu izziņas procesu vērstā izziņa ietilpst epistemolog̣ijas pētījumu sfērā. Braiens Megi (Magee Bryan) grāmatā "Filozofijas vēsture" skaidro, ka epistemologija ir izziņas teorija jeb filozofijas nozare, kas pēta, ko un kā mēs varam zināt un vai vispār mēs kaut ko varam zināt, kā arī, kas īsti ir zināšanas (8).

Gadsimtu gaitā izziņas teorijas un pats izziņas raksturs ir mainījies. Līdz 20.gs. sākumam var runāt par klasisko izziņas teorijas posmu, bet nākamais periods iezīmējas ar neklasisko jeb moderno priekšstatu ieviešanos.

Klasiskais priekšstats nozīmē, ka izziņas procesa attīstības gados izziņa tika uzskatīta par veidu, kā iekḷūt nepieejamajā, esamības būtībā. Tika atzīta augstākas absolūtas esamības pastāvēšana, izziņai tikai jāpārvar šķēršļi, ko tai rada jutekḷi un aplamie prāta slēdzieni. Izzināt nozīmē iekḷūt fenomena būtībā, attēlot to ideālā formā un pārvērst reālas darbības shēmā, respektīvi atpazīt, uzzināt. Gnostiķi arī nenoliedza absolūtās esamības pastāvēšanu, taču uzskatīja, ka to nevar izzināt ar jutekḷiem un prāta slēdzieniem. Agnosticisms kā mācība par neiespējamību gūt ticamas zināšanas (kuru patiesums ir pierādāms) postulēja, ka mums nav pamata runāt par materiālu substanci (arī par garīgu substanci nē - par garu vai Dievu), nedz arī par mūsu prātu. Viss, kas ir dots, ir impresijas, iespaidi. Uzskati, ka pastāv mūsu prāts un ārējā pasaule, ir ticības lieta, nevis pierādījums (13). Klasiskajā epistemologijā izziņas process tiek aplūkots kā subjekta (tā, kurš izzina, indivīda, arī - lasītāja/lietotāja) un objekta (tā, kurš tiek izzināts, - pasaule, zināšanu kopums, sakrātu zināšanu bāze bibliotēkas veidolā, tās krājums) MIJIEDARBĪBA. Par izziņas sākumpunktu izvēloties objektu, tas pats nosaka subjekta meklējumu virzienu un izziņas procesa raksturu. Saskaņā ar Platona mācību (9) patiesās zināšanas objekts nāk no ideju, nekustīgu ideālu formu pasaules. Objekts pats nosaka ne tikai izziņas procesu, bet arī paša izzinošā subjekta īpašības. Izziņas process šeit ir kā pazīšana, dvēseles atcerēšanās par sastapšanos ar ideālo formu pasauli. Subjekts ir iekšēji radniecīgs, piederīgs objektam, starp tiem nav plaisas, tie abi ir pasaules veseluma dal̦as, tādēl izziņas process vienlaikus ir viens no veidiem, kā atjaunot pasaules veselumu. Tātad varam secināt, ka klasiskajā epistemoloǵijā subjekta (indivīda, lasītāja/lietotāja) - objekta (zināšanu) mijiedarbībā piedalās bibliotēka - piedalās izziņas procesā kā instruments, process un rezultāts. 
Neklasiskais priekšstats. Otrā izziņas tradīcija jeb veids ir saistīts ar jaunā laika filozofijas priekšstatiem. Šajā gadījumā teorija ir orientēta uz izzinošo subjektu (uz lasītāju jeb indivīdu). Taču tas nav empīriskais subjekts - konkrētais cilvēks (vai konkrētais lasītājs), kam ir savas uztveres īpatnības, neatkārtojama dvēseles struktūra. Tas ir "tīrais subjekts", īpašā veidā iekārtots izziņas spējas nesējs, subjekts, kurā nemājo citas vēlēšanās kā vien vēlēšanās zināt, nekādu citu uzmanības vērtu spēju kā vien izziņas spējas. Subjekta izzinošo spēju analīze (informācijpratība) dod atslēgu uz izzināmo objektu (bibliotēkas misijas un krājuma un zināšanu izpratne caur subjektu). Subjektā viss ir iekārtots tā, lai viņa apziņas struktūrās varētu atspoguḷot universālo pasaules kārtību (kas savukārt atspoguļotu bibliotēkas kā objekta uzkrātās zināšanas kopumā). Pasaule eksistē saskaņā ar prātam aptveramiem likumiem, un šajā gadījumā izziṇa nav vienkārši pazišsana vai atcerēšanās. To var saukt par reproducēšanu (atspogulošanu) vai konstruēšanu. Konstruēšanas raksturu noteic indivīda apziņā esošās apriorās pirmspieredzes struktūras (5). Tā ir pasaules konstruēšana no zināmām detaḷām, kuras procesā piedalās bibliotēka kā konstruēšanas procesa palīginstruments.

Pastāv vēl viena epistemoloǵijas tradīcija, kas aplūko zināšanu izpratni jeb izziṇu kā subjekta un objekta objektivētu mijiedarbību. Šīs koncepcijas ietvaros izziṇas rezultātu nav iespējams sadalīt subjekta un objekta aktivitātēs. Izziṇa ir pasaulē veikto indivīdu darbību kondensēta (savērsta, saritināta) forma, kas sniedz iespēju izzināt objektu, pie tam konkrētā sociālvēsturiski determinētā formā, kas izziņai uzliek savus ierobežojumus. Kā vienu no šì izziņas modeḷa paveidiem var uzskatît marksistisko izziņas teoriju, kam raksturīgas klasiskā izziņas veida iezīmes. Pastāv kontrolējošā instance - pašapzināšanās, kas veido saikni nevis starp subjektu un objektu, bet starp iekšējo un ārējo aktivitāti. Cilvēka priekšmetiskajai aktivitātei kā izziņas pamatam piemīt vēsturiski noteiktas īpatnības. Tomēr pilnīgas un pabeigtas zināšanas tēls, kā arī piln̄̄ga izziņas subjekta tēls saglabājas arī šajā izziņas teorijā. Nākotne, sabiedrībai pārvarot iekšējās pretišksības, indivīdi, atbrīvojušies no šķiru, nacionālajiem un individuālajiem ierobežojumiem, patiesi kḷūs par universāliem izziņas subjektiem, kas, mijiedarbojoties ar bibliotēkās apkopoto, sakārtoto un piedāvāto izziņas objektu jeb zināšanām, atklās sev pasauli visā tās pilnībā.

Otrs šāda izziṇas model̦a paveids - evolucionārā (ǵenētiskā) epistemoloǵijas teorija (12). Saskaņā ar šo teoriju, nav principiālu atšķirību starp cilvēka un dzīvnieka izziņas darbību. Tā ir īpaša attiecību strukturēšanas forma starp organismu un vidi. Cilvēka izziṇas aparāts un infuzorijas kustības principā pakḷautas vieniem un tiem pašiem likumiem, izziṇas uzdevums - saglabāt līdzsvaru starp vidi un organismu. Izzinošā darbība - tā ir adaptīvā darbība, kas izveidojusies ilgā evolucionārās attīstības posmā. Apziṇa darbojas kā nepieciešams izziṇas kā pielāgošanās formas videi elements. Šāds funkcionāls indivīda izzinās aktivitātes traktējums ir vērsts uz cilvēka un dabiskās vides attiecībām un neietver skaidrojumu personības izzinošajām aktivitātēm, kas izpaužas radošajā, kultūras un sociālajā sfērā.

Līdz ar 20.gadsimtu nemainīgā absolūtā objekta, subjekta un objektīvās realitātes jēdzieni un to attiecības kā izziṇas priekšnoteikums zaudē strikti izstrādātās aprises. Šaubām tiek pakḷuta mūsu vērtējošās institūcijas - apziņas - bezkaislība. Notiek jaunu izziñas pamatu un pamatinstrumentu meklējumi - hermeneitikā, fenomenolog̣ijā, aksiologiijā un semiotikā (10). Izziņas process tiek aplūkots no 
cilvēka-pasaules, kā arī no cilvēka-sabiedrības attiecību aspekta. Jaunu izziņas ideju tapšana notiek galvenokārt urbanizācijas rezultātā. Lielajās pilsētās vairs nav kopēja centra, tās atgādina labirintu vai skudru pūzni. Notiek vispārpieņemto normu, kas regulē realitātes uztveres, izpratnes un novērtēšanas procesu, inflācija. Lielpilsētas iedzīvotājs ir spiests veikt lielu vienota tēla savākšanas darbu - no dažādām detaļām. Bijušo apzinātā un neapzinātā, acīmredzamā un acīm neredzamā robežu sabrukšana saasina iztēli, bet kopējā ideologiskā un politiskā horizonta trūkums - palielina konteksta nozīmi. Pilsēta atslogo domu un pārslogo redzi. Relatīvisms, nejaušība kā mūsdienu domāšanas un zināšanu apgūšanas stila iezīmes nav intelektuālās darbības un izziņas darbības apzināts produkts, tās rodas ikdienības līmenī.

Iezīmējas zibšņu kultūra un zibšņveida izziņa - spontāns, uzplaiksnījumveida izziņas process, kas nebalstās uz secīgu, ilgstošu un laikā nepārtrauktu izziņas procesu. Autoresprāt, izvirzāms apgalvojums, ka dabā un cilvēka apziñā liktās pamatstruktūras ir elastīgas, arī iepriekšminētajās formās tiktāl saskanīgas, lai pasauli būtu iespējams izzināt, tikai šajā procesā nepieciešams izziņas palīginstruments, kas nodrošinātu izziņas procesu, procesa norises gaitā savāktu jaunizstrādātās zināšanas un tās savukārt piedāvātu izziņai jeb ievadītu informācijas apritē. Šāds palīginstruments izziṇas procesā ir bibliotēka - gan kā zināšanu savācēja, gan sakārtotāja, piedāvātāja un jaunu vērtību radītāja. Mūsu eksistence paredz noteiktu saskaņu ar pasauli, citādi mēs nevarētu eksistēt. Taču atškirīibā no citām dzīvām būtnēm, kam šì ierakstītība pasaulē ir dota iedzimtības ceḷā (izziņas procesi notiek instinktīvi, bez refleksijas par tiem), indivīds ir apveltìts ar kvalitāti, kas vinu gan šķir no pasaules, gan dod iespēju eksistēt tajā uz citiem, metafiziskiem noteikumiem. Prāts, gudrība un apzināts izziņas process šim nolūkam speciāli radītā institūcijā ir kvalitāte, kas cilvēku padara par indivīdu. Cilvēkam saskaņa ar pasauli jāsasniedz izziṇas procesā, izmantojot visu iepriekšējo paaudžu uzkrāto pieredzi, cilvēces atmiņu - uz valodas bāzes un izmantojot bibliotēku kā palīginstrumentu šîs pieredzes apzināšanā, filtrēšanā un tālākizmantošanā.

Epistemologiija pēta izziņas procesus attiecībā uz pirmās pakāpes informācijas plūsmu, tad bibliotēkai kā indivīda izziņas procesa palīginstrumentam ir saistība ar otrās pakāpes informācijas plūsmu - zīmju sistēmā kodētu informāciju, kas fiksēta uz ilgmūžīga materiāla. Bibliotēka ir plaši pieejama, veic tiražētas informācijas glabāšanu un izplatīšanu pēc iespējas lielākam l̦aužu lokam, piedalās zināšanu uzkrāšanā, sakārtošanā, izplatīšanā un jaunu radīšanā, resp., kalpo kā izziņas procesa palīginstruments (sk. 2. att.).

Ar šì palīginstrumenta palīdzību mēs pārejam no izziņas izpratnes uz bibliotēkas izpratni.

Bibliotēkas izpratnes aspekti. Komunikācija ar bibliotēku un tās saturu - grāmatu (visās materiālas izpausmes formās!) ir indivīda izziņas un intelektuālās attīstības augstākā forma.

GNOZEOLOĢISKAIS aspekts nozīmē izzināt bibliotēkas vietu indivīda izziņas procesā un zināšanu asimilācijas procesā, informācijas izplatīšanā un mantojuma saglabāšanā un nodošanā nākamajām paaudzēm, uzziṇu vai zināšanu apguves vieta. Bibliotēku apzinām kā homo sapiens informacionālās atmiņas un pieredzes uzkrāšanas un izzināšanas vietu. 


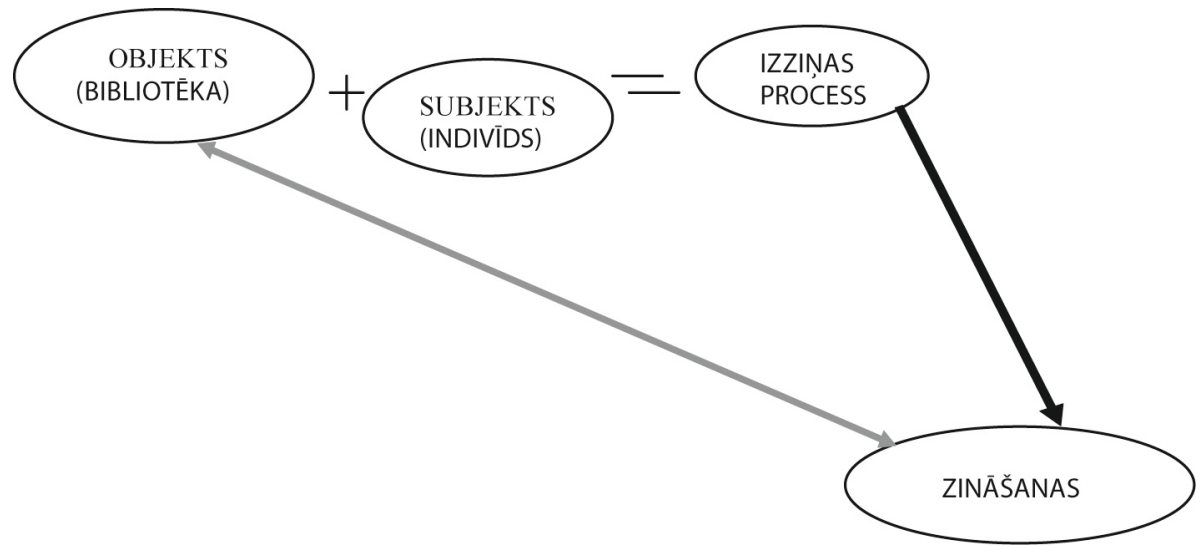

2. attēls. Bibliotēkas un izziņas procesa atgriezeniskā saistība

AKSIOLOGISKAIS aspekts - bibliotēka kā fenomens, kas ietver kultūras, sociālās un saskarsmes vērtības.

FENOMENOLOGISKAIS aspekts. Fenomenologija - mūsdienu filozofijas mācība par apziņas parādībām, viens no izziņas teorijas galvenajiem virzieniem. Vārds fenomenologija cēlies no vārda fenomens (grieķiski phainomen), kas burtiskā tulkojumā nozīmē tas, kas rādās, parādās.

Fenomens:

1. parādība, kas sevi atklāj;

2. sevī noslēgta, pašpietiekama, tālāk neatvasināma garīga apziṇas izpausmes forma;

3. reta, neparasta, sevišksa parādība (4).

Fenomenologiju kā jaunu filozofisko virzienu 20.gs. sākumā izstrādāja vācu filozofs Edmunds Gustavs Albrehts Huserls (E. Husserl) (3). Viņš norādīja, ka objekti mūsu apziņā pastāv tādi, kādi tie mums šķiet, neatkarīgi no tā, vai tiem piemīt vai nepiemīt cita veida esamība. Tādēl mēs tos varam izpētît, lietojot stingrus likumus, un savos spriedumos neņemt vērā objektu iespējamo esamību. Fenomenologijija pēta objektus tādus, kādi mums tie šksiet (6).

Fenomenolog̣ijas pamatjautājumu var formulēt šādi: kas ir cilvēka apziņa, kāda ir tās struktūra un veidotie priekšstati?

Fenomenoloğija pievēršas parādībām jeb fenomeniem kā izziņas un uztveres objektiem, nevis kā neatkarīgi eksistējošiem faktiem un notikumiem, cenšoties izzināt, kādā veidā cilvēki domā par apkārtējo pasauli un kā viņi to izskaidro. Pretstatā pozitīvismam, fenomenoloǵija uzskata, ka realitāte pēc savas būtības ir relatīva (tāda, kas pastāv un mainās atkarībā no apkārtējiem apstākḷiem) un subjektīva.

Parādības, ko aplūko fenomenoloǵija, ir cieši saistītas ar būtībām. Parādībai jeb fenomenam tiek piešķirts būtības statuss, t.i., parādība pati par sevi ir kaut kas vērā ņemams, tai ir sava esamība. Fenomens sevi atklāj caur sevi pašu. Tam, ko dzird, redz un pārdzīvo cilvēks, ir sava realitāte (3). 
Fenomenolog̣ija ir pretstats naturālistiski, uz vienkāršu dabas skaidrojumu orientētajām zinātnēm, jo tā interesējas par cilvēka apziņā un tās apkārtnē jeb cilvēka pasaule notiekošo. Cilvēka pārdzīvojumu pasaule atškiiras no pasaules ainas, par kuru runā dabaszinātnes. Piemēram, mēs redzam zibeni, bet pērkona grāvienu dzirdam pēc ilgāka laika. Tas, ka pērkons atskan vēlāk, ir parādība, jo būtībā zibens un pērkons ir vienlaikus, mums tikai šksiet, ka grāviens noskan vēlāk. Fenomenoloǵija nerunā par pērkona grāviena un zibens saistību no dabaszinātņu viedokḷa, bet gan parāda cilvēka uztverē notiekošo, pērkona grāviena pārdzīvojumu un tā jēgu cilvēka apzin̄ā. Fenomenologiski aplūkotā parādība jeb fenomens ir nozīmīgs cilvēku dzīves pasaulē pats par sevi (3).

Fenomenologiija nepazīst objektu ārpus apziņas, kuru varētu izzināt. Tā ir mācība par apziņas fenomeniem. Mūsu uztvere, fantāzijas tēli un atspoguḷojumi, domāšanas akti un sajūtas - tas viss būtībā ir apziņas saturs jeb mūsu pārdzīvojumi.

Fenomenologiija palīdz saprast, ka ne katru priekšmetu var uztvert kā fenomenu. Fenomena rašanos l̦oti skaidri parāda gruzīnu filozofs Merabs Mamardašvili (Мераб Мамардашвили): "Nekas nav fenomens. Kaut kas var tikai kḷūt par fenomenu. Un tikai ar vienu nosacījumu: ja starp mani un rozi (vai tintnīcu) ir kaut kas noticis. Ja starp mani un priekšmetu nav notikusi tikšanās, nav iespējams prasīt, lai es izdzirdētu tā balsi" (7, 96.lpp.).

Notikums starp cilvēku un priekšmetu būtībā ir priekšmeta jēgas rašanās un aptveršana apziņā. Fenomenoloǵiju interesē mūsu apziņas iespējas, nevis no apziñas neatkarīga ārpasaule. Piemēram, katram cilvēkam var veidoties savs priekšstats par bibliotēku. Veidi, kā cilvēki uztver nozīmi „bibliotēka”, var būt ļoti atšķirīgi. Kādu cilvēku bibliotēka saista ar apziņu par to, ka tajā ir iespējams saņemt visus nepieciešamos materiālus darbam vai studijām, bet cits bibliotēku saistīs ar nepieklājīgu un neviesmīlīgu bibliotēkas garderobisti. Vēl citam nebūs sava priekšstata par bibliotēku, jo viņš savā dzīvē ar tādu nekad nav saskāries. Līdz ar to jāatzīst, ka nav stingri dotas, ārpus apziņas fiksētas nozīmes „bibliotēka”. Pastāv pati reālā celtne ar tās telpām un iekārtojumu, bet fenomenolog̣ija nerunā par bibliotēkas ēkas arhitektūru vai iekārtojuma stilu, bet gan par apziņas filozofiju.

Centrālais jēdziens fenomenoloǵijā ir apziņas intencionalitāte, tas ir, vērstība uz objektu, bet ne attieksme pret reālu empīrisku objektu ārpus apziņas. Fenomenologijija nepazīst empīrisko pieredzi. Priekšmeti atklāj savu nozīmi mūsu apziņai bez kaut kādas saistības ar pieredzi vai praksi (6).

Galvenās fenomenologijas metodes ir fenomenologiskā redukcija - atteikšanās no spriedumiem par realitāti ārpus subjektīvās pieredzes - un transcendentālā (visplašākā, vispārīgākā) redukcija - izziṇas subjekta kā „tīras” transcendentālas apziņas aplūkošana (6).

Fenomenolog̣ijā ir svarīgi, kā cilvēks priekšmetu uztver, pārdzīvo, ienes savā saprašanas laukā, ko nozīmē vārdi, kā tie ieklaujas cilvēka dzīves pasaulē. Fenomenoloǵija - iekšējas pieredzes filozofija. Mēs iedziļināmies mūsu pašu radītājā pasaulē. Mēs paši radām savu jēgpilno pasauli un pārdzīvojot atpazīstam to, ieliekam tajā sevi. Pēc E.Huserla domām, nevienam nav aizliegts pētīt cēloņus un reducēt lietas uz to izcelšanos, kā to dara vairākums zinātņu, taču ar šādu pieeju nevar izsmelt fenomenus to dziḷākajā būtībā (3). 
Ideja par to, ka apziņā ir priekšmetiskums, ir viena no galvenajām fenomenologiijas tēzēm. Apziņa vienmēr ir apziṇa par ... Apziņa ir vērsta uz kaut ko. Noskaidrojot, uz ko ir vērsta apziņa, tiek atbildēts uz jautājumu kas?

Fenomenoloǵija vēršas pret redukcionistisku pieeju. Redukcionisms nozīmē lietas būtību nesaskatīt pašā lietā, bet reducēt, tas ir, attiecināt uz kaut ko citu. Piemēram, ja mēs X pilsētas bibliotēkā sastapām nelaipnu garderobisti, mēs nedrīkstam izdarīt secinājumu, ka tāpat mūs uzņems X pilsētas citās bibliotēkās vai Y pagasta bibliotēkā. Katra bibliotēka ir jāuztver tās pašas esamībā, tās izpausmes ir jāpieņem kā fenomens (parādība, kas sevi atklāj). Ja bibliotēkā ir nelaipns apkalpojošais personāls, tad bibliotēka tāda arī ir. Bibliotēka ir jāsaprot, vadoties no tās pašas izpausmēm, nevis jāreducē uz neskaitāmām cēloṇu un apstākḷu sakritībām.

Fenomenoloǵija māca jaunu domāšanas veidu - virzịt apziṇu tā, lai neapēnotu neviena tēla pašvērtîbu. Tā neḷauj, piemēram, bez iedziḷināšanās secināt, ka Latvijas valstij nav nekādas jēgas, jo tā ir maza valsts. Latvijai ir pašvērtība, jo tā pastāv un cilvēku dzìves pasaulē tai ir noteikta jēga. Mēs nedrīkstam izdarīt secinājumu, ka maza pagasta bibliotēka ir nevajadzīga, jo tās dokumentu krājums ir neliels. Taču arī šai bibliotēkai ir pašvērtība, tā pastāv, un noteikti pastāv arī cilvēki, kuriem tā ir vajadzīga.

Tagad atgriezīsimies pie jautājuma par bibliotēkas fenomenu. Bibliotēka - reāls fenomens, pārdomu objekts, parādība, kas jāizprot, lai varētu nešaubīties par tās tiesībām pastāvēt.

Bibliotēka mūsdienās cilvēkiem rada dažādas asociācijas un priekšstatus: viens bibliotēkā saskata tikai grāmatu krātuvi, cits bibliotēkā kā saistošu atrod tikai iespēju izmantot internetu, bet vēl citi bibliotēkas nākotni saskata virtuālā bibliotēkā. Šajos priekšstatos un asociācijās atspoguḷojas fenomenologiskā cilvēku apziņas un uztveres dažādība, balstīta uz katra indivīda personīgo pieredzi.

Bibliotēku iespējams aplūkot no dažādiem viedokḷiem - kā konkrētu institūciju vai arī kā sociālu fenomenu. Ir jāapzinās bibliotēka kā sociāls izziṇas fenomens ar konkrētu misiju sabiedrībā, kas nepieciešams sabiedrības attīstībai un kura izzušana radīs sabiedrībai neatgūstamus zaudējumus.

Bibliotēka ir daudzfunkcionāla institūcija, tā ir līdzdalīga sociālajos procesos. Bibliotēka darbojas kā informācijas, kultūras un izglītības iestāde, izziṇas palīginstruments. Ideālā variantā visām šìm funkcijām harmoniski jāpastāv līdzās. Bibliotēkas fenomens pastāv tieši tajā, ka tā nekādos apstākḷlos nekḷūst tikai par informācijas centru, kultūras vai izglītības iestādi, bet organizatoriski apvieno visas nosauktās darbības jomas izziņas procesa nodrošināšanai un zināšanu izplatīšanai.

HERMENEITISKAIS aspekts - palīdz mums caur bibliotēku izprast un izzināt un interpretēt cilvēces zināšanu kopumu, un akumulēt iegūto pieredzi, jo lasīšana (izziṇa) ir nemitīga hermeneitiskās kustības īstenošana, ko virza veseluma jēgas gaidas un kas beidzot piepildās veseluma jēgīstenojumā caur atsevišķo. Prast lasīt nozīmē, ka burti it kā pazūd un konstituējas tikai runas jēga.

SEMIOTISKAIS ASPEKTS - simbols tiek interpretēts kā augstākā zīme, tādēl mēs varam izprast BIBLIOTĒ $K U$ kā parādību kultūras kontekstā - kā simbolu un metaforu. Lai šajā aspektā izprastu bibliotēku, jāuzsver komunikācijas ideja, kurā bibliotēku redzam kā instrumentu izziņai, komunikācijai un kultūrai, kultūras semiotisko sistēmu. 
EPISTEMOLOĢSKAIS aspekts. Epistemoloğija pēta izziņas procesus attiecībā uz pirmās pakāpes informācijas plūsmu - tiešiem iespaidiem, kas sniedz informāciju par pasauli. Bibliotēkai kā indivīda izziṇas palīginstrumentam (ja bibliotēku aplūko no izziņas aspekta jeb no epistemolog̣iskā aspekta) ir darīšana ar otrās pakāpes informācijas plūsmu - zīmju sistēmā kodētu informācijas plūsmu, kas fiksēta uz ilgmūžīga materiāla, - tiražētas informācijas pārvaldīšana un izplatīšana pēc iespējas plašākam indivīdu lokam.

Bibliotēkas darbība attiecas uz:

1. metodoloǵiju - mācību par konkrētai zinātnes (resp., bibliotēkzinātnes) nozarei raksturīgām metodēm, kas tiek lietotas noteiktās izziņas procesa sfērās;

2. sociālo epistemoloǵiju - zinātni par zināšanu lomu sabiedrībā, kā arī zināšanu ietekmi uz personību un sabiedrību kopumā.

No metodologiijas aspekta var izdalīt indivīda apziņā notiekošo izziņas operāciju analogus bibliotēku darbībā - informācijas uzņemšanas, apstrādes, sistematizācijas, uzglabāšanas un pārraides procesiem.

Attiecībā uz sociālo epistemolog̣iju ir svarīgi izpētīt, kā viens no sabiedrisko zināšanu uzkrāšanas, saglabāšanas un izplatīšanas orgāniem - bibliotēka - ietekmē pašu indivīda izziņas procesu. Saskaņā ar viena no sociālās epistemoloǵijas zinātnes radītājiem - amerikāņu bibliotēkzinātnieka Dž.Šñras (Shera Jesse Hauk) uzskatiem (14) pašas zināšanas ir nevis objektīva, no subjekta neatkarīga parādība (zināšanas bez subjekta), bet dinamiska parādība, kas rodas komunikāciju procesā. Tādēl ir svarīgi izpētīt, kāda ir izziṇas un zināšanu mijiedarbe ar indivīda apzinas struktūrām.

Pašu izziņas procesu ietekmē:

1. iedzimtās izziņas struktūras, kas raksturīgas visiem cilvēkiem;

2. konkrētā sociālā vidē vai nācijas kultūrā pastāvošās izziņas struktūras, kas cilvēkiem tiek ieaudzinātas.

Tātad bibliotēkai kā svarīgam sociālās komunikācijas posmam jāatbilst gan augšminētajām katra atsevišķa indivīda izziņas struktūrām, gan sabiedrības struktūrai, diferencēti apkalpojot katru sociālo slāni.

Tāpat kā izziṇas teorija, līdz ar sabiedrības struktūru vēsturiski ir mainījušās arī bibliotēkas funkcijas. Savos pirmsākumos tā bija teju sakrālas ezotēriskas informācijas par pasaules tapšanu un tās noslēpumiem glabātāja, kas parastiem mirstīgajiem nav pieejama, bet gadsimtu gaitā tās funkcijas kḷuvušas aizvien pragmatiskākas, lietišksākas, paplašinoties tieši komunikatīvajā sfērā. Pieaugot šai informējošajai dimensijai, bibliotēkai jaunās tūkstošgades gaitā ir jāsaglabā kaut daḷa no savām pirmatnējām funkcijām izziņas procesā. Jāveicina indivīda izziņa ne tikai tīri pragmatiskajā (tūlìtēja rezultāta, tūlītēja labuma gūšana) sfērā, bet arī likt tam atcerēties par izziņas garīgajiem eksistenciālajiem iemesliem.

\section{IZMANTOTIE AVOTI}

1. Filozofijas atlants. Pēteris Kuncmanis, Francis Pēteris Burkarts, Francis Vīdmanis; Aksela Veisa zīm.; no vācu val. tulk. Vilnis Zariņš. Rīga : Zvaigzne ABC, 2000. 251 lpp. ISBN 9984-17-601-0 
2. Hegel, Georg Wilhelm Friedrich. The phenomenology of mind. $2^{\text {nd }}$ rev.ed. Mineola; New York : Dover Publications, 2003. XIiii, 481 p. Dover Philosophical classics. ISBN 9780486432519

3. Huserls, Edmunds. Fenomenologija. Tulk. Rihards Kūlis, Aigars Dāboliņš. Rīga : LU Filozofijas un socioloǵijas institūts, 2002. 438, [2] lpp. Cilvēks un sabiedrība. ISBN 9984-624-19-6.

4. Ideju vārdnīca : domātāji, teorijas un jēdzieni filozofijā, zinātnē, religigijā, politikāa, vēsturēe un mākslā. Ovens Adikibi, Bernards Baleins, Elizabete Brejī u.c. - Rīga : Zvaigzne ABC, 1999. - IX, 659 lpp. ISBN 9984-0466X.

5. Kants, Imanuels. Praktiskā prāta kritika. No vācu val. tulk. R.Kūlis. Rīga : Zvaigzne, 1988. 191 lpp. : portr. Avots. Pagātnes domātāju darbi.

6. Kūle, Maija, Kūlis, Rihards. Filosofija: eksperimentāla mācību grāmata. Rīga: Burtnieks, 1996. 653 lpp. ISBN 9984-9129-6-5.

7. Mamardašvili, Merabs. Domātprieks : Filozofiski raksti, esejas, sarunas. Rīga : Spektrs, 1994. 201 lpp. ISBN 9984900223

8. Megi, Braiens. Filozofijas vēsture. Rīga : Zvaigzne ABC, 2000. 240 lpp. : il. ISBN 99844176088

9. Platons. Valsts. Rīga : Zvaigzne ABC, 2001. - 186, [2] lpp. Avots. ISBN 9984220648.

10. Vitgenšteins, Ludvigs. Logiski filozofiskais traktāts. Kentaurs XXI, Nr.6, 119.lpp.

11. Popper, Karl Raimund. Realism and the Aim of Science : from the Postscript to the Logic of Scientific Discovery. London; New York : Routledge, 1999. Xxxix, 420 p. : fig. ISBN 0415084008.

12. Марков, Б. В. Теории познания и структуры повседневности. Философская антропология : Очерки истории и теории. СПбб 1997, Гл. 2, с. 241-252. http://www. abuss.narod.ru/Biblio/markov.htm (Resurss apskatīts 2006.gada 15.decembrī)

13. Фолмер, Герхард. Эволюционная теория познания. http://www.philosophy.ru/ library/vollmer/05.html\#A5-3 (Resurss apskatīts 2006.gada 15.decembrī)

14. Шира, Джесс X. Введение в библиотековедение : основные элементы библиотечного обслуживания. Москва : Высшая школа, 1983. 256 с. 


\section{Digitālo fotogrāfiju lasītprasme}

\section{Maira Dudareva}

Cilvēki sazinās, izmantojot dažādas komunikācijas formas. Komunikācija norit, apmainoties ar dažādā veidā fiksētu informāciju, arī ar zināšanām, kas atveidotas gan rakstiska teksta veidā, gan attēlos. Ar digitālās fotogrāfijas attīstību un ērto lietošanu ir pieaugusi vizuālo attēlu lietošana.

Tātad aizvien lielāku nozīmi daudzās dz̄̄ves nozarēs iegūst attēls, t.sk. arī digitālā fotogrāfija, un aizvien vairāk rodas vajadzība attēlus analizēt, sakārtot, lai varētu atrast, lai tie nepazustu vai neaizietu bojā.

Lasot grāmatu, mēs sekojam sižetam, cenšamies izprast sniegto informāciju un nozīmes. Grāmatu izlasot, mēs pārdomājam nozīmes un saistības starp tām. Dažādiem lasītājiem būs dažādi viedokḷi par izlasīto, jo katram kaut kas cits būs svarīgāks, un katrs saskatīs kaut ko citu. Grāmatu var lasīt ar pārlēcieniem, un grāmatu var lasīt, stingri iedziļinoties tekstā. To pašu var teikt arī par skatīšanos un redzēšanu. Var virspusēji tvert vizuālās lietas, kā braucot automašīnā, kad ātri gar acīm pazib dažādas vietas, objekti, ainavas, un var tās aplūkot l̦oti vērīgi, pamanot katru sīkumu. ${ }^{1}$

Lai definētu, kā cilvēki saprot vizuālo, jānoskaidro, kā viņi to redz, uztver un interpretē. Esot klāt kādā notikumā, bieži dzirdēts teiciens: paši savām acīm taču redzējām. Bet divi cilvēki, redzot vienu un to pašu, diezin vai to attēlos un raksturos vienādi, jo viss tiek skatīts caur kultūras un pagātnes struktūru un filtriem² ${ }^{2}$ Redze ir dabisks fiziologisks process, bet to nevar teikt par vizuālo elementu uztveri un sapratni. Tās ir atkarīgas no personas kultūras, vēstures, no konteksta, kas jau ir zināms par pasauli, gaumes, interesēm un ieradumiem. T. Širato un Dž. Vebs norāda, ka vizuālā pratība (visual literacy) ir spēja saprast konkrētu lietu redzēšanas likumus un nosacījumus, lietojot tos konkrētā kontekstā. Tas, ko mēs saprotam no tā, ko redzam, ir atkarīgs no mūsu kultūras konteksta, mūsu pašu ieradumiem, arī no tā, ko mēs zinām par to, kā nozīmes tiek veidotas mūsu kultūrā ${ }^{3}$.

Ieraugot attēlu ar vitrāžu, mēs nevaram vizuāli noteikt, ka tā ir Parīzes Dievmātes katedrāle un tā ir Francija. To mēs nosakām interpretācijas cel̦ā, izmantojot mūsu zināšanas un pieredzi, un mēs veidojam stāstu par šo attēlu, iekḷaujot ne tikai vizuāli redzamo.

Svarīgs paṇēmiens vizuālā teksta nozīmes veidošanā ir stāstījums vai stāsts. Pirmkārt, redzot lietas, mēs aktīvi saistām tās ar mūsu apkārtni, nevis vienkārši reproducējam visu, kas ir mūsu redzes robežās. Otrkārt, katra skatīšanās darbība un 
redzēšana ir arī neredzēšanas darbība, jo kādām lietām jāsaglabājas arī neredzamām: ja mēs veltām uzmanību kaut kam vienam, cits paliek neredzams. Treškārt, pakāpe, kurā mēs redzam, fokuss un pasaulei ap mums veltîtā attieksme ir atkarīga no specifiska konteksta, kurā mēs uztveram sevi. Uztvere un jēga ir psihologisks un fiziologisks produkts, ko iespaido kultūras pieredze, jo mēs lietas redzam atkarībā no mūsu kultūras konteksta. ${ }^{4}$

Pirmā un viena no svarīgākajām vizuālo materiālu lasīšanas tehnikām ir atlaš̌šana un izlaišana vai izslēgšana (omission), jo, kā jau tika minēts, jebkura aplūkošanas darbība ietver arī neredzēšanas vai izslēgšanas darbību. Pirmo atlasi veic fotogrāfs, izdarot izvēli, kādus objektus un kādā veidā ietvert attēlā un ko atstāt aiz kadra. Skatītājs veido struktūru un veic novērtēšanu par vietu, attiecībām starp objektiem un stāstu, kas ietverts fotogrāfijā. Šīs darbības: atlasīšana, izslēgšana strukturēšana un novērtēšana sastāda vizuālo tekstu. ${ }^{5}$

Cilvēku pieredze ir valodiska, jo viņš pasauli uztvert un saprot kā objektu, kas tiek formulēts valodā. Dokumenta teksts ir pašindeksējošs, ko nevar teikt par attēlu. Attēlu teksti nav konstruēti tādā veidā, kas piel̦auj vieglu elementu vai noteikumu iegūšanu no priekšmeta. Fotogrāfijas kaut kādā ziņā ir atlase no lielas, l̦oti lielas grupas datu plūsmas. Tās ir analogas reprezentācijas ar izteiktu gradāciju no gaišā uz tumšo. Tās neuzrāda viegli saskatāmus lietvārdu/darbības vārdu analogus. Šeit nav neviena likuma, lai pārtulkotu visu attēlu vai tā daļas vārdos. ${ }^{6}$ Vecais teiciens "viens attēls atsver tūkstoš vārdus" labi parāda komunikāciju dziḷumu, kas ir iespējams ar attēlu tekstiem. "Un, ja fotogrāfija attēlo tūkstoš vārdus, tad to var lasīt tūkstoš veidos un veidot neskaitāmus sižetus, jo attēls ir atvērts personīgajai interpretācijai un nosacīti nepieejams ikvienam, kam trūkst šīs personīgās lasītprasmes" "T. Taču nav neviena izteiciena, cik daudz vārdu vai kuri vārdi ir vēlami, lai aprakstītu individuālu attēlu. Teksta dokumentam ir viegli sajūtamas nozīmes vienības, elementi un sakopojumi. Fotogrāfijai tādu nav. ${ }^{8}$

Gombrihs uzskata, ka attēlu pareizas lasīšanas veiksme ir saistīta ar trīs mainīgajiem: kodu, parakstu un kontekstu. Ir jābūt spējīgam un izglītotam piekḷūt visiem trijiem lielumiem. Ja kāds no tiem netiek ievērots, attēla stāstījuma iespējas tiek sašaurinātas. ${ }^{9}$

Katra fotogrāfija tiek veidota no zīmēm (cilvēki, viṇu apǵērbs,viņu sejas izteiksmes un pozas, telpa starp viṇiem, darbības vieta), kur katru zìmi var iztirzāt kā individuālu tekstu. ${ }^{10}$

Viens no analītiskajiem rīkiem vizuālās kultūras las̄̄šanai ir semiotika. Zīme ir komunikācijas pamatvienība. Būtiska zīmes īpašība ir tā, ka zīme var apzīmēt vai aizstāt nevis atsevišksu objektu vai konkrētu parādību, bet gan veselu objektu vai parādību grupu. Tāpēc tiek runāts par jēdzienu "zīmes apjoms". Jo vairāk konkrētu reālās pasaules objektu attēlo dotā zīme, jo lielāks ir tās apjoms. Zīmes apzīmēto objektu kopumu sauc par tās denotātu. Būtiska zīmes īpašība ir spēja izraisīt cilvēkā priekšstatu par zīmes apzīmētā objekta parādības raksturu. Ziṇu kopumu par apzīmēto objektu un tā saiknēm ar citiem objektiem sauc par zìmes konceptu. ${ }^{11}$

Zīme iegūst jēdzienu atkarībā no tā, cik daudz zīmju kopā atrodas, no veida, kā tās tiek sakārtotas attiecībā viena pret otru, un konteksta, kādā tās tiek lasītas. Zīmju sakārtojums var būt stingri apdomāts, kā, piemēram, gleznā, kur katrs elements 
(zīme) ir mākslinieka izvēlēts un stingri pārdomāts. Zīmju sakārtojums var būt arī patval̄ịss, piemēram, elementu (zīmju) sakārtojums dabiskā ainavā, kur viss ir dots jau sakārtots un skatītājs var tikai izvēlēties, kā viņš redz, un domās sakārtot un veidot atbilstošu efektu. Tajā pašā laikā divi blakus stāvoši cilvēki par vienu un to pašu ainavu var teikt: „Cik skaisti!” vai arī "Cik vientulīgi!"”2.

Pat ja zīmes tiek sakārtotas, fiksētas acīmredzami vienādi, atšķirīga virz̄iba vai perspektīva liks veidot atšķirīgu tekstu. Zīmju novietojums, fons, attiecības veido tekstu, un, kaut ko mainot, teksts jau būs cits. Citiem vārdiem, teksts nāk no zīmes spēka, iedarbīguma jēdziena un kopā ar veidu, kā šīs zīmes ir sakārtotas vai organizētas tekstā, nosaka kontekstu fotogrāfijai. Konteksts nozīmē vidi, kurā teksts dzimst. Konteksts ir neparasti dinamisks un nepastāvīgs tāpēc, ka apvieno visu, iekḷaujot tā vidē cilvēkus, viṇu vēsturi, konkrētos notikumus. ${ }^{13}$

Aplūkojot fotogrāfiju kolekciju, stāsts var būt daudz bagātāks un saturīgāks nekā vienā fotogrāfijā. Mēs varam uzzināt par ǵimeni, viṇu dzīvi, precībām, nacionalitāti, viņu tieksmēm, jo teksta veidošanā tiek izmantotas arī atmiņas un pieredzē gūtās zināšanas, kā arī kultūras vēstures zināšanas. Cita teksta izmantošana, lai radītu jaunu tekstu, tiek dēvēta par intertekstualitāti, un teksta veida nosaukums ir žanrs. Žanrs var tikt definēts kā teksta veids, kas veido nozīmes noteiktā veidā no asociācijām ar speciālu sociālu mērķi un sociālu kontekstu. ${ }^{14}$

Fotogrāfijas tulkošana verbālā veidā ir sarežǵīts process. Tas ir saistīts ar dokumenta nozīmju interpretēšanu un to izteikšanu valodiski, bet š̄ procesa mērķis ir tādā veidā attēlot dokumenta būtību. Tāpēc ir nepieciešamība pēc semantiskās informācijas, jo informāciju par attēlu var dot tikai cilvēks, kas šo darbu analizē. Viena no raksturīgākajām grūtībām attēlu indeksēšanā ir atrast veidu, kā tos analizêt. Vienam attēlam var būt daudz nozīmju un ne tikai tāpēc, ka tajā ir daudz informācijas, bet gan tāpēc, ka attēlā var attēlot daudz abstraktu jēdzienu.

Fotogrāfiju analīzi var veikt trīs līmeņos: aprakstošais jeb faktuālais līmenis, kad tiek noskaidrots, ko var identificēt (vispārīgais, dal̦ēji specifiskais); simboliskais jeb interpretatīvais līmenis, kad tiek noskaidrots, vai ir metaforiskā nozīme (dal̦ēji specifiskais, līmenis "par" (pēc Šatfordes), abstraktais, asociatīvais; personiskais līmenis, kad tiek raksturota personīgā reakcija uz fotogrāfijā redzamo (ieviesis Barts), abstraktais, asociatīvais, „par” līmenis.

Perceptuālajā līmen̄̄ aplūko attēla raksturojumu, kas ir tieši atvasināts no attēla vizuālajām īpašībām. Attēla vizuālo raksturojumu nosaka krāsa, stāvoklis, struktūra un kompozīcija - elementu pozīcija attēlā un relatīvas telpiskās attiecības starp elementiem. Kompozīcija ir viena no īpašībām, kas piemīt vizuālajam resursam. A. Džeimsa un Š Čanga model̦a pirmie četri līmeņi ietilpst perceptuālajā līmen̄̄ ${ }^{15}$

Konceptuālais līmenis ietver attēla satura semantisko informāciju. Šì līmeņa raksturošanai nepieciešama kompetence un zināšanas. Pēc S. Šatfordes, A. Džeimsa un Š. Čanga pieejas, šo līmeni varam iedalīt trijos apakšlīmeņos - vispārīgais, specifikais un abstraktais. Veidojot attēla raksturojumu, visi trīs jēdziena raksturojuma veidi var tikt lietoti vienlaikus. Konceptuālais līmenis raksturo darba būtību. Konceptuālais raksturojums var būt par vietu un objektiem šajā vietā. Konceptuālais apraksts sastāv no konceptuālo īpašību komplekta: notikums, vieta, laiks un attiecībām starp objektiem ${ }^{5}$. Vietas, laika, notikuma klases atbilst S. Šatfordes (1986) 
jautājumiem "kur”, “kad”, "kas”, „kāpēe”, „kāds?”. Konceptuālo objektu klases ir tieši savienotas ar perceptuālo līmeni. Konceptuāls objekts attiecas uz vienu vai vairākiem perceptuāliem attēla elementiem. Aprakstot ainavu un tajā izdalot objektus, piemēram, "māja", tas var būt konceptuāls objekts ar perceptuālām iezīmēm. Šis objekts attiecas tieši uz vizuālo objektu attēlā ar šādu vizuālo raksturojumu: māja ir kvadrātveida, ar noteiktu krāsu. Citā attēlā konceptuālais objekts "māja" attiecas uz diviem vizuāliem elementiem: sarkans trijstūris uz brūna kvadrāta augšpuses. "Augšpuse" ir relatīvs telpisko attiecību piemērs starp diviem elementiem. Saite starp konceptuālu un perceptuālu elementu ir skaidrāka vispārīgajā un specifiskajā apakšlīmenī. Abstraktiem objektiem ne vienmēr ir tiešs uztveres līdzinieks. ${ }^{16}$

Vispārīgie jēdzieni. Vispārīgajā līmenī tiek aplūkoti plaši zināmi jēdzieni, un akcents ir uz attēla perceptuālo aspektu. Šis apakšlīmenis nepieprasa no indeksētāja plašas zināšanas, jo balstās uz zema līmeņa procesu. Pēc Panofska pieejas, tas būs preikonografiskais līmenis. A.Džeimss un Š. Čangs definē vizuālo objektu kā realitāti, kas ir redzama. ${ }^{17}$

Vispārīgā vieta. Attēls var tikt indeksēts saskaṇā ar individuāliem objektiem, kas parādās tajā. Ir iespējams attēlu indeksēt visu kopā, balstoties uz visu objektu grupu, ko tas satur, un to sakārtojumu. Piemēram, pilsēta, ainava, dzīvestils, portrets, iekštelpas, ārskati. Šajā līmenī nav jāzina konkrēta iela, èka, konkrētas personas vārds. ${ }^{18}$

Specifiskie jēdzieni. Šis apakšlīmenis aplūko specifisku attēla jēdziena informāciju. Šajā līmenī objekti, vietas tiek identificēti un nosaukti un tiek pieprasītas konkrētas attiecīgās jomas zināšanas. Atšķirība starp vispārīgajiem un specifiskajiem jēdzieniem ne vienmēr ir skaidra. ${ }^{19}$

Armitadže un Ensers formulēja šo problēmu šãdi: būtību vienmēr var interpretēt saistìtā hierarhijā, - galvenais jēdziens, apakšjēdziens, un ne vienmēr ir acīmredzams, kurā līmenī sastopas unikālākā īpašība. ${ }^{20}$ Lai atšķ̧irtu vispārīgo un specifisko (vai "unikālo") jēdzienu, var lietot E.Rošas pamatlīmeņa kategorijas. Pamatlīmeņa kategorijas ir pamatlīmeņa abstrakcijas, kurās var iegūt visvairāk informāciju ar vismazāko izziṇas piepūli (Roša, 1973). ${ }^{21}$

\section{SPECIFISKĀ VIETA}

Šis līmenis ir līdzīgs vispārīgās vietas līmenim ar atšķirību, ka šeit ir nepieciešams pievienot arī konkrētu informāciju par vietu. Dažādi attēla objekti var sniegt būtisku informāciju, lai precizētu attēlā redzamo specifisko vietu. Arī viens objekts var būt pietiekams informācijas avots, lai konkretizētu vietu. Piemēram, attēls, kurā skaidri redzama Doma baznīca, nosaka, ka tā ir Rīga ${ }^{22}$.

\section{ABSTRAKTIE JĒDZIENI}

Šajā apakšlīmenī tiek pievienotas attēla abstraktās, asociatīvās nozīmes. Lietotās zināšanas šajā līmenī ir interpretatīvas un skatījums var būt ḷoti subjektīvs. ${ }^{23}$ 


\section{ABSTRAKTI OBJEKTI}

Šajā līmenī ir nepieciešamas specializētas vai skaidrojošas zināšanas par to, kāds objekts ir attēlots. Šis ir ikonoloǵiskais (interpretācijas) līmenis pēc Panofska model̦a vai "Par" līmenis pēc Šatfordes. Šis indeksēšanas līmenis ir vissarežḡîtākais, jo tas ir pilnīgi subjektīvs un var būt l̦oti atšķirīgi interpretējams. ${ }^{24}$

\section{ABSTRAKTA VIETA}

Šis līmenis attiecas uz to, ko attēls ataino kopumā, un šeit parādās abstrakti, emocionāli jēdzieni, kā ar̄̄ darbības. Šajā līmenī attēla raksturošanai būtiska ir indeksētāja personīgā reakcija uz attēlā redzamo un tā radītajām asociācijām. ${ }^{25}$

Varam secināt, ka, analizējot fotogrāfiju, tā jāaplūko trīs līmeņos. Tomēr pārsvarā fotogrāfijas tiek analizētas vispārīgajā un specifiskajā līmenī, l̦oti nedaudz vai nemaz tās tiek aplūkota abstraktajā līmenī, jo šis līmenis prasa subjektīvo attieksmi pret attēlā redzamo.

\section{IZMANTOTĀ LITERATŪRA}

1. Agejevs, Vladimirs. Semiotika. Rīga : Jumava, 2005. 207 lpp.

2. Armitage, L., Enser, P. Analysis of user need in image archives. Journal of Information Science. No.23 (4), 1997, p. 287-299

3. The identification of the elements [online]: Photographic Heritage E-learning. Socrates Minerva. The European Commission, 2005. Available: http://www.photherel.net/notes/ aspects/content/asp2bi.

4. Hollink, Laura, Schreiber, Guus, Wielinga, Bob, Worring, Marcel. Classification User Image Descriptions [online]. University of Amsterdam, Business Informatics. Available: http://www.cs.vu.nl/ laurah/papers/Hollink_coid.pdf

5. Jaimes, Alejandro, Shih-Fu, Chang. A Conceptual Framework for Indexing Visual Information at Multiple Levels. In: IS\&T/SPIE Internet Imaging [online]. Vol. 3964, San Jose, CA, : Image and Advanced TV Laboratory, Department of Electrical Engineering Columbia University, 2000. Available: http://www.ctr.columbia.edu/ ajaimes/Pubs/ spie00_internet.pdf

6. Jespersen, Heather P, Jespersen, John, Kresten. The Problem of Subject Access to Visual Materials. In: Journal of Education Media \& Library Sciences [online], No.42, Sept. 2004), p.37-48. Available: http://research.dils.tku.edu.tw/joemls/42/42-1/37-48.pdf

7. O'Connor Brian Pictures, Aboutness, and User-Generated Descriptors.. Available http://www.asis.org./SIG/SIGVIS/b_oconnor.html

8. Schirato, Tony, Webb, Jen. Understanding the visual. Singapore: SAGE Publications, 2004. 213 lpp.

\section{ENDNOTES}

1 Tony Schirato and Jen Webb, Understanding the visual (Singapore: SAGE Publications, 2004).

2 Turpat.

3 Turpat.

4 Turpat. 
5 Turpat.

6 Brian O'Connor, "Pictures, Aboutness, and User-Generated Descriptors", available http://www.asis.org./SIG/SIGVIS/b_oconnor.html .

7 Schirato and Webb, Understanding the visual.

8 O'Connor, "Pictures, Aboutness, and User-Generated Descriptors".

9 Schirato and Webb, Understanding the visual.

10 Turpat.

11 Vladimirs Agejevs, Semiotika (Rīga : Jumava, 2005).

12 Schirato and Webb, Understanding the visual.

13 Turpat.

14 Turpat.

15 Laura Hollink, Guus Schreiber, Bob Wielinga, Marcel Worring, Classification User Image Descriptions [online]. University of Amsterdam, Business Informatics. Available at http://www.cs.vu.nl/ laurah/papers/Hollink_coid.pdf.

16 Turpat.

17 Alejandro Jaimes and Chang Shih-Fu, A Conceptual Framework for Indexing Visual Information at Multiple Levels. In IS\&T/SPIE Internet Imaging [online]. Vol. 3964, San Jose, CA.: Image and Advanced TV Laboratory, Department of Electrical Engineering, Columbia University, 2000. Available: http:/www.ctr.columbia.edu/ ajaimes/Pubs/ spie00_internet.pdf

18 Turpat.

19 Turpat.

20 L. Armitage and P.Enser, "Analysis of user need in image archives,". Journal of Information Science. No.23 (4), 1997, p. 287-299.

21 Heather P. Jespersen and John Kresten. The Problem of Subject Access to Visual Materials. In Journal of Education Media \& Library Sciences [online], No.42, (Sept. 2004), p. 37-48. Available at http://research.dils.tku.edu.tw/joemls/42/42-1/37-48.pdf.

22 Jaimes and Shih-Fu, A Conceptual Framework for Indexing Visual Information at Multiple Levels.

23 Turpat.

24 Turpat.

25 Turpat. 


\title{
Pamatizglīitibas reforma un bibliotēku loma tajā
}

\author{
Dženija Dzirkale-Maļavkina \\ Latvijas Universitāte
}

\begin{abstract}
Aizvadīto neatkarības gadu laikā Latvija uzsākusi mērķtiecīgu gaitu uz savu iedzīvotāju izglìtošanu, organiski kopsaistot mācību un audzināšanas procesus dzīves pieredzes (zināšanu, attieksmju, prasmju) apguvei. Cilvēce ir uzkrājusi l̦oti daudz pasaules dižāko prātu radītas zināšanas, taču radušās ievērojamas problēmas šo zināšanu saprātīgā apguvē un cilvēcīgā (humānā) izmantošanā. Šodien galvenais ir nevis zināšanas pašas par sevi, bet gan prasme iegūt savai dzīvei nepieciešamās zināšanas (izziṇa), kā arī prasme š̄is zināšanas labi (apdomāti jeb vērtīborientēti) izmantot savā dzìves praksē (rīcībā). Zināšanas - visa pamats, taču tas ir tikai pamats. $^{1}$
\end{abstract}

Zināšanu ieguvē būtiski mainās skolotāja loma - viņš vairs nav vienīgais zināšanu avots, jo skolēni tās var iegūt saziņas ceḷā no tradicionālo bibliotēku un/vai interneta informācijas krātuvēm. Skolotājs kḷūst par skolēnu patstāvīgi īstenotu zināšanu ieguves procesa vadītāju un, pats galvenais, šo iegūto zināšanu analīzes un jaunu zināšanu sintēzes procesu vadītāju. Skolēnu domāšanas procesu organizācija un vadība visjaunāko laiku skolotāja izglītojošās darbības galvenā sūtība un būtība.

Mācot vienu mācību priekšmetu, jāzina, kā šis mācāmais priekšmets saistās ar visu pārējo, ko skolēns mācās skolā un ko izzina ārpus tās. Integrācija nav „kokteilis”, bet gan mērḳtiecīgi sakopoti priekšmeti pēc noteiktas koncepcijas. Saturs parādās kā veselums, un skolotājs strādā veselumā. Mācību priekšmeti jātuvina pēc loǵikas principiem, nevis mākslīgi. Kontekstā viss ir saistīts kompetenču līmenī. Temats ir tikai līdzeklis, ar kuru var veidot „,salikumu”. Svarīga ir patiesi dziḷa integrācija, tā ir prasmju integrācija. Vienā priekšmetā apgūtais jaunā kvalitātē papildina arī citā priekšmetā apgūstamo.

Lai arī nav viennozīmīgas integrētu mācību definīcijas un dažādi autori izmanto dažādus jēdzienus idejas aprakstī̌sanai (starpdisciplinārās, starppriekšmetu, transdisciplinārās, integratīvās u.c.), jāmēǵina izprast lietas būtību. Izmantosim š̄ jēdziena integrēšana skaidrojumu ${ }^{2}$ pedagogijāa - tas ir process, kurā atsevišķi elementi, apakšsistēmas un daḷas tiek saistīti vienā sistemātiskā veselumā (sistēmā). Izglìtības procesā tā ir, piemēram, tēmu, problēmu risināšana, apguve, izpēte, praktiski saistot vienā veselumā atsevišķos mācību priekšmetos apgūstamās vai apgūtās zināšanas un prasmes. Tas var notikt īpaši izveidotu integrētu mācību priekšmetu veidā, kā arī integrēti aplūkojot atsevišķas mācību satura daḷas. 
Mācību satura integrācija nav pašmērķis. Nepieciešamība pēc tā rodas noteiktā sistēmas attīstības posmā, kad tā saskaras ar jaunām prasībām, kuras vairs nespēj īstenot, saglabājot līdzšinējo veidolu. Pretruna starp pieaugošo zināšanu apjomu un ierobežoto laiku to apgūšanai ir viena no virzošajām izglītības pretrunām, kuru risinot radušās jaunas mācīšanās teorijas, mācību metodes, darba organizācijas formas.

Jau angḷu domātājs Herberts Spensers viens no pirmajiem izsaka domu, ka vairs nav iespējams iemācīt visu (1861). Risinājums, viņaprāt, ir svarīgāko zināšanu atlase. Šim principam ir bijuši daudzi sekotāji, kuri piedāvājuši katrs savu „svarīgāko zināšanu” modeli, un arī patlaban no sabiedrības diskusiju loka neizzūd doma par skolēnu slodzi un nepieciešamo zināšanu minimuma samazināšanu. Taču šis risinājums rada jaunas problēmas - iegūtajām zināšanām ir fragmentārs, nesaistīts raksturs, tādēḷ skolēniem neveidojas sistēmiska pasaules kopaina. Skolēni spēj veiksmīgi darboties, kad tipveida zināšanas ir jāizmanto tipveida situācijās, taču nepietiekami attīstās uzdevumu analīzes prasmes, kas nepieciešamas nepazīstamas situācijas izvērtēšanai un risinājuma līdzekḷu noteikšanai. Princips ,vai-vai” vienmēr balstās uz apzinātiem zaudējumiem, tiek piedāvātas tikai to variēšanas iespējas. Nozīmīgi ieguvumi ir panākami, orientējoties uz principu ,gan-gan”. Gan jaunie priekšmeti, gan līdzšinējie; gan praktiski pielietojamās zināšanas, gan vispārējās; gan tipveida uzdevumi, gan sarežǵîtas situācijas. Organizēt mācību saturu tā, lai īstenotos „gan-gan” princips ${ }^{3}$ - tas ir viens no satura integrācijas uzdevumiem jaunajā „Valsts pamatizglītības standartā”, (1998).

Pamatizglītības satura reformas sagatavošanas posms sākās 1998.gadā. Tas sevī ietvēra gan problēmas izpētes posmu, noskaidrojot, kas tieši esošajā mācību saturā ir jāmaina un kāpēc tas ir jādara, prognozējot 21.gadsimta skolēna intereses un vajadzības, gan mācību satura dokumentu izstrādes posmu, gan pārmaiņu izplatǐšanas posmu, sagatavojot skolotājus pārmaiṇu īstenošanai, veidojot mācību līdzekl̦us, ar ko skolēniem strādāt. Pārmaiṇu ieviešana jeb pieņemšana sākās ar 2005.gada 1.septembri un skāra 1., 4. un 7. klasi. Ieviešana ilgs trīs mācību gadus līdz 2007./2008.mācību gada beigām. Tātad 2005./2006.mācību gadā reformā tika iesaistīit tie skolēni, kuri mācījās 1., 4., un 7. klasē, 2006./2007.mācību gadā 1., 2., 4., 5., 7., 8.klašu skolēni, bet 2007./2008.mācību gadā visi 1.- 9.klašu skolēni.

Šajā laikā visā pamatizglîtības posmā būs notikusi pāreja uz jauno mācību saturu, būs ieviests jauns mācību priekšmets - sociālās zinības.

Līdz šim izglītības sistēma uzsvēra zināšanu nozīmi un mācību process skolā bija virzịts uz zināšanu ieguvi, turpretī tagad izglītība tiek piedāvāta plašākā skatījumā. Līdztekus konkrētām zināšanām skolēni vienlaikus iegūs arī universālus darbības instrumentus - vispārējās prasmes, kas dos iespējas viņiem veiksmīgi darboties gan pazīstamās, gan jo īpaši nezināmās, neskaidrās dzīves situācijās.

Skolēni

- mācīsies zināt, tas ir - mācīsies mācīties, lai gūtu labumu no izglīîibas sniegtajām iespējām visa mūža garumā;

- mācīsies darīt;

- mācīsies dzīvot kopā, attīstot izpratni par citiem cilvēkiem un savstarpējās atkarības atzī̌sanu, realizējot kopējus projektus un mācoties risināt konfliktus plurālisma, savstarpējās izpratnes un miera garā; 
- mācīsies būt, lai attīstītu savu personību un spētu darboties ar pieaugošu patstāvību, spriedumiem un personīgu atbildību ${ }^{4}$.

Kopumā pamatizglīīibas satura reformas mērkisis ir uzlabot mācīšanu un mācīšanos. Šim nolūkam :

- mācību procesā jāpāriet no formālas informācijas apguves uz prasmēm daudzveidīgi darboties ar informāciju;

- jāievieš un jāizmanto mūsdien̄̄gas mācību metodes un informācijas tehnologijas;

- jānodrošina izglītības jomu ietvaros saskaņota mācību satura ieviešana un mācību priekšmetu integrācija;

- tiks reformēts pamatizglītības un vispārējās vidējās izglīitibas saturs.

Varam pieṇemt, ka viss mācību saturs modelējas pēc ,puzles principa”, jo tas tiek organizēts četrās izglītošanās jomās: valoda, cilvēks un sabiedrība, māksla, tehnologiju un zinātņu pamati. Savukārt, katrā izglītošanās jomā integrētā veidā ietilpst vairāki mācību priekšmeti.
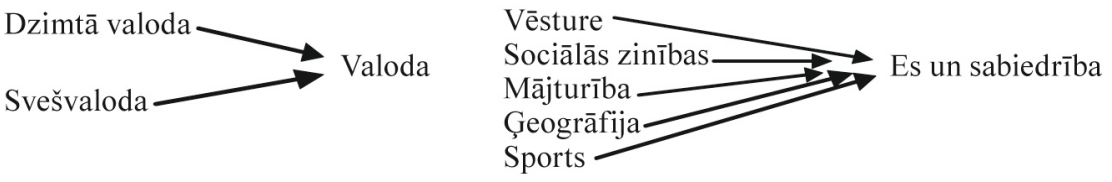

Pie tam mācību priekšmets mājturība iekḷaujas trīs jomās, bet ğeogrāfija - divās jomās ${ }^{5}$.
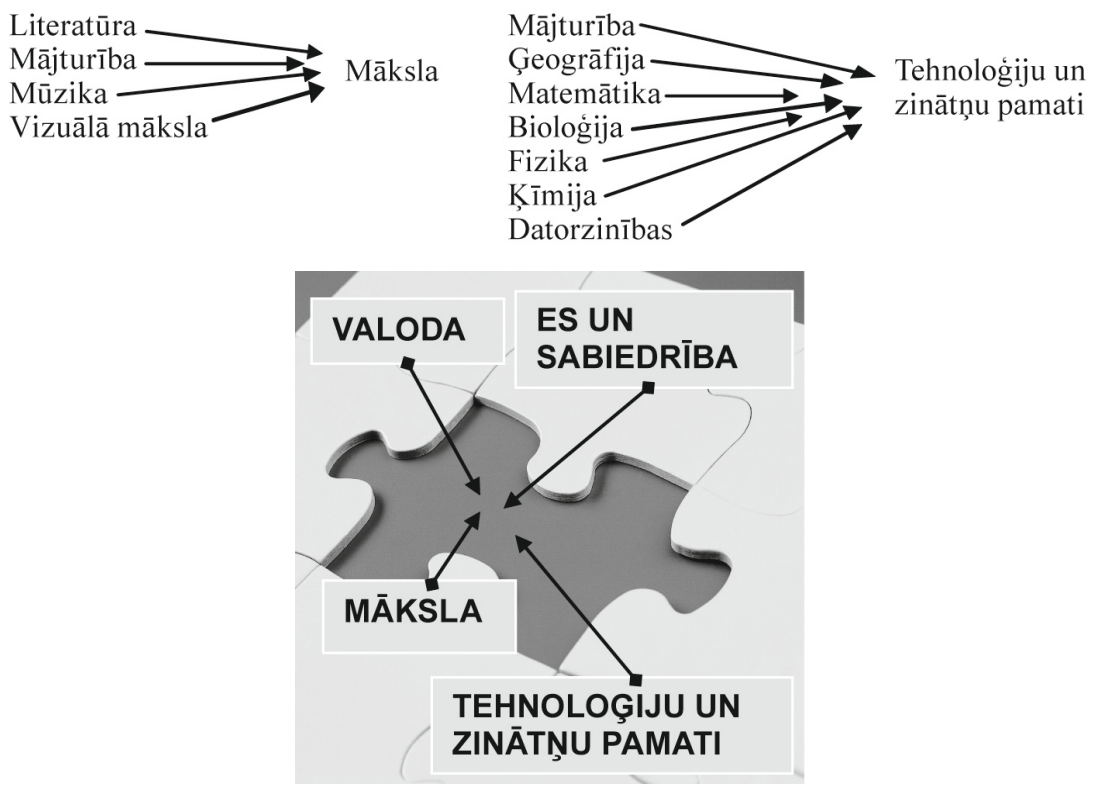

Mācību procesa "puzles princips"

Jāpiezīmē, ka ieviesti ne tikai jauni mācību priekšmeti (informātika no 5.klases, dabaszinības, sociālās zinības), bet arī ietvertas vairākas jaunas tēmas - vide, 
veselība un drošība, profesijas izvēle, vērtībizglītība. Vispārīgo prasmju īstenošana ir visu mācību priekšmetu uzdevums. Tā visa rezultātā ievērota mērķu, uzdevumu, obligātā satura un prasību pēctecība.

Ļoti nozīmīgs un akcentējams tas, ka standartā ir noteikti skolēnu sasniedzamie rezultāti 3., 6. un 9.klases beigās, akcentējot skolēnu gatavību dzīves darbībai. Šeit mēs galveno uzsvaru liksim uz prasmēm strādāt ar dažādiem informācijas avotiem un tekstiem.

Pēc 3.klases skolēni

- prot iegūt nepieciešamo informāciju no vairākiem avotiem (mācību grāmata, prese, vecāku stāstījums) un to izmantot savu spriedumu veidošanai un pamatošanai;

- prot nolasīt informāciju no tabulām, risinot savai ikdienas dzīvei nozīmīgus uzdevumus;

- prot interpretēt un izmantot vizuālo informāciju;

- prot izdalīt būtiskāko.

Pēc 6.klases skolēni

- prot izvēlēties rakstīto materiālu;

- prot izmantot dažādus informācijas avotus (grāmatas, vārdnīcas, datora datubāzes);

- spēj kombinēt informāciju no dažādiem informācijas avotiem un teksta veidiem;

- prot novērtēt iegūtās informācijas ticamību;

- ar izpratni lieto terminoloǵiju;

- prot saskatīt un labot savas kḷūdas.

Pēc 9.klases skolēni

- prot informāciju iegūt no daudzveidīgiem avotiem un cel̦iem, to skaitā no zinātniskām grāmatām un žurnāliem, prot spriest par iegūtās informācijas ticamību, izslēdzot aizspriedumus, informācijas tendenciozu interpretāciju;

- prot daudzveidīgi interpretēt tekstu;

- prot paust savus uzskatus par lasīto;

- lieto dažādus tekstus kā informācijas avotus un modeli, lai izstrādātu radošos darbus;

- zina un prot pielietot pareizrakstības likumus.

Skolēnu izglītošanas procesā iesaistīti daudzi dalībnieki. Tā ir skola (izglītības standarti, mācību priekšmetu programmas, interešu izglītība, projekti, pētnieciskie darbi u.c.), ǵimene (sociālais stāvoklis, materiālais nodrošinājums, kultūra, tradīcijas u.c.) un atbalsta iestādes - bērnu un jauniešu centri, mūzikas/mākslas/sporta skolas, kultūras centri un bibliotēkas. Tāpēc vienlīdz svarīga loma skolēnu dzīves prasmju veidošanā ir visiem šñ procesa dalībniekiem.

Līdz ar to „Valsts pamatizglītības standartā” definētās zināšanas un prasmes būtu jāzina katram, kas ir saskarē ar bērnu un jauniešu izglītošanās vajadzībām. Svarīgi 
zināt un izprast tos procesus, kas notiek izglītības sistēmā kopumā un konkrētajā administratīvās teritorijas skolā/skolās.

Kad skolēns ir saṇēmis uzdevumu, kas saistīts ar patstāvīgu tā izpildi, konkrētas informācijas iegūšanu ārpus klases un mācību grāmatas (uzdevums, referāts, pētniecisks darbs, papildu informācija, personīga interese u.tml.), viņš dodas uz skolas bibliotēku kā atbalsta iestādi. Skolas bibliotēka ir daļa no vispārējās skolas informacionālās vides, un tās galvenā funkcija - atbalsts mācību procesam konkrētajā skolā. Diemžēl skolas bibliotēka ikdienā nevarēs pilnībā nodrošināt skolotāju un skolēnu augošās prasības pēc dažāda satura un dažāda veida informācijas. Tālākais cel̦š ved uz tuvāko publisko bibliotēku. Savukārt, viena no galvenajām publisko bibliotēku funkcijām ir - atbalsts iedzīvotāju mūžizglītībai ar tās rīcībā esošo resursu un pakalpojumu pieejamības nodrošināšanu.

Līdz ar to pieaug publisko bibliotēku nozīme arī vispārējās izglītības vajadzību nodrošināšanā ar

- atbilstoša satura drukātiem resursiem;

- atbilstošiem elektroniskiem resursiem, internetu, programmatūru;

- pieeju bibliotēku informācijas sistēmām, kopkatalogiem, datu bāzēm;

- tehnisko nodrošinājumu: kopēšanu, izdruku, skenēšanu, video/DVD, audio iekārtām;

- izglītojošiem pasākumiem, dažādiem projektiem, apmācību, konsultācijām, bibliotēkmācības stundām, individuālo palīdzību.

Bērni un jaunieši ir īpaši nozīmīga bibliotēkas lietotāju kategorija. Tā ir jaunā paaudze, kas daudz labāk pārvalda informācijas un komunikācijas tehnologijas un prot svešvalodas, tai ir citas dzīves vērtības un mērķi. Lai veiksmīgi īstenotu izglītojošo darbību bibliotēkā, nepieciešama nopietna bibliotekāru apmācība praktiskajā pedagogijā un psihologijāa, jo, kā jau tika minēts, līdz ar izmain̄ām mācību saturā skolās mainās mācīšanās teorijas un metodes, rodas nepieciešamība izprast, kāda ir š̄ īpašā mērksauditorija - skolēni, kādas ir viṇu vajadzības un kādas prasmes jāpalīdz attīstīt. Skola viena pati to nevarēs veikt. Tāpēc tik svarīga ir visu izglītošanas procesa dalībnieku līdzdalība. Jo īpaši svarīga loma ir bibliotēkām.

Skolām jāmeklē šie partneri, nepieciešams veidot un attīstīt sadarbības programmas. Sabiedrībā notiekošie procesi aizvien vairāk veicina šos partnerības meklējumus. Gan skola, gan bibliotēka būs ieguvēji, ja darbosies koordinēti un sadarbojoties. Tas palīdzēs atrast jaunus informācijas resursus, vietu, kur skolēni var patstāvīgi mācīties un risināt savas informācijas problēmas, partneri dažādu skolēnu vispārējo dzīves prasmju apgūšanas kopprojektu īstenošanā u.tml.

Savukārt, bibliotēkām tas palīdzēs

- izprast mācību procesa norises skolā;

- izprast skolotāju un skolēnu vajadzības;

- ikdienas darbā balstīties uz izpratni par tām zināšanām un prasmēm, kas jau ir konkrētā vecumposma skolēniem;

- pilnveidot bibliotekāra kompetenci saziṇā (komunikācijā) ar bērniem un jauniešiem sarežğîitajā sociālajā vidē; 
- veidot pedagoǵisku pieeju bibliotēkmācības stundu un izglītojošu pasākumu plānošanā un organizācijā;

- labāk plānot bibliotēkas darbu ar bērniem un jauniešiem;

- atbilstošāk komplektēt bibliotēkas krājumus.

Šodien vispārējo prasmju kopumā ietilpst tādas prasmes, kas veicina pašvērtējumu, saskarsmi, sazināšanos un sadarbību, lēmumu pieņemšanu, problēmu risināšanu u.c. Vide, kurā skolēniem būs jādzīvo, dažādās zināšanu jomas un problēmas nebūs nošķirtas atsevišksi, bet veidos sarežgīitu veselumu. Kopīgi atbalstot skolu, varam veicināt mācību satura integrācijas īstenošanu.

\section{IZMANTOTIE AVOTI}

1 Broks A. Kādu kam izglītību kādai dzīvei? Skolotājs, 2005. 2: 13.-22.

2 Pedagoǵijas terminu skaidrojošā vārdnīca. Rīga, Zvaigzne ABC, 2000. 69.-70. lpp.

3 Muraškovska I. Pamatprincipi mācību satura integrācijai, Skolotājs, 2006. 4: 16.-20.

${ }^{4}$ Pamatizglîtības satura reforma [tiešsaiste] Pieejams: http://isec.gov.lv/vecakiem/index. shtml

5 Valsts pamatizglītîbas standarts. Lielvārds, 1998. 32 lpp. 


\title{
Informācijas pārvaldība izglītības iestāžu bibliotēkās
}

\author{
Gita Komarova
}

21. gadsimts Latvijā iezīmējis pāreju uz informācijas sabiedrību, kurā brīvi pieejama kvalitatīva informācija. Informācijas un zināšanu lomas pieaugums mūsu sabiedrības dzīvē radikāli maina izglītības iestāžu bibliotēku darba organizāciju un funkcijas. Izglītības iestādēs ir main̄ijušās studiju/mācību metodes, aizvien svarīgāku vietu pedagogu darbā ieņem konstruktīvisms. Pedagogam mācīšanās procesā ir palīga loma, skolēni-studenti paši konstruē savas zināšanas. Izglītības procesā vienlīdz nozīmīgi kḷuvuši abi procesi - gan mācīšanās, gan mācīšana. Tas nozīmē, ka mācību vai studiju procesa nodrošināšanā ir mainījusies gan pedagogu, gan izglīīibas iestāžu bibliotēku loma. Bibliotēkas kḷuvušas par sabiedrības zināšanu bāzi un sociālās saskarsmes centru, kas rada iespēju personībām informāciju pārvērst zināšanās.

Latvijā izglītības iestāžu bibliotēku darbību reglamentē dokumenti - tiesību akti: (publiskās varas institūcijas tiesību normu jaunrades akti: Satversme, likumi, kodeksi, Ministru kabineta noteikumi, pašvaldību saistošie noteikumi). ${ }^{1}$

Darbs skolu/augstskolu bibliotēkās tiek organizēts saskaņā ar Bibliotēku likumu, bibliotēku darbu reglamentējošiem Latvijas Republikas Ministru kabineta izdotajiem normatīvajiem aktiem, ievērojot starptautisku organizāciju izstrādātas vadlīnijas, rekomendācijas un priekšlikumus, kas nosaka principus, ko valstis brīvprātīgi var piemērot bibliotēku nozares jaunrades procesā: starptautiskie standarti, ANO dokumenti, UNESCO dokumenti (publisko bibliotēku, skolu bibliotēku manifesti u.c.), IFLA vadlīnijas, ES dokumenti (Eiropas Parlamenta rezolūcija par bibliotēkām modernajā sabiedrībā, EK un EP programmas, projekti, vadlīnijas).

\section{IZGLĪTİBAS IESTĀŽU BIBLIOTĒKU VIETA UN LOMA INFORMĀCIJAS SABIEDRİBĀ}

Aizvien biežāk mūsdienu sabiedrība tiek dēvēta par informācijas sabiedrību, kuru raksturo divas kvalitātes - informācija un zināšanas. Plašais informācijas daudzums, informācijas pakalpojumi, to pieejamība, attīstītas informācijas un komunikāciju tehnologiijas, uz zināšanām balstīta ekonomika rosina Latvijas izglītības iestāžu bibliotēkas nodrošināt pieeju daudzveidīgai un mācību/studiju virzieniem atbilstošai informācijai, atbalstot skolēnu, audzēkṇu, studentu, pedagogu, akadēmiskā personāla mācību, studiju un pētniecības darbu, ar informācijas resursu un informācijas pakalpojumu 
sistēmu palīdzību optimizēt mācību/studiju procesu, sniegt ieguldījumu izglītības procesā un pievienotās vērtības veidošanā.

Pēc savas būtības izglītības iestāžu bibliotēkas ir sabiedriskas informācijas telpas, kurā skolēni/ audzēkṇi/ studenti tiek iesaistīti patstāvīgā mācīšanās procesā, kuru veicina bibliotēku informācijas resursi un pakalpojumi. Aizvien vairāk skolu/augstskolu/citu mācību iestāžu bibliotēkas attīstās hibrīdbibliotēku virzienā. Lietotājiem paralēli tradicionāliem informācijas resursiem tiek piedāvāti kvalitatīvi elektronisko resursu krājumi un elektroniskās izguves iespējas. Nenoliedzami, bibliotēkas ir neatnemama izglītības procesa sastāvdal̦a. Izglītības iestāžu bibliotēkas darbību veicina arī integrācija informācijas apmaiṇā ar citām publiskajām un zinātniskajām bibliotēkām. Daudzas Latvijas izglītības iestāžu bibliotēkas savos attīstības plānos ietver - tīklveida darbības model̦a ieviešanu, kā arī uz informācijas tehnologijām bāzētu pakalpojumu piedāvājumu attīstī̌sanu, personāla vispārējo kvalitāšu pieauguma veicināšanu. Bibliotēkas apkalpo lietotājus, ievērojot to informacionālās vajadzības, orientējas arī uz attālināto lietotāju apkalpošanu. Aktīvi piedalās finanšu piesaistes un sadarbības projektos gan vietējā, gan starptautiskā mērogā. ${ }^{2}$

\section{IZGLİTĪBAS IESTĀŽU BIBLIOTĒKU GALVENĀS FUNKCIJAS}

Bibliotēku pamatfunkcija ir informācijas plūsmas organizēšana un tās pieejamības nodrošināšana. Izglītības iestāžu bibliotēku pamatuzdevums ir saturiski atklāt, izplatīt un piedāvāt informācijas resursus atbilstoši lietotāju vajadzībām, kas lielā mērā nosaka pakalpojumu klāstu un to daudzveidību. Tā kā bibliotēku pakalpojumi ir orientēti uz lietotāju vajadzību un informācijas resursu mijiedarbību, lai nodrošinātu vidējo un augstāko mācību iestāžu izglītības procesu, tad viena no galvenajām bibliotēku darba funkcijām ir būt par informācijas centru. Bibliotēkas, darbojoties kā informācijas centri, nodrošina lietotājiem pieeju dažādiem dokumentu veidiem: iespiestajiem informācijas avotiem: mācību grāmatām, seriālizdevumiem, uzziņu izdevumiem, zinātniskajām publikācijām, kartogrāfiskajiem dokumentiem; attēlizdevumiem u.tml.; elektroniskajiem informācijas avotiem: tiešsaistes un lokālajiem; avotiem, kas radīti uz tehnolog̣iju bāzes: audio un videoierakstiem, mikroformām u.c. ${ }^{3}$

Neviena sabiedrība nav iedomājama bez izglītotām personībām. Mūsu valsts ikvienam sabiedrības loceklim piedāvā dažādas izglīî̄bas iespējas - vispārējo, profesionālo un augstāko izglîtību, tāpēc izglītības iestāžu bibliotēkām jākḷūst par vienu no līderēm informācijas sabiedrības informacionālajā telpā, kas aktīvi piedalās informācijas plūsmas pārvaldībā un tās sistemātiskā sakārtošanā, sistematizēšanā. ${ }^{4}$

Ar informācijas pakalpojumu kā zināšanu izplatīšanas formu starpniecību izglīî̄bas iestāžu bibliotēkas realizē arī kultūras centra funkcijas, radot tās lietotājiem pieeju nacionālajam un pasaules kultūras mantojumam, sniedzot informacionālo atbalstu skolēnu/studentu radošās darbības izpausmēm, attīstot interešu pasākumus. Savukārt ar lietotāju izglītošanu informācijas patstāvīgā meklēšanā arī elektroniskajā vidē, kā arī atbalstot interaktīvās izglītības un tâlmācības iespēju attīstību, mācību iestāžu bibliotēkas veic izglītības un tālākizglītības/mūžizglīî̄bas centra funkcijas ${ }^{5}$. 


\section{IZGLİTĪBAS IESTĀŽU BIBLIOTĒKU INFORMĀCIJAS PĀRVALDİBAS KOMPONENTI}

> Informācijas pakalpojumi, kas nodrošina zināšanu izplatīšanu;

> informācijas resursi: bibliotēku rīcībā esošās informācijas sistēmas, materiālajos nesējos fiksētā informācija, klasifikācijas sistēmas, kas nodrošina saiti starp lasītāju (lietotāju) un informāciju maksimāli efektīvu;

lietotāju informacionālo vajadzību izpēte, to piesaistīšana;

> bibliotēku darbības analīze - SWOT (SVID) metodes pielietošana (fenomena vai procesa stipro un vājo pušu, iespēju un draudu noteikšanas un analīzes metode);

profesionāli bibliotēku darbinieki, gatavi nepārtrauktai tālākizglītībai.

\section{INFORMĀCIJAS PĀRVALDĪBAS IESPĒJAS}

Valsts līmenī informācijas pārvaldības process veidojas: ievērojot norises izglītībā, formulējot attīstības stratēgiju, mērķus un uzdevumus, nosakot sadarbības partnerus. Sekmīgai informācijas pārvaldībai nepieciešamas Izglītības un zinātnes ministrijas, Kultūras ministrijas kopējas stratēǵijas bibliotēku attīstībā, ierēdṇu izpratne par norisēm un jauninājumiem bibliotēku jomā, kopīgi bibliotēku speciālistu un valsts ierēdņu semināri, vēlama būtu arī bibliotekāro speciālistu dalība skolu direktoru vai augstskolu akadēmiskā personāla sanāksmēs, vienots elektroniskais katalogs tiešsaistē. Vietējā līmenī mācību iestāžu bibliotēkās informācijas pārvaldības process veiksmīgi veidojas, ja skolu/augstskolu vadība iekl̦auj bibliotēku attīstības pasākumus savos stratēgiskajos plānos, ja bibliotēku personāls, veidojot informācijas pārvaldības koncepcijas, spēj panākt vadības izpratni par norisēm un jauninājumiem bibliotēku jomā, ja tiek nodrošināta bibliotekāro speciālistu dalība izglītîbas iestāžu vadošā un pedagoǵiskā personāla sanāksmēs.

\section{IZGLĪTİBAS IESTĀŽU BIBLIOTĒKU INFORMĀCIJAS PAKALPOJUMI}

Sekmīgai mācību iestāžu bibliotēku lietotāju (skolēnu/audzēkṇu/studentu/ pedagogiskā un akadēmiskā personāla) apkalpošanai jebkuras skolas/augstskolas bibliotēkai jānodrošina universālais informācijas pakalpojums jeb:

$>$ brīva pieeja informācijai ikvienam indivīdam nepārtraukti un labā kvalitātē;

$>$ brīva pieeja visiem informācijas resursiem: valsts nozīmes, biznesa, finanšu, tirgus, preču informācijai, kā ar̄̄ zinātniskai, tehniskai, tehnoloǵiskai, ekonomiskai, kultūras, vispārējai uzziņu un izklaides informācijai;

> kvalitatīvi uzziṇu informācijas pakalpojumi;

$>$ informācijas tīkli un sistēmas;

> pakalpojumi arī elektroniskajā vidē;

> informācijas masīvs digitālā formā u.c. 
Izglītības iestāžu bibliotēkām kā jebkurai publiskai bibliotēkai raksturīgi trīs produkti un pakalpojumu veidi - kolekcija/krājums, informācijas pakalpojumi (krājuma izsniegšana, uzziņas, lasītavas, informācijas tehnolog̣iju izmantošanas iespējas u.c.), pakalpojumu programmas (publicitāte, lietotāju informacionālā izglītošana, izstādes, tematiski informācijas avotu popularizēšanas pasākumi u.c.).

Krājums ir viena no sekmīgas informācijas pārvaldības sastāvdaḷām arī izglîtības iestāžu bibliotēkās. Organizējot darbu ar kolekcijām, bibliotēkām būtu jāvērš uzmanība avotu kvalitātei, apjomam, resursu dažādībai. Nepieciešama arī komplektēšanas politikas izstrāde, kurā atspogul̦otos krājumu attīstības koncepcija atbilstoši konkrētas mācību iestādes profilam un lietotāju informacionālajām vajadzībām. Svarīga vieta bibliotēku informācijas masīvā ir uz tehnolog̣iju bāzes radītiem un elektroniskajiem informācijas nesējiem (audio, videokasetes, lasāmatmiņas kompaktdiski, interaktīvie diski, videodiski, digitālie videodiski).

Nozīmīga loma lietotāju informacionālajā apkalpošana ir informācijas tehnologiju izmantošanai. Ar informācijas un komunikāciju tehnoloǵiju palīdzību bibliotēkas personāls veic jaunu informācijas avotu radīšanu (lokālās un tiešsaistes datu bāzes u.c.), iegūst informāciju par citu iestāžu kolekciju saturu, pieeju dažādu veidu informācijas avotiem.

Mācību procesa veicināšanas programmu organizēšana iespējama gan skolu, gan augstskolu bibliotēkās. Skolu bibliotēkās: sadarbībā ar priekšmetu skolotājiem un klašu audzinātājiem bibliotēku personāls sagatavo pārskatus par dažādu tematiku, veic bibliografēšanu, organizē bibliotekārās stundas u.c. Augstskolu un citu izglìtības iestāžu bibliotēkās: studentu/audzēkṇu informācijas prasmju attīstīšanas programmas, lokālo datubāzu veidošana u.c.

Ikviena bibliotēka ir Latvijas informācijas sistēmas būtiska daļa. Izglītības iestāžu bibliotēku galvenie mērķi - ar informācijas resursiem un pakalpojumiem, kā arī ar kompetentiem darbiniekiem būt par neatņemamu izglītības procesa sastāvdaḷu un sabiedrisku informācijas telpu, kurā skolēni/studenti iesaistās patstāvīgā mācīšanās procesā, bet pedagogiskais akadēmiskais personāls - profesionālās kvalifikācijas celšanā.

Nenoliedzami, ikviena bibliotēka ir sabiedrības apziņas (kultūras mantojuma un pieredzes) izpausmes forma, bet tās izpausmes veids ir informācija - galvenā funkcija un darbības lauks.

\section{IZMANTOTIE INFORMĀCIJAS AVOTI}

Karnītis, Edvīns. Informācijas sabiedrība - Latvijas iespējas un uzdrošināšanās. Rīga: Pētergailis, 2004. 208 lpp. ISBN 9984-33-074-5.

Turlajs, Jānis. Bibliotēku politika Latvijā. Bibliotēkas Pasaule, 2000. 16: 5.-12. ISSN 14076799.

Challenge and change in the information society. London:Facet Publishing, 2003. XVI, 239 p. ISBN 1-85604-453-X.

Clayton, P., Gorman, G.E. Managing information resources in libraries : collection management intheory and practice. London : Library Association Publishing, 2001. XVI, 272 p. ISBN 1-85604299. 
Libraries in the information society. Ed. By T.V.Ershova, E.Hohlov. Munchen: K.G.Saur, 2002.172 S. (IFLA publications; 102). ISBN 3-598-21832-X.

\section{ENDNOTES}

1 Šmite, Darja, Dosbergs, Dainis, Borzovs, Juris. Informācijas un komunikācijas tehnoloǵijas nozares tiesību un standartu pamati. Rīga: LU Akadēmiskais apgāds, [2005]. 207 lpp. ISBN 9984-770-79-6

2 Bibliotēku darba vide : Starptautiski izstrādāts materiāls. Daiga Rallıa etc. Rīga : [Kultūras koledža], [2003]. 60 lpp.

3 Gudakovska, Iveta. Augstskolas bibliotēkas attīstības konsekvences. No: Latvijas Universitātes Raksti: Jubilejas izdevums. Rīga: Latvijas Universitāte, [2004], 203.-208. lpp. ISBN 9984-770-41-9.

${ }^{4}$ Sporāne, Baiba. Bibliotēkas informacionālās telpas un lietotājvides saskarsme=Library Informational Environment and Users Environment Communication: [ziņojums starptautiskā konf. "Robežu paplašināšana: identitātes un kopienas" 2005.g. 9.-12 nov. Rīgā] . No: LU SPPI; Stratēgiskās analīzes komisija. Starptautiskā konferences "Robežu paplašināšana: identitātes un kopienas" materiāli. Rīga: LU Akadēmiskais apgāds, [2006], 409.-427.lpp. ISBN 9984-783-86-3.

5 Bibliotēku darba vide: Starptautiski izstrādāts materiāls. Daiga Ralı̣a etc. Rīga : [Kultūras koledža], [2003]. 60 lpp. 


\title{
Bibliotekārā valeoloǵija* - jauna zinātniskā disciplīna?
}

\author{
Elita Lazda
}

Latvijas Universitātes Sociālo zinātṇu fakultātes

Komunikāciju zinātņu doktorante

Valeoloǵija tiek saprasta kā zinātne par veselīgu dzīvesveidu. It kā jau būtu skaidri šīs jaunās zinātniskās disciplīnas motīvi: šodien tiek novērota strauja sabiedrības veselības pasliktināšanās. Par ko ir šī zinātniskā disciplīna - par veselību vai veselīgu dzīvesveidu? Ja tā ir par veselību, tad šì zinātniskā disciplīna jāattīsta mediķiem, kuru pārzin̄ā ir arī veselības uzlabošanas profilakse. Valeologi tam nepiekrīt un apgalvo, ka šì zinātne ir nevis medicīniska, bet gan izglītojoša rakstura. Savukārt, izglītības virziena pārstāvji uzskata, ka svarīgs ir gan dzīvesveids, gan dzīves ideāls, kuru ņemot vērā, cilvēks māk apzināties savu sūtību, saprast savus mērksus. Cilvēks apzinās, pēc kā tiekties un dēl kā dzīvot ${ }^{18}$.

Pirmās programmas un mācību grāmatas par šo jauno zinātnes disciplīnu tiek datētas apmēram ap 1997.gadu. Valeoloǵija ir pilnīgi nošķirta no klasiskās medicīniskās zinātnes, lai gan š̀ zinātne ir nedaudz sarežǵītāka kā fundamentālo zinātṇu sistēma. Kā jau zināms, Vispasaules Veselības Organizācija (VVO jeb angliski WHO) ir piedāvājusi medicīniskajai attīstībai integrālu koncepciju, kuras pamatideja tiek balstīta uz to, ka XXI gadsimtā medicīnai jāpāriet no „sargā un aizsargā" pozīcijām uz ,sociāli konstruktīvajām” pozīcijām, kuras būtu saistītas ar pašu veselību un cilvēku ilgdzīvošanu, pie tam principiāli jāmaina ārsta loma. No „slimību ārstētāja” jākḷūst par ,veselības konstruktoru”, bet „slimību medicīnai” jākḷūst par ,veselības medicīnu”.

Veselība - sistematizētas zināšanas, kurās savstarpēji tiek saistīta sabiedrības un individuālā veselība. Vispasaules Veselības Organizācijas speciālisti, 1946. gadā pieņemot šīs organizācijas statūtus, kuri stājās spēkā 1948. gadā, uzskata, ka veselība jātraktē ne tikai kā slimību un fizisko defektu neesamība, bet arī kā pilnīga fiziskā, garīgā un sociālā labklājība**. Šis traktējums pašā būtība nosaka, ka jēedziens „,veselība” jāsaprot daudz plašāk nekā tikai no mediciniskā viedokḷa, kaut vai tādēḷ, ka veselības jēdziena traktējumā ir iekḷauti vārdi „sociālā labklājība",, 12 .

Viena no pagājušā gadsimta īpatnībām ir stihiska zinātnisko disciplīnu rašanās, to diferencēšanās, pētniecisko virzienu formēšanas tempa paātrināšanās. Bieži vien pētniecības problēmas neiekl̦aujas klasiskajā zinātnes struktūrā, tādēl kḷūst par jaunām patstāvīgām zinātnes disciplīnām, kas spēj iekḷauties izglîtības sistēmā. Paralēli šim procesam notiek arī zināšanu integrācija, kuras rezultātā rodas megadisciplīnas, kas 
ietver gan virkni zinātnisko disciplīnu, gan vairākas specialitātes un izpētes nozares. Dr. philol. A. Ogurcovs***, piemērojot kādai zinātniskai disciplīnai zinātnisko taksonomiju, nosaka to kā sistematizācijas formu zinātnē. Tā ir saistīta ar zināšanu institucionalizāciju, kura atpaz̄stama pēc vispārpieņemtām normām un zinātnisko pētījumu izvirzītajiem ideāliem. Tā formē zinātnisko sabiedrību, kurā ir viena tipa literatūra (piemēram, mācību grāmatas), kurā ir noteiktas komunikācijas formas starp zinātniekiem, kurā ir patstāvīgi funkcionējošas iestādes, kuras ir atbildīgas par izglītību. Piemērs zinātnes integrācijai ir arī valeoloǵija, par kuru I. Brehmans ${ }^{* * * *}$ teicis: zinātnei par veselību jābūt integrētai, un tā rodas, saskaroties ekologiijai, bioloǵijai, medicīnai, psihologiijai, pedagoǵijai un citām zinātnēm. Tādēḷ ir skaidrs, ka šajā uzskaitîjumā nozīmīga vieta jāierāda arī profesioloǵijai, it sevišksi tai zināšanu jomai, kura aptver darba apstākḷu veidošanu un darbaspēju saglabāšanu ${ }^{13}$.

Darbaspējas ir parametri, kas nosaka resursu līmeni, kuri var tikt izmantoti, lai tiktu izpildīts kāds darba uzdevums. Kad runā par kāda konkrēta darba izpildītāja darbaspējām, tiek ņemta vērā vispārējā (potenciālā) darbaspēja, proti, tie resursi, kuri principā varētu tikt izmantoti pie maksimālas noslogotības un faktiskās (standarta) darbaspējas - tie resursi, kuri parasti tiek izmantoti. Faktiskā darbaspēja vienmēr ir zemāka nekā potenciālā. Apzinoties un konstatējot šo faktu, vadības speciālisti, to vidū personālvadības, neuzrāda šīs nesakritības iespējamos iemeslus. Tiek uzskatīts, ka viens no galvenajiem faktoriem, kas ietekmē darbaspējas un gala rezultātā padarītā darba kvalitāti katram darbiniekam atsevišķi un visam kolektīvam kopumā, ir labvēlīga darba apstākḷu sistēma, bet cilvēks - nepieciešamākais elements darba procesā $\bar{a}^{14}$.

Šodien daudzas profesionālās jomas saistītas ar psihisko spriedzi un stresu. Urbanizācija, dz̄ives tempa paaugstināšanās, informacionālā pārpilnība, savu spēku pārvērtěšana, vēlēšanās piepildīt savas vēlmes, nepamatoti ilga pacietība, savas sirdsbalss apslāpēšana, vēlmju nepiepildīšana, kā arī apziņa, ka realitāte neatbilst iedomātajam, bailes nokavēt, bailes aizmirst, bailes kaut ko palaist garām, komunikatīvais stress, ko rada informācijas pārpilnība, troksnis, agresīva vide, tas viss rada un attīsta psihiskas patalog̣ijas, kas savukārt izvirza virkni svarīgu uzdevumu psihohigiēnai un psihoprofilakei, kā cilvēkam saglabāt psihisko noturību.

Psihohigiēna - higiēnas nozare, kas pēta dzīves apstākḷus, kuri psihiski ietekmē cilvēku un izstrādā noteiktus pañēmienus, lai varētu saglabāt un nostiprināt psihi. Psihohigiēnas prasības darbā - nepieciešami apstākḷi, lai uzlabotu darba efektivitāti, jo cilvēka smadzen,u „rezerves” nav neizsmel̦amas. Ir tādas slodzes, kas var izjaukt cilvēka normālo psihisko stāvokli - un ne tikai psihisko, bet arī vājināt vispārējo fizisko veselības stāvokli, tādējādi mazinot viņa darbaspējas.

Indivīda potenciāls formējas uz bāzes, kas sastāv no psihiskās un fiziskās veselības un iedzimtajām psihologískajām īpatnībām. Tas noteiktā veidā ietekmē darbinieka darbaspējas un produktivitāti, viṇa psihologiisko stāvokli un emocionālo noturību, veicot savus darba pienākumus. Iedzimtās psihologiskās īpatnības (temperaments, dotības, spējas, raksturs) nosaka viņa spējas un vēlēšanos veikt kādu darbu. Uz dotību bāzes formējas radošās spējas, bet temperaments nosaka cilvēka uzvedības modeli dažādās situācijās. Viss minētais noder par bāzi, lai realizētu speciālista potenciālu kādā no darbības spējām. Viens no šîs problēmas galvenajiem aspektiem - individuālā noturība stresa situācijā̄s ${ }^{18}$. 
Ir zināms, ka cilvēka organisms spēcīgi reaǵē uz stresiem. Ilgstoši spēcīgi sociālie, biologiskie un fiziskie stresi rada tā dēvēto „dzīves stresu”, kura attīstības mehānisms un sekas pāriet socioloǵiskās, psiholoǵiskās un fizioloǵiskās problēmās. Tâs nav tik būtiskas, lai nekavējoties izvirzịtu pasākumu plānu, kā tās novērst, bet tās ne mazāk ietekmē sabiedrības veselību, kas saistīta ar profesionālo darbību. Šīs problēmas svarīgākie aspekti - individuālā stresogēnā jūtība saistībā ar izvēlēto profesiju. Tas viss pilnā mērā attiecas uz bibliotekāro profesiju.

Viens no garīgās piepūles radītājiem ir tas, ka šī profesija ir saistīta ar informāciju. Bibliotekāram informāciju nākas uzṇemt vairākos līmeņos, kas diferencējas atkarībā no tā specialitātes un pienākumu funkcijām. Ja nepārtraukti netiek iegūta, sintezēta un analizēta informācija (atpaz̄̄̌šanas darbības), nav iespējama bibliotekāra profesionālā (praktiskā) darbība. Viena no raksturīgākajām jeb specifiskākajām īpašībām bibliotekārajā profesijā ir tā, ka bieži vien praktiski nav iespējams atdalìt un norobežot, kāda informācija, kādas zināšanas nepieciešamas darbam, bet kādas sev, tā teikt, ,dvēselei”"16.

Mūsdienu bibliotēkzinātne kā disciplīnu komplekss, kas radies, integrējoties tradicionālajai (klasiskajai) bibliotēkzinātnei ar sociāli humanitārajām un eksaktajām zinātnēm, viennozīmīgi ir zinātnietilpīga. Piemēram, bibliotekārā tehnolog̣ija, bibliotekārā sociologija, bibliotekārā pedagoǵija, bibliotekārā psiholog̣ija, biblioterapija, bibliotekārā ētika, bibliotekārā filozofija kopš pirmā soḷa izglītības sistēmā turpinājusi veiksmīgi attīstīties, paplašinot savu empīrisko un teorētisko bāzi, tādejādi iegūstot zinātniskajai disciplīnai visas nepieciešamās pazīmes. Tā rezultātā bibliotēkzinātne iegūst ne tikai sarežg̀ītu, bet arī dinamisku disciplināro struktūru. Un tomēr, šì struktūra mūsdienās ir vēl tālu no optimālā, jo ne visi fenomena „,bibliotēka” komponenti kḷūst par zinātnisko pētījumu objektiem.

Bibliotekārā profesija ir daudzpazīmju objekts. Bibliotekārā profesiologiija kā pētniecības objekts ir rezultāts starpdisciplīnu mijiedarbībai uz bibliotekārās bāzes. Bibliotekārā profesiologiija ir mācība par bibliotekāru, proti, cilvēcisko faktoru bibliotekārajā vidē, kurai piemīt virkne problēmlauku, no kuriem trīs balstās uz socioloǵisko, psiholoǵisko un ekonomisko pieeju; aplūkojot cilvēcisko faktoru bibliotekārajā vidē, savukārt, trīs citas pieejas ir kompleksas: sociāli ekonomiskā (sociālais darbs), psihologiski ekonomiskā (psihologiskais darbs), sociāli psiholog̣iskā. Šīs uzskaitītās pieejas tādā vai citādā veidā attīstās, bet pat tādā lielā kompleksā izpētes laukā kāa „Bibliotekārā profesija: šodienas esamība un perspektīvas" jautājumi par bibliotēkas darbinieku veselību, arī - profesionālo veselību, netiek aizskarti. Zinātniekiem, kuri ir ieinteresējušies par bibliotekāro profesiolog̣iju kā zinātnes disciplīnu, empīriskajā bāzē ir pieejami nepiln̄̄gi dati. Protams, šie dati ir interesanti, bet sakarā ar straujajām un pamatīgajām izmain̄ām bibliotekārās informācijas vidē, kas atstāj visdažādākajā veidā iespaidu uz šajā sfērā strādājošajiem, arī uz veselību un darba spējām, šie dati var tikt izmantoti diezgan ierobežoti. Šì situācija bibliotekāro profesiju nepadara pievilcīgu un nenotur speciālistus ${ }^{13}$.

Visi darba pienākumi bibliotēkā pieder pie garīgas piepūles amatiem jeb bibliotekārais darbs galvenokārt prasa garīgo piepūli, tātad - jebkurš bibliotekārais amats satur nepieciešamību pielietot garīgu piepūli, būtībā tas būtu jāsaprot kā darba procesa piesātināšana ar garīgo piepūli un radošajiem elementiem. Viss bibliotekārā 
darba komplekss procesā ar bibliotēkas lietotājiem ir pārsātināts ar augstu atbildību, jo notiek režīmā ,jautājums-atbilde" (bibliotekārā apkalpošana), kas sevī ietver lielu emocionālo spriedzi un sarežgīitības pakāpi.

Bibliotekārā darba īpatnības ir jāskata kopumā ar pozitīviem faktoriem, piemēram, iespēja kontaktēties ar apmeklētāju, brīva pieeja literatūrai, laba darba organizācija un morālais klimats kolektīvā. Protams, ir arī negatīvie faktori, piemēram, fiziskā pārslodze, emocionālā spriedze, darba vienveidība un izteikti tehniskais raksturs dažiem bibliotekārajiem procesiem. Tas viss l̦auj ar pārliecību apgalvot, ka mūsdienīga bibliotekāra darbā ir sastopami nopietni draudi darbaspējai, fiziskajai un psihiskajai veselībai.

Lielāko draudu rada stress, informacionālā un emocionālā pārpūle, kas rada nopietnas sekas. Šīs īpatnības bibliotekārajā darbā jāņem vērā, lai varētu darbiniekiem sagatavot adekvātu reakciju, būt gataviem pieņemt atbilstošus līdzekḷus un lēmumus.

Šodien bibliotēkzinātṇu studentiem pasniegtās disciplīnas, piemēram, „Bibliotēkzinātne un bibliogrāfija”, „Lietišķā informātika” un „Dokumentoloǵija” praktiski dod visām bibliotēkām iespēju iegūt profesionāli sagatavotus darbiniekus. Vēl nesen bija runa tikai par profesionālo sistēmu „cilvēks-cilvēks”, bet tagad jau jārunā par sistēmu „cilvēks-mašīna”, „cilvēks-zīmju sistēma”. Pati bibliotekārā profesija aizvien vairāk pēc darba formas un būtības integrējas šajās sistēmās. Tādā veidā veselības saglabāšanās problēmas nevar vairs tikt aplūkotas tikai no tradicionālā bibliotekārā darba pozīcijām un pēc tradicionālajām bibliotekārajām tehniskajām iespējām ${ }^{14}$.

Bibliotekārās apkalpošanas darbiniekiem vēl jāpievieno emocionālā stresa draudi, kas rodas, pastāvīgi kontaktējoties ar bibliotekārās iestādes apmeklētājiem, kuri demonstrē visu psihoemocionālā stāvokḷa spektru. Pētot bibliotekāro profesiju un bibliotekāro darbu, ir iegūti rezultāti, kas norāda, ka komunikatīvajām funkcijām nepieciešams labi sagatavots speciālists. Plašie kontakti ar lasītājiem, tekstu pārpilnība un emocionālā informācija, nevienādais temps un darba ritms, daudzu bibliotekāro procesu rutīna rada augstu psihisko spriedzi uz darbības emocionālā fona. Tādēḷ reizēm bibliotekāri, kontaktējoties ar apmeklētājiem, mēdz būt saspringti un pat „neatvērti”.

Viena no parādībām profesionālajā nespējā adaptēties var izpausties kā „emocionālā sadegšana”, kas var izpausties, piemēram, bezmiegā; negatīvā attieksmē pret apmeklētājiem; negatīvā attieksmē pret pašu darbu; nepamatotā medikamentu lietošanā; apetītes trūkumā vai tieši otrādi - pārēšanās, negatīvā ,es-koncepcijā”; agresivitātē, kas izpaužas aizkaitinājumā, spriedzē, trauksmēe, nemierā, dusmās; mainīgā garastāvoklī; cinismā; pesimismā; bezcerībā; apātijā; depresijā; jēgas neredzēšanā un pastāvīgā vainas izjūtā.

Tādā veidā „emocionālās sadegšanas” sindroms izjauc emocionālo līdzsvaru profesionāliem, kuri strādā tādos apstākḷlos, kur ir cieša un intensīva sadarbība ar citiem cilvēkiem emocionālās spriedzes atmosfērā.

Jau vairākus desmitus gadu turpina pieaugt garīgā, emocionālā un informacionālā pārslodze bibliotēkas darbiniekiem, un tas ietekmē viṇu fizisko un psihisko veselību ${ }^{18}$.

Bibliotēkas speciālistu profesionālā kultūra ir pastāvīgs komponents bibliotekārās profesioloǵijas vidē. Pienācis laiks pievērst uzmanību bibliotekāru profesionālajai veselībai, citiem vārdiem sakot - valeoloǵiskajai kultūrai. 
Kulturoloǵijā ir vairākas kultūras definīcijas. Viena no tām definē, ka kultūra (lat. cultura 'kopšana, apstrādāšana, audzināšana') - viss, ko cilvēku sabiedrība radījusi ar cilvēku fizisko un garīgo darbu atšķirībā no dabas parādībām; šaurākā nozīmē - cilvēku garīgās dzīves un sociālās uzvedības normu sfēra ${ }^{19}$.

Š̀̃ definīcija ietver novērtēšanas elementus. Kultūra tiek vērtēta kā cilvēku sasniegumu summa. Ja šo pašu domu izsaka daudz īsāk, tad var teikt, ka kultūra veidojas no tā, ko un kam dara cilvēki, kā viṇi uztver izdarīto. Tātad profesijas pamatbūtība ir cilvēka (strādnieka) kultūras līmenis, viņa gatavība īstenot darbību. Tas nozīmē, ka jābūt nepieciešamajām iemaṇām šī darba veikšanai - profesionālajām, komunikatīvajām un adaptīvajām.

Profesionālā kultūra ietver sevī ne tikai darbā iegūtās iemaņas, bet arī visu cilvēka iekšējo kultūru, proti, dzīves veida vērtības. Cilvēka būtība izpaužas viņa darbībā, notiek mijiedarbība starp personību un darbību, kas l̦auj runāt par bibliotekāru kā par personību un profesionāli.

Mūsdienās daudzas profesijas, arī informacionālajā sfērā, saistītas ar psiholoǵisko spriedzi un stresu. Franču ārsts un filozofs Kabanis ${ }^{* * * * *}$ XVIII gs. beigās rakstīja, ka ir vēl viens iemesls garīgajām slimībām, proti, apkārtējā vide, kurā dzīvo un strādā cilvēka smadzenes. Ja sociālā dz̄ive pastāvīgi ir izkroplotota un cietsirdīga, smadzeņu darbība biežāk novirzās no pareizā cel̦a ${ }^{20}$.

Personības potenciāls formējas, pamatojoties uz diviem iedzimtiem komponentiem - psihiskā un fiziskā veselība, kā arī iedzimtās psihologiiskās īpatnības. Šie komponenti tieši ietekmē cilvēka darbaspējas un produktivitāti, kā arī viņa psiholoǵisko un emocionālo stāvokli darba veikšanas laikā $\bar{p}^{17}$.

Viens no bibliotekāru riska faktoriem ir informācijas pārpilnība, kuru iegūst kontaktējoties (ar lasītājiem, dokumentiem), - tas ir komunikatīvais stress. Ir pētījumi, kuri apstiprina, ka informācijas pārpilnība, kuru iegūst no televīzijas, grāmatām, reklāmām un žurnāliem, tagad arī no interneta, negatīvi ietekmē cilvēku veselību. Ārsti ir pat devuši nosaukumu šai slimībai - ,informacionālās pārpilnības sindroms”. Nav vajadzīgas lielas iztēles spējas, lai varētu iedomāties šo datu ekstrapolāciju bibliotekārajā sfērā. Tādēḷ vien var secināt, ka, meklējot bibliotēkas darbinieku informacionālās pārpilnības lokālās problēmas risinājumus, kā arī izveidojot profesionālo valeologijiju, kuras sūtība ir saglabāt veselību veselajiem, tā turpmāk būs mūsdienīga un aktuāla ${ }^{16}$.

Par valeoloǵiju, kurai ir gan dedzīgi atbalstītāji, gan noliedzēji, nevar vairs uzdot jautājumu „būt vai nebūt?”, bet principiāli rodas jautājums „kādai būt?”. Pie tam kā jebkura zinātniskā disciplīna, kura tikai formējas, valeolog̣ija atrodas zinātniskās sistēmas pašnoteikšanās, pozicionēšanās etapā, mēǵinot apzināt savas blakusproblēmas, kā arī meklējot iespējas starpdisciplinārajai sadarbībai. Šodien attīstās divi virzieni - medicīniskā un izglītojošā valeoloǵija. Protams, notiek arī attīstība citos virzienos, bet tā nav sistemātiska. Zinātnieki to skaidro, pamatojoties uz vairākiem faktoriem, bet visbiežāk - trūkst izpratnes par šīs zinātniskās disciplīnas nepieciešamību, pastāv iekšējais profesionālais konservatīvisms medicīnā, psihologijāâ, izglītîbā un citās jomās. Kā viena no svarīgākajām problēmām paliek izpratnes ,veselība” definēšana, kuru mediksi aplūko no tradicionālajām pozīcijām „,veselība-slimība”, savukārt citu jomu zinātnieki cenšas ieviest savu izpratni. Jebkurā gadījumā trūkst konsenss, lai šo problēmu varētu kaut nedaudz sākt risināt. 
Valeoloǵijas apmācības svarīgākie uzdevumi ir atrast veidu, kā cilvēkam formēt individuālo veselību, dzīvesveidu, nodrošināt optimālu pastāvēšanu un attīstību.

Sabiedriskās funkcijas, uzdevumi un mērkịi, kā arī profesijas piederība tipam „cilvēks-cilvēks”, l̦auj teikt, ka bibliotekārus gaida nopietna problēma - radīt adekvātu cilvēku attieksmi pret sevi, savu veselību, dzīvesveidu un apkārtējās vides veselību. Nozīmīgu vietu šīs jomas zināšanās un mākā jāien̦em profesionālajai veselībai. Tādēl ar pārliecību var teikt, ka drīz vien kā minimums attīstīsies divi valeologiijas virzieni - lasītāju valeolog̣ija (bibliotekārās iestādes lietotāji) un bibliotekārā valeogija (bibliotekārās iestādes subjekta darbība) ar nosacījumu, ka būs starpdisciplinārā mijiedarbība, piemēram, starp vairākām sociāli humanitārajām zinātnēm ${ }^{15}$

Piemēram, notiks plaša sadarbība visām humanitārajām zinātnēm ar sociāli informacionālo ekoloǵiju un profesiologiju. Būtu jāpanāk, lai mācību procesa speciālo disciplīnu blokā parādītos integrētais kurss „Bibliotekārā valeoloǵija”, kur kopā ar problēmām par bibliotekāro iestāžu subjektu veselības saglabāšanu tiktu veikta analīze un rasti risinājumi tehnologiskajai, ētiskajai un estētiskajai profesionālajai darbībai ${ }^{14}$.

N̦emot vērā, ka bibliotekārās valeoloǵijas centrā ir bibliotekāro darbinieku darbības procesi, kḷūst redzams, ka bibliotekārā valeologija ir l̦oti aktuāla. Tā kā bibliotekārais darbs ir pārsātināts ar intelektuālu darbu, bibliotekārā darba psihohigiēnas problēmas izpētē un psihiskās veselības saglabāšanas profilakses sistēmas izstrādāšanā, kas ietver darbinieku apmācību psihohigiēnā, vajadzētu iekḷaut psihoekologiskās un profesionālās darbības lauka principus, psihiskās atveselıšanās metodiku, psihologiskās un informacionāli psihologiiskās aizsardzības pañēmienus ${ }^{18}$.

Profesionālā veselība - tā ir organisma spēja saglabāt un aktivizēt kompensatorus, vairogus, regulējošos mehānismus, kas nodrošina cilvēka darbaspējas, cilvēka personības attīstības efektivitāti, veicot profesionālo darbību.

Veselība valeologijāa - cilvēka spēja izpildīt savas biosociālās funkcijas mainīgā vidē ar pārpūli, bet bez zaudējumiem.

Valeoloǵiskā kultūra kā daļa no pamatkultūras iekl̦auj sevī ne tikai cilvēka darbības objektīvus rezultātus, kas izpaužas cilvēka un sabiedrības veselībā, bet arī cilvēka subjektīvās spējas un varēšanu, kas izpaužas darbībā, kura vērsta uz organizētu individuāli veselīgu dzīves veidu.

Veidot bibliotekārā darbinieka ,aizsargus no briesmām”, kas saistītas ar profesionālo darbību, - šis uzdevums ir perspektīvs un grūts. Faktiski tas ir komplicēts uzdevums, kura atrisināšana balstās uz pedagoǵiskajiem, psiholoǵiskajiem, socioloǵiskajiem, tehnoloǵiskajiem, ekonomiskajiem, profesionālās izglìtības, medicīniskajiem un valeologiskajiem sasniegumiem.

Visu šo uzdevumu galvenajam mērḳim vajadzētu būt bibliotekārās vides speciālista veselības saglabāšana, - gan fiziskās, gan psihiskās veselības. Jāatrod atbildes, kā iegūt spējas un māku saglabāt un uzturēt profesionālo veselību ${ }^{17}$. Secinājums ir viennozīmīgs - tai jābūt bibliotekārajai valeoloǵijai, kas palīdzēs iegūt šīs spējas un māku! 


\section{IZMANTOTIE INFORMĀCIJAS AVOTI}

1. Агаджанян, Н.А., Алексеев, С.В., Ананьев, В.А., Андреев, Ю.А. Валеология человека: здоровье -любовь - красота: В 2 кн., 5 т. - 2-е изд., доп. и откорректир. СПб.: Petroc, 1998. (Валеол. семинар акад. В.П.Петленко). (Кн.1. (Т.1-3). 718 с.: ил.;Кн.2. (Т.4-5). 830 с.: ил.)

2. Апанасенко Г.Л. Валеология в практике семейной медицины // Медицина Украины. - 1996. 3: 33-34.

3. Апанасенко, Г.Л. Валеология: имеет ли она право на самостоятельное существование? // Валеология. 1996. 2: 9-15.

4. Апанасенко, Г.Л. Валеология: состояние и перспективы развития // III национальный конгресс по профилактической медицине и валеологии. С.Петербург, 28-31 мая 1996 г.: Тез. докл. СПб., 1996. С.17-18.

5. Апанасенко, Г.Л. Валеология: стратегия здравоохранения будущего // IV национальный конгресс по профилактической медицине и валеологии; II национальный конгресс по натуротерапии и рекреации: Материалы конгрессов; С.-Петербург, 19-22 июня 1997 г.- СПб.: Издат. дом «Здоровый мир», 1997. С.8-10.

6. Баевский, Р.М., Берсенева, А.П., Максимов, А.Л. Валеология и проблема самоконтроля здоровья в экологии человека: Учеб.-метод. пособие: В 2 ч. Магадан: Сев.-Вост. науч. центр ДВО РАН, 1996. - Ч.1. - 55 с.: ил. - Библиогр.: c.51-53.

7. Гамаюнов, С.А. “Что скрывается под маской валеологии?” Информационный листок центра “Жизнь”. М., 1999

8. Силуянова, И.В., Юдин, Б.Г. Воспитание наукой. Чему и как будут обучаться будущие Врачи в XXI веке? // Медицинская газета. 9.8.2000.

9. Силуянова, И.В. "Клятва врача России" в контексте морального сознания Православия.// Православие и проблемы биоэтики. ЦОС МП. Выпуск 1.М. 2001, c.74-81.

10. Силуянова, И.В. Сделай себя сам. Профессия и нравственность.//Медищинская газета. № 39, 25.05.05, с.12.

11. Силуянова, И.В. Этико-правовые вопросы взаимоотношения “врач-пациент" в условиях современной медицины // Вестник оториноларингологии Материалы 3-й Российской научно-практической конференции "Наука и практика в оториноларингологии”. М. 2004, с.41-45.

12. Силуянова, И.В. Искушение “клонированием” или человек как подобие человека. M., 1998

13. Соколов, А.В. Библиотеки и социальные коммуникации. Лекции // Науч. и техн. б-ки. 1994. № 8-11; Эволюция социальных коммуникаций: Учеб. пособие (СПб.; Изд-во Лен. обл. пед. ин-та, 1995. 163 с.).

14. Савич, Л.Е. Библиотечная валеология в системе подготовки информационнобиблиотечных кадров. (tiešsaiste). (Skatīts 2006.g. 31.oktobrī). Pieejams: http:// libconfs.narod.ru/2002/1s/s1_p39.htm

15. Савич, Л.Е. Библиотечная валеология-нужна ли новая научная дисииплина? (tiešsaiste). (Skatīts 2006.g. 31.oktobrī). Pieejams: http://libconfs.narod.ru/2001/9s/s9_ p42.html

16. Савич, Л.Е. Проблемь здоровья и труд библиотекаря. (tiešsaiste). (Skatīts 2006.g. 31.oktobrī). Pieejams: http://libconfs.narod.ru/2000/5s/5s_p29.htm

17. Савич, Л.Е. Профессиональная и валеологическая культура информационнобиблиотечного специалиста общее и частное. (tiešsaiste). (Skatīts 2006.g. 31.oktobrī). Pieejams: http://libconfs.narod.ru/2004/s7/s7_p27.htm 
18. Савич, Л.Е. Психогигиена библиотечного труда - необходимая составная часть библиотечной валеологии. (tiešsaiste). (Skatīts 2006. g. 31. oktobrī). Pieejams: http:// libconfs.narod.ru/2003/s7/savich.htm

19. Svešvārdu vārdnīca (kompaktdisks) : Jumavas datorenciklopēdija. Rīga : izdevniecība Jumava, 2002. 1 kompaktdisks; Sistēmas prasības: Microsoft Windows 95, 98, Me or 2000 , Pentium II or faster processor, $50 \mathrm{Mb}$ free space on hard disk, $128 \mathrm{Mb}$ or more RAM

20. Evene.fr Toute la culture (tiešsaiste) Tout Pierre-jean-Georges Cabanis Sur (Skatīts 2006. g. 31. oktobrī) Pieejams: http://www.evene.fr/celebre/biographie/pierre-jean-georgescabanis-2726.php

21. Актуальные вопросы валеологии: (Экспресс-диагностика индивид. психофизиол. параметров личности): Материалы регион. науч.-практ. конф., г. Екатеринбург, $27-$ 28 марта 1997 г. - Екатеринбург, 1997. 64 с.

22. Проблемы валеологизации образовательной среды. Межрегиональный опыт, перспективы. Научно-методическое пособие (Кемеровский госуниверситет. Сибирский филиал Института общего образования Министерства образования России, Кемеровский областной психолого-валеологический центр ДО АКО). Кемерово: Кузбассиздат, 1999. 293 с.

23. Сборник программ общепрофессиональных дисциплин по специальности “Валеология" / Под ред. Тороховой Е.И. (Московский педагогический государственный институт). М.: Флинта, Наука, 1999. 136 с. ISBN 5-89349-189-0

\section{ENDNOTES}

* Veselības saglabāšanas paņēmieni (valeolog̣ija)

** (WHO's Constitution) - angl̦u val.

*** Strādā Krievijas Zinātṇu akadēmijas Filozofijas institūtā.

**** Izraēls Brehmans (1921-1994) - vadošais zinātniskais farmakologs, medicīnas zinātņu doktors, profesors, valeologijijas zinātnes pamatlicējs

****** Pjērs Žans Žoržs Kabanis (fr. Pierre Jean Georges Cabanis) (1757.g.5.jūnijs-1808.g. 5.maijs) — franču folozofs-materiālists un ārsts. 


\section{Informācijas transformācija zināšanās: ierobežojumi un dilemmas}

\section{Baiba Mūze}

Informācijas sabiedrībā svarīga loma ir zināšanu pārvaldībai. Uz zināšanām balstīta ekonomika ir pamats sabiedrības dzīves līmeņa paaugstināšanā. Valsts attīstībā aizvien nozīmīgāka kḷūst sabiedrības spēja radīt jaunas zināšanas un izmantot tās ikvienā darbībā, sekmējot tautsaimniecības attīstību un vispārējā dzīves līmeņa celšanos $(9,99.1 p p$.).

Latvijas "Informācijas sabiedrības attīstības pamatnostādnēs 2006.-2013. gadam" (5) uzsvērta informācijas un komunikācijas tehnologijiju izmantošana dzìves kvalitātes paaugstināšanai un uz zināšanām balstītas ekonomikas veidošanai. Viens no informācijas sabiedrības veiksmīgas attīstības priekšnosacījumiem ir bagātīgs informācijas pakalpojumu klāsts un to saturs, kura nodrošināšanā piedalās arī bibliotēkas ar digitālajiem resursiem un citām publiski pieejamām zināšanu krātuvēm (2). Bibliotēku pamatuzdevumi - resursu veidošana un informācijas pieejamības nodrošināšana - apliecina, ka bibliotēkas ir mūžizglītības bāze.

“Latvijas izglītības pamatnostādnēs 2007.-2013.gadam” izteikta atziṇa: katram iedzīvotājam jānodrošina iespēja iegūt kvalitatīvu izglītību mūža garumā atbilstoši individuālām interesēm, spējām un valsts ekonomiskās attīstības vajadzībām (8).

Informācijas sabiedrības veidošanā bibliotēkām ir stratēǵiska loma. Bibliotēkas ir zināšanu ieguves avots, kas saviem lietotājiem padara viegli un ātri pieejamas visu veidu zināšanas un informāciju (4). 21.gadsimta bibliotēku uzdevums ir piedāvāt kvalitatīvus informācijas pakalpojumus, lai jebkuram sabiedrības loceklim nodrošinātu informācijas pieejamību un iespēju informāciju transformēt zināšanās.

Valsts integrētās informācijas sistēmas sekmīgā nodrošināšanā ir svarīgi, lai katrs tās ietvaros nodrošinātais pakalpojums būtu kvalitatīvs un katra izpildītājinstitūcija (to skaitā bibliotēka) atbildētu par tā izpildi (15).

Bibliotēkas misiju un atbildību ietekmē sabiedrības attīstības virzieni. Informācijas sabiedrībā galvenais bibliotēkas uzdevums ir nodrošināt informācijas pieejamību, zināšanu sabiedrībā - informācijas transformāciju zināšanās.

Lai apstrādātie dati tiktu nodoti tālāk kā organizēta informācija, radītu izpratni un zināšanas, informācijas apstrādes procesā bibliotēkās svarīgi ir radīt bāzi informācijas pievienotajai vērtībai, veidojot kvalitatīvus katalogus un citas bibliogrāfiskās datubāzes. Kā atzinuši amerikāṇu informācijas speciālisti Diāna J.Kanningama 
(Diana J.Cunningham), Marija T.Ašere (Marie T.Ascher) un Helena-Anna Brauna (Helen-Ann Brown), "vērtības pievienošana informācijai ir daļa no mūsdienu bibliotēku būtības un kompetences. Informācijai tiek pievienota vērtība, nodrošinot tai ērtāku un vienkāršāku pieeju ar indeksēšanas un bibliogrāfiskās aprakstīšanas palīdzību, veidojot sistēmu, lai loǵiskāk organizētu informāciju un vienkāršāk to varētu meklēt. Bibliotekāri līdz ar to pievieno vērtību arī savu bibliotēku krājumiem (virtuālajiem un reālajiem), palīdzot lietotājiem virzīties plašajā literatūras klāstā, sistēmās un saskarnēs un nodrošinot apmācību, uzziņu pakalpojumus un palīdzību meklēšanā" (1).

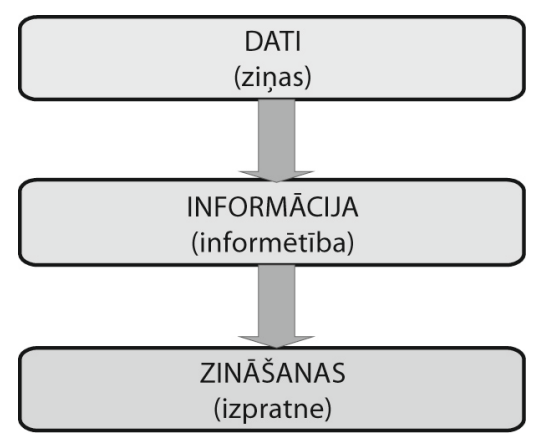

\section{1. attēls. Jaunu zināšanu un izpratnes radīšanas modelis (14, 170.lpp.)}

Uz zināšanām balstītā informācijas sabiedrībā nozīmīgi ir nodrošināt ne tikai nepieciešamo informācijas infrastruktūru, bet arī zināšanas. Bibliotēkās apstrādātie dati nododami tālāk kā organizēta informācija, lai tā radītu izpratni un zināšanas. Datu apstrāde atbilstoši lietotāju vajadzībām, kuras mērķis izgūt informāciju, dod iespēju informāciju transformēt jaunās zināšanās. Mūsdienu bibliotēku darbā tiek atbalstîtas jaunas konceptuālās nostādnes. Mainījušies normatīvie dokumenti, kas nosaka datu apstrādes, informācijas organizēšanas un resursu veidošanas principus. Dinamiski mainās arī bibliotēku darbības novērtēšanas principi, aizvien lielāku nozīmi piešķirot darba kvalitātes un veiktspējas kvalitatīvajiem rādītājiem. Datu apstrādes un informācijas organizēšanas principi atspogul̦oti teorētiski konceptuālajā modelī "Funkcionālās prasības bibliogrāfiskajiem ierakstiem" $(6 ; 18)$.

Informācijas izguves un zināšanu radīšanas sistēmā galvenie elementi ir šādi:

- informācijas avots;

- informācijas speciālists;

- lietotājs;

- bibliotēku informācijas sistēma;

- informācijas un komunikācijas tehnoloğijas.

Bibliotēkzinātnes speciāliste Baiba Sporāne uzsver bibliotēkas ārējo sociālo funkciju - nodrošināt informācijas pieejamību (17, 197.-198.lpp.). Bibliotēkas veido dažādus informācijas resursus (elektronisko katalogu, citas bibliogrāfiskās datubāzes, krājuma unikālo materiālu digitālās kolekcijas), kā arī izmanto citus ārējos informācijas resursus. Problēmas un ierobežojumi var negatīvi ietekmēt jebkura informācijas resursa izmantošanu. 


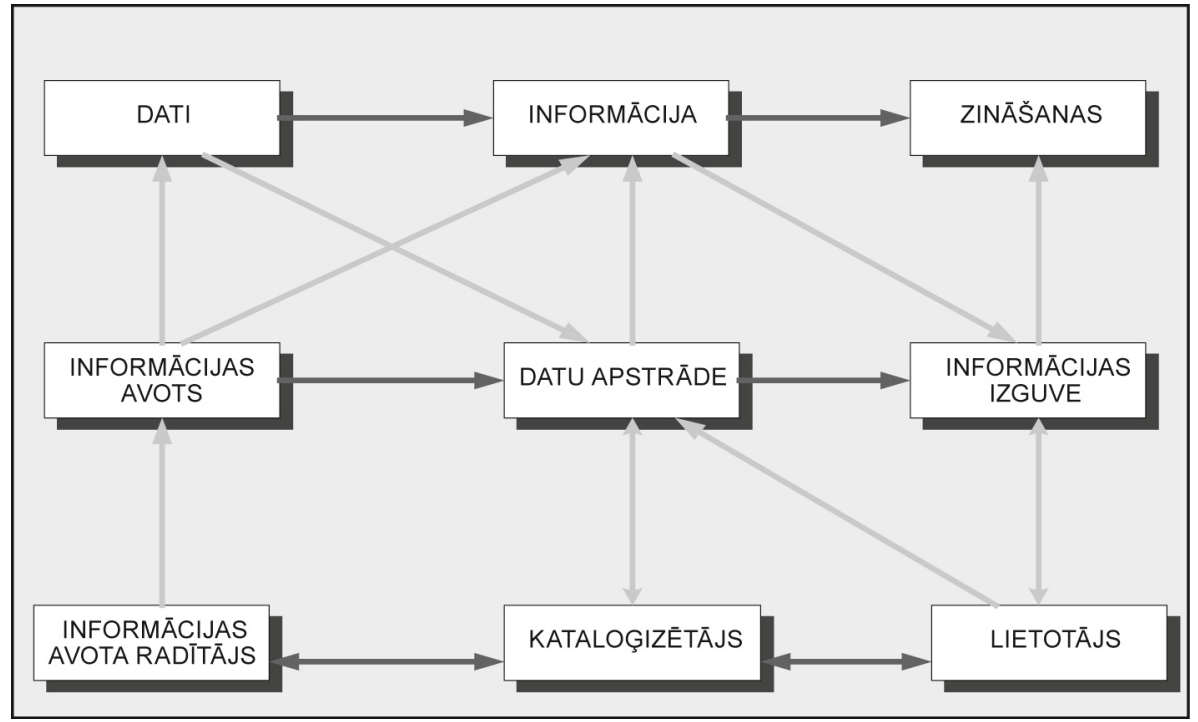

2. attēls. Informācijas izguves un zināšanu radī̌sanas sistēma (14, 13.lpp.)

Informācijas izguvi un tās transformāciju zināšanās negatīvi ietekmē vairākas problēmas un ierobežojumi. Jebkurā no sistēmas DATI $\rightarrow$ INFORMĀCIJA $\rightarrow$ ZINĀŠANAS elementiem sastopamas problēmas, kuras pastiprina vairāki faktori. Informācijas sabiedrības veidošanu ierobežo vairāki apstākḷi: nepietiekamas prasmes informācijas un komunikācijas tehnoloǵiju izmantošanā un informācijpratībā, kā arī nepietiekams tiešsaistes pakalpojumu un satura apjoms.

Informācijas un komunikācijas tehnoloğijas piedāvā bibliotēkām jaunus izaicinājumus, dod iespējas plašākai informācijas pieejamībai un izguvei. Tomēr informācijas izmantošanai mūsdienās raksturīgās pretrunas rosina uzdot jautājumus: vai piedāvātā INFORMĀCIJA var radīt IZPRATNI (ZINĀŠANAS)? Vai BIBLIOTEKĀRS un INFORMĀCIJAS SAN̦ĒMĒJS gatavs transformācijai?

Informācijas transformācijas procesā var saskatīt vairākas dilemmas. Publikācijā izmantotas atziņas, kas iegūtas autores veiktajā valsts un reǵionālās nozīmes elektronisko katalogu kvalitātes pētījumā, un tās detalizēti ir atspoguḷotas promocijas darbā (14).

\section{Dilemma Nr. 1}

\section{INFORMĀCIJAS UN KOMUNIKĀCIJAS TEHNOLOĢIJAS PIEDĀVĀ PLAŠ̄̄KAS IESPĒJAS INFORMĀCIJAS PIEEJAMĪBAI? vai \\ INFORMĀCIJAS UN KOMUNIKĀCIJAS TEHNOLOGIJAS RADA PIEEJAMĪBAS IEROBEŽOJUMU?}

Informācijas izguvi un izmantošanu ietekmē ne tikai tās fiziskā, bet arī intelektuālā pieejamība vai tās ierobežojumi. Baiba Holma, viena no Latvijas informācijas zinātnes speciālistēm, uzskata, ka "fiziskā pieejamība vēl nenozīmē 
intelektuālo pieejamību. Informācijas lietotājiem termins informācijas intelektuālā pieejamība nozīmē atrastā informācijas avota saprotamību un atbilstību informācijas lietotāja zināšanām, tāpēc to var uzskatīt par vēlamo rezultātu ikvienai informācijas meklēšanas situācijai”" (3, 440.lpp.).

Novērtējot Latvijas lietotāju prasmes un pieredzi informācijas tehnologiju izmantošanā, kā arī informācijas resursu un meklēšanas sistēmas nepilnības, jāatzīmē, ka informācijai piemīt ierobežota intelektuālā pieejamība. Komentējot "Informācijas un komunikāciju tehnologijas izglītības kvalitātei programmu 2007.-2013.gadam”, Viesturs Krievāns izteicis atziņu, ka jānodrošina kvalitatīva informācijpratība un datorpratības apguve (12).

\section{FIZISKĀ PIEEJAMİBA}

Bibliotēku veidotajiem informācijas resursiem (elektroniskie katalogi, bibliogrāfiskās datubāzes, digitālās kolekcijas) ne vienmēr ir nodrošināta pastāvīga fiziskā pieejamība. To ietekmē tehnologiska rakstura problēmas. Fizisko pieejamību informācijas meklēšanas sistēmai norāda šādi galvenie kritēriji:

- vai katalogam/datubāzei ir pastāvīga pieejamība;

- vai iespējams veikt informācijas izguvi;

- kāds ir meklēšanas ātrums.

Lielākajai daḷai valsts nozīmes un reǵionālo informācijas resursu ir attālā pieeja tīmeklī. Tomēr ne visiem resursiem tā ir nodrošināta, un tie ir izmantojami tikai bibliotēkā uz vietas.

Jāatzīmē, ka neatbilstoša tehniskā infrastruktūra un nepietiekams informācijas un komunikācijas tehnologiju atbalsts ierobežo fizisko piekḷuvi informācijai.

Informācijas izmantošanu negatīvi ietekmē tehnoloǵiskās un komunikāciju problēmas, kuru dēl bieži vien katalogi nav pieejami. Piemēram, bibliotēkas katalogam tiek izmantots ports, kas lielai dal̦ai lietotāju ir bloḳēts - līdz ar to pieeja katalogam ir ierobežota. Pieejamību ierobežo arī lietotāju licenču skaita ierobežojums, tādējādi ierobežojot datu lejupielādi ar Z39.50. Sakarā ar servera zemo veiktspēju apgrūtināta ir vairāku informācijas resursu izmantošana, jo meklēšana un atlases rezultāta izmantošana notiek ļoti lēni.

Informācijas izguvi var ierobežot arī bibliotēku informācijas sistēmas funkcionālās nepilnības - ierobežotas iespējas datu apstrādē vai informācijas izguvē. Piemēram, bibliotēku informācijas sistēmai var būt nepilnīgas meklēšanas iespējas, ierobežots meklēšanas kritēriju skaits, atlases rezultāts netiek atspoguḷots atbilstoši standartizētajām prasībām, nav nodrošināta autoritatīvo datu kontrole un citas nepilnības, kas negatīvi ietekmē informācijas izguvi un izmantošanu.

\section{INTELEKTUĀLĀ PIEEJAMĪBA}

Informācijas resursu intelektuālo pieejamību ietekmē to izmantošanas ērtums un vienkāršība, izgūtās informācijas iespējas - vai tās nodrošina informētîbu un dod iespēju radīt izpratni. 
Elektronisko katalogu pieejamību ietekmē saskarnes valoda. Lai nodrošinātu katalogu plašāku izmantošanu Latvijā un starptautiskajā vidē, saskarnei vajadzētu būt ne tikai valsts oficiālajā valodā, bet arī krievu un angḷu valodā. Visu pētījumā iekl̦auto katalogu saskarne ir latviešu un angl̦u valodā, bet tikai 13 katalogiem arī krievu valodā. Abu nozīmīgāko informācijas resursu - Valsts nozīmes bibliotēku kopkataloga un Nacionālās bibliogrāfijas datubāzes - saskarne nav pieejama krievu valodā. No tā var secināt, ka krievvalodīgajiem lietotājiem minēto resursu pieejamība ir ierobežota. Šāda situācija neveicina sabiedrības integrāciju, jo visiem lietotājiem nepiedāvā vienādas iespējas.

Nepietiekami tiek izmantotas iespējas informācijas resursu veidošanā dažādām lietotāju grupām, piemēram, bērniem, jauniešiem, lietotājiem ar īpašām vajadzībām.

Tā kā elektroniskie katalogi Latvijas bibliotēkās sākti veidot tikai 20.gadsimta 90.gados, tad ne visos vēl ir pieejama informācija par visu bibliotēkas krājumu. Dati liecina, ka lietotājiem elektroniskajos katalogos nav pieejama informācija par gandrīz pusi no pētījumā iekḷauto bibliotēku krājumos apkopotajiem dokumentiem, bet gandrīz nevienā bibliotēkas tīmekḷa vietnē par to nav sniegta informācija. Tas maldina lietotāju, meklēšanā nesaņemot nepieciešamo informāciju vai arī saņemot neatbilstošu rezultātu. Tādējādi lietotājam nav pieejama informācija par visu bibliotēkas krājumu - apmēram pusei krājuma ir ierobežota pieejamība.

Tikai par 5 valsts un reǵionālās nozīmes katalogiem uzrādīta informācija, kāds ir atlasītā rezultāta atspoguḷošanas ierobežojums. Līdz ar to lietotāji tiek maldināti par 12 katalogu (71\%) saturu.

Pozitīvi jāatzīmē, ka visos elektroniskajos katalogos pieejama palīdzība, lai lietotājam būtu iespēja iepazīties, kā pareizi veidot meklēšanas pieprasījumu, izvēlēties meklēšanas kritēriju un ievadīt vērtību. Lielākajai daļai katalogu ir iespēja jautāt bibliotekāram vai rakstīt lietotāja komentārus par kataloga izmantošanu, aizsūtot elektronisko vēstuli. Tomēr aptaujas dati liecina, ka lietotāji nepietiekami izmanto piedāvātās palīdzības iespējas. To var izskaidrot ar bibliotekāru kūtro attieksmi palīdzības teksta sastādīšanā, kā arī ne vienmēr lietotājs atbildi saņem operatīvi.

Katalogu saskarne un piedāvātās izmantošanas iespējas nereti nav draudzīgas lietotājam, ir nesaprotamas un sarežginiti izmantojamas. Informācijas pilnvērtīga izguve ir atkarīga no tā, vai lietotājam ir saprotamas funkcionālās iespējas, komandpogu apzīmējumi un lietošana. Ne reti saskarnē sastopami apzīmējumi, kuri ir saprotami tikai informācijas speciālistam.

Aptaujāto lietotāju galvenie pārmetumi katalogu veidotājiem ir par to, ka par katalogiem un to izmantošanas iespējām netiek sniegta pietiekama informācija, katalogi netiek pietiekami reklamēti, bibliotēku tīmekḷa vietnēs netiek sniegta saprotama palīdzība katalogu izmantošanā. $24 \%$ no aptaujātajiem lietotājiem atzinuši, ka bibliotēku speciālisti pārāk maz uzmanības pievērsuši, lai pilnveidotu katalogu pieejamību.

Bibliotēku tīmekḷa vietnēs pieejamās informācijas analīze apstiprina lietotāju pārmetumus, jo lielākai daḷai bibliotēku ir tikai norāde uz katalogu. Par 8 no pētītajiem katalogiem (47\%) bibliotēkas tīmekḷa vietnē sniegta pilnīgāka informācija elektroniskajā katalogā iekḷauto materiālu raksturojums un hronologiskais periods. 
Svarīgi ir sniegt lietotājam informāciju, vai katalogā pieejamas ziņas tikai par vienu vai vairākiem kopkataloga bibliotēku krājumiem, par kāda perioda un kādu veidu izdevumiem iekḷauti ieraksti.

Pilnvērtīgāku informācijas pieejamību nodrošina saites uz citiem resursiem, it sevišksi gadījumos, ja vajadzīgo informāciju izvēlētajā resursā nav izdevies atrast. Ja bibliotēkas katalogam vai citam informācijas resursam nodrošināti vairāki pieejas veidi, tas paplašina tā pieejamību un izmantojamību. Piemēram, Ventspils bibliotēkas veidotie resursi pieejami bibliotēkas tīmekḷa vietnē, Kurzemes virtuālajā kopkatalogā un Augstskolu un speciālo bibliotēku virtuālajā kopkatalogā. Tas dod iespēju lietotājam dažādos veidos piekḷūt bibliotēkas veidotajiem resursiem.

Elektronisko katalogu un citu datubāžu saskarne un piedāvātās izmantošanas iespējas bieži ir nedraudzīgas lietotājam, ir nesaprotamas un sarežğīti izmantojamas. Kā pieejamības ierobežojums jāatzīmē arī nekorektā informācijas izguve, kas neatbilst meklēšanas pieprasījumam, nav ticams rezultāts vai lietotāja vajadzībām neadekvāta izmantošana.

Bibliotēku katalogos un citās datubāzēs nepietiekami izmanto iespējas veidot saites uz pilntekstu vai citu saistīto informācijas resursu. Maz tiek izmantota iespēja datubāzes ierakstam pievienot papildu informāciju par resursu - anotāciju, attēlus, saites. Nepilnvērtīgā saišu un norāžu sistēma neveicina informācijas lauka paplašināšanu un resursu pieejamību. Tādējādi veidotas informācijas izguves sistēmas tikai dal̦ēji atbilst starptautiskajām vadlīnijām un teorētiskajām koncepcijām par informācijas lietotāju vajadzībām $(6 ; 7 ; 18)$.

\section{INFORMĀCIJAS IZGUVE}

Informācijas izmantošanas kvalitāti ietekmē izguves iespējas: meklēšanas veidi un kritēriji, atlasītās informācijas attēlojums, izvadformas, dokumentu saņemšana.

Ne vienmēr tiek nodrošināti vairāki meklēšanas veidi un ar meklēšanu saistîtie procesi: vienkāršā un paplašinātā meklēšana, pārlūkošana, filtrēšana, precizēšana, kārtošana un citas iespējas.

Pilnvērtīga meklēšanas procesa nodrošināšanā svarīgs ir meklēšanas kritēriju kopums - cik un kādi kritēriji ir izmantojami, kā arī to konfigurācija meklēšanas procesam. No tā ir atkarīga meklēšanas rezultāta precizitāte un atbilstība pieprasījumam. Ne vienmēr meklēšanas kritēriju apzīmējumi ir saprotami lietotājam un izprotama to funkcionalitāte. Tas nelabvēlīgi ietekmē meklēšanas procesu un ierobežo korektu pieejamību informācijai.

Nozīmīgi ir nodrošināt informācijas pieejamību pēc visbiežāk izmantotajiem kritērijiem - meklēt pēc zināmas personas, dokumenta nosaukuma vai temata. Diemžēl jāatzīst, ka Latvijas bibliotēkās veidotajās informācijas izguves sistēmās tematiskā datu apstrāde un līdz ar to meklēšana ir nepilnvērtīga. Ierobežota ir tematiskā informācijas izguve gan pēc klasifikācijas indeksiem un tematiem, gan pēc tematiskajiem priekšmetiem. Vienotās bibliotēku informācijas sistēmas ietvaros vajadzētu izstrādāt kopīgus principus informācijas tematiskās izguves uzlabošanai.

Atlasītās informācijas kopumam vajadzētu būt pieejamam vairākās attēlojuma formās, lai lietotājs ērti var izmantot nepieciešamo. Informācijas atlases rezultātu 
izmantošana dažādām lietotāju grupām var atškirties - bibliotekāram nepieciešams ierakstus skatīt un veikt profesionālas darbības, izmantojot bibliogrāfisko vai mašīnlasāmās kataloǵizācijas formātu, savukārt gala lietotājs vēlas iegūt ērti izmantojamu attēlojumu vai ierakstus izgūt bibliogrāfisko norāžu formātā. Ne visi katalogi un bibliogrāfiskās datubāzes nodrošina minētās iespējas, tādējādi ierobežojot informācijas izmantošanu.

Ziṇas par iespējām saņemt vajadzīgo dokumentu vai pieeju elektroniskajam resursam ne vienmēr ir saprotamas. Vajadzētu pilnveidot apzīmējumus informācijas krātuvēm, sniegt nepieciešamo informāciju par tās atrašanās vietu un pieejamības nosacījumiem, kā arī saprotami raksturot piedāvātos dokumentu saņemšanas pakalpojumus.

\section{Dilemma Nr. 2 \\ BIBLIOTEKĀRAM IR PIETIEKAMI AR LĪDZŠINĒJO KVALIFIKĀCIJU?}

vai

\section{BIBLIOTEKĀRAM JĀBŪT INFORMĀCIJAS SPECIĀLISTAM?}

21.gadsimtā ir mainījušies bibliotekāra uzdevumi un pienākumi, tas izvirza nepieciešamību iegūt jaunas zināšanas un prasmes. Bibliotekārs, kurš profesionālo izglītību ieguvis agrāk, nevar pilnvērtīgi veikt darba pienākumus, ja nepārzina mūsdienu filozofiski teorētiskās koncepcijas par informācijas izguvi un tās nozīmi zināšanu veidošanā. Mūsdienu datu apstrādes metodologija izvirza jaunus konceptus, apstrādi saistot ar lietotāja vajadzībām un informācijas izguvi. Jaunie izaicinājumi izvirza nepieciešamību bibliotekāriem piedalīties tālākizglītības procesā un bibliotēkām būt pamatam mūžizglìtības nodrošināšanā.

Bibliotekāra zināšanas var ietekmēt informācijas izguvi - nodrošināt jaunas papildu iespējas informācijas resursu veidošanā, pilnvērtīgā informācijas izguvē vai ietekmēt negatīvi un radīt ierobežojumus.

No bibliotekāra zināšanām ir atkarīgs, kādi informācijas resursi tiek veidoti un piedāvāti. Nepietiekama kvalifikācija var ierobežot informācijas resursu klāstu, veidošanas metodes, piedāvātos pakalpojumus un informācijas izmantošanu. Nepiln̄̄gi tiek izmantota iespēja radīt pievienoto vērtību informācijai.

Informācijas speciālistam nepieciešamas zināšanas ne tikai par mūsdienu datu apstrādes metodoloǵiju, bet arī informācijas organizēšanas jaunākajām vadlīnijām. No tā, cik kvalitatīvi ir organizēta informācija, ir atkarīga tās izguves kvalitāte.

Lai nodrošinātu pilnvērtīgu informacionālo apkalpošanu, informācijas speciālistam jāzina mūsdienu konceptuālās atziṇas par lietotāju apkalpošanu, lietotāju vajadzības un jaunu pakalpojumu veidi. Jāatzīst, ka nepietiekami tiek veikta lietotāju vajadzību apzināšana un analīze. Līdz ar to resursu veidošana un pakalpojumu piedāvājums ne vienmēr atbilst lietotāju vajadzībām. Nav regulāras un sistemātiskas informācijas resursu kontroles, bibliotēkās trūkst pašu izstrādātas metodikas un arī lietotāju apmierinātības analīze tiek veikta nepietiekami. Tādējādi nav iespējams plānot un veikt informācijas pakalpojumu pilnveidi, lai mazinātu informācijas izguves ierobežojumus. 


\title{
Dilemma Nr. 3 \\ MŪSDIENU LIETOTĀJS PILNVĒRTĪGI SPĒJ IZMANTOT INFORMĀCIJAS IZGUVES IESPĒJAS?
}

\author{
vai
}

\section{MŪSDIENU JAUNĀS IESPĒJAS RADA IEROBEŽOJUMUS UN TRAUCĒ INFORMĀCIJU PĀRVĒRST ZINĀŠANĀS?}

Informācijas transformācija zināšanās lielā mērā ir atkarīga no paša lietotāja zināšanām un prasmēm. Augstāks zināšanu un informācijpratības līmenis veicina kvalitatīvāku informācijas transformāciju zināšanās.

Vērojumi un pētîjumi apliecina, ka liela daļa Latvijas sabiedrības vēl ir nepietiekami sagatavota pilnvērtīgai informācijas izguvei, tādēḷ ir ierobežota informētība un izpratne. Dažādām lietotāju grupām vērojama atšķirīga sagatavotība informācijas izguvē. Informācijas un komunikācijas tehnologiijas rada jaunas iespējas informācijas resursu veidošanā un izmantošanā, tomēr rada arī jaunus ierobežojumus. It sevišķi gados vecākiem lietotājiem trūkst prasmes izmantot informācijas un komunikācijas tehnoloǵijas, tas ierobežo piekḷuvi informācijai.

Līdz šim Latvijā ir ierobežotas iespējas informācijpratības ieguvē. Bibliotēku darbiniekiem pašiem bieži vien trūkst nepieciešamās kvalifikācijas, un līdz ar to viṇi nespēj nodrošināt lietotāju apmācību informācijpratībā. Situācija varētu uzlaboties ar Bila un Melindas Geitsu fonda līdzdalību „Valsts vienotās bibliotēku informācijas sistēmas" jeb Gaismas tīkla realizēšanā (13), valstī nodrošinot apmācību publisko bibliotēku darbiniekiem un tālāk to nododot vietējiem iedzīvotājiem - bibliotēku lietotājiem.

Ne vienmēr nepieciešamo palīdzību un konsultāciju iespējams lietotājam saṇemt no bibliotēkas darbinieka.

Digitālajā vidē vairākos informācijas apstrādes un izguves posmos var saskatīt vairākus ierobežojumus, dilemmas un negatīvi ietekmējošos faktorus. No vienas puses, tiek piedāvātas jaunas lielākas iespējas un izaicinājumi, bet, no otras puses, jauni ierobežojumi.

Priekšnosacījumi sekmīgai informācijas transformācijai zināšanās ir kvalitatīva datu apstrāde, bibliogrāfiskās informācijas organizēšana un izmantošanas iespējas atbilstoši lietotāju vajadzībām, kā arī informācijas speciālistu un lietotāju kvalifikācija, sagatavotība jaunajiem izaicinājumiem digitālajā vidē.

Galvenās dilemmas:

- ja informācijas fiziskā vai intelektuālā pieejamība ir ierobežota, tad informācijas transformācija zināšanās ir apgrūtināta;

- ja informācijas izguves iespējas nav atbilstošas lietotāju vajadzībām, tad lietotājam ir ierobežotas iespējas informāciju transformēt zināšanās.

Informācijas sabiedrības veidošanās periodā bibliotēkām jākḷūst par bāzi informācijas resursu veidošanā, lietotāju informētības nodrošināšanā un izpratnes radīšanā. Bibliotēku misija nel̦auj bibliotēku darbiniekiem nogaidīt vai turpināt tikai tradicionālo informācijas pakalpojumu nodrošināšanu. Tām jābūt gatavām pieņemt jaunus izaicinājumus, veidot mūsdien̄̄gus informācijas resursus un nodrošināt 
kvalitatīvus informācijas pakalpojumus. Bibliotēkām jācenšas pilnveidot informācijas pakalpojumu sistēmu un mazināt vai pat pilnībā novērst jebkuru ierobežojumu un barjeru, kas traucē informācijas transformāciju zināšanās.

\section{IZMANTOTIE INFORMĀCIJAS AVOTI}

1. Cunningham, Diana J., Ascher, Marie T., Brown, Helen-Ann. The Added Value of an Informationist at New York Medical College : proceedings of the contributed papers session of 94th annual conference [online]. Special Libraries Association, 2003. [cited 13-10-2006]. Available: www.sla.org/division/dbio/newyork/cunningham.htm

2. Gudele, Ina. Informācijas sabiedrības attīstības pamatnostādnes 2006.-2013.gadam [nepublicētais materiāls]. [Rīga], 26.04.2006. Elektroniskās prezentācijas izdruka.

3. Holma, Baiba. Daži informācijas intelektuālās pieejamības aspekti globālās informācijas telpas kontekstā. No: Sociālo un politisko pētījumu institūts (SPPI), Stratēẹiskās analīzes komisija. Robežu paplašināšana: identitātes un kopienas : starptaut. konf. ziņojumi, Rīga, 2005.g. 9.-12.nov. [Rīga] : LU Akadēmiskais apgāds, 2006, 440.-452. lpp. ISBN 9984-783-86-3.

4. IFLA/UNESCO Public Libraries Manifesto [online]. 1994. [cited 20-10-2006]. Available: http://www.ifla.org/VII/s8/unesco/eng.htm

5. Informācijas sabiedrības attīstības pamatnostādnes 2006.-2013. gadam [tiešsaiste]. [skatīts 10-12-2006]. Rīga, 2006. Pieejams: http://www.eps.gov.lv/files/projekti/ IUMEPLPam_150606_ISAP.doc

6. International Federation of Library Associations (IFLA). FRBR: Functional Requirements for Bibliographic Records - Final Report [online]. [B.v. : IFLA, b.g.]. [cited 02-10-2006]. Available: http://www.ifla.org/VII/s13/frbr/frbr1.htm.

7. International Federation of Library Associations (IFLA). Guidelines for Online Public Access Catalogs (OPAC) Displays [online]. 2003. [cited 02-10-2006]. Available: http://www.ifla.org/VII/s13/guide/opacguide03.pdf

8. Izglītības attīstības pamatnostādnes 2007.-2013.gadam [tiešsaiste]. [skatīts 10-122006]. Rīga, 2006. Pieejams: www.izm.gov.lv/getfile.aspx?sid=118

9. Karnītis, Edvīns. Informācijas sabiedrība - Latvijas iespējas un uzdrošināšanās. Red. Dzintra Dāvidsone ; māksl. Mārtiņš Krūklis. Rīga : Pētergailis, 2004. 208 lpp. : diagr., sh., tab. Bibliogr. norādes parindēs. ISBN 9984-33-074-5.

10. Karnītis, Edvīns. Informācijas sabiedrība - nākotnes sabiedrības organizācijas modelis [nepublicētais materiāls] : elektroniskā prezentācija. [Rīga, 2006]. [skatīts 11-11-2006].

11. Karnītis, Edvīns. Informācijas sabiedrības veidošana Latvijā ; Latvijas izaugsmes modelis un Nacionālais attīstības plāns [nepublicētie materiāli] : elektroniskās prezentācijas. [Rīga, 2006]. [skatīts 11-11-2006].

12. Krievāns, Viesturs. Informācijas un komunikācijas tehnoloǵijas izglītības kvalitātei (IKTIK) programma 2007.-2013.gadam [nepublicētais materiāls]. 02.08.2006. Elektroniskās prezentācijas izdruka.

13. Kultūras informāeijas sistēmas. Ar Bila un Melindas Geitsu fonda atbalstu tiek uzsākts vērienīgs Latvijas publisko bibliotēku attīstības projekts [tiešsaiste]. Rīga : Kultūras informācijas sistēmas, 2006, 30.nov. [citēts 01-12-2006]. Pieejams: http://www.kis.gov. $\mathrm{lv} / \mathrm{lv} / \mathrm{c} 1 / \mathrm{n} 341 /$.

14. Mūze, Baiba. Bibliotēku elektroniskie katalogi un to kvalitāte [nepublicētais materiāls] : promocijas darbs. Latvijas Universitāte. Rīga, 2006. 218 lp. +88 lp pielikumi.

15. Rozenštrauhs, Ivars. Integrēta valsts informācijas sistēma IVIS [nepublicētais materiāls]. 26.04.2006. Elektroniskās prezentācijas izdruka. 
16. Saracevic, Tefko, Kantor, Paul B. Studying the Value of Library Information Services. JASIS [Journal of the American Society for Information Science], vol.48, Nr.6, 1997, June. Available also: www.asis.org/Publications/JASIS/v48n0697.html.

17. Sporāne, Baiba. Bibliotēkas informacionālās telpas un lietotājvides saskarsme. No: Sociālo un politisko pētījumu institūts (SPPI), Stratēgisiskās analīzes komisija. Robežu paplašināšana: identitātes un kopienas : starptaut. konf. ziņojumi, Rīga, 2005.g. 9.-12.nov. [Rīga] : LU Akadēmiskais apgāds, 2006. 409.-427.lpp. ISBN 9984-783-86-3.

18. Starptautiskā bibliotēku asociāciju federācija (IFLA). FRBR: Funkcionālās prasības bibliogrāfiskajiem ierakstiem [tiešsaiste] : gala ziņojums. Rīga : Latvijas Nacionālā bibliotēka, 2005. [skatīts 10-12-2005]. Pieejams: http://www.lnb.lv/struktura/BI/ standartiz/FRBR.pdf. 



\section{Education, Knowledge and Social Change}





\title{
The Production of Knowledge in Social Work - The Importance of Learning from Practice (A 'Mode 2' Perspective on Doing Research in Social Work)
}

\author{
Monica Kjørstad \\ Oslo University College
}

\section{INTRODUCTION}

In professional circles of social work there is a general consensus to make greater efforts in providing research that scrutinises professional practice. A discussion has taken place for many years within the international social work community about the ways in which research about social work should be undertaken. The discussion addresses research methods, theory of science and how knowledge should be understood. In light of the debates about social workers' professional identity, disagreements about how research should be conducted seem almost inevitable.

Based on the large public economic resources that are allocated to the social sector, the authorities are demanding evidence-based knowledge about the practice of social work. Too little is known about the effects and consequences of the methods and interventions of social work and there is an increasing demand for systematic evaluation of social work practice. An interpretation of this is that the authorities are asking for research that is objective, theory-based and repeatable; they want studies that are able to legitimate social work intervention and find the best practice and methods for social work. The concept evidence-based knowledge points to the idea that curative or ameliorative interventions must be founded upon scientific evidence (EKELAND 1999).

An issue of central importance is whether it will be sufficient to travel the road of positivist social science when trying to understand the cultural and, as is often the case, the cross-professional approach in social work practice. Another issue is whether or not knowledge about totalities and complexities can be used to determine the level where the demand for evidence is appropriate. Scientific "truth" is established, ultimately, in the course of scientific communication. This social reality is mirrored in the work of Bruno Latour, who points out the difference between identifying new knowledge and getting acceptance or establishing a consensus for the validity of that new knowledge. A lot depends upon professional networks and 
relationships (LATOUR 1987). In a day and age that, in part, evaluates the importance and the impact of research by counting the number of citations to it (Social Science Citation Index), the importance of professional networks and relationships should be discussed.

This common objective raises questions related to recent perspectives regarding the development of knowledge and the relationship between science and society and how to set standards for good scientific work. Far more people and institutions than earlier are participating in the production of knowledge and they are erasing time-worn distinctions between basic and applied research and between theory and practice. The shift parallels basic changes that have occurred in the world community. Increasing commercialisation of research, increasing globalisation, and the massive growth in the numbers who receive a higher education, are trends that have converged to make the production of new knowledge more open to, and more interactive with, an increasingly complex and insecure world order (SøRENSEN 2001). This may create possibilities for new forms of socially distributed knowledge production based on reflexivity, organisation, cooperation and participation and represents a challenge for both practitioners as well as researchers in social work and other similar disciplines. Formulating research questions and evaluating results will occur in a greatly expanded public space. This is a general tendency that will affect most academic disciplines. The present article is presenting an example from research in social work, based on an empirical project.

\section{SOCIAL WORK AND THE DEVELOPMENT OF KNOWLEDGE}

Social work is a profession where the object is to provide material aid and social/personal support to people who find themselves in difficult life-situations. The material aid is often economic social assistance or other material provisions. Social and personal support often consist in providing counselling to make long-term changes that will ameliorate the difficult life-situations, and this social and personal support are often dependent upon an informal contract between the client and the social worker. Examples of problems that require long-term social and personal support are drug dependency and lack of housing. The field of action for social work is the level between the individual and society, and the particular knowledge that characterises social work is correspondingly situated. Some professionals and researchers emphasise adjustment, while others emphasise change. The International Federation of Social Workers (IFSW) adopted the following definition of social work in the year 2000 .

The social work profession promotes social change, problem solving in human relationships and the empowerment and liberation of people to enhance well-being. Utilising theories of human behaviour and social systems, social work intervenes at the points where people interact with their environments. Principles of human rights and social justice are fundamental to social work.

Since social work is practiced in a concrete societal context, the conditions that are emphasised will vary from country to country. The practice of social work is, to a great extent, culturally determined, and this makes it difficult to find a definition that 
can unite social workers in different parts of the world. At international conferences, for example, questions about poverty, crime and mortality rates for children in South Africa may be discussed in one room, while social workers from Norway, in a neighbouring room, discuss how to help temporarily unemployed people to maintain a reasonably high standard of living. This dependency upon context makes it necessary to tolerate different understandings about what is or what should be the content of social work. When it comes to the practice of social work, the IFSW asserts:

Social work utilises a variety of skills, techniques, and activities consistent with its holistic focus on persons and their environments. Social work interventions range from primarily person-focused psychosocial processes to involvement in social policy, planning and development. These include counselling, clinical social work, group work, social pedagogical work, and family treatment and therapy as well as efforts to help people obtain services and resources in the community. Interventions also include agency administration, community organisation and engaging in social and political action to impact social policy and economic development. The holistic focus of social work is universal, but the priorities of social work practice will vary from country to country and from time to time depending on cultural, historical, and socio-economic conditions.

Social work has been constructed by combining knowledge from several other disciplines; its emphasis upon a comprehensive view that includes social and societal perspectives as well as personal and relational circumstances, has always been central to its identity. It applies theories from sociology, psychology, political science and anthropology, but as a field of research, social work is less developed than the other disciplines. There is, however, a tendency to make the field of social work more academic, a tendency that is also found within other professions, for example nursing. In the IFSW document, social work's theoretical foundation is formulated as follows:

Social work bases its methodology on a systematic body of evidencebased knowledge derived from research and practice evaluation, including local and indigenous knowledge specific to its context. It recognises the complexity of interactions between human beings and their environment, and the capacity of people both to be affected by and to alter the multiple influences upon them including bio-psychosocial factors. The social work profession draws on theories of human development and behaviour and social systems to analyse complex situations and to facilitate individual, organisational, social and cultural changes.

Social work has at times been characterised as transdisciplinary, hybrid, ambiguous, and with unclear criteria for research quality. From some disciplinary positions these may be seen as grave weaknesses. It may however also be seen as the strength of social work, considering the character of the challenges that must be faced in practical day-to-day activities as well as in research. This is perhaps also the tendency in more traditional disciplines that are slowly discovering the ambiguity and uncertainty dimension which always has been the strength and the weakness of social work (PARTON 2000). 


\section{A PERSPECTIVE FOR UNDERSTANDING THE DEVELOPMENT OF SOCIALLY SITUATED KNOWLEDGE}

The more recent perspectives concerning the relationship between research and society were presented in the controversial book "The New Production of Knowledge: The Dynamics of Science and Research in Contemporary Societies" in 1994 which has been extensively discussed (GiBBons et al. 1994). Gibbons et al. launched the theses that the focal point in the production of knowledge was a change from a discipline-based regime, which they term mode 1 , to a new mode that is more characterised by its problem-orientation and by its habit of crossing professional lines of demarcation, which they term mode 2, or trans-disciplinarity (Sørensen 2001). This concepts points to the practice within society in general, and in the scientific community in particular, of communicating in a way that transgresses boundaries and barriers. This break-through quality is changing scientific practices. These are knowledge producing processes that intermingle and, when they do so, they produce more robust knowledge as a consequence (Sørensen 2001). The starting point of the authors was an acknowledgement of the parallel expansion in the number of knowledge-producers and in the demands for specialised knowledge. The traditional and institutional locations for these discussions have previously been board rooms in industry and rooms peopled by the higher echelons within the public bureaucracy and within universities, but these places will no longer have an exclusive privilege to influence the course and direction of research (Sørensen 2001).

The production of knowledge in mode 2 has five characteristics:

1) Formulating the research problem. The people who will be applying the results of research are in close contact with those who will be performing the research, and dialogue between the two will affect the formulation of the research problem. This is different from the Mode 1 practice where specific disciplines or professions determine and formulate research problems within the frame of the disciplines.

2) Trans-disciplinarity. Trans-disciplinarity implies a continuing mobility between differing theoretical perspectives and practical methods for problem-solving. In Mode 2, new disciplinary formations are developed from activities, movements and practices that don't seem to belong to any existing or established discipline. The creative activity is not only expressed by developing new theories and concepts, it can also be seen as being in the capacity to mobilise and handle diverse perspectives and methodologies.

3) Organisation. Projects have become the rule and are no longer the exception. Groups of people are collected for a limited time in flat organisations (i.e. little or no hierarchy) which are often outside of the university structure. Communication is not limited to the established meeting-places and it can occur quickly and spontaneously by making use of modern information and communication technology. Research communities have open borders that facilitate participation, and this provides research projects with new and sometimes quite unexpected contributions. 
4) The reflexive quality of knowledge production. Research develops within a social context. 'Reflexive' implies that the researcher should be aware of her own position in relation to the research subject.

5) The search for socially robust knowledge. Knowledge production is shaped by and occurs as a result of the constant interaction between those performing research functions and the environments that are relevant to and dependent upon those research functions. As a consequence, a clear and unambiguous criterion for quality control is weakened and these communities must learn to live with the conflict between different definitions of scientific quality and practical usefulness.

This perspective certainly challenges the greater part of the established research communities, and the criticism of the conclusions of Gibbons et al. has been quite aggressive. The authors have been criticised for presenting an oversimplified description of reality, turning a blind eye to the lessons of history and for not defining or developing the sociological concepts that are employed (SHINN 2002, Elzinga $2004)^{1}$. It is argued that Gibbons et al. present an overoptimistic vision of the changes affecting science and society today, and that they have underestimated the extent to which these transformations have been the results of political and social choices. For at least five centuries knowledge has been of crucial interest to power (PESTRE 2003). Pestre argues "...that knowledge has always mattered tremendously to states and to economic elites; that most knowledge producers have always been attentive to the interests of those elites; and that science has always directly contributed to, and has been a major resource for, changes in social ideologies." (Pestre 2003). He points out two aspects of contemporary society in general. First - the reassertions of power by "big business" and financial capital, resulting in the reversal of many processes of social protection, and - second - the emergence of new, influential social groups (mostly young, educated people) which have developed new values and modes of social action. Unprivileged groups and interests have become less visible and the norms of social justice and identities have changed. In today's risk society things are more often than not done prior to an analysis of their long-term consequences. There is definitely justification to be conscious about these tendencies for the development of knowledge in social work too.

\section{AN EMPIRICAL EXAMPLE OF THE DEVELOPMENT OF KNOWLEDGE IN SOCIAL WORK}

The title of the research project that constitutes this article's raw material is Challenges and Ethical Dilemmas in the Social Worker's Role During the Implementation of Work-fare (KJøRSTAD 2002; KJøRSTAD 2005). The project concerns itself with the implementation of work-fare in Norwegian social policy. The project has attempted to cast light upon situations that challenge the social worker's professional integrity. Social workers are legally required to evaluate every application for economic social assistance by determining whether or not it is appropriate to require applicants to accept work or to fulfil other specific conditions before aid is granted. This requires that the social worker is particularly in tune with 
the client's need for self-determination Previous research in this field in Norway has mostly focused on the quality of the relation between the social worker and the client, or has been comparative studies of different types of workfare. In the present project, however, the focus has been shifted to the dynamics between the social and political paradigms and the "modus operandi" of the social workers. In this dynamic field the broader structures and the concrete practice influence each other. In other words, you have to look at the factors that construct the role of the social worker as well as the role of the client. In a way, they are "in the same boat" directed by the administrative system, the social security laws and the very personal situation that has brought the two together (JOHANSSON 1992; KJøRSTAD 2002). The study is based on theories of bureaucratic ethics focusing on the ethical position of the social workers taking a gate-keeping position. Social workers in a bureaucratic organisation must relate to a number of ethical relations: to clients, colleagues, employers, politicians and the population at large (KJøRSTAD 2005; LUNDQUIST 1988; LuNDQuist 2001; RothSTEIN 2003; Svallfors 2002).

\section{Methodology and design}

It was necessary to construct a research design that would make it possible to understand meaningful characteristics of the latent meaning of the situations and the events under study and get access to the social workers' practical insights and judgements (Alvesson and Sköldberg 1998). For that purpose, seminars and case conferences with the participating social workers were arranged in order to discuss preliminary findings, initial interpretations and practical experiences. This is a way of validating research data and findings, by continuously discussing how they are to be interpreted with the informants themselves (Kvale 1997; Kvale 1995). This research design implies that the knowledge and experiences of the professionals, whose work is being studied, are a vital source of knowledge. A multidimensional qualitative method was applied, based on 12 observations of consultations with clients, 12 interviews with the social workers, four group interviews with heads of social agencies, eight case discussions and two dialogue conferences. In addition document studies were made. All parts of the research process were videotaped. The study covers five social agencies in the same town. The research process may be subdivided in two main stages: the first stage, observations from the "outside", consisted of observations and interviews. The second stage, experiences from the "inside", consisted of case conferences and dialogue conferences (Kjørstad, in press).

\section{Methodological reflections}

It turned out that the characteristics from the mode 2 production of knowledge were relevant for the project. Knowledge within mode 2 research is derived from a wider panorama of interests, and the research design is more often than not a product of negotiation. Facts and artefacts are created, maintained and changed within social processes. The construction of facts and artefacts does not solely occur in the course of experiments, interviews, text analyses and such. Every aspect of the research process (constructing the research design, organising interviews, making observations, discussing cases and participating in conferences with informants, etc. can be understood as reflecting a social situation that in this particular case was influenced 
by the actions of both parties. During this process "raw data" (every-day knowledge) were gradually elaborated and transformed into practical knowledge. This elaboration turned out to be more important than expected. In combination with observations and interviews, the articulating activities involved in discussions and in the dialogue conferences have provided a more authentic picture of the implementation practice than one would have achieved from written texts (FLOERSCH 2000).

The dialogue conferences strengthened the initial impression that the social workers do take an unreasonable responsibility for the clients' problems and thereby run the risk of disempowering them. They also seemed to take unreasonable personal responsibility for shortcomings of the current policy. This represents a form of decentralisation of a societal dilemma (VIKE et al. 2002). The social workers expressed a feeling of inadequacy and of having a bad conscience when they were expected to implement a social policy that occasionally was felt as being unrealistic. As an example they referred to the lack of suitable educational programmes for the clients, on-the-job or elsewhere. The social workers did not seem to be aware of power as a mutual, productive force in relation to their clients. In that perspective power might function as a fuel to drive a process of constructive change. Increasing the students' consciousness about this presents a challenge for improvements in the education of social work.

The importance of maintaining a reflexive approach in relation to objectivity is a central aspect of Mode 2 research. Sandra Harding has used the concept strong objectivity as an ideal, maintaining that critical reflection about the researcher's own position within a particular historical and cultural context responds to the demand for objectivity(Harding 1992). Science, when seen as being a reflexive project, seriously concerns itself with its position (role) as a producer of knowledge, and reflections concerning the researcher's role are an important part of the production of knowledge. Positivism's demand for distance may be answered by pointing to the situatedness of knowledge. ${ }^{2}$

The project is an example of an intensive research design that makes it possible to uncover generative mechanisms that works behind 'the observable'(DANERMARK et al. 2002). The aim is that the researcher and the practitioner should develop mutual confidence and share a curiosity about the mechanisms that causes a specific practice to be "good" or "bad", and how it may be improved. This procedure is in accordance with the mandate that research in social work should have, always to take into consideration the consequences for those who are dependent on social assistance. An important experience was that the contributions of the practitioners proved invaluable and that they turned out to become active partners in the research process. This is in accordance with the Mode 2 perspective which implies that far more people and institutions than earlier are participating in the production of knowledge.

The design for the project was constructed to handle qualitative data and does not necessarily accommodate society's demand for evidence-based research if it is defined as being based on cause and effect explanations. If however evidence-based research and practice is defined as based on professional assessment and interpretation, professional arguments and ethical deliberation, the project is an example of evidencebased research that has many of these qualities (Kjørstad, in press). 
However, it is obvious that such an approach demands a great deal of prudence in order to avoid purely subjective errors. There is a risk that the inductive and communicative methods that are employed will only bring forth trivial findings - one may simply be unable to transcend a frog's-eye view. This is an important criticism of Mode 2 research and implies that social research can be reduced to a reformulation of common sense understandings; the results of (social) research may be trivialised by reducing its perspectives to those of the actors under study (Alvesson and SkÖLDBERG 2000). In a sense, all knowledge derived from social research must begin with an understanding of the perspectives of the actors under study, but there is no reason to limit social research to knowledge at that level (Alvesson and DeEtz 2000; Alvesson and Sköldberg 1998; Bourdieu 1977; Kvale 1997). Deductive methods, on the other hand, are seldom useful when trying to understand the complexities that constitute social phenomena.

In summary, social work is built upon the understanding that human action and human change occur in a specific social and societal context. The particular social context is a condition for and a result of human action (MORÉN 1994; MorÉn 1994; Morén 2001). How to make social work an academic profession is a complicated issue and, from my point of view, it may be impossible or undesirable strictly to delimit social work practice from other closely related professions. The study of the practice of social work requires a perspective that includes individual and societal conditions and an understanding of the dialectical relationship between the two dimensions. To achieve this, the knowledge base in social work must be inter-disciplinary (Kjørstad, in press). The comprehensive and interdisciplinary dimension of social work implies that socially situated knowledge is necessary to advance the discipline. This is in accordance with the general tendency within other social science disciplines.

These matters do not solely affect research methodology; they have a more general impact upon the relationship between research and society as well. Research has many qualities that are also found in democratic activities. Like democratic practice in general, it must be open and transparent for public scrutiny and it must be useful and serve the interests of society as a whole. In this day and age, demands for better communication and cooperation across professional lines are frequent in the internal discourse of science. Almost as frequent are the demands being made by political authorities and by the general public for greater access to the findings of research. The demand for an increase in the supply of research findings that are readily available to the public and accessible in layman's terms continues to grow. The challenge to the research community is to set a course between the Scylla of scientific relativism and the Charybdis of the academic ivory tower.

\section{REFERENCES}

Alvesson, M. and Deetz, S. 2000. Kritisk samhällsvetenskaplig metod. Lund: Studentlitteratur. Alvesson, M. and Sköldberg, K. 1998. Tolkning och reflektion. Vetenskapsfilosofi och kvalitativ metod. Lund: Studentlitteratur.

Alvesson, M. and Sköldberg, K. 2000. Reflexive methodology: new vistas for qualitative research. London: Sage Publications.

Bourdieu, P. 1977. Outline of a Theory of Practice. Cambridge: Cambridge University Press. 
Danermark, B., Ekström, M., Jakobsen, L. and Karlsson, J.C. 2002. Explaining Society. Critical realism in the social sciences. London and New York: Routledge.

Ekeland, T.J. 1999. 'Evidensbasert behandling: kvalitetssikring eller instrumentalistisk mistak'. Tidsskrift for Norsk Psykologforening.

Floersch, J. 2000. 'Reading the Case Record: The oral and Written Narratives of Social Workers'. Social Service Review: 169-192.

Gibbons, M., Limoges, C., Nowotny, H., Schwartzman, S., Scott, P. and Trow, M. 1994. The New Production of Knowledge: The Dynamics of Science and Research in Contemporary Societies. London: Sage.

Harding, S. 1992. "After the Neutrality Ideal: Science, Politics and "Strong Objectivity". Social Research 59.

Johansson, R. 1992. 'Vid byråkratiens grenser: om handlingsfrihetens organisatoriska begränsningar i klientrelaterat arbete'. Lund: Arkiv Avhandlingsserie.

Kjørstad, M. 2002. 'Sosialhjelp og arbeidsplikt. Utfordringer og etiske dilemmaer for sosialarbeiderrollen ved iverksettingen av arbeidslinjen'. Oslo: Oslo University College.

Kjørstad, M. 2005. 'Between professional ethics and bureaucratic rationality. The challenging ethical position of social workers who are faced with implementing a workfare policy'. European Journal of Social Work 8: 381-398.

Kvale, S. 1997. Det kvalitative forskningsintervju. Oslo: Ad notam. Gyldendal.

Kvale, S.a.E., Remi Th. 1995. 'Issues of Validity in Qualitative Research'. Lund: Studentlitteratur.

Latour, B. 1987. Science in Action: Milton Keynes.

Lundquist, L. 1988. Byråkratisk etik. Lund: Studentlitteratur.

Lundquist, L. 2001. 'Etik och förvaltning' in Rothstein, B. (ed.)) Politik som organisation. Förvaltningspolitikens grundproblem. Stockholm: SNS Förlag.

Morén, S. 1994. 'Social Work is beautiful. On the charachteristics of social work'. Scandinavian Journal of Social Welfare 3: 158-166.

Morén, S. 1994. 'Social Work organizations from within'. International Social Work, SAGE Publications 37: 277-293.

Morén, S. 2001. Förändringens gestalt. Om villkoren för mänskligt bistånd. Stockholm: Norstedts Juridik AB.

Nowotny, H., Scott, P. and Gibbons, M. 2001. Re-Thinking Science. Knowledge and the Public in an Age of Uncertainty. Cambridge: Polity Press.

Nowotny, H., Scott, P. and Gibbons, M. 2003. 'Mode 2'Revisited: The New Production of Knowledge'. Minerva. Kluwer Academic Publishers: 179-194.

Parton, N. 2000. 'Some Thoughts on the Relationship between Theory and Practice in and for Social Work'. British Journal of Social Work 30: 449-463.

Pestre, D. 2003. 'Regimes of knowledge production in society: Towards a more political and social reading'. Minerva. Kluwer Academic Publishers 41: 245-261.

Rothstein, B. 2003. Sociala fällor och tillitens problem. Stockholm: SNS Förlag.

Shinn, T. 2002. 'The Triple Helix and New Production of Knowledge: Prepackaged Thinking on Science and Technology'. Social Studies of Science 32: 599-614.

Svallfors, S. 2002. 'Political Trust and Support for the Welfare State: Unpacking a Supposed Relationship' in Rothstein, B. and Steinmo, S. (eds.) Restructing the Welfare State: Political Institutions and Policy Change. Basingstoke: Palgrave Macmillan.

Sørensen, K.H. 2001. 'Mot et nytt vitenskapsregim?' Forskningspolitikk.

Vike, H., Bakken, R., Brinchmann, A., Haukelien, H. and Kroken, R. 2002. 'Maktens samvittighet: om politikk, styring og dilemmaer i velferdsstaten' in Vike, H. (ed.)). Oslo: Gyldendal akademisk. 


\section{ENDNOTES}

1 Nowotny et al. argue that their contribution to the debate in question compiles an assortment of reflective essays; they do not pretend to be a collection of empirical studies. They make three claims that are meant to answer, to some extent, the criticisms they have received. First of all, Mode 1 and Mode 2 exist side by side in our contemporary world of research. Their second claim is that Mode 2 has developed from Mode 1, but that the two modes are essentially different. Their third claim is that neither of the two modes is better than the other; Mode 1 and Mode 2 are simply two essentially different modes. Their purpose was twofold: to point to the need to develop a new language for research and to analyse trends in the developments taking place in the relationship between research and society Nowotny, H., Scott, P. and Gibbons, M. 2001. Re-Thinking Science. Knowledge and the Public in an Age of Uncertainty. Cambridge: Polity Press. Nowotny, H., Scott, P. and Gibbons, M. 2003. 'Mode 2'Revisited: The New Production of Knowledge'. Minerva. Kluwer Academic Publishers: 179-194.

2 Situatedness refers to the place from which one makes observations about the world. Knowledge is professionally situated when the researcher is aware of his or her own preferences and their connection to contexts in which those preferences arise (Gullestad 1999; Harding 1992). 


\section{Knowledge Society: The Position of a Family}

\section{Olga Lavrinenko}

The main aim of the National Development Plan of Latvia is well-coordinated and sustainable development, as well as the promotion of Latvia's competitiveness. In order to reach the standard of living typical of developed countries, the main resource is considered to be the "knowledge and wisdom of inhabitants, their skilful and purposeful application" [4]. According to this model of development, knowledge is seen as "the driving force that increases the quality of the labour force" [4], uses capital and develops technologies. Latvia has chosen the way of development of economy that is based on knowledge.

In order to move towards the goal set by the National Development Plan of Latvia, it is necessary to analyse the present situation related to education as a value, the quality of education and social dialogue in our society. The position of parents is rather significant, because during childhood pupils form their attitude to education, and realise their main duty - studying. The analysis of focus groups conducted in Latgale in the framework of the project "Education in the Knowledge Society in Latvia" can be found in the articles of professor V. Meñšikovs, and researchers V. Boronenko and L. Panina. In their articles, the position of parents is described in detail. In this article, the author would like to analyse the standard of a young person who has finished school, because the focus groups showed some contradictory assessments of this kind of standard in the points of view of parents.

While analysing Helga Trupel's report, Members of the European Parliament Committee on Culture and Education emphasised the significance of the creation of a unique European system of education of adults according to eight key criteria [5]. It would let citizens of the European Union adapt more quickly to the changing labour market, where the leading role is played by the knowledge of employees.

According to the report, these are the key abilities and skills:

- knowledge of the mother tongue;

- knowledge of foreign languages;

- knowledge of mathematics and basic knowledge of science and technology;

- the ability to work with a computer;

- the ability to learn;

- the ability to interact at the interpersonal, intercultural and social level;

- basic knowledge of business administration;

- knowledge of culture. 
As mentioned in the report of the Committee, "all citizens must have key knowledge and skills, thus, contributing to the conduct of reforms, which is impossible relying upon only educational programmes of the European Union".

What skills have to be considered basic, i.e. skills necessary for a young person who starts adult life? Taking into consideration standards of school education and the above mentioned key abilities and skills, which are in demand in a constantly changing labour market, the author of the article has made an attempt to work out the structure of knowledge, skills and abilities of pupils who have finished secondary school.

\section{THE RESULT OF SCHOOL EDUCATION \\ (Hierarchical structure of knowledge, skills and abilities of pupils who have finished secondary school.)}

A1. Work with a text

A1.1. Ability to understand texts of other people (reading, retelling, analysis of the text)

A1.2. Ability to make up texts (writing of essays, compositions, reports, summaries, abstracts)

A1.3. Knowledge of the national language (grammatically correct written and spoken language)

A1.4. Pupils have read many books and have judgments about them)

A2. Communicative competence

A2.1. Communicative skills (ability to give arguments, to criticise, to come to an agreement, to ask and answer questions)

A2.2. Knowledge of two foreign languages (spoken language, translation, reading authentic books)

A2.3. Ability to pass exams and tests (without stress and with good results)

A2.4.Ability to search for information in reference and specialised literature, encyclopedias

A2.5. Ability to work with the Internet (searching for information, participation in interactive communication)

A3. Intellectual and creative skills

A3.1.Ability to think and to analyse (solution of complex and interesting problems)

A3.2.Ability to create or invent something new (number of creative works, experiments and "inventions" of pupils)

A3.3. Research skills (the number of research techniques, which can be used by a pupil and the number of research works)

A4. Self-organisation of a pupil

A4.1. Ability to organise pupil's spare time and his/her activities (planning and implementation of plans)

A4.2. Ability to show him/herself and his/her work (nice and efficient showing of the results)

A4.3. Ability to act independently and to be responsible (individual projects in the conditions of a lack of time and resources) 
A5. Erudition and competence in various spheres

A5.1. Competence in various spheres of human life (solution of complex crossword puzzles)

Figure 1. Hierarchical structure of knowledge, skills and abilities of pupils who have finished secondary school

The abovementioned criteria were evaluated by 12 experts (sub-elements were used only for the formation of notional context evaluated indices) $[2,3]$. The experts who participated in the survey were parents of 2 and more pupils from Daugavpils who have higher education. Calculation of five basic elements of the list of criteria (A1, A2, A3, A4, A5) was carried out with the help of Saaty's method [1].

The essence of the method is as follows: it is necessary to determine the dominant eigenvector with the help of successive comparison of the criteria in pairs. Such analysis provides the possibility of putting priority on the characteristics in order.

In other words, the system of comparison of data in pairs leads to the result, which can be presented in the form of an inversely symmetrical matrix. The element of the matrix $\mathbf{a}(\mathbf{i}, \mathbf{j})$ is the intensity of occurrence of the element of hierarchy $\mathbf{i}$ in comparison with the element of the hierarchy $\mathbf{j}$, which is evaluated according to the scale (elaborated by the author) from 1 to 9 , where the numbers mean the following [1]:

\begin{tabular}{|l|}
\hline 1 - equal importance \\
\hline 3 - moderate importance \\
\hline 5 - strong importance \\
\hline 7 - very strong importance \\
\hline 9 - extreme importance \\
\hline $2,4,6,8$ - corresponding intermediate values \\
\hline
\end{tabular}

If after the comparison of the first factor $\mathbf{i}$ with the other one $\mathbf{j}$, the result is $\mathbf{a}(\mathbf{i}, \mathbf{j})=\mathbf{b}$, it means that after the comparison of the second factor with the first one, the result is $\mathbf{a}(\mathbf{j}, \mathbf{i})=\mathbf{1} / \mathbf{b}$.

During the comparison of data in pairs there is one usual question:

- Which factor out of the two is more preferable?

\begin{tabular}{|c|c|c|c|c|c|}
\hline & $\begin{array}{c}\text { Work } \\
\text { with } \\
\text { a text }\end{array}$ & $\begin{array}{c}\text { Communica- } \\
\text { tive } \\
\text { competence }\end{array}$ & $\begin{array}{c}\text { Intellectual } \\
\text { and creative } \\
\text { skills }\end{array}$ & $\begin{array}{c}\text { Self- } \\
\text { organisation } \\
\text { of a pupil }\end{array}$ & $\begin{array}{c}\text { Erudition and } \\
\text { competence in } \\
\text { various spheres }\end{array}$ \\
\hline Work with a text & 1 & $1 / 5$ & $1 / 3$ & $1 / 2$ & $1 / 2$ \\
\hline $\begin{array}{c}\text { Communicative } \\
\text { competence }\end{array}$ & $5 / 1$ & 1 & $1 / 1$ & $1 / 1$ & $1 / 2$ \\
\hline $\begin{array}{c}\text { Intellectual and creative } \\
\text { skills }\end{array}$ & $3 / 1$ & $1 / 1$ & 1 & $3 / 1$ & $1 / 1$ \\
\hline $\begin{array}{c}\text { Self-organisation of a } \\
\text { pupil }\end{array}$ & $2 / 1$ & $1 / 1$ & $1 / 3$ & 1 & $1 / 3$ \\
\hline $\begin{array}{c}\text { Erudition and compe- } \\
\text { tence in various spheres }\end{array}$ & $2 / 1$ & $2 / 1$ & $1 / 1$ & 3 & 1 \\
\hline
\end{tabular}

Figure 2. An example of evaluation of main elements of the structure $(\mathrm{A} 1, \mathrm{~A} 2, \mathrm{A3}, \mathrm{A4}, \mathrm{A5})$ by a parent - expert 
The relative value of each separate object in the hierarchy is determined by the evaluation of the corresponding element of dominant eigenvector in the matrix of priorities, which is normalised to 1 . The procedure of determination of dominant eigenvectors allows approximation with the help of calculation of the geometric average.

Let $A_{1} \ldots A_{n}$ be the multitude of $\mathbf{n}$ elements, then $W_{1} \ldots W_{n}$ correlate with each other in the following way:

\begin{tabular}{|c|c|c|c|}
\hline & ${ }_{\mathrm{A}} 1$ & $\cdots$ & ${ }_{\mathrm{A}} \mathrm{n}$ \\
\hline $\mathrm{A}_{1}$ & 1 & $\ldots$ & $\mathrm{W}_{1} / \mathrm{W}_{\mathrm{n}}$ \\
\hline$\cdots$ & $\cdots$ & 1 & $\mathrm{~A}_{\mathrm{n}}$ \\
\hline $\mathrm{A}_{\mathrm{n}}$ & $\mathrm{W}_{\mathrm{n}} / \mathrm{W}_{1}$ & $\cdots$ & 1 \\
\hline
\end{tabular}

The evaluation of components of dominant eigenvectors takes place according to the following scheme:

$$
\begin{aligned}
& \mathrm{X}_{1}=\left(1 *\left(\mathrm{~W}_{1} / \mathrm{W}_{2}\right) * \ldots *\left(\mathrm{~W}_{1} / \mathrm{W}_{\mathrm{n}}\right)\right)^{1 / \mathrm{n}} \\
& \mathrm{X}_{\mathrm{n}}=\left(\left(\mathrm{W}_{\mathrm{n}} / \mathrm{W}_{1}\right)^{*} \ldots *\left(\mathrm{~W}_{\mathrm{n}} / \mathrm{W}_{\mathrm{n}-1}\right) * 1\right)^{1 / \mathrm{n}} \\
& \operatorname{SUM}\left(\mathrm{X}_{\mathrm{i}}\right) \\
& \operatorname{WEIGHT}\left(\mathrm{A}_{1}\right)=\mathrm{X}_{1} / \operatorname{SUM}\left(\mathrm{X}_{\mathrm{i}}\right) \\
& \operatorname{WEIGHT}\left(\mathrm{A}_{\mathrm{n}}\right)=\mathrm{X}_{\mathrm{n}} / \operatorname{SUM}\left(\mathrm{X}_{\mathrm{i}}\right)
\end{aligned}
$$

The so-called index of coordination (ic) is a rather useful sub-product of the theory. It gives information about the degree of deviation in coordination [1]. Together with the matrix of pair comparisons, there is a scale of evaluation of the degree of deviation in coordination. If the deviation exceeds the established limits, then the researcher should check these results in the matrix.

\begin{tabular}{|c|c|c|c|c|c|c|c|c|c|c|}
\hline The size of a matrix & 1 & 2 & 3 & 4 & 5 & 6 & 7 & 8 & 9 & 10 \\
\hline Incidental coordination & 0 & 0 & 0.58 & 0.9 & 1.12 & 1.24 & 1.32 & 1.41 & 1.45 & 1.49 \\
\hline
\end{tabular}

Table 2. Coordination averages for the matrix with the size 1 to 10

If this scheme is applied for the above-mentioned example evaluation of main elements of the structure (A1, A2, A3, A4, A5) by a parent - expert, the result is the following:

\begin{tabular}{|c|c|c|c|c|c|}
\hline & A1 & A2 & A3 & A4 & A5 \\
\hline A1 & 1 & 0,2 & 0,333333 & 0,5 & 0,5 \\
\hline A2 & 5 & 1 & 1 & 1 & 0,5 \\
\hline A3 & 3 & 1 & 1 & 3 & 1 \\
\hline A4 & 2 & 1 & 0,333333 & 1 & 0,333333 \\
\hline A5 & 2 & 2 & 1 & 3 & 1 \\
\hline sum & 13 & 5,2 & 3,666667 & 8,5 & 3,333333 \\
\hline & & & & & \\
\hline & $\mathrm{X} 1$ & 0,44093 & & & \\
\hline & $\mathrm{X} 2$ & 1,201124 & & & \\
\hline
\end{tabular}




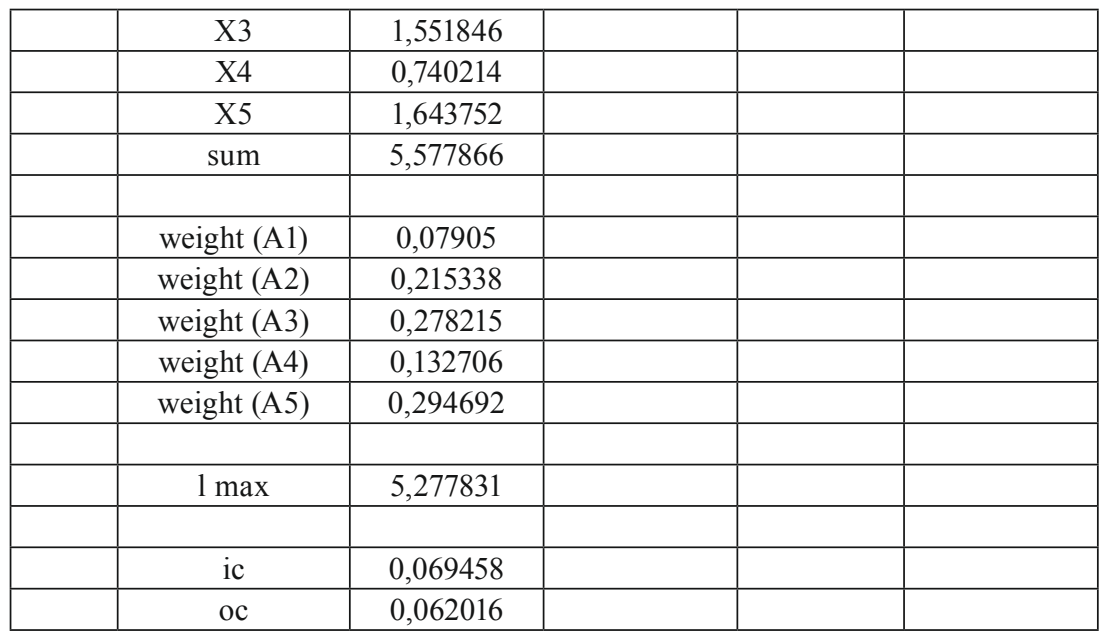

Thus, having analysed the hierarchy, 12 matrices of judgments have been formed. On the basis of each matrix, the dominant eigenvalue, priority vectors, index of coordination and relations of coordination were determined. As a result, the following median values have been calculated.

\begin{tabular}{|c|c|}
\hline Weight A1 & 0,09 \\
\hline Weight A2 & 0,20 \\
\hline Weight A3 & 0,28 \\
\hline Weight A4 & 0,12 \\
\hline Weight A5 & 0,30 \\
\hline
\end{tabular}

Relations of coordination in the matrices mentioned above do not exceed $10 \%$ and, consequently the following statement is acceptable.

Result $=0,09 * \mathrm{~A} 1+0,2 * \mathrm{~A} 2+0,28 * \mathrm{~A} 3+0,12 * \mathrm{~A} 4+0,3 * \mathrm{~A} 5$

As the analysis shows, such criteria as erudition and competence in various spheres have the biggest value -0.3 , intellectual and creative skills -0.28 , communicative competence -0.2 . Self-organisation of pupils and work with a text have the smallest values, 0.12 and 0.09 , correspondingly.

The fact that erudition and competence in various spheres of human life prevail shows that parents still perceive education from the point of view of industrial society. This opinion is confirmed by the conclusions of focus groups: "pupils who have finished school cannot be demanded on the labour market, because they have not been trained (theory and practice are different notions); knowledge acquired at school has to find practical application, and parents' wish to shift part of the responsibility for upbringing of their children to teachers (the teacher has to arouse interest in pupils; speculations about an ideal teacher; not all teachers love children)". Probably, these views of parents are inspired by the collectivistic approach, which existed in Soviet times and still prevails due to inertia.

However, the fact that there is no big difference between competence in various spheres and creative skills (0.02) and between competence in various spheres and 
communicative competence (0.1) leaves hopes that parents' opinions will transform and they will give preference to the formation of the model of a pupil oriented on post-industrial society.

As to social dialogue, focus groups make the following conclusion: "social dialogue is not possible, because there are too many different opinions and it is impossible to take all of them into account". However, if there are many different opinions, it is still possible to find consensus. Most probably, it hasn't happened yet, because subjects of the dialogue are different.

\section{BIBLIOGRAPHY}

1. Saati T. The Analytic Hierarchy Process. New York: Mc.Graw - Hill International,1980.

2. Vasermanis E., Šķiltere D., Krasts J. „Prognozēšanas metodes”, Rīga 2004, -14.-15. lpp.

3. Крымский С.Б., Жилин Б.Б., Паниотто В.И. «Экспертные оценки в социологических исследованиях». Киев, «Наукова думка», 1990.- 175-205.

4. www.nap.lv.

5. http://www.2edu.ru/2edu/2edu.nsf/Display?OpenAgent\&PageName=doc.html\&root_ $\mathrm{id}=$ articles\&doc_id=348D5B131055F483C32571BF00453143. 


\section{The Components of the Quality of Education: Opinions of Social Groups Involved in the Education System}

Ludmila Paṇina

Daugavpils University

Currently, it is the quality of education that has become the main factor of education development. The quality of education is an aggregate of features and properties that reveals the degree to which the learning process and the learning outcome correspond to the needs and requirements of society and the individual, as well as to social norms and government education standards. The quality of education is a social product expressed in the personal achievements of a pupil or a graduate and which depends on the positions and joint efforts of all the groups involved in the educational process.

\section{RESEARCH ON THE QUALITY OF EDUCATION CONDUCTED IN LATVIA AND IN THE WORLD}

At present, both local and national level education administration authorities conduct various evaluations of the quality of education. In Latvia, the quality of education is assessed by such organisations as the Centre for Curriculum Development and Examinations [ISEC], the Higher Education Quality Evaluation Centre [HEQEC], and the State Agency for Assessment of the Quality of General Education [SAAQGE]. The unified examination system, as well as the system of accreditation and licensing of education establishments are also meant to monitor the quality of education. Recently, various conferences, symposiums, and seminars have been devoted to issues of education quality measurement. However, despite this, a concept of the quality of education is still being defined. For example, while assessing the quality of education, only some criteria are usually taken into account: either pupils' achievements during the study process (average marks, results of exams, participation in competitions, etc.) or compliance with certain standards (the compliance of a study programme with the outcome). Another issue often discussed is that young people who have finished higher education are not prepared for the demands of the labour market, a problem usually explained with reference to an insufficient quality of education.

The above-mentioned institutions do not assess the whole system of education. As a rule, they supervise only the main factors of the quality of school education. 
Education experts from the EU and the USA suggest comprehensive assessment of school education, which is based on various groups of indices. For example, a model elaborated by the European Commission uses 16 indicators divided into four groups for assessment of the quality of school education: ${ }^{1}$

\begin{tabular}{|c|c|c|c|}
\hline $\begin{array}{l}\text { Indicators on } \\
\text { attainment }\end{array}$ & $\begin{array}{l}\text { Indicators on success } \\
\text { and transition }\end{array}$ & $\begin{array}{c}\text { Indicators on } \\
\text { monitoring of education }\end{array}$ & $\begin{array}{c}\text { Indicators on resources } \\
\text { and structures }\end{array}$ \\
\hline $\begin{array}{l}\text { 1. Mathematics } \\
\text { 2. Reading } \\
\text { 3. Science } \\
\text { 4. Information and } \\
\text { communication } \\
\text { technologies (ICT) } \\
\text { 5. Foreign languages } \\
\text { 6. Learning to learn } \\
\text { 7. Civics }\end{array}$ & $\begin{array}{l}\text { 8. Drop-out rates } \\
\text { 9. Completion of upper } \\
\text { secondary education } \\
\text { 10. Participation in } \\
\text { tertiary education }\end{array}$ & $\begin{array}{l}\text { 11. Evaluation and } \\
\text { steering of school } \\
\text { education } \\
\text { 12. Parent participation }\end{array}$ & $\begin{array}{l}\text { 13. Education and } \\
\text { training of teachers } \\
\text { 14. Participation in pre- } \\
\text { primary education } \\
\text { 15. Number of students } \\
\text { per computer } \\
\text { 16. Educational } \\
\text { expenditure per } \\
\text { student }\end{array}$ \\
\hline
\end{tabular}

The 16 indicators presented in this table lead to the identification of five key challenges for the future:

- the knowledge challenge. The challenge of the knowledge society brings people back to the essential purposes of school education, in relation to the world of work, to social life and lifelong learning. It raises questions about the assessment and testing of knowledge and more demanding resources of skills, attitudes and motivation to learn. It questions curriculum content and the prioritisation and compartmentalisation of 'subjects';

- the challenge of decentralisation. It raises questions about comparability, equity, quality assurance and inspection. Empowering stakeholders at lower levels means making them responsible for defining what they understand by quality in education and giving them 'ownership' of their part in the education system;

- the resource challenge. In most European countries there are twin trends, which increase resource demands at both ends of compulsory schooling. More and more people are using the education system for a longer and longer period of their lives, thus, increasing resource demands on education;

- the challenge of social inclusion. All European education systems aim to be inclusive, to offer children and young people the opportunity to benefit from school education and to prepare them for life after school. This indicator is a reminder that the relationship between school and society is a vital ingredient in policy-making;

- the challenge of data and comparability. The challenge of comparability is to create an open and positive climate for dialogue. Comparison which is perceived as unfair becomes detrimental to the positive and constructive use of benchmark data. The obvious place to start is standards attained by children at school - their outcomes on leaving school, their acquisition of basic skills at key stages of development. 
Another education model elaborated by a school from the USA suggests 12 indicators, which are rather similar to the above-mentioned ones: ${ }^{2}$

Schools (school-level factors)

1. Leadership that facilitates student learning

2. Parental/Community involvement

3. Organisational adaptability

4. Safe and orderly learning environment

5. District policies to support learning

Teachers (teacher-related factors)

6. Teacher/teaching quality

7. Professional development programme

8. Teacher efficacy

Classrooms (classroom-focused factors)

9. Effective instructional programmes and methods

10. School database collection and analysis to improve instructional programmes

Students (student-centred factors)

11. Readiness to learn

12. Connectedness to school and engagement in academics and extra curricular programmes

Another model ${ }^{3}$ draws attention to three "elements" of school education - the teacher, pupil and school.

Latvian researchers have participated in international comparative projects related to the quality of education since 1991. The conceptual approach of this research stipulates that in order to assess the quality of education, it is necessary to study not only a pupil, a school and the education system, but education in the socioeconomic context as well. The research instruments are common for all participating countries (15-45 countries took part in the research): pupils' tests, as well as surveys of pupils, their parents, teachers, and school directors. The research embraces three levels of education - pre-school, basic, and secondary education. The results of the research have made it possible to evaluate the quality of education in Latvia and to compare it with education in other countries. Different skills and knowledge of various fields have been analysed and compared: pupils' literacy, ability to use information technologies, knowledge of mathematics and natural sciences, civic education, general readiness for life and further education. ${ }^{4}$

However, even today Latvian society has two absolutely opposite opinions about how to evaluate the quality of state general education. There is an opinion that pupils do not have sufficient skills to use acquired knowledge. The same problem has been mentioned by auditor general I. Sudraba, who participated in the audit of the system of state general education: "... schools do not teach pupils to analyse and to make logical judgements; they teach only to mechanically reproduce information." 5 However, officials of the system of state education believe that the quality of school 
education is evaluated on the basis of pupils' formal theoretical knowledge. From this point of view, pupils in Latvia show rather good results and, consequently, the quality of education can be evaluated as positive.

The afore-mentioned difference is well-formulated by teachers during the discussions of focus groups (see below): we mechanically teach children in order to convince them that they have to know it, that it is like this and not vice versa. We don't have time to develop their understanding. Another teacher said: "In this case, there should be another way to assess pupils' knowledge. It is the state's fault. For an exam a pupil has to know figures, facts, and events. However, our aim is to get a person who can analyse, understand, etc. After studies at school, a pupil doesn't have to know the date of an event by heart, but has to be able to analyse this event". It is obvious that the education system insists on knowledge of a particular theoretical programme, while the labour market, establishments of higher education and society demand a flexible person who easily adapts to new conditions, possesses good analytical skills, and understands not only events, but the prerequisites and consequences as well.

In order to get an idea about the situation in the sphere of education and to work out suggestions for improving the quality of education, it is not enough just to analyse pupils' study results or to observe formal requirements during the implementation of the programme. Other factors influencing the quality of education should also be taken into consideration. Having taken international experience into account, it is possible to distinguish three main components which influence the quality of school education:

1. the quality of pupils (of "raw material");

2. the quality of teachers and lecturers;

3. the quality of the learning process.

Generally, people do not have a common opinion about qualitative education. That is why it is important to consider all opinions and ideas of people involved in the process of education. This is the only way to achieve high quality of learning outcomes (see Figure 1).

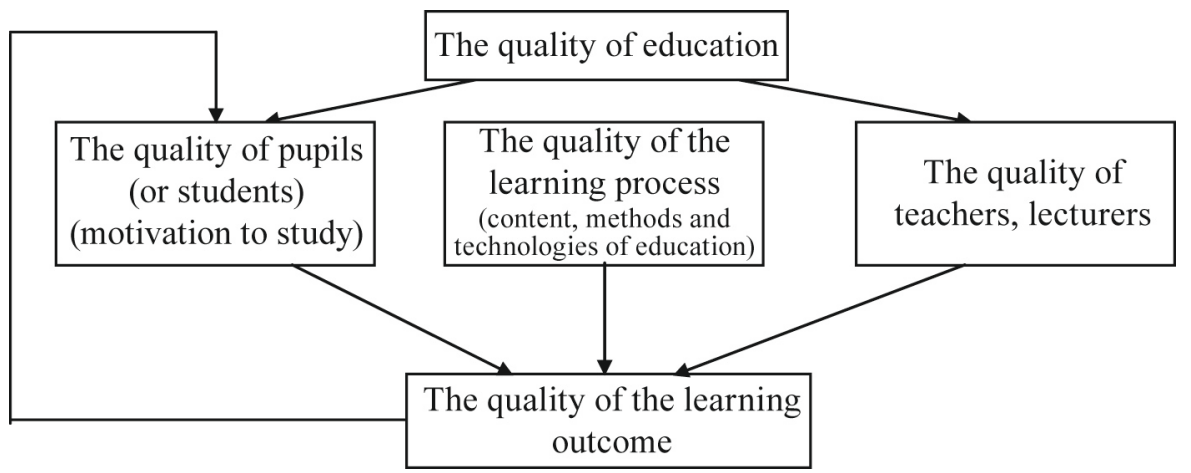

Figure 1. The basic indices of the quality of education 


\section{THE QUALITY OF SCHOOL EDUCATION: OPINIONS OF PARTICIPANTS IN FOCUS GROUPS}

The quality of education was one of the issues discussed in the framework of the project of the Strategic Analysis Commission under the auspices of the president of Latvia "Education in the Knowledge Society in Latvia". Due to the fact that many characteristic features of the quality of education are impossible to evaluate quantitatively, it is possible to get a complex index of the quality of education using qualitative methods. In order to get more precise information during the investigation, focus groups discussions were organised. The focus groups provided the possibility of discovering all the opinions and evaluations of all the groups involved in education - parents, pupils and teachers - about the quality of education and its components, as well as the ability of other groups to influence it. The focus groups took place in two Latvian regions - in Zemgale (in Bauska and Jelgava) and in Latgale (in Daugavpils and Preilii). Four focus groups were organised in each town: three homogeneous groups, each including teachers, pupils or parents, and one heterogeneous group, where the representatives of all the groups took part. This provided the possibility to compare the significance of components of qualitative education and its content both in the regional context and in the opinion of different groups involved in the process.

The evaluation of the quality of education was divided into several related components:

1. the quality of pupils;

2. the quality of the learning process;

3. the quality of teachers;

4. the quality of the learning outcome.

\section{The quality of pupils (motivation to study, particular abilities and skills)}

The paradigm of education is changing and more and more attention is being paid to an individual as the main value of the process of education. This places the consumer of knowledge, i.e. a pupil, in the centre of the process of education. Indeed, a pupil is a person who attends lessons, reads and studies textbooks, and uses new education technologies. That is why it is possible to talk about the quality of a pupil or raw material for schools, who is to be converted into the outcome of the process of education (who also will make the final outcome of the process of education). The quality of a pupil can be characterised with the help of the following indicators:

- Initial knowledge, abilities, and skills;

- Willingness to study and motivation;

- General intellectual level;

- Memory and similar features (attention, persistence, diligence);

- Talents;

- Discipline;

- Capacity for work. 
In order to evaluate the quality of a pupil during the research, two aspects were taken into consideration: the initial qualification for a certain level of education and motivation - willingness to study. While discussing the beginning of studies at primary school, pupils emphasised factors of socialisation, but rarely mentioned the problems related to preparation of children in kindergartens or at home. Some parents think that for a child the transition from kindergarten to school is not as difficult as the transition from primary to basic school. As one possible explanation, psychological factors can be mentioned: difficulties to adapt to various teachers' requirements, increasing independence, as well as a lack of self-motivation.

Teachers emphasised that "at primary school pupils are taught how to survive in a collective, but at secondary school a lot depends on how much somebody wants to achieve". They also underline the role of parents in this process and the influence of one's family on the pupil's motivation.

\section{Quotations from focus groups about the quality of initial knowledge at all stages of education:}

"I think that pupils have a good pre-school education. I'm satisfied with the education children get at kindergartens." [a parent from Jelgava]

"There are children with different levels of knowledge in Form 1. And I would like to mention that it mostly depends on parents." [a teacher from Jelgava]

"There should be some initial knowledge in every sphere." [a pupil from Bauska]

"I was well-prepared for Form 1. I could read well enough and was able to count. [a pupil from Bauska]

"They [pupils] have to adapt to such conditions." [a teacher from Bauska]

"Children get used to the system of education at kindergartens; because professionals work there who prepare children like at school, and pupils don't feel the difference. Kindergartens also have programmes, so children come to school with particular knowledge and abilities." [a teacher from Bauska]

"Of course there is a lot of knowledge. The question is: how much of it every pupil will take. Schools give, your task is to take!" [a parent from Bauska]

Teachers highlight problems such as a lack of motivation and responsibility. A teacher from Daugavpils pointed out that pupils often have negative motivation ("the only thing that matters is not to get a " 2 "), but not a positive one ("to get knowledge and good marks"). Teachers also put emphasis on the fact that pupils often can not give a comprehensible reason why they study. However, pupils themselves think that they understand the importance of education in their future life.

Talking about motivation, it is worth mentioning the disproportion of "rightsduties", which was mainly pointed out by teachers. Teachers said that nowadays pupils with the help of government and non-governmental organisations are very well informed about their rights, which they often use even to blackmail teachers. 
However, pupils' responsibilities and duties are not well-known and clear to them. It is one of the causes which leads to a lack of upbringing and motivation. Speaking about this issue, teachers also emphasised the responsibility of parents.

\section{The quality of the learning process (equipment of schools)}

The quality of the learning process can be characterised using the following indicators:

- material-technical basis;

- infrastructure;

- content of education and study programmes;

- education technologies.

Basically, all focus group participants expressed similar opinions about education methods. As the most successful methods, pupils mentioned work in groups and interactive methods, the latter being emphasised by the teachers as well. The teachers also mentioned the necessity to develop communicative and analytical abilities that can be acquired both during independent studies and work in a team. Moreover, according to teachers, it is necessary to develop such skills as the ability to work independently, to organise work, to defend one's opinion, and to find practical applications for one's knowledge. One of the teachers pointed out: "We increase the amount of knowledge, but we lose creative people. Our aim is not only to teach how to think logically, speak and work with a text, but to teach to analyse the information, to make conclusions, in other words, to adapt to different situations in a rapidly changing life". Another teacher said: "At secondary school, the most useful methods are ones that make pupils work independently. They work themselves, develop some idea themselves, make their own conclusions, and then present the results to others". Pupils think in a similar way. It is important for them to express their thoughts and know that a teacher is listening (even if the teacher does not accept these thoughts, it is enough just to listen).

As to the means of education, both teachers and parents mentioned the inadequately large number of textbooks and outdated methodological materials (geographical maps, history atlases, etc.). Parents are concerned with the fact that pupils work less with textbooks, and that books are changed too often.

Teachers, in turn, do not appreciate the fact that study programmes, plans, and standards are altered too often. Because of the bureaucracy caused by these changes, there is no time to study the subject.

Almost all the participants expressed similar opinions about the assessment system at schools. Pupils mentioned that there is no motivation to study well if there is a "passed"/"not passed" system, there is just a motivation to try a little in order to meet the minimal requirements for "passed". All the participants noted that the current system of knowledge assessment does not stimulate an improvement in quality. Similarly, parents evaluated the system of tests as a form of knowledge control. Parents emphasised that it does not stimulate improvement in quality: tests limit a person, because they let him figure out the correct answer or to guess it, as a result, there is no need to learn and acquire the necessary knowledge. 
Regarding education methods, pupils and their parents have the firmest position. They think that the lack of motivation should be compensated by the teacher's supervision (teachers should control both deadlines and the quality of homework). However, all the participants of the discussions shared the opinion that methods have to be chosen according to pupils' specific features of memory and perception, even if it is too complicated for a teacher. The pupils also mentioned that teachers have to apply different methods.

The analysis of the focus groups shows that all the respondents pointed out that the quality of the process of education depends on how well pupils are motivated, supervised and interested in education. Opinions differed only when it concerned the question: "who will motivate, supervise and arouse pupils' interest". Parents think that the school has to do it, but teachers, in their turn, point out that it has to be done both in the family and at school.

It is interesting that representatives of all discussions - teachers, pupils, parents, school administration - in both regions came to a common conclusion that methods should be chosen according to pupils' abilities, his or her physical development, specific features of memory, level of psychic development; a teacher has to understand what kind of person each pupil is. It is necessary to use various methods according to the situation, group, and particular pupil, work in groups being considered the most successful method by all the participants of the discussions. Pupils from Latgale and Zemgale, as well as some teachers drew special attention to issues of mutual respect. Teachers from Latgale emphasised content and stability problems of study programmes; teachers from Zemgale highlighted the fact that study programmes overload pupils.

\section{The quality of teachers}

According to the opinion of all the groups involved in the discussions, the central figure of the process of education is a teacher. That is why the process of improving quality has to be linked to the training of pedagogical personnel. But the question arises as to how to evaluate the quality of a teacher? It is a very important question, because the answer will influence the content of education, the quality of study programmes, study methodology and methods, the competitiveness of pupils on the labour market, as well as other components of the quality of education. Besides, a teacher does not just pass on knowledge, but creates a personality, his or her perception of the outer and inner world. That is why it is possible to conclude that the quality of a teacher is a complex notion, which includes:

- competence (knowledge and experience in some definite science or practical sphere);

- the ability to perform a pedagogical activity;

- care (the ability to take pupils' different, specific features of character, etc., into consideration);

- the ability to make contacts with the inner and outer environment;

- the ability to apply innovations in the process of education;

- research activity. 
Concerning this issue, the most diverse evaluations and attitudes were given. However, both parents and teachers emphasised that the process of education cannot be separated from the upbringing process. Thus, a teacher has to be not just a professional, but an adviser and educator as well.

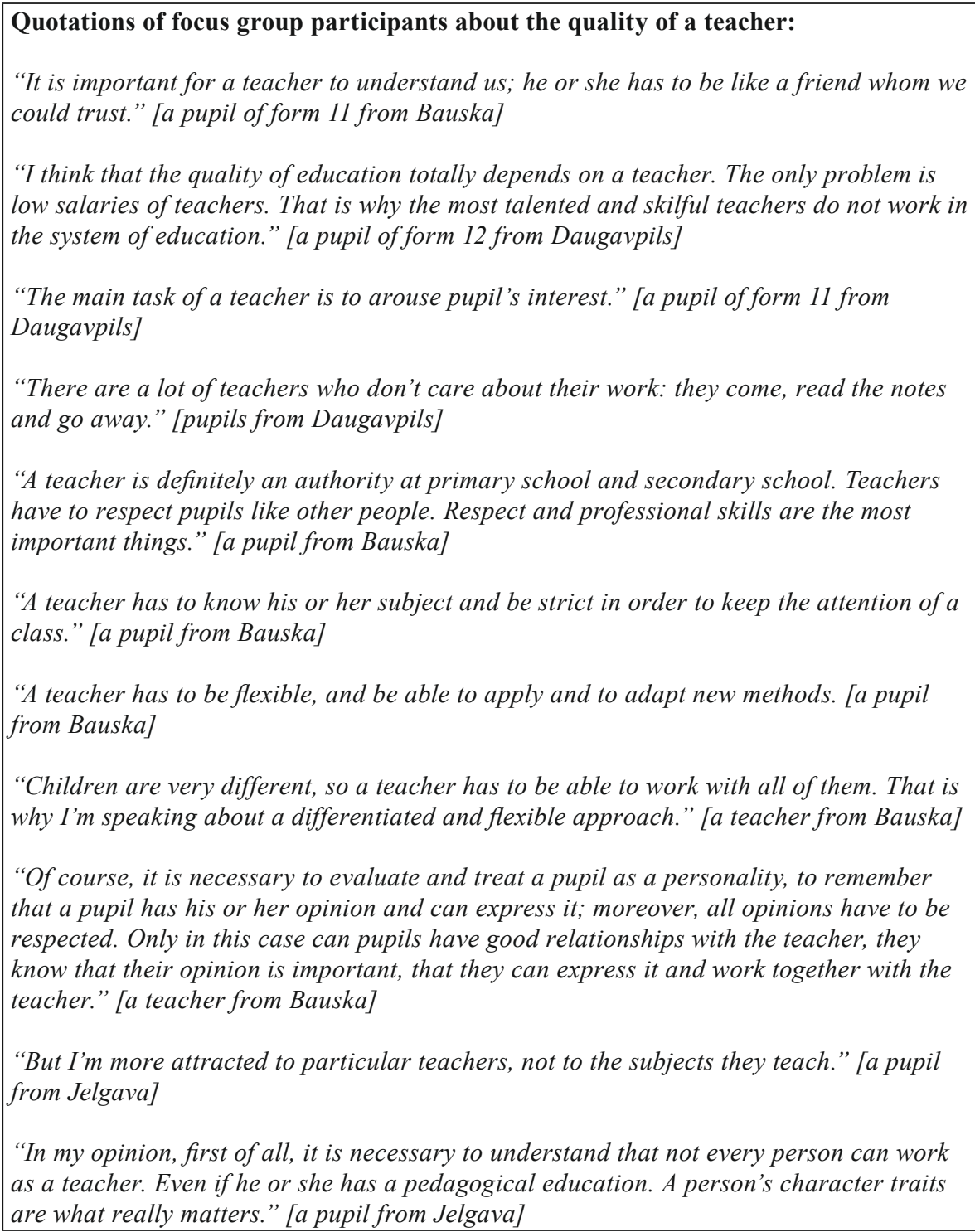

Speaking about an "ideal" teacher, pupils often emphasised such features as being strict, objective and authoritative. In the description of teachers, an "ideal" professional is a person who knows the subject well and can combine it with various methods and psychological skills. 
All the pupils, as well as the parents pointed out that the teacher's main aim is to arouse pupil's interest in the subject, so that later this interest would stimulate the pupil to study further.

Parents said that at primary school personal qualities are more significant than professional ones. However, for pupils of higher forms, the teacher's knowledge of his or her subject is more important than character. According to pupils, the most important task of a teacher at nursery and primary school is not to let the desire to learn disappear. Parents also mentioned that the process of education can not be separated from the upbringing process, that is why the teacher's duty is to bring up pupils as well. Moreover, the teacher's duty is also to arouse children's interest in studies and to offer interesting materials.

According to the pupils, a teacher is the basis of qualitative education and its most important element. The pupils think that the teacher's main aim is not just to teach and raise children, but to arouse interest. If a teacher is an expert in his or her profession (and has a decent salary), he or she would be able to arouse pupils' interest in studies, and would positively influence "teacher-pupil-parents" cooperation.

Teachers themselves think that the most important factor hindering improvements in the quality of work is the attitude of society, that is to say, the low prestige of a teacher's profession. Another negative factor is that teachers have to spend too much time on bureaucratic work, time which could have been spent on pupils. Consequently, the quality of education depends on the motivation of personnel. The teacher must have a social status such that the teacher's profession becomes more prestigious and more attractive to society.

As to this issue, participants' opinions were rather similar. Moreover, all the groups - teachers, pupils, parents - from both Latgale and Zemgale expressed the same idea: "A teacher should be flexible, should have good knowledge of his or her subject, should be able to adapt to different situations and should be a good psychologist." Pupils in both regions also pointed out that a teacher should study all the time, should keep up to date and should attend seminars and conferences.

\section{Quality of outcome = pupils who have finished schools}

It is obvious that one of the most important components of the quality of education is the outcome of education: pupils' knowledge, skills and attitudes. As a rule, respondents pointed out that schools must prepare not professionals with a specific specialisation, but broadly educated personalities. The importance of general subjects was emphasised by pupils themselves. They say that it is difficult to tell in advance which subjects will be necessary in life, moreover, a wider outlook gives more chances to evaluate and apply one's own abilities. Children consider that the aim of secondary school is to help a person to understand what he or she wants and can do in the future.

According to parents, in order to get a qualitative outcome, it is not enough just to teach children, it is also necessary to teach parents as well. They have to be involved not just in extracurricular activities, but also in the process of education and to help their children as much as they can. 
In the focus groups, the teachers expressed differing opinions concerning school functions. One half of the teachers emphasised that the main function of school is to prepare broadly educated personalities. The others pointed out that after finishing school, a pupil does not have to be erudite, it is important to concentrate attention on particular subjects which will be necessary in the future profession. However, the children themselves think that multi-faceted development is the best thing that one can get at school, because in the future it will help to solve various problems.

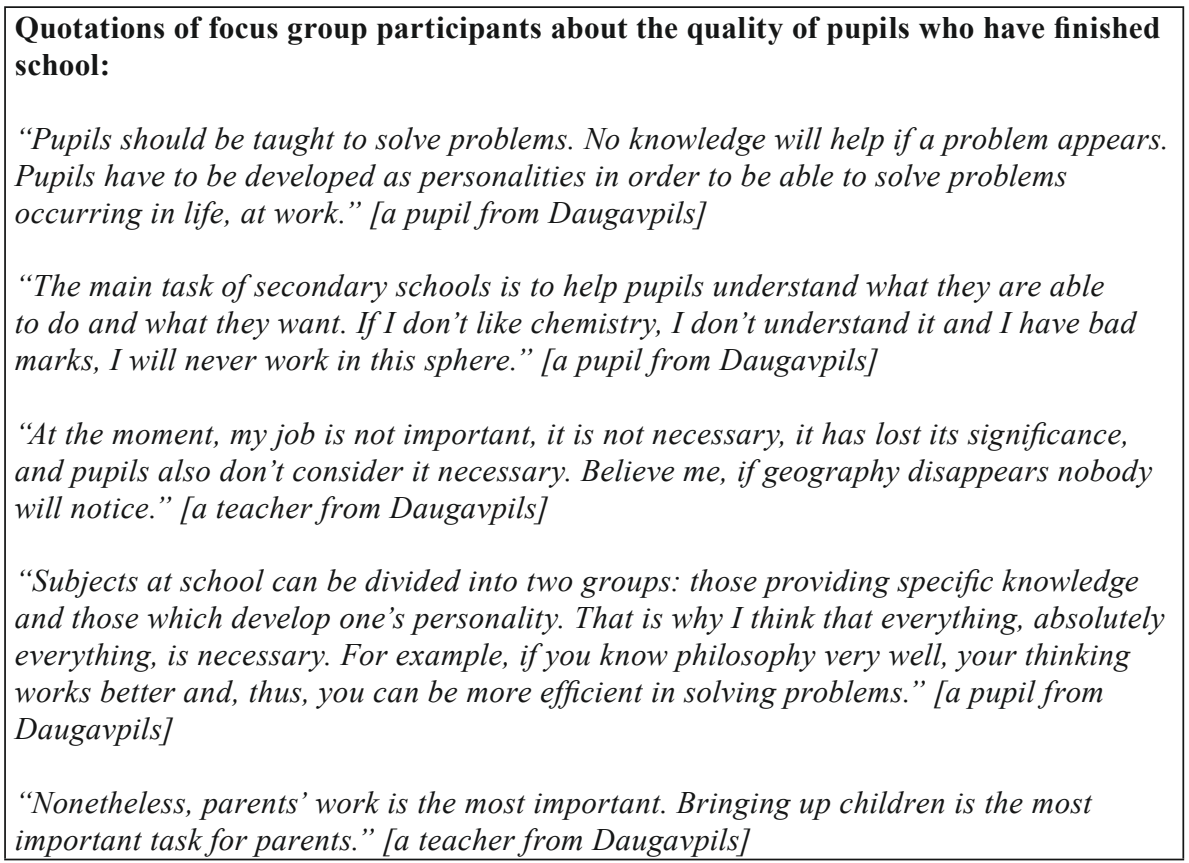

It is possible to say that the pupils divided into two groups: the idealists, who perceive education widening their outlook (knowledge is a means to other ends) and the pragmatists, who think that secondary school must teach some particular abilities to be applied practically in the future, especially on the labour market. Thus, during the discussions, differing pupils' motives for studies were revealed: opportunities to get a better job (material security), possibilities to acquire knowledge and skills, preparation for studies at establishments of higher education, communication with people of the same age, etc.

In the author's opinion, it is possible to single out three main problems related to the quality of education in Latvia, taking into account the opinions of respondents expressed during the research:

\section{The low prestige of the teacher's profession}

First of all, this profession is not prestigious, because the salary is not considered to be satisfactory and because a teacher should possess special traits of character. Nowadays, people who work at schools are either "fanatics" who adore their job or those who simply cannot find another job. Teachers' salaries must be high enough so 
that a teacher has some free time to devote to out-of-class activities and preparation for lessons. It is the only way to let teachers work creatively, apply modern technologies, and arouse pupils' interest. This problem was pointed out by all the participants of the focus groups. Moreover, taking into consideration the fact that in most cases the respondents emphasised the leading role of a teacher in providing a qualitative education, it could be the most important obstacle to improving the quality of education on the whole.

\section{A lack of pupils' motivation and qualitative upbringing}

The teachers emphasised a lack of motivation and responsibility. A teacher from Daugavpils said that pupils often have a negative motivation ("the only thing that matters is not to get a "2"), not a positive one ("to get knowledge and good marks"). Moreover, it is worth mentioning that pupils are ignorant of their duties and do not fulfil them.

\section{The lack of social dialogue among the groups involved in the process of education}

Pupils and parents try to shift the responsibility for poor outcomes to teachers. The parents say that they work too much, and that is why a school has to take over the functions of upbringing, not even mentioning help in studies. Pupils have learned to exercise their rights, but nobody has explained that they have duties as well. One of the most important problems is a lack of motivation. The only way to achieve an acceptable quality of education is to promote social dialogue among all the groups involved in the process of education (the quality of the learning process, the quality of teachers, and the quality of the "raw material"). This would also promote economic efficiency of education and development of sustainable education.

The quality of education is a complicated notion. In order to define this notion, it is necessary to use a process-oriented approach to elaborate a system of quality management. It would increase consumer satisfaction by meeting their demands. The main characteristics of the process-oriented approach are continuous management, succession of separate education processes and interrelations within the system, as well as combination and interaction.

The quality of education (the quality of outcome) is a complex index that is based on the quality of a teacher's work, the initial knowledge and motivations of pupils, and the quality of the learning process (education methods, systems of evaluation, etc.). A constant interest in studies and studying results can be encouraged by a teacher's skilful work. A restoration of prestige of education and the teacher's profession is connected with a substantial increase in teachers' salaries. In order to raise the quality of education, updated education methodology is necessary, as well as new motivated specialists who are able to attract pupils' attention and develop their creative potential. ${ }^{6}$ A qualitative process of education requires modernisation and optimisation of the material basis of all educational establishments, as well as up-to-date teaching aids. The system of education has to provide all groups of citizens with equal chances to get a primary, basic, general or professional secondary education. 
In conclusion, it should be mentioned that all the participants of DFG said that a teacher has the biggest influence on the quality of education. According to pupils and parents, the abilities of teachers can reduce the negative aspects of the process of education. However, it should not be forgotten that the quality of education does not depend on the teacher alone. It is necessary to look for common solutions and ways of cooperation, not to shift responsibility from one side to another. The best result may be achieved only as a result of a successful social dialogue.

\section{BIBLIOGRAPHY}

1. Dzelme J. Izglìtības indikatoru izmantošana augstākās izglītības vērtēšanā. http://www. aiknc.lv/lv/kopmat.php.

2. Dreijere V. "Valsts kontrole sola izrevidēt milzīgo izglītības sistēmu," Diena 13.11.2006 1.lpp.

3. Eglīitis J. "Izglìtības kvalitātes mērīšana. Pārmainas Latvijas izglīî̄iā: izaicinājums sistēmas vadībai”. Pārskats par izglītību Latvijā 2001./2002. gadā. R. 2002.

4. European Report on the Quality of School Education. Sixteen Quality indicators. European Commission, May, 2000.

5. Geske A., Grīnfelds A., Kangro A. "Izglīitības kvalitāte Latvijā starptautiskā un nacionālā kontekstā." Ceļā uz sociālo saliedētību un labklājību. Pārskats par izglìtību Latvijā 2000. gadā, R. 2001.

6. Handbook of the Sociology of Education / edited by Maureen T. Hallinan, Springer 2006.

7. Izglìtības attīistības pamatnostādnes 2007.-2013.gadam. R. 2006

8. Izglītības kvalitāte un efektivitāte Latvijā. Izglītîbas un zinātnes ministrija, Izglìtīibas sistēmas attīstîbas projekts, R. 2004.

9. Latvijas Nacionālais attīstības plāns 2007.-2013. www.nap.lv

10. Quality Education Model. Preliminary Report, August 1, 2006. The Quality Education Commission, 255 Capitol St. NE Salem, Oregon.

\section{FOOTNOTES}

${ }^{1}$ European Report on the Quality of School Education. Sixteen Quality indicators. European Commission, May, 2000. p.6.

2 Quality Education Model. Preliminary Report, August 1, 2006. The Quality Education Commission, 255 Capitol St. NE Salem, Oregon p. 27-28.

3 For more details: A.Gamoran, W.G.Secada, C.B.Marrett "The Organizational Context of Teaching and Learning," Handbook of the Sociology of Education, edited by Maureen T. Hallinan (Springer 2006), pp. 37-63.

${ }^{4}$ Geske A., Grīnfelds A., Kangro A., „Izglītības kvalitāte Latvijā starptautiskā un nacionālā kontekstā," Ceḷā uz sociālo saliedētību un labklājību. Pārskats par izglītību Latvijā 2000. gadā, (Rīga 2001).

5 Dreijere V. „Valsts kontrole sola izrevidēt milzīgo izglîtības sistēmu,” Diena 13.11.2006 p.1.

* The outcome of one step of education (e.g., a person who has finished basic school) is "raw material" for the next step (e.g., a pupil of secondary school).

${ }^{6}$ Latvijas Nacionālais attīstības plāns 2007.-2013. p.14. 


\title{
Education and Its Consequences in a Changing World: A Challenge to the Knowledge Society
}

\author{
Juris Tipa \\ Student, University of Latvia
}

The homepage of Latvia's Ministry of Welfare states that "work is one of the most important human activities which provides the means for survival, creates the the foundation for creative thinking, self-realisation and social contacts." I doubt that anyone would deny this statement. I also doubt that someone would deny the importance of education as organised knowledge contributing to the development of the human personality. We could assume that both work and education determine the social value of people in our society and determine life opportunities and the quality of life. Inadequate or insufficient education can become a significant barrier for occupying a good position in the labour market, but the absence of work or low paid work can negatively affect a person's material situation and psychological wellbeing.

But what is education really and what does it give to us? How and by whom is education shaped? How is education related to the labour market? What consequences and risks does it involve and how should we deal with them? These are the questions that I will try to answer in my essay. To achieve these objectives, I will use the example of the generation in Latvia which is currently aged between 45-55 years.

If we assume that there is a certain circulation of capital in the labour market, then education should also be perceived as a form of capital. Cultural capital is the famous term in sociology widely described by French sociologist Pierre Bourdieu. He described three forms of capital - economic, social and cultural. Economic capital mostly refers to economic resources, social capital to group membership, relationships and social networks created by people, and cultural capital can be seen in knowledge and skills. According to Bourdieu, cultural capital exists in three forms: embodied (a person's character and way of thinking formed by socialisation), objectified (things which are owned, such as scientific instruments or works of art) and institutionalised (educational qualifications and their value can be measured only in relationship to the labour market). Thus, below, I discuss "cultural capital" in its institutionalised form. Bourdieu notes that cultural capital can be acquired and distributed through the family and educational system, so the family is the indirect reproducer of state and governmental values, and formal mass education is the direct reproducer of these institutionalised values. Moreover, Bourdieu implies that cultural 
capital can be converted into economic capital. ${ }^{2}$ This means that certain knowledge, education or skills can be converted into economical means, for example, into a higher income, a better job, etc.

Though Forms of Capital was written by Bourdieu more than 20 years ago, other authors have elaborated on the concept of cultural capital in similar ways more recently. "In advanced societies, cultural capital is the counterpart of economic capital. Economic capital is not only shares and bonds and material goods. It is also know-how on how to handle monetary assets and how to behave in the world of corporations and finance". "From an economic viewpoint, the most important function of universal education is that it provides the economic subsystem with efficient and productive labour forces... Schools (used here as a generic term for all levels of formal education) are thus thought of as the 'great socialisers'."4 This means that we are all carriers and reproducers of cultural capital deposited by education.

Further, I will describe a particular generation in Latvia in the context of cultural capital and the labour market. My sybject is people who gained education during the Soviet Union (in the Latvian SSR) in the beginning of the 1980s and afterwards had to face the labour market in an independent capitalist Latvia after the collapse of the USSR in 1991. These persons are primarily in the age group 45-50 years old. As theoretical background for this description, I will use a publication of Ritma Rungule and Ilze Koroleva "Old" education in new conditions". In this publication, the authors describe longitudinal research on people who graduated from secondary schools in the Latvian SSR during the period 1983-1985. The study stressed their further education choices and pursued their success in the labour market thereafter. The authors described the education system in the Soviet Union as highly centralised (as we know, the economy was highly centralised as well in the USSR), standardised and highly regimented. A rapid increase in the spread of secondary education resulted in a decrease in quality due to its mass character. On the other hand, universities were not able to matriculate all the people who wanted to. Education was focused on meeting the needs of the country or society in general and not on the value that the individual could receive from education personally. Education was under the complete control of the government and was used for the needs of government. Often people were prepared to work only in a certain factory or certain job. Every ministry (or economic department) tried to open its own "secondary specialised education" or schools (PTU, technical college) to provide itself with a labour force. Students who graduated from these "medium specialised education" schools had fewer opportunities to enter university because of the narrow education they received in "specialised education" schools. The education system resulted in relatively young (14-15) individuals in the Soviet Union being divided into educational paths which determined their future careers.

According to Rungule and Korolyeva, the majority of people in the Latvian SSR were involved in "medium specialised education" and a minority of them continued education in independent Latvia. ${ }^{5}$ This means that persons who received "medium specialised education" (both in PTU or a Technical college) in the Soviet Union received knowledge (usually technical) that was meant for a narrow range of functions within the plans of the regime and government. Education lost its long term value and became usable only for "here and now" actions. And with the same 
educational and labour experience background they had and still have to face new education and labour market strategies in independent Latvia.

After the fall of the USSR, education became a part of the free market. A majority of the factories for people educated in "medium specialised" institutions were shut down or went bankrupt. Skills these people received during their Soviet education period became inapplicable. This generation had to resocialise in terms of the knowledge and qualities demanded in the labour market which were not topical before (language skills, information technologies, client service skills, etc). Of course this caused a high rate of unemployment and low paid jobs among this generation. As Hans Melberg suggests, capitalism should be seen as a "creative" system because new inventions, new technologies, changing preferences and external shocks are constantly changing the structure of the markets. ${ }^{6}$ When new technologies are invented there is no demand anymore for workers who were doing certain functions before the invention of a particular technology. This also pertains to knowledge - before the invention, a specific kind of knowledge was needed to perform the necessary functions. After the invention, different knowledge is needed for operating with new technologies. For those whose knowledge is not needed anymore in the labour market, gaining the demanded "new" knowledge (skills, education etc.) is becoming more and more complicated. For many, this is a serious tragedy, as he or she cannot earn the necessary means for surviving. Cultural capital earned has devaluated; in other words, the bankruptcy of factories and the regime also bankrupted the cultural capital of many people. People who are about 45-50 years old and older are the most vulnerable social group in the labour market. If they lose a job, it is very hard to find a new one because of lack of knowledge or cultural capital in demand. ${ }^{7}$

This example demonstrates the statement of Ulrich Beck that: "Risks have become an intellectual and political web across which tread many strands of discourse relating to the slow crisis of modernity and industrial society". ${ }^{8}$

Who could predict that the Soviet Union would fall? Who could predict that what we learned and practiced for decades would become inapplicable after a year? If we are not aware of the presence of risks, it doesn't mean they are not there.

In terms of modernity, changes that occurred after the fall of the USSR resulted in an individualisation of social agents. Every person not only became able to completely make his own social biography, but was even forced to do so. Risks that are attached to this process were redistributed from the governmental level (as in the Soviet Union) to the individual level (as in independent Latvia). According to Beck, this is one of the indicators of "labour market flexibility" - "redistribution of risks away from the state and the economy towards the individual". ${ }^{9}$ Beck continues that the labour market in a free market economy functions as a motor of individualisation or individualisation of social inequality. People demand the right to develop their own perspective on life and act upon it. Sudden individualisation can be insecure or can cause a wave of unemployment. Individualisation is directly related to risk because it means separation of the individual from traditional support networks (community, family) which could be seen also as habitual support networks. Everyone who enters the labour market has to face its three dimensions - education (choosing and planning one's educational course to became a producer of individual labour), 
mobility (to escape economic ruin a person is forced to take charge of his own life, which means that a person is removed from traditional patterns and arrangements) and competition (rests upon the interchangeability of qualifications and thereby compels people to advertise the individuality and uniqueness of their work and their own accomplishments which results in individualisation among equals). ${ }^{10}$ As we can see, these conditions are not similar to the ones that were significant for labour markets in the Soviet Union. Mobility and competition in general were indirect and mild because people were prepared to work in a certain position. It excludes significant upward career mobility (direct upward mobility in the Soviet Union was possible only within the Party and Unions, as business activities were illegal) and decreases competition (as noted before, in a centralised system there were more or less as many professionals prepared as were needed).

Conditions we have to face in the labour market also determine our behaviour according to our culture. This has also been indirectly described by Beck: "Unemployed people have a lot of time on their hands and financially are very insecure. But paradoxically, their receipt of unemployment benefits obliges them to do nothing. They might be compared to thirsty people who have promised not to drink one drop of extra water because they are officially given one glass a day to moisten their parched throat. Otherwise they are "social cheats", whose transgression is harmful to the public good." 11

However, I would like to argue that unemployment benefits don't inescapably oblige an unemployed person to do nothing. The choice between passivity and activity is determined by several factors - how else can we explain that one person is passive and "does nothing," but another is actively looking for a job despite the "unemployment benefits". ${ }^{12}$ It depends primarily on cultural capital, but of course also on other forms of capital mentioned by Bourdieu. For example, if a person is accustomed to double-morals since Soviet times, this habit became a part of his cultural capital. On the other hand, if we look into unemployment statistics of Latvia, we see that the highest unemployment is for the age group $45-60$ years. ${ }^{13}$ This is precisely the generation which graduated from secondary schools in the Latvian SSR around the beginning of the 1980s. The most active applicants for unemployment benefits are also from this age group. It is no secret that people also have unofficial jobs in order to have a double income (the welfare benefit plus the unofficially earned income). ${ }^{14}$ This position is understandable, because the way these people were living was suddenly no longer possible and they had to adapt to completely new rules of the game. This caused significant psychological discomfort, and there is a lack of faith in the "new system" - perhaps in 10 years there will be a need to "resocialise" again. From the "here and now" education in the Soviet regime, people of that generation are practicing a "here and now" labour market strategy. By this I mean their emphasis on any kind of immediate income, ignoring the long term perspectives, credit ratings, etc. Here again we can see the effect of cultural capital.

Looking at the current situation, it seems that higher education has taken the place held by "medium specialised" education during the Soviet period. Because of the easy accessibility of higher education (student credits, scholarships, etc.), it has partly lost its great importance in upward mobility and has turned into an institution which students continue after their graduation from secondary schools. ${ }^{15}$ What does 
this mean and where is it taking us? I would say that it is a new risk to face, and we are facing it already as a great divide between formal knowledge (theory) and particular skills (experience). It is quite common today for young people to become unemployed after graduating from university because they have no work experience (a "good CV") which is demanded in the labour market. Paradoxically, these youngsters are in the same situation as the "Soviet generation" previously described. Of course both cases entail a social tragedy, but there is also a difference - in most cases, unemployed "university graduates" are treated in the labour market as a social risk group, but people aged 45-55 (and older) are not, despite the fact that unemployment rates can be similar. This "Soviet generation" is like a dying plant, and it seems that society is counting on a "demographic wave" to wash away this generation with its cultural capital. I think it is even more tragic, the emphasis is on the young generation, but the elderly people are almost "taken to the forest", as the folk saying goes, to get rid of them.

"Economic needs determine the educational system."16 This statement could be the conclusion of this paper, as in both the Soviet Union and independent Latvia the economy is one of the key factors determining the education system. In a centralised regime, education is fully planned, but in a capitalist regime it is based on "freedom of choice" and free "market self-regulation" (which limits the freedom of choice at the same time). People in both systems face risks, as the regime can change or the economic situation or market demands can change. Any of these changes affect cultural capital in the form of new demands for knowledge and skills. Education and added cultural capital is one of the main determinants of opportunities in the labour market. Of course, we are also dependent on our social networks (social capital) and wealth (economic capital), but speaking in general terms, our opportunities are based in cultural capital. As I emphasised about the current period, opportunities are particularly based on knowledge and skills in the form of cultural capital.

As elsewhere in the world, Latvia has gone through cultural capital transformation primarily caused by technological development and political change. "The fast development of Information and Communication Technology (ICT) has brought about deep changes in our way of working and living, as the widespread diffusion of ICT is accompanied by organisational, commercial, social and legal innovations. Our society is now defined as the "Information Society", a society in which low-cost information and ICT are in general use, or as the "Knowledge(-based) Society", to stress the fact that the most valuable asset is investment in intangible, human and social capital and that the key factors are knowledge and creativity." 17

What kind of issues need to addressed in this changing world full of risks? Currently, the concept of "life-long" education is as topical as ever, as is e-learning, distance learning, continuing education, correspondence courses, etc. Basically it is anti-theory and anti-practice to say that "You can't teach an old dog new tricks". ${ }^{18}$ Education shouldn't be perceived and treated as something "age", "time" or "institutionally" limited, but more as a continuing process. In Bourdieu's terms, we could say there is a need for permanently renewable cultural capital. "Lifelong learning" as an approach which is based on awareness of changes, preparedness, and flexibility. If the labour market is flexible, its clients should also be flexible. 
Paraphrasing Beck ${ }^{19}$ :"Labour market flexibility means: Cheer up, your skills and knowledge are not absolute, and no one can say what you must learn in order to be needed in the future".

\section{REFERENCES}

Beck, Ulrich. Brave New World of Work (Polity Press, 2000).

Beck, Ulrich. Risk Society: Towards New Modernity (Sage, 1993).

Bornschier V., Herkenrath M., König C., "The Double Dividend of Expanding Education for Development," International Sociology, Vol. 20(4), (December 2005), pp. 506-529.

Bourdieu, Pierre. Forms of Capital, 1986, from http://www.viet-studies.org/Bourdieu_capital. $\mathrm{htm}$, viewed on 25.10.2006.

Broady D., "What Is Cultural Capital? Comments on Lennart Rosenlund's Social Structures and Change," 2001, at http://folk.uio.no/potnes/6.\%20Broady.pdf , viewed on 25.10.2006.

Melberg, Hans. "Unemployment: Micro- or Macro-theories?", 1992, http://www.geocities.

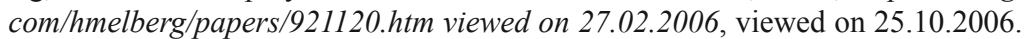

Rungule, Ritma and Koroḷeva, Ilze. "Vecā izglītîba jaunajos apstākḷos" in Sabiedrības pārmaiņas Latvijā, ed. Aivars Tabuns, (Rīga: Jumava, 1998), p. 255 - 277.

Tabuns, Aivars. "Publiskie intelektuāḷ", Kultūras Diena, 16.04.2005, pp. 16-17.

Tipa, Juris. "Riga's unemployed aged 45 - 55 attitudes towards education," unpublished term paper, 2005.

European Union homepage of Knowledge society http://ec.europa.eu/employment_social/ knowledge_society/index_en.htm, viewed on 27.10.2006.

State agency of employment of Latvia, "Report on employment statistics," http://www.nva. lv/index.php?cid $=1 \&$ mid $=109 \& \mathrm{txt}=104 \&$ from $=0$, viewed on 15.10 .2006 .

http://www.lm.gov.lv/?sadala=253 - Homepage of Welfare ministry of Republic of Latvia, viewed on 27.10.2006.

http://en.wikipedia.org/wiki/Lifelong_learning - Lifelong learning, Wikipedia online encyclopedia, viewed on 27.10.2006.

\section{ENDNOTES}

1 Homepage of the Ministry of Welfare of the Republic of Latvia athttp://www.lm.gov. $\mathrm{lv} /$ ?sadala $=253$, viewed on 27.10.2006.

2 Pierre Bourdieu, , Forms of Capital (1986), from http://www.viet-studies.org/Bourdieu_ capital.htm, viewed on 25.10.2006.

3 D. Broady, "What Is Cultural Capital? Comments on Lennart Rosenlund's Social Structures and Change," (2001) from http://folk.uio.no/potnes/6.\%20Broady.pdf, viewed on 25.10.2006.

${ }^{4}$ V. Bornschier, M. Herkenrath, C. König, "The Double Dividend of Expanding Education for Development," from International Sociology, Vol 20(4) December 2005: pp. 506529.

5 Ritma Rungule and Ilze Koroḷeva, "Vecā izglītîba jaunajos apstākḷos,"in Sabiedrības pārmaingas Latvijā, ed. Aivars Tabuns (Rīga: Jumava, 1998), pp. 255 -277.

6 Hans Melberg, "Unemployment: Micro - or Macro - theories?" (1992) http://www. geocities.com/hmelberg/papers/921120.htm, viewed on 25.10.2006.

7 Juris Tipa, "Riga's unemployed aged 45 - 55 attitudes towards education," unpublished term paper, University of Latvia, 2005. 
${ }^{8}$ Ulrich Beck, Risk society: Towards new modernity, (Sage publishers: 1993), p. 3.

${ }^{9}$ Ulrich Beck, Brave new world of work (Polity Press: 2000), p. 3.

10 Ulrich Beck, Risk Society: Towards New Modernity (Sage: 1993), pp. 92-94.

11 Ulrich Beck, Brave New World of Work (Polity Press: 2000), p. 90.

12 Juris Tipa, "Riga's unemployed aged 45 - 55 attitudes towards education," unpublished term paper, University of Latvia, 2005.

13 "Report on employment statistics by the State agency of employment of Latvia," available at http://www.nva.lv/index.php?cid $=1 \& \mathrm{mid}=109 \& \mathrm{txt}=104 \&$ from $=0$, viewed on 15.10.2006.

14 Juris Tipa, "Riga's unemployed aged 45 - 55 attitudes towards education," unpublished term paper, 2005.

15 Aivars Tabuns, "Publiskie intelektuāļi," Kultūras Diena, 16.04.2005, pp. 16-17.

16 J. Demaine, Contemporary Theories in The Sociology of education (Macmillian Press: 1991), p. 121.

$17 \mathrm{http} / / /$ ec.europa.eu/employment_social/knowledge_society/index_en.htm - European Union homepage of Knowledge society, viewed on 27.10.2006.

$18 \mathrm{http} / /$ en.wikipedia.org/wiki/Lifelong_learning - Lifelong learning, Wikipedia online encyclopedia, viewed on 27.10.2006.

19 Beck U., 2000, Brave new world of work (Polity press), p. 3. 


\title{
Social Partnership and the Quality of Education in Latvia
}

\author{
Vladimirs Meņšikovs and Elita Jermolajeva
}

The place of a person within a society and his/her interaction with the community can result in three different conceptual models or basic approaches to education:

1. state-public,

2. personal, and

3. public-personal.

The main feature of a state-public approach is that the interests and needs of the state and of the society are primary in comparison with the interests and needs of pupils. There are several conditions which encourage application of this approach. It was and remains typical of societies with dictatorial regimes; it is possible to distinguish between two types of approach: authoritarian and manipulative.

In the personal approach, the pupils' interests and needs dominate over the interests of the society and the state. Efficient education is impossible without active, unlimited involvement of pupils, and they have to act willingly. There are two directions in the personal approach: free upbringing and upbringing with pedagogical support.

The third model is a public-personal approach. In this case, public interests in education remain, because their absence hinders the development of culture and, consequently, of society. However, the whole system of education, as well as each school, form the possibilities and conditions for each pupil's free, full and unique development, helping them to become individuals.

The public-personal approach gives pupils the possibility to criticise teachers and the administration. However, pupils' rights and freedoms have to be coordinated. Moreover, each school has to form a council consisting of pupils with significant rights. In addition, pupils together with other groups involved in the process of education have to participate in social dialogue, which can gradually develop into a social partnership. Pupils will have additional civic activities, if they participate in democratic movements for children or teenagers.

The concept of social partnership was developed in the West at the end of the 1970s after the neoconservative revolutions. Nowadays, this concept is often used in the social and political life of Latvia as an integrated technology that balances the interests of different social sectors: the state, business and non-governmental organisations (the "third" sector). 
Nowadays, the interaction of civil society and the state is the most significant factor shaping the future of democracy in Latvia. Civil society and citizen's initiative are considered an antidote to degeneration and disintegration of democratic political institutions and a source of their restoration. ${ }^{1}$

Recently, the importance of social dialogue was emphasised by the Latvian Confederation of Employers and the Free Trade Union Confederation of Latvia. ${ }^{2}$ According to Elina Egle, the general manager of Latvian Confederation of Employers, "Competitiveness and sustainability of Latvia at the moment are impossible without a coherent social dialogue in the country. The current situation in Latvia shows that social dialogue can be the most efficient form of communication between government, employers and trade unions in Latvia, which would promote peace and stability. In the future, we will meet a larger number of challenges in the process of forming this communication if we want to stabilise the competitiveness of Latvia in the EU." Peteris Krigers, head of the Free Trade Union Confederation of Latvia, has commented in a similar vein: "Social dialogue is one of the most efficient ways for employers and employees to have their rights and interests defended and for the companies and branches to be represented in the country and in Europe."

\section{SHORT REVIEW OF THE RESEARCH „EDUCATION IN THE KNOWLEDGE SOCIETY IN LATVIA"}

The National Development Plan 2007-2013 emphasises that the main resource in Latvia is people's knowledge. "For the country's uninterrupted and balanced development at all levels, it is necessary to shape an educated and knowledgeable society by providing a coordinated and planned creation, accumulation, dissemination and application of knowledge... The country's task is to give every individual the opportunity to acquire a general primary and secondary education, as well as good quality higher and vocational education possibilities." 3

In the 1990 s and in the beginning of the $21^{\text {st }}$ century, members of Latvian society thought that their education was good enough and they were completely satisfied with it. For example, in February 2004, this opinion was expressed by $61 \%$ of Daugavpils inhabitants. ${ }^{4}$ A lot of people considered that a ,good education" was an important factor for a successful career; however, the factor "personal relations" was considered just as important. A good education quite often didn't imply the quality of education; it mostly meant the ability to adapt to new economic conditions (a boom in the sphere of services) and the possibility to continue education at institutions of higher education. It was only after Latvia became a member of the EU and the Latvian labour market became subject to remarkable changes that people began to feel the real demands of the labour market in different spheres. At the moment, a lot of employers are not satisfied with the level of formal education. Moreover, quite often the social capital of employees (personal relations) is not taken into consideration. The labour market has to be efficient; otherwise, the interests of employers and the state will suffer. Even employees will not have the opportunity to ensure their welfare if it is not effective. However, the efficiency of the labour market is impossible without qualitative higher education, without such factors as the willingness to be flexible, to take risks, to explore Western business experience and an ability to collaborate with people. 
Latvian data show that sometimes those who leave primary or secondary school do not continue their studies (5\% and 22.5\%, respectively). Sociological research shows that there are more discrepancies between the system of education in Latvia and the requirements of the 21 st century. This problem is caused by two phenomena: on the one hand, the meaning/role of education in society and the growth of its importance together with the "knowledge economy," the "knowledge century", etc; on the other hand, the lack of a quality system of education.

Social groups and institutions involved in the process of education do not function as a single interactive system, the task of which is to create a competitive employee for the labour market and an active fellow-citizen for society. As a result, parents, pupils and students, teachers, as well as officials of educational institutions are not satisfied with the current situation.

First of all, all the participants in the process of education have to realise the importance of education in the development of society, as well as their mutual responsibility for the further development of the system of education, for its efficiency (price-quality) and accessibility. Secondly, the participants involved in the process of education have to start a social dialogue and to exchange opinions. Social dialogue is an instrument for reducing social stress. The next step in the solution of problems related to the sphere of education is a forum. A forum is a public discussion during which all the participants ask questions, give suggestions and comments, thus, elaborating a joint programme of cooperation, concepts, etc. A social partnership is a process of constructive interaction (implementation of a joint programme, concept or strategy) in which all the participants solve a social problem in a way which suits all parties involved and society as a whole.

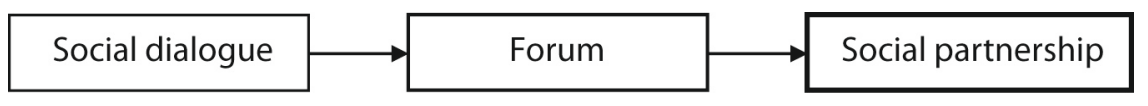

A social partnership is based on:

- good will;

- confidence that one's partners' specific interests and motives are legitimate;

- the willingness to break old habits, traditions and customs;

- joint detection and solving of problems;

- respect and acceptance of one's partners' main conditions, abilities and restrictions;

- discarding the idea of changing one's partner;

- the willingness to be influenced, if it helps to find a new approach;

- acceptance that conflicts in the partnership are possible, but they do not exclude the possibility of a joint action plan.

As to the present society of Latvia, interaction mainly takes place at the stage of social dialogue. This means that there exists only the exchange of opinions and the identification of problems of a specific group. However, the forum and social partnership are the most significant stages at which understanding of the mutual responsibility of partners, formation and implementation of joint programmes, 
action and development plans take place. In practice, examples of sustainable social partnerships are very rare. As a rule, one is most likely to find fragmentary forms of social dialogues or short-term social forums. For example, several mechanisms of social dialogue are used by state and local governments, as well as representatives of non-governmental organisations. It is possible to mention the Ministry of Education and Science, which organised discussions about legislative and strategic documents in the sphere of education, the activities of local governments (for example, the youth conference "Young People's Involvement in Civil Society" organised by the Daugavpils City Council on January 27, 2006), or such activities of nongovernmental organisations as Politika.lv and Neolain.lv (issues relating to education have been widely discussed on the web sites of these organisations). Nevertheless, these activities have only a consultative character. It is necessary to solve problems together, so that every group involved in the process could achieve its aims, in spite of different and quite often contradictory opinions, differences in the availability of resources, etc. The development of the system of social partnership allows balancing the interests of all the groups involved in the process with the help of cooperation and compromise, gradually leading to a social consensus.

The analysis of the involvement of social partners in the sphere of education shows that it is insufficient in all forms and at all stages. This can be partially explained with reference to a lack of mutual awareness and interest. However, the basic factors are misunderstanding of the importance, place and role of social partners in the process of education, as well as a lack of confidence among potential partners for various reasons: political, socio-cultural, economic, etc. (low level of social capital). A lack of cooperation between social partners and education institutions also derives from the past, as cooperation did not exist in the previous system. As a result, there are no stable mechanisms of cooperation, which has a negative influence on the quality of education and the diversification of supply according to the needs of a dynamically developing society.

A more efficient process of cooperation connected with education is in the interest of all social partners: employers, employees, representatives of high schools, state and non-governmental organisations. Social partnerships have just appeared and a social dialogue has just begun, developing as an exchange of opinions between social partners with the state acting as an intermediary.

\section{THE AIM OF THE RESEARCH}

This project is „exploratory research” aimed at detecting the key factors that should be taken into consideration. The final aim of the research "Education in the Knowledge Society in Latvia" is to define resources for social dialogue existing in 2006, to evaluate their weaknesses and strengths, and to draft recommendations on developing social dialogue both at the state and local level.

The main tasks of the research and directions of the focus group discussions:

1. Education as a value from the viewpoint of various groups;

2. Evaluation of the quality of education;

3. Basic issues in the economics of education;

4. Social dialogue and its development in the sphere of education. 


\section{METHODS OF THE RESEARCH}

1. Analysis of other research conducted in 2000-2006;

2. Research on the social partners:

- $\quad$ differentiated focus groups (pupils, teachers, parents);

- integrated focus groups;

- $\quad$ seminars in the regions (Latgale, Zemgale);

3. Analysis of documents that characterise the cooperation of social partners, special attention being paid to the mechanisms used by the administration of state and local governments;

4. Analysis of documents of the Ministry of Education and Science reflecting involvement of the social partners in the administration of education (and decision-making related to education);

5. Preparation of a report and of a list of articles.

\section{HYPOTHESIS OF THE RESEARCH}

Poor social dialogue (partner relationships) between agents in the education market and other groups involved in the sphere of education is caused by insufficient social capital, i.e. there is no confidence between the various groups involved in education.

It is possible to identify 10 basic target groups involved in solving problems related to education at different levels. These groups are: (1) teachers; (2) pupils; (3) parents; (4) students (potential employees); (5) educators; (6) officials of local governments and education departments; (7) employers; (8) administration of education institutions; (9) experts in the field of pedagogy, psychology, sociology, etc., and (10) representatives of the mass media specialising in education issues.

\section{SOCIAL DIALOGUE IN EDUCATION: EVALUATION, PROBLEMS AND SOLUTIONS}

Before conducting focus groups in Zemgale and Latgale, the researchers of the project "Education in the Knowledge Society in Latvia" themselves analysed the strengths and weaknesses of social dialogue and evaluated its threats and opportunities (see Figure 1).

Experts found that there is social dialogue in the system of education, but that it does not have a regular character. Several events called "forums" took place, but there is no system, no common aim, and no elaborated mechanism. The main threat is the inability to find a common language and to compromise, the inability to set common aims because the participants in the dialogue lack experience. The transition of education to a new stage of social development, as well as the formation of a society that corresponds to a new knowledge-based economy is impossible without efficient social dialogue. 
SWOT analysis of social dialogue: experts' opinion

Figure 1

\begin{tabular}{|c|c|}
\hline $\begin{array}{l}\text { Strengths } \\
\end{array}$ & Weaknesses \\
\hline 1. The dialogue takes place, but it is not regular & 1. The dialogue is occasional and irregular \\
\hline $\begin{array}{l}\text { 2. There are institutional agents (coordinators) } \\
\text { who are interested in it }\end{array}$ & $\begin{array}{l}\text { 2. During the dialogue, participants speak } \\
\text { different "languages" }\end{array}$ \\
\hline 3. Information is available on the Internet & $\begin{array}{l}\text { 3. There is neither a system, nor a single } \\
\text { central forum }\end{array}$ \\
\hline $\begin{array}{l}\text { 4. Both pupils and teachers realise that changes } \\
\text { are necessary }\end{array}$ & $\begin{array}{l}\text { 4. It is difficult to orient oneself in the } \\
\text { information available on the Internet }\end{array}$ \\
\hline $\begin{array}{l}\text { 5. The quality of education on several levels } \\
\text { has already been evaluated (both local and } \\
\text { international reports) }\end{array}$ & $\begin{array}{l}\text { 5. There is limited access to the Internet, } \\
\text { communication techniques are not qualitative }\end{array}$ \\
\hline $\begin{array}{l}\text { 6. There are many means to encourage and } \\
\text { sustain the dialogue among partner institutions }\end{array}$ & $\begin{array}{l}\text { 6. The dialogue exists only on the principle } \\
\text { of volunteer participation, there is no } \\
\text { institution to unite everyone }\end{array}$ \\
\hline Opportunities & $\begin{array}{c}\text { Threats } \\
\end{array}$ \\
\hline $\begin{array}{l}\text { 1. With the help of the dialogue, it is possible } \\
\text { to achieve the goals of each group, i.e. to raise } \\
\text { competitiveness and the quality of education }\end{array}$ & $\begin{array}{l}\text { 1. Inability to find a common language while } \\
\text { searching for a compromise }\end{array}$ \\
\hline $\begin{array}{l}\text { 2. It is possible to attract finances from various } \\
\text { sources }\end{array}$ & $\begin{array}{l}\text { 2. Inability to see and to establish common } \\
\text { goals }\end{array}$ \\
\hline $\begin{array}{l}\text { 3. In order to raise the quality of education, there } \\
\text { is an opportunity to commercialise education }\end{array}$ & $\begin{array}{l}\text { 3. They do not want to invest resources (time, } \\
\text { finances, people) into the dialogue }\end{array}$ \\
\hline \multirow[t]{4}{*}{ 4. Life-long education as a core of the dialogue } & $\begin{array}{l}\text { 4. Commercialisation of education obstructs } \\
\text { availability of education }\end{array}$ \\
\hline & 5. Unpredictable influence of policy \\
\hline & $\begin{array}{l}\text { 6. Inability or unwillingness of authorities to } \\
\text { accept new ideas }\end{array}$ \\
\hline & $\begin{array}{l}\text { 7. Due to the lack of information, people's } \\
\text { interest can decrease }\end{array}$ \\
\hline
\end{tabular}

The analysis of the focus group discussions organised in Bauska, Jelgava, Daugavpils and Preili showed that little attention was paid to social dialogue among teachers, pupils and parents. Parents are the weakest link in the dialogue. Why? It was mentioned that parents, as a rule, have difficulties in their personal and professional lives, they do not have the necessary knowledge and skills to discuss important issues with teachers as equals. Teachers and pupils also are not sure whether they need this triangular dialogue or not. Teachers and the school administration, first of all, mentioned not the triangular dialogue, but communication between a teacher and a pupil. At the moment, the social dialogue mostly corresponds to the transition of education from state-public to the public-personal model.

On the one hand, all participants of focus groups want social dialogue, but on the other hand, there were some problems between partners during discussions pupils especially opposed the views and opinions of teachers or parents. As a result, the discussion sometimes was merely a monologue.

It was suggested to pay more attention to school councils, non-governmental organisations, closer cooperation of schools and high schools, as well as the 
environment of education institutions and relationships within them (honesty, accessibility, tolerance, solidarity).

Members of focus groups also discussed financial instruments (teachers' salaries, materials and technical equipment, etc.) as tools for improving the quality of education and, in their opinion, increasing mutual understanding and cooperation between sides towards a good partnership. These practical solutions need to be supplemented by social dialogue.

On October 11, 2006, Daugavpils University organised an international scientific conference "Education in the Conditions of Social Change". During the round table discussions, issues related to the transition of social dialogue to partnership were discussed as well. Unfortunately, the participants of the discussion did not talk about social dialogue, paying a lot of attention to other topics, such as the value of education, the quality of education, the economics of education. The only exception was the speech of Jānis Duksinskis, head of the Department of Education of Daugavpils City Council (now a member of the Saeima or Latvian Parliament), who agreed that it is necessary to elaborate specific mechanisms to stimulate the formation and expansion of social dialogue, using the experience of Finland.

\section{CONCLUSIONS AND RECOMMENDATIONS}

\section{Transition from social dialogue to partnership can resolve problems}

Due to the formation of a knowledge society in Latvia, a new public-personal conceptual model of education has gradually appeared. It involves not only pupils and teachers, but also all groups interested in education who can influence its development. These are opinion-makers, parents, non-governmental organisations, businessmen, journalists covering issues related to education, etc.

It is difficult to exaggerate the opportunities for social dialogue and of social partnership in the sphere of education, because they get different participants of the system of education together and let them find common answers to topical questions related to the quality, efficiency and accessibility of education.

\section{The research covers wide range of problems}

The research on social dialogue touches upon a wide range of problems connected with education:

- Familiarisation with social dialogue, taking into consideration changes in the conceptual model of education and the formation of a knowledge society in Latvia;

- Identification of subjects and the analysis of their specific features and needs;

- Formation of social dialogue and definition of development resources (socio-economic, institutional, educational, etc.);

- Familiarisation with implementation mechanisms of social dialogue among participants in the process of education (socio-political mechanisms, economic, socio-cultural, etc.); 
- Analysis of the place and role of social dialogue in the life process of individuals, social communities and Latvian society.

Research on these issues can become the basis for future education policy aimed at the formation of a knowledge society in Latvia.

\section{Social dialogue: more precise statement of the hypothesis}

Insufficient social capital in society is not the only reason for undeveloped poor social dialogue among agents of the education market and other participants in the process of education. The problem is much more complex. A socio-cultural reality has emerged consisting of controversial „life worlds" which do not stick together. "... The systems of values and repertory of sense are not the common property of all members of society anymore. An individual grows up in the world, where there are neither common values which determine people's behaviour in different spheres of life, nor a common reality which is identical for everyone." ${ }^{5}$ The contemporary pluralism of "life worlds", in the opinion of Thomas Luckmann, does not necessarily lead to total disorganisation. Moreover, without social dialogue, it is impossible to establish the basic principle of human social life - the principle of a reciprocity of perspectives.

\section{The research has to be continued}

The qualitative research "Education in Knowledge Society in Latvia" showed the topicality and diversification of social dialogue in the system of education. However, several issues were not reflected in the focus group discussions. The participants of the discussions paid special attention to other topics of the project - motivation and the quality of education. That is why quantitative research is needed aimed only at the transition from social dialogue to partnership in the process of education in Latvia.

\section{ENDNOTES}

1 Anthony Giddens, The Third Way (Cambridge: Polity Press, 1988), p. 78.

2 "Veiksmīgas sadarb̄̄ibas piemēri. Rokasgrāmata darbiniekiem un darba devējiem." ES Phare projekts "Divpusēja sociālā dialoga veicināšana: politikas dokuments un pilotprojektu ieviešana”, Rīga, 2004.

3 "Latvian National Development Plan 2007-2013" available at www.nap.lv.

4 LZP projekts "Pilsētas socioloǵiskās problēmas."

5 Лукман Т. Некоторые проблемы современных плюралистических обществ // Социальные процессы на рубеже веков: феноменологическая перспектива. М.: МГИМО, 2000. p. 6. 


\section{Changing Minority/ Immigrant Identities}





\title{
If Push Comes to Shove. Territorial Identification among the Baltic Russians
}

\author{
Kjetil Duvold \\ Department for Northern European Studies Humboldt University
}

"There are some people who never wanted an independent country and they don't want one now... They are disloyal to this country and don't accept it." Vaira Vīkse-Freiberga, President of Latvia. ${ }^{1}$

\section{INTRODUCTION}

'Political community' appears to be a notoriously difficult concept for quantitative investigation. Quite frequently, the concept is reviewed in relation to other, equally intangible concepts, such as 'identity', 'belonging', 'loyalty', 'boundaries', and so forth. The literature on these topics is undoubtedly extensive and versatile, but the lack of rigorous definitions might well be a source of frustration for scholars who actually want to test the validity of some of the assumptions that are being made. One set of problems is that there are different notions of what a political community ought to contain. Perhaps the most striking difference in this respect is represented by individualist versus communitarian visions of society (i.e. Etzioni 1993). In this article, however, I will make an effort to avoid normative statements about the extent and depth of the political community.

Another kind of problem is that scholars rarely agree on the appropriate level of investigation. Identities are multiple, which means that many people belong to several communities. A political community, however, must refer to some form of political order. Usually, such order is embodied within states, although political communities on the sub- and supra-/transnational levels have become increasingly vital.

A political community binds together a specific territory and its inhabitants. In a Rechtsstaat, the inhabitants - the demos - enjoy certain rights and obligations as members of the political community. Citizenship may, in other words, be regarded in relatively simple terms: as a set of rules of inclusion and exclusion (Brubaker 1992). But citizenship can also be seen as a tool to create a political community (Weiler 1997). To put it another way, nation-building is a long-term process of turning citizenship from a formal category to an active identity (i.e. Bendix 1964, Rokkan 1970, Marshall 1973).

The trouble is that in states marked by significant shares of ethnic minority groups, the boundaries of the political community might not coincide so neatly 
with the borders of the state. In fact, ethnic minorities often feel stronger loyalty towards their 'own kind' (which may or may not have co-nationals in another state). Many plural states have recognised the presence of cultural or kinship-based loyalties, allowing institutional mechanisms - federalism, consociationalism, cultural autonomy, etc. - to compensate for the lack of a homogenous, 'national' political community (i.e. Lijphart 1977).

By applying territorial identity as a yardstick, this article will examine the nature and degree of political community in the Baltic countries - three countries that, after regaining independence in 1991, had to come to terms with the presence of large numbers of comparatively recent immigrants - a legacy of 50 years of forced cohabitation with Soviet Russia. The prospects of including minority groups in the mainstream political community might depend on (i) the character of the minority composition, size, and level of mobilisation; and (ii) how the mainstream political community is defined - in 'neutral' terms (in which case citizenship and residency is the chief criterion for membership), or as an ethnically/linguistically defined entity. In the latter case, immigrants - or 'non-nationals' - are less than likely to be considered full members of the 'community'. In other words, if the minority group is sizeable and self-conscious, while the state - and what it entails in terms of institutions - at the same time is defined in narrow, ethno-cultural terms, the chances are that the minorities will fail to feel much attachment to the mainstream political community. Space does not permit an in-depth analysis of the conditions for integration in the Baltic countries. From a comparative vantage point, I will simply take a closer look at the development of territorial identification in the Baltic countries. The Russianspeakers may well have different forms of identification, but as I will put forward: does lack of identification with the country of residence suggest disloyalty to it?

\section{A MULTILEVEL CLASSIFICATION OF POLITICAL SUPPORT}

The political community can be examined as part and parcel of the overall support for the political system. David Easton (1965) has presented what remains perhaps the most persuasive classification of political support. In Easton's scheme, the political community - defined as 'a group of persons bound together by a political division of labour' - ranks as the most profound type of support (Easton 1965: 177). Easton goes as far as claiming that the political system cannot really exist without this requisite support $(1965,171-219)$. To constitute a political community, Easton suggests the necessity of 'some cohesive cement - a sense or feeling of community among its members' $(1965,176)$. Political community does not necessarily mean a national community, although it certainly is the most common form of political community. Easton argues that a 'we-feeling', based on shared history and experience that lead people to identify with a political entity of common origin and destiny, is necessary for the community to exist: "whether we are referring to the shared history of the members of a system or to the current collective experiences, if these factors are to have any impact on the community feelings of the members of the system and especially upon upcoming generations, they must be interpreted and codified in a form that makes them readily visible, accessible, and transmissible over the generations' $(1965,333)$. 
Easton is not alone in presenting the case for the political community. Dankwart Rustow, for instance, pointedly included the community-level as a precondition for successful democratisation: "( $\mathrm{t}$ )he vast majorities of citizens in a democracy-to-be must have no doubts or mental reservations as to which political community they belong to' (Rustow 1970: 351). Karl Deutsch made a similar point, stating that a single 'people' is the result of regular communication among those who constitute this 'people', while those who do not share these communicative habits are considered as external to the 'people' in question (Deutsch 1953, 60-80). Minority groups that are not part of the political community are likely to be seen as aliens, and a potential threat to the community - an 'enemy within', as it were. As Juan Linz and Stepan $(1978,28)$ have put it: 'in a political system characterized by limited consensus, deep cleavages, and suspicions between leading participants, semi-loyalty is easily equated with disloyalty by some of the participants'.

The importance of a cohesive political community is certainly not restricted to democracies. To an even greater extent than democracies, authoritarian regimes try to appeal to patriotic (or chauvinistic) sentiments among their citizens, often by driving a wedge between those who are 'insiders' and those who are 'outsiders' of the political community. This is part of a simplistic logic of using nationalist rhetoric to legitimise the regime. Exactly for that reason, many democrats (at least liberal democrats) have an uneasy relationship with the notion of political community - to the extent that the community 'excludes' and 'includes' in equal measures. Herein lays a stereotypical image of democracy and nationalism which has been the preoccupation of many scholars of both subjects: namely that nationalism is 'bad' and 'primitive', while democracy is 'good' and 'progressive'. 'Democracy' and 'nationalism' are indeed based on different, sometimes conflicting, logics, as suggested by Linz and Stepan (1997). On the other hand, the two concepts are also highly interwoven, in the sense that popular sovereignty invokes two distinct, but related images: majority rule by the citizens of a given state, and the deep-seated expression of a long-term community. In the somewhat provocative words of Ghia Nodia $(1994,4)$ : 'democracy never exists without nationalism'. Notwithstanding the fact that 'nationalism' itself can have rather diverging connotations, the essential point to keep in mind is, I believe, that democracy inescapably exists only within communities of people - whether those communities are homogenous and closely knit, or if they are multicultural and founded on political rather than cultural criteria.

\section{MEASURING SUPPORT FOR THE POLITICAL COMMUNITY}

In his classification of political support, David Easton (1965) distinguishes between three domains, namely (i) the authorities, (ii) the regime, and (iii) the political community. ${ }^{2}$ This threefold classification puts us in a good position to differentiate between rather fluctuating attitudes to a temporary government or its leaders, via more stable convictions about principles of government (primarily between liberal democracy and authoritarian alternatives), and more deep-seated attachments to the country and the nation as a whole.

The utility of Easton's model rests on the fact that it is highly applicable for quantitative investigations. Several major studies, such as the World Values Studies 
(WVS) the Eurobarometer, and the New Europe Barometer/New Democracies Barometer (NEB/NDB), tap different levels of support for political systems that are directly applicable to this conceptualisation. In this article, I will concentrate on the Baltic section of the NEB/NDB - namely the New Baltic Barometer (NBB) applying some key items in order to measure support for the political community in Estonia, Latvia and Lithuania.

Being recently independent states with sizeable ethnic minorities, the Baltic countries are particularly interesting cases in terms of political community and territorial identification: there can be no doubt that these concepts are of utmost importance for the understanding of Baltic democracy - perhaps most visibly in Estonia and Latvia. It is nevertheless hard to link political community and territorial affiliation to democracy and democratisation. Questions related to identity and belonging are thoroughly covered in the scholarly literature on ethnicity and nationalism, but the idea of a political community is too often taken for granted by students of democracy and democratic consolidation. One reason for this gap might be that it is extremely difficult to measure support for the political community (Klingemann 1999, Berglund 2003). Ordinary citizens are likely to have opinions about their government, institutions and even the principles of democracy. But identification with territory and political community may simply be too abstract perhaps even too profound - for articulation.

One possible way of measuring such support is to look at the level of patriotism. A standard question runs like this: 'How proud are you to be a citizen of this country?' Unfortunately, it makes little sense to ask about citizenship in the present study - given the fact that many of the individuals under investigation do not have citizenship at all, or are citizens of another country. Another possible measurement, however, is to examine the degree of territorial identity. The question in the New Baltic Barometer goes as follows: 'With which of the following do you most closely identify with?' The categories of answers (of which the respondents are given two) range from the local community and region, via their country of residence, to Russia and Europe.

Of course, territorial identity does not necessarily equate loyalty to the political community. While the latter refers to a collection of people who comply with the orders of a political unit, the former suggests not much more than emotional attachment to a particular piece of land, including memories that are connected with it. Hence, there is a strong possibility that individuals with roots elsewhere continue to identify with their distant (or not-so-distant) 'homeland', while remaining loyal to the political community in which they reside. However that may be, it is certainly more of an uphill struggle to create a cohesive political community - however 'civic' - if large minority groups do not identify with the country. Indeed, it may well turn out to be a manifestation of political tensions.

\section{TERRITORIAL IDENTITY IN ESTONIA, LATVIA AND LITHUANIA}

The Baltic countries have made strong efforts to re-establish and strengthen their respective political communities after half a century of Soviet integration. They have chosen a one-nation, or Staatsvolk, model for building their national political 
community, despite the presence of large shares of ethnic minorities, who largely arrived during the 'illegitimate' Soviet years. Exactly what the national community, the demos, should look like - who should be members and who should be excluded has been a matter of controversy in all three countries. However, this strategy has caused relatively little tension in comparatively homogenous Lithuania, while it has created significant friction in Estonia and in Latvia - two countries that experienced some of the most dramatic population change in communist Europe. In a dramatic attempt to readjust the ethnic 'imbalance' caused by Soviet policies, Estonia and Latvia quickly decided to exclude all Soviet-era minorities (and their descendants) from the citizenry, even if they retained full social rights as legal residents of the republics. Instead, these minorities had to 'earn' their citizenship by demonstrating linguistic competence and 'loyalty' towards the new state. They were, in other words, asked to adjust to a pre-defined political community. Many of them have been willing and able to do so, while others do not want or cannot join this political community. Meanwhile, there is a lingering suspicion among some 'core nationals' that the minorities are not - and will never be - loyal residents.

Officially, the citizenship issue was never presented primarily as a question of ethnicity or nationhood. Rather, it was the legal arguments that prevailed. Estonia, Latvia and Lithuania were occupied by the Soviet Union: they were not establishing, but restoring independence in 1991. ${ }^{3}$ This position was strengthened by the fact that most Western states never de jure recognised the Soviet incorporation of the three republics. Hence, the immigration that took place in the Soviet period was 'illegal immigration', and the migrants were 'occupiers', 'settlers', etc. To accept them as citizens of the restored republics would be the same as accepting the Soviet annexation, the argument went. ${ }^{4}$ Clearly, underneath this reasoning lies a much more profound issue of demographic balance: numerically speaking, the minority groups of Estonia and (especially) Latvia were large enough to alter the configurations of the republics - and perhaps the democratic regimes themselves. It is easy to envisage the powerful impact of a 40 per cent-strong Russian-speaking electorate in Latvia. Even if Latvians were not in acute danger of becoming a minority in their own country, the strong presence of a Russian-speaking electorate would have had a serious impact on Latvian politics, not least on the municipal level, where Russian-speakers are in the majority, or at least plurality, in most of the urban areas - Riga included.

The ethnic scene in Lithuania differs somewhat from the Estonian and Latvian patterns, the minority groups being considerably smaller and, moreover, divided between Russian and Polish nationals who, besides, were granted access to Lithuanian citizenship right from the start. Nevertheless, Lithuania also has some 'stateness' issues to be reckoned with. Just as in the Estonian and Latvian cases, Lithuania is a 'nationalising' state, in which identity politics continues to play a prominent role not least in terms of evaluating the Soviet past and the contemporary role of Russia. In this respect, the differences between Estonia, Latvia and Lithuania seem to be a matter of degree. However, by removing the citizenship issue from the political agenda, there can be no doubt that Lithuania eliminated a major obstacle towards building democracy based on demos rather than ethnos (Duvold 2006).

Do the Baltic minorities actually identify themselves with respectively Estonia, Latvia and Lithuania? The numbers presented in Figure 1 indicate that they do not. To 
be more precise, the minority populations in Estonia and Latvia tend to identify with Russia (or, to a much smaller extent, with some other CIS countries). Conversely, precious few see themselves as 'Estonians' or 'Latvians'. Among the Estonian minorities, only two per cent consider themselves primarily as Estonians. Asked about their secondary identity, only one further per cent of the Estonian Russians identify with the country they live in. The picture is somewhat different in Latvia, where 5 per cent consider themselves as primarily Latvians, and another 8 per cent consider it as their secondary identity. The slightly higher number of 'integrated' minorities in Latvia might be due to the more dispersed and more enduring presence of Russians in Latvia - notably in the capital and in the region of Latgale. Indeed, some of them have roots back to pre-Soviet times. However that may be, these figures may not be encouraging reading for those who would like to see speedy integration in the two countries.

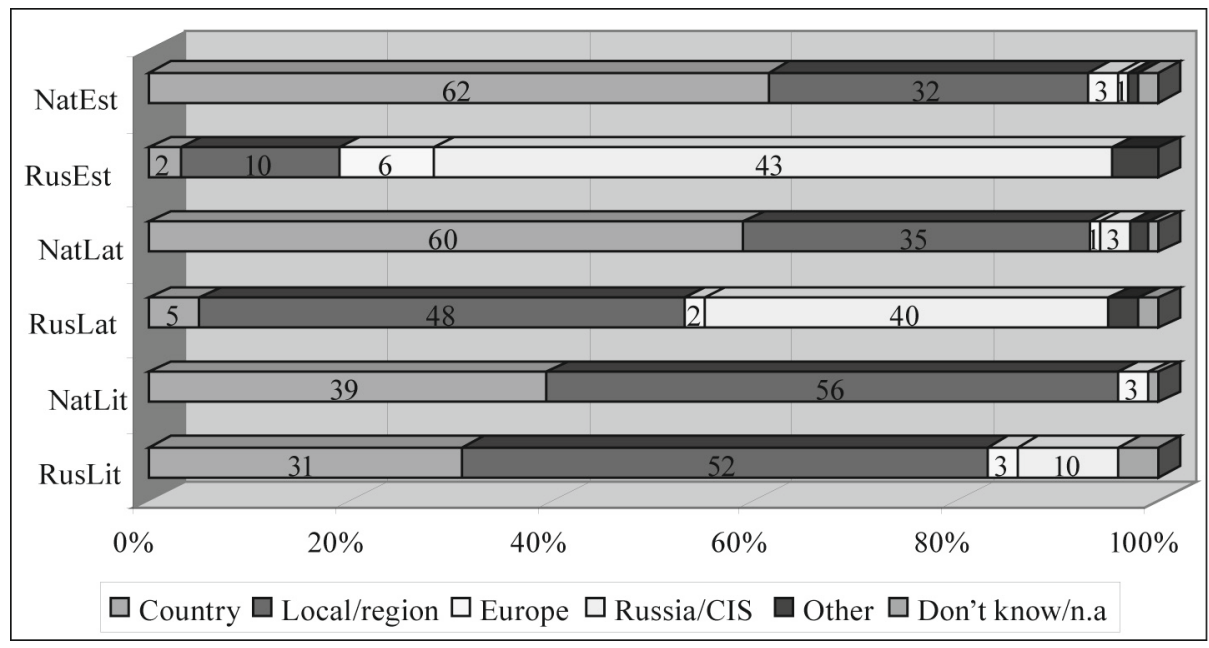

Figure 1, Primary identification among natives and Russian-speakers, 2004 (\%)

Note: The question reads: "With which of the following do you most closely identify yourself?" 1. Local community or city in which I live; 2 Region; 3 This country; 4 Europe; 5 Russia, 6 Other CIS; 7 Other.

Source: New Baltic Barometer, 2004

How can we best interpret the glaring differences between native- and Russianspeakers? It could be inferred that most people in the Baltic countries, like much of post-communist Europe, tend to identify themselves in ethno-lingual terms: being 'Estonians' or 'Latvians' might simply seem like an alien idea to most of the minorities. Every citizen was irrevocably classified according to ethnic origins during Soviet times. In keeping with Soviet practise, identity was ascribed to people - even though it was assumed (or hoped) that they would all identify themselves as 'Soviet citizens' one day (which, with the benefit of hindsight, was far from being a likely outcome).

However, there are at least two objections to the idea that a Baltic identification is unthinkable for a local Russian. First, even if we accept that they primarily see themselves as Russians, we could at least expect that some of them would disclose 
their secondary identity as 'Estonian' or 'Latvian' - which they clearly do not. Some of them mention 'Europe' (notably in Estonia), others mention their local community or region (notably in Latvia).

The second reason why the absence of identification with Estonia or Latvia seems so puzzling is found in the contrasting example of the Lithuanian minorities. The bulk of these people identify themselves primarily or secondarily as 'Lithuanians'. A closer inspection reveals that some 30 per cent of them identify with Lithuania first, while another 50 per cent identify with their village or local community first. Interestingly, the figures for ethnic Lithuanians are rather similar (56 per cent identify primarily with their village or region, and just 39 per cent with the country). It should also be noted that ethnic Estonians and Latvians are much more likely to identify primarily with their country than ethnic Lithuanians - which seems to suggest that the nature of identification is more polarised in the two former countries.

Table 1

Primary and secondary identification among the minorities (\%)

\begin{tabular}{|c|c|c|c|c|c|}
\hline & & Baltic identity & Local identity & European identity & Russian identity \\
\hline \multirow{8}{*}{ 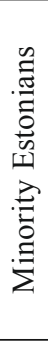 } & Born outside & 2 & 12 & 13 & 73 \\
\hline & Born in the republic & 4 & 15 & 24 & 56 \\
\hline & Non-citizen & 2 & 14 & 12 & 72 \\
\hline & Citizen & 4 & 12 & 25 & 58 \\
\hline & $18-39$ years & 2 & 7 & 38 & 52 \\
\hline & $40-59$ years & 3 & 15 & 16 & 66 \\
\hline & $60+$ years & 4 & 15 & 6 & 77 \\
\hline & Total & 3 & 13 & 18 & 66 \\
\hline \multirow{8}{*}{ 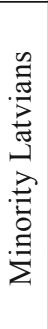 } & Born outside & 10 & 21 & 5 & 60 \\
\hline & Born in the republic & 12 & 18 & 7 & 61 \\
\hline & Non-citizen & 7 & 17 & 6 & 67 \\
\hline & Citizen & 16 & 22 & 8 & 54 \\
\hline & 18-39 years & 16 & 16 & 11 & 56 \\
\hline & $40-59$ years & 8 & 19 & 6 & 66 \\
\hline & $60+$ years & 17 & 23 & 3 & 53 \\
\hline & Total & 11 & 19 & 6 & 61 \\
\hline
\end{tabular}

Note: First and second identities have been collapsed into: 1. Country (country first OR identifies with country second AND local, regional or unspecified identity first); 2. Local/ regional (identifies with local or regional identity first or second AND other identity is either local or regional or other unspecified); 3. European (identifies with Europe first or second; 4. Russian/CIS (specifies Russian, Byelorussian or Ukrainian as either first or second identity) AND does not specify country of residence as first identity. Other/ don't know have been excluded from the table. See Figure 1 for further details

Source: New Baltic Barometer, 2004

A closer examination of the minority populations of Estonia and Latvia discloses some interesting variations. Table 1 takes four types of identifications into consideration, namely national, local/regional, European and Russian/CIS identities. As expected, the table reveals that Russian-speaking Estonians who were born outside the republic and/or are not citizens of the country today are most likely to identify 
with Russia. Likewise, people above 40 years are more attached to Russia than the younger cohorts. All this makes rather good sense, but - somewhat curiously - these relationships are rather weak in the case of Latvia. Indeed, Latvian Russian-speakers who are 60 years or more are least likely to identify with Russia (while they are actually more likely to identify with Latvia than those who are under 40). Moreover, place of birth does not matter in terms of territorial identification for Latvia's minorities. In terms of citizenship, though, Russian-speakers who hold Latvian citizenship are less likely to identify themselves with Russia. Finally, Russianspeakers in Estonia are also more prone to identify with Europe than the equivalent population in Latvia. The younger generations, citizens and those who were born in the country - three qualities that often overlap - are the most 'European' Russianspeakers in Estonia.

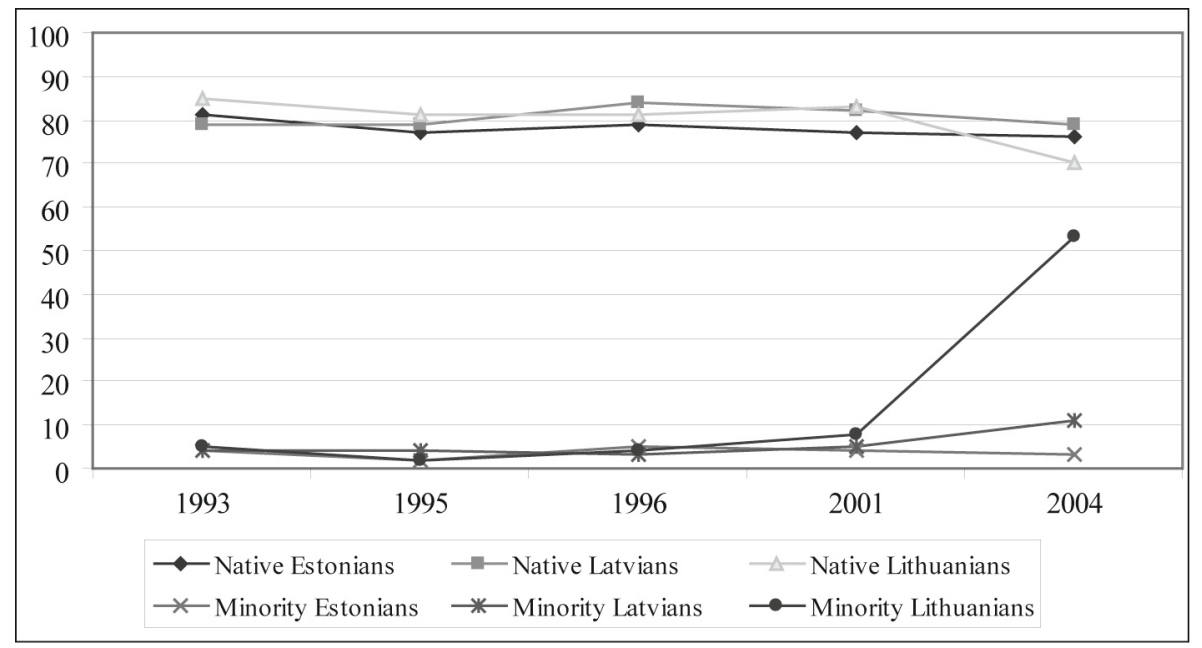

Figure 2, Baltic identification among majority and minority groups, 1993-2004 (\%)

Note: Only those who identify with the country are included in the figure. See Figure 1 for details.

Source: New Baltic Barometers, 1993, 1995, 1996, 2001 and 2004

Identities rarely change very quickly. Indeed, NBB data from 1993 to 2004 show a great deal of stability among most national groups in the Baltic countries (see Figure 2). Natives have to a great extent identified with their country all along, while the minorities have tended to identify with the Russian hemisphere. There are two exceptions here - both of which concern Lithuania. The first is a recent trend among native Lithuanians to identify with other levels of territory than the nationstate. By 2004, only 70 per cent of the Lithuanians identify primarily or secondarily with their country - a figure that is $10-15$ per cent lower than in the 1990s. In its place, there is a growing trend towards sub-national identification. ${ }^{5}$

This factor brings us to the other departure from the general patterns: the Russian-speaking minority of Lithuania. Throughout the 1990s, the Lithuanian minorities resembled the minorities of Estonia and Latvia, in the sense that very few of them identified with the country they lived in. The 2004 NBB survey discloses an astonishing break with this pattern, since country-identification has quadrupled. 
Therefore, a note of caution might be appropriate here: as long as the 2004 data stand out so radically compared with previous surveys, we do not yet know whether this pattern will be sustained.

There are two dominant minority groups in Lithuania, namely Poles and Russians. Many Poles would not identify themselves with Russia or any other CIS country, although the distinction between 'Polish' and 'Belarusian' is rather tricky within the historically contested borderlands of south-eastern Lithuania. Many of them tend to identify with their local community or, fairly surprisingly, with the country as a whole. A closer inspection reveals that also many of the Russians in Lithuania identify with either the local community or Lithuania as a whole. In the 2004 NBB survey, only some 20 per cent of them identified primarily or secondarily with Russia or another CIS country. ${ }^{6}$

Strictly speaking, our data do not lend themselves to the conclusion that a shared political community does not exist in the Baltic countries. What we do know, however, is that the bulk of the Russian-speaking minorities in Estonia and Latvia identify themselves as 'Russians', and not at all with the country they reside in. Even Russian-speakers who hold Estonian or Latvian citizenship tend not to identify with the country in which they are citizens, which might suggest that citizenship has not yet become an efficient tool to create cohesive political communities - embraced by natives and minorities alike - in either Estonia or Latvia. It might be that they understand identification in narrow, ethnic terms. Hence, 'Estonian-ness' or 'Latvianness' may simply be categories of identification that most of them never even would consider - unless, perhaps, if one of their parents is an ethnic Estonian/Latvian. A relevant question, nevertheless, is why so many more minority Lithuanians tend to identify with the country they live in. Surely, the same categories of identification apply to Lithuania as well. The contrasting example of Lithuania might indicate that the Russian-speaking minorities can be integrated into a single, national political community - even though the relative smallness of Lithuania's minority groups may also play a role.

\section{IF PUSH COMES TO SHOVE: THE ISSUE OF LOYALTY}

Can we envisage strong support for the political community in the absence of a cohesive national identity? Germany is an interesting, if somewhat special, case in point. Despite strong, stable support for democratic principles over the last few decades, German 'patriotism' is still regarded as somewhat suspect by many ordinary Germans (Klingemann 1999, Ekman 2001). National identity can also be a fairly awkward concept in multi-ethnic states. Nevertheless, countries like Switzerland and the United States of America are underpinned by national identity of a different kind, formed by centuries of common history. In the absence of a common understanding of history, it is undoubtedly more problematic to build a common political community. Native Estonians, Latvians and Lithuanians differ dramatically from the Russians in terms of historical perceptions - of their own country in general, and the nature of the Soviet Union, in particular.

It is also possible to envisage the emergence of a common identity based on civic virtues - perhaps akin to what Habermas (1992) has baptised 'constitutional 
patriotism'. However, the notion of national identity in the Baltic countries is not yet underpinned by shared civic virtues. As mentioned earlier, nationality in the Soviet Union was understood in rigid, ethnic terms, inscribed in every passport. The national elites of the successor states have continued to focus on national identity in a fairly narrow, ethno-cultural sense - more in terms of ever-presence than activity, to borrow from Leonidas Donskis $(2002,29)$.

If the minorities counted not more than tiny fractions of the total populations, they would in all likelihood have been fairly 'manageable' from a majority perspective. Even if they had resisted assimilation, small and relatively insignificant minority groups could - to put it bluntly - easily be ignored from a nation-building perspective. It may seem unnecessary to repeat it: the Baltic minorities - in Estonia and Latvia particularly - are too large and self-conscious to be ignored, let alone be assimilated.

Many local leaders, including even the President of Latvia, have questioned the loyalty of some of the minorities: can the state trust them, or are they potential 'fifth-columnists' for Russia? By way of illustration, during the discussions of the draft amendments to the Citizenship Law in Latvia in 2005, there were strong attempts to introduce the notion of 'loyalty' into the amended law - which basically would make it possible to deprive a person of his/her citizenship if the person 'acts against national interests'. Keeping in mind Juan Linz and Alfred Stepan's words, quoted above, that 'semi-loyalty is easily equated with disloyalty by some of the participants', the bifurcated communities of Estonia and Latvia do not seem to be fertile breeding ground for the kind of 'state loyalty' demanded by many nationalminded politicians.

But although there can be no doubt that many Russian-speakers feel attached to Russia - much more so, it seems, than to the country they reside in - we do not have much evidence to claim that they are actually disloyal to their country of residence and its political system. Apart from a few fringe groups, there is little active opposition to the current regimes. The level of conflict remains low and the fact is that many of them apply for citizenship. Where they would stand in case of serious strife with Russia is obviously a hypothetical question. But even without aid from Russia, there could be limits even to this form of passive loyalty in the long run. In Albert Hirschman's (1971) famous terms, the non-citizens are more or less deprived of an institutionalised voice. On the other hand, very few of them have opted for exit, in the sense that emigration to Russia has been rather limited. With the exception of a discarded referendum on autonomy in north-eastern Estonia and similar attempts in south-eastern Lithuania in the early 1990s, the Baltic minorities have not really pursued collective exit either. So the question is really whether they are 'passive' (which arguably is yet another form of exit) or genuinely 'loyal'. For how long will they stay quiet without a proper voice? Speedy naturalisation might be the key to this dilemma. But it is hard to determine the future political behaviour of Russian-speakers after naturalisation.

The question of loyalty is immensely complex and we are far from being in a position to estimate the loyalty of the Russian-speakers in the Baltic countries - let alone predicting future loyalties. It is always easier to observe breaches of loyalty 
than confirmations of it. There are numerous historical examples of minorities showing disloyalty towards the state they reside in. Such cases are most likely to occur during a major political crisis, perhaps also including an external actor (particularly the 'external homeland', to apply Brubaker's (1996) terminology). The way the Sudetan Germans welcomed the Nazi-occupation of Czechoslovakia is an obvious case in point. A far more recent - and perhaps more parallel - example can be found in Moldova, where the Russian minorities of Trans-Dniester greeted the arrival of Russian troops. Unquestionably, it will be a mammoth task to turn the Russians of Moldova into 'loyal' citizens of Moldova. And herein lays one of the main differences between the Russian-speakers in Trans-Dniester and, say, Estonia's Ida-Virumaa region: the former managed to mobilise against Moldovan independence right from the start, whereas the Russians in north-east Estonia were pacified very quickly. For sure, some Russian-speakers in the Baltic countries also attempted to tighten the links with Moscow just before and after the de facto independence of the republics. But 15 years after independence, comparatively few Russian-speakers are likely to consider any alternatives to the existing Baltic states.

\section{REFERENCES}

Bendix, Reinhard (1964) Nation-building and Citizenship: Studies of our Changing Social Order. New York: Wiley.

Berglund, Sten (2003) 'Prospects for the Consolidation of Democracy in East Central Europe', Japanese Journal of Political Science, vol. 4 (2), 191-213.

Brubaker Rogers (1992) Citizenship and Nationhood in France and Germany. Cambridge: Harvard University Press.

Brubaker Rogers (1996) Nationalism Reframed: Nationhood and the National Question in the New Europe. Cambridge: Cambridge University Press.

Deutsch, Karl W. (1953), Nationalism and Social Communication: an Inquiry into the Foundations of Nationality. New York: John Wiley \& Sons.

Donskis, Leonidas (2002) Identity and Freedom: Mapping Nationalism and Social Criticism in Twentieth-century Lithuania. New York: Routledge.

Duvold, Kjetil (2006) Making Sense of Baltic Democracy: Public Support and Political Representation in Nationalising States. Örebro: Örebro Studies in Political Science 14 (Doctoral dissertation).

Easton, David (1965) A System Analysis of Political Life, New York and London: Routledge.

Ekman, Joakim (2001) National Identity in Divided Germany: Continuity and Change. Örebro: Örebro Studies in Political Science 3 (Phd dissertation).

Etzioni, Amitai (1993) The Spirit of Community: Rights, Responsibilities, and the Communitarian Agenda. New York: Crown.

Habermas, Jürgen (1992), 'Citizenship and National Identity: Some Reflections on the Future of Europe', Praxis International, 12/1: 1-19.

Klingemann, Hans-Dieter (1999) 'Mapping Support in the 1990s: A Global Analysis' in Norris, Pippa, ed. Critical Citizens: Global Support for Democratic Governance. Oxford: Oxford University Press.

Lijphart, Arend (1977) Democracy in Plural Societies: A Comparative Exploration, New Haven: Yale University Press.

Linz, Juan J. and Alfred Stepan (1978) The Breakdown of Democratic Regimes. Baltimore: Johns Hopkins University Press. 
Linz, Juan J. and Alfred Stepan (1996) Problems of Democratic Transition and Consolidation: Southern Europe, South America, and Postcommunist Europe. Baltimore: Johns Hopkins University Press.

Marshall, Thomas H. (1973) Class, Citizenship and Social Development. Greenwood: Westport.

New Baltic Barometer/New Europe Barometer (1992-2004), machine-readable data file. Used with permission.

Nodia, Ghia (2002) 'The Impact of Nationalism' in Diamond, Larry and Marc F. Plattner, eds., Democracy after Communism, Baltimore: The Johns Hopkins University Press.

Norris, Pippa (1999) 'Introduction: The Growth of Critical Citizens?' in Norris, Pippa, ed. (1999) Critical Citizens: Global Support for Democratic Governance. Oxford: Oxford University Press.

Popovski, Vesna (2000) National Minorities and Citizenship Rights in Lithuania, 1989-93. Basingstoke and New York: Palgrave.

Rokkan, Stein (1970) Citizens, Elections, Parties. Oslo: Universitetsforlaget.

Rustow, Dankwart A. (1970) 'Transitions to Democracy: towards a Dynamic Model'. Comparative Politics, April 1970.

Weiler, J. H. H.: 1997, "To be a European citizen: Eros and civilization". Journal of European Public Policy 4(4), pp. 495-519.

\section{ENDNOTES}

${ }^{1}$ Quoted from the International Herald Tribune, December 14, 2005, at http://www.iht. com/articles/2005/12/14/news/latvia.php - last accessed December 16, 2005.

2 Pippa Norris (1999) expands on Easton's classification by introducing finer distinctions. More specifically, she divides public support into five distinct, but interrelated aspects of the political system: (a) actors; (b) institutions; (c) performance; (d) principles; and (e) belonging. As in the case of Easton's classification, these five aspects form a 'ladder' of some sort.

3 Lithuanians tend to refer to their independence from 1990, since Lithuania declared independence on March 13 that year. However, Lithuania - like Latvia and Estonia was not de facto independent before August 1991.

${ }^{4}$ Somehow, though, the fact that Lithuania decided to grant citizenship to all its inhabitants the so-called 'zero-option' - weakens the 'legalistic' arguments employed by Estonia and Latvia. Nevertheless, Lithuanian officials were always keen to express 'complete understanding and support' for the Estonian and Latvian position (Popovski 2000, 71-72).

5 It is however appropriate to add a nuance to this picture: the Lithuanian-speaking NBB sample includes a number of respondents who consider themselves to be of Polish origin, but chose Lithuanian as the language of the interview. Likewise, some of the respondents who chose Russian do in fact consider themselves to be Polish or Belarusian.

${ }^{6}$ There is one difficulty here, however: dividing up the Lithuanian sample into Russian and Polish sub-parts presents problems of sample size. 


\title{
The Behavioural Strategy of the Russian Ethnic Minority in Latvia: Peculiarities of Structuration
}

\author{
Vladislavs Volkovs \\ Dr.sc.soc., Associate professor Daugavpils University
}

\section{TOPICALITY OF THE RESEARCH TOPIC}

Russians are the second largest ethnic group in Latvia, consisting of 652,200 people and constituting $28.6 \%$ of its population; Russians outnumber the aggregate share of other ethnic minorities in the country - Belarussians, Poles, Ukrainians, Lithuanians, Jews, etc. Moreover, in some of the biggest towns in Latvia - in Riga, Daugavpils and Rezekne - Russians constitute the biggest ethnic group (Iedzivvotāju...2006: 1-3). Since the restoration of independence in 1991, both the absolute number of Russians and their share in the population have been decreasing because of emigration and the natural reduction of the population. However, net migration has become negative and the rate of the natural reduction of the population has slowed since 2000. This shows that the situation has become stable and that the indices of demographic properties of ethnic groups in Latvia have been improving. It is obvious that in the near future Russians will continue to be the largest ethnic minority in the country and maintain their share in the total population. Moreover, Russians are one of several ethnic groups in Latvia which practice endogamous marriages (like Latvians and Roma/Gypsies); this points to the high potential of the reproduction of ethnicity among Latvian Russians.

However, reproduction of Russian ethnicity takes place within the context of a Latvian national state. This influences the particular political, socio-economic, as well as religious features of the reproduction of ethnicity. Russians in Latvia have elaborated and implemented their own adaptive strategy of ethnic behaviour for more than 15 years. The two main aims of this strategy are to maintain the facilitating conditions for Russian ethnicity in Latvia and to promote socio-economic and political integration into civil society and the national state of Latvia. Consequently, a question arises whether the strategy of ethnic behaviour chosen by the Russian ethnic minority is adequate to attain these aims.

In this article, the author analyses the peculiarities of the behavioural strategy of Russians in Latvia according to the standards and values of the quality of their life. The author has formulated the following hypothesis: the peculiarities of structuration 
of ethnic behaviour characteristic of the Russian minority create favourable conditions for the formation of a vertical model of ethnic social stratification in the society.

\section{STRUCTURATION OF ETHNIC BEHAVIOUR OF THE RUSSIAN MINORITY UNDER THE INFLUENCE OF THE STANDARDS OF THE QUALITY OF LIFE}

Quality of life is a sociological category that is applied to show the degree of satisfaction with materialistic and cultural needs of people in all aspects of social life (Shuessler, Fisher 1985, p. 131). Interest in this scientific concept has been growing since the mid 1960s. This time period is characterised by the change from industrial to post-industrial civilisation. Sociologists have concluded that the cause for such global social changes is not only the transformation of production technologies, principles of social stratification and types of social institutions predominant within an industrial society. Post-industrial civilisation is also a new type of social human orientation. According to Ronald Inglehart, "cultural changes take place when materialistic preferences of values are transformed into post-materialistic ones: the attention paid to prosperity, well-being and security is exchanged for quality of life" (Inglehart 1989, p. 250).

The quality of life of a personality, being free from pressure and the obligation to provide physical and material security for oneself and family, is aimed at social contacts, participation in political activities, creation of a favourable ecological, psychological and cultural environment, and development of unbiased opinions. At the same time, the quality of life is not just a growing interest in social values in an individual's life; it also develops social standards important for those who are willing to gain success in the individual process of socialisation.

The dominant norms and standards of the quality of life are an important social factor which influences the collective behaviour of the representatives of ethnic communities. As Talcott Parsons put it, social standards in a society can contribute to the integration of a social system as well as differentiate and stratify the society into groups that are different in their unequal degree of comprehension of the requirements of social standards (Парсонс 2000, p. 574). According to Parsons, stratification into ethnic groups is one of the aspects of the system of social stratification depending on the degree and peculiarities of how the common social standards are gained. (Парсонс 2000, pp. 616-617) In order to understand the particular features of the structuration of behaviour of ethnic groups in a social system, it is necessary to know the thesis of sociological studies of Ralf Dahrendorf. He put forward an idea that stratification is a result of the unequal positions of actors towards dominant values and norms (Darendorf 2002, p. 446). According to Dahrendorf's theory, dominant norms in a society exert a differentiating influence on actors' social positions: "norms... do not favour some roles but do support others; social stratification exists in terms of differential distribution of sanctions, which are related to the norms" (Dahrendorf 2002, p. 474). As the reality of multicultural Latvian society shows, the dominant social norms and standards of the quality of life can also structure the behaviour of social and ethnic groups, thus, influencing ethnic stratification of the social system. 
The term "structuration" and its definition are borrowed from a popular theory of Anthony Giddens. According to Giddens, the notion "structuration" is the most significant component necessary for understanding the system of social and ethnic stratification which has been established and/or is being established in the society. The notion of structuration permits a dynamic look at the system of social stratification from the viewpoint of behaviour of a collective subject: constant components of behavioural tactics of a social subject turn out to be the most significant dynamic factor of the formation and functioning of the system of stratification and social inequality in the society.

Giddens shows that it is possible to explain the system of social stratification of a society as being a result of the "reproduction of institutionalised practices" in everyday, "routine" life of people. Structural components of society "exist only due to continuous reproduction of various forms of social behaviour in time and space" (Giddens 2003, p. 15). At the same time, behavioural practices help social identities to realise themselves. These identities, in turn, act as "markers" of social communities. These markers coordinate social communities with the help of an aggregate of normative rights, duties, as well as with social roles in the society (Giddens 2003, p. 385-386).

Research on the structuration of ethnic behaviour of the Russian population in Latvia is topical at the moment because there is a necessity to find out the importance of both theoretical and practical properties of the issue: is the ethnic factor a cultural or a psychological phenomenon, or is it closely related to economic and political phenomena; has it become a fundamental component which forms the system of social stratification in Latvia or not? Structuration of relations of ethnic groups is a result of behavioural strategies of these groups within multiethnic society. According to Karl Deutsch and Donald Horowitz, it is the process of social mobilisation which shows the potential of ethnic groups and which forms patterns of ethnic behaviour of these groups (Deutsch 1961, p. 493; Horowitz 1985, p. 99). In this respect, ethnic groups do not differ from other social actors, the behaviour of which is formed by needs, as well as by attempts and abilities to satisfy them (Horowitz 1985, p. 100). In reality, it is characteristic of different ethnic groups to have different degrees of social claims. As a result, they occupy different niches of social stratification in the society (Horowitz 1985, p. 196).

Donald Horowitz distinguished between two different ethnic systems. The first one corresponds to the rigid vertical hierarchy of ethnic groups. In this type of hierarchy one group is dominant and the other is subordinate. The second possible system of interrelationships of ethnic groups is their parallel existence (Horowitz 1985, p. 22). According to Horowitz, irregularity in modernisation of different ethnic groups leads to an "ethnic division of labour" both within one society and within different societies (Horowitz 1985, p.108).

Ethnic and socio-economic stratification are similar social phenomena, but they are not absolutely identical. These stratification systems are related to different approaches of ethnic and economic groups to material and intellectual resources, and authorities. Despres holds that ethnic stratification is related to the person's ascribed status, whereas socio-economic stratification is mainly related to the person's achievements in economic life (Despres 1975, p. 195). 
As Rothschild notes, for a society with various ethnicities, it is characteristic to have both socio-economic and ethnic stratification. Moreover, ethnic stratification quite often appears as socio-economic stratification - they overlap with each other (Rotčailds 1999, p. 35). Rothschild notes that in a society with various ethnicities the overlapping of ethnic and social economic stratification can lead to the politicisation of the ethnic issue. That is why it is necessary to encourage the development of a system of ethnic stratification which would not lead to the socio-economic discrimination of the representatives of ethnic minorities.

Rothschild distinguishes 3 models of ethnic stratification: a vertical model, in which ethnic stratification is based on the subordination of ethnic groups into economic life, as well as into the system of political power; parallel segments, when ethnic groups exist as relatively autonomous social, economic and political communities; cross-patterned reticulation, in which "each ethnic group has a range of economic functions and specialities, and each economic category and sector includes members of numerous ethnic groups" (Rotčailds 1999, p. 74).

Rothschild thinks that for a democratic society with various ethnicities the reticulation model of ethnic stratification is best suited. In the conditions of the reticulation model it is possible to reach the optimal integration of ethnic minorities integration of "life possibilities", when the differences on such indices as mortality, literacy, quality of housing, employment rates, etc. between ethnic groups decrease (Rotčailds 1999, p. 94). The analysis of the ethnic behaviour of the Russian minority towards the dominant standards and values of the quality of life reveal an obvious trend which can increase the possibility of formation of the vertical model of ethnic stratification mentioned by Rothschild.

Ethnicity, as a resource of the quality of life, is topical for Latvian society due to the multiethnic nature of its population. In such a situation, another issue acquires practical and scientific importance: whether there are differences in the quality of life among the national groups of the country. If such differences do exist, are they significant? Do they promote social discrimination among the national groups in cultivation of the present values and standards of the quality of life in the development of society?

Civil society and a democratic state are interested in the universal nature of values and standards of the quality of life. This issue is especially topical for Latvia, because the principles of a democratic national state require good relations between ethnic groups in civil society. The most acceptable model for the present Latvian situation is the establishment of values and standards of the quality of life which would not promote discrimination among the representatives of all ethnic groups. In this case, ethnic differences will not mean differences in the quality of life; on the contrary, they will become mere cultural differences.

In this article, the differences in the quality of life of the two major ethnic groups - Latvians and Russians living in Latvia - are considered. This choice was made in order to reflect the distribution of the major ethnicities in the given community (Latvians, $\mathrm{N}=601$, Russians, $\mathrm{N}=322$ ). The source of the sociological data is the research "The Quality of Life in Latvia" conducted in 2005 by professor Tālis Tisenkopfs. 
Differences in the quality of life of ethnic groups are analysed according to the following principles:

1. Opinions about life conditions;

2. Opinions about life objectives and values;

3. Opinions about networks of social interaction which show the level of social integration of this group within civil society.

\section{OPINIONS ABOUT LIFE CONDITIONS}

Respondents' views on life conditions can be divided into two parts - objective and subjective. The objective part is the evaluation of respondents' existing life conditions. The subjective part is the respondents' evaluation of their abilities to set life goals and their satisfaction with the results of their efforts in order to achieve these goals.

There are differences in this respect in the answers of Latvian and Russian respondents. Russian respondents' evaluation of their life conditions was more positive than that of Latvians. However, the same Russian respondents were less satisfied with their efforts to achieve life goals (Tables 1 and 2).

Table 1

Attitude to social opportunities in a local area (reply: "very good opportunities") (\%)

\begin{tabular}{|c|c|c|c|c|c|}
\hline & & $\begin{array}{c}\text { All the } \\
\text { respondents }\end{array}$ & Latvians & Russians & $\begin{array}{c}\text { Mann-Whitney U } \\
\text { Asymp. Sig. (2- } \\
\text { tailed) }\end{array}$ \\
\hline 1. & To receive education & 15 & 14 & 16 & 0.213 \\
\hline 3. & $\begin{array}{c}\text { To get a required professional } \\
\text { qualification }\end{array}$ & 9 & 8 & 11 & 0.003 \\
\hline 4. & To find a job & 4 & 3 & 5 & 0.044 \\
\hline 5. & To spend accommodation & 5 & 4 & 7 & 0.209 \\
\hline 6. & To use everyday services & 11 & 10 & 12 & 0.852 \\
\hline
\end{tabular}

(Significance $\mathrm{p}<0,001$ )

Table 2

Satisfaction with one's life spheres (replies: "satisfied" and "fully satisfied") (\%)

\begin{tabular}{|c|c|c|c|c|c|}
\hline & $\begin{array}{c}\text { All the } \\
\text { respondents }\end{array}$ & Latvians & Russians & $\begin{array}{c}\text { Mann-Whitney U } \\
\text { Asymp. Sig. (2- } \\
\text { tailed) }\end{array}$ \\
\hline 1. & $\begin{array}{c}\text { Present working place in } \\
\text { general }\end{array}$ & 41 & 46 & 35 & 0.000 \\
\hline 2. & $\begin{array}{c}\text { Salary at the main place of } \\
\text { work }\end{array}$ & 22 & 23 & 20 & 0.055 \\
\hline 3. & $\begin{array}{c}\text { Work environment and } \\
\text { conditions at main place of } \\
\text { work }\end{array}$ & 37 & 42 & 29 & 0.000 \\
\hline 4. & Income & 21 & 23 & 19 & 0.109 \\
\hline
\end{tabular}




\begin{tabular}{|c|c|c|c|c|c|}
\hline 5. & $\begin{array}{l}\text { Welfare of the person and } \\
\text { family }\end{array}$ & 24 & 25 & 24 & 0.650 \\
\hline 6. & The level of qualification & 44 & 45 & 42 & 0.314 \\
\hline 7. & The level of education & 51 & 52 & 48 & 0.781 \\
\hline 8. & Health & 51 & 54 & 49 & 0.215 \\
\hline 9. & Flat, lodging & 55 & 55 & 55 & 0.891 \\
\hline 10. & $\begin{array}{l}\text { Life environment in city, } \\
\text { region, village }\end{array}$ & 54 & 59 & 51 & 0.019 \\
\hline 11. & $\begin{array}{l}\text { Work resources in the place } \\
\text { of residence }\end{array}$ & 18 & 16 & 24 & 0.406 \\
\hline 12. & $\begin{array}{c}\text { The possibility to run a } \\
\text { business in place of residence }\end{array}$ & 9 & 9 & 11 & 0.075 \\
\hline 13. & $\begin{array}{c}\text { Safety in the place of } \\
\text { residence }\end{array}$ & 43 & 48 & 36 & 0.000 \\
\hline 14. & $\begin{array}{l}\text { Social integration, equal } \\
\text { possibilities in the place of } \\
\text { residence }\end{array}$ & 31 & 35 & 24 & 0.012 \\
\hline 15. & $\begin{array}{l}\text { Ecological situation in the } \\
\text { place of residence }\end{array}$ & 49 & 54 & 42 & 0.001 \\
\hline 16. & Family life & 64 & 66 & 61 & 0.484 \\
\hline 17. & $\begin{array}{l}\text { Support and protection } \\
\text { received from relatives, } \\
\text { friends, colleagues }\end{array}$ & 66 & 69 & 61 & 0.024 \\
\hline 18. & $\begin{array}{c}\text { Support and protection } \\
\text { given to relatives, friends, } \\
\text { colleagues }\end{array}$ & 56 & 57 & 56 & 0.743 \\
\hline 19. & $\begin{array}{l}\text { Amount of time dedicated to } \\
\text { family }\end{array}$ & 53 & 48 & 51 & 0.838 \\
\hline 20. & $\begin{array}{l}\text { Amount of time dedicated to } \\
\text { oneself }\end{array}$ & 51 & 52 & 49 & 0.802 \\
\hline 21. & $\begin{array}{c}\text { Possibilities to realise hopes } \\
\text { and objectives in the working } \\
\text { place }\end{array}$ & 27 & 29 & 25 & 0.009 \\
\hline 22. & $\begin{array}{l}\text { Possibilities to realise hopes } \\
\text { and objectives in the family }\end{array}$ & 40 & 39 & 44 & 0.191 \\
\hline 23. & $\begin{array}{c}\text { Possibilities to realise own } \\
\text { hopes and objectives }\end{array}$ & 37 & 37 & 36 & 0.837 \\
\hline 24. & $\begin{array}{c}\text { Possibilities to spend free } \\
\text { time as desired }\end{array}$ & 39 & 40 & 38 & 0.973 \\
\hline
\end{tabular}

(Significance $\mathrm{p}<0.001$ )

At the same time both Latvian and Russian respondents gave a similar evaluation of their subjective abilities to set life goals in different spheres of life (Tables 3). 
Table 3

Subjective Ability to Affect Different Spheres of Life (replies: "to a considerable degree" and "to some extent") (\%)

\begin{tabular}{|c|c|c|c|c|c|}
\hline & & $\begin{array}{c}\text { All } \\
\text { respondents }\end{array}$ & Latvians & Russians & $\begin{array}{l}\text { Mann-Whitney U } \\
\text { Asymp. Sig. (2- } \\
\text { tailed) }\end{array}$ \\
\hline 1. & Situation on the labour market & 21 & 24 & 19 & 0.004 \\
\hline 2. & $\begin{array}{c}\text { Salary in the main place of } \\
\text { work }\end{array}$ & 13 & 12 & 14 & 0.306 \\
\hline 3. & $\begin{array}{l}\text { Work environment and } \\
\text { conditions in the main place } \\
\text { of work }\end{array}$ & 16 & 17 & 15 & 0.007 \\
\hline 4. & Income & 23 & 22 & 26 & 0.429 \\
\hline 5. & $\begin{array}{l}\text { Welfare of the person and } \\
\text { family }\end{array}$ & 30 & 31 & 29 & 0.388 \\
\hline 6. & The level of qualification & 49 & 51 & 47 & 0.400 \\
\hline 7. & The level of education & 51 & 54 & 48 & 0.241 \\
\hline 8. & Health & 49 & 51 & 50 & 0.767 \\
\hline 9. & Flat, lodging & 57 & 58 & 56 & 0.252 \\
\hline 10. & $\begin{array}{l}\text { Life environment in city, } \\
\text { region, village }\end{array}$ & 10 & 11 & 10 & 0.019 \\
\hline 11. & $\begin{array}{l}\text { Work resources in the place } \\
\text { of residence }\end{array}$ & 6 & 6 & 6 & 0.857 \\
\hline 12. & $\begin{array}{l}\text { The possibility to run a } \\
\text { business in the place of } \\
\text { residence }\end{array}$ & 5 & 4 & 6 & 0.882 \\
\hline 13. & $\begin{array}{c}\text { Safety in the place of } \\
\text { residence }\end{array}$ & 9 & 11 & 7 & 0.316 \\
\hline 14. & $\begin{array}{l}\text { Social integration, equal } \\
\text { possibilities in the place of } \\
\text { residence }\end{array}$ & 7 & 6 & 8 & 0.200 \\
\hline 15. & $\begin{array}{l}\text { Ecological situation in the } \\
\text { place of residence }\end{array}$ & 15 & 16 & 13 & 0.536 \\
\hline 16. & Family life & 68 & 69 & 67 & 0.501 \\
\hline 17. & $\begin{array}{l}\text { Support and protection } \\
\text { received from relatives, } \\
\text { friends, colleagues }\end{array}$ & 50 & 49 & 52 & 0.691 \\
\hline 18. & $\begin{array}{l}\text { Support and protection given } \\
\text { to relatives, friends, colleagues }\end{array}$ & 67 & 67 & 68 & 0.178 \\
\hline 19. & $\begin{array}{c}\begin{array}{c}\text { The amount of time can } \\
\text { dedicate to family }\end{array} \\
\end{array}$ & 65 & 67 & 63 & 0.471 \\
\hline 20. & $\begin{array}{l}\text { That amount of time that can } \\
\text { dedicate to oneself }\end{array}$ & 66 & 67 & 66 & 0.870 \\
\hline
\end{tabular}

(Significance $\mathrm{p}<0.001$ )

Apart from instrumental resources for personal development, social conditions also include symbolic values related to the identity of the state and civil society. The results of the sociological research prove that there are significant differences 
between Latvians and Russians in the attitude towards symbolic values, such as the feeling of belonging to Latvia (Table 4).

Table 4

The Feeling of Belonging to Territorial Units (reply "belong to a considerable degree") (\%)

\begin{tabular}{|c|c|c|c|c|c|}
\hline & & $\begin{array}{c}\text { All } \\
\text { respondents }\end{array}$ & Latvians & Russians & $\begin{array}{c}\text { Mann-Whitney U } \\
\text { Asymp. Sig. (2-tailed) }\end{array}$ \\
\hline 1. & Town, district, village & 45 & 51 & 37 & 0.002 \\
\hline 2. & Latvia & 46 & 54 & 37 & 0.000 \\
\hline 3. & European Union & 11 & 11 & 11 & 0.751 \\
\hline
\end{tabular}

(Significance $\mathrm{p}<0.001$ )

However, Russian respondents who are employed in the high technology field, have higher education and those who belong to the middle class show higher rates of feeling a sense of belonging to territorial units (Table 5).

Table 5

The Feeling of Belonging to Territorial Units of Russians Living in Latvia (\%)

\begin{tabular}{|l|c|c|c|c|c|}
\hline & $\begin{array}{c}\text { All } \\
\text { Russians }\end{array}$ & $\begin{array}{c}\text { Russians - paid } \\
\text { employees, } \\
\text { specialists, } \\
\text { businessmen and } \\
\text { self-employed }\end{array}$ & $\begin{array}{c}\text { Russians } \\
\text { with } \\
\text { higher } \\
\text { education }\end{array}$ & $\begin{array}{c}\text { Russians working in finance, real } \\
\text { estate, rental, computer services, } \\
\text { state administration and protection, } \\
\text { compulsory social insurance, education } \\
\text { and science, health and social care, } \\
\text { public, social and individual services }\end{array}$ \\
\hline 1. & $\begin{array}{c}\text { Town, district, } \\
\text { village }\end{array}$ & 37 & 38 & 42 & 46 \\
\hline 2. & Latvia & 37 & 48 & 41 & 46 \\
\hline 3. & $\begin{array}{c}\text { European } \\
\text { Union }\end{array}$ & 11 & 10 & 14 & 16 \\
\hline
\end{tabular}

\section{VIEWS ABOUT LIFE OBJECTIVES AND VALUES}

Views about life objectives and values are an important index of the quality of life. The development of life objectives of Latvian social and ethnic groups is much influenced by the environment, the sum total of institutions, norms, values, and widespread social practices. At the same time, research suggests that life objectives of ethnic groups in Latvia to a considerable degree depend on socioeconomic conditions and on the information and cultural space developed in the Latvian community. The character of the life objectives of ethnic groups in Latvia, thus, depends on the predominant attitude to existing life conditions: adaptive, which is oriented to the acceptance of the established conditions, or innovative, which is related to the critical evaluation of established social conditions, and to the improvement of these social conditions. It is obvious that an important element of the innovative strategy is a person's willingness to get education, to search for information sources, to acquire modern information technologies, to develop one's personality, as well as to take care of one's health, etc. Tables 6-7 show that this kind of strategy is more characteristic for Latvians than for Russians. 
Table 6

Motivation to Continue to Study (\%)

\begin{tabular}{|c|c|c|c|c|c|}
\hline & & $\begin{array}{c}\text { All the } \\
\text { respondents }\end{array}$ & Latvians & Russians & $\begin{array}{c}\text { Mann-Whitney U } \\
\text { Asymp. Sig. (2-tailed) }\end{array}$ \\
\hline 1. & Provision of well-being & 61 & 57 & 72 & 0.010 \\
\hline 2. & $\begin{array}{c}\text { To receive a professional } \\
\text { qualification }\end{array}$ & 13 & 14 & 12 & 0.954 \\
\hline 3. & Personality development & 13 & 15 & 10 & 0.787 \\
\hline
\end{tabular}

(Significance $\mathrm{p}<0.001$ )

Table 7

Use of the Library During the Last Year (\%)

\begin{tabular}{|c|c|c|c|}
\hline $\begin{array}{c}\text { All the } \\
\text { respondents }\end{array}$ & Latvians & Russians & $\begin{array}{c}\text { Mann-Whitney U } \\
\text { Asymp. Sig. (2-tailed) }\end{array}$ \\
\hline 39 & 47 & 26 & 0.000 \\
\hline
\end{tabular}

(Significance $\mathrm{p}<0,001$ )

As to realisation of life plans, the results of the research show that there is no significant difference between Latvians and Russians during the last year. Regarding the realisation of plans in the search for a better work place, purchase of real estate or other property, and the enlargement of social contacts, the results are practically the same among both Latvians and Russians. However, Russian respondents take less care about their health than Latvians, they attend seminars and courses less frequently, are less interested in the improvement of their qualification, do not insure their property as often and are not as interested in signing contracts about the second and third pension level.

The respondents' views about desirable developments in their place of living is mainly based on practical considerations, one of which is an interest in employment. Views about the necessity of developing a major sphere of the national economy, similar to other social spheres, are also related to the number of representatives of the concrete ethnic group employed in that sphere (Table 8).

Table 8

Economic Sectors to Be Developed (\%)

\begin{tabular}{|c|c|c|c|c|c|}
\hline & & $\begin{array}{c}\text { All } \\
\text { respondents }\end{array}$ & Latvians & Russians & $\begin{array}{c}\text { Mann-Whitney U } \\
\text { Asymp. Sig. (2-tailed) }\end{array}$ \\
\hline 1. & Food processing & 29 & 31 & 25 & 0.057 \\
\hline 2. & Wood processing & 34 & 39 & 26 & 0.000 \\
\hline 3. & Extraction of minerals & 3 & 4 & 3 & 0.755 \\
\hline 4. & Crafts & 31 & 35 & 25 & 0.003 \\
\hline 5. & Trade & 27 & 26 & 29 & 0.222 \\
\hline 6. & Agriculture & 34 & 37 & 26 & 0.001 \\
\hline 7. & $\begin{array}{c}\text { Tourism and } \\
\text { entertainment }\end{array}$ & 57 & 61 & 49 & 0.001 \\
\hline 8. & Culture & 37 & 39 & 34 & 0.139 \\
\hline
\end{tabular}




\begin{tabular}{|c|c|c|c|c|c|}
\hline 9. & Education & 33 & 32 & 34 & 0.697 \\
\hline 10. & Construction & 33 & 31 & 39 & 0.018 \\
\hline 11. & Information technologies & 18 & 18 & 17 & 0.731 \\
\hline 12. & Transport and storage & 15 & 14 & 17 & 0.209 \\
\hline 13. & Financial services & 16 & 16 & 18 & 0.399 \\
\hline 14. & Health care, rehabilitation & 45 & 48 & 37 & 0.001 \\
\hline 15. & Other & 2 & 2 & 2 & 0.633 \\
\hline
\end{tabular}

(Significance $\mathrm{p}<0.001$ )

The table shows that Latvian respondents are more interested than Russians in the development of such spheres of the national economy as food and wood processing, different kinds of crafts, agriculture, tourism and entertainment, culture, health protection and rehabilitation. These are the spheres in which more Latvians than Russians are employed. At the same time, Russian respondents would more often like to see the development of trade and construction - spheres which employ a larger number of Russians. Among Latvian respondents, there are slightly more people who would like to run their own business or to choose an independent kind of professional activity.

\section{VIEWS ON SOCIAL NETWORKS}

A well-developed network of social interaction provides a person, as well as social and ethnic groups, with wide possibilities to find partners in order to fulfil life objectives. Social interaction includes the system of institutions, norms and values which facilitate social integration of a person into the society, as well as widespread practices and the system of viewpoints oriented towards the creation and maintenance of social relations.

This research helps to reveal attitudes to the whole network of institutions, values, and social subjects connected with the functioning of the social interaction system in the Latvian community. The research shows respondents' attitudes to such structural elements of social interaction as:

1. The subjects of the public sphere of social life - state authorities, local governments, European Union, non-governmental organisations;

2. The subjects of the economic sphere of social life - employers, employees, colleagues, partners from Latvia, partners from abroad;

3. The subjects of the private sphere - friends, relatives, members of the family;

4. Social values and norms which are regulated by scientific discoveries, patriotism, religious beliefs;

5. Subjective viewpoints of the participants of communication - reliance on destiny, reliance on one's own powers, readiness to take a risk, common sense.

The research showed that the network of social interaction established in social and private life is used in different ways by Latvian and Russian respondents in 
order to fulfil their life objectives. Contrary to Russians, Latvian respondents to a greater degree use the network of interaction represented in social life (Table 9).

Table 9

Aspects Affecting the Ability to Act and to Fulfil Hopes and Objectives (Reply - "affects positively")(\%)

\begin{tabular}{|c|c|c|c|c|c|}
\hline & & $\begin{array}{c}\text { All the } \\
\text { respondents }\end{array}$ & Latvians & Russians & $\begin{array}{c}\text { Mann-Whitney } \\
\text { U Asymp. Sig. } \\
\text { (2-tailed) }\end{array}$ \\
\hline 1. & State institutions & 7 & 8 & 5 & 0.662 \\
\hline 2. & Local government & 12 & 15 & 6 & 0.179 \\
\hline 3. & Employer & 19 & 22 & 15 & 0.089 \\
\hline 4. & Employees & 6 & 6 & 5 & 0.011 \\
\hline 5. & Scientific discoveries & 32 & 35 & 27 & 0.124 \\
\hline 6. & EU & 19 & 21 & 14 & 0.177 \\
\hline 7. & Belief in God & 32 & 30 & 34 & 0.186 \\
\hline 8. & Reliance on destiny & 24 & 24 & 26 & 0.314 \\
\hline 9. & Reliance on one's own forces & 72 & 77 & 68 & 0.015 \\
\hline 10. & Member of the family & 67 & 70 & 64 & 0.080 \\
\hline 11. & Relatives & 49 & 49 & 52 & 0.534 \\
\hline 12. & Colleagues & 30 & 32 & 28 & 0.189 \\
\hline 13. & Friends & 47 & 48 & 47 & 0.903 \\
\hline 14. & Non-governmental organisations & 10 & 11 & 7 & 0.372 \\
\hline
\end{tabular}

(Significance $\mathrm{p}<0.001$ )

Latvian respondents more often than Russian ones named various public institutions, individual motivation, and social partners as helping them to fulfil their goals. This concerns state authorities, local government, employers, scientific discoveries, the EU, non-governmental organisations, partners from Latvia and foreign partners, as well as patriotism, common sense and readiness to take a risk.

As to such aspects as employees, religious beliefs, reliance on one's destiny, relatives, friends, and colleagues, there is no significant difference between the attitude of Latvians and Russians. Having analysed established elements of the network of social interaction in the social and private sphere, it is possible to say that such differences prove that the Latvian part of society has a greater potential and communication possibilities. That is why the Latvian population has a higher level of social integration, which is an important index of the quality of life in the information society. At the same time, it turned out that Russian respondents have a higher level of autonomisation than Latvians and, consequently, a lower level of social integration.

An important sign of the development of social interaction is in political life, in the sphere of citizens' political participation. However, a lack of citizenship hinders the participation of a large part of the minority community. As a result, according to the research, the number of Latvian respondents as conventional and non-conventional participants of political life is higher than the number of Russians (Table 10). 
Political Participation (reply: "participated in) (\%)

\begin{tabular}{|c|c|c|c|c|c|}
\hline & & $\begin{array}{c}\text { All the } \\
\text { respondents }\end{array}$ & Latvians & Russians & $\begin{array}{l}\text { Mann-Whitney U } \\
\text { Asymp. Sig. (2-tailed) }\end{array}$ \\
\hline 1. & Parliamentary elections & 62 & 79 & 40 & 0.000 \\
\hline 2. & City council elections & 66 & 83 & 43 & 0.000 \\
\hline 3. & $\begin{array}{c}\text { Organisation of election } \\
\text { campaigns }\end{array}$ & 6 & 9 & 3 & 0.006 \\
\hline 4. & $\begin{array}{c}\text { Persuaded someone to vote } \\
\text { for a particular political } \\
\text { party }\end{array}$ & 13 & 14 & 12 & 0.568 \\
\hline 5. & $\begin{array}{l}\text { Participation in referendum } \\
\text { organisation }\end{array}$ & 23 & 31 & 9 & 0.000 \\
\hline 6. & $\begin{array}{l}\text { Participation in meetings, } \\
\text { pickets, demonstrations }\end{array}$ & 10 & 10 & 10 & 0.710 \\
\hline 7. & Participation in strikes & 2 & 3 & 2 & 0.264 \\
\hline 8. & $\begin{array}{l}\text { Writing letters to president } \\
\text { and prime-minister }\end{array}$ & 2 & 2 & 1 & 0.283 \\
\hline 9. & $\begin{array}{l}\text { Writing letters to ministers } \\
\text { and top officials }\end{array}$ & 5 & 6 & 3 & 0.076 \\
\hline 10. & $\begin{array}{c}\text { Writing letters to city } \\
\text { council }\end{array}$ & 8 & 9 & 5 & 0.033 \\
\hline 11. & $\begin{array}{l}\text { Writing letters to } \\
\text { newspapers }\end{array}$ & 8 & 9 & 5 & 0.080 \\
\hline 12. & $\begin{array}{l}\text { Meeting with members of } \\
\text { parliament }\end{array}$ & 13 & 17 & 7 & 0.000 \\
\hline 13. & $\begin{array}{l}\text { Meeting with members of } \\
\text { city council }\end{array}$ & 25 & 32 & 12 & 0.000 \\
\hline 14. & $\begin{array}{l}\text { Meeting with ministers and } \\
\text { top officials }\end{array}$ & 12 & 15 & 6 & 0.000 \\
\hline 15. & Meeting with reporters & 16 & 19 & 9 & 0.000 \\
\hline 16. & $\begin{array}{c}\text { Discussion of social } \\
\text { activities }\end{array}$ & 14 & 19 & 8 & 0.000 \\
\hline 17. & $\begin{array}{c}\text { Participation in the } \\
\text { discussion of city or regional } \\
\text { development planning }\end{array}$ & 10 & 14 & 4 & 0.000 \\
\hline 18. & Political party membership & 2 & 3 & 1 & 0.015 \\
\hline 19. & $\begin{array}{c}\text { Non-state organisation } \\
\text { membership }\end{array}$ & 5 & 7 & 2 & 0.001 \\
\hline 20. & $\begin{array}{c}\text { Purposeful distribution } \\
\text { of politically-oriented } \\
\text { information }\end{array}$ & 4 & 4 & 2 & 0.194 \\
\hline 21. & $\begin{array}{c}\text { Giving charity to political } \\
\text { parties }\end{array}$ & 1 & 2 & 0 & 0.028 \\
\hline
\end{tabular}

(Significance $\mathrm{p}<0.001$ )

A particularly large difference can be seen in such forms of political interaction as participation in elections to the Saeima and local government, letter writing to the 
President, Prime Minister, Ministries, local governments, meetings with the deputies of the Saeima and local government, ministers, officials and journalists, participation in public discussions, strikes (twice as often), referendum organisation, work in nongovernmental organisations, participation in discussions about the development of the town or region (3 times as often), membership of a political party.

The difference between Latvian and Russian respondents in political participation is very significant. However, as for the sphere of work and economic life, the difference is minimal or does not exist at all. Both Latvian and Russian respondents rely to the same extent on various social subjects and sources of help while searching for work (Table 11).

Table 11

Actions While Searching for Work ( reply- "certainly") (\%)

\begin{tabular}{|c|c|c|c|c|c|}
\hline & $\begin{array}{c}\text { All the } \\
\text { respondents }\end{array}$ & Latvians & Russians & $\begin{array}{c}\text { Mann-Whitney U } \\
\text { Asymp. Sig. (2-tailed) }\end{array}$ \\
\hline 1. & Would turn to employer & 59 & 62 & 56 & 0.031 \\
\hline 2. & $\begin{array}{c}\text { Would turn to State } \\
\text { Employment Agency }\end{array}$ & 39 & 37 & 40 & 0.706 \\
\hline 3. & $\begin{array}{c}\text { Would look through } \\
\text { advertisements in newspapers }\end{array}$ & 64 & 65 & 64 & 0.522 \\
\hline 4. & Would use Internet & 39 & 40 & 40 & 0.501 \\
\hline 5. & $\begin{array}{c}\text { Would use help of family } \\
\text { members }\end{array}$ & 47 & 48 & 48 & 0.564 \\
\hline 6. & $\begin{array}{c}\text { Would use help of relatives, } \\
\text { friends or neighbours }\end{array}$ & 52 & 51 & 54 & 0.680 \\
\hline 7. & $\begin{array}{c}\text { Would try to start own } \\
\text { business }\end{array}$ & 11 & 9 & 13 & 0.838 \\
\hline 8. & $\begin{array}{c}\text { Would try to become self- } \\
\text { employed }\end{array}$ & 15 & 15 & 16 & 0.277 \\
\hline
\end{tabular}

(Significance $\mathrm{p}<0.001$ )

Social interaction in a society with various ethnicities helps a person to develop communication skills in different languages. The respondents' answers show, first of all, that $98 \%$ of both Latvians and Russians have the Latvian or Russian language as their mother tongue, respectively. It means that both Latvians and Russians have linguistic identity as their ethnic identity. Secondly, both these languages are widespread among both ethnic groups: the Latvian language among Russians and the Russian language among Latvians.

However, there are $58 \%$ of Latvians who said that the level of their Russian language knowledge is ,very good", but only $26 \%$ of Russians gave the same evaluation to their Latvian language knowledge. The following peculiarity of Latvian language knowledge among Russian respondents was also found: in Riga, Zemgale and Latgale the level of Latvian language knowledge was similar to the average indices in the country $(25 \%, 29 \%$, and $26 \%$, respectively). In Vidzeme the level turned out to be higher $-40 \%$, but in Kurzeme lower $-17 \%$. Latvians whose knowledge of the Russian language is ,very good” live mainly in Riga (74\%) and in Latgale (71\%), as for Zemgale, Vidzeme and Kurzeme, the numbers are $60 \%$, $47 \%$ and $44 \%$, respectively. As is clearly evident from the data mentioned above, 
the highest number of Russians who know the Latvian language very well is in Vidzeme $-40 \%$, however, it is lower than the amount of Latvians who speak Russian at the same level in any region of Latvia.

As concerns respondents' knowledge of the English, German and French languages, the level among both Latvians and Russians is approximately the same. As for the English language, 26\% of both Latvian and Russian respondents answered that their knowledge is "very good" or "quite good"; as for the German language, the same level was marked by $9 \%$ of Latvians and $6 \%$ of Russians; as for the French language, $1 \%$ of representatives of both ethnic groups claimed to know it very well.

How is it possible to evaluate differences in significant aspects of the quality of life between Latvians and Russians in Latvia? In the author's opinion, the social behaviour of the Russian population in Latvia is to a considerable degree influenced by the strategy of behaviour formed in the conditions of industrial society. Moreover, one can detect some negative aspects in the social behaviour of a significant part of the Russian population in Latvia that are typical of the standards of industrial society. As an example, one can mention maximal adaptation to the existing socioeconomic conditions in society; the significant role of material motivation in life as compared to individual development of one's personality and, as a result, neglect of one's health if maximisation of individual resources for economic or labour activity is required. It is obvious that the Russian national minority in Latvia has to adapt to the standards of the quality of life which have been formed by post-industrial civilisation. This is the type of social behaviour which will have a favourable influence and will decrease differences in the quality of life among national groups in Latvia, thus, decrease the possibility of vertical ethnic stratification emerging in Latvian society.

Since restoration of independence in Latvia in 1991, the Russian ethnic minority has gradually chosen a behavioural strategy. For this type of strategy, it is characteristic that the objective requirements of socio-economic conditions, political institutions, norms and values of culture are interpreted through the situational perception of Russian ethnic consciousness, as well as through constant components of identity of the Russian ethnic minority. Structuration of the ethnic behaviour of Russians in Latvia has been mentioned by a number of ethno-sociological researchers. At the same time, the results of this research have shown that sometimes the particular features of ethnic behaviour of the Russian minority coincide with the characteristic features of behaviour of Latvians or other ethnic groups. The research has also revealed significant differences in the behaviour of Russians and Latvians. Russians in Latvia to a greater extent than Latvians aim not at innovative life strategies, but at adaptive ones. In the behaviour of Russians there are fewer attempts to develop networks of social communication, to become involved in politics, etc. It is obvious that the characteristic features of structuration of ethnic behaviour of such a large ethnic group as Russians promotes the formation of a vertical system of ethnic and social stratification. In such a system of ethnic stratification, the social positions of Russians are less favourable than those of Latvians. 


\section{BIBLIOGRAPHY}

Darendorf R. (2002) Sovremenoje polozhenije teorii socialjnoj stratifikacii. - Tropi iz utopii.Moskva: Praksis.

Despres L. (ed.)(1975) Ethnicity and Resource Competition in Plural Societies. - The Hague, Paris: Mouton.

Deutsch, K.(1961) Social Mobilization and Political Development. - American Political Science Review 55 (Sept.)

Giddens A. (2003) Ustrojenije obschestva: Ocherk teorii strukturacii. - Moskva: Akademicheskij projekt.

Horowitz D.L (1985). Ethnic Groups in Conflict. - University of California Press, Berkeley. Iedzīvotāju nacionālais sastāvs pašvaldībās (dati uz 01.01.2006). - http://www.pmlp.gov.lv. Inglehart R. (1989) Cultural Shift in Advanced Industrial Society. - Princeton: Princeton University Press.

Latvijas iedzīvotāju sadalījums pēc nacionālā sastāva un valstiskās piederības (dati uz 01.01.2006). - http://www.pmlp.gov.lv.

Parsons T. (2000) Novij analiticheskij podhod k teorii socialjnoj stratifikacii. - O structure socialjnogo dejstvija. - Moskva: Akademicheskij projekt.

Rotčailds Dž. (1999) Etnopolitika: konceptuālās aprises. - R.: Izdevniecība AGB.

Shuessler K.F., Fisher, G.A.(1985) Quality-of-life research and sociology. - Annual Review of Sociology - vol.11. 


\title{
Russian Migrants in Denmark: Phenomenon of Double Marginality
}

\author{
Andrey Lukyanov \\ Ph.D., Associate Professor, Department of Sociology, \\ State University of Service and Economy, St. Petersburg, \\ the Russian Federation
}

\section{THE ETHNIC SITUATION IN DENMARK}

Denmark is one of the countries in Europe which does not have many foreigners, meaning it lacks a tradition of immigration and integration. Up to the second half of the $20^{\text {th }}$ century Denmark was almost a mono-ethnic state with the only non-indigenous groups being people from Greenland, Iceland and some other colonies. Only Greenlanders were representatives of non-European culture, traditions and religion, but as a Danish colony Greenland received Danish culture in the form of literature, language, and the Lutheran church as the official religion. People from the colonies did not generate any problems for Danish society, and they were largely assimilated.

In 1956 Denmark decided to help Hungarian refugees, marking a first step on the way to becoming a multiethnic state and society. Until 1972, when the EU stopped almost all forms of "guest work", Denmark took in many refugees from Eastern Europe and thousands of guest workers from Turkey, Yugoslavia, Pakistan and North Africa. But the majority of foreigners came as guest workers and their residence status was temporary. This meant that they had no plans about integration, taking Danish language courses, etc. All foreign workers were accepted by the government, local people, trade unions and the aliens themselves as temporary, which is why the guest workers did not think about integration and some kind of contact with the local population. Later it was decided that it could be useful for foreign workers to get some information about Denmark, Danish labour law and the political system from special newspapers in foreign languages issued in cooperation with foreign embassies. In general, foreign workers were isolated from other workers and Danish every day life.

Many foreign workers received permission to stay in Denmark permanently, later received Danish citizenship and brought their own families from the countries of origin to the Kingdom. Most foreigners in Denmark consisted of foreign workers, but with time, a steady stream of refugees played a big role in forming Danish multiethnic society. 
Refugee flows changed at the beginning of the 1970s, when the number of East Europeans decreased, but people began to arrive in Denmark from regions such as Uganda, Chile, and Vietnam, etc. All these people arrived in the Kingdom of Denmark after agreement with the UN and the UNHCR. As of 1980, an increasing number of asylum seekers and refugees came from the Middle East (Iran, Iraq, Palestine, etc.), and since 1990, from former Yugoslavia.

Up to the mid-1970s all refugees were located only in Copenhagen and Århus, the second largest city in Denmark (and this was a mistake, as it created the basis for the emergence of ghettos and problems with the integration of foreigners in the future). But after the arrival of Vietnamese, provincial cities and towns were also involved in the process of refugee accommodation. In the 1990s almost all Danish communities received refugees from various countries. Now all refugees and other foreigners have to attend language classes where they learn Danish and the culture and traditions of Denmark, get advice and other assistance to better integrate in Danish society.

According to the Danish Statistical Office, there are about 300,000 foreigners in Denmark, that is, people with foreign citizenship compose about $5 \%$ of the Danish population (in 1984 there was about 1\%). The majority of foreigners settled in the Copenhagen area. The population of foreigners is nationally and religiously diverse: a quarter are from Nordic and EU-countries, every third alien is Christian. 20\% of foreign citizens were born in Denmark.

\section{RUSSIAN MIGRANTS IN DENMARK AND DOUBLE MARGINALITY}

The number of Russian migrants is not large - about 3200 people, most of whom are women - 2292 (1311 of them are married to Danes). As married women comprise the majority of Russians in Denmark, I selected them as the target group for my research.

The phenomenon of marginality is topical and important in our time of change: people in the context of globalisation are forced to move not only from country to country, but also between branches and industries, strata of society etc. Therefore sociologists talk about so-called "new marginal groups".

Russian women began to come to Denmark in the 1990s, during the socalled perestroika, when the economic and political situation in the USSR/Russia was uncertain and many individuals (especially of ethnic German and Jewish origin) decided to move from Russia to other countries. But all these people have encountered problems with integration in the society of their new "homeland". Most are marginal, meaning they have problems with accepting their new culture, and the host society does not want to accept them as equal citizens.

But there are differences between Russian migrant groups, for example, in Germany and in Denmark. In Germany the "Russians" (or more precisely, the ethnic Germans) live together in the same city districts and have a large community with cultural institutions (schools, newspapers, churches, etc.), while in Denmark the Russians live among Danish people and are "well integrated" (that is, Russians who 
are members of Danish families know Danish traditions, language and everyday life better than isolated groups of asylum-seekers or refugees). But the question is whether the Russians are truly integrated or maybe they are latent marginals.

When I began my work with Russians in Denmark, I had some assumptions about how marginal my fellow countrymen were. I presumed that many of them have difficulties in finding work, with daily contacts, friends, family life, etc. But research in marginality is complicated by a number of factors:

1. As a rule respondents don't know about marginality as a social phenomenon, meaning the researcher must devise other questions indicating marginality. In my research I chose questions about everyday and job contacts, perception of Danish traditions, etc.;

2. Research about marginality can be conducted using two kinds of data: statistical information and the results of qualitative explorations;

3. In marginality research we need to use questions of a private character and it is necessary to formulate them very carefully.

Over several years I had the opportunity to observe the life of Russian people in Denmark, and my opinion is that they are marginal, they live in a marginal situation typical for migrants. On the basis of extended interviews with 10 Russian women who are married/divorced (which was a part of my Ph.D. project about the quality of life in Denmark and North-West Russia), I could make the following conclusions:

1. Russian migrants in Denmark are well-integrated on the common, everyday level: they need to be like Danes because they live with Danish partners, have children with their Danish spouses and learn about Denmark from their husbands and his relatives.

2. Russian migrants have many problems with integration on the official level; because of Danish policy towards foreigners, Russian migrants are not recruited to take part in integration processes: they are married to Danes and this means that their spouses or partners must help them to be integrated in Danish society.

3. The majority of Russian migrants in Denmark have a high level of education (a university degree), but they cannot use it in the Kingdom of Denmark and need to take unqualified work or just be housewives. This is a manifestation of marginality of social roles: "former" engineers work as labourers, not because of their poor education or qualification, but only because of their national origin.

4. Cultural marginality is also a part of life of Russian migrants in Denmark. In spite of everyday contacts with Danes, they don't identify themselves with Danes, but they are not real Russians anymore. They are between two cultures, and we feel it in their language - many migrants talk to each other in a kind of pidgin. The severance from Russia made these migrants marginal in both their country of origin and in their new homeland. Because of this severance from their country of origin, many Russians abroad don't want to move back to Russia and are satisfied with their low social position in their new homeland. 
5. My opinion is that many migrant groups in Denmark (including the Russians) are part of a process of structural marginality. They do not have many possibilities to be well-integrated and to demonstrate their loyalty to their new homeland. In fact there are many incidences of discrimination, which lead to an intensification of marginality.

Unfortunately, my research on the marginal situation of Russians in Denmark was a pilot study, but nevertheless it can suggest some tendencies regarding the marginality phenomenon in Europe. The conclusions above suggest the necessity of seeking to understand the migration process in greater depth: real integration is not possible without the minimisation of marginality. The phenomenon of double marginality in the migration context needs to be given more attention by the authorities and researchers.

\section{REASONS FOR MARGINALITY AS A PART OF SOCIAL DECOMPOSITION}

How can one reduce marginality and decomposition? I suppose that only dialogue, study, information and work together can make aliens into real citizens. Social activity of new citizens in public life can make them more open and tolerant towards things that are not acceptable in their countries of origin, but are usual and tolerated in Western or European cultures: pluralism, freedom of expression, etc. There are some good examples of positive cooperation between migrants and local people. In Germany, France, the Netherlands, and Denmark some migrants are members of community councils and parliaments, in civil society many aliens and Europeans try to combat fascism, nationalism, religious fanaticism and prejudices on both sides. Currently, when all European states are becoming increasingly diverse, it is vitally important to forge a new policy built on dialogue, trust and mutual respect.

Despite the concept of "the third way" and other ideas on improving integration, one sees a progressive growth of intolerance in Danish society. There is almost no dialogue, but the preservation of old traditions and prejudices. The Danish People's Party has a good chance of winning elections again. The electorate is interested in "invandrerspørgsmål" - the Aliens question - more than in other important problems, such Denmark's role in the Iraq war, environmental problems and unemployment. The Danish People's Party portray aliens as the root of all Danish problems. Instead of social democratic softness and cultural relativism, there is more and more xenophobia at the moment. Xenophobia is a new mantra in modern Danish policy, as social democrats and other left political powers use it in the elections as well. But this propaganda and strict rules for family reunion cannot resolve problems with integration, tolerance and criminality in the milieu of aliens. I think that Denmark needs a real open debate about the multiethnic society, tolerance and intolerance, one standard for all and other related issues. This debate could give the Danes more knowledge about aliens and their own Danish traditions, and hinder the Danish People's Party from abusing the national idea. Today the Danish People's Party can present itself as the sole guardian of Danish traditions and (importantly in this context) of the Danish Folk Church (Dansk Folkekirke) - the state church in Denmark. Dansk Folkekirke has a special status in Denmark: the Church is part of 
the state and there is a Church Ministry with special authority concerning the registry of births, deaths and names. This undemocratic tradition and law is not acceptable in a multiethnic and multi-religious state: why should Catholics, Moslems, Orthodox or atheists register the birth of their child in the Lutheran Church? Shouldn't this be the job of the State? And why should the State pay the salaries of priests in Folkekirke, and not to all priests? All people in Denmark pay taxes, and it would be more democratic and fair if priests of other churches received salaries from the state or if nobody received it. This means that a multiethnic society (with all due respect to recipient countries) requires reforms in all spheres of public and political life, also in the status of churches.

\section{FINAL POINTS: MULTIETHNIC SOCIETY AND COMMON CIVIL SOCIETY}

The multiethnic society is already here and we cannot ignore it any more. In the context of modern world development, globalisation and the North-South divide, it will be impossible for a small country like Denmark and for Europe to escape aliens in our everyday life. But we can escape civil war in our countries and national conflicts like those in former Yugoslavia.

It would be better if new citizens in our countries learn democratic traditions, our social rules and humanistic worth and retain the opportunity to be Moslems, Hindus or Orthodox, within limits, of course. And these limits are civil society, respect for other cultures, religions, opinions, preferences and rights. Only in this case can we talk about real cohesion and tolerance.

\section{SOURCES}

1. www.dst.dk

2. www.danskfolkeparti.dk

3. www.folketinget.dk

4. www.radikale.dk

5. www.politi.dk

6. www.udlst.dk

7. www.kirkeministeriet.dk

8. www.kritiskemuslimer.dk

9. www.rusmark.dk

10. www.danrus.dk

11. www.rusforum.dk

12. www.ortodoks.dk

13. www.russiskhus.dk

14. www.dkrus.dk

15. www.dansk-russisk-hus.dk 


\title{
The Challenge of Emigration for Population Policy in Latvia
}

\author{
Parsla Eglite \\ Institute of Economics Riga, Latvia
}

\section{CONSEQUENCES OF EMIGRATION}

Latvia has experienced several voluntary and compulsory waves of emigration which have varied in terms of the reasons, directions, composition of the people involved, share of those who returned, and social and demographic consequences. Up to now, public debate has focused primarily on forced population transfers during and after World War II. These included the deportation of hundreds of thousands of people to the Eastern regions of the former USSR as part of Stalinist repressions during the 1940s and the slightly smaller scale (at least 30,000 persons) detention and mobilisation of labourers by the Nazis in the opposite direction. Almost 200,000 left the country as conscripts of the confronting Soviet and Nazi armies; at the beginning of WWII some 50,000 refugees fled to the East, but at the end of the war up to 280,000 fled to the West $[11,13]$.

Most of those who survived, except for refugees to the West, returned 1-15 years after they had left the country. The share of those returning from rather recent waves of voluntary emigration has been smaller. This was the case at the end of the 19th century, when several tens of thousands left to colonise free land in several regions of Russia; at the end of the 1920s almost 30,000 left for Brazil following the initiative of a certain religious sect [9]. Since Latvia regained independence in 1991, at least 150,000 postwar colonists from other republics of the former USSR have left, though the intensity of this ethnic repatriation slowed 5 years after independence [2: 18-19].

During the 1990s voluntary emigration to the West started and gradually became more and more intense, especially after EU accession in 2004. As most of these migrants intend to stay abroad for a rather short period, they do not declare a change of residence and their number is not reflected in statistics. According to labour registers in some Western countries, the total amount of actual émigrés from Latvia could be as high as 60,000-100,000 [8: 46-47].

This recent wave of emigration has several peculiarities in comparison with previous outflows:

- the diversity of individual motivations;

- the longevity of the process; 
- short or interrupted stays abroad;

- dominance of young people among participants,

- depopulation in the sending country which limits the possibilities to compensate losses of the population and labour supply.

The latter marks a great difference with traditional sending countries in Asia and Africa which have high fertility and population growth rates. Emigration from these countries to some extent helps to level off population growth, the employment rate and income levels with receiving countries. In Latvia, in contrast, emigration may well cause faster aging, shortages in the labour supply, some increases in wages, corresponding decreases in investments, as well as smaller effects from investments in demography and education. Instead, the most advanced EU member states receive a relatively qualified labour force without any delay and investments. It may well enlarge existing difference in living standards between sending and receiving countries [7].

Because of these consequences, current emigration has evoked negative public evaluations and requires an appropriate migration policy.

\section{MIGRATION POLICY}

Migration policy may be defined as the state's attitude to certain flows of migration and activities to regulate their intensity. Since Latvia regained independence in 1991 migration policy priorities have changed significantly. Initially, the priority was to support repatriation in all directions - migration of ethnic Latvians from Russia and exile in Western countries towards Latvia and emigration of aliens from other republics of the USSR. There was special law on repatriation which envisaged compensation for travel expenses and a municipal flat freed up by émigrés. In addition, the United States financed housing construction in Russia for Soviet military personnel leaving Latvia.

The next task was to remove legal barriers for travel between Latvia and most other European countries. After Latvia joined the EU in 2004 not only visa-free travel and 90 days' stay was allowed, but also free movement of migrant workers, and in three countries employment without working permits.

Due to inevitable structural changes in the economy, shortages of certain specialists occurred. To address such problems, a special Law on immigration was adopted allowing enterprises to invite migrant workers from so-called $3^{\text {rd }}$ countries if the Employment office over a month's period could not offer a local labourer of the qualification required and the employer guaranteed a salary at the average level for Latvia.

Due to the free movement of labour some $5 \%$ of the active age population have left Latvia for more prosperous EU member states, shortages of labour force have become more frequent and employers have demanded a liberalisation of immigration rules. These demands are not popular with the public or officials because both groups are well aware of the likely consequences. During the Soviet occupation from 1944 to 1989 Latvia experienced massive immigration of colonists from other republics of the former USSR (mainly Russia, Belorussia and Ukraine). It caused drastic changes 
in the ethnic composition of the population: the share of ethnic Latvians decreased from $77 \%$ in the prewar period to $52 \%$ in 1989 and such a proportion did not facilitate the integration of all the ethnic groups even if there had not been the state's policy of Russification. The age composition also changed. Among migrants the share of young people 16-29 years of age was twice as large than among residents of Latvia, but their fertility was lower because they settled mainly in the large cities where housing conditions were poor precisely as a result of intensive immigration. Over 30-40 years of working life these deformations of the age composition led to excessive aging, which is currently still a problem [3]. Similar observations were made in some other European countries [5, 12].

The same possible consequence of further immigration was calculated by Austrian demographers for their country. Their conclusion is the same as that made in Latvia: minimisation of aging and the sustainable reproduction of the active age population is possible only through support to families to raise the birth rate. The problem is that this supplement to the labour force can be expected only in some 18-20 years. In the meantime employment and migration policy should be implemented $[10,14]$.

Immigration is hardly suitable for Latvia, as the situation differs considerably from that of the old EU member states. Wages and living standards in the country are several times lower and can't motivate guest workers from traditional African and Asian sending countries rather close to the more advanced European states [1]. Latvian employers hope to hire a labour force mainly from neighboring Russia and Belarus as there would be fewer language barriers. Nevertheless in all the services and companies of industrial branches owned by European investors, skills in the state language, English or German would be necessary. Wage differences with the old EU member states could well motivate guest workers to further migration. The latter is not beneficial neither for employers nor the local community, which is interested to become as integrated as possible to avoid conflicts and indifference to the culture, environment and development of the country.

Another reason for instituting a migration policy is the demographic consequences of current emigration from Latvia. As already mentioned, traditionally, sending countries have extremely high birth rates, low employment and widespread poverty. In such situations emigration to prosperous countries and remittances to families left in the homeland help to level population growth and standards of living in sending and receiving countries.

By contrast, in Latvia the birth rate is too low even for the replacement of generations and emigration may cause additional loss of potential parents. This means that there are no possibilities to compensate the loss of human resources caused by emigration and a supply of guest workers to the old member states of the EU will stop in about 10 years, not to mention the extreme aging and shortage of the labour force in Latvia and some other East European countries.

Demographic losses in these countries are connected with economic losses; the means invested in upbringing and education of young people up to graduating secondary school then benefit not the homeland, but more prosperous hosting countries. Due to such an unfair redistribution, differences in welfare in old and new member states increase, rather then level out. 
All these reasons lead to the conclusion that the most desirable goal for migration policy of Latvia would be minimisation of emigration and promotion of remigration of recent labour migrants from current receiving countries [6]. Such goals do not mean any limitation on travel for studies, professional contacts and experience, tourism, etc., but only to avoid a redistribution of population. Such a policy is rather successfully enforced in Ireland and is currently being initiated in Lithuania. The state's activities necessary to meet the goals of migration policy can be chosen according to the results of several surveys recently carried out among potential migrants, actual émigrés and those who have returned [4 etc].

\section{ACTIVITIES TO AVOID LOSSES FROM EMIGRATION}

The former USSR and DDR eliminated emigration by exclusively restrictive methods and military force which is contradictory to the very principles of freedom and democracy, not to mention the free movement of workers within the EU. The best results in all kinds of social regulations could be attained through the elimination of obstacles or limitation to desirable activities.

According to the results of surveys recently carried out in Latvia, the main reason behind current emigration is low pay for work and rather bad working conditions, as well as difficulties in finding a proper job in some small towns and rural areas. Accordingly, the decisive means to minimise emigration would be leveling of wages and social guarantees with the more advanced receiving countries. Some farseeing companies and employers have already started to gradually increase wages and implement other improvements, while others rely on the eventual possibility of hiring guest workers from Eastern neighbors ready to work for rather low pay. Such actions temporarily make the latter companies more competitive and undermine the improvements achieved by others. The situation could be changed by certain activities of the state.

First of all, the legally established minimum wage should be increased. The current level is the lowest in the EU and provokes employers to pay part of the real wage unofficially, thereby avoiding any taxes and insurance. This has far-reaching consequences on the state's possibilities to guarantee a proper pension and support families, all of which could raise the general welfare.

No less important is increasing wages in the public sector to avoid losses of qualified employees leaving for other countries and other branches of the national economy. Among employees of the public sector are teachers, researchers and physicians. Low salaries among the latter have already resulted in pronounced aging within this professional group. This may well cause a lack of medical services for residents of rather remote areas. A shortage of teachers is already a problem in large cities because there are more possibilities to find other work which is more appropriate for their diploma but better paid (especially those teaching foreign languages, IT, chemistry, etc.). Higher wages for teachers would not only keep them at school, but also raise the prestige of university education. Up to now, education is not as popular among boys as among girls, and this is one of the reasons for the current shortage of specialists in industry and construction. 
The preservation of low wages was until recently thought to be attractive for foreign investors. But since Latvia joined the EU this argument has lost its validity as potential workers prefer to earn more working abroad. Employers and the ruling political parties must recognise that cheap labour is not the right way to a knowledgebased society with high productivity and a sustainable supply of qualified labour.

To ensure the latter in addition to raising wages the state is expected to bring its family policy up-to-date. The income of families with children can be increased and the shortage of well-educated young employees reduced if the demand for places in child-care centers just after the end of fully paid child-care leave (1 year) would be satisfied. Municipalities could devote more finances for this task on the condition the state covers all the expenditures for competitive wages to well-educated careers in child-care centres.

The financial situation of families with school-children would be improved and the necessity to go abroad for additional income diminished if the monthly family allowance would be increased at least in August to cover additional expenditures for text-books, school bags and pupil's clothes.

All the mentioned proposals are not new but repeatedly postponed by ruling bodies because of the limited national budget. At the same time, proposals to introduce taxes on profits from dividends, property sales, etc. are repeatedly rejected. These profits are supposed to become capital for investments, modernisation of production and new working places. Current emigration shows that in reality these hopes have not materialised, and raising profits for owners is not the right means to avoid population losses.

Up to now remote areas have suffered these losses most of all as they have lower rates of employment and residents have fewer possibilities to choose a proper job. Among the reasons one could mention equal tax rates in the capital city and the most remote rural districts, a rather sparse population density, the poor condition of local roads and the insufficient frequency of public transport. Regional policy could be implemented by differentiation of the profit tax by distance from the capital city and additional investments for modernisation of all kinds of infrastructure outside the most advanced central part of Latvia. More information for employers about the possibilities to use different kinds of distance work could also be of some help.

In spite of existing unemployment levels, employers used to explain their demand for immigrants with reference to the imbalance between the qualifications of the unemployed and graduates of all levels of education and the demand for certain specialists. This problem is partly caused by the low motivation of boys to learn after basic school and technological change, which makes it next to impossible to foresee the demand for specialists several years ahead, thereby permitting greater planning in tertiary education. One solution could be the renewal of mandatory secondary education, which could be comprehensive or vocational depending on the choices of students. Sufficient graduates could be trained to add to the skills of any profession in a short enough time period.

Some means for the proposals above could be saved in the state's budget by decreasing the number of civil servants which currently keeps increasing as the population decreases. This goal may be achieved by reducing the number of ministries 
to the previous level: from 18 to 12 ; by combining all the specialised e-registers; by properly defining the tasks and expected results for each of the departments. The latter would allow eliminating those that had already fulfilled their task, become superfluous or ineffective.

The lack of proper statistics on emigration mentioned above hinders evaluation of the losses caused by emigration and drafting and implementing an effective migration policy.

In the situation of free movement of labour within the EU data on labour migration could be collected from related offices in the hosting countries. The problem lies in different rules for registration of guest workers used by each of the member states, while a draft set of common rules has already been prepared. Certain data on family members and students abroad could be collected during the coming Census in 2010 or 2011, if not only the resident population but also those present were registered. It is unfortunate that this was not done in 2000, but even these data will demonstrate the sad consequences of an ineffective social and population policy.

\section{CONCLUSIONS}

As is evident from the proposals outlined above, most are not specifically targeted at migration, but rather address family or employment policy in a context of aging, depopulation and a decreasing supply of labour. This is not by chance. People always tend to migrate from regions with a poor standard of living to those with higher standards, and parents are forced to limit the number of children in their family if their income is too low for the maintenance of two or three offspring and they are not confident about employment and higher income in the future. Accordingly, a real increase in earnings and a gradual leveling of the standard of living in all the member states of the EU would help both to minimise emigration and raise fertility.

It follows that a migration policy aiming to revert the outflow is an inseparable part of population policy and can be successful only if the latter is implemented on a full scale. Up to now all the laws and decrees of the Government are accepted in compliance with the Constitution, directives of the EU and possibilities of the state budget without taking into account the preconditions for reproduction of the population. On the contrary, the shock therapy used to ensure the transition to a free market economy led to an unprecedented increase in premature deaths, a decrease in women's employment and also the birth rate - especially in families with single earners. All this resulted in the current decrease in the number of the active age population, extreme aging and depopulation. The situation could change on the condition that state policy is carried out in accordance with the needs and desires of the population.

In the National Development Plan for 2007-2013, recently accepted by the Saeima, a high quality of life is already recognised to be the main goal. Correspondingly, all population policy measures should be implemented before a large portion of the population is lost. 


\section{BIBLIOGRAPHY}

1. Bauer T.K., Haisken- De New J.P., Schmidt C.M. "International labour migration, economic growth and labour markets: the current state of affairs." In: The New Demographic Regime. Population Challenges and Policy Responses. UW, New-York and Geneva, 2005; 111-135.

2. Demography 2006, Rīga, Central Statistical Bureau of Latvia, 2006.

3. Eglīte Pārsla. "Demographic Consequences of the Soviet Occupation in Latvia." In: The Soviet Occupation Regime in the Baltic States 1944-1959: Policies and Their Consequences. Symposium of the Commission of the Historians of Latvia, Vol. 9. Riga, 2003: 256-268.

4. Eglīte P., Markausa I.M., Pavlina I., Brants M. „Leaving Latvia since joining EU.” (Contents, tables and summary in English) Apcerējumi par Latvijas iedzīvotājiem / Nr.12 Rīga: LZA Ekonomikas institūts, 2006: 7-57.

5. Heran Francois. „Cinq idees recues sur l'immigration.” Population \& Societe. INED, Paris, No 397, Janvier 2004: 4.

6. Indāns I., Roze M. "Migration Policy in Latvia after the EU Enlargement." In: A look into the Future: Latest Demographic Projections. Commission of Strategic Analysis, Research Papers 2(8) 2006. Rīga: Zinātne, 120-133.

7. Karnītis E. „Dzīves kvalitāte kā Latvijas nākotnes mērķis.” Nacionālās intereses: formulējuma meklējumos. Statistiskās analīzes komisija. Zinātniski pētnieciskie raksti 1/ 2004: 105-120.

8. Latvian Institute of International Affairs, Konrad Adenauer Stiftung. Immigration policy in Latvia - the problems and future perspective. Riga, 2006. Summary: 46-47.

9. Latvijas Padomju Enciklopēdija 3. sēj. "Emigrācija", 1983: 165.

10. Lutz W., Sherbov V. "Can Immigration Compensate for Europe's Low Fertility." European Demographic Research Papers, 2003/1: 16.

11. Misiunas R., Taagepera R. The Baltic States: Years of Dependence 1940-1980. - London, 1983: 333.

12. Saczuk K. A "Development and Critique of the Concept of Replacement Migration." CEFMR Working paper 4/2003: 22.

13. Šmulders M. "The Results of 70 Years of Bilateral Relations between Latvia and the USSR“// Latvijas Zinātñu Akadēmijas Vēstis, 1992 - 1: 31-38.

14. Vignon J. "Responses to the new demographic: present and future strategies for the European Union." In: The New Demographic Regime: Population challenges and Policy Responses. UN, New York and Geneva, 2005: 45-56. 


\title{
(New) Markers of Lithuanian National Identity: Re-Defining Global and Native
}

\author{
Jolanta Kuznecoviene \\ Vytautas Magnus University, Lithuania
}

This paper presents research conducted by the Centre of Social Anthropology at Vytautas Magnus University. The research was conducted from September 2005 to December 2005 and is based on 40 semi-structured interviews with informants who are inhabitants of Lithuania and call themselves Lithuanians. The research sample proportionally represents different age, gender and education groups, as well as different regions of Lithuania. The main aim of the research was to find out what people think when they talk about being Lithuanian, in other words, what does it mean for them "to be Lithuanian".

The paper presents data revealing both the main features and markers of changing Lithuanian national identity under conditions of globalisation and the accession of Lithuania to the European Union, as well as the problems related to the processes of mobility and immigration of EU citizens to Lithuania.

The research is based on the following theoretical ideas:

1. The nation could be described in relation to the concepts of citizenship or culture (Lindholm 1993, 4; Smith 1991, 9ff).

2. National identity is always contextualised: the context or the situation determines the prominence or neglect of certain features/markers of national identity (Greenfeld 2001, 251; Barth 1969, 14; Valantiejus, 1999,7).

3. The content of identity could never be understood as a stable and unchangeable phenomenon (Miller 1995, 17,18, 22).

4. It is impossible to mark one or several features/markers which could be used as peremptory criteria of national identity (Miller 1995, 45).

5. If we claim that a certain group of people is a nation, that means that we have to say not only something about their culture, behaviour and physical features, but how they understand themselves as well (Miller 1995, 45).

6. There is no single feature/marker that is shared by all people assigned to one nation (Miller 1995, 45). 


\section{MARKERS OF LITHUANIAN NATIONAL IDENTITY}

One of the first questions to our informants was "Why do you conceive yourself as being Lithuanian?" To answer this question, many of the informants used terms such as "origins", "born/raised in Lithuania", "language" and "love towards Lithuania".

\section{Born and raised in Lithuania}

The markers "born" and "raised" are almost never separated and detached from each other in the responses of our informants. Mostly "born" goes together with "raised" in terms of content and priority of articulation. The fact of being born or not in Lithuania is not a criterion for describing a person as Lithuanian or nonLithuanian:

"Firstly, because I was born here, I have lived all my life here... I was born and raised in Lithuanian culture." (man, 25)

"Say... if you have been born [of Lithuanian parents] in another country and after two or three years move to Lithuania...I think...it is not important [where you were born]. The faster you return back to Lithuania, say from Zimbabwe, the more the fact of the birth, that physical fact, loses its meaning." (man,26)

"Born" is the beginning of being raised in a certain environment or country. According to our informants, environment is everyday life, surrounding culture, traditions, mores, people. The environment highlights Lithuanianness relating a person with the traditions, mores, culture. This statement was illustratively explained by one of the informants: "a human being is an object with certain features given depending on the environment. If he adopts the features of the environment, he could be considered a member of that nation." (man, 36)

The majority of the informants thinks that "to live in the Lithuanian environment" is the determining factor for becoming Lithuanian:

"Let's say, if you are born here, I still think that Lithuania is there, because you are part of Lithuanian society from the very moment of birth, you are connected with the mores, traditions, or some other features why you conceive yourself being Lithuanian." (man, 20)

"Born in the Lithuanian environment" is named by the informants as one of the main markers of Lithuanianness - a guarantee and confirmation of being Lithuanian.

However, according to the research data, the informants give different meanings to the term "Lithuanian environment". The content of the concept "Lithuanian environment" was revealed by the analyses of the meanings of the terms "Lithuanian/ non-Lithuanian", "native/strange".

\section{Native/strange}

Some of the informants clearly separate the concepts Lithuanian/non-Lithuanian. Usually, in doing so, they use markers based on archaic Lithuanian traditions, mores and symbols of material culture. This group of informants sees non-Lithuanianness/ 
strangeness in the culture of youth, in the festivals which have recently begun to be celebrated in Lithuania, in the titles, labels, brands and even in the forms of free time:

„For instance, weddings have absorbed many details from America. A bridal party - what does it mean, this contemporary hen-party? (...) the party for the groom as well. It's absolutely non-Lithuanian. Again, All Souls day, Halloween, misrepresent our traditional festivals. The titles of companies, shops - plaza, glaza, maza... I don't understand anything, even youth music, groups such as "Yva" - what is yva? It would be better if it were fly agaric.” (woman, 47)

The other group of informants depicts the "melting" of boundaries between Lithuanian and non-Lithuanian things and behaviour. They use more abstract markers for Lithuanian and non-Lithuanian than the previously mentioned group and easily "transform" non-Lithuanian into Lithuanian. We detected the following strategies used by our informants for "transforming" non-Lithuanian to Lithuanian:

1. Denying strangeness as a barbarism. For instance, the informants were asked to name strange (non-Lithuanian) things or behaviour in their everyday life and one of the informants even questioned the notion of "stranger". According to him, that which is common in the whole world or Europe is not strange. Global does not mean strange, it is merely that which exists everywhere. Global culture becomes part of local culture, and there is no danger in becoming non-Lithuanian by consuming it. Global/strange is understood as global/native or just native:

"But I don't know what "strange" means. They are global, in the sense that they are everywhere (...). You see Coca-Cola, it is all over Europe, all over the world. You see kids with roller-skates or motorbikes or with something else - it is inseparable." (man, 20)

"But everything is a strange culture to us - the symphony and movies did not originate in Lithuania. But people did not become non-Lithuanian from that." (man, 48)

2. In this case, the denial of strangeness in the surrounding cultural environment is based on the understanding of culture as a regularly changing phenomenon. For example, one informant states that processes of "non-Lithuanian" transformation into "Lithuanian" are inescapable. Everything that now seems and is described as strange will later become native:

"I suppose it is inescapable. I think that what we will see in the future anyway will be very different. What we call non-Lithuanian will seem Lithuanian in the future." (man, 33)

"Maybe such things are traditional. Generally, views are changing. During a wedding newlyweds were sprinkled with grain, or people were turning so that the harvest would be successful. Now nobody does so anymore. I don't think that people who don't do so are not patriotic or non-Lithuanian. And these [traditions], no matter how important they were hundreds of years ago, there is no such thing anymore. And that's OK, it is as it should be. Indians don't take scalps any more either." (man, 48)

3. This strategy means that the conflicts of global/local, strange/native are eliminated, the uniqueness of Lithuanian culture is preserved by the transformation of 
"what" (Lithuanian/non-Lithuanian) into "how" (Lithuanian/non-Lithuanian way of doing something). Merely the process of consumption of some non-Lithuanian thing transforms that non-Lithuanian thing into something Lithuanian. Lithuanianness is spiritualised, announced as invisible, as an unavoidable part of the representation of the social world and culture visually defined as "strange":

"I agree in the sense that there is an invasion from the West, from the East and everywhere, but I think that everything a Lithuanian does, he does differently - he does it the Lithuanian way... And when we eat roast, which is obviously non-Lithuanian, but is prepared by Mrs. V, then it becomes Lithuanian and....and we eat it as Lithuanians. So I do not see anything to blame in that, this is a part of our contemporary culture. And I think (...) you make it Lithuanian yourself (...).” (man, 33)

\section{Love for Lithuania}

According to the research data the content of this marker of Lithuanian national identity could be described firstly as an emotional attachment to Lithuania. According to the words of informants, Lithuanianness is based on "deeper things". "Deeper things" are respect, love to Lithuania, "the pull to return", "a craving", "the effect of returning", "nostalgia", "love towards the land", "patriotism":

"I think like this and like that, but Lithuanianness sits somewhere deeper anyway. And it is nostalgia, ... patriotism or love towards Lithuania or some deeper things, the meaning of which is not expressed by superficial things." (man, 33).

The majority of informants say that love towards Lithuania means the ability to forgive, tolerate the difficulties and shortages which people face while living in Lithuania:

"First of all, it is the love of your country. What does it consist of? It consists of... first of all, that even after a long time, even a very long time, it is returning back to Lithuania, it is... love, when you stay on the hill somewhere, by a lake, and everything around belongs to Lithuanians. There is my country, there I am, my nationals, it does not matter what they are, even very bad, but any way they are mine. And this is Lithuanianness in my opinion." (man, 25).

The second important component of the marker "love to Lithuania" is the moral obligation to Lithuania. To be Lithuanian means to be a patriot, and to be a patriot first of all means not to talk negatively about Lithuania, not to be passive about everything that is happening in Lithuania. Frequently, "love to Lithuania" is combined with civic activity:

Interviewer: what does it mean to be a patriot in your opinion?

"For instance, not to litter. In terms of speech, not to defame the place where I was born, that country (...). For me patriotism is that you are interested a little bit in the political life of Lithuania... I do not spit on that, if there are some useful solutions for Lithuania and I am reacting to that, I say that as a patriot, that is very good, if something is negative, 
I say, that is nonsense, that is bad. This is one of the manifestations of patriotism." (man, 26).

When talking about the marker "love to Lithuania", the majority of informants do not describe love to Lithuania as a romantic feeling intrinsic to just a few people. In many cases, it is an imperative demand or one of the main markers of Lithuanian national identity.

\section{Citizenship}

Respondents distinguish between being a Lithuanian citizen and being Lithuanian, as well as between citizenship and nationality. According to informants, this point of view is rooted in the content of the Lithuanian passport. According to the law, when filling the documents for receiving a Lithuanian passport, a person must point out whether and which nationality to inscribe in the passport. The majority of the informants stated that citizenship is a formal relation between a person and the state, encompassing some political and social rights and obligations. According to a few informants, for the Lithuanian citizen, being Lithuanian is an "inner" feature, in contrast to the "outer" feature - having a passport. Lithuanianness is described by informants not as a document, but as patriotic, loving feelings, thoughts and behaviour towards Lithuania. Lithuanianness, according to them, is a wider concept, including more feelings (precisely feelings, and not civil rights and obligations). That is why it is impossible to be Lithuanian if one does not have the feelings mentioned previously. A passport is not a criterion for Lithuanianness. It confirms the right to live in Lithuania, describes a person's relations to the state and the law, but not Lithuanianness. The majority of informants describe the passport and citizenship as a necessary but insufficient condition for a non-Lithuanian to become a Lithuanian:

"If a man is a Lithuanian citizen, it does not mean that he is Lithuanian. These two things have nothing in common". (woman, 49)

"For me... nationality is more than citizenship. It is natural, if I was born, raised, lived here and raised my kids here, then I am a Lithuanian citizen, but citizenship is a narrower concept than to feel that I am Lithuanian, ... which is more feelings, features. It is a wider concept". (woman, 52)

When a line of separation between the Lithuanian and the Lithuanian citizen is drawn in that way, a Lithuanianness in which moral and emotional components predominate becomes a "privileged" feature, not shared by everyone and, contrasted to citizenship, which is easily achieved, more juridical and "less real".

Though the previously described notions of being Lithuanian and being a Lithuanian citizen are common to many informants, this is not the only approach. Undoubtedly, one finds also the view that "a Lithuanian citizen with non-Lithuanian origins is not Lithuanian". However, our research results show that there are also such notions as "half-Lithuanian", "not a real Lithuanian", "not a pure Lithuanian", which reflect a looser separation between a Lithuanian and a Lithuanian citizen:

"If he, let's say, came here while being in his thirties, lived a certain time and received a passport, I don't think he is already a real Lithuanian". (woman, 38) 


\section{Race}

The majority of informants stated that race is an extremely significant marker of Lithuanian national identity. For many informants all the features that have been described previously become absolutely insignificant because persons from another race are not accepted as Lithuanians. It was frequently acknowledged as "my problem" by informants; however, the verdict was very strict - a black person cannot be Lithuanian, even if of one's own flesh and blood:

"[If your son married a black woman]. My grandson could be a citizen of Lithuania, but never a real Lithuanian!

Why not?

Because there are no black Lithuanians anywhere in the whole world". (woman 49)

"If a black person got a Lithuanian passport in his early twenties in a strange way, it means he is Lithuanian. But still, I don't consider this person to be a real Lithuanian. Only white people could be real Lithuanians”. (man 18)

\section{BECOMING A LITHUANIAN}

The research revealed several different standpoints on a non-Lithuanian person becoming a Lithuanian.

\section{THE POSSIBILITY OF BEING ACKNOWLEDGED AS LITHUANIAN}

Although many informants perceive Lithuanianness as an innate feature, the majority of informants accept the possibility of becoming Lithuanian:

"Of course, you can choose to become whatever you want, not only Lithuanian". (woman 30)

Doubts about the possibility of becoming Lithuanian are usually based on the view that people are related with their motherland and cultural origins by a strong emotional tie:

"All of us are related to our Motherland [...]. Wherever you're born, wherever you've grown ... and... to change to... someone else, I think it is very hard". (woman, 68)

This attitude is a demand for cultural assimilation and denies the possibility of emotional relations developing with the new homeland. However, the informants who acknowledge the possibility of becoming Lithuanian point out the fact that in order to become a real Lithuanian it is necessary to stay and live in Lithuania a long time. The most plausible chance of becoming Lithuanian is for those who are children, grandchildren and great-grandchildren of those who came to Lithuania. Another possibility of becoming a Lithuanian is related to a person's desire and endeavours:

"If there is a strong intention... you could become... if someone tries hard enough to be a Lithuanian..." (woman, 65) 
"I think there are people who have something deep in their origins and kinship... Grandparents or something like this..." (woman, 56)

"Only over a long time period, fifty or eighty years, could a person almost become a Lithuanian..." (man, 90)

"But this one, no way... yes, no way... . Only children, grandchildren and great-children... [will become Lithuanians]." (woman, 30)

\section{Adequacy to the criterion}

Another position that has been clarified during the research is based on the concept of "becoming". The main criteria (factors) suggested by the respondents are: "assimilation to Lithuanian culture", "use of the Lithuanian language", "love of Lithuanian culture", and an "inner feeling of being a Lithuanian".

If a non-Lithuanian person respects Lithuanian culture then he/she certainly may become a Lithuanian. Respect for Lithuanian culture means to be immersed in Lithuanian culture and to participate in it:

"I suppose a person who wants to become a Lithuanian should know the culture, famous people and be deeply interested in the culture. Some should participate in this activity, but of course, not everybody is able to do that..." (woman, 38)

A frequently mentioned criterion "to respect Lithuanian culture" is very close to the marker mentioned by informants "to belong to Lithuanian culture". Here, belonging is usually perceived as a spontaneous, inevitable process that takes place:

"If you live among these people, a person spontaneously gets used to it.

Everything is so close to you, when you live among people". (woman, 38)

The feature "to respect Lithuanian culture" means to celebrate all the Lithuanian holidays, practice Lithuanian customs, to be interested in cultural life, visit the theatre, and even acquire the Lithuanian spirit. The "Lithuanian spirit" is "the smell of the atmosphere, nature and the Land". The "Lithuanian spirit" is Lithuanianness. According to informants, there is only one way to acquire the "Lithuanian spirit" - to live in Lithuania. However, informants stated that children, grandchildren and great-grandchildren of Lithuanians have the opportunity to acquire the spirit:

"I suppose he really is interested in Lithuanian culture. He reads... gets involved... visits theatres and gets used to it in this way. There are [national] holidays, customs (...) he at least tries follow, understand and get to know it". (woman, 56)

Informant: "If a person assimilates and naturally passes on Lithuanian uniqueness to their children and even grandchildren, then the children and grandchildren could certainly be regarded as natives [Lithuanians]."

Interviewer: "You are saying they have to give something, but what do they have to give exactly?"

Informant: "All that "Lithuanian spirit"... that is called Lithuanianness." Interviewer: "How is it passed on to children?

Informant: "There are so many ways... but even being in a certain country, all the surroundings, the mood of nature, the smell of the land, the taste, 
the colours, plus the history of the country, all these stories and so on and so forth..." (woman, 30)

The meaning of "belonging" means becoming one of "us". "Being one of us" means to be and to act in a "Lithuanian way" or "as a Lithuanian":

"If a person does everything... as a Lithuanian, his manners are like our own, then there is a chance he could get used to Lithuanians, but only in a long period, not at one go..."

"What is a long period?"

"Well, many, many years... (...) ten, twenty". (woman, 78)

Discussing the issue of becoming Lithuanian, language is a critical factor. The majority of informants stated that language is a particularly significant factor during integration into another culture. Having no language skills is equated with a reluctance to accept Lithuanian culture and Lithuania itself. However, knowing the language is not enough to become Lithuanian:

"If a person comes to Lithuania and lives here, he certainly must know Lithuanian”. (man ,49)

Interviewer: "So, you're saying that a person who is not Lithuanian but knows the Lithuanian language may become a Lithuanian?"

Informant: "Yes, indeed, he may become Lithuanian, but it is not enough to know Lithuanian. "Mm... only to have some skills in Lithuanian... I suppose it is not enough" (woman, 38).

Though stereotypically possible, the concept "to be worthy of Lithuania" implicates action. The criterion "to be worthy" firstly is characterised through the concept of self-devotion and loyalty to Lithuania. The concept "to be worthy" usually doesn't mean specific and heroic acts. It is quite enough to do one's daily duties, to be an honourable Lithuanian and do the best for Lithuania in general. If someone loves Lithuania or wants it to be known in the world (according to informants, it is not necessary to do something grand, it is quite enough to want something grand to become a Lithuanian) - it means he/she deserves to become a Lithuanian. The concept "to deserve" also means that it's quite enough to glorify Lithuania academically or culturally without doing something special.

Interviewer: "What needs to be done for a person to be worthy of being Lithuanian?"

Informant: "He must be fair. I mean, you don’t have to be "fal $\square$ yvu", a person with bad intentions for yourself and don't do too much harm to others. (...) Even doing one's daily duties... (woman, 30)

The next criterion mentioned for "becoming" Lithuanian is the necessity of feeling. To "feel Lithuanian" means to have an "inner feeling, inner knowing". It also means to be committed to Lithuania, to love Lithuania and to be a patriot:

"I suppose that there are inner affairs, inner understandings, inner feelings, but definitely not external features that determine whether one becomes Lithuanian". (woman, 56) 
"I suppose it's the same in all kinds of fields? It is possible to be deserving in all of these fields: art, sports, politics or even business. The most important is that all these external aspects should be related somehow to the inner feeling. But if all the activity is done with love and self-denial towards Lithuania, then this person could be [Lithuanian], I suppose..." (man, 49)

The research revealed several different aspects about the possibility of becoming a Lithuanian. Though many informants deny the possibility of becoming a Lithuanian, the majority acknowledged that "becoming" is closely related with certain criteria: "respect for Lithuanian culture", "getting used to Lithuanian culture", "Lithuanian skills", "worthy of being a Lithuanian", an "inner feeling of being Lithuanian", "being a patriot of Lithuania". Though the informants noted that these criteria are essential, moral and emotional criteria are critical and the remainder are necessary, but insufficient.

To summarise, the process of globalisation that is represented as a socio-cultural phenomenon regularly changes the socio-cultural setting. The meaning of the concepts "Lithuanian/non-Lithuanian" acquires features that unify different cultures. The hypothetical assumption of this research could be formulated thus: the processes just named "aggravate" the search for unique/exclusive "natives" and easily identified or objectified markers of Lithuanian national identity and make the features of the moral-emotional dimension determining criteria of Lithuanian national identity.

\section{BIBLIOGRAPHY}

1. Barth, Fredrik. 1969. Ethnic Groups and Boundaries: the Social Organisation of Cultural Differences. London: Allen and Unwin.

2. Greenfeld, Leah. 2001. "Etymology, definitions, types", Encyclopedia of Nationalism, Volume 1. pp. 251-265.

3. Lindholm, Helena. 1993. "Introduction: A Conceptual Discussion" in Helena Lindholm (ed.). Ethnicity and Nationalism. Formation of Identity and Dynamics of Conflict in the 1990s. Nordnes. Goteburg.

4. Miller, David. 1995. On Nationality. Oxford: Clarendon Press.

5. Smith, Anthony. 1991. National Identity. Penguin Books.

6. Valantiejus A. 1999. $\square$ iuolaiki $\square$ kas tapatumas. Istorijos ir dabarties vertinimo kriterijai.// Sociologija. Mintis ir veiksmas 3 (5):5-15. 


\section{Latvia: Social and Political Dilemmas}





\title{
Changes in the Towns and Countryside of Latvia after Accession to the European Union
}

\author{
Liga Rasnaca \\ University of Latvia doctoral student \\ Zenija Kruzmetra \\ University of Latvia doctoral student \\ Dina Bite \\ University of Agriculture
}

\section{INTRODUCTION}

The Lisbon strategy of the European Union and the corresponding aims of sustainable development of the EU envisage economic and social cohesion, the provision of equal opportunities for all members of society, the involvement of every individual in economic, political and social processes, the consolidation of society, and balanced national development. The unbalanced regional development of Latvia is recognised as a challenge in the policy document the "Basic Postulates of Sustainable Development of Latvia". Latvia is becoming a typically mono-centric state with a fragmented administrative territorial system. The transformation from a socialist to a market-oriented democratic state and post-industrial society is a dynamic process of change even in the 21 st century.

\section{METHODS}

The research was carried out as a case study involving the analysis of policy documents and interviews with experts (40). The areas researched were chosen according to two criteria: distance from the capital (more than 100km) and distance (more than $20 \mathrm{~km}$ ) from important employment centres. Field work was carried out in all the regions of Latvia:

- Kurzeme - Piltene, Pāvilosta

- Vidzeme - Ape, Gaujiena

- Zemgale-Viesīte, Aknīste.

- Latgale - Dagda, Robežnieki.

Interviews were carried out in 8 rural residential areas, involving six small towns that are not district centres (see figure 1). 


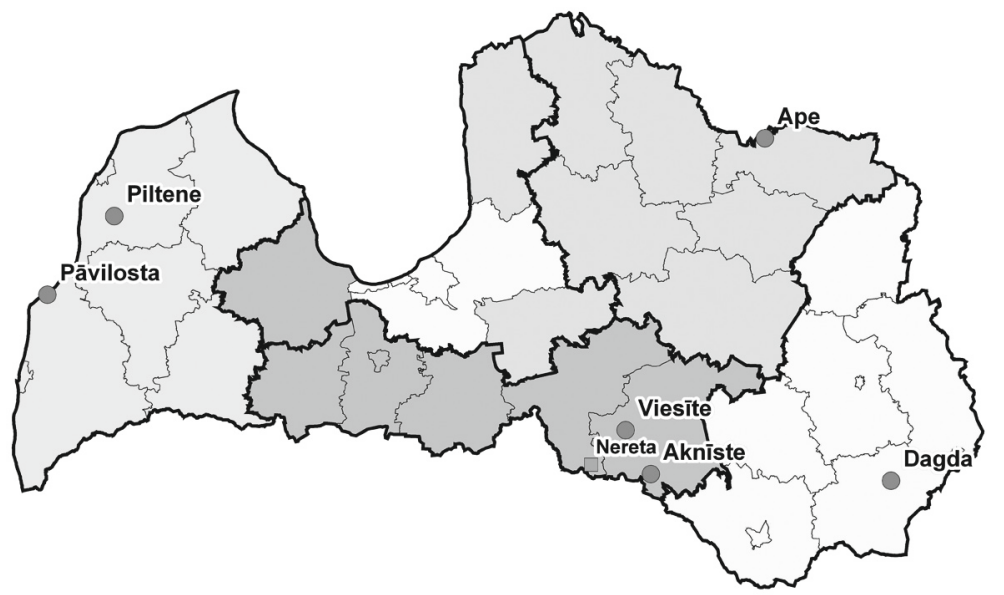

Figure 1. Small Towns in which Field Work was Conducted

The small towns do not fulfil administrative functions as district centres ${ }^{1}$. At the same time, these small towns are centres of first level municipal governance including the surrounding territory (Ape, Viesite, Akniste) or without the surrounding territory (Dagda). Small towns in Latvia are not centres to which people migrate; on the contrary, they are places from which people migrate. As in other countries in the northern EU, people from rural territories migrate to large centres ${ }^{2}$.

Municipal leaders or their deputies in charge of territorial planning, social issues and support for entrepreneurship were intentionally chosen for interviews. Local employers and temporarily employed respondents were selected according to accessibility. Their interviews provided the opportunity to explore the views of people in various social positions.

The transformation from socialist republic to independent state and EU member state entails social, demographic and economic changes. In the course of the research, attention was paid to several aspects of these changes:

- If residents of rural areas and small towns have experienced any changes during the last three years, what was the nature of those changes?

- How do leaders, municipal specialists, employers and those employed temporarily characterise the changes?

- Are the changes connected with accession to the EU?

- At what decision-making level can political agents influence the course of these changes?

The stance towards the changes was analysed with regard to migration and employment patterns. The role of different agents in the process of change is characterised by political expectations from the state, the EU, municipalities and NGOs.

Heretofore, differences in employment levels and population movements have not been well documented in small towns and the surrounding territories. There is no consensus about political solutions necessary to provide equal employment and social security opportunities for inhabitants of small towns and surrounding areas. The 
research explored the views of municipal leaders and employers regarding changes after accession to the EU and their ideas about future development. The main research assumptions concerned the ways in which people cope with changes, the possibility to explain coping patterns through path-dependency and flexibility, as well as the possibility of small towns to become "activity centres" for surrounding areas.

\section{THEORETICAL FRAME}

The theoretical frame includes characteristics of possible ways people react during social and economic transformation. The disposition towards changes differs due to the flexibility of agents during economic and social change. The changes in the sphere of employment are essential features of the transformation. Changes in employment opportunities, labour market structure, job security and mobility are evident after accession to the EU. This study examines employment issues in the context of migration problems. According to the "push-pull" model, migration is more intensive from places with high unemployment, especially longterm unemployment, many labour force dropouts, suggesting that migration is most sensitive to lengthy spells of joblessness. This hypothesis was confirmed in studies of migration and long-term unemployment in the USA during the Great Depression ${ }^{3}$. A similar study in Latvia at the beginning of the 21 st century is difficult to conduct due to a lack of statistical data about migration and emigration from small towns. The American study reveals that migration was greatest from the places where the search for work by the unemployed was most intense, where the proportion of long-term unemployed was higher. The relationship of joblessness to short or long distance migration needs further research ${ }^{4}$.

A neo-institutional perspective allows explaining employment differences at the micro-level through path-dependence ${ }^{5}$. The theory of neo-institutionalism tends to explain why changes fail, why a society facing reforms encounters and manages problems, and how individuals react to change. Resistance to change is characterised by the concept ,path dependence” which can be interpreted as ,dependence on a certain kind of past". The notion can be applied to individuals and social institutions, with emphasis on the interdependence of people and situations in resisting change ${ }^{6}$. The past is a difficult-to-change pattern of action created by social institutions, organisations and individuals. The notion of path-dependency is also used by proponents of evolutionary models of economics in which technological change, a growing intensity of capital use and changes in production structures are seen as the main drivers of change.

Path-dependency could be explained as individual rigidity concerning an acquired profession, skills and education, as well as to a workplace or previously successful behaviour in the labour market. The welfare policy of "old member states" in the European Union can be explained as path-dependency, as institutional dependency on state welfare institutions. Due to the low level of social security benefits (the guaranteed minimum income level is 24 lats per month in 2006) ${ }^{7}$, especially for those long out of the labour market and living far from large cities, it is not plausible that such "welfare dependency" could often take place in Latvia's small towns and adjacent territories. 
Flexibility means survival in a constantly changing environment that demands adjustment ${ }^{8}$, especially during the transformation from a socialist to a market economy and the associated changes in the labour market, local governance and social security systems. Flexibility refers to adaptability and versatility. A person's understanding of this varies depending on their location in the system (employer, employee or unemployed). Flexibility can empower persons by giving them new skills and flattening organisational hierarchies, or it can be accompanied by an intensification of work and routine tasks. Job security is unfeasible.

Functional flexibility and external flexibility refers to employers, employees and municipal actors. Functional flexibility could expand the roles and responsibility of workers, although it could make them worse off, resulting in intensification of work and less control over its pace. For employees the reorganisation of work often entails expanding their responsibilities, flattening the organisational hierarchy, reducing employment and introducing instability into the labour market. All these features had taken place in Latvia's labour market in the 1990s and some are still taking place in small towns and surrounding areas.

External flexibility can be implemented in various ways: downsizing the workforce or affecting vulnerable groups in the labour force (women after maternity leave, pre-retirement employees, young and low-skilled employees). As a result, some workers (e.g., women, rural residents) are ready to accept insecurity, low pay, and bad working conditions, including even informal employment without any social security. A lack of unionisation of a large part of rural workers may reinforce the vulnerability of these groups.

Employment "inflexibility" is linked to cultural values reflecting the gender structure of society. "Inflexibility" could be explained as resistance to changes, barriers at the individual, organisational or macro-level (the state and the EU).

The Latvian National Development Plan ${ }^{9}$ declares that the individual is at the centre of development, but this is not always evident to specialists of economic and rural development. They occasionally stress as a problem not the lack of employment in towns and rural territories, but the still "great number of small farms and support of the EU for landscape maintenance" $"$.

Both trade unions and families can play a positive role in labour market flexibility under two conditions. The first is selective measures aimed to promote the employability of weaker members of society, while strengthening support from the family and trade unions. The second condition is that losers in the process of change perceive the difficulties as being temporary and understand the long term opportunities wrought by changes in the labour market. Companies in less developed areas may be allowed to adopt a more flexible labour market regime if this temporary advantage is used to build a stronger position - one compatible with the general regime. ${ }^{11}$

Resistance to change can be explained through a neo-institutional perspective. Resistance can be characterised by a culture of interaction and communication, language and people relay symbols as representatives of experience. Neoinstitutionalism suggests that interaction patterns strongly influence people's thinking. To understand how collective representations become meaningful in everyday life, 
social researchers need to observe how groups and individuals coordinate themselves according to patterns of interaction. Everyday interaction helps reproduce social inequality. The resistance to change is generated as resistance to the dominant culture. (The culture of entrepreneurs and politicians differs from that of working people, especially those who do not have a regular paid job.) Neo-institutional theory suggests that changes in employment practices have little influence, if adoption is ritualistic or if organisational commitment is weak ${ }^{12}$.

Path-dependence helps explain the role of institutions:

- Varied degrees of success in post-socialist development can be explained through institutional patterns, traditions, resistance to transformations.

- Path dependence flows from shared historical experience. Legacies include local institutions, precedents, mutually consistent expectations and norms for social roles. Past events and strategic choices structure the search for new solutions.

- Building on past experience could mean exclusion of others.

- Post-industrial relations affect localities differently because the institutions are different and because solutions are determined by different configurations among local agents ${ }^{13}$.

Barriers to the implementation of changes were analysed with reference to the influencing agents (the state, municipality, an individual, organisation) and their connection with flexible, situationally appropriate, non-traditional action (not pathdependency).

\section{MAIN FINDINGS}

It is important to study the possibility of small towns functioning as activity centres since the imminent administrative-territorial reform (ATR) will make them centres of larger territories, including adjacent small municipalities. What is the role of "activity centres"? The most important role of small towns for the population in the surrounding area is to provide employment opportunities and render services ${ }^{14}$. In the research project, small towns were conceived in terms of:

- Providing places of employment;

- Instituting active employment policy measures;

- Having educational institutions;

- Having the necessary infrastructure for basic services (transport, post, IT);

- Having social and health care services and institutions.

The analysis of the interviews shows that not one of six small towns provides working places for the surrounding local population, even if it is possible to hire additional employees in local enterprises. During the research, only two small towns had possible additional workplaces - Dagda (sewing firm) and Pavilosta (fishing preserves factory). The free workplaces in both cases are not fulfilled by employees from local surrounding areas because of a lack of regular public transport connecting those centres with adjacent areas and low wage levels (which do not permit buying 
and using personal transport). An additional factor is that in both cases the work is hard, monotonous and without career prospects. Thus, the job slots in the fishing industry in Pavilosta are filled by workers from the nearby city of Liepaja from which there is regular bus transport. Such transport is not available for the population living in the surrounding area due to the low density of the population and the costs of bus service. Thus, there is no evidence regarding the possibility of small towns to become employment centres for surrounding rural areas. The provision of basic services, social and health care in small towns is often better than in local municipalities in the surrounding area, but the problem is the lack of regular public transport, which makes these services inaccessible for people from the surrounding area.

There are institutions of secondary education in all small towns included in the case study. The problem is ensuring the necessary number of pupils in each class; the threshold is higher for towns than for rural localities. This means that Piltene secondary school needs 15 pupils for opening class, but Nereta, with a similar number of inhabitants, needs only 8 . Vocational education institutions function in two towns (Ape, Dagda), but these institutions don't meet local demand for qualified specialists.

"There have been no changes in vocational education. No connection between the Ministry and the municipalities ... Nobody wants to work with heavy machinery, to weld... We should have an agreement about technical things". (Municipal representative, Dagda)

Representatives of municipal government mention the lack of qualified mechanics and technicians in the local labour market, - a lack not addressed by the local vocational school. Change requires action by the central government which is in charge of vocational education.

The disposition to change or resistance to new situations is revealed in the ways people react during a transformation. An analysis of the interviews leads to the identification of three patterns of social activity during the transformation in small towns and surrounding areas:

1) according to previous experience - in a traditional way;

2) leaving the village, town, and/or state;

3) flexible, non-traditional solutions, action using local resources.

The first way rural people and inhabitants of towns react to changes can be called a traditional approach. It is expressed as the implementation of usual, time-tested actions and behavioural models. This means using old-fashioned concepts, nonscientific, emotional evaluations typical of a traditional society ${ }^{15}$. Rural people stick to conservative concepts and traditional farming during the process of change. The traditional type of action is characterised by relying on previously accepted patterns and resisting change without flexibility at the individual or organisational level.

The clearest example of traditional action concerned the tendency of respondents to separate professions by gender:

"The men who want to work and have not become socially degraded all have a job. There is enough work for men. Even if you need something done, there is nobody to call... Women have fewer jobs... I started to raise 
this issue. As a response they opened a workshop for making clothes. We already started training, but the company sews coats for export and the qualifications of our people were too low. This is a painful issue here women don't have a job." (Municipal representative, Nereta)

This example shows the stability of gender stereotypes in the traditional distribution of roles. Men's professions are linked with physical strength and higher mobility, for example, woodworking or a job at the nearest town using organised transportation. Women's work is associated with service, education, health care and is characterised by less mobility. The stability of gender stereotypes in rural regions is evident in the results of a survey "Gender Stereotypes in Society” conducted in March $2006^{7}$. For instance, rural people stress the role of men as bread winners and the necessity for men to be successful professionally. The main role of women is still considered to be family care. The respondents have similar ideas regarding age limits for certain professions, for instance, a shop assistant at a town shop: „You think you could work at this shop at your age?!" (Local employer, Ape)

While there is a lack of employees in typically male and female professions, especially after Latvia joined the EU, the traditional approach to addressing employment problems is stable. Thus, gender and age stereotypes can be considered barriers to rural development:

"It is bad with jobs for women. While a man can go into the forest and somewhere else, it's harder for women. Sewing here goes on in two shifts. Here nearby. And there are mornings and days when they are really working in two shifts, but there are also mornings and days when there are dark windows. Obviously, there are no orders. " (Local employer, Viesite)

As can be seen, the traditional approach to the employment problem is stronger than the imperative of efficiently using resources. This is also evident in the desire to develop agricultural branches (dairy, grain) by those who acknowledge that they are not likely to be sustainable and stable:

“...dairy farms have 12-20 cows and my heart is not calm about them. What will happen if gas or milk prices rise? Prices are rising all the time. They had found their niche. Their herd is stable. " (Municipal representative, Viesite)

Respondents pointed out circumstances that engendered models of traditional behaviour. Individuals outside the regular formal labour market are not ready to accept discipline.

"The unemployed are used to going to work when they want to. When I can - I go, when I cannot - I don't go. ” (Local employer, Viesite)

Age stereotypes influence not only employees, but also employers and municipal representatives. Individual flexibility means readiness to change one's social position or place of work. A lack of individual flexibility is used as an argument for not starting some activity:

"Where do I go anymore? When I look at my personal code - should I boil over anymore?! It isn't so easy to start from the very beginning now." (Local employer, Ape) 
"But I think that there are definite age limits. I don't think that I am too old to change my living space, but I'm old enough to prepare for it seriously and to find the most important arguments for it." (Municipal representative, Gaujiena)

Municipal workers, local employers and the temporarily employed mention the inflexibility of state policy as a barrier to flexible action and opportunities in economics and the social sphere. State institutions did not take into account the specific difficulties of developing entrepreneurship in territories far from large cities - the distance, lack of specialised workers, inaccessible services and insufficient investments in infrastructure development, especially for roads.

"It is not convenient for investors to take materials here and then take the production back to Riga. I say, don't take it back to Riga, take it farther to Latgale, but they all disagree. Maybe it won't be too far in a couple of years, I don't know." (Municipality representative, Gaujiena)

Summarising the response to change, we have to conclude that the traditional approach is quite common. Moreover, an old-fashioned understanding of the countryside linking it with agricultural production limits other possible development opportunities.

The second way people react to change is to leave the place where the negative consequences of changes (unemployment, a lack of services) are more acute. Outmigration is a solution of sorts to the socio-economic problems of people in many regions of Latvia. People move to places where they can satisfy their needs, where life conditions are better, where there are jobs or better paid jobs. So the migration reveals the territories in which where people can satisfy their needs and where they cannot. Migration flows show uneven levels of territorial development; they show which territories are more attractive to people. The socio-economic processes of the country are reflected in migration flows.

Border-zone regions are especially subject to migration. They are situated far from employment centres. The main motivation for migration is looking for a job or a better paid job.

"My husband is in England, by the way. We have to educate our daughter she is the only child in our family. We cannot manage it with my salary and the poor wages he earns here. And all of us cannot be entrepreneurs and successful businessmen, you know". (Municipal representative, Gaujiena)

People of various ages, genders, both single and married people, and people with different educational levels and professional backgrounds are involved in migration.

"No, both men and women go. There are, of course, people who come back and say they have severely damaged their health. But they go, they go together with their families. And now when they come here for vacation, they say - you know, nothing attracts me here anymore. And I say to themyou have property, a house here. Let it be for now. Whole families go, children go to school there. They say they won't come to Latvia, why? I go there, I enjoy the education there. Why should I come back here where I don't feel I am needed? Such pessimism... I remember, one of the 
politicians said in one of his interviews - yes, we already have experience in integrating foreigners. So!" (municipal representative, Gaujiena)

There are varying numbers of migrants from small towns and the surrounding areas. The largest number of migrants is from Piltene. Thirty people have left for other countries from Piltene. The destination for migrants is different - regional centres, the capital Riga, border regions of neighbouring states, Ireland, Great Britain and other countries. Information about those people is received from their relatives and friends.

"There is no precise information about how many people have left, to which countries and for how long. More and more people are leaving. Two years ago we knew about all of them. Now the process is out of control. We don't even know where the people are, whether they stay in Riga or some other city or have left the country." (municipal representative, Akniste)

In some places one can notice that the "money of the workers abroad comes back" flats and houses are renovated, durable household goods are bought, loans are repaid.

"There was Lucija, who was unemployed. She had even taken a loan and left. Now she has already earned the money and the loan has been repaid. Everything is OK. In the autumn, it will be a year since she is there. There are maybe more people in debt in the cities, but also in the country it is very hard to pay back loans." (municipal representative, Akniste).

"We don't feel the foreign earned money flowing back. Money from those who have left comes through the families, mortgages, payments for water are paid. Some improve their houses. But they don't build new ones." (municipal representative, Ape).

The system of social security and the economy of neighbouring countries is assumed to be more progressive, better set up, and more friendly towards working people. The opportunity to work and move freely to Estonia is also counted as a benefit from joining the EU.

"The attitude is quite different in Estonia. They understand price changes, take them into account when changing wages. Our municipality cooperates with Mooniste, Estonia. There is social insurance, including health insurance. If there is idle time because of the employer, the workers are paid. Now both borders are open 24 hours and a guard is common. In Estonia 1 child is already at school, there is a salary, everything goes on. There are supplements for those attending schools that are farther away. Such a good example nearby, we could take it and implement it. Estonia is more economical!" (municipal representative, Ape)

The third way people behave during the transformation is flexible adaptation to a situation or new, non-traditional action. Some municipal leaders demonstrated their ability to see local development possibilities and weaknesses. For example, they see the possibility to use our traditions in musical education to sell services for Estonian children, but they have no resources to provide the necessary quality of roads, which is the function of the central government.

"We don't have the road for economic cooperation. Estonian children would like to come to our music school, but they cannot!" (municipal representative, Gaujiena) 
Leaders of local municipalities see possibilities to develop the bioenergy potential of Latvia, to support cooperation between farmers and energy producing biofuel, organising clusters, but state support is necessary.

"Biofuel is a great resource for rural development, we should promote the interest of landowners about it. A fuel supplement that could generate income would be very beneficial.“ (municipal representative, Dagda)

Only one municipality feels a sharp lack of workers as the result of migration, especially youth migration. Local citizens, municipal leaders and specialists have reacted flexibly and adapted, supporting the development of the local port and windsurfing. As a result there are additional jobs in Pavilosta, but a lack of available housing (bought by tourists for summer time) limits the possibilities to attract new specialists.

"One's energy occasionally disappears when struggling with the lack of a workforce. We don't have cleaners, workers who cut grass. No people who work. No youth who do physical work? We're like Europe where nobody is doing "black work". It is hard to attract new specialists to Pavilosta. The properties have Jurmala prices, people from Riga mainly buy them. Local people in Saka region sell it, then they leave. Old Pavilosta is "a dead city" now. ...Houses are guarded, people live there one month in the summer, and then they are left empty. There are no apartments to attract people. Officially unemployment is $4 \%$ and it diminishes step by step. We need a tourism centre specialist." (municipal representative, Pavilosta)

Flexibility could lead to negative consequences, as well, if it means temporary employment, living without a regular paid job, or without social security. Municipal social workers assume that there is informal employment of registered unemployed people.

"Practically there are no unemployed people. There are people who are not willing to work. Salary is very important. The first question is about the salary. Then he counts if it is more profitable for him to work an informal temporary job (without paying taxes) or to go to work (with taxes). But it is not profitable. An unemployed person is used to going to work when he wants. When I can - I go, when I cannot, I don't go." (municipal representative, Viesite)

So the lack of regulation promotes the lack of appropriate skills and the custom of working informally. It is not profitable to give this up, as long-term social security is not considered important enough to accept a lower income and regular job discipline.

The municipal representatives don't see reserves in the workforce among unemployed or temporarily employed persons, but many of them need help in integrating in the labour market. That means that barriers to starting regular work are not only subjective, but also objective. These barriers are the lack of regular public transport from many places near small towns, a lack of vocational education far from centres, incomes too low to permit buying a car. A temporarily employed person in Piltene and Rivas (20 km from Pavilosta) expressed a viewpoint different from that of municipal representatives. 
"If I was 30 years younger I would be in Ireland now. It is a bad situation with a job. There is something in the summer, but in the pre-retirement age...It is not worth going to Ventspils, you spend all you earn on transport. Odd jobs are paid 5 lats per day. Builders are needed, but at 50 you are already too old. For a living we have sorrel, potatoes, we help neighbours, work for ourselves and somehow manage. I would like a job with taxes for my pension but... The government should think. The biggest farms get money from the EU." (temporarily employed, Piltene)

The job seeker from Piltene expresses the wish to work officially with paid taxes because his retirement is close and he appreciates the connection between taxes and his pension. But there are no opportunities in the local labour market of the town. So he continues to work odd jobs in agriculture because the minimum wage in the city of Ventspils (44,000 residents) does not cover transportation and lunch expenses.

He sees possible solutions in a state policy reminiscent of socialism. At the same time, his pride does not allow him to look for help at the local level. The man would be ready to go to seek a job in some other country if he was younger; and he would be also be ready to go to work to Ventspils for a higher wage.

"The government should think...Industry could be developed, we had a jam shop on the collective farm, and the beer brewery was closed. We have no training courses here for large families. My family has neither begged nor asked anything of anybody. " (temporarily employed, Piltene)

Obviously both views are reasonable because the job seekers themselves recognise the importance of a decent salary. At the same time, it does not mean that in the case of equal wages, the job seekers would be ready to choose the informal job.

Pavilosta is becoming a tourism and windsurfing sport centre. A lack of housing and regular public transport from outlying areas of the municipality hinders employment opportunities in centres with developing businesses (for instance, the bus goes $20 \mathrm{~km}$ to Riva from Pavilosta just once a week only in the summer).

A temporarily employed person who lives $20 \mathrm{~km}$ farther is not satisfied with the situation.

"The bus comes once a week, but sometimes in the morning it does not turn in here if there are no people coming to Rivas, then it turns around and goes back. We are stuck here. The auto shop comes twice a week, the school bus drives regularly in winter, but workers cannot catch it after work. Berry selling is hindered by a transportation problem, as the collectors do not come here. The lack of transport stops everything. We work in the forest in the summer - planting, forking, and the employer drives us with his transport in the morning and in the evening, and pays a minimum salary. There is almost nothing to do in winter." (temporarily employed, Sakas region, Pāvilosta)

A situation similar to Rivas can also be observed at the forestry village $8 \mathrm{~km}$ from Piltene (three residential block houses). In locales such as those mentioned above, with weak service, labour and public transportation possibilities, even individual flexibility and readiness to work in various jobs does not solve unemployment 
problems. Only a flexible approach on the part of local employers can provide opportunities for at least temporary work.

\section{CHANGES AFTER JOINING THE EU}

All the representatives of the local municipalities involved in the research marked the influence of the EU on social and economic changes within the local community. The influence of the EU is connected with three directions: financing from structural funds, the common payment area, and agricultural support policy and migration.

"Many people leave for Estonia to work because saw-mills are closed here because of the high costs. There is a higher minimum wage and attitudes towards people are different as well." (municipalities representative, Ape)

"Workers go to Estonia from Ape during the season because the wages are stable and higher. Wages in Estonia are three times those in Latvia. Estonians don't come to work in the wood-processing and furniture sectors. The director of the kindergarten adjusts his working hours to make it possible to go to work to Estonia." (municipal representatives, Ape).

The most intense outmigration was connected with joining the EU. Representatives from all the municipalities noted that "it started some 3-4 years ago... the boom of mass departures".

Representatives of municipalities most often mention support from EU structural funds for infrastructure development and addressing social and unemployment problems.

"I can tell that there are three levels of using the money - the big ones can develop, medium size entrepreneurs have an incentive to work because people cannot work all the time like robots. A worker is involved in the process. He feels necessary, he goes, arranges things. You know, there is the organisation of rural women.... So they learned and then the money from Europe appeared. We went to a camp, studied, and acted it out. There was small project "Be as you want to be". There are also natural projects. If the foreigners give the money, it is at the level of an unemployment benefit, and it is impossible to develop for such a small sum. One can survive, but nothing comes of it without our own money. My women added this bit to their own bit and then it worked. They started successfully. It is already the third year." (municipal representative, Viesite)

The local employer, the owner of pet store, argues that to buy equipment using EU funds is not advantageous. It is more expensive due to bureaucratic demands. In contrast, agriculture support payments are judged to be very useful. Farmers, especially medium and small farms, are often targeted to receive agricultural support. So local agricultural advisers work as agents promoting flexibility.

"We advise people in writing projects. We often have to encourage people to take a project, that it is going to be all right (they will get 700 lats per year during the next 5 years)...EU money helps!!! Farmers would be broke without it." (municipal representative, Piltene). 
At the same time, local people who are temporarily employed are reserved. They do not point out any gains.

"More chairs in the Council, higher prices, there was a bar and it closed. It is bad that bread is sold already cut in slices because it grows mouldy quickly." (temporarily employed, Piltene)

This respondent does not understand which changes are connected with joining the EU. He personally does not feel support from agricultural support payments or projects funded by structural funds. But it is interesting that insufficient changes in local life are associated with joining the EU. It is possible that the pessimistic position can be explained by the lack of social prospects and social security.

Actions of the auditing departments are sometimes too strict and bureaucratic. Often, people in local municipalities mistakenly link it with the EU.

"I have a guest house. I am fed up with the demands of state institutions All the departments: the Food Veterinary Department, the Department of Citizenship and Immigration, the Sanitary Inspection, the State Revenue Department, the Work Inspection etc. They asked: "Where is the toilet especially for the maid?" Why can't our home-grown cucumbers be sold in the local shop? It is easier to do nothing." (local employer, Ape)

„Earlier, there was a range of lunch options, but not now - the demands are too high. In fact, everybody gave up. Two cafes at once were closed with those standards. Now nobody tries anymore." (local employer, Dagda)

The evaluation of the bureaucratic barriers is similar in various locales. They are described in equally negative terms in border areas of Latvia and Estonia and also $300 \mathrm{~km}$ farther in Dagda, not far from the border with Belarus.

From the viewpoint of local entrepreneurs, bureaucratic norms are one of the main barriers to entrepreneurship and employment because rural entrepreneurs already have to overcome problems created by distance, poor infrastructure and bad road quality. At the same time, implementation of EU demands and the perception thereof is influenced by the flexibility of representatives of state institutions in applying them. Overenthusiastic monitoring and insufficient information combined with threats of punishment immediately evoke the protests of rural entrepreneurs. There is a lack of information about the working methods of supervisory institutions. Nobody mentions trade unions as agents for solving employment problems. Maybe the actions of unions have not reached places far from large cities in Latvia, or the lack of trust in unions is inherited from socialism?

\section{CONCLUSIONS}

Residents of towns and their surrounding areas notice changes in Latvia after joining the EU and they connect them with a growth in opportunities for agricultural production, infrastructure improvements and migration. People who do not have a permanent job have not felt the changes. The changes are not noticeable in social security and the informal employment sphere.

The research suggests that there are three ways inhabitants of towns and adjacent areas react in coping with social and economic changes: in a traditional way; by 
leaving and moving to a place with greater social and economic stability; or in a non-traditional way, by responding flexibly to opportunities and the challenge of change. The features of flexibility and path-dependency were observed by different agents: municipal representatives, local employers and temporary employees.

All three groups of respondents perceive the certainty of transformation as greater possibilities for mobility, less stability in the labour market, and the necessity of flexibility in individual behaviour. Respondents expressed uncertainty about the stability and sustainability of state policy providing social security and the availability of transport and health care, especially to communities in small towns and rural areas. Temporary employees are not certain about the positive direction of social and economic changes.

\section{BIBLIOGRAPHY}

Boyd, R.A. "Migration of Despair": Unemployment, the Search for Work, and Migration to farms During the Great Depression, Social Science Quarterly, Volume 83, No.2, June 2002, Southwestern Association, 554-567.

Crouch, C., Farrell, H. "Breaking the path of institutional development? Alternatives to the new determinism." Rationality and Society, 2004, Sage Publications Vol.16(1):5-43, www.sagepublications.com.

Dažādā Latvija: pagasti, novadi, pilsētas, rajoni, reǵioni. Vērtējumi, perspektīvas, vīzijas. Rīga: Latvijas Statistikas institūts, Valsts reǵionālās attīstības aǵentūra, 2004.:105-109.

DiMaggio, P. "Culture and Economy." In: Smelser,N.Swedberg R.(ed.) The Handbook of economic sociology, Princeton University Press,Chicherster, West Sussex, 1994,27-57.

Esping-Andersen, G., Regini, M. (2000) Why Deregulate Labour Markets?, Oxford University Press.

Garantētais minimālais ienākumu līmenis. Skat. 09.12.2006. http://www.lm.gov.lv/search. php?searchtxt=GMI.

Gouliquer, L. "Pandoras Box: The Paradox of Flexibility in Today's Workplace," Current Sociology, January 2000,Vol.48(1): Sage Publications, London, Thousand Oaks, 29-38, www.sagepublications.com.

Hage, J. "Adaptive Costs: A New Institutional Paradigm of Rules for the Competitive Game," Current Sociology, July 2001,Vol.49(4): SAGE Publications, London, Thousand Oaks,45-66 www.sagepublications.com.

Latgales pilsētu attīstības stratēgija(2001), http://www.latgale.lv, skat. 10.12.2006.

Latvijas Nacionālais Attīstības Plāns 2007-2013, LR RAPLM,2006.

Pehkonen, A. "Why people migrated to the countryside in Finland in the 1990s?", Migration Letters, Volume:2, No:2,pp.153-163. October 2005, 153 (ISSN: print:17418984\&online:1741-8992).

Rozentāls, A. "Latvijas lauku nākotne - skaista ainava bez ražošanas?" Skat. 06.11.2006.

http://www.delfi.lv/archive/print.php?id=15986561.

Sabiedrībā pastāvošie dzimumstereotipi. Tirgus un sabiedriskās domas pētījumu centrs SKDS, 2006.gada marts. Skat. 10.12.2006. http://www.lm.gov.lv/doc_up1/SabiedribaPastavosie Stereotipi2006.pdf.

Scott, J., Marshall, G. (eds.), 2005. Oxford Dictionary of Sociology: Third Edition. Oxford University Press. 


\section{ENDNOTES}

${ }^{1}$ Dažādā Latvija: pagasti, novadi, pilsētas, rajoni, reǵioni. Vērtējumi, perspektīvas, vīzijas. Rīga: Latvijas Statistikas institūts, Valsts reǵionālās attīstības aǵentūra, 2004.:105-109.

2 Pehkonen, A. "Why people migrated to the countryside in Finland in the 1990s?," Migration Letters, Volume:2, No:2,pp.153-163. October 2005, 153 (ISSN: print:17418984\&online:1741-8992).

3 Boyd, R.A. "Migration of Despair": Unemployment, the Search for Work, and Migration to farms During the Great Depression, Social Science Quarterly, Volume 83, No.2, June 2002, Southwestern Association, 554-567.

4 Ibid.

5 Crouch, C., Farrell, H. "Breaking the path of institutional development? Alternatives to the new determinism," Rationality and Society, 2004, Sage Publications Vol.16(1):5-43, www.sagepublications.com

6 Hage, J. "Adaptive Costs: A New Institutional Paradigm of Rules for the Competitive Game," Current Sociology, July 2001,Vol.49(4): SAGE Publications, London, Thousand Oaks,45-66 www.sagepublications.com.

7 Garantētais minimālais ienākumu līmenis. Skat. 09.12.2006. http://www.lm.gov.lv/ search.php?searchtxt=GMI.

${ }^{8}$ Gouliquer, L. "Pandoras Box: The Paradox of Flexibility in Today's Workplace," Current Sociology, January 2000,Vol.48(1): Sage Publications,London, Thousand Oaks, 29-38, www.sagepublications.com.

9 Latvijas Nacionālais Attīstības Plāns 2007-2013, LR RAPLM,2006.

10 Rozentāls, A. "Latvijas lauku nākotne - skaista ainava bez ražošanas?" http://www.delfi. lv/archive/print.php?id=15986561, skatīts 06.11.2006.

11 Esping-Andersen, G., Regini, M. (2000) Why Deregulate Labour Markets?, Oxford University Press, pp.5-6.

12 DiMaggio, P. Culture and Economy, In: Smelser,N.Swedberg R.(ed.) The Handbook of economic sociology, Princeton University Press, Chicherster, West Sussex, 1994,27-57.

13 Crouch, C., Farell, H. "Breaking the path of institutional development? Alternatives to the new determinism." In: Rationality and Society. Sage Publications. 2004,Vol.16, 5-43, www.sagepublications.com.

${ }_{14}$ Latgales pilsētu attīstības stratēgija, 2001. http://www.latgale.lv, skat. 10.12.2006.

15 Scott, J., Marshall, G. (eds.), 2005. Oxford Dictionary of Sociology: Third Edition. Oxford University Press, p.668.

16 Sabiedrība a pastāvošie dzimumstereotipi. Tirgus un sabiedriskās domas pētījumu centrs SKDS, 2006.gada marts. Skat. 10.12.2006. http://www.lm.gov.lv/doc_upl/SabiedribaPas tavosieStereotipi2006.pdf. 


\title{
Corruption in Public Procurement: Corruption Risks
}

\author{
Kristine Beinarovica, Ph.D. \\ University of Latvia
}

\section{INTRODUCTION}

State and regional governments spend $10-15 \%$ of their combined budgets on public procurement. This attracts the interest of both entrepreneurs, as well as those who hold the public purse strings. Corruption scandals are often connected with public procurement and the procurement system is recognised as one of the spheres with a tendency to be under the influence of corruption. Bribes can dictate not only the winner of the contract, but also the size and specifics of the purchase. ${ }^{1}$ At present, state orders are considered a primary source of bribery and corruption where the risk of corruption is especially high. ${ }^{2}$ Corruption risks exist in any situation where officials are authorised to take decisions on every aspect of a situation. However, the existence of a corruption risk in public procurement does not testify to the actual presence of corruption. Corruption risks provide signals about the potential existence of corruption. It is important to note that these risks can be reduced, first of all by recognising them, but they cannot be eliminated entirely.

\section{PROCESS OF PUBLIC PROCUREMENT AND CORRUPTION RISKS}

In the process of public procurement, one can distinguish between direct and indirect actors or groups of actors. The first diagram shows the interaction between the main corrupted actors involved in the public procurement process. The diagram outlines the interests of actors, i.e. the process of influencing public procurement (see diagram 1). The diagram shows eight windows, where each window includes one actor or group of actors. In the centre of the central window there is the process of public procurement which can be influenced by all actors or groups of actors using the resources at their disposal.

Public procurement commission members are very important actors in the process of public procurement. They stand close to the ministries and other political forces and can include several corruption risks. The goal of this text is not to analyse the importance of the role of procurement commission members in the public 
procurement process and who are the actual actors behind the public procurement commission members, but to examine corruption risks in the process of public procurement, including risks of commission members of the public procurement.

Diagram 1

Interaction between the Main Corrupted Actors

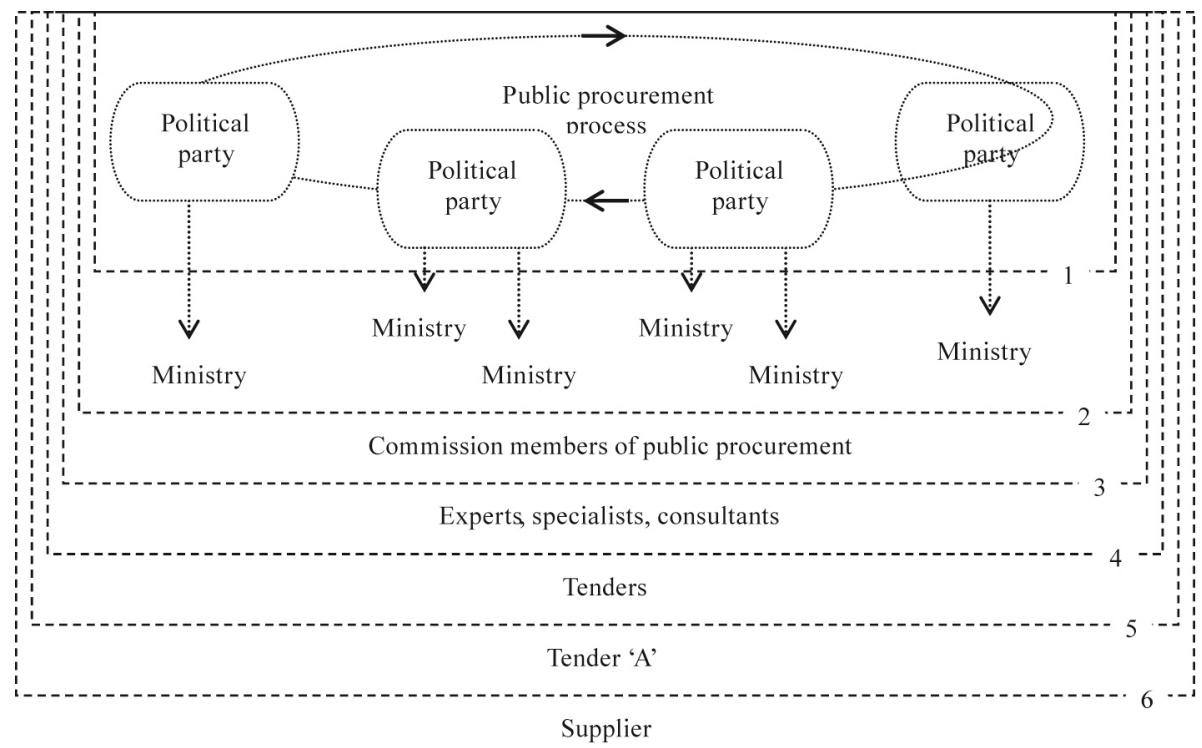

Tender 'A' representatives

\section{COMMISSION MEMBERS OF PUBLIC PROCUREMENT AND CORRUPTION RISKS}

Although the procurement procedure in accordance with which the customer selects suppliers is defined, there is an opportunity for customers and procurement commission members to influence the process of public procurement to the advantage of a certain tender or political force. Criminal cases instituted by the Anti-Corruption Bureau point to the tendency that procurement commission members are under a high risk of corruption - there is a risk that, for example, procurement commission members collaborate with potential tenders and include requirements in procurement regulations that correspond only to the interests of one entrepreneur.

There are various normative acts and obligatory procedures, however, the diversity of construction projects ordered, purchasable goods and services always leaves a certain decision-making freedom for officials. For example, officials arrive at a decision on which article to purchase, with definite specifications and specialists to involve for providing consultations. In procurement, much power is concentrated in the hands of procurement commission members and the decisions of commission members are important and conclusive. Power concentrated in hands of procurement commission members hides in the condition that they develop regulations, then choose the applicants and evaluate proposals of tenders. The commission decides 
whom to contract with and rejects other proposals, thus, terminating certain legal relations with them.

\section{CORRUPTION RISKS IN VARIOUS STAGES OF THE PUBLIC PROCUREMENT PROCESS}

The public procurement process can be divided into a number of stages. Corruption in government contracting can have different forms, including bribery, deception and abuse. Analysis of corruption risks in public procurement can be carried out dividing the procurement process into separate stages. The majority of procurement contracts have the following procedure:

1. The decision to contract: determination of need, where the decision to procure or vend goods and services is concluded;

2. Determination of contract characteristics and technical specifications;

3. The contracting process gives wide scope to start a certain type of action, for example - public bidding, closed bidding, pre-selected contractor list, open contracting, sole-source choice, etc.

4. Contract awarding that concludes with choosing the winner;

5. Contract performance and supervision.

In analysing corruption risks in public contracting, corruption researchers Klitgaard, Maclean-Abaroa and Parris divide the public procurement process into four stages: ${ }^{3}$

1. first stage - government establishes and publicises the need for a good or service;

2. second stage - vendors submit proposals to meet the need;

3. third stage - government evaluates proposals and selects the winner;

4. fourth stage - supplier performs the contract.

As a result of the procurement process designed by Klitgaard, Maclean-Abaroa and Parris, procurement starts when the government establishes the need for a good or service. As displayed in practice, not always government and municipal institutions have the necessary knowledge and information to specify their needs. Especially in the high technology sphere, it is not unusual that suppliers are more professional and well-informed, thus giving scope for corruption.

In the process of technical specifications development, any member of the commission can communicate with potential tenders and coordinate requirements set in the regulation to ensure the success of a particular entrepreneur. A frequent corruption risk is revealing confidential information about prices, for example, how much the institution has planned to spend for this procurement so that the tenders could adjust their proposals.

Frequently, procurement commissions on purpose "forget" to include specific requirements in the process of developing specifications, especially in development of technical specifications. A tender that has got acquainted with the procurement regulations and knows about this error ignores it, but later, in the stage of contractual 
commitment performance, requires vastly higher payment from the customer. The party submitting the tender is not guilty, the customer pleads a lack of expertise and experience in carrying out the specific procurement, though the true reasons for this customer oversight often are different. "Mistakes" made by procurement commission members in the process of technical specification development are one of the corruption risks in the procurement process and the cost of one such 'mistake' can be very high.

Analysing the exclusion of specifications and over-specification in the identifying stage of the need for public procurement, there is no absolute answer if specifications should be precise or adjustable, the risk of corruption exists in both cases. On the one hand, excessively vague specifications may encourage suppliers who are not able to ensure the work to submit a proposal; on the other hand, more detailed and accurately established specifications decrease the number of contractors who are able to submit proposals. In the first case there is an increase in administrative costs in the evaluation process and possible situations when a good or service does not comply with that required. In the second case the competition is limited. In both cases there is space for corruption. Strong specifications limit the freedom of action, but may increase monopoly power among vendors.

In the stage of need identification any action that differs from standard procurement procedures can indicate collusive action. Possible indicators include obscure or nonexistent specifications, requests for specific trademarks and equipment or evidence that vendors have been extraordinarily active in identifying the needs of local governments.

In the second stage of the procurement process, interested tenders submit their proposals for satisfying the need. The risks that exist in the stage of submitting proposals is a secret agreement between vendors. Vendors can agree among themselves, ensuring that one of them will get the contract. The Canadian Competition Policy bureau distinguishes four categories of speculative proposals: ${ }^{4}$

1. Cover proposals - companies submit proposals, usually for a price that is too high, thus ensuring that a certain party will win the contract;

2. Consolidation of proposals - companies refrain from submitting proposals, thus allowing a specific party to get the contract;

3. Rotation of proposals - companies exchange proposals among themselves and each gets a part;

4. Market share - companies share the market by definite rules, based on region, product uniqueness or some other position and refrain from violation of the defined market borders and competition.

Several potential corruption indicators can be distinguished that are useful in providing signals about collusion in the stage of proposal submitting. For example, the number of companies that submits proposals for a specific type of contract or in a certain region remains small or consistent for a long period of time, not taking into account many potential competitors. When the public sector market shares that are owned by one company in a high number of competitors stays consistent, this can indicate potential corruption. In all submitted proposals, one can detect the same handwriting or the manner of writing of one vendor. Any of these examples can 
indicate a risk, and the occurrence of several indicators at the same time demands detailed investigation.

In the stage of evaluation of the proposals, there is an increased risk of bureaucratic corruption to review the proposal in favour of a certain vendor. In the stage of evaluation the problem is in the freedom of evaluation that provides procurement commission members an opportunity vary their interpretations of previously defined specifications, thus giving way to corruption. Many events can provide a signal about potential corruption in the stage of evaluating a vendor. For example, a contract is granted to a vendor who did not submit the cheapest proposal or to someone who has no previous experience. In this case none of the indications is absolutely safe and necessarily points to corruption in public procurement. However, it does raise doubts about potential corruption in procurement and indicates that the procurement process has not been as efficient as it could be.

In the stage of contract performance a certain number of indicators can be linked with corruption risks though they never serve as absolute indicators of corruption. For example, the event in Latvia that is connected with the building of the new bridge when the contract foresees unexpected price increases explained with reference to inflation or cases with changed specifications.

Risks of corruption are especially high during the stage of concluding the contract, when vendors are investigated to choose the contractor. Corruption risks can occur before starting the process of contracting when the decision is made as to whom to contract. Some procurements begin already knowing who is going to win the contract. As soon as the process of contracting is finished and the contractor is chosen, there is room for abuse - not performing the contract, contract discussion, change of order, overcharging. ${ }^{5}$

\section{CONCLUSION}

Procurement contracting often entails large monetary sums and the involvement of well-known people employed in the government or the public sector. Corruption in public procurement can be extremely damaging to a municipality because of distorted incentives and undermined public trust. Corruption risks in public procurement can appear in tenders or other procurement procedures, including the process of preparing technical specifications.

Corruption and conflicts of interest can influence the process of making decisions and rules and a wide range of violations connected to state and local government procurement where an important role is assigned to public procurement commission members. Procurement commissions evaluate proposals submitted by tender, design procurement regulations and specifications, as well as select the vendor. The process of public procurement is full of corruption and potential corruption risks, though these risks do not always testify to corruption. Strong rules are applied to the public procurement system that define selection of goods or services and prescribe independent state order supervision mechanisms. However, often state and local government officials have the opportunity to take decisions concerning large amounts of money in public procurement. If officials are dishonest and the public procurement system is incomplete, there is a high potential for illegal channels of power and 
local government money going to meet private needs. In public procurement, once encounters cases when the commission is inconsistent in applying specifications. In these situations the needs of state or local governments should be taken as a basis and the procurement commission should act on the basis of its honour. However, our own honour is sewn with such fragile and transparent threads, that not only others, we ourselves cannot feel the border and suddenly realise that we are on the other side of the discontinuous line of honour.

\section{ENDNOTES}

1 Rose-Ackerman, S., Corruption and Government, Causes, Consequences, and Reform, Cambridge University Press, 1999, p. 59.

2 Public Procurement and Privatisation - Sources, http://www.psiru.org/corruption/ CorruptionnewsSub.asp?Subject=PP (acessed 9.09.2006.).

3 Klitgaard R., Maclean-Abaroa R. and Parris H.L. Corrupt Cities. A Practical Guide to Cure and Prevention, ICS Press, 2000, pp. 119-120.

${ }^{4}$ Four Categories of Bid-rigging, Competition Bureau Canada, http://www.competitionbureau.gc.ca/internet/index.cfm?itemID=2222146\&lg=ee (accessed 15.09.2006.).

5 Corruption in public procurement, Utstein Anti-Corruption Resource Centre, http://www. u4.no/themes/procurement/procurementintro.cfm\#1 (accessed 15.09.2006.). 


\title{
Formation of Coalition Governments During the $8^{\text {th }}$ Saeima in Latvia
}

\author{
Ilona Golubeva \\ Master's student University of Latvia
}

\section{INTRODUCTION}

As is common in parliamentary democracies, the core of executive power in Latvia consists of a coalition government. It is essential for the development of the state that the government is stable and lasts long. Although it is impossible and, in fact, even unnecessary to separate different stages of a government's "lifespan", the coalition formation process can be considered especially significant, because it can influence to a great extent the way a government operates afterwards.

During the 14 years since 1993 , when the $5^{\text {th }}$ Saeima elections were held, 12 coalition governments ${ }^{1}$ have been formed. Thus, the average lifespan of each government is rather short. Although parties that form these governments and the political personnel have changed to a much lesser extent, such unstable governments create doubts about the potential of guaranteeing continuity in the decision-making process, especially because a great share of time is spent on settling disagreements.

The aim of this article is to examine government formation processes during the $8^{\text {th }}$ Saeima ${ }^{2}$ in Latvia. The "viable government" theory of Budge and Keman comprises the theoretical base for this analysis. This particular theory of government formation is chosen because it explains not only minimal winning governments, but also minority governments and surplus governments, which makes it applicable to the situation of Latvia.

\section{"VIABLE GOVERNMENTS" AND PRINCIPLES FOR FORMING THEM}

The aim of coalition government theories is to explain the process of coalition government formation and to analyse different factors that influence this process by restricting or facilitating the formation of specific governments. That is necessary in order to predict which government will be formed. It is possible by knowing how power is distributed among political parties in the legislature and what the ideological stances of these political parties are.

The pioneers of coalition theories are the founders of game theory Neuman and Morgenstern, as well as Riker and Downs. During the 1960s-1970s De Swaan, 
Leiserson and other researchers developed the debate about the coalition formation process, focusing on the elaboration of different theories of winning governments. At present other scientists, such as Laver, Shepsle, Budge, Keman, Schofield, Strom are developing and complementing the concepts of the aforementioned pioneers of coalition theories in order to analyse the formation of coalition governments in parliamentary democracies of West European countries starting with the mid 20th century until now.

Budge and Keman criticised the existing theoretical models for their restricted view on coalition governments and developed their own approach towards the analysis of the government formation process. The authors emphasise the need to link both possible motivations - policy-seeking and office-seeking - of political actors and avoid using mathematical methods and spatial models when they study the behaviour of political actors. ${ }^{3}$ They use viability criterion instead of the majority principle ${ }^{4}$ and argue that governments in parliamentary democracies can be formed not only when a permanent parliamentary majority supports it (moreover - not only minimal winning, but also surplus coalitions) and minority governments can be formed and be stable. ${ }^{5}$ Thus, the "Integrated theory of democratic party government" is based on a so-called concept of "viable" government. The basic principles of this theory are:

1. In parliamentary democracies the party or combination of parties which can win a legislative vote of confidence forms the government.

2. Parties seek to form a government capable of surviving legislative votes of confidence which will most effectively carry through their declared policy preferences under existing conditions.

3. (a) The chief preference of all democratic parties is to counter threats to the democratic system.

(b) Where no such threats exist, but socialist-bourgeois differences are important, the preference of all parties is to carry through policies related to these differences.

(c) Where neither of the preceding conditions hold, parties pursue their own group-related preferences.

4. Within parties, and subject to overall policy agreements and disciplinary and procedural constraints, factions seek to transform their own policy preferences into government policy most effectively. ${ }^{6}$

When one adjusts the theoretical scheme developed by Budge and Keman to the situation in Latvia after the elections of the 8th Saeima, it can be concluded that a coalition government would consist of those parties that can gain parliamentary support in a vote of confidence and whose political preferences are the closest. Such a government would also include "normal" parties.

It is obvious that a left-wing ${ }^{8}$ party - the union of political parties "For Human Rights in the United Latvia" (hereafter-FHRUL) - would be excluded from the coalition formation process, mainly because its political stances are rather incompatible with those of other political parties. After the examination of political programmes of parties which gained representation in the Saeima, it becomes clear that the main difference between right-wing and centre parties appears regarding ethnic issues, therefore a party that claims to be rather nationalistic - the Union "For 
Fatherland and Freedom/Latvia's National Independence Movement" (hereafter, "For Fatherland and Freedom/LNIM") would not be included in the governing coalition. The People's Party, being a "normal" party, should be in the government. Similarly, the place of New Era - at least theoretically - would be in the government. There are several reasons for that - first of all, this party won the elections, second - it was agreed by other political parties and society in general that New Era has to form the government, third - the political priorities of New Era are close to those of other right-wing parties, inter alia the People's Party. Consequently, if a "viable" government was formed based on the theoretical principles proposed by Budge and Keman, the core should consist of New Era and the People's Party, attracting either the Union of Greens and Farmers or the Latvian First Party or both.

\section{THE FORMATION OF THE REPSE, EMSIS AND KALVITIS GOVERNMENTS}

Further in this article the process of forming the coalition governments led by Einars Repse (New Era), Indulis Emsis (the Union of Greens and Farmers) and Aigars Kalvitis (the People's party) will be discussed, followed by an estimation of whether any of them coincided with the theoretical model of a "viable" government.

\section{The Government of Einars Repse}

Negotiations about forming a coalition started immediately after the announcement of the provisional results of the parliamentary elections (October 2002) and the party that gained the largest number of votes - New Era - undertook the initiative. Under guidance of leader Einars Repse, New Era quickly reached an agreement with the Latvian First Party and formed a bloc. Almost at once a consensus was reached with the Union of Greens and Farmers and the Union "For Fatherland and Freedom/ LNIM" about the creation of a coalition that had the support of 55 deputies in the Saeima. All right-wing and centrist political parties almost immediately expressed a rather categorical denial regarding possible cooperation with FHRUL and all its constituent parties.

New Era emphasised that all right-wing parties would not be included in the government because a four party government is optimal. Repse argued - "therefore a competition will exist among right-wing political parties and they won't have the possibility to be capricious". The office of the Prime minister and eight other ministerial offices was another demand of New Era. The activities of this party in the coalition formation process can be assessed as very categorical - various non-negotiable conditions and principles were put forward, such as the repeal of the Coalition board and others. New Era also defined its political aims - the fight against corruption and smuggling, as well as an improvement in the collection of taxes. The coalition was formed by sorting out those parties that did not object to the requirements of New Era. As was said before, a bloc with the Latvian First Party was formed immediately and the Union "For Fatherland and Freedom/LNIM" and Union of Greens and Farmers joined soon afterwards.

The Latvian First Party demanded not cooperating with any party that was previously in power and with FHRUL. Therefore, initially it considered staying in 
opposition, if the government was formed by the People's Party, FHRUL, the Union "For Fatherland and Freedom/LNIM" or the Union of Greens and Farmers. However, later it agreed to join a coalition which consisted of the two parties mentioned above. The Latvian First Party stressed its "special relations" with New Era - the other new political party elected in the Saeima. The Latvian First Party regarded New Era as its ideologically closest partner; it accepted all the conditions New Era put forward.

The only principle that the Union "For Fatherland and Freedom/LNIM" had was a government that would not include FHRUL. At the same time, the Union "For Fatherland and Freedom/LNIM" did not have any major objections regarding the requirements of New Era - neither political, nor technical.

Also the Union of Greens and Farmers, just like both political parties mentioned above, already from the beginning of the government's formation was not against the ideas of New Era. The only party the Union of Greens and Farmers was not ready to work with together in the coalition was FHRUL.

The People's Party, on the contrary, expressed a more critical and negative attitude towards the formation process of the new government. While it emphasised that Repse must be invited to form the Cabinet, the People's Party had objections towards many of the principles named by New Era - publicly open proceedings of the Cabinet, abandonment of the Coalition agreement and the Coalition board and others. The People's Party stressed that only a government that would consist of both New Era and the People's Party as two ideologically close parties can be stable. This party did not question the right of New Era to nominate the Prime minister and also did not try to show any initiative in the coalition building process.

It took a few days after the announcement of the election results to form the coalition. However, afterwards the distribution of political offices began and it almost led to the collapse of the coalition. On the other hand, a secondary role was allocated to the elaboration of the Government's declaration. Several reasons can be found to explain that - firstly, party positions regarding all relevant issues were so close that it did not make any sense to waste time on such discussions; secondly, political priorities were valued by political actors as less relevant than the possibilities to gain office. Although political preferences of the parties that formed the coalition were rather congruent, not conflicting, the subsequent discussion in this article shows that the second reason mentioned above explains why the government declaration did not play a significant role in the government formation process.

The inability to reach agreement on who will get the "money ministries", especially, the Ministry of Transport and the Ministry of Economics, the demand of the Union of Greens and Farmers to get more ministerial offices, the unwillingness of the Union "For Fatherland and Freedom/LNIM" and the Latvian First Party to give up any of the offices they desired, and the passivity of all coalition parties in assuming responsibility for the "sad ministries" - the Ministry of Culture, the Ministry of Welfare and the Ministry of Justice -, almost broke down the "coalition that was formed alarmingly quickly" .

On the $5^{\text {th }}$ of November 2002, the President of Latvia Vaira Vike-Freiberga invited Einars Repse to form the Cabinet and he completed the coalition building process in four days. The government which consisted of New Era, the Union of 
Greens and Farmers, the Latvian First Party and the Union "For Fatherland and Freedom/LNIM" was approved by the majority of the deputies when all 55 of those who belonged to the parties forming the government voted for it.

No role in the formation of this government was played by the political priorities of right-wing and centrist parties (except claiming that any cooperation with FHRUL is impossible). Moreover, they were almost not mentioned during the coalition building negotiations. Even the collaboration of New Era and the People's Party was impeded by the psychological incompatibility of the personalities of their leaders and the discrepancies in attitudes towards the style of functioning, but not ideological contradictions. Moreover, the decision of other political parties regarding participation in the coalition building process was not based on ideology. Whether a party was included in the government or not depended primarily on their ability (or inability) to agree to the conditions put forward by New Era and their ability (or inability) to come to an agreement with other political parties about the distribution of offices. The harsh fight for the "money ministries" that are responsible neither for solving social issues, nor improving living standards, nor promoting social cohesion, nor the administration of the health system and the system of justice, prove that political stances did not play a significant role. If parties tried to attain political aims that they stated in their political programmes, they would compete for the Ministry of Welfare, Ministry of Health and other "unpopular" ministries.

\section{The Government of Indulis Emsis}

The government of Einars Repse resigned on 5 February 2004, soon after the ministers of the Latvian First Party left it and when the minority government of Repse could not gain the support of the parliament in the vote for amendments in the Education Law. New Era called this vote the equivalent of a vote of confidence for the government.

Two weeks after the resignation of the minority government of Repse, the President of Latvia Vaira Vike-Freiberga invited Indulis Emsis to form the Cabinet. This politician was chosen because "the Union of Greens and Farmers agreed to cooperate with all parties elected in the Saeima and it did not have any categorical requirements". Vike-Freiberga emphasised that "a stable government that would consist of centre and right-wing parties must be formed in this Saeima and it is just a question of good will."10

Immediately after the resignation of the government, New Era claimed that it would stay in opposition if all its demands were not taken into an account - firstly, Repse as Prime minister, secondly, the previously closest ally - the Latvian First Party - cannot be included in the coalition, thirdly, the Union "For Fatherland and Freedom/LNIM" - as its closest partner now - must be a member of the coalition. New Era regarded cooperation with the Latvian First Party as impossible due to its "unclear ideology" (a left-wing party) left and joined the faction of the Latvian First Party, but the ideological stances of New Era and the People's Harmony Party regarding ethnic issues are significantly different. New Era categorically objected to a coalition of all five right-wing and centrist parties. When it became clear that Emsis would try to gain the parliament's support in any case (even for a minority Cabinet) and the 
demands of New Era would not be taken into the account, this party finally gave up its requirement regarding Repse as the Prime minister. However, New Era did not agree to join the model of government that was proposed by Emsis and invited other parties to start negotiations once more under the guidance of Krisjanis Karins (New Era) as the potential Prime minister. Other parties rejected this initiative.

Also the People's Party put forward several principles - it was desirable that the core of this government consisted of the People's Party and New Era, and that all five right-wing parties were included in the government. The People's Party stressed that also the Latvian First Party should be a coalition member. Although initially the People's Party did not object that Repse could be repeatedly nominated as the Prime minister, later the representatives of that party noted that they would not support his candidacy. ${ }^{12}$ Moreover, the People's Party consistently expressed support to Emsis as the potential Prime minister even when it became clear that he would lead a minority government. This decision was justified by the need to form a government quickly due to the proximity of accession to the European Union and NATO. However, the People's Party lodged a requirement for Emsis - his Cabinet should become a majority government within 100 days.

The aim of the Union "For Fatherland and Freedom/LNIM" was a "stable majority government", in which New Era would be definitely included. Although this party considered cooperation with the People's Party and the Union of Greens and Farmers possible, it claimed that the Prime minister should be a member of a party that has a rather large representation in the Saeima.

The minority government which consisted of the Union of Greens and Farmers, the People's Party and Latvian First Party was approved by 56 votes. All deputies of the parties that formed the government, one deputy of New Era and the deputies of the People's Harmony Party voted for the approval of this government. Deputies of Latvia's Socialist Party and FHRUL did not participate in the voting, and New Era and the Union "For Fatherland and Freedom/LNIM" voted against the government. Left-wing parties claimed that they did not vote against the government, because the Union "For Fatherland and Freedom/LNIM" was not included in it. It can be seen that this government was approved by the direct and indirect support of left-wing parties. However, Emsis, as well as representatives of the People's Party repeatedly stressed that even so, the government would be "right-wing", it would pursue "nationally right-wing policies" 13 and would not yield to any demands of left-wing parties, for example, to ratify the Framework Convention for the Protection of National Minorities or grant voting rights in local elections to the non-citizens of Latvia.

Political scientist Daunis Auers claims that the minority government of Emsis gained parliamentary support because the political stances of the coalition parties were relatively similar, but the opposition was split. ${ }^{14}$ The only ideological obstacle for cooperation could emerge between the People's Party and the "newly made Latvian First Party" regarding the education reform. ${ }^{15}$

Emsis achieved a positive vote for his government by reducing the quorum (the voting was held when several deputies were either on missions abroad or serving as observers in the European Parliament), having left-wing parties either refrain from participation in voting (Latvia's Socialist Party and FHRUL) or supporting the 
government (People's Harmony Party) and offering political offices to "convince" politicians to vote for the government.

Based on the previously discussed considerations, it can be concluded that during the formation of this government parties consistently adhered to the principles they had initially stated. New Era (although later it gave up its demand that Repse has to be nominated as the Prime minister) and the Union "For Fatherland and Freedom/ LNIM" did not change their positions and did not join the coalition formed by Emsis; the People's Party persistently acted in conformity to what it had stated before. The Latvian First Party, as one of the largest obstacles to cooperation between New Era and the People's Party, can be considered a rather passive agent, because its inclusion in the government was basically determined by the relations of New Era and the People's Party. However, two issues need to be stressed - firstly, the political stances of the parties as an obstacle to cooperation were mentioned only regarding the leftwing parties and the Latvian First Party, but were not named as an impediment for the collaboration of other parties. Secondly, in spite of what parties had officially stated, this coalition of right-wing parties was approved by the direct and indirect support of left-wing parties, which is in conflict with the principles of those parties in the coalition. Therefore it can be concluded that New Era and the Union "For Fatherland and Freedom/LNIM" acted in conformity to their principles to a larger extent than coalition parties.

\section{The government of Aigars Kalvitis}

The government of Emsis was the first government in Latvia that resigned when parliament did not approve the state budget. On October 28, 2004, in the first reading of the state budget, deputies of the People's Party, in the guidance of which the budget was elaborated, voted against it. Article 30 of the Rules of Order of the Saeima prescribes that a government collapses on such an occasion. Immediately after that formation of a new government started and this time the People's Party took the initiative to lead the negotiations about the "formation of a new right-wing majority government".

The President of Latvia insisted that it is crucial that "a stable government with strategic aims which could foster the cohesive development of Latvia is formed". ${ }^{16}$ Although the President of Latvia explained why she began consultations with all parties elected in the Saeima only twenty days after the Cabinet of Emsis had collapsed, experts argue that Vaira Vike-Freiberga allocated too much time for mutual negotiations among the parties. Afterwards she arranged meetings with all three Prime ministerial candidates - Krisjanis Karins from New Era, Aigars Kalvitis from the People's Party and Ainars Slesers from the Latvian First Party - and as a result invited Aigars Kalvitis to form the Cabinet. The President of Latvia claimed that this candidate had previous experience being a member of the Cabinet and the Saeima. Moreover, representatives of other parties that had been elected to the parliament agreed to cooperate with Kalvitis as Prime minister.

Party negotiations until the nomination of Kalvitis were long and complicated. As was already mentioned before, the People's Party undertook the initiative in the coalition building process. One of the reasons was that the People's Party was responsible for the collapse of the Cabinet of Emsis. The People's Party immediately 
stressed its readiness to participate in a government which would be headed by a member of New Era and called other parties not to exclude the Union of Greens and Farmers from the coalition negotiations. However, both of the largest rightwing parties - New Era and the People's Party - should form the core of the new government.

Talking about the distribution of the offices, Kalvitis proposed a "principle of two level parity", which implied that New Era and the People's Party would get an equal number of ministerial offices, but the smaller parties - a smaller (but equal) number of such offices. ${ }^{17}$

Immediately after the nomination of Kalvitis, the Union of Greens and Farmers emphasised its readiness to participate in a government formed by Kalvitis. Moreover, the principles under which Kalvitis intended to organise the Cabinet's work satisfied the Union of Greens and Farmers. Its representatives also announced that "there are no programmatic differences between us [the Union of Greens and Farmers and the People's Party]".

The Latvian First Party actively participated in the coalition building negotiations, but, similarly to the Union of Greens and Farmers, did not pose any specific programmatic or office requirements (except the office of the Minister of Children and Family Affairs). In general, this party was ready to take part in any Cabinet model regardless of whether it was led by a representative of New Era or the People's Party. ${ }^{18}$ After the nomination of Kalvitis the Latvian First Party expressed its readiness to support the type of government he proposed, because no contradictions exist between the political priorities of both parties. The only demand was the office of the Minister of Children and Family Affairs (which they eventually received).

The position of New Era was rather inconsistent during the process of government formation - both before and after the nomination of Kalvitis. Although New Era had stated that it would never participate in a government together with the Latvian First Party and it would never participate in a government without the Union "For Fatherland and Freedom/LNIM" being a member of that government, eventually it decided to participate in the Cabinet of Kalvitis in which the Latvian First Party was included and the Union "For Fatherland and Freedom/LNIM" was excluded. As New Era had always emphasised (the People's Party did the same) that it had no major programmatic differences with the People's Party that could obstruct their possible cooperation, it can be concluded that the main factor which influenced the decision of New Era was the distribution of offices and the model of cooperation proposed by Kalvitis. New Era had several demands regarding ministerial offices. In addition, although New Era consistently objected to the formation of a five-party coalition government, shortly before the announcement of the Union "For Fatherland and Freedom/LNIM" that it would not participate in the coalition, New Era seemed to be ready to take part also in a government that consisted of all five right-wing parties. The representatives of New Era also argued that they needed to receive the office of the Minister of Children and Family Affairs, because otherwise New Era would not have the chance to fulfil its programmatic priorities. However, this did not prevent New Era from deciding to become a member of the government in spite of not getting the previously mentioned office. ${ }^{19}$ The other requirement of New Era, which was taken into the account, was open meetings of the Cabinet. 
Immediately after the collapse of the government, the Union "For Fatherland and Freedom/LNIM" discussed the necessity to form a stable right-wing government that would not depend on the support of left-wing parties. Moreover, only a government that would consist of both New Era and the People's Party would be stable. The Union "For Fatherland and Freedom" stressed that it wished to cooperate closely with New Era and even to take a decision whether to participate in the Cabinet or not together. Also, this party argued that it cannot cooperate with any of the left-wing parties and the Latvian First Party (because of the five deputies who previously were members of the People's Harmony Party) due to programmatic reasons. According to the Union "For Fatherland and Freedom/LNIM", the coalition should consist of the New Era, the People's Party, the Union of Greens and Farmers and itself. ${ }^{20}$ After the nomination of Kalvitis, the Union "For Fatherland and Freedom/LNIM" bound itself together with New Era, claiming that it would take part in the government only if New Era did. When New Era announced that it would not support the Cabinet of Kalvitis if Repse did not receive an office in the government, the Union "For Fatherland and Freedom/LNIM" tried to persuade New Era to become a coalition member, but after long and complicated discussions, it decided to be in the coalition despite the possible negative decision of New Era. ${ }^{21}$

All five right-wing parties started to develop the Declaration of the Cabinet, but after New Era decided not to join the Cabinet, four parties - the People's Party, the Latvian First Party, the Union of Greens and Farmers and the Union "For Fatherland and Freedom/LNIM" - continued working on it. But the Union "For Fatherland and Freedom/LNIM" eventually did not sign the coalition agreement. The official statement was that it is essential that the offices are concentrated in the hands of the largest parties. However, this party promised to support the Cabinet in the vote of confidence (which is in contradiction to the previously declared inability to cooperate with the Latvian First Party).

The Cabinet of Kalvitis (New Era, the People's Party, the Union of Greens and Farmers and the Latvian First Party) was approved by 75 deputies ( 23 deputies were against). All right-wing parties, including the Union "For Fatherland and Freedom/ LNIM", supported the government. The approval of the Cabinet of Kalvitis was jeopardised not by the inability of political parties to agree on the values, political priorities, or tasks that should be achieved, but by the inability to reach agreement on much more pragmatic issues, for instance, the conflict regarding Andris Skele (the People's Party) and Repse as candidates for ministerial posts or which party would be responsible for the Ministry of Children and Family Affairs, etc. The only requirement that these parties had with regard to political priorities was not to include any left-wing parties in the Cabinet. However, there is an exception even here - the Union "For Fatherland and Freedom/LNIM" claimed that it would never, under any circumstances, cooperate with Latvian First Party due to the five deputies that were elected from the FHRUL list and chose to join Latvian First Party. However, Fatherland later took part in the development of the Coalition agreement and the Declaration of the Cabinet of Kalvitis together with Latvian First Party. Although it did not join the coalition, it supported the Cabinet (which included the Latvian First Party) in the vote of confidence.

The process of coalition formation can be characterised as long and rather chaotic, the stances and demands of political parties were inconsistent and often 
changed. It is obvious that all right-wing parties repeatedly stressed that there were no major programmatic obstacles to the creation of a stable right-wing government. However, this process of coalition formation in reality was rough and long.

\section{CONCLUSION}

The theory of a viable government prescribes that if, as a result of the coalition building process, a government that coincides with the theoretical model is formed, it should be stable. Thus, the first relevant question that should be answered is - was a viable government formed during the $8^{\text {th }}$ Saeima? If it was formed, was it truly viable? If not, what factors (features of the government formation process) affected it and led to the formation of a government which was not viable?

When one compares the model of a viable government to the Cabinets that were formed during the $8^{\text {th }}$ Saeima, a conclusion can be drawn that the government of Kalvitis corresponds to the formal model of a viable government. However, a paradox can be observed. Firstly, this Cabinet was formed as the third one, after two previous Cabinets proved unsuccessful. Secondly, despite the fact that this coalition practically consisted of parties that should theoretically be able to work together in a viable government, it collapsed when ministers of New Era resigned (April 2006). Although the Cabinet of Kalvitis did not resign afterwards, one can claim that his government was no longer "viable". It can be assumed that if more than half a year was left until the next elections and any major decisions were to be taken (for example, the state budget), its longevity was questionable (especially due to the reason that now the composition of the Cabinet of Kalvitis was equal to the composition of the Cabinet of Emsis).

How can one then explain why a viable government was not formed? The analysis of coalition formation during the $8^{\text {th }}$ Saeima shows that the programmatic political priorities were not the main factor shaping parties' attitudes to the coalition that was being built. It was repeatedly stressed by all right-wing parties that there were no significant ideological obstacles to the formation of a viable government and one Cabinet even coincided with that model. However, even when ideologically close parties formed the coalition, the formation process was long and complicated and parties could not cooperate long due to prevailing personal disagreements and discontent with the distribution of power.

Can then offices be considered as the main motivation for a party? Although it notably characterised the formation process of the Cabinet of Repse, when parties' inability to distribute the "power" ministries almost jeopardised the approval of the Cabinet, also the analysis of the Cabinets of Emsis and Kalvitis proves that parties easily step back from their previously stated political objectives in order to get an office. Also personal conflicts among politicians and rhetoric that is not followed by consistent action show that parties do not follow the ideological stances named in their programmes. Moreover, the creation of new political offices, as well as usage of the existing ones in order to gain support in the vote of confidence leads to the conclusion that political positions play only a secondary role compared to the motivation to join the coalition to receive offices. 
Political stances are important only regarding the attitudes towards cooperation with FHRUL (no cooperation is claimed to be possible due to incompatible attitudes towards all major political, social and economic issues). Therefore it can be concluded that political office is apparently not the only motivator that influences the behaviour of political actors. Although it plays the most significant role, parties cannot completely ignore the promises that they have given to voters. Therefore, also political programmes are important to some extent.

Thus, probably, a theoretical model that was developed on the basis of stable West European parliamentary democracies cannot be adjusted to the analysis of coalition government formation in young democracies, including Latvia. Other significant factors should probably be taken into the account, namely, civic and political culture, values and their influence on the political processes in the country.

\section{LITERATURE}

1. 8. Saeimas vēlēšanu rezultāti. www.cvk.lv. Centrālā vēlēšanu komisija, 15.09.2006.

2. Auers D. Vai mazākuma valdība var būt ilgtspējīga? www.politika.lv 16.03.2004.

3. Budge I., Keman H. Parties and Democracy.Coalition Formation and Government Functioning in Twenty States. Oxford: Oxford University Press, 1990.

4. Egle I. "Ir cerības uz labēju valdību." Diena, October 6, 2002, pp. 1,2.

5. Egle I. "Partijas būs jāvieno premjeram." Diena, February 20, 2004, pp. 1,3.

6. Egle I. "Pirmā partija kḷūst par šķērsli lielāko spēku sadarbībai." Diena, February 17, 2004, pp. 1,4 .

7. Egle I. "Tautas partija sola uzticību Emsim." Diena, March 8, 2004, pp. 1, 3.

8. Ikstens J.” Politika Latvijā. Politiskās sistēmas evolūcija pēc 1991.gada.” http://www. politics.lv/psistema/frame_psistema.htm.

9. “JL neizšķiras, vai strādās Kalvī̌sa valdībā.” LETA, 25.11. 2004, at http://www.tvnet.lv/ zinas/latvija/article.php?id=67413.

10. Laver M., Schofield N. Multiparty Government: the Politics of Coalition in Europe. Oxford: Oxford University Press, 1990.

11. Laver M.J., Budge I. (eds.) Party Policy and Government Coalitions. New York: St.Martin's Press, Inc., 1992.

12. Leiserson M. Power and Ideology in Coalition Behavior: An Experimental Study. In: The Study of Coalition Behavior. Theoretical Perspectives and Cases from Four Continents. Eds. Sv.Groennings, E.W.Kelley, M.Leiserson. New York: Holt, Rinehart and Winston, Inc., 1970, pp. 323-335.

13. Lulle, A. "LPP un JL sarunas velta budžetam." Neatkarīgā Rìta Avīze, November 2, 2005, p. 1.p.

14. Lulle A. "Jaunais laiks paliek Repšes ķīlnieki." Neatkarīgā Rìta Avīze, November 30, 2004, pp. 1,3.

15. Lulle B. "Partijas bloķējas un spriež par nosacījumiem.” Neatkarīgā Rīta Avīze, October 9, 2002, pp. 1,3.

16. Lulle B. "Prezidente lūko valdības veidotāju." Neatkarīgā Rīta Avīze, October 15, 2002, pp. 1,3 .

17. Lulle B. "TP grib būt valdībā kopā ar JL, bet ne Repšes virsvadībā." Neatkarīgā Rìta Avizze, February 19, 2004, p. 3.

18. Margeviča A. "Jaunais laiks prasa Kalvītim 7 portfel̦us." Neatkarīgā Rīta Avìze, November 27, 2004, pp. 1,3. 
19. Norgaard O (et.al.) The Baltic States after Independence. Cheltenham: Edward Elgar, 1999.

20. "Prezidente izvēlas premjeru. Kalvīti sarauj!" LETA, 24.10. 2004, at http://www.tvnet. lv/zinas/latvija/article.php?id=67413.

21. "Prezidente konsultācijas ar partijām sāks pēc 18.novembra." LETA, 29.10. 2004, at http://www.tvnet.lv/zinas/latvija/article.php?id=65825.

22. "Prezidente neuzticēs valdības veidošanu Repšem vai Emsim." LETA, 18.11 2004., at http://www.tvnet.lv/zinas/latvija/article.php?id=67085.

23. Riker W. The Theory of Political Coalitions. London: Yale University Press, Ltd., 1962.

24. "TB/LNNK kā premjera kandidātus redz Karinu un Ārgali." LETA, 15.10. 2004., at http://www.tvnet.lv/zinas/latvija/article.php?id=67413.

25. Ware A. Political Parties and Party Systems. Oxford: Oxford University Press, 1996.

\section{ENDNOTES}

1 The terms "government" and "Cabinet" will be considered identical in this article.

2 Six political parties gained representation in the 8th Saeima (elections were held on October 5, 2002) - New Era, the union "For Human Rights in the United Latvia", the People's party, the Union of Greens and Farmers, the Latvian First party and the Union "For Fatherland and Freedom/LNIM". See the results of the 8th Saeima elections at www.cvk.lv.

3 Budge I., Keman H. Parties and Democracy.Coalition Formation and Government Functioning in Twenty States. Oxford: Oxford University Press, 1990, p. 33.

${ }^{4}$ Until the assumption dominated that parties try to maximise the number of offices they gain through the coalition negotiations, it was clear why the only option was a winning government. As soon as the notion of a desire of parties to pursue their political preferences appeared in the theoretical discourse, minimal and surplus governments were no longer considered to be deviant cases. Moreover, theoretical models were created to explain why these governments are formed. (Laver M., Schofield N. Multiparty Government: the Politics of Coalition in Europe. Oxford: Oxford University Press, 1990,pp. 66-67., pp.69-72.)

5 Laver M.J., Budge I. (eds.) Party Policy and Government Coalitions. New York: St.Martin's Press, Inc., 1992, pp.8-9., pp. 6.-7.

6 Budge I., Keman H. Parties and Democracy.Coalition Formation and Government Functioning in Twenty States. Oxford: Oxford University Press, 1990, p.34.

7 According to the theory of Budge and Keman, "normal" parties are those parties that have previous experience being a member of the Cabinet. (Budge I., Keman H. Parties and Democracy. Coalition Formation and Government Functioning in Twenty States. Oxford: Oxford University Press, 1990, pp. 43,48.)

8 Ibid, pp.44.

9 The terms "right-wing" and "left-wing" parties will be used in this article. Although traditionally the division between "right-wing" and "left-wing" parties is based primarily on their attitudes towards socio-economic issues, here the division will be based on the attitude towards socio-economic issues and also, which is specific in the case of Latvia, towards ethnic issues. (Ikstens J. Politika Latvijā. Politiskās sistēmas evolūcija pēc 1991. gada. http://www.politics.lv/psistema/frame_psistema.htm) As Norgaard argues "two cleavages - economic and national - need to be examined". (Norgaard O (et.al.) The Baltic States after Independence. Cheltenham: Edward Elgar, 1999, p.101.) 
10 Lulle B. "Prezidente lūko valdības veidotāju." Neatkarīgā Rīta Avīze, 15 October 2002, p. 1,3 .

11 Egle I. "Partijas būs jāvieno premjeram. Diena,"20 February 2004, pp. 1, 3.

12 Egle I. "Pirmā partija kḷūst par šķērsli lielāko spēku sadarbībai." Diena, 17 February 2004, p. 1,4.

13 Lulle B. "TP grib būt valdībā kopā ar JL, bet ne Repšes virsvadībā." Neatkarīgā Rīta Avīze 19 February 2004, p. 3.

14 Egle I. "Tautas partija sola uzticību Emsim.” Diena, 8 March 2004, p. 1, 3.

15 Ware states that a minority government can function if the opposition is fractionalised and if the probability of conflict is larger in any other model of government than in the current one. See Ware A. Political Parties and Party Systems. Oxford: Oxford University Press, 1996, pp. 339.

16 Auers D. "Vai mazākuma valdība var būt ilgtspējīga?" www.politika.lv.

17 "Prezidente konsultācijas ar partijām sāks pēc 18.novembra." LETA, 29.10. 2004, at http://www.tvnet.lv/zinas/latvija/article.php?id=65825.

18 “Prezidente izvēlas premjeru. Kalvīti sarauj!" LETA, 24.10. 2004, at http://www.tvnet. lv/zinas/latvija/article.php?id=67413.

19 A representative of the LKatvian First party noted after negotiations with New Era that "There are no fundamental contradictions between us, at least not concerning the main issues." Lulle, A. "LPP un JL sarunas velta budžetam." Neatkarīgā Rìta Avīze, 2 November 2005, p. 1.

20 Margeviča A. "Jaunais laiks prasa Kalvītim 7 portfel̦us." Neatkarīgā Rīta Avīze, 27 November 2004, pp. 1,3.

21 “TB/LNNK kā premjera kandidātus redz Kariṇu un Ārgali.” LETA,15.10. 2004, at http:// www.tvnet.lv/zinas/latvija/article.php?id=67413.

${ }^{22}$ Lulle A. "Jaunais laiks paliek Repšes ķīlnieki." Neatkarīgā Rìta Avīze, 30 November 2004 pp. 1,3. 


\title{
Causes of Cabinet Instability in Central and Eastern Europe
}

\author{
Maruta Lāce \\ University of Latvia
}

\section{INTRODUCTION}

Cabinets are creators of state policy, which is why it is important that they are able to work not only for a few months, but for the entire time between elections. The longer the cabinet works, the greater the possibility that the cabinet can implement its policy and be effective (with "effectiveness" understood here as an ability to make both popular and unpopular decisions).

It is important to emphasise two problems concerning cabinets - firstly, problems related with the process of cabinet formation; secondly, problems related with the duration and effective work of the cabinet. Although a correlation exists between duration and effectiveness, it cannot be maintained surely that a cabinet which has worked for a long time (for instance, all the time between the elections) has worked effectively. There are many other factors (for example, the ability of a prime minister as a leader, the competence of ministers, the cabinet's ability to make essential decisions for society), which have an impact on every cabinet's effectiveness. Cabinet stability is vital in many aspects - because concrete policy cannot be implemented in the short-term and because cabinet stability is assumed to be an indicator of regime stability.

Ten Central and Eastern European (CEE) countries - eight European Union (EU) member states (Estonia, Latvia, Lithuania, Hungary, Poland, the Czech Republic, Slovenia and Slovakia) and two EU candidate countries (Rumania and Bulgaria) are discussed in this article. At this moment, CEE countries are in the period of democracy consolidation, wherein these countries are characterised by implementation of difficult reforms, accession negotiations and accession to international organisations (for instance, in the EU and NATO).

CEE cabinet instability is an urgent problem because CEE countries are often characterised by a lack of party succession, low voter party identification, weak party discipline and party inability to cooperate that make policy implementation more difficult. Empirical data suggest that CEE cabinets are more unstable than Western European (WE) cabinets - the average duration of WE cabinets usually is approximately 100 days longer than the average duration of CEE cabinets (see Table1). 
Table 1

Average Duration of Cabinets in WE and CEE Countries (in days)

\begin{tabular}{|c|c|c|c|}
\hline $\begin{array}{c}\text { WE country } \\
(1945-1999)\end{array}$ & $\begin{array}{c}\text { Average duration } \\
\text { of cabinets }\end{array}$ & $\begin{array}{c}\text { CEE country } \\
(1990-2003)\end{array}$ & $\begin{array}{c}\text { Average duration } \\
\text { of cabinets }\end{array}$ \\
\hline Austria & 878 & *Bulgaria & 590 \\
\hline Belgium & 528 & The Czech Republic & 869 \\
\hline Denmark & 636 & Estonia & 477 \\
\hline Finland & 398 & Hungary & 1096 \\
\hline France & 502 & Latvia & 340 \\
\hline Germany & 686 & Lithuania & 447 \\
\hline Ireland & 900 & Poland & 449 \\
\hline Italia & 350 & Romania & 370 \\
\hline Luxemburg & 1121 & Slovakia & 593 \\
\hline Spain & 750 & Slovenia & 604 \\
\hline Norway & 775 & & \\
\hline Portugal & 327 & & \\
\hline Sweden & 725 & & \\
\hline The UK & 994 & Average duration of & \\
\hline $\begin{array}{c}\text { Average duration of } \\
\text { cabinets in WE countries }\end{array}$ & 684 & cabinets in CEE countries & \\
\hline
\end{tabular}

Sources: 1. Data about the cabinets in Western Europe. Huber J. D. and Martinez-Gallardo C. Cabinet Instability and the Accumulation of the Experience in the Cabinet: The French Fourth and Fifth Republics in Comparative Perspective. 2002, p. 38. http://www.nyu.edu/gsas/dept/ politics/seminars/huber\&martinez-gallardo.pdf (accessed 28.10.2006).

2. Data about the cabinets in Central and Eastern Europe. Müller-Rommel F., Fettelschoss K. and Harfst P. Party government in Central Eastern European democracies: A data collection (1990-2003). 2004, EBSCO data base. http://search.epnet.com (accessed 10.03.2006).

* EU candidate country

The aim of the article is to clarify the reasons for cabinet instability in CEE and to determine whether CEE cabinets can be regarded as more unstable than WE cabinets. Taking into account history and the political situation, CEE cabinets differ from WE cabinets, therefore the causes of CEE cabinet instability are discussed at the beginning of the article, followed by a discussion on the duration of CEE cabinets and the differences among CEE cabinets.

\section{POTENTIAL CAUSES OF CABINET INSTABILITY IN CEE}

A peculiarity in CEE is that many parties are represented in the parliaments. Usually there are four parties on average in CEE. The trend is towards a decline over time. This significant quantitative party presentation is most probably shaped by the fact that voters need time to gain knowledge about the representative who can best stand for and defend their interests in the parliament. However, sometimes it is difficult to differentiate between the parties, as they split and unite according to electoral needs, ${ }^{1}$ besides parties did not have enough time in the 1990 s to develop strong organisations and membership bases. To govern a country in transition 
period is difficult, because of the many reforms that have to be implemented. That shortened the lifespan of parties and encouraged the birth of new ones. Parties invest in coalitions for different reasons. In CEE there are compelling reasons to be in power, rather in the opposition in the transition period. ${ }^{2}$

The high degree of parliamentary fragmentation is also explained with reference to a lack of parliamentary practice. In the West, parliamentary practices evolved over decades and sometimes over one or two centuries, whereas Eastern European cabinets are in a state of "development". 3

As many parties are represented in the parliaments in CEE, there is a greater possibility that more than one party forms the cabinet. The larger the number of parties in the cabinet, the more cabinet decision-making is conflictual. In some CEE countries (Latvia, Poland, Slovakia, Slovenia, Romania) the number of parties in cabinet was between three and four, in the remaining it ranged between 1.5 and 2.7 (until 1999). ${ }^{4}$

Since 1989, CEE countries have been in the process of transition from planned to market economies. The common goal for these countries has been to gain membership in the EU. ${ }^{5}$ Under the market principles, the market functions as an important mechanism in adjusting production and consumption, or supply and demand in the economy. Transition to a market economy involves the following seven issues - privatisation of state-owned enterprises; liberalisation of domestic and foreign transactions, introduction of currency convertibility, and establishment of free competition; establishment of a banking sector composed of a central bank and commercial banks; establishment of a stock market; establishment of a tax system and public finance based on a market economy; establishment of other institutions necessary for a market economy to function; training of human resources necessary for a market economy. ${ }^{6}$

The transition in Poland, Hungary, the Czech Republic, and Slovakia has shown significant progress, however, there are countries where economic transition is slow and still underway. ${ }^{7}$ Transition is one of the possible causes of cabinet instability in CEE, because in some countries where the transition is rather successful, cabinet instability is not so marked. Successful transition can be explained by the different status of each CEE country in the Soviet era, for instance, the Baltic States were in the USSR, but Hungary and the Czech Republic were satellite countries, where the impact of the USSR was not so marked.

The communist legacy also characterises CEE countries. Most elites were socialised in a system where all directives came from above, with one party (i.e., the Communist Party) claiming nearly all political payoffs. As a result politicians have little experience with bargaining and compromise, they are accustomed to an 'us versus them' way of thinking and winner-take-all norms, and they may see the world in strict moral terms. Another feature of the communist legacy is deep affective dislikes between parties that grow out of experience with the communist regime. This dislike mainly extends from parties with roots in the opposition towards parties associated with the old regime, which we call communist successor parties. ${ }^{8}$

CEE has a strong culture of personalisation (actors play a key role in the political system). The Western starting point is often what; the Eastern one tends to be who. ${ }^{9}$ Many commentators on East European politics capture the lack of organisational 
continuity among post-communist politicians by referring to them simply as "political tourists" or "institutional nomads". ${ }^{10}$

As many parties are represented in the parliaments in CEE, the role of the president could be rather important in forming cabinets. The president's role is to nominate an acceptable prime minister in a situation when no party has received a marked majority after elections (this is often the case in the Baltic States and Bulgaria). ${ }^{11}$

Prime ministers are typically the most powerful members of the cabinet. They play an important role in the process of cabinet decision-making. ${ }^{12}$ In the transition period a strong prime minister (PM) could increase the effectiveness of the government* even if the party system is not well established. The key role of the PM is to preserve harmony in the coalition, that means keeping to coalition goals and arbitrating conflicts. ${ }^{13}$ In order to guarantee continuity in objectives during the transition, important decisions should not be made without a basic consensus with the opposition. In that case the PM can rely on greater consensus and that stabilises the government. Especially in periods of political and economic instability, strong social support is needed and then there is a need for strong leadership of a cooperative type. ${ }^{14}$

The authority and effective power of the PM varies among Eastern European countries. Prime ministers in the Baltic States seem often to be 'first among equals', although some have been described as having had an 'authoritarian' style and attempting to impose their views. ${ }^{15}$

Table 2

Types of Cabinets in CEE (1990-1999)

\begin{tabular}{|c|c|c|c|}
\hline Country & $\begin{array}{c}\text { Average number of } \\
\text { parties in office }\end{array}$ & $\begin{array}{c}\text { Number of coalition } \\
\text { cabinets }\end{array}$ & $\begin{array}{c}\text { Number of single-party } \\
\text { cabinets }\end{array}$ \\
\hline Latvia & 3.4 & 8 & 0 \\
\hline Estonia & 2.3 & 7 & 0 \\
\hline Poland & 3.3 & 7 & 3 \\
\hline *Bulgaria & 1.5 & 5 & 3 \\
\hline *Romania & 3.2 & 5 & 0 \\
\hline Slovakia & 3.2 & 5 & 0 \\
\hline The Czech Republic & 2.7 & 4 & 0 \\
\hline Hungary & 2.7 & 4 & 3 \\
\hline Slovenia & 3.2 & 4 & 0 \\
\hline Lithuania & 2 & 3 & 0 \\
\hline
\end{tabular}

Source: Müller-Rommel F. Cabinets in Post-Communist East-Central Europe and in the Balkans: Empirical Findings and Research Agenda. In: Cabinets in Eastern Europe. Eds. J. Blondel and F. Müller-Rommel. New York: Palgrave, 2001, p. 195.

Mostly coalition governments are formed in CEE (also in WE) (see Table 2) ${ }^{16}$ because usually no single party has a full majority in the parliament. In theory, there is a widespread belief that coalition governments are more unstable than singleparty governments. This is partly true, because a major distinguishing mark of single-party government is its ideological homogeneity and more extensive internal policy agreements that produce more stable and long-lived governments. ${ }^{17}$ However, it is important to emphasise that since 1945, some countries (Austria, Ireland and 
Luxembourg - all with experiences of coalition governments) have had stable coalition cabinets with an average life-span of between two and three years or more. In other countries (particularly in Belgium, Finland and Italy) coalition governments have been far more fragile, with cabinets lasting on average under a year and a half only one year in Italy's case. ${ }^{18}$

Countries with short-lived governments tend to have large, complex party systems in which the parties represent radically different ideological and policy positions (this often characterises CEE countries). These factors make the task of maintaining the coalition in government much more difficult than one made up of only two or three parties with a moderate stance and flexible policy positions. ${ }^{19}$

Although both WE and CEE countries have coalition cabinets, CEE coalition cabinets are less stable than WE coalition cabinets because the latter have a longer experience of coalition cabinets. Cabinet instability can be promoted by the lack of experience (the trend is in decline over time); by rather marked parliamentary fragmentation that characterises WE cabinet instability, too; by two to three parties in the cabinet that make consensus more difficult in the coalition; by the strong culture of personalisation; by the transition to market economy - it is also one of the possible causes of cabinet instability in CEE because in some countries where the transition is rather successful, cabinet instability is not so marked and vice versa.

\section{CABINET DURATION IN CEE}

From the early 1990 s to the end of 2003, a total of sixty-eight party governments were formed in ten CEE countries. The number of governments varied appreciably from one country to another during this period: Latvia had ten, Poland nine, Estonia and Romania eight, while the Czech Republic and Hungary had four (see Table 3). ${ }^{20}$

Table 3

Cabinets in CEE (1990-2003)

\begin{tabular}{|c|c|}
\hline Country & Number of cabinets \\
\hline Latvia & 10 \\
\hline *Romania & 10 \\
\hline Estonia & 10 \\
\hline Poland & 9 \\
\hline Lithuania & 7 \\
\hline *Bulgaria & 6 \\
\hline Slovakia & 6 \\
\hline Slovenia & 6 \\
\hline The Czech Republic & 4 \\
\hline Hungary & 4 \\
\hline Average & 6.8 \\
\hline Total & 68 \\
\hline
\end{tabular}

Source: Müller-Rommel F. and Fettelschoss K. Cabinet Government and Cabinet Ministries in Central Eastern European Democracies: A Descriptive Cross National Evaluation. 2004, p. 5. http://www.essex.ac.uk/ecpr/events/jointsessions/paperarchive/uppsala/ws10/ MullerRommelFettelschoss.pdf (accessed 10.03.2006).

* EU candidate country 
The duration of WE governments is usually measured by the number of days, months, or years that governments are in office. This approach has most recently been applied to the analysis of cabinet stability in three post-communist states. It can, however, be argued that this measurement is not sufficient to examine cabinet stability in CEE. Therefore, the duration of ministers and prime ministers in office has to be added to the traditional measurement of cabinet duration.

If one bears in mind that the democratic system was new in CEE, the party governments of these ten countries performed surprisingly well during the phase of institutional transition and consolidation. On overage, 68 CEE governments (19902003) lasted 584 days (Table 4). However, there are appreciable variations within single countries and cross-nationally. Hungary has by far the most stable cabinets (three of the four governments lasted around four years). On the other hand, the most instable government system exists in Latvia (among the ten cabinets in Latvia, nine lasted between 0.19 and 1.26 years). In other countries (Bulgaria, Slovenia, Slovakia) a slow but constant growth in cabinet stability was found. The duration of cabinets in Bulgaria, for instance, increased from 1.14 years (first cabinet) to 4.18 years (last cabinet). In only one country (Latvia) cabinets lasted on average less than one year. In seven out of ten countries, the duration of cabinets ranged between 1.01 and 1.65 years (Bulgaria, Estonia, Lithuania, Poland, Romania, Slovakia, and Slovenia). Hungary and the Czech Republic performed best in terms of cabinet duration; therefore, I could assume that governments in Hungary and in the Czech Republic are as stable as several Western European governments. ${ }^{21}$

Table 4

Cabinet Duration in CEE (1990-2003)

\begin{tabular}{|c|c|}
\hline Country & Average cabinet duration (in days) \\
\hline Hungary & 1096 \\
\hline The Czech Republic & 870 \\
\hline Slovenia & 604 \\
\hline Slovakia & 593 \\
\hline *Bulgaria & 590 \\
\hline Estonia & 477 \\
\hline Poland & 449 \\
\hline Lithuania & 447 \\
\hline *Romania & 370 \\
\hline Latvia & 340 \\
\hline Average cabinet duration in CEE & 584 \\
\hline
\end{tabular}

Source: Müller-Rommel F. and Fettelschoss K. Cabinet Government and Cabinet Ministries in Central Eastern European Democracies: A Descriptive Cross National Evaluation. 2004, p. 8. http://www.essex.ac.uk/ecpr/events/jointsessions/paperarchive/uppsala/ws10/ MullerRommelFettelschoss.pdf (accessed 10.03.2006).

* EU candidate country

Empirical research has proved that the duration of prime ministers in office has an impact on cabinet decision-making. The longer a prime minister holds office, the more we can expect that he 'controls' the behaviour of his ministers in cabinet. The longer a prime minister is in office, the higher the chances that the ideology of the prime minister's party will directly influence the content of decisions in cabinet. 
Up to the end of 2003, 48 persons served as prime ministers in ten CEE countries. They lasted on average 2.4 years in office. Variations around this average are large, however; fifteen prime ministers held office for less than one year, twenty remained in office for less than three years and thirteen above three years. Nine prime ministers stayed in office above four years. They were Klaus (the Czech Republic) and Meciar (Slovakia) with 5 years each; Laar from Estonia with 4.8 years; Vacaroiu from Romania with 4.1 years and Zeman (the Czech Republic), Horn (Hungary), Buzek (Poland), and Dzurinda (Slovakia) with 4 years each. The record is held by Dronovsek of Slovenia, who stayed in office for 9.4 years. ${ }^{22}$

Overall, two thirds of the prime ministers $(66 \%)$ seem not to have stayed in office long enough to exercise a major policy impact and only a very small group of (9) prime ministers (16\% of the total) can be assumed to have had enough time to develop and implement effective policies (Table 5).

Table 5

Prime Minister Duration in Office in CEE (1990-2003)

\begin{tabular}{|c|c|c|}
\hline Country & Number of prime ministers & Average prime minister duration (in days) \\
\hline Slovenia & 2 & 1884 \\
\hline The Czech Republic & 3 & 1210 \\
\hline Slovakia & 3 & 1186 \\
\hline Hungary & 4 & 1096 \\
\hline Estonia & 5 & 763 \\
\hline *Bulgaria & 6 & 590 \\
\hline Poland & 7 & 578 \\
\hline Latvia & 6 & 567 \\
\hline Lithuania & 6 & 521 \\
\hline *Romania & 6 & 493 \\
\hline
\end{tabular}

Source: Müller-Rommel F. and Fettelschoss K. Cabinet Government and Cabinet Ministries in Central Eastern European Democracies: A Descriptive Cross National Evaluation. 2004, p. 9. http://www.essex.ac.uk/ecpr/events/jointsessions/paperarchive/uppsala/ws10/ MullerRommelFettelschoss.pdf (accessed 10.03.2006).

* EU candidate country

The duration of ministers is indirectly linked to cabinet decision-making, in particular to the quality of decisions in the cabinet. It can be assumed that those ministers who stay in office for a long period are more politically experienced and more familiar with the administrative rules than ministers who remain in the cabinet only for a relatively short time. For Western Europe ministerial duration is twice as high as cabinet duration, moreover, almost half of the ministers were in office for more than fours years and only a minority of ministers served less than one year.

In CEE, the picture looks remarkably different. Until the end of 2003, there were 877 ministers. Overall, we find two patterns: those countries where the ministerial duration scores above average (the Czech Republic, Hungary, Slovakia, Slovenia) and those countries where the duration of ministers is below average (Poland, Bulgaria, Romania, Estonia, Latvia, Lithuania) (Table 6). More than half of the ministers $(59 \%)$ were in office for less than two years and only in three countries 
(Hungary, Slovenia, Slovakia) the majority of ministers remained in office for more than two years. ${ }^{23}$

It can be assumed that a minimum duration of three years is needed for a politician to be effective ${ }^{24}$. If this statement also stands as an indicator for political experience, we find the most effective and professional ministers in the Czech Republic, Hungary, Slovakia, and Slovenia. At the same time, there are countries with truly ephemeral ministers who have served on average less than one year. Among them are Bulgaria, all three Baltic States, Poland, and Romania. In these countries, cabinet decision-making is presumably less effective. ${ }^{25}$

Table 6

Ministers' Duration in Office in CEE (1990-2003)

\begin{tabular}{|c|c|c|}
\hline Country & Number of ministers & Average ministers' duration (in days) \\
\hline Slovenia & 67 & 929 \\
\hline Slovakia & 72 & 882 \\
\hline Hungary & 89 & 865 \\
\hline The Czech Republic & 69 & 858 \\
\hline *Romania & 99 & 706 \\
\hline Estonia & 77 & 693 \\
\hline Poland & 131 & 610 \\
\hline Latvia & 71 & 589 \\
\hline Lithuania & 93 & 565 \\
\hline *Bulgaria & 109 & 530 \\
\hline
\end{tabular}

Source: Müller-Rommel F. and Fettelschoss K. Cabinet Government and Cabinet Ministries in Central Eastern European Democracies: A Descriptive Cross National Evaluation. 2004, p. 10. http://www.essex.ac.uk/ecpr/events/jointsessions/paperarchive/uppsala/ws10/ MullerRommelFettelschoss.pdf (accessed 10.03.2006).

* EU candidate country

Many Western observers think that CEE governments are ineffective ${ }^{26}$ because the duration of cabinets has been linked to the concept of cabinet effectiveness. Short-lived cabinets are regarded as being ineffective in terms of policy making, while long-lasting cabinets are more effective. ${ }^{27}$ However, as I mentioned before, not all the cabinets which are stable are effective.

It can be concluded that the assumption that CEE cabinets are much more unstable than WE cabinets was not confirmed. There are some CEE countries characterised by extremely unstable cabinets (for example, Latvia), however, the average CEE cabinet duration is not much worse than that in Western democracies, besides it is important to emphasise that CEE countries are characterised by a slow, but constant increase in cabinet stability. In the future, that gives hope that CEE cabinets will be as stable as WE cabinets. Research on cabinet stability shows that there are differences between CEE countries and that is why further in the article more attention will be paid to the degree and nature of differences among CEE countries. 


\section{DIFFERENCES AMONG CEE COUNTRIES: HUNGARY, THE CZECH REPUBLIC, POLAND AND LATVIA}

The comparative record of cabinet stability shows an interesting variation across the post-communist democracies. Whereas each cabinet has been remarkably stable in post-communist Hungary, no cabinet has survived in its original composition in Poland. Latvia also is characterised as a country with especially unstable governments, but the cabinets that have been formed in the Czech Republic show a mixture of stability and instability. ${ }^{28}$

Despite the similarities in the political trajectories of the post-communist democracies, theory has identified a critical difference that makes their respective records of cabinet stability diverge. Although all four states offer examples of successful democratic consolidation as well as a functioning Western-style party system, the presence of a dominant central player has made successive Hungarian legislatures qualitatively different from their Polish, Czech and Latvian counterparts by creating the most ideal conditions for cabinet stability. ${ }^{29}$ Despite the gradual reduction in the powers of the president, cabinet stability could not be maintained in Poland at the same level as Hungary because of the absence of a dominant central party in successive Polish parliaments. ${ }^{30}$

There is not a dominant party in the parliament of Latvia, which can be explained with distrust of political parties. As there are only few citizens who are involved in political parties and civil society is just developing, people have no direct tie to political processes. Moreover, it is important to emphasise that the process of decision-making often is not clear. If there is an event in the mass media which casts doubt on a certain party's honesty or loyalty to its voters, or the political party in electioneering makes a commercial attacking another party or splitting the nation, citizens' opinions about political parties can change radically, and no party can get a full majority in the parliament.

Three countries (Hungary, the Czech Republic and Poland) are similar in terms of degree of parliamentary fragmentation. The average values of the effective number of parties* are 3.4 in the three Hungarian parliaments (1990, 1994 and 1998), 3.9 in the Czech Republic (1996 and 1998) and 3.43 in Poland (1993 and 1997), ${ }^{31}$ however, in Latvia the degree of parliamentary fragmentation is very high $-7.3(1993,1995$, 1998 and 2002), ${ }^{32}$ although the effective number of parties in parliament is on the decline. The effective number of parties in the 1991 Polish Sejm shows a high degree of party system fragmentation; however, following a change in the electoral law in 1993, the fragmentation of the Sejm dropped significantly in 1993 and in 1997.33

In terms of cabinet structure, both similarities and differences can be identified across the four states. With regard to composition, all but one of the post-election cabinets, i.e. those that arise immediately after a general election, was formed by coalitions of parties. ${ }^{34}$ The four states differ in terms of the size of their governing coalitions. Hungary constitutes an extreme case in this respect, because each of its cabinets has been based on an oversized majority coalition, i.e. it contained at least one superfluous party whose exit would have left the majority status of the coalition intact. The other extreme is the Czech Republic, where both cabinets were in a minority position. Poland has a more mixed record than the other two states - while 
the pattern in the 1991 Sejm was minority cabinets, both cabinets formed after the next two general elections were minimum winning coalitions. ${ }^{35}$ Finally, in Latvia there are both majority coalition governments and minority coalition governments. ${ }^{36}$

It is important to emphasise that the size of the governing cabinet is not always related to cabinet stability, for instance, in Hungary, each cabinet was stable and based on a majority coalition of parties; however, majority status does not predict the stability of cabinets in Poland (also in Latvia), where all post-election majority coalitions were terminated prematurely. ${ }^{37}$

The fragmentation of the parliamentary party system does not predict cabinet stability in all four countries. According to this hypothesis, the more fragmented the party system in the legislature, the greater the number of coalition combinations that parties are capable of forming, which makes any given cabinet in a fragmented legislature potentially more unstable. The 1991 Sejm was the most fragmented and indeed it also saw the formation of the most unstable cabinets of all. At the other extreme, the least fragmented legislature was the 1994 Hungarian parliament, which featured a very stable cabinet. However, there are two anomalous cases. The first is the 1997 Sejm, which was less fragmented than two of the three Hungarian parliaments, 1990 and 1998, yet the cabinet formed therein was more unstable than any cabinet in Hungary. The second is the 1998 Czech Chamber, which was more fragmented than the 1997 Sejm; however, it produced a much more stable cabinet. ${ }^{38}$

Table 7

Latvia compared to Hungary

\begin{tabular}{|c|c|c|}
\hline & Latvia & Hungary \\
\hline Number of cabinets & 10 & 4 \\
\hline Average cabinet duration (in days) & 340 & 1096 \\
\hline Number of prime ministers & 6 & 4 \\
\hline Average prime ministers duration (in days) & 567 & 1096 \\
\hline Number of ministers & 71 & 89 \\
\hline Average ministers duration (in days) & 589 & 4 \\
\hline Number of majority coalition cabinets & 5 & 0 \\
\hline Number of minority coalition cabinets & 4 & 0 \\
\hline Number of one-party cabinets & 0 & \\
\hline
\end{tabular}

Sources: 1. Müller-Rommel F. "Cabinets in Post-Communist East-Central Europe and in the Balkans: Empirical Findings and Research Agenda." In: Cabinets in Eastern Europe. Eds. J. Blondel and F. Müller-Rommel. New York: Palgrave, 2001, p. 195.

2. Müller-Rommel F. and Fettelschoss K. Cabinet Government and Cabinet Ministries in Central Eastern European Democracies: A Descriptive Cross National Evaluation. 2004, p. 5. http://www.essex.ac.uk/ecpr/events/jointsessions/paperarchive/uppsala/ws10/ MullerRommelFettelschoss.pdf (accessed 10.03.2006).

It can be expected that states where the head of state has significant powers over the composition of the cabinet will see a greater degree of cabinet instability, especially at times of divided partisan control over the executive and legislative branches of government. Of the four states, Poland has the strongest chief executive, although successive constitutional changes in 1992 and 1997 curtailed the powers of the president. Nonetheless, still noone can answer the question why coalition cabinets 
remained unstable in Poland even as the successive constitutional amendments of 1992 and 1997 reduced the powers of the head of state and introduced measures to strengthen cabinet stability, in particular the constructive vote of no-confidence. ${ }^{39}$

There are certain differences between post-communist countries, especially between Latvia and Hungary (Table 7) and also Poland and Hungary, and it cannot be maintained that all CEE cabinets are much more unstable compared to WE cabinets. Empirical data show that unstable cabinets are not only in CEE countries (Latvia, Poland), but also in WE countries (Italy, Finland) and that stable cabinets are not only in WE countries but also in CEE countries (Hungary, the Czech Republic).

\section{CONCLUSIONS}

In this article the specific features of ten CEE countries' (Estonia, Latvia, Lithuania, the Czech Republic, Hungary, Poland, Slovenia, Slovakia and Rumania, Bulgaria) cabinets are discussed to clarify the factors that promote CEE cabinet instability and to ascertain whether CEE cabinets are much more unstable than WE cabinets.

The first essential conclusion is that parliamentary fragmentation promotes CEE (also WE) cabinet instability, because usually at least three to four parties form the parliament, whereas three parties on average form cabinets in certain CEE countries (for instance, in Latvia and Slovenia), which makes the decision-making process more difficult. The lack of parliamentary practice, the communist legacy, the lack of politicians' experience in making compromises, small membership in the political parties that can promote mistrust in the cabinet also usually characterise CEE cabinets and make them more unstable than WE cabinets. Taking into account the historical legacy, personalities in CEE are more important than ideologies, whereas if the country has a problem with leadership, especially in the transition period, that can promote cabinet instability. As these ten CEE countries are characterised by parliamentary fragmentation, the role of the president in the process of cabinet formation can be rather large. Some hold that a strong president can impact negatively on cabinet stability. However, in the case of Poland, the power of the president was reduced, but that did not promote cabinet stability as expected. Cabinet stability can also be promoted by the transition to a market economy, because in some countries (Hungary), where the transition is rather successful, cabinet instability is not so marked and vice versa.

The second important conclusion is that CEE cabinets are almost as stable as WE cabinets. There are extremely unstable cabinets in certain CEE countries (for instance, in Latvia). However, the average duration of ten CEE cabinets (584 days) compared to the average duration of WE cabinets (684 days) is not so different. CEE countries also are characterised by a slow, but steady increase in cabinet stability that gives hope that CEE cabinets will be as stable as WE cabinets in the future.

Looking closely at several CEE countries - Hungary, the Czech Republic, Poland and Latvia - it is important to emphasise that cabinet instability is not present in all CEE. For example, Hungary has very stable cabinets. That can be explained with reference to a dominant party in the parliament and oversized coalition cabinets. However, a lower degree of parliamentary fragmentation and a reduction in presidential powers did not promote cabinet stability in Poland. 
Not only one factor, but many factors together have an impact on cabinet stability, whereas a general assumption that CEE cabinets are much more unstable than WE cabinets cannot be sustained because the empirical data show that stable and unstable cabinets have existed in both WE and CEE countries.

\section{BIBLIOGRAPHY}

Budge I., Keman H. Parties and Democracy: Coalition Formation and Government Functioning in Twenty States. New York: Oxford University Press, 1993.

Cabinets in Eastern Europe. Eds. J. Blondel and F. Müller-Rommel. New York: Palgrave, 2001.

Hogwood P. and Roberts G. K. European Politics Today. Manchester: Manchester University Press, 2003.

\section{SOURCES}

Annual Evaluation Report (2002). Chapter 2: "Ex-post Evaluation, II. Thematic Evaluation" Transition to a Market Economy in Eastern Europe: Poland and Hungary. http://www. jica.go.jp/english/evaluation/reports/pdf/2002_0111.pdf (accessed 28.10.2006.).

Druckman J. N. and Roberts A. "Context and Coalition-Bargaining. Comparing Portfolio Allocation in Eastern and Western Europe." Party Politics. 2005, vol. 11, no. 5, pp. $535-555$.

Fettelschoss K. Duration and De-Selection of Ministers in CEE. 2005. http://www.essex. ac.uk/ecpr/events/jointsessions/paperarchive/granada/ws10/Fettelschoss.pdf (accessed 10.03.2006).

Huber J. D. and Martinez-Gallardo C. Cabinet Instability and the Accumulation of the Experience in the Cabinet: The French Fourth and Fifth Republics in Comparative Perspective. 2002. http://www.nyu.edu/gsas/dept/politics/seminars/huber\&martinezgallardo.pdf (accessed 28.10.2006).

Interview with Jean Blondel (23.11.2004). The Public Policy site www.politika.lv (accessed 14.04.2006).

Kostova D. Coalition Governments and the Decision Making Process in CEE. University of Uppsala, Sweden, April 13-18, 2004. http://www.essex.ac.uk/ecpr/events/jointsessions/ paperarchive/uppsala/ws10/Kostova.pdf (accessed 03.03.2006).

Kreuzer M. and Pettai V. Patterns of Political Instability: Affiliation Patterns of Politicians and Voters in Post-Communist Estonia, Latvia and Lithuania. 2003, 22 (pp. 76 - 98) p., EBSCO data base. http://search.epnet.com (accessed 10.03.2006).

Müller-Rommel F. and Fettelschoss K. Cabinet Government and Cabinet Ministries in Central Eastern European Democracies: A Descriptive Cross National Evaluation. 2004. http://www.essex.ac.uk/ecpr/events/jointsessions/paperarchive/uppsala/ws10/ MullerRommelFettelschoss.pdf (accessed 10.03.2006).

Müller-Rommel F., Fettelschoss K. and Harfst P. Party government in Central Eastern European democracies: A data collection (1990-2003). 2004, EBSCO data base. http:// search.epnet.com (accessed 10.03.2006).

Nikolenyi C. "Cabinet Stability in Post-Communist Central Europe." Party Politics. 2004, vol. 10 , no. 2 , pp. $123-150$.

The official home page of Central Election Commission. http://www.cvk.lv (accessed 26.09.2006). 


\section{ENDNOTES}

1 Kostova D. Coalition Governments and the Decision Making Process in CEE. University of Uppsala, Sweden, April 13 - 18, 2004, p. 5. http://www.essex.ac.uk/ecpr/events/ jointsessions/paperarchive/uppsala/ws10/Kostova.pdf (accessed 03.03.2006).

2 Ibid, p. 6.

3 Druckman J. N. and Roberts A." Context and Coalition-Bargaining. Comparing Portfolio Allocation in Eastern and Western Europe.” Party Politics. 2005, vol. 11, no. 5, p. 539.

${ }^{4}$ Müller-Rommel F. Cabinets in Post-Communist East-Central Europe and in the Balkans: Empirical Findings and Research Agenda. In: Cabinets in Eastern Europe. Eds. J. Blondel and F. Müller-Rommel. New York: Palgrave, 2001, p. 194.

5 Transition to a Market Economy in Eastern Europe: Poland and Hungary, p. 100. http:// www.jica.go.jp/english/evaluation/reports/pdf/2002_0111.pdf (accessed 28.10.2006.).

6 Transition to a Market Economy in Eastern Europe: Poland and Hungary, p. 101. http:// www.jica.go.jp/english/evaluation/reports/pdf/2002_0111.pdf (accessed 28.10.2006.).

7 Ibid., p.100.

8 Druckman J. N. and Roberts A. "Context and Coalition-Bargaining. Comparing Portfolio Allocation in Eastern and Western Europe." Party Politics. 2005, vol. 11, no. 5, p. 541.

9 Fettelschoss K. Duration and De-Selection of Ministers in CEE. 2005, p. 4. http:// www.essex.ac.uk/ecpr/events/jointsessions/paperarchive/granada/ws10/Fettelschoss.pdf (accessed 10.03.2006).

${ }_{10}$ Kreuzer M. and Pettai V. Patterns of Political Instability: Affiliation Patterns of Politicians and Voters in Post-Communist Estonia, Latvia and Lithuania. 2003, pp. 84, EBSCO data base. http://search.epnet.com (accessed 10.03.2006).

11 Kostova D. Coalition Governments and the Decision Making Process in CEE. University of Uppsala, Sweden, April 13 - 18, 2004, p. 67 http://www.essex.ac.uk/ecpr/events/ jointsessions/paperarchive/uppsala/ws10/Kostova.pdf (accessed 03.03.2006).

12 Müller-Rommel F. and Fettelschoss K. Cabinet Government and Cabinet Ministries in Central Eastern European Democracies: A Descriptive Cross National Evaluation. 2004, p. 8. http://www.essex.ac.uk/ecpr/events/jointsessions/paperarchive/uppsala/ws10/ MullerRommelFettelschoss.pdf (accessed 10.03.2006).

* The word "government" in the article is used as a synonym to the word "cabinet".

13 Kostova D. Coalition Governments and the Decision Making Process in CEE. University of Uppsala, Sweden, April 13-18, 2004, p. 12. http://www.essex.ac.uk/ecpr/events/ jointsessions/paperarchive/uppsala/ws10/Kostova.pdf (accessed 03.03.2006).

14 Ibid.pp. 11.

15 Blondel J. "Cabinets in Post-Communist East-Central Europe and in the Balkans: Introduction." In: Cabinets in Eastern Europe. Eds. J. Blondel and F. Müller-Rommel. New York: Palgrave, 2001, p. 9.

${ }^{16}$ Hogwood P. and Roberts G. K. European Politics Today. Manchester: Manchester University Press, 2003, p. 144.

17 Budge I. and Keman H. Parties and Democracy: Coalition Formation and Government Functioning in Twenty States. New York: Oxford University Press, 1993, p. 172.

18 Hogwood P. and Roberts G. K. European Politics Today. Manchester: Manchester University Press, 2003, p. 144.

19 Ibid., p. 145.

${ }^{20}$ Müller-Rommel F. and Fettelschoss K. Cabinet Government and Cabinet Ministries in Central Eastern European Democracies: A Descriptive Cross National Evaluation. 2004, p. 5. http://www.essex.ac.uk/ecpr/events/jointsessions/paperarchive/uppsala/ws10/ MullerRommelFettelschoss.pdf (accessed 10.03.2006). 
${ }^{21}$ Müller-Rommel F. and Fettelschoss K. Cabinet Government and Cabinet Ministries in Central Eastern European Democracies: A Descriptive Cross National Evaluation. 2004, p. 7. http://www.essex.ac.uk/ecpr/events/jointsessions/paperarchive/uppsala/ws10/ MullerRommelFettelschoss.pdf (accessed 10.03.2006).

22 Müller-Rommel F. and Fettelschoss K. Cabinet Government and Cabinet Ministries in Central Eastern European Democracies: A Descriptive Cross National Evaluation. 2004, p. 8. http://www.essex.ac.uk/ecpr/events/jointsessions/paperarchive/uppsala/ws10/ MullerRommelFettelschoss.pdf (accessed 10.03.2006)

${ }^{23}$ Müller-Rommel F. and Fettelschoss K. Cabinet Government and Cabinet Ministries in Central Eastern European Democracies: A Descriptive Cross National Evaluation. 2004, p. 9. http://www.essex.ac.uk/ecpr/events/jointsessions/paperarchive/uppsala/ws10/ MullerRommelFettelschoss.pdf (accessed 10.03.2006).

24 Interview with Jean Blondel (23.11.2004)at www.politika.lv (accessed 14.04.2006).

25 Müller-Rommel F. and Fettelschoss K. Cabinet Government and Cabinet Ministries in Central Eastern European Democracies: A Descriptive Cross National Evaluation. 2004, p. 10. http://www.essex.ac.uk/ecpr/events/jointsessions/paperarchive/uppsala/ ws10/MullerRommelFettelschoss.pdf (accessed 10.03.2006).

26 Blondel J. "Cabinets in Post-Communist East-Central Europe and in the Balkans: Introduction." In: Cabinets in Eastern Europe. Eds. J. Blondel and F. Müller-Rommel. New York: Palgrave, 2001, p. 11.

27 Müller-Rommel F. "Cabinets in Post-Communist East-Central Europe and in the Balkans: Empirical Findings and Research Agenda." In: Cabinets in Eastern Europe. Eds. J. Blondel and F. Müller-Rommel. New York: Palgrave, 2001, p. 195.

28 Nikolenyi C. "Cabinet Stability in Post-Communist Central Europe." Party Politics. 2004, vol. 10, no. 2, p. 123.

29 Ibid., p. 147.

${ }^{30}$ Ibid, p. 146.

* The effective number of parties is one of the most often used aggregate quantities to describe partisan configurations, and has extensively been used in comparative political party literature. More importantly, researchers have modeled the effective number of parties into statistical models as dependent variables. [Won-ho Park, 2004]

31 Nikolenyi C. "Cabinet Stability in Post-Communist Central Europe." Party Politics. 2004, vol. 10, no. 2, p. 125.

32 The official home page of Central Election Commission. http://www.cvk.lv (accessed 26.09.2006).

33 Nikolenyi C. "Cabinet Stability in Post-Communist Central Europe." Party Politics. 2004, vol. 10, no. 2, p. 126.

34 Ibid, p. 128.

35 Ibid, p. 129.

36 Müller-Rommel F. "Cabinets in Post-Communist East-Central Europe and in the Balkans: Empirical Findings and Research Agenda." In: Cabinets in Eastern Europe. Eds. J. Blondel and F. Müller-Rommel. New York: Palgrave, 2001, p. 195.

37 Nikolenyi C. "Cabinet Stability in Post-Communist Central Europe." Party Politics. 2004, vol. 10, no. 2, p. 132.

38 Nikolenyi C. "Cabinet Stability in Post-Communist Central Europe." Party Politics. 2004, vol. 10, no.2, p. 132.

39 Ibid., p. 133. 

LU Akadēmiskais apgāds

Baznīcas iela 5, Rīga, LV-1010

Tālrunis: 7034535

Iespiests

SIA "LATGALES DRUKA" 